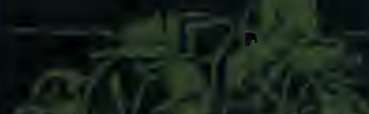

$(15 \%$ :

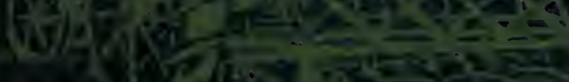

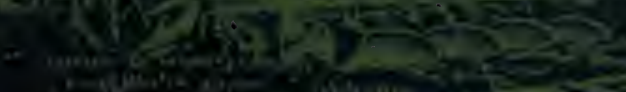

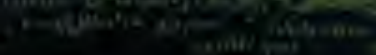
$\rightarrow$

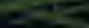

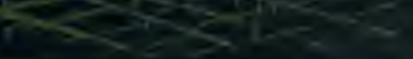

\title{
ELEMENTARY
}

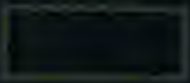
AGRICULTURE 


\section{F. ROEISOA}

- - $\quad x-\infty-1$

\section{UNIVERSITY OF CALIFORNIA AT LOS ANGELES}
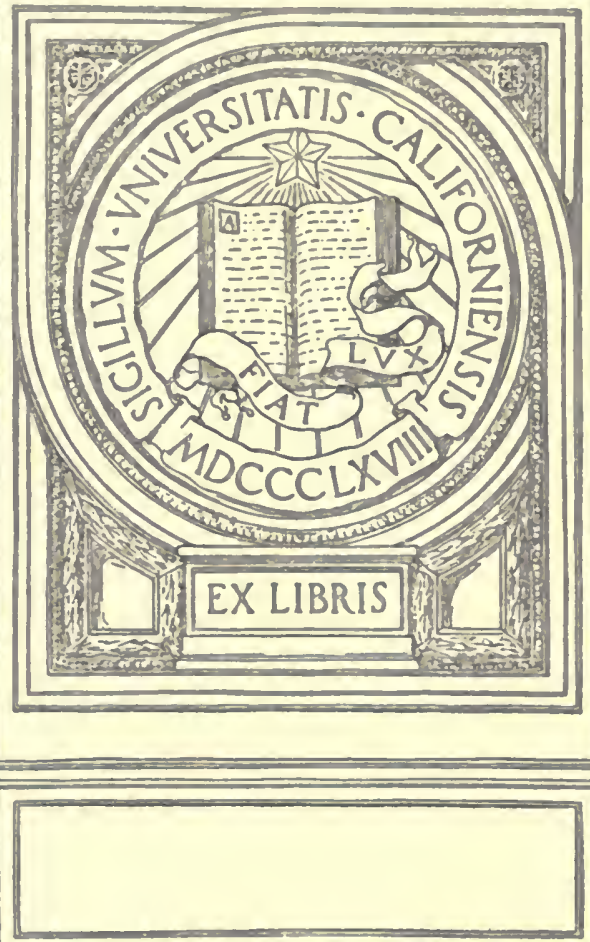


Digitized by the Internet Archive in 2007 with funding from Microsoft Corporation

http://www.archive.org/details/elementaryagricu00grimiala 
$t^{-5}$ 


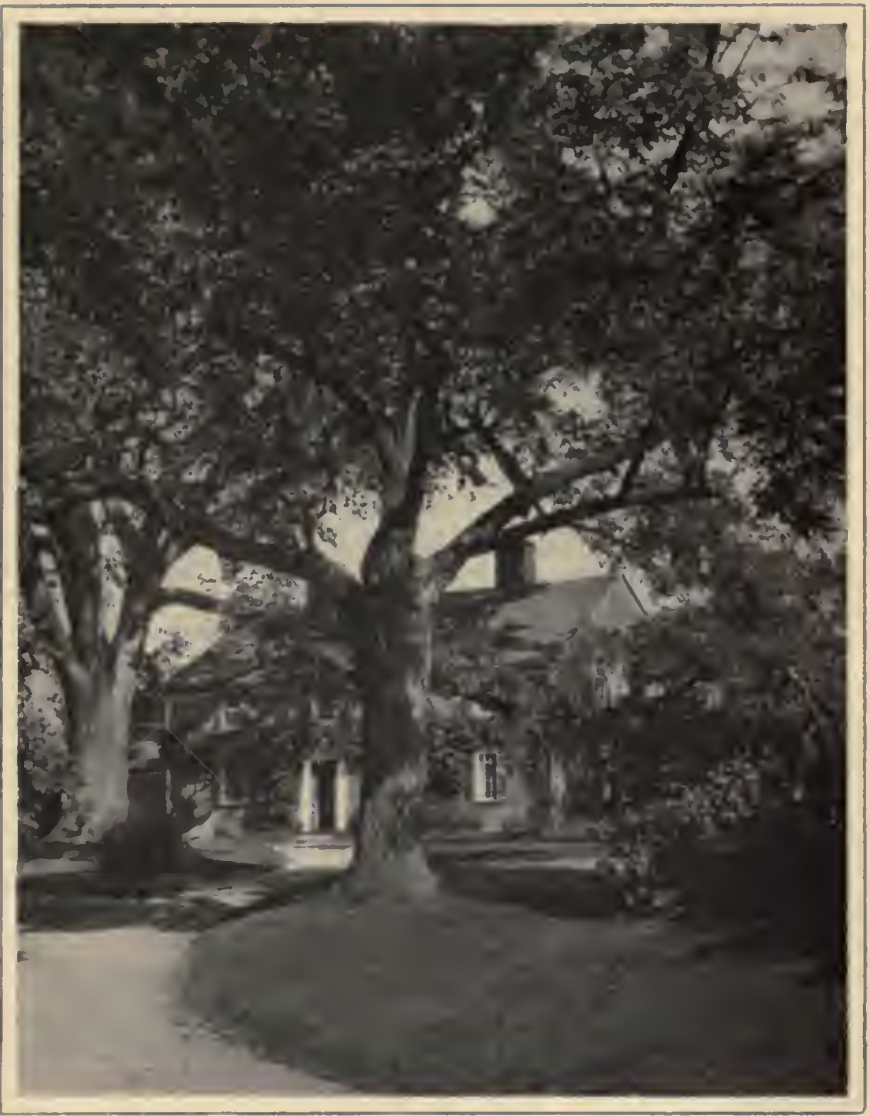

A FARM HOME 


\section{E LEM ENTARY}

\section{A GR I C ULT URE}

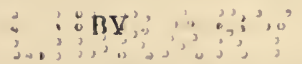

\section{JAMES S. GRIM, PH.D.}

KEYSTONE STATE NORMAL SCHOOL, KUTZTOWN PENNSYLVANIA

"No other occupation opens so wide a field for the profitable and agreeable combination of labor and cultivated thought, as agriculture."

- Abrainam Lincoln.

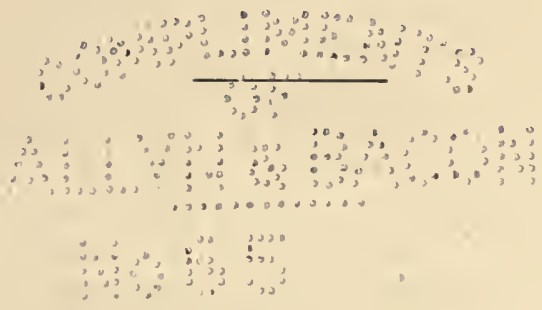

\section{A L L Y A N B ACON}




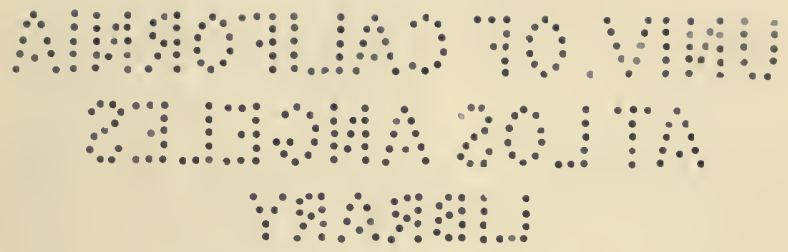

COPYRIGHT, 1916, BY

JAMES S. GRIM

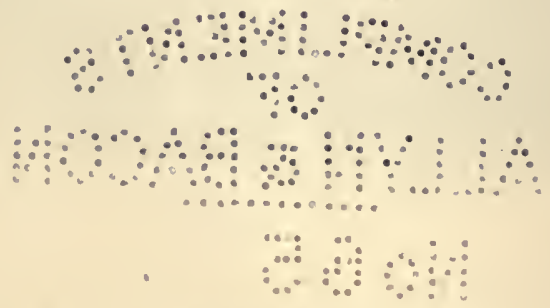

Norwood press

J. S. Cushing Co. - Berwick \& Smith Co. Norwood, Mass, U.S.A. 


\section{$-87$}

\section{PREFACE}

Farming is a business - our chief business. But the study of agriculture should be not only economic; it should be educational and social as well. Good homes, good schools, good roads, must wait on good business.

Elementary Agriculture is an attempt to utilize the social values of farm life as educative material; it aims to make country boys and girls love farm life, not only because this life is worthy and wholesome, but because farming, if directed by a trained mind, is a most interesting and profitable calling. This book places the emphasis on doing something as a home exercise or project, both for its educational and for its material value; it aims to correlate with farm life, when possible, such related subjects as arithmetic, history, literature, geography and the sciences generally; and it gives pointed suggestions at the end of each chapter for practical and.productive work.

The social and the economic treatment, which has been generally ignored, takes up the first six chapters. But the first lesson may start with corn and the seasonal sequence of subjects may follow in order. Most teachers prefer to select their own order of chapters to suit local conditions, and to this plan Elementary Agriculture is particularly well adapted.

The study of agriculture is wider than the study of any textbook. Books on agriculture are mere guides or instruments imperfect at best; they must be judged by what they lead to rather than by what they contain. They should not be compilations of agricultural bulletins written by experts. These bulletins are readily available, and no textbook can take their place.

The time has come when we must mobilize our instructional resources in agriculture. They have not been doing effective iii 
team work. Coöperative associations, churches, schools, individuals, all have special fields of activity, but none can do its best work unless it works with and borrows from all the others. When this idea is applied to students of agriculture it means that an important part of their education consists in locating their fellow workers and in coöperating with them freely and wholeheartedly. Elementary Agriculture aims to teach them this.

The author gratefully acknowledges his special obligations to the following: Dr. Harold G. Foght, specialist in Rural School Practice, United States Bureau of Education; Professor C. H. Lane, Chief Specialist in Agricultural Education, United States Department of Agriculture; Thomas J. Mairs, Professor of Agricultural Education, Pennsylvania State College; L. H. Dennis, Director of Agricultural Education, Harrisburg, Pa.; Professor Frank App, Agronomist, New Jersey Agricultural Experiment Station; William D. Hurd, Director Massachusetts Agricultural College; Superintendent E. M. Rapp, Reading, Pa.; Professor W. Theo. Wittman and Dr. Franklin Menges of the Pennsylvania Department of Agriculture; Albert E. Wilkinson, Professor of Horticulture, Cornell University, New York; Dr. William Frear, Professor of Experimental Agricultural Chemistry and Vice-Director of Pennsylvania State Experiment Station; Arthur E. Grantham, Professor of Agronomy, Delaware Agricultural Experiment Station; Mr. Charles S. Adams, County Agriculturist, Reading, Pa.; George H. Von Tungeln, Associate Professor of Rural Sociology, Iowa Agricultural College, and several other members of the Iowa Agricultural College.

J. S. G.

Kutztown, Pexssy.vasia. 


\section{ACKNOWLEDGMENT OF ILLUSTRATIONS}

National Stockman and Farmer.

$357,368,373,374,375,378,389,395,397,400,401,402$, 410, 411, 412, 413, 418, 419.

Department of Agriculture, Washington, D.C.

77, 89, 135, 196, 197, 325, 326, 328, 329, 351, 352, 382, 433,435 .

College of Agriculture, Vermont.

$2,3,55,63,115,144,199,200,201,214,244,246,247$, 300 .

College of Agriculture, Pennsylvania.

$$
107,129,138,140,141,276,370,384,425 .
$$

College of Agriculture, Missouri.

$62,86,87,108,399,403,437$.

College of Agriculture, New Jersey.

$$
\text { 231, } 232 .
$$

College of Agriculture, Delaware.

$$
372,426 .
$$

Bureau of Vocational Education, Harrisburg, Pa.

$$
28,42,322,366,441 .
$$

International Harvester Company.

8 (Copyrighted 1913, by Keystone View Company), $20,26,34,67,81,110,123,142,143,281,288$. 



\section{TABLE OF CONTENTS}

\section{PART I}

\section{RURAL LIEE AND ACTIVITIES}

OH APTER

1. The Farmer and Nature ..$\quad \cdot \quad \cdot \quad \cdot \quad \cdot 1$

II. The People of the Farm . . . . . . . . 16

III. Country Children . . . . . . . . . 31

IV. The Affairs of the Farm . . . . . . . . 45

V. The Business of Farming . . . . . . . . 61

VI. Rural Conveniences . . . . . . . . 77

\section{PART II}

\section{THE SOIL AND ITS IMPROVEMENT}

VII. The Soil .

VIIl. Plant Food . . . . . . . . . . . 112

IX. Fertilizers . . . . . . . . . . 123

X. Soil Management . . . . . . . . . 134

\section{PART III}

\section{CROPS}

XI. The Nature and Work of Plants . . . . . 152

XII. How New Plants are Started . . . . . . . 160

XIII. More about Starting New Plants . . . . . . 171

XIV. Making Better Plants . . . . . . . . 190

XV. Common Diseases of Crops . . . . . . . 208

XVI. The Farm Garden . . . . . . . . . 221

XVII. Keeping the Garden Produce . . . . . . . 231

XVIII. Potatoes . . . . . . . . . . 243

XIX. Corn . . . . . . . . . . 251 
CIIATIR

$X X$. Small Grain Crops

$X X I$. Forage Crops

XXII. Weeds .

XXIII. The Orchard

XXIV. Timber Trees

XXV. Ornamental Plants

300

$\mathrm{XXVI}$. Insects and Birds .

\section{PAR'T IV}

STOCK

XXVII. Improvement and Feeding . 355

XXVIII. Cattle 366

XXIX. Milk and Its Products.

XXX. Horses .

$X X X I$. Sheep and Swine.

XXXII. Poultry

\section{PART V}

\section{FARM ECONOMICS}

XXXIIl. Farm Finance 446

Appendix A .

Charts of United States Products. Appendix B .

I. Value of Farm Property.

II. Farms Classified by Size.

III. Number of Domestic Animals.

Appendix C .

Agricultural College of the United States. Appendix D .

Magazine Articles on Agriculture. Appendix E .

Constitution of Boys' Pig Club. Appendix F .

Use of Farmers' Bulletins. Appendix G .

Report of a Pupil's Project. Appendix $\mathrm{H}$.

\section{Supplies.}

Farm Journals. 


\section{LIST OF ILLUSTRATIONS}

FIGURE

PAGE

1. A Farm Home . . . . . . . . Frontispiece

2. A Farm Brook . . . . . . . . . . . 2

3. Elms at the Water's Brink . . . . . . . 3

4. A Pleasant Farmhouse . . . . . . . . . . 4

5. A Quiet Corner of the Farm . . . . . . . . 5

6. Variation in Timothy Heads . . . . . . . . 6

7. Plowing along the Nile . . . . . . . . 8

8. Head of Fox . . . . . . . . . . 10

9. Rattlesnake ; Copperhead; Garter Snake; Water Snake . . 10

10. The San José Scale . . . . . . . . . 11

11. Orchard and Forest . . . . . . . . . . 12

12. Nature in the City . . . . . . . . . 12

13. Spinning Flax . . . . . . . . . 16

14. Plowing with Oxen . . . . . . . . . 18

15. Sowing with Tractor and Drill . . . . . . 18

16. Making Brooms on the Farm . . . . . . . 19

17. Cyrus H. McCormick . . . . . . . . 20

18. Type of Barn a Century Old . . . . . . . 21

19. A Modern Homestead . . . . . . : . . 23

20. Barn at Mt. Vernon . . . . . . . . . 24

21. An Industrial Center . . . . . . . . . . . 26

22. Hard Work . . . . . . . . . . . 27

23. Blacksmithing . . . . . . . . . . . . 28

24. The Best Farm Crop . . . . . . . . . 31

25. Light Work for Children . . . . . . . 32

26. Comparative Values . . . . . . . . . . 34

27. Tablet at Union Station, Washington . . . . . 35

28. Farm Pets . . . . . . . . . . . 37

29. Organized Play . . . . . . . . . . . 38

30. Home Work . . . . . . . . . 39

31. Boy Scouts at Camp . . . . . . . . , 41

32. Rope Splicing . . . . . . . . . . 42

33. The Typhoid Carrier . . . . . . . . . 46

34. Caught! . . . . . . . . . . 47

35. The Country School . . . . . . . . . 48 
36. Coöperation of Farmers

37. Club Members Working their Projects

38. Poultry Club Member .

39. School Exercise in Pruning .

40. An Agricultural Fair

41. An Orchard Meeting

42. Farmers and their Wives

43. Tree Planting Demonstration

44. Agricultural College Bulletin

45. Farmers Shipping by Rail .

46. Farmers Shipping by Boat .

47. A Successful Farm

48. A Bumper Potato Crop

49. Making Sure of Clean Milk .

50. European Peasant Farmers .

51. Intensive Farming

52. Small Fields and Tenant Farms

53. Farm Labor .

54. Bad Farming

55. A Windmill on the Farm

56. Getting the Morning Mail

57. The Automobile on the Farm

58. Stone Crusher

59. Models Illustrating Road-Building

60. Effect of Narrow Tires.

61. Effect of Broad Tires . . . . . . . . 87

62. Kitchen Conveniences . . . . . . . . 89

63. Handy Farm Implement . . . . . . . . 90

64. Grain Elevators . . . . . . . . . 91

65. Clod of Soil Magnified. . . . . . . . . 93

66. Relative Sizes of Soil Particles . . . . . . . 94

67. Clay . • . . . . . . . . . . 95

68. Sand . . . . . . . . . . . . . 96

69. Bottle of Soil Sifted . . . . . . . . . . 97

70. Disintegration . . . . . . . . . 98

71. How Roots Hold the Soil . . . . . . . 99,

72. Studying Soils . . . . . . . . . . 1011

73. Capillary Attraction . . . . . . . . . 103;

74. Ditching Machine . . . . . . . 107

75. Part of Irrigation Dam . . . . . . . . 108

76. Pumping Water to Irrigate Farm Lands . . . . . 110

77. Root Hairs on Wheat 
FIGURE

78. Soil in Good Tilth

79. Curly Kale . .

80. Nodules on Bean Roots

81. Sweet Clover on Shallow Limestone Soll .

82. Spreading Manure

83. Proper Care of Manure

84. A Lime Kiln

85. Preparing Stone Lime

86. A Pile of Slacked Lime

87. Effect of Tillage .

88. A School Garden

89. Spreading Lime .

90. The Common Plow

91. The Spaulding Plow.

92. Traction Plow and Disk Harrow

93. Furrows Properly Turned .

94. Spring-Tooth Harrow .

95. Extension Harrow

96. Timothy in Bloom

97. Plant Cells .

98. Chlorophyll Bodies of a Leaf

99. Millet Seed .

100. The Life Story of a Pear

101. Staminate Flowers and Pollen of Corn Plant

103. Corn Silk

104. Effect of Poor Pollination

106. Seeds and Flowers of the Potato Plant

107. Sections of Corn Kernels

108. Poor Alfalfa Seed

109. Good Alfalfa Seed

110. Alfalfa Seeds after Testing.

111. Roots of Wheat Seedlings .

112. Buds in the Axils of Leaves

113. Breathing Pores of a Leaf .

114. Geranium Cutting

115. Rose Cuttings

116. Stolons of White Clover

117. Strawberry Runners . 
120. Budding

121. Grafting Exercise

122. Luther Burbank .

123. Varlation in Plant Breeding

124. Corn Bagged

125. Prize Corn .

126. Tomatoes

127. Niagara Grapes .

128. Improved Blackberry

129. Blackberry Field

130. Improved Crab Apple .

131. Compound Microscope

132. Bacteria

133. Plum Rot

134. Peach Rot

135. Shot-Hole Fungus on Apple Leaves

136. Anthracnose on Bean Pod.

137. Potato Blight

138. Clean and Smutted Oats

139. Corn Smut .

140. Black Knot on Plum Twigs

141. A Wood-Destroying Fungus

142. A Farm Garden .

143. Handy Garden Tools .

144. Asparagus Plot

145. Bush Beans Ready to Cover

146. Hill of Sweet Corn

147. Bantam Sweet Corn

148. Bean Plant .

149. Making a Hot-Bed

150. A Bean Project .

151. Celery

152. Kitchen Canning

153. Home Canning Outfit .

154. Yeast .

155. Molds .

156. Dried Corn .

157. Canned Corn

158. Dried Peaches

159. Dried Apricots

160. Dried Apples 
163. Covering Potatoes with a Two-Winged Plow . . . . 244

164. Cultivating Potatoes .

165. Class Selecting Seed Potatoes . . . . . . . 246

166. Potato Digger

167. A Good Potato Crop

168. Sweet Potatoes .

169. Good and Bad Seed

170. Class Selecting Seed Corn .

172. Removing Seed for Testing

173. Box Method of Testing Seed

174. Starting a Corn Variety Test

175. Six Types of Corn

176. Result of not Testing Seed .

177. Wheat Grains

178. Threshing Wheat

179. A Wheat Variety Test .

180. Oats - Natural Size

181. Oats as Planted in Drills

182. Buckwheat - Natural Size .

183. Buckwheat Planted in Drills

184. Barley Grains

185. Rye Grains .

186. Cutting Forage

187. A Typical Meadow

188. Hay Tedder at Work .

189. Red Top

190. Timothy Seed

191. Seed of Kentucky Blue Grass

192. Hay Loader

193. The Alfalfa Plant

194. Red Clover.

195. Red Clover Seed. Natural Size

196. Dodder, a Parasite on Clover

197. Alsike Clover

198. Soy Beans .

199. Building a Cheap Silo.

200. Cow Peas

201. A Cement Silo 
FIOURE

204. Wild Carrot

205. Moth Mullein

206. Milkweed .

207. Fennel

208. Two Kinds of Plgweed

209. Canada Thistle

2io. Plantain

211. Tumble Grass

212. Chicory

213. Apple Orchard in Winter

214. An Old Orchard .

215. Grape Twigs

216. Peach Twigs

217. Apple Shoots

218. Pruning Peach Trees. 
FIGTRE

246. Angoumois Grain Moths and Grain Weevils

247. Potato Beetle . . . . . .

248. Insects on Leaves

249. Toads Eating Caterpillars .

250. Tent Caterpillars

251. Work of Walnut Caterpillars

341

252. Shot-Hole Borer.

342

253. Work of the San Jose Scale

343

254. Scale Parasite . . . . . . . . . . 344

255. Work of the Scale Parasite. . . . . . . . 344

256. The Coddling Moth . . . . . . . . 346

257. Ichneumon Flies. . . . . . . . . . . . 347

258. Bee Hives in an Orchard . . . . . . . . . 349

259. Bird Boxes. . . . . . . . . . . 350

260. Red-Headed Woodpeckers . . . . . . . . 351

261. The Crow . . . . . . . . . . . 352

262. A Dairy Herd . . . . . . . . . . . 355

263. A Holstein Calf . . . . . . . . . . 357

264. Beef Cattle in Pasture . . . . . . . . . 359

265. An Elaborate Dairy Barn . . . . . . . . 360

266. Live Stock Judging . . . . . . . . 366

267. Hereford Cow . . . . . . . . . 368

268. Shorthorn Bull . . . . . . . . . . 369

269. Herefords at Pasture . . . . . . . . . 369

270. Aberdeen Angus Bull. . . . . . . . . 370

271. Raising a Holstein Calf . . . . . . . . 371

272. Jersey Cows . . . . . . . . . . 372

273. Guernsey Cow . . . . . . . . . 373

274. Ayrshire Cow . . . . . . . . . . 374

275. Holstein Cow . . . . . . . . . . 375

276. Interior of Dairy Barn . . . . . . . 378

277. Milk Pails . . . . . . . . . . . 382

278. Butter Making Outfit . . . . . . . . , 384

279. Testing Milk. Babcock Tester . . . . . . 385

280. A Dirty Cow . . . . . . . . . . . 388

281. A Clean Cow . . . . . . . . . . . 389

282. Milk from the Clean Cow . . . . . . . 390

283. Milk from the Dirty Cow . . . . . . 390

284. Germs of the Dairy . . . . . . . . . 391

285. Blooded Saddle Mare . . . . . . . . . 395

286. Horse Barn . . . . . . . . . . 396

287. Percheron Stallion . . . . . . . . 397 
rorke

288. Percheron Brood Mares

289. Clydesdale Stallion

290. Belgian Stallion.

291. Shire Stallion

401

292. Pair of Mules

402

293. Ralsing a Colt

403

294. A Flock of Sheep

405

295. Hampshire .

296. Shropshire .

297. Merino

298. Cheviots

412

413

299. Sheep Feeding in Rape Field . . . . . . . 415

300. Pigs Feeding on Alfalfa

301. Berkshire

302. Duroc-Jersey

303. Chester White Pig in Unattractive Pen

304. Bacon and Ham

422

305. A Poultry Project

425

306. White Leghorn

426

307. Minorca Cock

427

308. Egg Yields .

309. Barred Plymouth Rock Hen . . . . . . . 428

310. Buff-Orpington .

311. White Wyandottes

430

312. Rhode Island Reds

313. Brahma Cock and Hen

314. A Setting of Eggs

315. Poultry Feed

434

316. Feeding the Chickens .

435

317. Small Chicken House.

318. Putting Chicks in the Brooder

319. A Colony Hen-House .

320. Modern Poultry House and Yard

321. High School Boys Preparing for the Poultry Show 
ELEMENTARY AGRICULTURE 



\title{
ELEMENTARY AGRICULTURE
}

\author{
PART I \\ RURAL LIFE AND ACTIVITIES
}

\author{
CHAPTER I \\ THE FARMER AND NATURE \\ Let Nature be your teacher. - Wokdswoktu.
}

1. The New Earth. - Everything we see is subject to constant change. We are told that our bodies change completely once every seven years. Orchards that are white with blossoms in May are laden with fruit in October. Meadows that are brown in autumn are to be carpeted in spring with a rich green. Through all the world, change is always going on. Many of the changes can be detected only by comparisons from week to week or month to month; and still others take place so slowly that even a lifetime is not long enough to see them. There may be a hill near your home. Can any one doubt, on seeing the muddy water running from its side, that in time, perhaps in a thousand or maybe in a million years, a large part of the hill will be carried away?

Thus, a new earth is forming every day. It is formed out of the old earth which, more or less rapidly, is being made over. New plants and animals and new particles of soil are ever taking the place of the old ones. Just as 
our bodies are constantly losing old matter and building up new matter, so are our fields, crops, stock, and lands. One of the never-ending joys that come to the farmer is

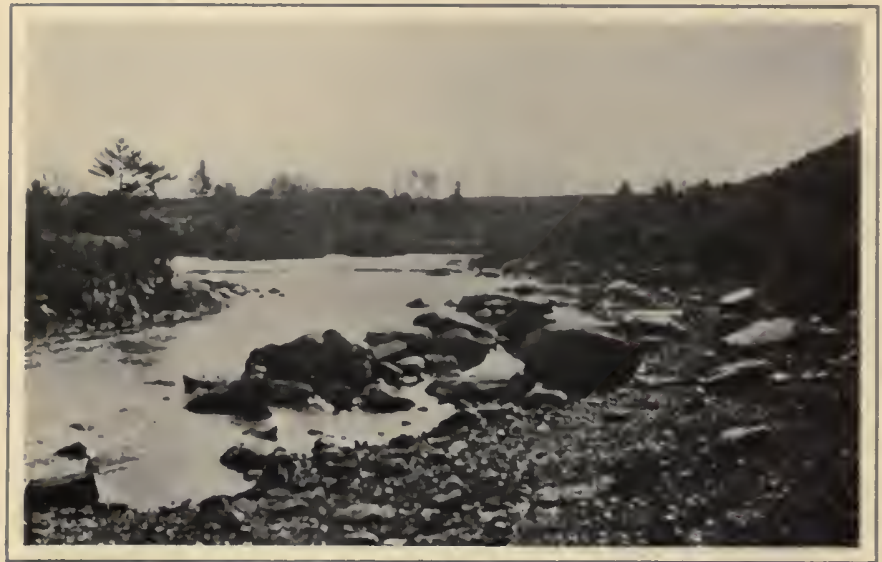

A FARM BROOK.

In every brook are forces which are constantly changing the face of nature.

the novelty of continually having a new earth with which to work.

2. Things that Abide. - There are invisible things in nature, however, that never change. These invisible changeless things we call forces of nature. The snow falls and warms the soil, and then melts and runs away as water. That is, moisture changes its form; but the invisible forces that formed the snow in the sky, and that caused it to fall and then melt, do not change. They abide, and are always ready to work when eonditions are favorable. The forces of nature are working to-day exactly as they did when the world was young, and they will continue to work forever, as far as human knowledge goes, precisely as we find them working to-day. 


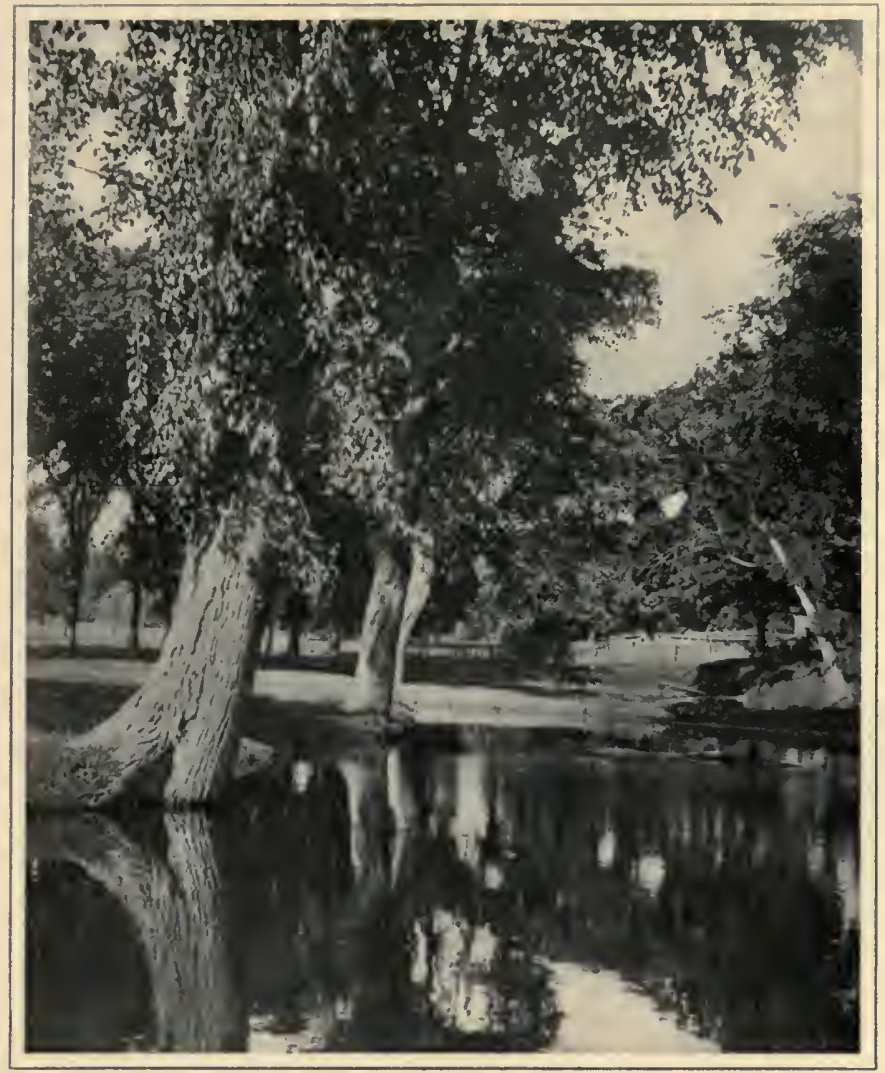

Elms at THE WATER'S BRINK.

The scene changes from day to day, but the forces which make it are eternal.

3. Natural forces at work on the farm are of three kinds, - the physical, the biological, and the chemical forces. a. A dashing rain falls on the corn field. The surface of the soil is thus compacted; its particles are pressed tightly together. The farmer knows that unless this crust is broken up the soil will lose a great deal of water 
by evaporation, and the eorn will suffer on that aecount. This rapid evaporation through a crusted soil is due to a physical force or prineiple (capillary attraction), about which more will be learned in Chapter VII. 'To prevent too rapid a loss of moisture the farmer cultivates, or breaks

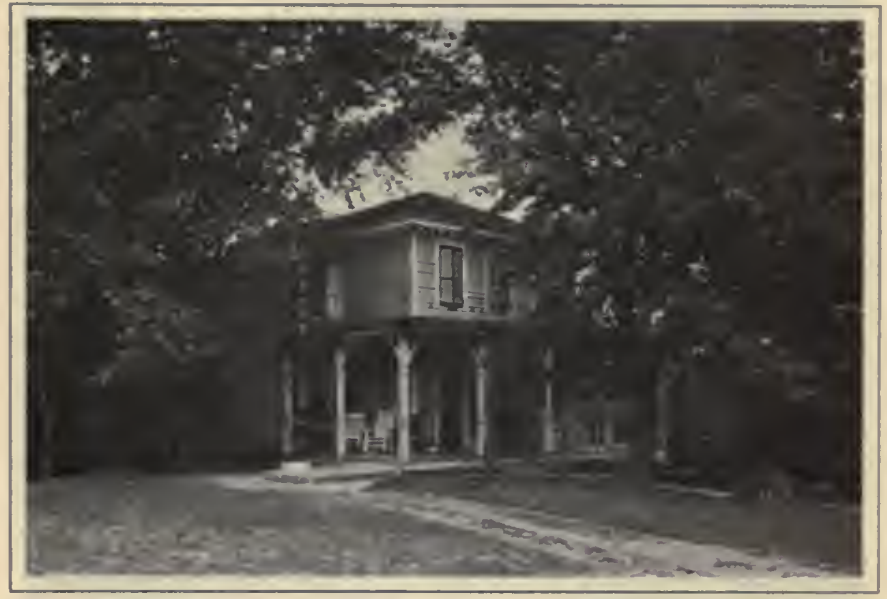

A Pleasant farmhouse.

Nature adds charm to the farmer's home.

up, the crust, beeause this principle acts more slowly in a loose soil.

b. A seed drops into the soil; it seems lifeless. It will remain apparently as lifeless as a pebble unless heat, moisture, and air are applied to it. In the soil, in a good season, it finds these three things, and it sprouts. Sprouting is growth, and growth is a biological principle.

c. A farmer spreads lime on the land; the lime "sweetens" the soil, and thus enables certain plants to thrive better. This work of lime illustrates a chemical principle. We shall explain these principles more in detail in later chapters. 
4. Natural Principles as Tools. - Now the loss of water from the surface of the corn field, the sprouting of the seed, and the action of lime, like all the principles or forces of nature, act continuously and are uniform under the same conditions. Man may interfere with them and prevent their operation here and there by changing the conditions; but he cannot destroy the principles themselves. We can regulate the loss of field water, to a great

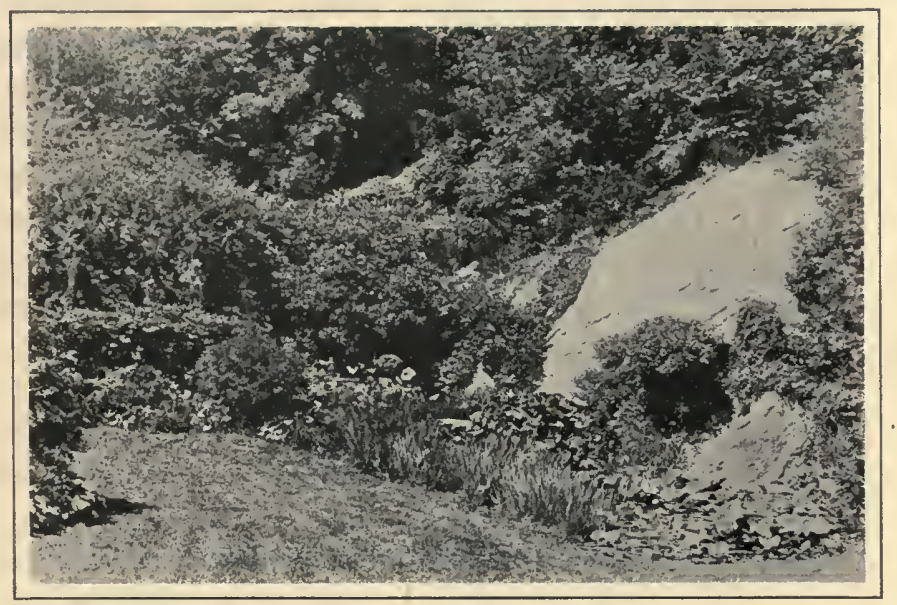

A Quiet Corner of the Farm.

extent, by cultivation and by other means; we can hasten the growth of seeds, by giving careful attention to their needs; and we can modify the action of lime in a field, by growing certain crops: but the principles themselves remain unchanged. Thus we may think of these forces as invisible tools with which the farmer must learn to work. He must learn to regulate the force of evaporation much as he learns to control a plow.

5. The first farmer was the first man who became conscious of the fact that there were plant forms which 
changed from time to time, and that there were forces which eaused these ehanges, but which did not themselves ehange. Then he began to work upon these forms through these forces. Let us say that he noticed a sort

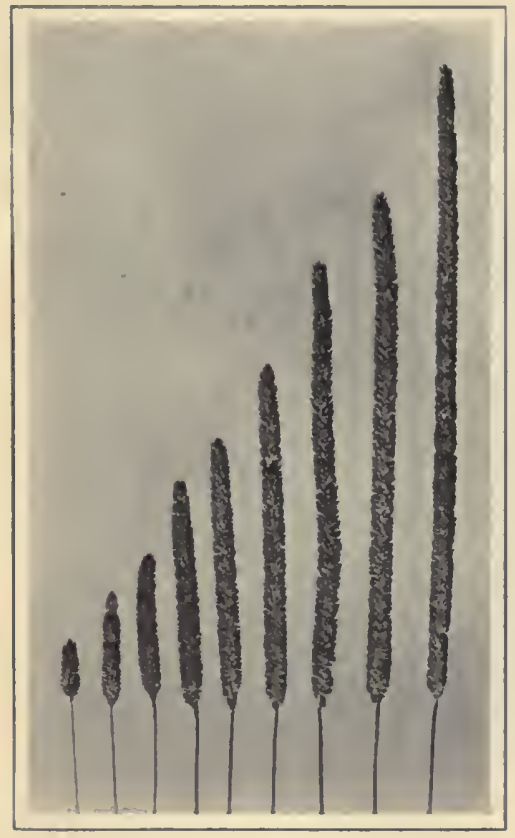

Variation in Timothy Heads.

These heads of timothy all grew in the same square yard. Selecting the best is the first step in improvement. of glass growing in an open space of the forest. We may suppose that this was wheat in its wild state. The man discovered that its seed was good to eat. But the good plant died. The man planted some seeds of it, however, and thus obtained another plant nearly like the first one. Then he planted seeds from the second plant, and from the third, and so on, and always obtained plant after plant that differed little from the first one which he found in the forest.

Thus this first farmer diseovered two things: namely, a form of plant structure which perished, and a force which did not perish. 'The form of the wheat plant he could see, and, in part at least, eould easily understand. But he saw also, dimly, that back of that grass form, and of every form, like a tree or a horse, lies a hidden prineiple of growth that carves out, as it were, the wheat or the tree or the horse 
into its shape. He saw that, because of this force, like produces like, and the new plant resembles the old one from whose seed it springs. This force was invisible. He could not understand it as readily as he could the plant form.

6. Our Trust in Natural Forces. - Only by slow steps have men learned to trust the regular action of these natural forces. There is a force, we have just said, that made the second and third wheat plants resemble the first one. We now call that force by the name heredity, and we are still learning much about its workings. We know surely, however, that, like all the forces of nature, heredity works constantly and uniformly under like conditions. But the first farmers, for thousands of years, thought that it was a goddess, and that it must be worshiped with prayer and sacrifices, or it might cease to work for the good of men.

It was natural for these first farmers to distrust the unseen forces - " the invisible tools" - with which they had to work, and to feel that these forces might stop working at any time as a punishment to men. The strange thing is that in our own day of so much knowledge, some farmers have made scant progress toward a proper outlook on nature. Such men still cling to old superstitions, and are particular to plant seed according to the "signs" of the almanac. Wise men trust to the regularity of natural forces.

7. Why Farmers Have Sought to Improve on Nature. - We know little that is really definite about the farmers of the earliest times. It is quite probable that the first men obtained their food and clothing from wild animals and wild plants. If the streams, hunting grounds, wild cereals, wild fruits, and wild roots had satisfied men's needs, we should not have the modern cattle, fruit, grains, or other good things of the farm of to-day. But the first men 
found it hard to live at all. Especially did many ehildren die from lack of proper food and elothing. To some minds it became a problem to supply the food and elothing needed. The first farmer who stirred a plot of ground with a crooked stick and then sowed there the seed of a wild wheat plant - instead of eating it - made a wonderful advanee. It

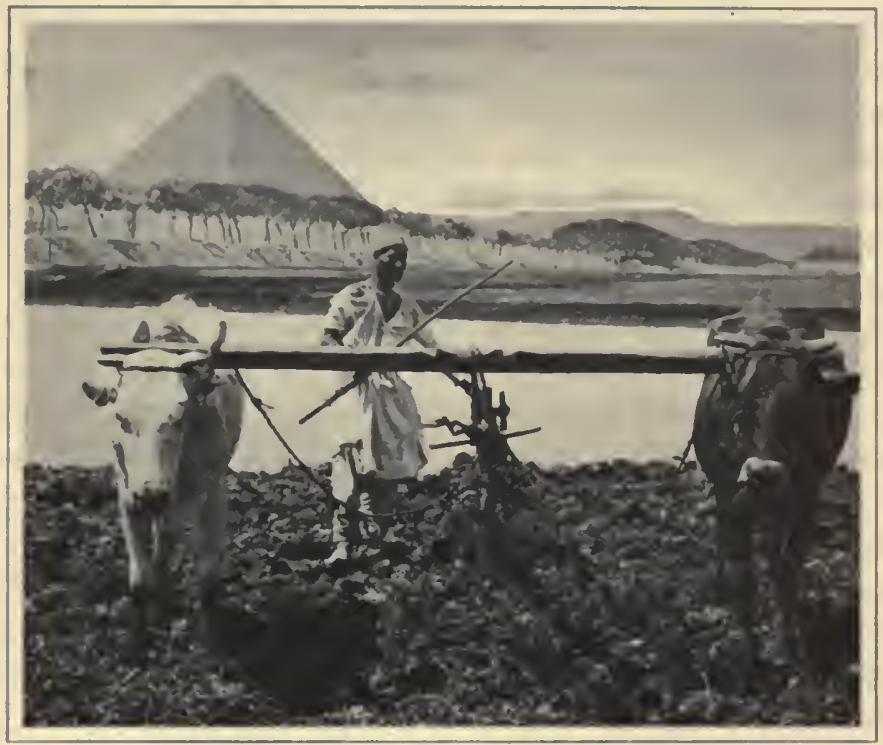

Plowing along the Nile.

Early farmers probably used some such simple tools.

was no longer neeessary to depend wholly on wild crops for food.

It had been noticed that the seeds of certain wild plants were covered with strong fibers, and women had sometimes woven these fibers together for clothing. At last a few of these hairy seeds were planted in a cultivated plot. This was the first cotton field. 
At some later time, a sharp eye noticed that if insects visited the cotton blossom, the seed was improved. Here was a suggestion of another great principle,- the principle of improvement through crosses (Chapter XIII).

So, too, the early horse was weak in body and slow of foot. Because of their needs, the early farmers improved it, as they improved the wild cow and the wild apple and the wild wheat, from a condition of little usefulness to a condition of greater and greater usefulness.

The betterment of plants, animals, and farm machinery rank among the greatest achievements of the human race; but this betterment is the result of human needs. The common things of the modern farm have been the products of yearnings for greater comfort. This aspiration has shown men how to transform the crooked stick with which the first farmer stirred the ground into the spade, the plow, the gang plow, the tractor plow.

In this betterment there have been four distinct stages. First, man used nature as he found her wild. Then he copied nature in her reproduction of like from like, as when he sowed the wheat, hoping ouly to receive a grain like the wild grain. Then he observed how nature sometimes made improvements, and he copied those methods; and finally he experimented to find how to make improvements faster than nature alone could make them. This last step is comparatively modern.

8. Does Everything in Nature Have a Use? - Every object exerts influence on other objects, and we cannot foresee all the consequences from the destruction of apparently useless things. Brook snails used to be thought useless; but now we know that they keep the water sweet by eating the germs in it, and also that they contribute to the plumage of a gorgeous waterfowl that feeds upon them. Throughout nature the lower life contributes to the higher life.

In the present imperfect state of our knowledge we 
ought to be very cautious in deciding that any plant or animal is more harmful than useful. We do feel justified in exterminating such plants as the poison ivy, quack-

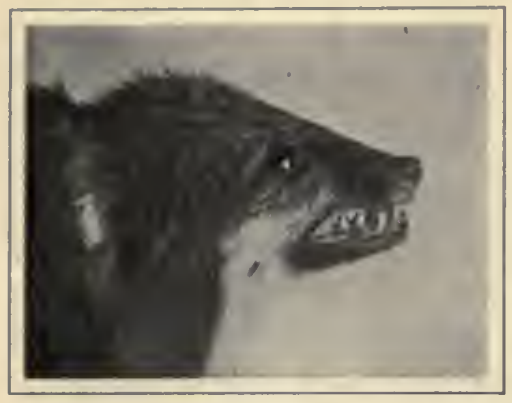

HeAd of Fox.

Foxes serve a useful purpose in cestroying animals, such as rabbits, that bark young trees and eat vegetables. griss, and the Canada thistle, and such animals as wolves, rattlesinakes, and discase-bearing mosquitoes and flies. On the other hand, the farmer is just beginning to recognize some of his best friends in nature.

Many of these friends long escaped notice beeause of their microscopic size. There lives in the soil a low form of life which we call bacteria. These microscopic bacteria enricl the soil by breaking down the complex bodies of larger animals and plants and making them over into plant food. Fertile soil teems with them. The rôle they play has been the subject of inuch recent study. It has been learned, for instance, that alfalfa will not usually grow well in a new district until the right kinds of bacteria lave been placed in the soil. These small agents, our invisible co-

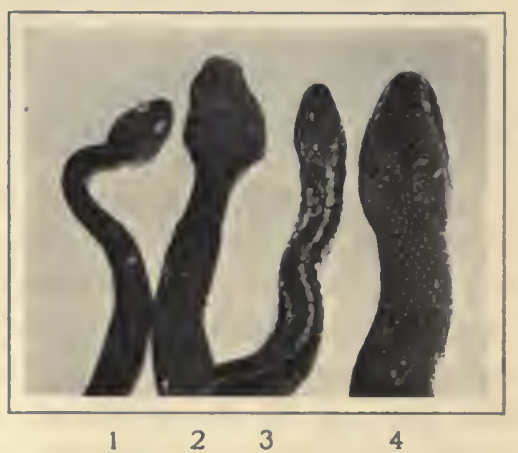

1, Rattlesnake; 2, Copperhead; 3. Garter Snake: 4, Water Snake.

Snakes render important service by destroying vermin, mice, and so on. 
workers, are in large measure responsible for soil fertility, and so for our very lives.

Other allies of man long remained unrecognized, not because they were small, but because no competent scientist had taken the trouble to investigate them. Certain insects belong to this class. 'To it belong also plants and animals of diverse groups. The following is a common example of this. Fastened to the window panes of the house or stable, during the fall, many dead flies may often be noticed. Growing out of each fly there is probably a fluffy growth, - the work of a beneficial fungus. For many years people did not know why flies died in this manner. They did not recognize the agent that kills the flies.

Other pests are often destroyed in some such manner, though no one can yet name the particular agent that wrought the

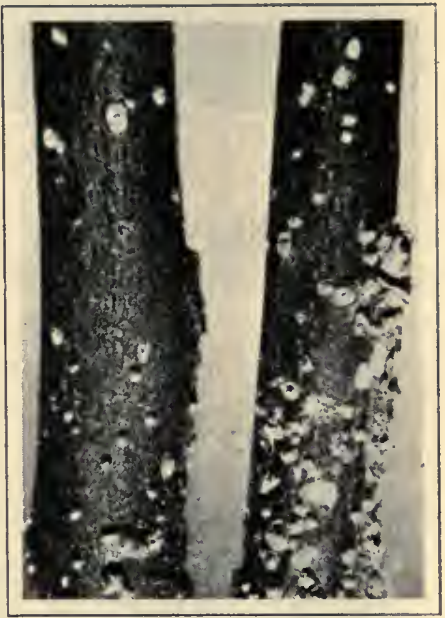

The San José Scale.

This pest has destroyed thousands of orchards. blessing. No doubt, many forms of life now thought useless will be proved to be helpful to man. There are few fields of human life where the highest scientific knowledge can play a more useful part than in agriculture. The best education is not thrown away upon the farmer.

9. Uses of Beauty. - Moreover, it is narrow for the farmer to look upon nature only from the viewpoint of his purse. "Man shall not live by bread alone." We ought to feel that we are made "brothers to the insensible 


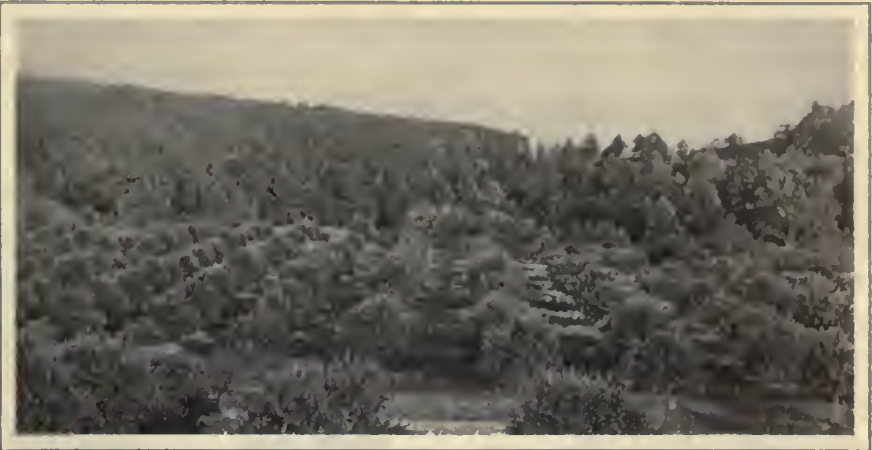

ORCHARD AND FOREST.

clod which the rude swain turns with his share and treads upon." The study of the clod, the star, the wayside flower, enlarges the mind and helps to give us a vision of the vast forces that work harmoniously throughout the universe.

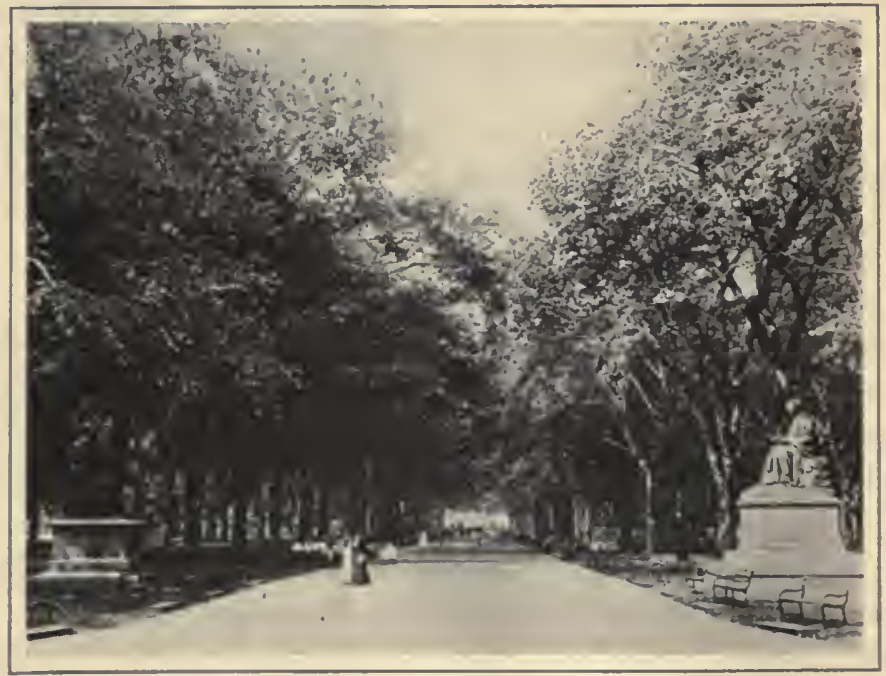

Nature in the City. 
And the farmer is poor indeed if the odor of clay is so fixed in his nostrils as to shut out the fragrance of flowers. The genius of man never invented a moving-picture outfit to show such splendors as may be seen in the glow of the dying day. Or, to take a homely scene, - the cow stands in a brook beneath a spreading tree; beyond stretches a meadow, or a field of corn; at a distance loom the farm buildings. A painting of this scene may bring fame and fortune to the artist. Wandering crowds may gather in a gallery to admire the colored canvas. But the country child may feast his eyes on the real scene the long seasons through. The farmer, in the following poem of Helen Hunt Jackson, would have been the richer if he had lifted his eyes to see what the poet saw :

\section{"Along Ancona's ${ }^{1}$ hills the shimmering heat,}

A tropic tide of air, with ebb and flow,

Bathes all the fields of wheat until they glow

Like seas of green which toss and beat

About the vines. ${ }^{2}$ The poppies, ${ }^{3}$ lithe and fleet,

Seem running, fiery torchmen, to and fro

To mark the shore. The farmer does not know

That they are there. He walks with heavy feet,

Counting the bread and wine of autumn's store;

But I, - I smile to think that days remain,

Perchance, to me, when the bread be sweet no more,

And red wine warm the heart in vain,

I shall be glad, remembering how the fleet

Lithe poppies ran like torchmen through the wheat."

1 Ancona is a beautiful town in Italy on the Adriatic.

2 Grapes and grain are the two prineipal products of the district.

8 The wild European poppy is a tall, wonderfully graceful, deep red, bellshaped flower, growing often in great numbers along the margins of grain fields. 


\section{Pimactical Questions}

1. Name a few changes in nature which you have noticed. 2. How is some farm you know different from what it was a year ago? 3. Name three natural principles with which the farmer inust work. 4. In what way can a form be distinguished from a principle? 5. In what way can a natural principle be spoken of as a farm tool? 6. Why have farmers sought to improve on nature? 7. In what way do wild plants differ from cultivated plants? 8 . Which is the more beautifnl, a good painting of a farm scene or the scene itself? 9. Can you think of anything in nature that is not useful to the farmer?

\section{Howe Fxercises}

1. In beginning the study of Farm Life we shonld recognize "the new earth," or the constant clianges everywhere at work. Let ins study some of these changes by making use of our local history and geograpliy. Ask your father or grandfather to relate how people farmed when he was a boy. Inquire as to what farm improvements were made during the last fifty years. When was the first reaper used in the neighborhood? The first Babcock tester? 'The first creain separator? The first gasolene engine? Inquire into the history of the local wood lots. How long ago were trees growing in fields which are now cleared and cultivated? Do the streams earry as much water as formerly? Are the numbers of horses, cows, sheep, and pigs increasing?

By sending a card to your state capital, much interesting loeal information can be obtained. Perhaps the assessor can also aid you. Get a knowledge of the local farm resources past and present. Write a report on what you have learned.

2. Look for any farm plant, like corn, wheat, potatoes, or onions, that may be found growing wild. Fxamine such plants carefully and tell in what way they differ from like plants properly cared for by man.

\section{SUGGESTIONS}

1. Pupils raised on a farm have usually a considerable body of first-hand knowledge of natural objects. Teachers should not ignore this knowledge, but should correct it and seek to organize it.

2. Agriculture is a stndy in which there must be continually a direct coutact with real and vital things. The teacher will not stop 


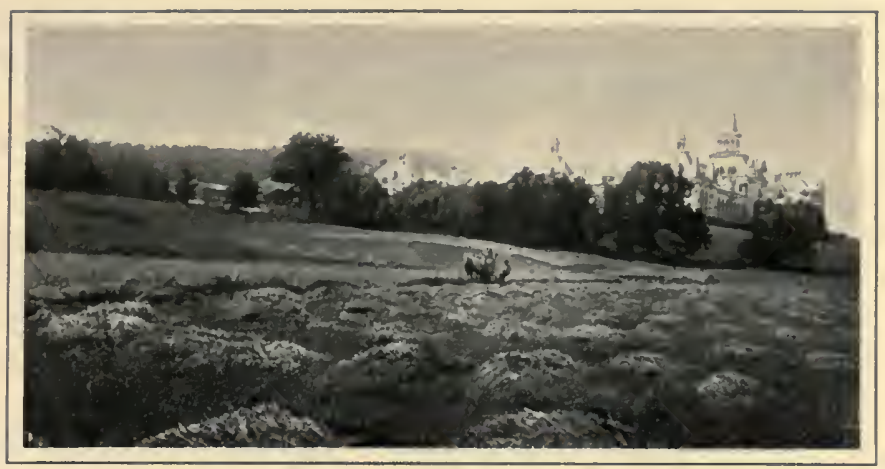

The FARM AND THE MARKeT.

with the book answers to questions, but will assign other questions that can be answered only from material at school or at home. Whenever possible the question should be in the form of a problem requiring practical work before it can be answered.

3. Some member of the class may be given a special topic, such as "the conflict between the farmer and nature." Farmers battling against weeds, pests, floods, droughts, storms, and diseases are suggestive points. The discussion of a topic should be entirely original - the result of direct observation.

4. In order to save time and enable pupils to get the clearest possible ideas on vital problems, it is advisable to correlate related subjects to agriculture. W'e must remember that we are not teaching certain school subjects merely, but are training future citizens: Subject matter organized on a rather artificial basis at best and placed into certain pigeon holes we call textbooks can always be reënforced and made dynamic if approached from several different points of view in the same discussion period: The Agricultural Educational Monthly, published by the United States Department of Agriculture and sent free to all who desire it, has been giving detailed directions on how best to connect with agriculture related school subjects such as history, literature, geography, botany, geology, and chemistry.

\section{REFERENCES}

Handbook of Nature Study. Comstock.

Nature Study and Life. Hodge.

Animals and Man. Kellogg. 


\section{CHAP'TER II}

\section{THE PEOPLE OF THE FARM}

The Country wins me still;

I never framed a wish, or formed a plan

That flattered me with hope of earthly bliss, But there I laid the scene. - CowPER.

10. Why Study about the Farm People. - In the study of agriculture we are especially interested in the people who follow farming as an occupation. The happiness, the well-being, and the mode of living of the people themselves are of more vital concern than the work they do. Better

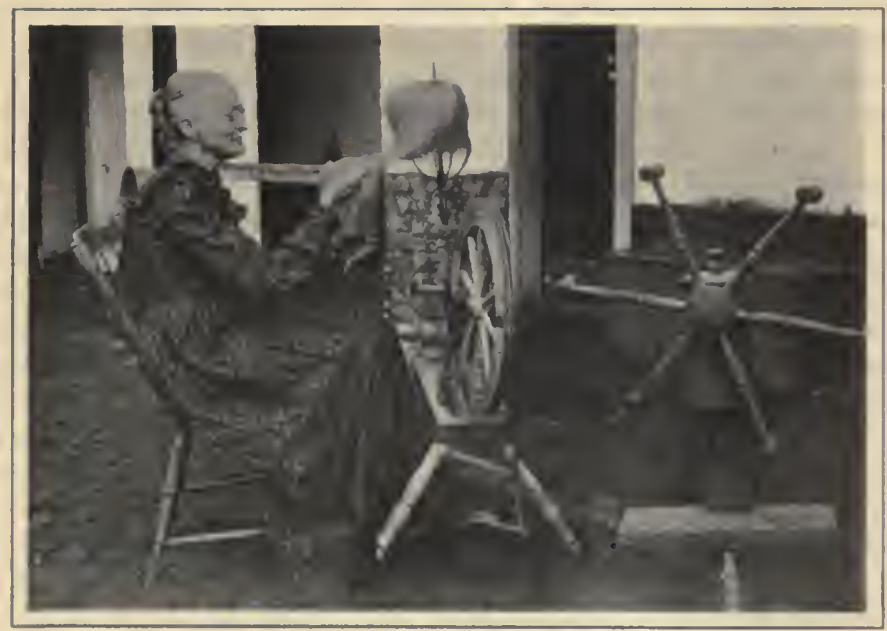

SPINNING FlaX.

Formerly a part of farm work. 
farming is worth while only if it bears fruit in better living. It is needful, therefore, to study farm life and farm business, just as it is needful to study flowers, fruits and farm stočk.

11. Population. - There are more than $100,000,000$ people living in the United States. These people may be divided into two classes, - the city divellers and the country dwellers. Since 1900 the United States Census Bureau regards all districts having a population of $2500 \mathrm{or}$ more as cities. The following table from the Census Reports shows the percentage of our population in country and in city at different periods :

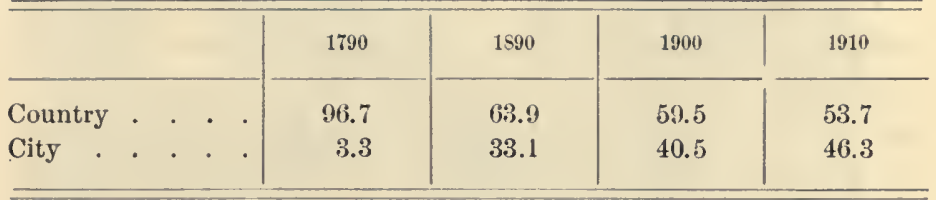

That is, when Washington was President, only one man out of thirty in America lived in town. Twenty-nine out of every thirty lived in the country. To-day the proportions are nearly half and half. ${ }^{1}$ The whole population has grown steadily during this century and a quarter; but plainly the country population and the city population must have grown at different rates. The following table from the Census Reports shoivs these rates:

\begin{tabular}{|c|c|c|c|c|c|}
\hline & $1790-1 S 20$ & $1820-50$ & $1850-80$ & $1850-1900$ & $1900-1910$ \\
\hline & Per Cent & Per Cent & Per Cent & Per Cent & Per Cent \\
\hline Increase in country dwellers & 34.1 & 30.3 & 24.2 & 14.3 & 11.2 \\
\hline Increase in city dwellers & 50.9 & 83.1 & 58.4 & 48.6 & 34.8 \\
\hline
\end{tabular}

1 The Director of the Federal Census Bureau, to whom these figures were submitted for verification, stated to the author that pupils should bear in mind that, were the dividing line between city and country 8,000 as in the 


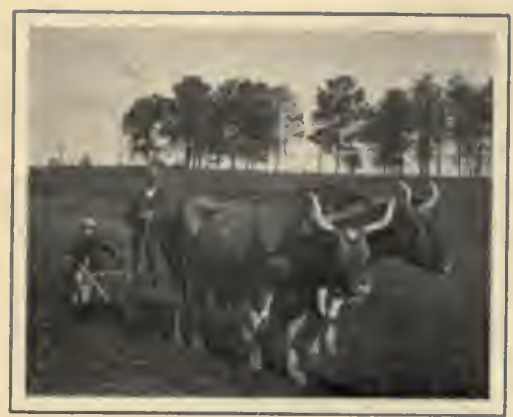

Plowing With Oxen.

Methods of 1860 .

When we became a nation, a rapid city growth was just beginning. 1 Ever since then that growth has been more rapid than the country growth. The rate of country growth, indeed, has decreased steadily from the first, and is now only a third of the rate of eity growth.

All these figures, it must be remembered, are for the nation as a whole. For some districts the facts are quite different. 'Thus, according to the last census rural Vermont showed a $70 s 8$ of 4.2 per eent; Ohio, 1.3 per cent; Indiana, 6.5 per cent; and Iowa, 7.2 per cent. The rural districts of the south Atlantic states, on the other hand, have been growing for the

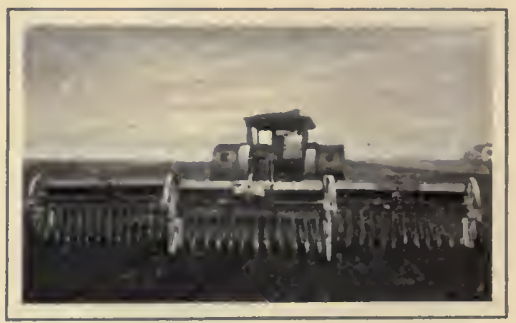

SOWING WITH TRACTOR AND DRILL. Methods of 1916. last century about as rapidly as have their cities, while, in industrial parts of the United States (New England, for

earlier censuses the per cent of rural population at the last decenntal ceusus would be 61.2 per cent of the total population insteal of but 53.7 per cent, as given in the table.

1 In 1790 there were only 6 cities of the United States having a population of 8000 or more; in 1910 there were 778 . In 1790, New York, the largest city, had a population of 49,401 . The figures for 1910 show that the number of residents of New York City iucreased nearly one hundred fold since 1790 , and that there are 101 cities of the United States having a population greater than New York City had in 1790 . 
example), eity increase has been very marked compared with rural increase.

12. There are three kinds of forces that affect the decrease of rural population:

a. The first kind has to do with the invention of new machinery. We are living in what has been called "a machine age." Machine labor is substituted for hand labor whenever the change can be made profitably.

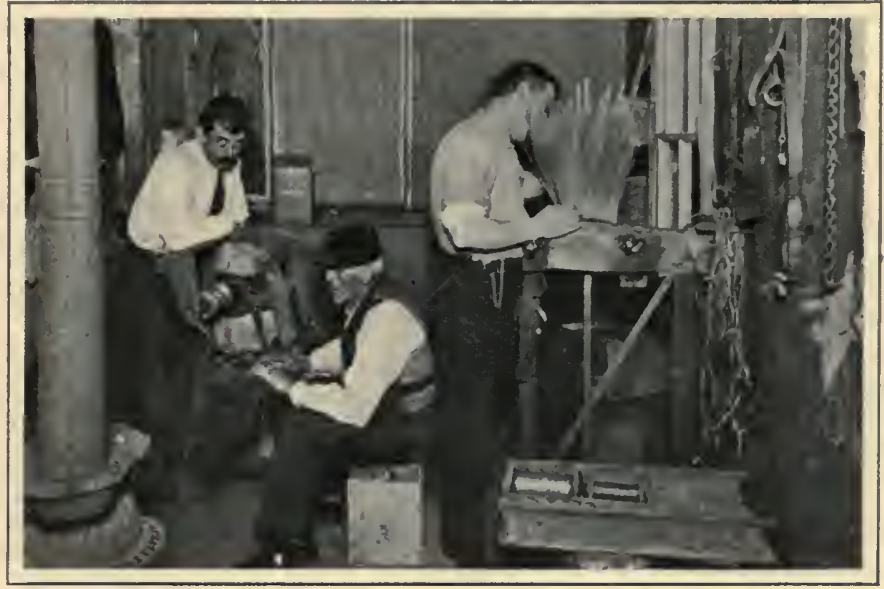

Making Brooms on the Farm.

In 1815 (one hundred years ago) Pennsylvania was already a leading manufacturing state; but its manufactures were still turned out, for the most part, on the farm. In that year, Pennsylvania manufactured only about one million yards of woolen cloth, and more than fifteen sixteenths of this was manufactured in family homes, by hand labor upon spinning wheel, loom and shuttle. These very simple machines were then in use in every farmhouse. Only one sixtecnth of the woolen cloth was manufactured in city factories, by large machinery. That was the "Age 
of Homespun," and the age of independence of rural families. Trade was in its infancy. Each family supplied most of its own needs. To-day (1915) Pennsylvania manufactures about 2000 million yards of cloth, and all of it is turned out from city factories that use costly and complex machinery with little hand labor.

In those early days when nearly all the cloth was woven on the family loom, the sons and daughters of farmers could

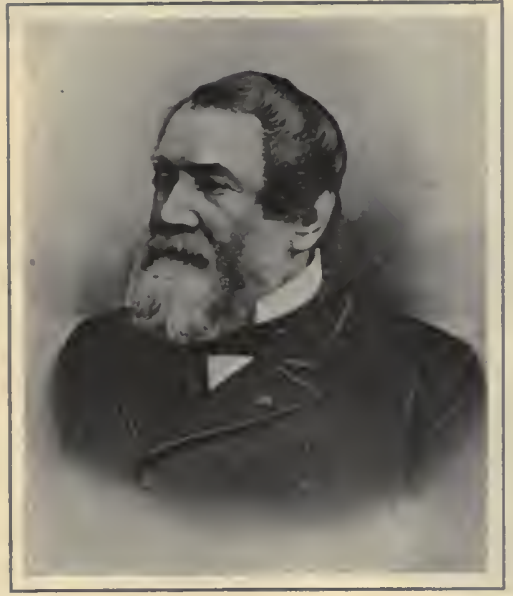

Cyrus H. McCormick. scarcely find work away from home. And, on the other hand, cities could not grow, because, with the simple farm tools of that time, it took many producers of food and clothing to supply one extra consumer.

But machinery increases production; and manufacturing machinery is so costly that the workers must come together to work in factories. From 1820 to

1850 (see table above) the cities of the United States increased 83.1 per cent in population. This was the period of their most rapid growth. This was also the period when machinery first began to be extensively used. Inventions applied to production and transportation were multiplying rapidly. Woolen mills, cotton mills, and furnaces sprang up. The invention of the steam locomotive made it possible to gather the raw materials together and carry them to distant factories. The demand for labor to operate the machinery grew apace. 
Farmers' sons left home to seek employment in the new enterprises.

But even the invention of machinery to work up and refine the raw materials of the farm eheaply and rapidly would not allow men to leave the countryside unless some ways were devised for each farmer to produce more fool than before. Otherwise, these new city laborers would have nothing to live upon. McCormick and others met this difficulty. The reaper of McCormick made it possible

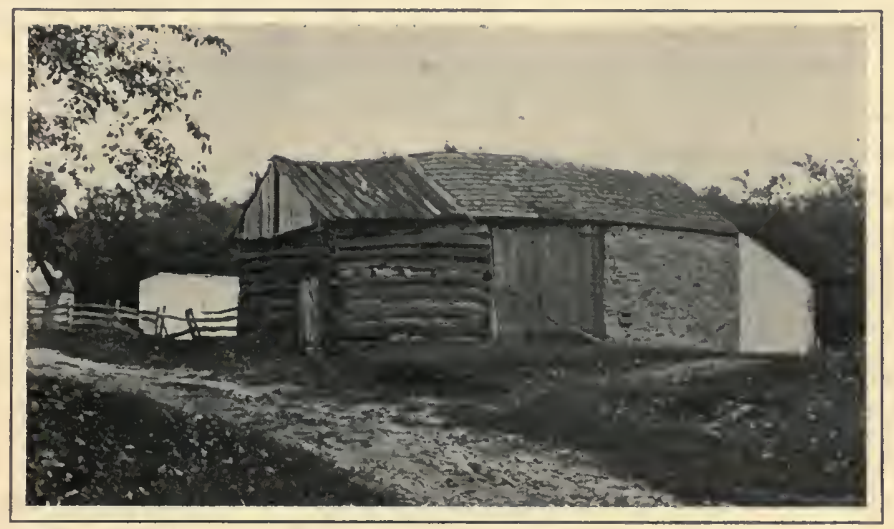

Type of Barn a Century Old.

for one farmer to produce more grain than four or five formerly. In 1845 the farmers produced 4.33 bushels of wheat to every inhabitant of the United States. In 1889, though the farming distriets at this time had lost in population relatively, the farmers produced 10 bushels of wheat to every inhabitant. Machinery, then, in city and in country, is the first important force affecting the growth of rural population.

$b$. The second group of causes for the relative decline in rural population is found in certain peculiarities of 
country life. Some features of farm life have failed to satisfy man's nature. Man is a social animal. He eraves companionship, and is not satisfied with the isolation that has been so marked in the past, and which is yet a characteristic of many farms. Many people, therefore, have left the country for the city for social reasons. The greater business opportunities and educational opportunities of the cities have also influenced a considerable body of country people to move there.

c. The third cause lies in the character of the farmer. Some farmers are not successful in their work. They may not be good farm managers. 'They can succeed best when working under the direction of a foreman. The big enterprises that require many foremen are naturally located in the centers of population. These unsuccessful farmers often move to the city to work under the direction of foremen. Then, too, some eity occupations are very remunerative. Farmers' sons who desire to be engineers, enter a profession, beeome a merchant, or engage in industrial work, find the financial opportunities of the eity attractive.

13. What Does Rural Migration Mean? - We have learned that, considering the entire United States, the rate of growth of the rural communities has been gradually declining for more than a century, but that in certain states the decline is greater than in others, and that especially in the South there has been no deeline at all, but a large increase, in the population of rural districts.

What does all this signify to the American farmer? What does it mean to the mation, to its institutions, to its future?

The trend to the city is found not alone in our country; it is world-wide. It is particularly marked in Europe. It is one of the marks of present-day civilization, and is 
largely the result of the railroad, the reaper, the traction engine, electricity, scientific agriculture, and factory machinery.

There is little in the present trend of rural population to occasion alarm. The cry "Back to the farm," or even "Stay on the farm," indicates an uneasiness for which there is little warrant. Young farmers who show peculiar aptitudes for other occupations can serve their day better by leaving the farm for the eity than by staying at home. Thousands of acres of poor farm land can best

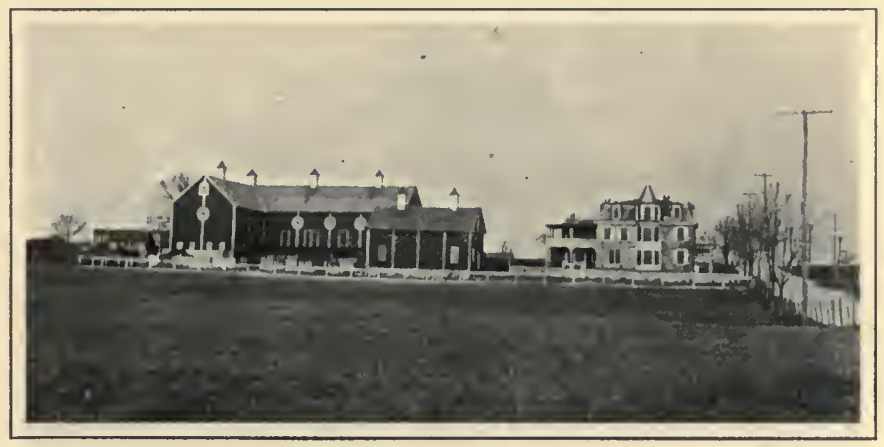

A MOdern Homestead.

be "abandoned." The railroads have made the New York City market more accessible to the Kansas farmer than it was to the Massachusetts farmer a century ago. The difference in freight rates from those two widely separated states to New York City is less than the difference in the cost of producing some farm crops on the hill slopes of Massachusetts and on the Kansas prairies. Farming is a business, and cannot long be run at a loss due to competition with better land, with better machinery, or with better market facilities.

Most farmers are beginning to understand the adapta- 
bility of certain crops to particular soils and special climatic conditions. During the past generations such questions were not carefully considered, and so countless unwise beginnings in farming were made. These attempts are now wisely being given up. Certain old hillside farms, covering in their total area thousands of acres, can be devoted to forestry more profitably than to general

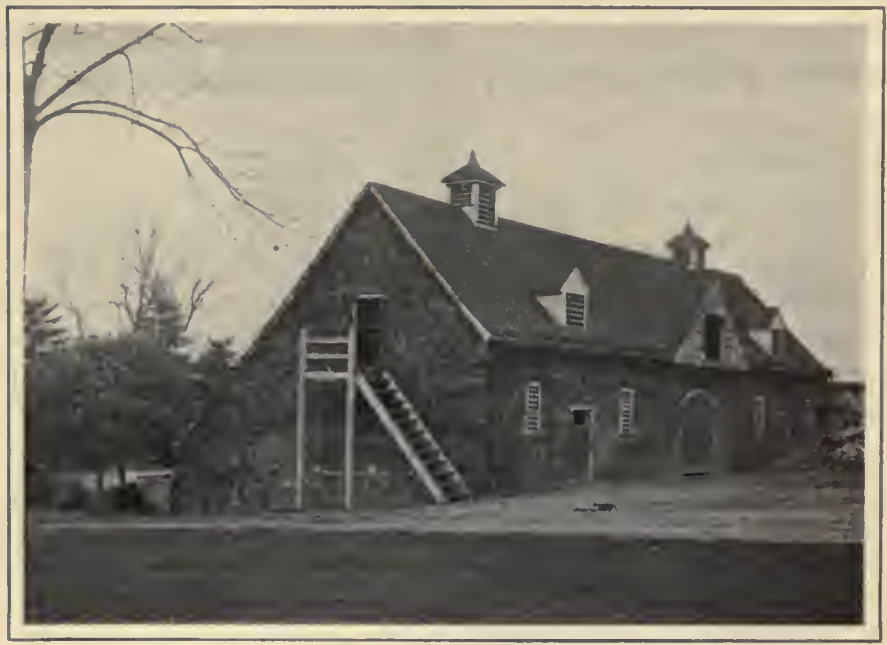

BARN AT MT. VERnON.

Washington was the most scientific farmer of his day.

farming. Such farms are not really being "abandoned"; they are merely being put to a more natural use.

If the South were to stop growing cotton; if the West were to stop growing the sugar beet; were the central states to stop growing corn; - that is, were any great section to fall off seriously in the crops especially adapted to its soil and climate, - then a note of alarm ought to be sounded. But nothing of this sort has taken place. The general result of the forces that are modifying the rate of 
increase of rural population will be a better organization of agricultural work throughout the country, a better adaptation of crops to soils, an increased efficiency, and a higher order of manhood and womanhood on the farm.1

It is true, to be sure, that many individual boys have left the farm for the city when it would have been better for them and for the nation if they had stayed. Some mistakes of this kind will always be made both in country and city. Perhaps they have been particularly common in the country because farm life has often been less attractive than it ought to have been, and far less attractive than it is coming to be under our modern conditions.

\section{Natural Attractiveness of Farm Life: Influence on} Character. - Says Washington Irving: "In rural occupation there is nothing mean and debasing. It leads a man forth among scenes of natural grandeur and beauty; it leaves him to the workings of his own mind, operated upon by the purest and most elevating of external influences. Such a man may be simple and rough, but he cannot be vulgar. The man of refinement therefore finds nothing revolting in an intercourse with the lower orders in rural life, as he does when he casually mingles with the lower orders of cities."

Farming is one of the freest and most independent of callings. The farmer is more or less detached from those influences of society and politics that bend men against their wishes and beliefs. He is the producer of the first necessities of life; and a consciousness of this tends to give him a robust character.

1 "Better let the lands be 'abandoned'; and stay 'abandoned'; better let the forest grow anew and untouched, where the fox may dig his hole unscared and the traveler lose his way in the wilderness, than that New England thought, New England culture, and New England statesmanship be turned over to a peasant class." - BREwkr, The F'arm and Farmer, the Bosis of National Strength. 
15. Influence on Physical Welfare. - Outcloor activities are refreshing, and act as a tonic to the body. 'This is cspecially true of outdoor work in the country. The noise and hurry of the city, and its indoor life, batter down and undermine the nervous system. Cities are learning the need of parks, open-air school buildings, and

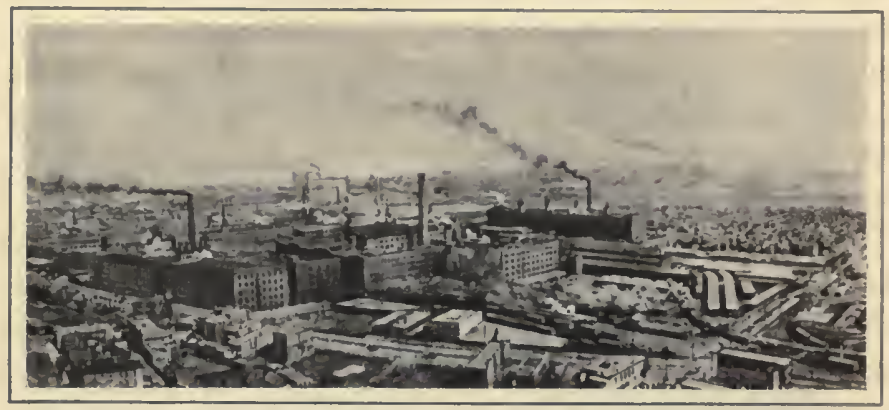

An Industrial Center.

Industrial workers labor under countless disadvantages, when compared with farm workers.

open-air sanatoriums, to enable people broken down in health to get fresh air, quiet, and sunshine to build them up. Farms have in themselves many of the advantages of parks and sanatoriums for maintaining and restoring health.

The superiority of the country in the conditions ${ }^{1}$ of wholesome life is fully proven by figures. The New York State Commission of Lunacy states, in its report for

1 Some diseases, notably typhold, are more prevalent in the country than in the city. There would be even fewer cases of typhoid in the eity were it not for the contaminated milk shipments of certain farmers. The eity boy, too, has generally the advantage of tested water, gymnasiums, swimming pools, dispensaries, hospitals, and other health conveniences. The point is, we must not think of the city-bred boy as necessarily weak and the conntry-bred boy as necessarily strong and healthy. We are speaking of natural as agalnst artificial advantages to physical welfare of city and country. 
1908, that more than three fourtlis of all insane patients in the state hospitals come from the city; and the National Census Report for 1910 gives the following table of average yearly death rates for each thousand of population of the age period indicated:

\begin{tabular}{|c|c|c|c|c|c|c|c|c|c|c|c|}
\hline & & & & $\begin{array}{l}\text { UNDER } \\
1 \text { Y YAR }\end{array}$ & $\begin{array}{l}1-5 \\
\text { YeARS }\end{array}$ & $\begin{array}{c}5-14 \\
\text { YEARS }\end{array}$ & $\begin{array}{c}15-24 \\
\text { YRARS }\end{array}$ & $\begin{array}{l}25-34 \\
\text { YEABS }\end{array}$ & $\begin{array}{l}35-44 \\
\text { YEARS }\end{array}$ & $\begin{array}{l}45-64 \\
\text { ÝEARS }\end{array}$ & $\begin{array}{l}65 \text { AND } \\
\text { OVER }\end{array}$ \\
\hline Cities & . & • & . & 184.7 & 59.7 & 4.3 & 5.9 & 9.1 & 12.1 & 24.3 & 90.9 \\
\hline Country & . & . & . & 117.4 & 34.4 & 3.2 & 5.3 & 6.8 & 8.0 & 15.7 & 76.8 \\
\hline
\end{tabular}

The wholesome nature of country life and of the farmer's work shows also in the figures that deal with moral health. Seven criminals are produced in the city

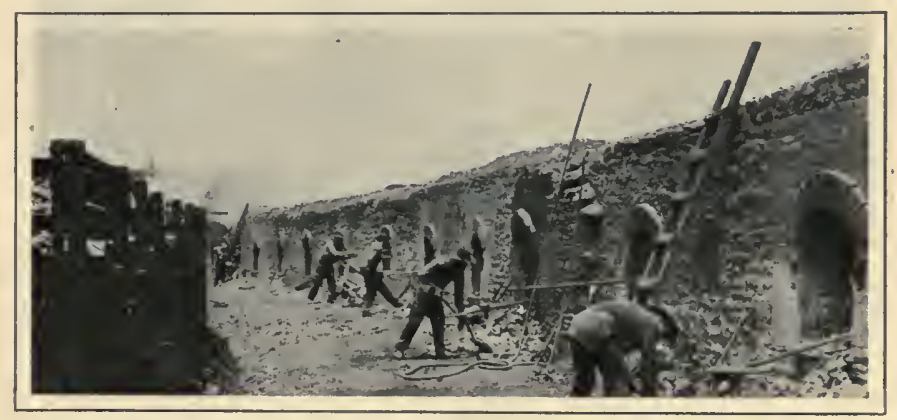

HARD WORK.

Which is more tiresome, shoveling fuel or pitching hay?

to one in the country. All reports upon suicide and upon divorce are alike favorable to the rural districts. And the census shows that less than one fourth the paupers come from country occupations.

16. The Growing Attractiveness of the Farm. - These conditions, just discussed, concerning the farmer's character 
and health, have existed for a long time with little ehange. Now let us note a very great change in another side of his life, $-a$ change that is making the farm more attractive to bright, intelligent boys and girls than ever before in the world.

In the past, farm work has been excessively hard, with a long labor day; and also it has been largely drudgery.

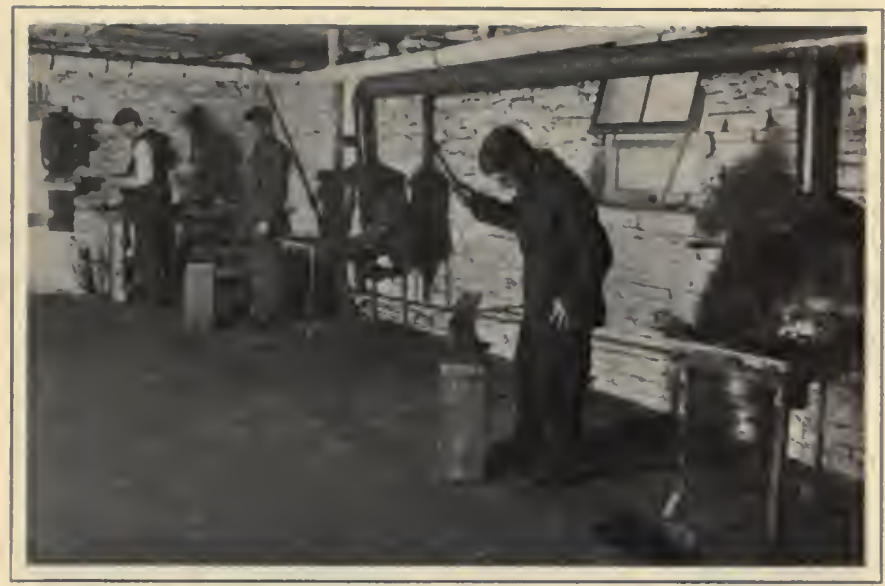

BLACKSMITHING.

Farm boys are now taught repair and construction of machinery.

That is, the work has been, in a large degree, a kind of work in which brains did not play a big part. That means that the work was necessarily uninteresting. Now the work is still hard even on the most progressive farms; and hours are still long; but more and more the farmer is mixing brains with muscle in his work. ${ }^{1}$ The sulky plow, the riding cultivator, the manure spreader, the milking

${ }^{1}$ The movement for the eight-hour day makes more beadway in industrial than in agricultural communities. Recent surveys, however, show that certain city laborers work as many hours as farm laborers. 
machine, the gasolene engine, - these and the many like contrivances on the modern farm not only shorten labor hours and reduce the severity and the more disagreeable features of the work, but also call for more mind, more ingenuity, more skill, than the older tools did.

Important as is this natter of labor-saving and minddeveloping machinery, it is only a small part of the vast change. There is a whole new world of knowledge opening to the twentieth-century farmer. He must "keep up" with these new discoveries in scientific farming, and know how to apply them to his conditions. He must know not only what crops best suit his soil, but also what ones are likely best to suit the market conditions of harvest time. He must know the principles of breeding plants and animals. No education, he finds, is "too good" for his use. More and more he takes on the air of a business man; and his growing prosperity wins him a new respect in the eyes of the world:

\section{Practical Questions}

1. According to the Census Bureau, how many inhabitants must a district have in order to be considered a city? 2. During any period of the last century has the country increased in population as rapidly as the city? 3. What is meant by the phrase "machine age"? 4. How can the machine take the place of a man? 5. In Pennsylvania a century ago was there more woolen cloth made in the large factories or in the homes? 6. What is meant by "The Age of Homespun"? 7. How did the "Age of Homespun " keep people on the farm? 8. How has invention retarded the growth in population of country districts? 9. What has been the main cause for the increase in the production of wheat? 10. What do you understand by the economic side of a farmer's life? The social side? 11. Is an economic force stronger than a social force? 12. Does the country satisfy man's social nature? 13. What is migration? 14. Has the son of a farmer a right to leave the farm to enter a profession? 15. Is it possible for a person who leaves the farm to go elsewhere 
than the city? 16. State three attractive features of farm life. 17. How does the business of farming compare with that of other occupations?

\section{Home Exercises}

1. Report the history of your own near relatives as to their occupation and place of living. If any have moved away from the old homestead, seek the reasons for this fact. Perhaps your parents can give all the desired information; if they cannot, write directly to these relatives about this matter.

2. Estimate the number of men required to do all the work now done by machinery on some farm near you.

3. Count the number of people in your school district. Compare this number with the corresponding number five and ten years ago.

\section{SUGGestioxs}

1. Emphasis should be placed on studying the people of the farm directly. Every community is a center of great interest, and many local facts pertaining to farm life should be gathered and recorded in the schoolroom for future reference.

To make country life better and more satisfying we must first know the facts. A mere statement of these facts is often sufficient to arouse interest in rural betterment.

2. It is not supposed, when the school assumes the position of leadership, that pupils pry into the private affairs of their neighbors. This is not only unnecessary but undesirable. Pupils, howerer, can gather a vast fund of valuable information on local conditions without giving offense to any one.

\section{RFFERENCES}

Constructive Rural Sociology. Gillette.

Rural Economics. Carver.

The Challenge of the Country. Fiske.

Country Life and the Country School. Carney.

Chapters in Rural Progress. Butterfield. 


\section{CHAP'TER III}

\section{OOUNTRY OHILDREN}

Now, while the growing boy's education must not be especially prejudiced in favor of any particular calling, there is no good reason why the farmer's son should not be given the benefit of every possible intimate and wholesome relation to the father's work and business. - McKeEvfr.

17. Farm Children as a Farm Crop. - It is a common saying that the most valuable crop on the farm is the children. Sometimes this saying is taken in a mistaken

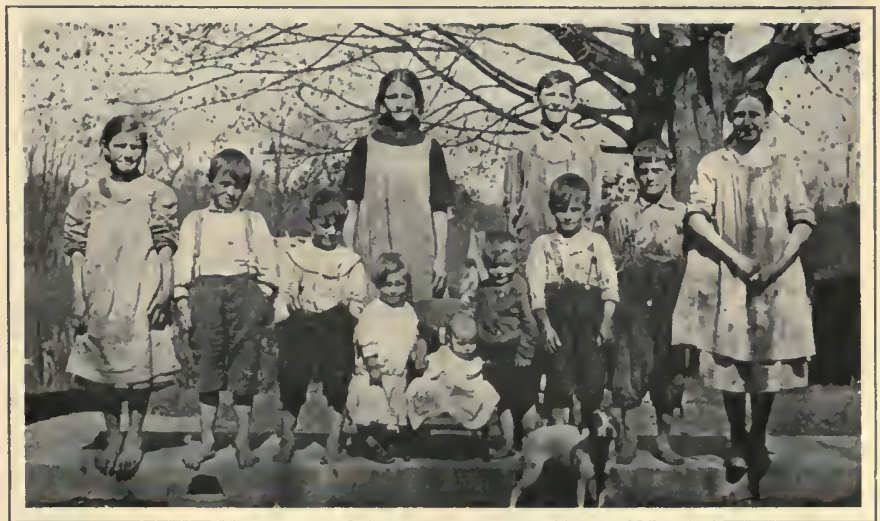

THE BEST FARM CROP.

All members of one farmer's family.

sense. Occasionally a selfish parent thinks of raising children for the profit which he himself can make out of them. 
It is true that nearly every day of the year, and especially during the summer, children of fit age can help in the lighter farm work. In some kinds of work a boy of ten years can do as much as a man. Undoubtedly farm children have more chance to do useful work, and to learn how to work, than city children have. And no doubt there is some temptation to a selfish, short-sighted farmer to

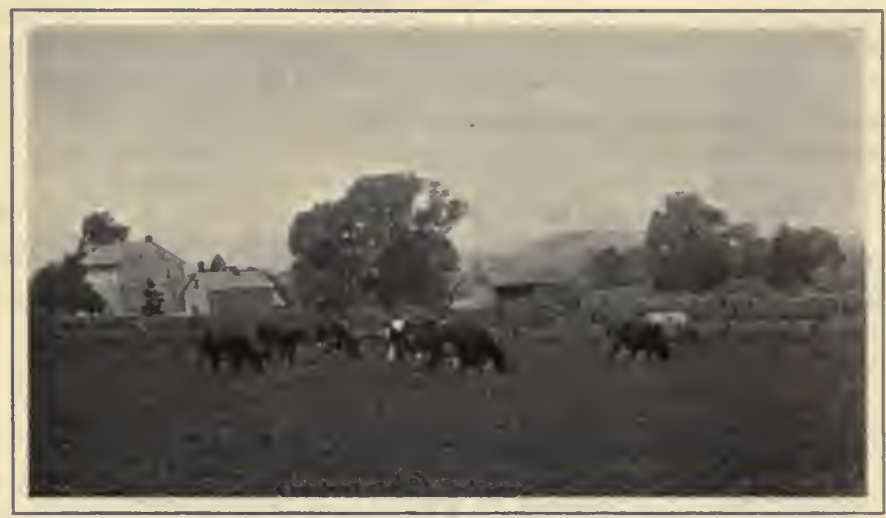

LIGHT WORK FOR CHILDREN.

Watching the cows.

overwork a child, just as there is temptation to overwork a colt.

"But it is not with regard to the work they do on the farm that children are ealled the "most profitable crop." Any child that is properly reared, in city or country, must cost many times more in money than he can possibly repay in labor while a child. To understand this, it is needful only to eonsider the care that a child must have; the oversight essential for his play, his schooling, his work; the large part of his childhood spent in sehool; the cost of his living; the taxes for his school, the money spent for books 
and other pleasures; and the early age at which many children insist on joining the wage-earning class on their own account: When we speak of children as the best farm crop, we are not thinking of their value to their parents in the work they do; we think of their value to the nation as future citizens and workers and men and women. Especially do we think of the better chance for developing a good and useful man or woman out of a country child as compared with the chance for a city child.

18. Country Children and City Children. - Professor Gillette of the University of North Dakota recently investigated the height, the weight, and the head circumference of a number of city and country boys and girls with the following results:

Countrer

\begin{tabular}{|c|c|c|c|c|c|}
\hline$S_{E X}$ & A.,E & NCMBER & IЕIGHT & WFIGIT & Iead Circunference \\
\hline Male . & 12 & 19 & 58.9 & $86.1 \mathrm{lb}$. & 21.34 inches \\
\hline Female. & 12 & 11 & 57.11 & $82.2 \mathrm{lb}$ & 21.34 inches \\
\hline Average & & & 58. & $84.14 \mathrm{lb}$ & 21.34 inches \\
\hline
\end{tabular}

Citr

\begin{tabular}{|c|c|c|c|c|c|}
\hline Sex & $A G E$ & Number & IIEIGHT & WEIGHT & IIfad Circumferexce \\
\hline Male. . & 12 & 20 & 56.5 & $80.7 \mathrm{lb}$. & 21.27 inches \\
\hline Female. & 12 & 20 & 57.77 & $80.47 \mathrm{lb}$. & 20.97 inches \\
\hline Average . & & & 57.14 & $80.58 \mathrm{lb}$. & 21.12 inches \\
\hline
\end{tabular}

It will be noticed, so far as these few individuals can show anything, that the country boy excels the city boy in every point considered, and that his sister falls below the city girl in but one point. These results are interesting; 
but on account of the small number of children studied, they cannot be accepted as fully correct for the average country and city ehild. They agree, in the main, however, with the results secured by the careful observations of other scientists. 'Thus, in his Psychology of the Country Boy, Professor Gold states that "while in the sprints the inability of the country boys to get a quick start acts as a

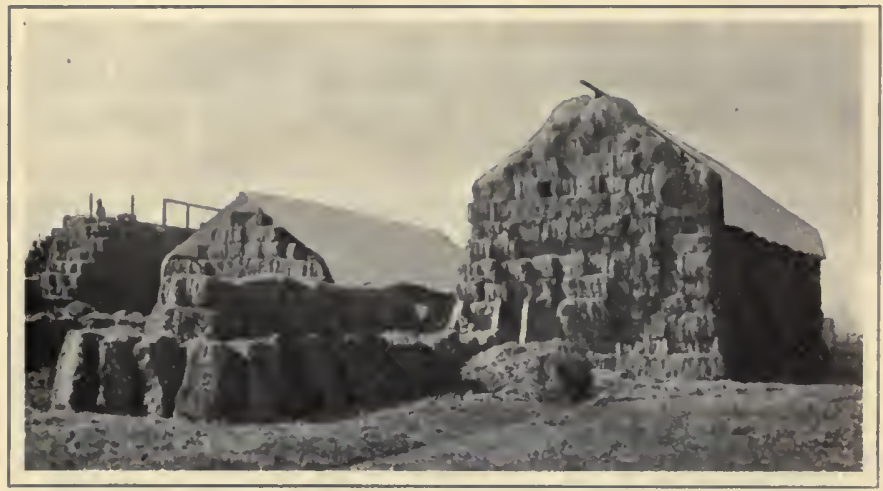

Comparative Values

The boy is a greater asset than the pile of hay on which he stands.

serious handicap, in the longer races they maintain a more regular pace and manifest greater endurance than city boys, even when there is a demand made upon the will to keep up the museles to a last supreme effort."

A very slight investigation will show that most of our presidents, great generals, statesmen, great business men, and famous writers were country-bred. Fiske says in his Challenge of the Country: "Early in the year 1912 some five hundred leading business and professional men of the cities of New York State met at a banquet under the auspices of the Young Men's Christian Association. During the evening it was discovered that nine tenths of 
these influential city leaders had come from country homes. They were born on farms in the open country or in rural villages of 2500 population or less."

From such statements it appears that in spite of the drawbacks of our rural life the farm home is the best place for child rearing. The crude materials for awakening the best efforts of a child are there. The open sky, the singing birds, the bursting buds, the babbling brook, are con-

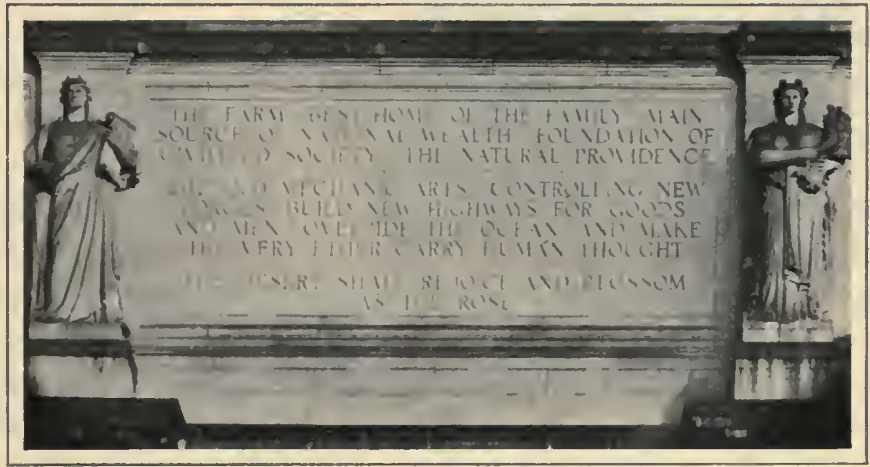

Tablet at Union Station, Washington.

stantly making an appeal for a wide outlook on nature. The many-sidedness of farm activities - plowing, dairying, harvesting, threshing, and marketing - form an ideal combination. The farm boy has opportunity - denied to his city cousin - to develop quiet resolution, thoughtfulness, and love of nature. With good reason, over the entrance to the great Union Station at Washington there has been carved the following inscription:

THF FARM: BEST HOME OF THE FAMILY: MAIN SOURCE OF NATIONAL WEALTH: FOUNDATION OF CIVILIZED SOCIETY: THE NATURAL PROVIDENCE. 
19. Drawbacks in the Farm as a Nursery. - An oak tree growing alone spreads out and forms many thick limbs. The growth that went into the limbs would have been more useful had it gone into the main trunk. It would have then formed a long, tapering body, yielding little waste in lumbering. Forest trees growing together produce this desired form. Like the solitary oak, ehildren brought up on a farm, away from the touch of close neighbor's, are in danger of developing characteristics, like side branches, that impair their usefulness.

Isolation or separation from other people is a weakness of our rural life. The country is too often a mere collection of homes, rather than an association, or a community, of homes. Alone with nature, young people tend to become selfish and do not learn to coöperate. They receive little practical training in service to any outside the home. The little farm on which they were born and reared assumes too great an importance when compared with the rest of the world. The church and the sehool, - agencies that should train for rural service, - are frequently poorly adapted for effective work.

Farm crops often suffer from a bad environment and heredity. The climate may be too cold or too hot, too wet or too dry. 'The soil may be too rich or too poor. Diseases may appear. The seed may have been weak or diseased. All such conditions interfere with the best growth of the farm crops.

In the farm home, in like manner, children may be exposed to too high a temperature or to impure air. Their food may be too rieh or too poor. Eye strains, ear defects, and other general physical weaknesses may go uncorreeted. Parents may transmit tendencies to physical and moral weaknesses, thus giving their children poor bodies and minds. Little or no opportunity to develop the sense of 
ownership may be provided. No pets may be present in the home to stir up a feeling of companionship in the children. In many ways, on account of a weak heredity and a poor environment, the rural home may fail in securing the best conditions for child rearing. Probably more effort is now given to meet such needs in the average city home than in the average country home.

\section{There Should Be More Attention to the Health of Country Chil- dren. - To prevent dis- ease is to save money -} to say nothing of more important things. Costs

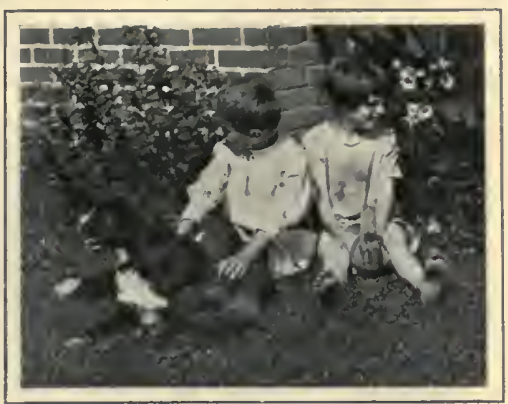

FARM PETS. come out of the same income, whether they are due to diseases of plants, of animals, or of children. It is as expensive to have to call in the doctor as the veterinarian. The farmer is obliged to raise more bushels of grain to the acre to keep up the regular income if he has also to pay doctor's bills. In school, in some measure, children are taught about the parts of their bodies, and how the body should be cared for, just as they are taught to care for dumb animals, but much more such education is needed.

Animals cannot do their best work when they do not feel well; nor can children. True, country boys may follow the plow for an entire day, swallow their meals, bathe infrequently, neglect to clean the teeth, or to change their clothing if wet, and sleep at night in a closed bedroom, and not know of any ill effects for years. This is because nature has been kind to them in giving them strong bodies, and because these evil habits are partly counteracted by 
the good side of their outdoor life. Still the results of such physical abuse will show themselves sooner or later. And poor health in child or man means less work and less pleasure, an added expense to the home.

21. Play. - Froebel, one of the world's most famous teachers, says, "A man is a whole man only when he plays." Play to the child is the same as sunshine to a stalk of corn. The child may grow without play just as

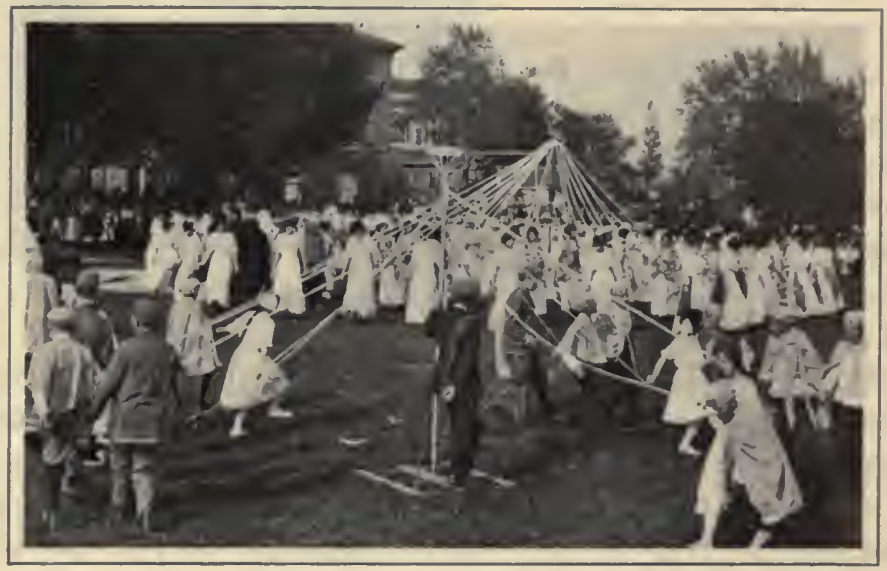

Organized Play.

the corn may grow without sunshine, but neither can grow very well. As a boy plays with his dog, he is training himself in the most practical fashion to work with the animal forces in later life. 'The doll is a means of teaching the girl to direct the affairs of her future home. And organized play is useful as a preparation for community service and for better coöperation in farm activities. Farmers who do not make provision for neighborhood contests and plays, either at the school or at some other community center, are not doing all that is best for the children. 
Professor McKeever says that rural play affords: (1) better physical health and increased power to resist disease; (2) enlarged opportunities for the outlct of free activities through the use of the hands and other parts of the body; (3) provisions against evil thoughts and deeds; (4) opportunities for getting along with one's' fellows and for learning to treat them with fairness and justice.

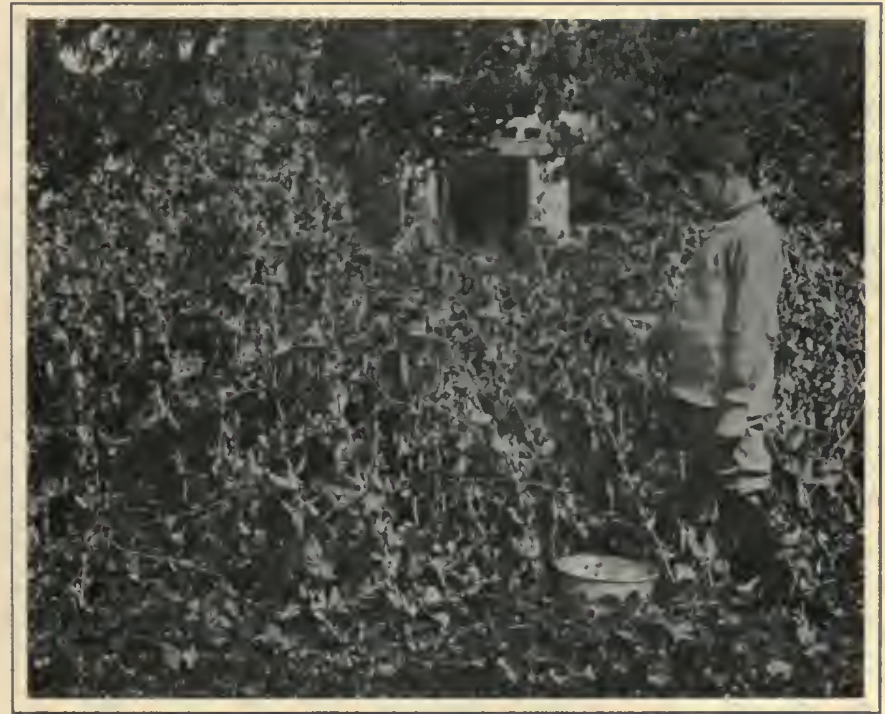

HOME WORK.

Boy gathering the peas he has planted and tended.

22. Work. - Definite tasks must be assigned the older children. And in no other occupation can children of all ages receive such a stimulating uplift from a variety of tasks as may be given on the farm. It is, however, just as harmful for children to work too much as too little. It is as bad to toil at tasks beyond their years as it is to loaf. 
In an increasing number of distriets, school credit is being allowed for home work. A boy who raises a hog, swats a fly, or produces a pint of pure milk to feed a sickly child is performing a patriotic service for his country. He becomes an honorable part of the great army that is doing the world's work. He is contributing something valuable to our common life. Sooner or later teachers will come to recognize such activities in grading their pupils.

23. Books. - Unlike most farm erops, a child matures slowly. The long period of infancy, childhood, and youth greatly extends his opportunities for mind growth. And during these years, if he has not formed the habit of loafing at questionable places, and if a fondness for good reading has been awakened in school, he can greatly enrich his mind from the treasures of literature.

Books are very valuable and very cheap. A farmer needs a seleeted library, - not only such books as pertain to agriculture and rural life, but also juvenile books, books of travel, history, fiction, poetry, and science. If he is a lover of good books himself, he most naturally will awaken a desire for good reading in his children. Thus he may multiply the pleasures and profits of farm work, and create a dislike for the low things of life.

24. Boy Scouts and Camp Fire Girls. - The rural movements, under the names of Boy Scouts and Camp Fire Girls, seek to develop the spirit of sympathetic fellowship, and to acquaint their members with a first-hand knowledge of nature about them. For the Boy Scouts the motto is "Know the seerets of the open country." Among their first duties are the following :

1. Know by sight and call ten common birds.

2. Know by sight and track ten wild animals.

3. Know by sight five common game fish. 
4. Know in the ficlds ten wild flowers.

5. Know the sixteen points of the compass.

6. Know the elementary rules for the prevention of typhoid fever.

7. Plant and cultivate, according to the latest scientific methods, not less than one half acre of some farm or garden crop.

8. Own and care for, according to latest scientific methods, some type of pure-bred domestic animal.

9. Maintain a bank account of not less than $\$ 15$.

10. Know the elementary rules for the prevention of tuberculosis.

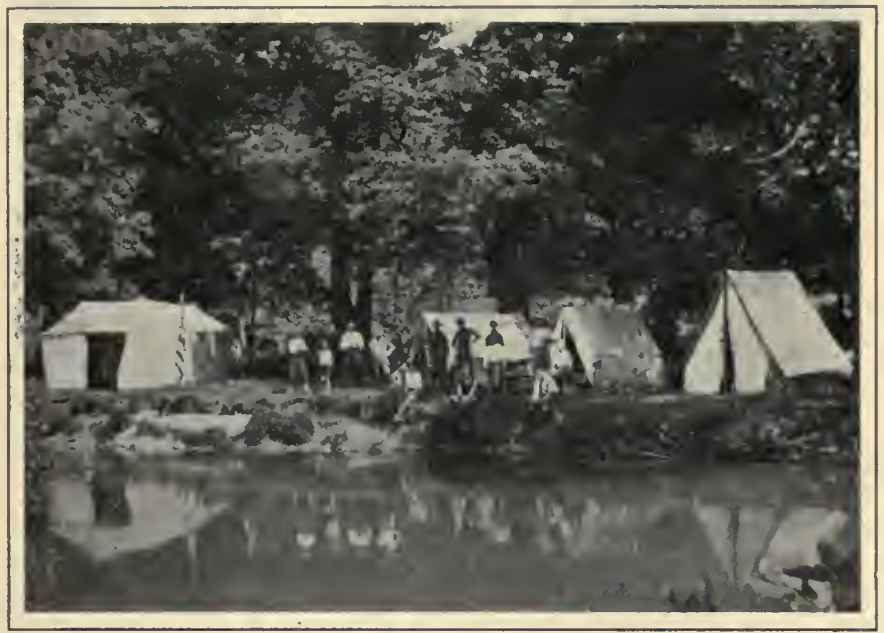

Boy Scouts at Camp.

Social "hikes" are taken, and promotions are made from the third to the first class. The duties in the advanced classes become more extended than those named above.

25. The Creed of the Country Boy. - "I believe that the country which God made is more beautiful than the city which man made; that life out-of-doors and in touch with the earth is the natural life of man. I believe that work is work wherever we find it, but that work with nature is 
more inspiring than work with the most delicate machinery. I believe that the dignity of labor depends not on what you do, but on how you do it; that opportunity comes to the boy on the farm as often as to a boy in the city; that life is larger and freer and happier on the farm than in the town; that my success depends not upon $\mathrm{my}$ location, but upon myself, - not upon my dreams, but

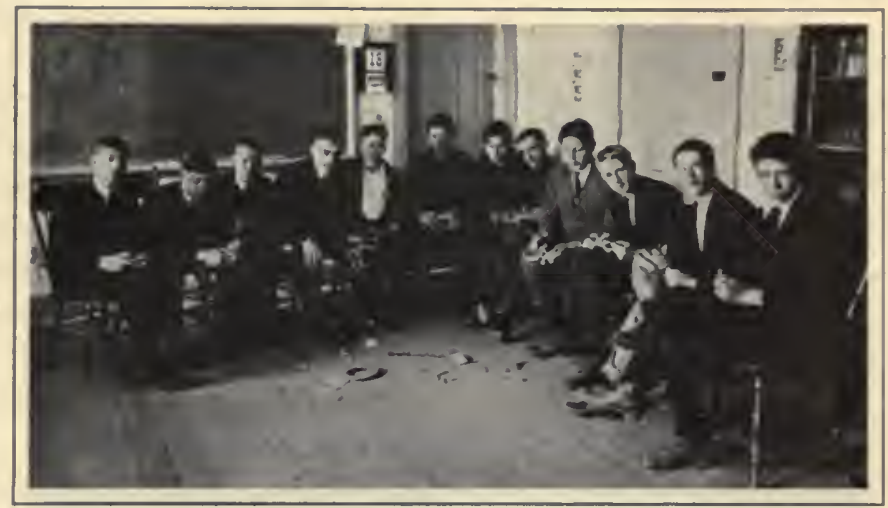

Rope Splicing.

Practical work for the country boy.

upon what I actually do, — not upon luck but upon pluck. I believe in working when you work, and in playing when you play, and in giving and demanding a square deal in every act of life." - EDward Osgood Grover.

\section{Practical Questions.}

1. How can farm children aid their parents? 2. How do country and city children compare? 3. In a race, why should not the country boy start as quickly as the city boy? 4. What Presidents of the United States came from the country? 5. Name some writers that were country-bred. 6. What side of country life appeals most to you? 7. How may children suffer from the effects of bad environment? 8. Give an experience with your dog. 9. Cau 
a dog reason? 10. Which position do you like best on the ball team? Why? 11. Do children like to work for their parents at home? 12. Which job on the farm do you like best? 13. Which least? 14. Do you belong to the Boy Scouts' or Camp Fire Girls' organization? 15. Do these organizations make better rural citizens? 16. Can you accept the "Creed of the Country Boy"?

\section{Home Exercises}

1. Organize a ball team among the farm boys and send a challenge to a suitable team near by. Work up enthusiasm for clean rural sports during the long summer months. If possible, organize township leagues. Sympathetic coöperation is what is needed.

Organize teams for different varieties of contests among the girls also. Advertise all contests widely. See that the older folks come out on a Saturday afternoon. They, too, need recreation.

2. Make a list of the books, periodicals, papers, pictures, and musical instruments you have at home. Read at least one book a month, and tell the story of what you have read to your class.

3. How many dollars did your father lose this last year through avoidable sickness in the family?

\section{Sugglistions}

1. The bringing-up of the right type of children that are content to stay on the farm, if they can be of greater service there, is as much a problem of agriculture as is soil fertility. The pupils should make a list of all the features of the farm environment that have most helped thein to grow physically, morally, and spiritually. As an illustration we present herewith a list of country-life pictures that are exerting an uplifting influence on the moral side.

Millet

The Gleaners

Angelus

Feeding Her Birds

Rosa Bonheur

Oxen Plowing

A Norman Sire

Weaning Calves

The Horse Fair

A Humble Servant
Dupré

Escaped Cow

The Hay Makers

Milking Time

Le Rolle

By the River

The Shepherdess 


\author{
Ruysdael \\ Landscape with Windmill \\ The Coming Storm
}

\author{
Constable \\ The Cornfield \\ Valley Farm
}

2. Those chapters of physiology that treat of alcohol and of the cigarette habit can be correlated with the ideas set forth in this chapter. The child may be shown that, even if he be viewed only as plants are viewed, all those agencies that retard his growth interfere with agricultural prosperity.

\section{REFERENCES}

Farm Boys and Girls. McKeever.

Rural Hygiene. Brewer.

Chapters in Rural Progress. Butterfield.

Constructive Rural Sociology. Gillette.

Play and Recreation. Curtis.

Country Life and the Country School. Carney.

The Challenge of the Country. Fiske. 


\section{CHAP'TER IV}

\section{THE AFFAIRS OF THE FARM}

The farm is out of doors. It has relations with everything out of doors, -with the wild animals as well as the rest. This general relationship has been little appreciated in a conscious way, and the result is the farming business has not yet been closely adapted to its environment. - BaILEY.

$I$ know of no pursuit in which more real and important service can be rendered to any country than by improving its agriculture and its breed of useful animals. - Groror W Asmiston.

26. A Larger Farm Life. - Farming has to do with making a living out of the land; but, still more, it has to clo with the farmer's life itself. The smith does not live in his shop, but goes home when the day's work is done. So do the merchant and the miner. But the farmer lives on his land as well as from it. The farm is his place of business, and also it is his home. Whatever concerns it affects not merely his wealth but also his welfare. Health, school, coöperation, community spirit, and all the agencies that uplift farm life and give it a wider outlook are vital affairs of the farm.

27. Health. - Filth, flies, and fever are a combination of vital concern to the farmer. If the filth, which includes refuse of almost any kind likely to be exposed around dwellings, is destroyed or made inoffensive, the flies and the fever need lesis attention. Without filth, flies will not breed. With filth, health is always endangered. So long as the house fly was regarded merely as an intruder in the 
household its presence was only annoying; but now when we know that it spreads the germs of typhoid, tubereulosis, and cholera among human beings, and of anthrax among eattle, it must be regarded as a menace.

Franklin said, "A people's health is a nation's wealth." Any condition that undermines health, whether it be the

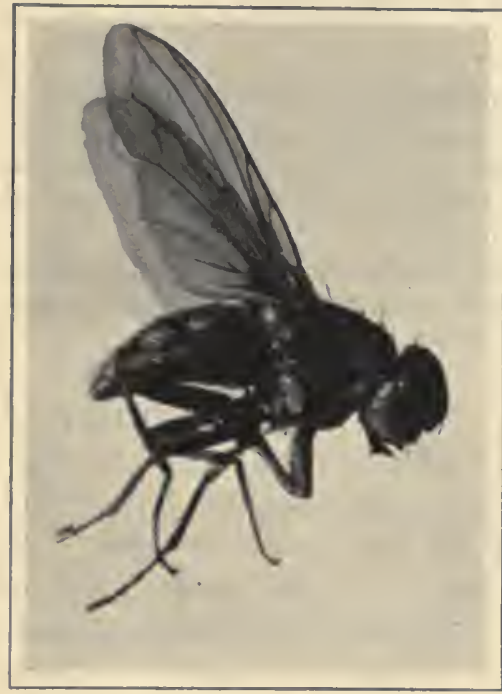

THE TYPHOID CARRIER.

The hairs on legs and body of the housefly carry disease germs. presence of flies, a lack of cleanliness or of suitable clothing, or the practice of wrong habits of living, limits happiness and impairs sueeess. Good farming requires health and cheerfulness. It is even more important for the farmer to keep himself and his family well and strong than to protect his crops and stock from pests and diseases.

28. Schools. - The rural schools cost, on an average, \$12.52 a year per pupil. The money spent in the city for the same purpose is $\$ 30.78$. His investment for schools is the best the farmer can make. His sehool taxes bring more good than the same money spent in any other way. In a free government, edueation should reach all. Children need trained minds whether they are to become lawyers, mechanies, engineers, or farmers. In the country not only such branches as arithmetic, history, and geography should be studied, but agriculture as well. Ninety per cent of 
the young people in our schools will remain in the community in which they were born and reared, and it is their duty and their right to become acquainted in school with some of the affairs of their mature life.

Our government and agricultural colleges are willing to send, for the most part free of charge, attractive and helpful bulletins that will explain in detail every difficult farm operation. Children in the country should learn to profit by the ideas found in these bulletins. Men study agriculture, ${ }^{1}$ just as they study law or medicine, and farmers need a special education in their walk of life to be entirely successful.

\section{Coöperation among} Farmers. - About half the farmers of the United States belong to coöper-

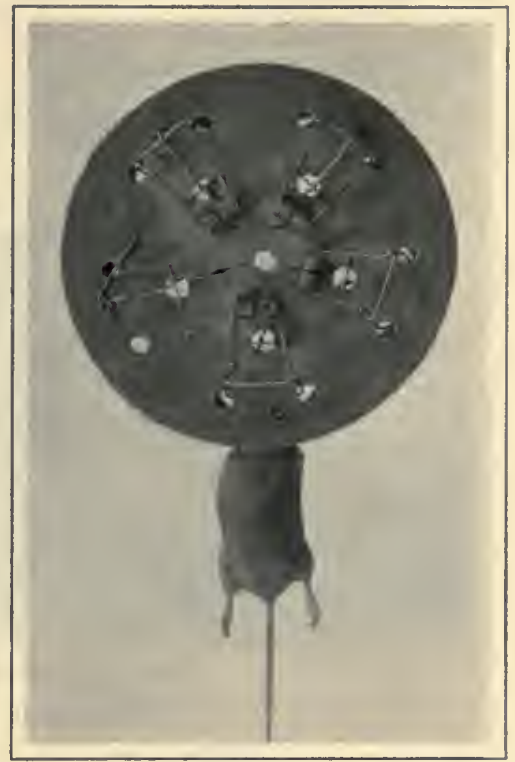

CAUGht!

Mice and rats are common carriers of disease germs.

ative societies. These societies operate irrigation plants, insurance companies, telephones, creameries, laundries, cheese factories, grain elevators, farmers' banks, and so

1 The farm management department of Cornell University gathered data recently relative to the labor income of more than thirteen hundred New York farmers. The University found that the labor income of the farmers who had completed the eighth grade only was $\$ 318$ per year; of those with a high school training was $\$ 622$ per year; while the farmers with a college course received $\$ 847$ per year. The investigation made by the United 
on. Farming is a business, and it must be based on business principles. By collective buying, the price of reapers has been reduced from $\$ 275$ to $\$ 175$; of threshers from $\$ 300$ to $\$ 200$; of wagons from $\$ 150$ to $\$ 90$. It has been estimated by Professor Valgren that the Mutual

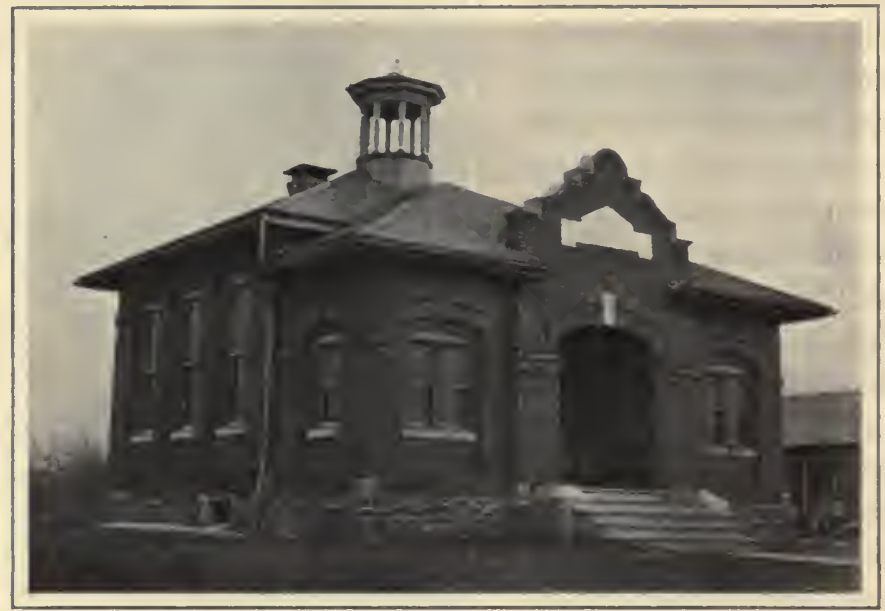

The COUntRY SchOOL.

A farm institution.

Fire Insurance companies save the farmers of Minnesota annually $\$ 750,000$.

The farmers of Denmark, however, for the last half century have best shown the advantages of working together. In 1864, after a ruinous war, with depleted soil fertility and with scant funds, the Danes started many

States Department of Agriculture of the labor income of two hundred seventyfour tenant farmers of Indiana is likewise very favorable to the work of the schools. The Department discovered that the farmers with a common school education made $\$ 742$ annually; with a high school training $\$ 1268$ annually; while the college trained tenant farmer was having a ycarly income of $\$ 1721$. These facts indicate strongly that it pays prospective farmers to prolong their schooling, even when one considers education as a financial investment merely. 
coöperative enterprises. At the present time they are the richest farming class in Europe in per capita wealth. Sir Horace Plunkett, a celebrated economist, states that coöperation made this wealth possible.

30. Community Spirit. - No farmer can realize the fruits of his best efforts without the friendly assistance of all good citizens of the community. If one spends his entire time working for himself, his life soon becomes dull. There are many social duties and social opportunities for country

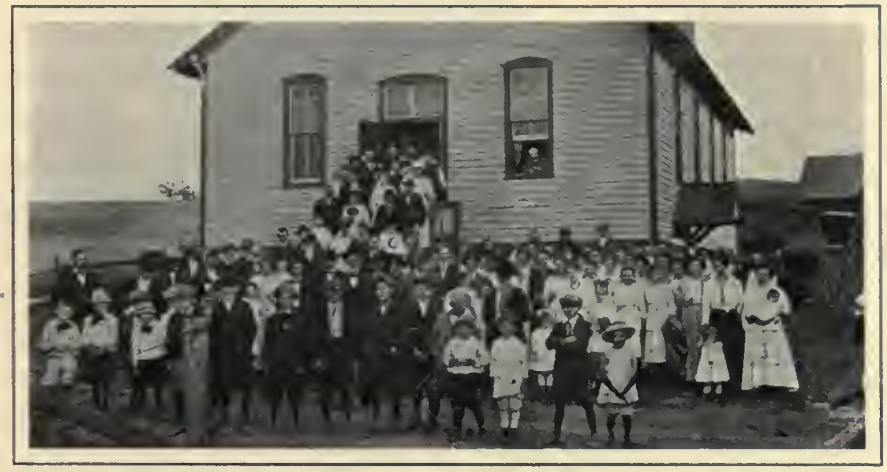

CoOperation of Farmers.

Grange meeting at a "rural center."

people. Granges, coöperative societies, rural betterment leagues, educational agencies, schools, churches, are fields in which farmers can profitably take an interest. The ideal farmer is one who not only does his own work well, and is neat and prosperous, but who also takes a lively interest in all forms of rural activities that promote the general wealth and welfare of the community. The farmer's happiness as well as his profits arise from being a part of a neighborhood instead of being merely a resident in it.

We naturally expect a community consciousness to be more highly developed in the centers of population where 
individuals are thrown closely together in their habits of living. Quite as naturally do we look for collective action in most of the rural districts of Europe, for the reason that the farms there are much smaller in size than the average of America, thus bringing the rural workers together more directly. Our broad acres, without the best means of communication and travel, do not lend themselves so readily to community planning.

One of the best means of fostering early in life a feeling that should later ripen into a wholesome coöperation is group contests. When a pupil raises a pateh of corn in competition with many others, he is receiving, no doubt, a kind of training which can not be excelled by any other method; but if we carry these indivilual contests very far, pupils begin to think too much of themselves, or of winning the prize. They become selfish and distrustful of others.

When, however, the young people of a farm section form a group or club and then plan and strive to get superior results as a group, each member becoming willing to sacrifice a little personal advantage for the good of the whole, we are laying the foundation for an efficient community spirit in later life. Just as we play or work together, as young folks, so later on we will select together certain varieties of fruit, kinds of poultry, cattle, or grains, and soon develop a high degree of local pride by produeing products of the highest merit. Instead of one farmer alone trying to place his district "on the map" there will be tcam work, united effort.

The leader of this community action, whether the local minister, teacher, or Y.M.C. A. director, will have one ideal; namely, to make the local farm life better for a!l, both socially and economically. Dealers who are looking for produce in large quantities will then soon learn that in the southern end of a certain county, for example, farmers 
by working together have developed fine herds of one standard breed or excellent apples of an approved variety. The dealers will say "for Holstein cattle we will go here; for Berkshire hogs we will go there." This is the fruit of a eommunity spirit. It pays. American farmers need to learn this lesson thoroughly.

31. Clubs. - In order to develop a better community spirit and to make country life more satisfying, many

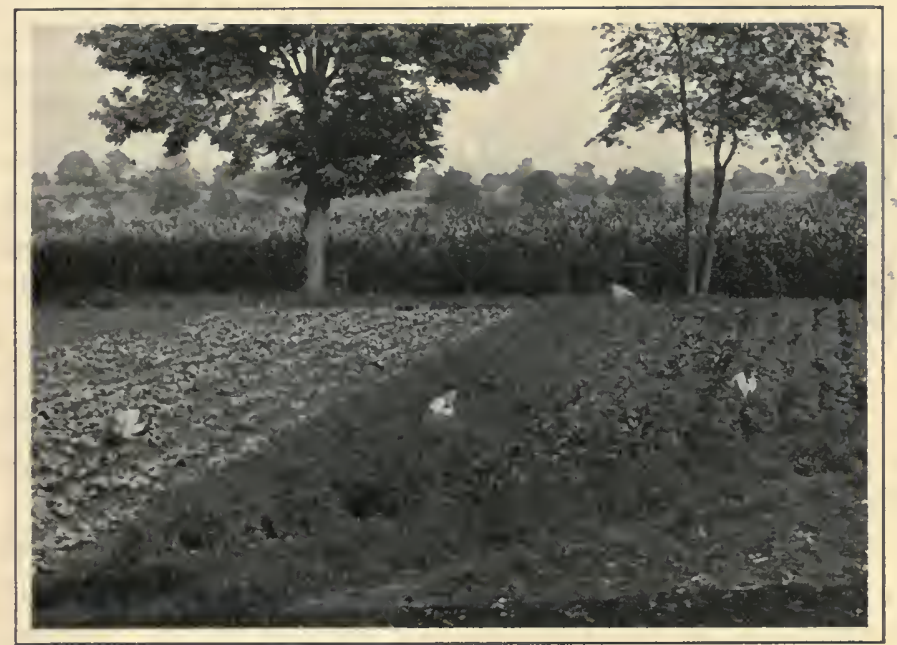

Club Members Working their Projects.

farmers' clubs have been organized. In 1914 there were more than 200,000 of them, and their popularity is growing. Sometimes the club membership is made up largely of the older boys and girls, including many who have left school. Some rural leader-teacher, superintendent of schools, or county agent - takes up club work with the young people and urges them to organize to work on some definite problem, such as potato growing, tomato growing, 
or corn growing. A letter may be sent to the state leader in charge of boys' and girls' clubs at the State Agricultural College. This organizer will take up the matter at once and discuss the plans to be followed.

If the young people decide to have a corn club, instructions for raising corn are sent from the Agricultural College to every member. The instructions are most practical and helpful, and contain the best advice that can be given. By following them, many hoys have surpassed their parents in

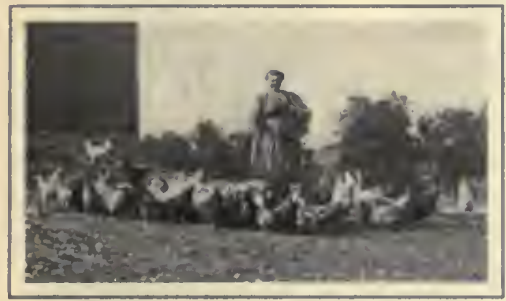

Poultry Club Member. producing greater yields per acre and in reducing the cost of production. Suitable prizes, perhaps a trip to Washington, are offered to the club member obtaining the best results. The basis of award is made according to such schemes as are given in this book at the end of the corn or potato chapter.

The club idea is now an important affair in many rural communities. Each member of a club is impressed with the fact that he has some worthy purpose in life. Circulars and bulletins that are sent to him free of charge take on a new meaning. The young farmer knows that thousands of other young people are facing the same difficulties that confront him; and a consciousness of this fact helps him to "make the best better."

32. Festivals. - Festivals of different kinds, such as eorn festivals, are excellent means for quickening the social life. When people get together and ask questions and listen to discussions of local problems, they will be benefited not only socially but in purse as well. The success of festivals 
depends largely on the leadership. The country teacher' is in a position to be the natural leader, but the pupils under her direction should do the main work.

Suppose we decide to have a corn festival during some future evening. The hall or schoolhouse should display corn and all its products. The pupils are expected to render selections or read essays on the different phases of corn growing. The festival means a corn night. Some

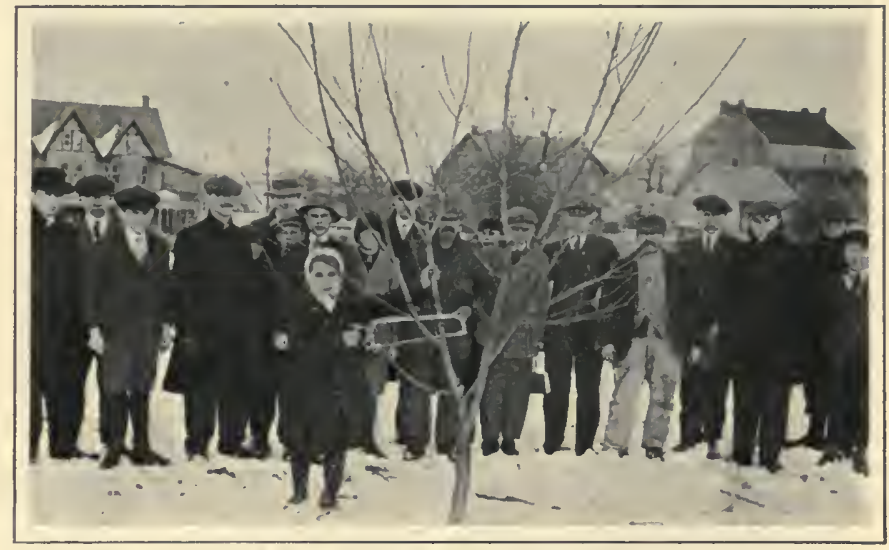

School Exercise in Pruning.

The farmers were invited to attend this demonstration.

one who has been successful in corn growing should give the others the benefit of his experiences. The members of the local corn club should learn at least one new thing in addition to having a good time socially.

Such festivals should be made very practical and helpful in every feature from first to last. The stringing and testing of seed corn may be demonstrated. A talk on seed selection and the points of corn judging would be helpful. Anything is in order that will lead to definite results. 
33. Agricultural Fairs. - Over 1200 county fairs are held in the United States yearly. At many of these the State Agricultural Colleges have exhibits. P'remiums are offered for the best specimens of fruit, sheep, model dairy barn, vegetables, preserves, beef and dairy products, swine, feed and forage crops, needlework, and for numerous other articles. Unfortunately, however, low-grade shows,

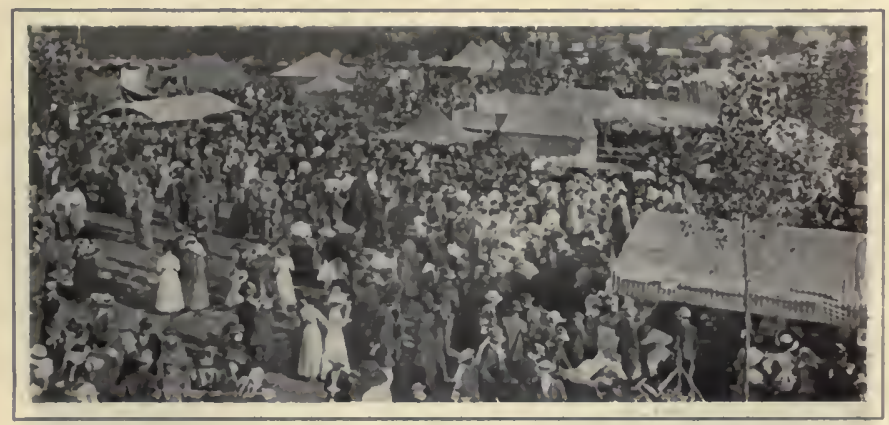

AN Agricultural Fair.

gambling devices, and fakers offset in part the services these fairs render the farmers.

Colleges of agriculture use the fair as a means of reaching the farmer personally, and for explaining the work of the college. Demonstration work is earried on. Results of investigations in fertilizing, spraying, erop rotation, and feeding are explained. Names and addresses of representative farmers are secured. Afterward, agricultural information is sent to them, and thus many projects for rural inprovement are started.

34. The Government and the Farmer. - In order to proinote better farming, Congress spends at least $\$ 20,000,000$ a year. The Secretary of Agriculture is a member of the President's cabinet. Every problem that concerns farm work is studied by experts of the Department of Agricul- 
ture. During 1912 there were 13,000 employees in this service, of whom 2,500 were stationed at Washington. Fifteen hundreil kinds of new seeds and plants were brought to the attention of farmers by the Department during the year 1914. Tests of the soil are made in all parts of the country in order that grazers, vegetable

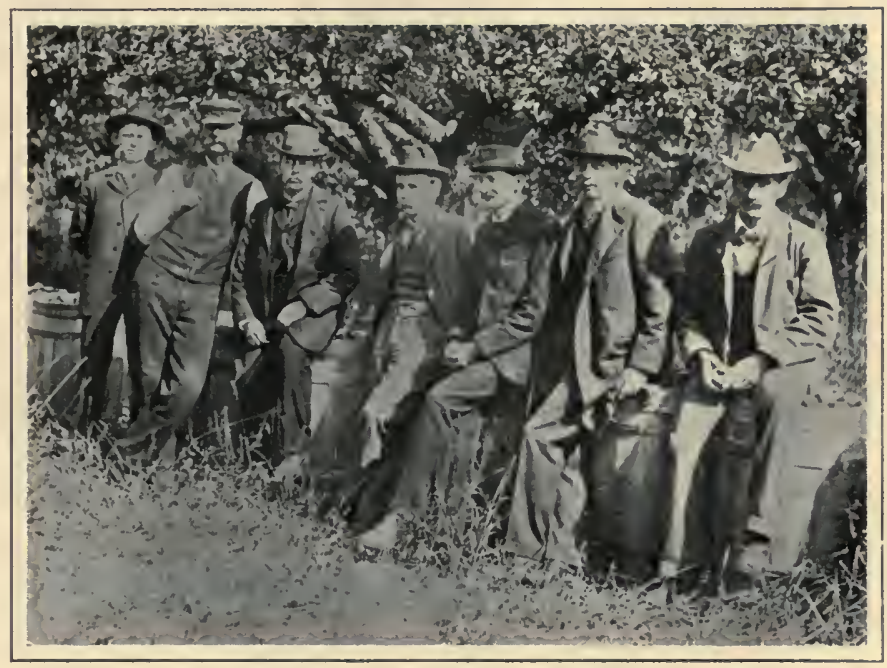

An ORChard Meeting. 1

growers, and others may know the exact character and needs of their lands.

In addition to this work done by the national government, each state and territory has its own Experiment Station and College of Agriculture. The New York State College of Agriculture at Cornell, for example, has a

1 From left to right: Prof. F. A. Waugh, Massachusetts Agricultural College; T. L. Kenny, owner of the orchard ; A.C. True, United States Department of Agriculture; Prof. G. L. Hills, Vermont Agricultural College; Prof. L. R. Jones, Wisconsin Agricultural College; Prof. S. A. Beach, Iowa Agricultural College; Prof. Johu Craig, Cornell University. 
faculty of over a hundred men, and expends over a half million dollurs annually on its work. The enrollment in most of the colleges for farmers has multiplied greatly during the last few years.

Recently, in a number of states, experts known as county agents are being located in the different counties to advise interested farmers personally on questions peculiar to their farms. These men are the apostles of scientific

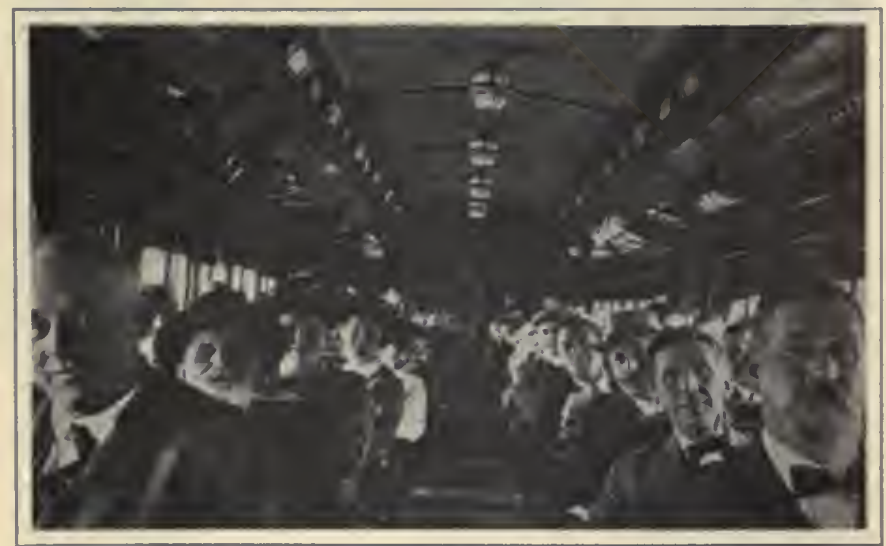

FARMERS AND theIr WIVES.

On an excursion to visit the State College of Agriculture.

agriculture. In the most vital way, they reach many who are not in the habit of looking beyond their neighborhood for assistance. The help rendered in this manner is of the most practical kind.

The county agents are carrying out some of the purposes of the Smith-Lever bill which became a national law May 8,1914 . This law provides for instruetive and praetical demonstrations in agriculture and home economics to persons not having the advantages of attendance at an agricultural college. To carry the provisions of the law 
into effect $\$ 480,000$ are appropriated annually to the several states from the national treasury.

The second year the law is in force an additional sum of $\$ 600,000$ is likewise appropriated, "and for each year thereafter for seven years a sum exceeding by $\$ 500,000$ the sum appropriated for each preceding year, and for each year thereafter there is permanently appropriated for each year the sum of $\$ 4,100,000$ in addition to the sum of $\$ 480,000$ hereinbefore provided." These sums are avail-

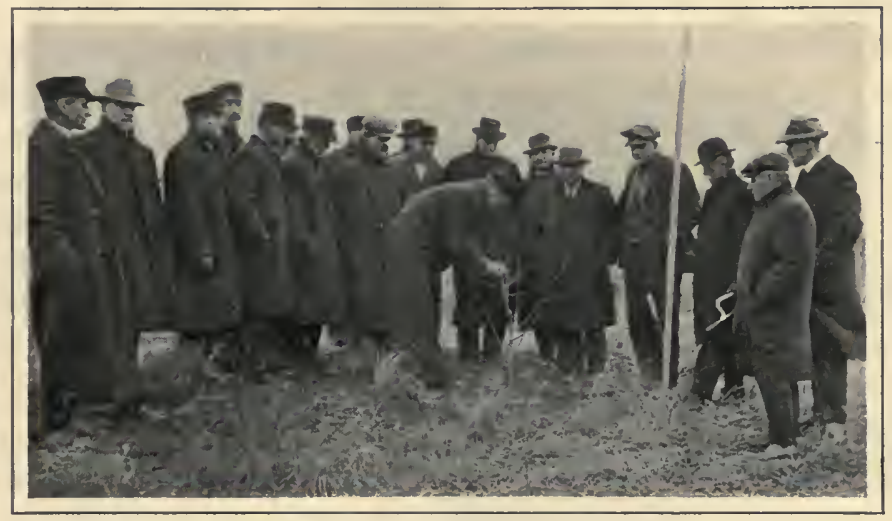

Tree Planting Demonstration.

A county agent in the center.

able to the several states on the basis of their rural population compared to the total rural population of the entire country, provided that the state legislature appropriates from its local treasury an amount equal to the sum provided for by the federal law.

35. The Need of Scientific Farming. - At the present time there is need of more scientific farming in America. When nearly everybody lived on the land, for each farm to produce sufficient food for itself until the next harvest was about all that was required. With the growth of 
cities, increasing demands were made upon the farm. But farming in America was on an unseientifie basis, ill-prepared to meet all the new demand.

This was partly due, perhaps, to the ease with which land was acquired. Most of the farm land in the central and western sections of our country was originally sold by the goverument very cheap, or even given away to settlers. In 1800, the government began to sell quarter-sections (160 acres) at $\$ 2$ an acre, taking one fourth in cash and giving eredit for the rest. This system led to a wild rush to the new lands, and the long lines of would-be buyers before the doors of the government land offices gave rise to the expression "doing a land-office business." In 1820, the government stopped giving eredit, but began to sell eighties ( 80 acres) at $\$ 1.25$ an acre. Then in 1862 , under the Homestead Law, it began to give land, in 160aere tracts, to any settler who would improve it and live upon it a certain length of time.

This generous policy of the nation in regard to its public lands had many good results; but it had at least one bad result. It encouraged careless and unscientific cultivation. Farming on these easily acquired lands was carried on in a very primitive way. Stock raising was little more than herding on the open range. Even for the tiller of the soil, plowing, sowing, and harvesting made up the whole business. The waste of the soil was tremendous, - and the soil is our most valuable national re8ource. It is partly because of these old, destructive methods of agriculture that the people of the United States are now facing a rapid increase in the cost of farm produce, and that some thinkers fear lest the food supply will not keep pace with our growing population.

Science is now laying the foundation for better and less wasteful farming. Chemistry teaches the scientific feed- 
ing of animals and the food requirements of crops. Physics unfolds the principles of the control of soil water and of the construction of farm machinery. Biology reveals the proper methods of combating harmful insects, and explains the nature of plants and animals. Economics considers the best plans for buying and marketing, the most efficient farm unit to operate, and the various questions of community efficiency. Scientific farming means systematic and intelligent management along all these lines.

36. Agricultural Publications. - Over 9,000,000 copies of farmer's' bulletins are distributed annually by the United States Department of Agriculture. Any person in our country can be enrolled on application, and can receive the free monthly list of available Department publications. These publications are sent, for the most part, free of charge, on request.

Interesting and in-

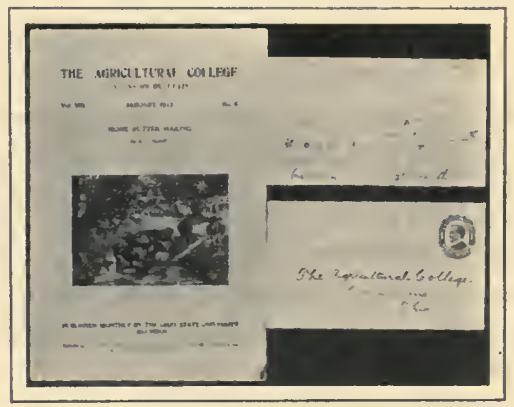

Agricultural College Bulletin. structive matter is also mailed free by the State Colleges and Experiment Stations. Helpful books relating to farming, country life periodicals, and carefully prepared matter sent to local newspapers exert great influence in rural sections. The state and local associations of stockmen, horticulturists, and grain growers distribute their proceedings widely. The printed page - attractive, readable, and reliable, as it has now come to beis awakening a better life in the country, and its influence for good cannot be measured. 


\section{Practical Questions}

1. How does the house fly affect the farmer's health? 2. In what way can health be considered as wealth? 3. What is the purpose of the rural school? 4. Why do pupils study agriculture? 5. What is meant by coöperation? 6. Give as many instances of coöperation as you can. 7. Of what value is an agricultural fair? 8. Name three ways in which the government helps the farmer.

\section{Home Exercises}

1. Visit the local cemetery and note the ages of about fifty people buried there. Average these ages and report. Compare the average with that of your near relatives at the time of death.

2. Make a list of all enterprises in which your parents coopperate with their neighbors, and with home aid estimate the resulting gain.

\section{Suggestions}

1. Farmers are missing an excellent opportunity if they do not keep in touch with the work the government is doing for them. It will be well to have a child in each family send a postcard either to Washington or to your state agricultural college for a free circular or bulletin that gives full information on some problem of local interest. This circular should become the property of the pupil, and naturally the parents would read parts of it. A course in agriculture, except in colleges, must be brief and deal mostly with a few general principles. Detailed information, such as no school text-book can give, is needed on wheat in Kansas ; potatoes in Maine; or cotton in Louisiana. It is the purpose of the "College Extension Service" of every state to give this information in readable and attractive bulletins suitable for recitation work in the schools. This service is free. Teachers should see that these helpful aids are not lacking.

\section{ReFERENCES}

Rural Hygiene. Brewer.

How to Coöperate. Myrick.

Outlines of Practical Sanitation. Bashore.

Farm Boys and Farm Girls. McKeever.

Country Life and the Country School. Carney.

Country Life. The Anuals, March, 1912.

The New Earth. Harwood.

The State and the Farmer. Bailey.

Our Furning. Terry. 


\section{CHAPTER V}

\section{THE BUSINESS OF FARMING}

Better farming, better business, better living. - Roosevelt.

At the head of all the sciences and arts, at the head of civilization and progress, stands, - not militarism, the science that kills, not commerce, the art that accumulates wealth, - but Agriculture, the mother of all industry and the maintainer of human life.

- James A. Garfield.

37. Why do we Farm? - We are likely to overlook the reason why more than one half of our people are farming. We see a man rising early in the morning and driving many miles to market, eager to sell his produce there; we see another man busily at work in the field; we see large barns and herds of cattle in many country places. What does it all mean? Why do we farm?

The main business of farming is to build the right kind of a home. Of course, means must be provided for this, and so farm operations must be gainful, but not necessarily as an end in themselves. It is unfortunate for farmers to be so interested in their work as to lose all taste for music, books, art, and the beautiful in nature. An appreciation of these things would greatly enrich their lives, and so help the "main business" of farming. It is true that one half of our people would starve if they were not fed by the farmers, and it is well for the farmer to feel that his work serves mankind as well as himself; but all this does not change the main issue of farming, - that of home building for the farmer and his family. 
38. Farming a Primary Industry. - According to a recent classification, there are about five hundred occupations followed in the United States. These are grouped under nine different headings : namely, Agriculture, Extraction of Minerals, Manufacturing Industries, Transportation, Trade, Public Service, Professional Service, Domestic Service, and Clerical Occupations. These are grouped

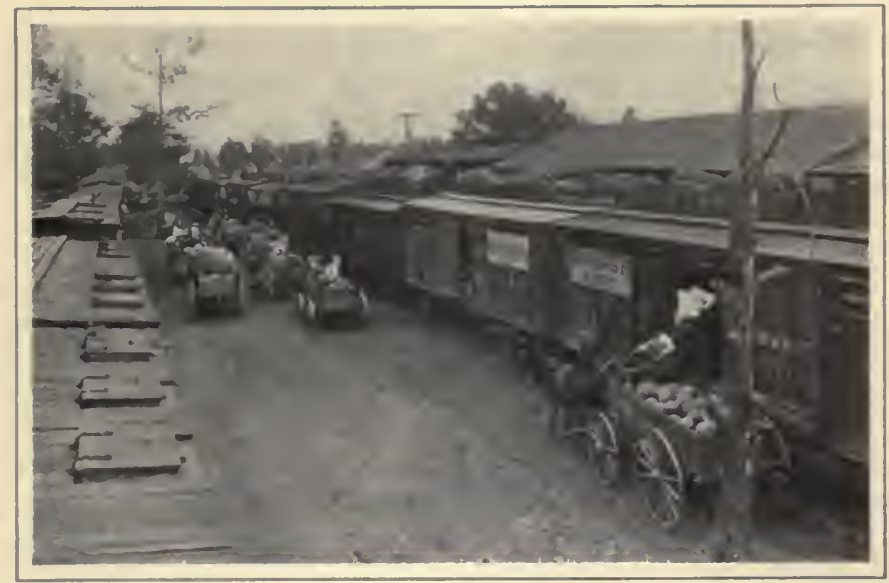

FARMERS SHIPPING BY RAIL.

again under three classes, - Primary Industries, Secondary Industries, and Personal Service.

Farming has always been, and must always remain, a primary industry. When agriculture declines, trade lags and every other occupation sooner or later feels the effects. True, farming is not the leading industry in every country, or in all parts of our country. But this is only because the farmer now finds it possible to ship his produce to those in other pursuits even at great distances, and in this way to relieve them of growing their own table supplies. Thus Danish farmers supply the great city of London 
with its bacon, butter, and eggs, and American or Australian farmers send England most of its grain food.

In America there is an army of over 10,000,000 workers with their families engaged in agriculture. But compared with the number of those engaged in personal service, and in secondary industries, like manufacturing, this vast army is becoming smaller and smaller. This decline has been partly explained in Chapter II. It is caused largely by the progress in the refinements of civilization. Raw mate-

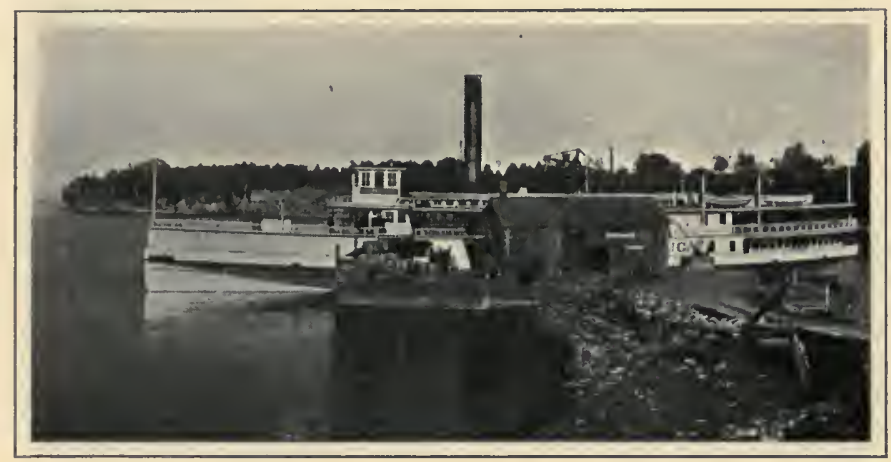

Farmers ShipPIng by BoAT.

rials are produced on the farm. The market demands finer and finer products from these materials, - finer and more attractive clothing, sugar, shoes, and the like. Standards of living are rising. Consequently, an increasing number of men are being withdrawn from farm work to those industries that elaborate and refine.

As was stated in the second chapter, the invention of new machinery will continue to cause men to shift from one or the other of these groups of occupations. The perfection of the reaper meant fewer men on the land and more in the mill. Labor-saving devices in the mills turn some of the workers back to the land. But however great 
the shift from one business to another, agriculture, taking the world as a whole, will always continue to be a primary and fundamental oceupation. Other occupations build upon it to a greater degree than it builds upon other occupations.

39. When is a Farmer Successful ? - A man succeeds, in a business way, if he makes more than he spends, and this business success is necessary to most other success. Before one can have music, books, or other means of fully satisfying the higher life, one must have money or credit.

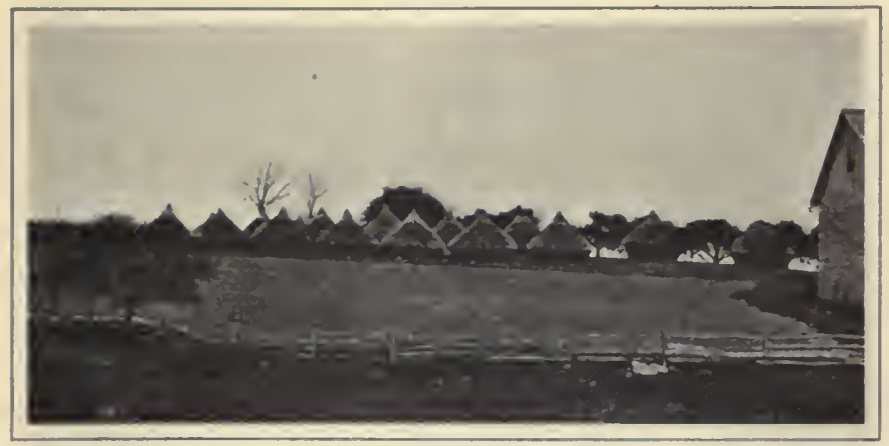

A Successful FARM.

Note the number of wheat stacks.

Credit usually comes from the application of good sense and intelligence to business; and the more credit the farmer has, the greater will be his opportunities to grade up his stock, install improvements and conveniences, and support such social and uplifting activities in his neighborhood as will awaken rural manhood.

Among the most successful farmers of the United States are those of southeastern Pennsylvania. Lancaster County, for example, has led all others for more than half a century in the valuation of farm produce. Its soil is as rich and productive to-day as it was two generations ago. 
The farmers produce good crops of corn, wheat, and other staples; and they also support schools and churches generously. In the long run the type of institution that feeds the mind depends upon the type of dairy, tillage, and orcharding that feeds the institution.

But the material success is desirable mainly for the sake of the higher success it makes possible. Farming must not merely support life: it must help to make life better

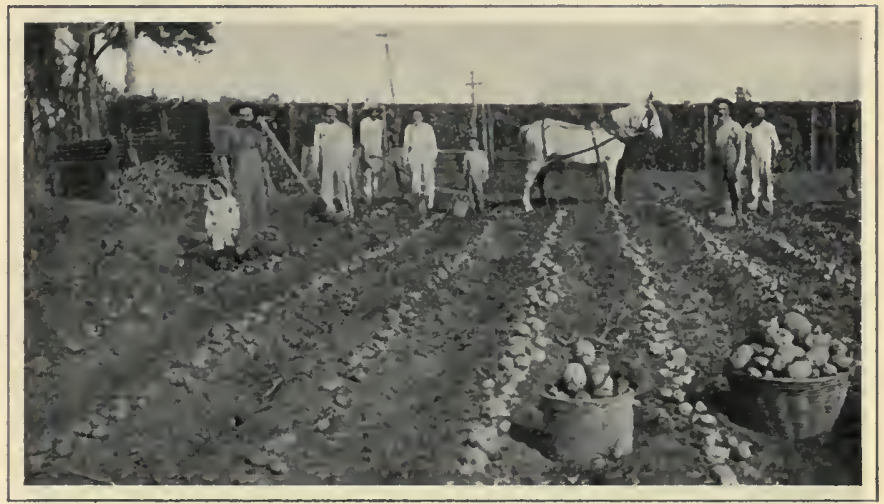

A Bumper Potato Crop.

worth living. The Lancaster corn and tobacco crops are best worth while because they flower into the Lancaster schools. A farmer is fully successful only if he enriches the world in the things both of the body and of the spirit. 40. High Cost of Living. - The cost of the necessities of life has been rising at the rate of about one per cent a year for the last two decades. It is often thought that the only cause of this lies in the farmer himself; in his lack of intelligence, skill, and business sense. The causes, however, are many, far-reaching, and world-wide. It costs the dairyman more, for instance, to produce the high-grade milk which the market now demands, than it costs to 
produce the low-grade milk which the market allowed a generation ago. More men are required to produce a ton of milk under modern conditions of sanitation. The cows must be kept clean, and be fed on wholesome, measured, and balanced rations; they must be tested for tuberell-

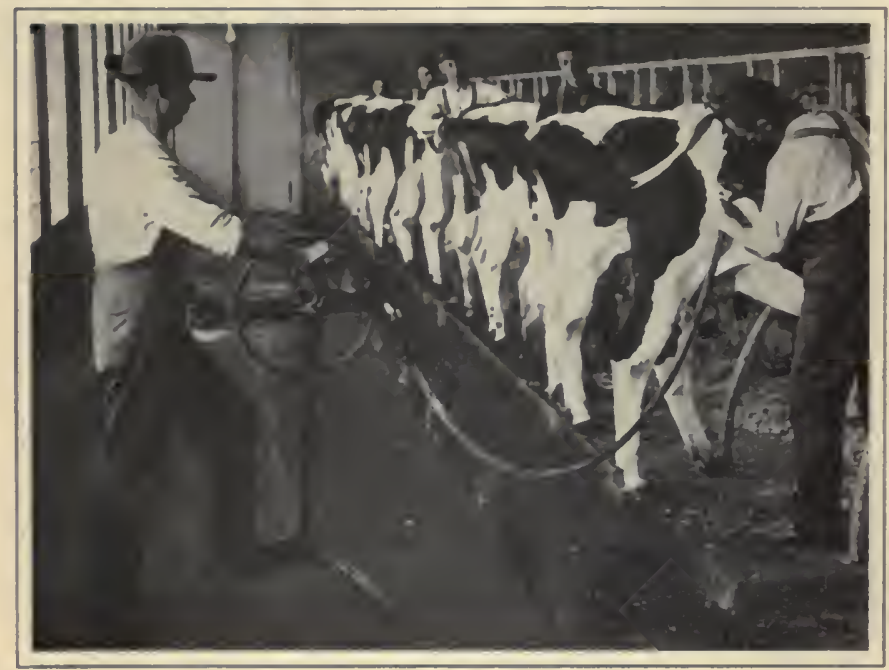

Making Sure of Clean Milk.

Milk produced under sanitary conditions commands a higher price than that obtained from dirty cows.

losis; and kept in a barn that is a model in cleanliness and construction.

The milker and all other helpers realize that they are producing a food that is readily contaminated. Consequently, special utensils must be provided for milking, cooling, and shipping; and since the market is willing to pay for the extra labor and investment, the price advances as the cost does. So, too, to run a commercial orchard to-day requires an investment in the proper applications 
for spraying, cultivating, picking, grading, and packing the fruit of which our fathers never heard. As the tastes of the market rise, the cost of supplying the superior quality of produce must also rise.

All this, however, is only one factor in the rise of the cost of farm produce. The profits of middlemen cannot be ignored; the lack of coöperation among the farmers themselves is involved; the rise in rents, tariffs, and

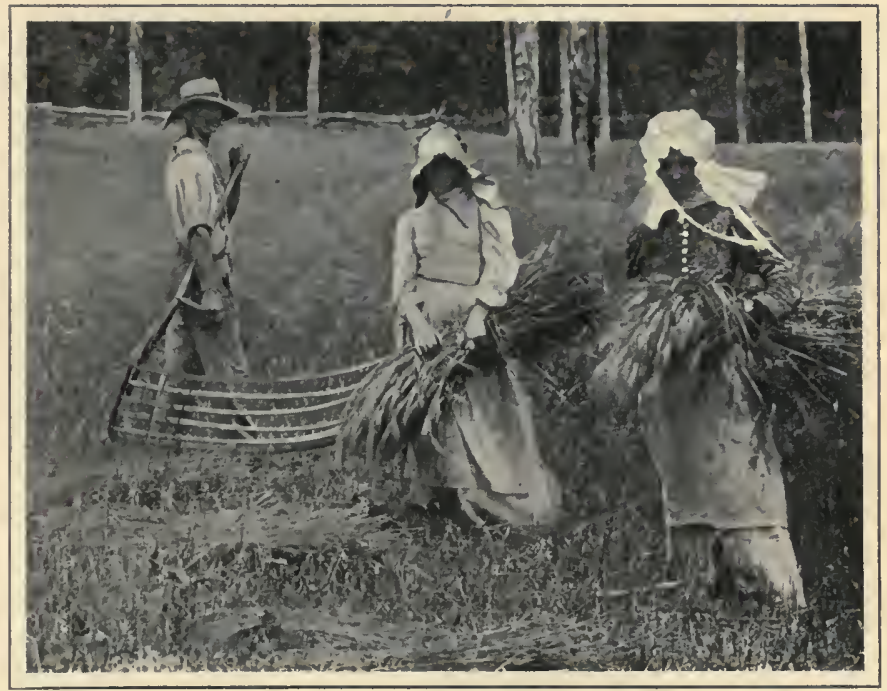

European Peasant Farmers.

wages is a thing to be considered; and the increase in the output of gold, which measures the value of produce, is of vital concern. Here we can merely mention such factors.

41. Different Ways of Comparing American and European Farming. - American farmers are frequently, but unjustly, compared with those of England, France, Denmark, and Germany in their yields per acre. Here the yield of wheat, corn, potatoes, barley, and other important crops is only 
about one half that of the eountries named. Consequently it is often thought that the American farmer is only one half as effieient as his brother in Europe, and that, if he would double his ontput to the acre, prices would fall considerably.

This is true in a small degree. But conditions here and abroad differ widely. Around Paris, for example, where one finds intensive types of European agrieulture,

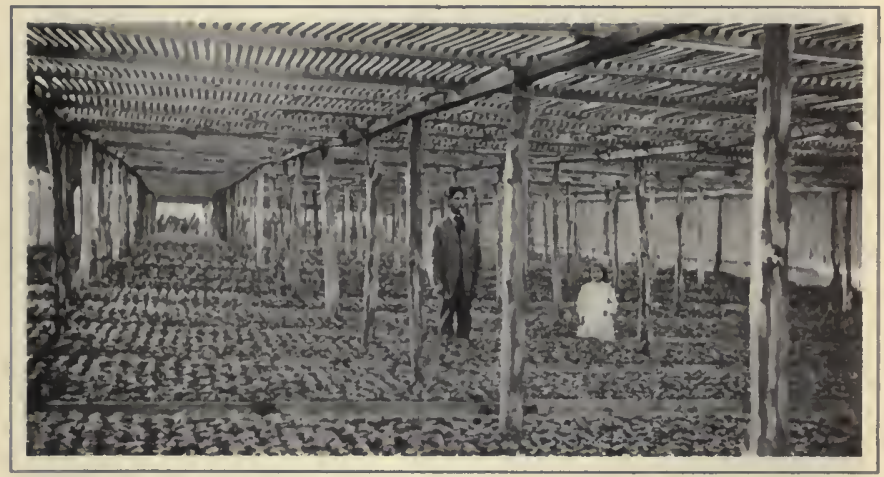

INTENSIVE FARMing.

Raising ginseng.

the land is owned mostly by city people, who pareel it out to tenants of the peasant class. Out of a few acres the peasints must support themselves and their families and pay their rent. "Intensive farning," on the order of our gardening, is the only farming possible on these highpriced lands. But it is just as fair to compare the yields per worker as the yields per acre; and the farmers of our country, with their large acreage and modern machinery, far exceed, per man, the output abroad. ${ }^{1}$

1 In Germany 76.4 per cent of all farm holdings are under 121 acres in size. In Eastern Flauders, Belgium, inore than 40 per cent of the farms are less than $12 \frac{1}{2}$ acres in size. The size of the average American farm is 138 acres. 
42. Tenants. - In the United States 37 farmers out of every hundred are tenants, or renters, of the farms they work. 'This is an increase of thirteen tenants per hundred farmers since 1810. In some sections of the South the proportion of tenant farmers exceeds ninety per cent, the large majority being negroes.

The main causes of the tenant class are:

(1) Increase in the price of land;

(2) The lure to the centers of population;

(3) The desire to make safe investments by men of means.

So long as free land could be secured from the government by any one who took the trouble to go west and to establish a claim, the price of land was low and labor was high. When the supply of free land became practically exhausted, ten or twenty years ago, land values began to rise, and it became increasingly difficult for men of meager means to buy farms.

43. Dangers of the Tenant System. - John Stuart Mill, a famous English writer of the last century, held that small farms, owned by those who work them, are necessary for individual and national well-being. Farm tenancy in America is not necessarily a bad thing. Most tenants are young farmers for whom tenancy is a stepping stone to ownership. There are nevertheless some undesirable features associated with it. Tenants are apt to take little interest in community affairs. As a rule they keep less

There are more than ten times as many people to the square mile in Germany, for instance, as in the United States, or, to be exact, 320 to 31 . Intensive cultivation is generally a necessity abroad; but, as yet, in many localities here, it is not yet advisable. Just as there is a point beyond which it is not profitable to add an additional pound of weight to growing steers, just so there is a limit to higher and higher yields of crops. A man may raise forty bushels of wheat to the acre and go in debt; another may raise twenty bushels to the acre and have a generous income. The cost of production, not the yield per acre, is the important thing. 
live stock than land-owning farmers do; and this means that too little manure is produced to maintain a permanent soil fertility. Good sehools, good churches, and good roads are best built up and maintained by a settled population. A tenant who is continually looking for a better farm, and a landlord who is only waiting for a price to sell at a profit, are neither of them likely to contribute anything to the permanent uplift of the eommunity.

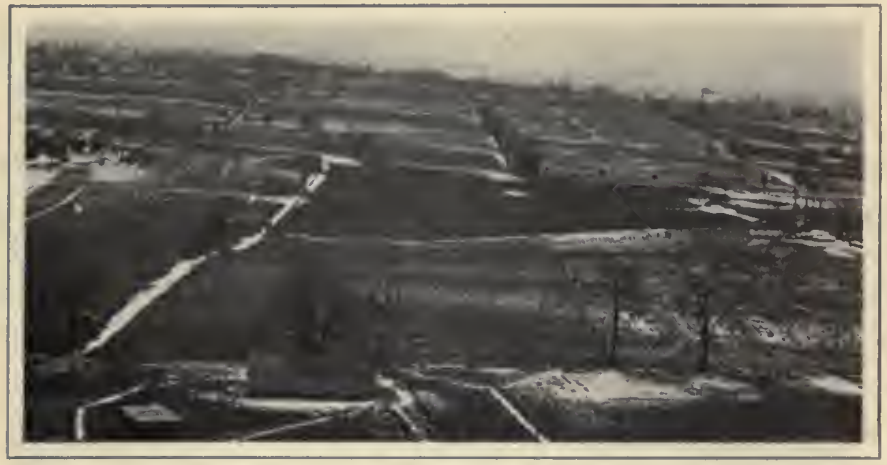

Small Fields and Tenant Farms.

44. Farm Labor. - The average American wages for farm laborers is $\$ 16.40$ per month, with board and lodging. The hours are long and the employment is irregular. The shorter hours and higher wages of the eities attract men. The scareity of suitable homes in certain sections make farm labor unattractive to married men with families. Immigrant laborers do not look with favor upon the separation from their countrymen which results from employment in the country.

Farm labor, however, has its attractive side. Mill workers, teamsters, miners, and railroad employees are frequently subjeeted to conditions of employment that endanger the body and undermine the health. Lawyers, 
doctors, and other professional people, while rated at having a better income than farm hands, are under much heavier expense. In addition to his regular wages, a married farm hand is usually allowed the use of a little

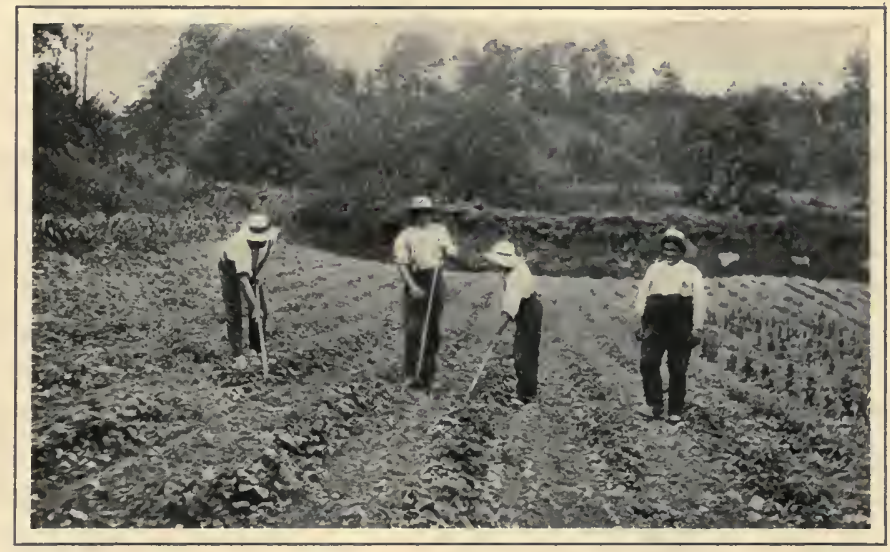

FARM LABOR.

The employer and the "hired man."

land for the growing of vegetables, and this materially reduces the cost of supporting his family.

Drudgery on the farm, too, is rapidly passing. ${ }^{1}$ Much hard work is now performed by machinery. The farm laborer is becoming a machinist. From the preparation of

"I emphatically deny the common notion that the farm boy's life is drudgery. Much of the work is laborious, and this it shares with all work that is productive; for the easier the job, the less it is worth doing. But every piece of farm work is also an attempt to solve a problem, and, therefore, it should have its intellectual interest; and the problems are as many as the hours of the day and as varied as the face of nature. It needs but the informing of the mind and the quickening of the imagination to raise any constructive work above the level of drudgery. It is not mere dull work to follow the plow, - I have followed it day after day, - if one is conscious of all the myriad forces set at work by the breaking of the furrow; and there is always a landscape, the free fields, the clean soil, the rain, the promise of crops. Of all men's 
the seed bed to the hauling of the produce to market, along the entire line of activities, invention is lightening the burdens of farm life. Rural engineers are constantly at work on new devices, - self-feeders, loaders, shellers, pneunatic stackers, automatie measures, potato diggers,

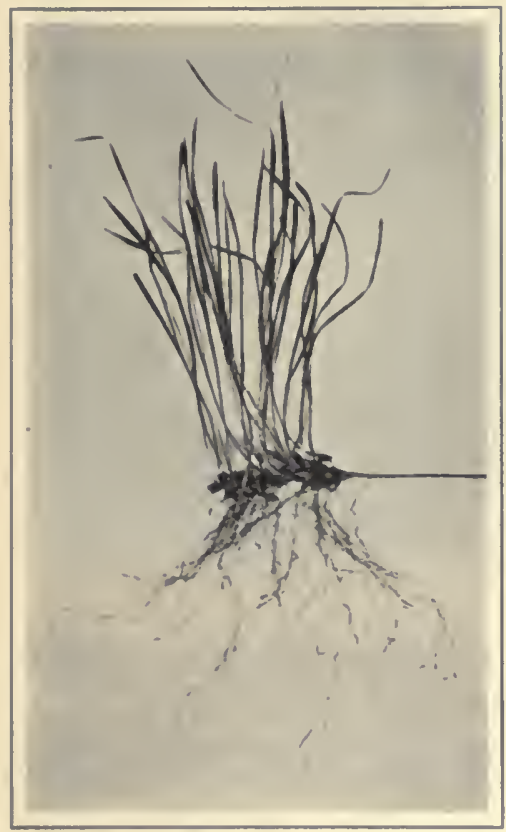

BAD FARMing.

Wheat sprouting before it is harvested. manure spreaders, and numerous contrivances that inultiply the gratification of the hired man.

One factor in the diffieulty of finding farm help is altogether good. This is the way in which the best farm laborers are continually working "1p into temants and land owners. 'The report of the Country Life Commission, page 39 , puts this thought well:

"So long as the United States continues to be a true democracy it will have a serious labor problem. As a democracy we honor labor, and the higher the efficiency of labor the greater the honor. The laborer, if he has ambition to be an efficient agent in the development of the comntry, will be anxious to advance from the lower to the upper form of effort, and from being a laborer himself to become a director

labors, the farmer's is the most creatlve. I eamot help wondering why it is that men will seek work in the grease and grime of a noisy factory, but will recull at what they call dirty work of the farm. So much are we bound by tradlion." - L. H. BAILEY. 
of labor. If he has nothing but his hands and his brains, he aims to accumulate a sufficient capital to become a tenant, and eventually to become an owner, of a farm home. A large number of our immigrants share with the native-born citizen this laudable ambition. Therefore, there is a common decrease of efficient farm labor by these upward movements."

45. Business Failures. - Agriculture as a business does not lend itself well to large units, that is, to the management of enormous areas and the investment of a vast capital under the direction of one man. A few men may control the iron or oil trade, or even regulate the price of meat or grain after they have been marketed, but the production of these necessities is mainly in the hands of men of small capital. A record of the failures of the "bonanza farmers," therefore, may pass without discussion here. Nor, even for the small farmer, can all the reasons for a lack of business success be mentioned. The following ones may be noticed:

a. Too much book learning. Some graduates of agricultural colleges fail, not because they know too much that is useful, but because they experiment too much with what is useless. Theories are valuable, but there must be a combination of brains, brawn, and sense.

b. Too little book learning. Some fairly successful farmers continue in the "calf paths" that were made by their ancestors. They mistrust improvements, and look upon higher education with misgivings. They lack the open mind; they will not read; they ignore the uplift that comes through contact with men of wide experience ; they become self-centered, selfish, self-sufficient, and consequently can show only decreasing returns for their labor.

c. Hostile environment. It costs about twice as much to produce a bushel of corn on a steep hillside as it does on a rich flood plain, a few hundred yards below. 
Farmers on the hill slopes of New England are working at a clisadvantage on account of the free trade with the riel, level lands of the West. While the yield per acre is higher in New England than in the western states, yet the cost of producing crops is also higher on account of the fact that large machinery cannot be used on the slopes. Many farms, therefore, have been abandoned for economic reasons, and are now growing forests, for which they are better adapted.

d. Personal peculiarities. Under this heading may be mentioned such weaknesses in eertain farmers as a tendency to laziness, shiftlessness, and alcoholism. Strong drink and laziness have darkened the prospects of many a homestead.

\section{Practical Questions}

1. How many different occupations are there in the country? In your neighborhood? 2. What is the difference between trade and transportation? Public service and domestic service? 3. In what sense is farming a primary industry? 4. Explain why the secondary occupations are gaining over the primary occupations. 5. Is the invention of machinery a benefit to the farmer? 6. What is meant by success in farm life? 7. Is it possible for a farmer to be a failure and yet be making more than he spends? 8. In what way is the farmer affected by the high cost of living? 9. State and discuss three causes that raise prices. 10. What is a tenant? 11. To what is our increase of tenancy dne? 12. Do tenants take as much care of farm properties as owners do? 13. Would you sooner work in a mill or on a farm? 14. Why are some farmers more successful than others?

\section{HoME EXERCISES}

1. Make a study and keep careful records of one farm operation as conducted by your father. Determine the gain or loss per cent in the operation, and, if possible, the reasons therefor.

2. Determine the per cent of tenant farmers of your school district and compare this number with that of ten years ago. 
3. Ask your father for the size of the home farm. Who has the largest farm in the neighborhood?

4. Keep a record for one week of the prices of farm produce as given in a city paper.

\section{Suggestions}

1. It would be interesting to count up all the occupations of the school district. Write the names on the board and the number of people following each. Use the classification of the Census Bureau, given at the beginning of this chapter. Is the number of different occupations increasing? Would it not pay the farmer to do his own carpentering and blacksmithing in order to reduce the number of separate occupations?

2. If any facts are available, it would be instructive to find out whether a farm boy who has left home has, in a given time, actually saved more than a young man that has stayed on the farm. While farmers seldom become millionaires, yet there are not a few opportunities for large incomes in almost every rural community. Do the farm patrons of the school study the bodily needs and wants of city people? Every farmer can spend a little time "just browsing" in the city market, studying the whims of buyers. He can then better understand why some sellers get more for their produce than others. A little knowledge of human nature brings better returns than much information on soil analysis.

3. A list of "Farmers' Bulletins" is appended at the end of nearly every chapter. These bulletins, unless otherwise stated, can be secured, in most cases, free of charge from the Secretary of Agriculture, Washington, D.C. A complete list of all bulletins available is not given. It is suggested that whenever pupils need fuller information on certain points they be encouraged to hunt for it, first, at their own state institutions, and then, failing to find it there, they should send to Washington. State publications are not often cited in the references, for the reason that such publications are not intended primarily for use beyond the state line. Each school should have a complete set of the publications of its own state and of those of Washington, at least a complete set of those publications which treat on subjects of local interest. Ordinarily, bulletins of a technical nature are not well adapted to school purposes, and should not be requested. In a general way local aids are to be preferred to those more distant. 


\section{REFFRENCES}

Country Life. The Annals, March, 1912.

Chapters in Rural Progress. Butterfield.

The Farmer's Business Ilandbook.

The Fat of the Land. Streeter.

Book-keeping for Farmers. Atkinson.

Farmers' Bulletins, Washington, D.C.

62. Marketing Farm P'roduce.

242. An Example of Model Farming.

280. A Profitable Tenant Dairy Farm.

325. Sinall Farms in the Corn Belt.

437. A System of Tenant Farming and its Results.

454. A Successful New York Farm.

635. What the Farm Contributes Directly to the Farmer's Living. 


\title{
CHAP'TER VI
}

\section{RURAL CONVENIENOES}

\author{
Ah, why \\ Should life all labor be?-Trnnyson.
}

46. Motor Power. - In Chapter II the statement was made that the invention of machinery has enabled the farmer to do more work than formerly, and thus has re-

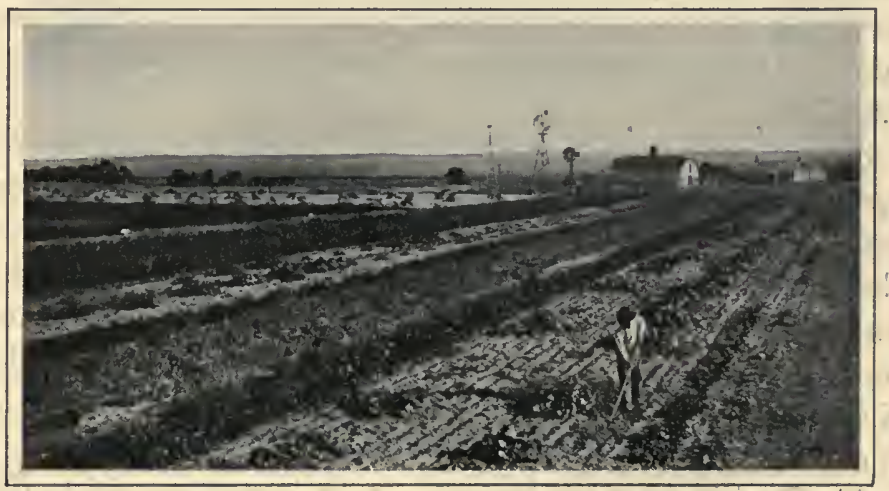

A Windmill on the Farm.

leased some farm labor to other occupations. "In Chapter $\mathrm{V}$ we noted briefly that machinery has also done away with much of the old drudgery for those who remain on the farm. This second fact deserves more detailed notice. It is important; for the drudgery element in farm work in the past has driven away many who could have rendered better service on the farm than elsewhere. 
$A$ motor is a machine that transforms energy from a form that is useless into a form that is useful. Windmills, a kind of motor, have been used for centuries for pumping water, especially in Holland. For the same purpose $h \dot{y}$ draulic rams are widely used. The rams are cheap and easily installed; and a slight flow of water, if it be steady, is enough to keep them in constant operation.

Perhaps the most useful motor for farm work is the gasolene engine. Gasolene engines operate wringers, separators, saws, vacuum cleaners, churns, dynamos, threshers, feed grinders, pumps, silo fillers, milking machines, sewing machines, and many other useful contrivances. The engines are easy to operate; they are safe; and they are made in different units of power, so as to meet the most diverse needs. They have probably done more to banish drudgery from farm life than any other machine.

Several manufacturing firms are beginning to sell electric equipment for farm work. This form of power has been used in rural Germany for several years. In many places electric power is transmitted over great distances into the country for the farm and household. It is beginning to replace the gasolene engine for many kinds of work. Electricity is clean and safe, and if it ean be secured at all, it can be used in any place and at any moment.

47. The telephone has become a very important aid to the farmer. From 1902 to 1907 the number of rural telephones increased threefold. In 1910, in Iowa and Illinois, there were 190,000 farms, and 174,000 rural telephones, or one for almost every farm. The lot of the farmer's wife is lonely enough at best, and the telephone helps to satisfy her longing for association with her neighbors.

Matters of business, social welfare work, and conferenees on all affairs of local interest find the telephone a helpful 
assistant. It means a great saving of time to call up the village store for needed supplies in order to have them sent out by the next car, or by some neighbor who happens to be in the village. When haying and harvesting are in progress, the notice of a probable change of weather may mean the saving of many dollars. In some places "Central " reports the weather forecast daily to all the farmers on the line.

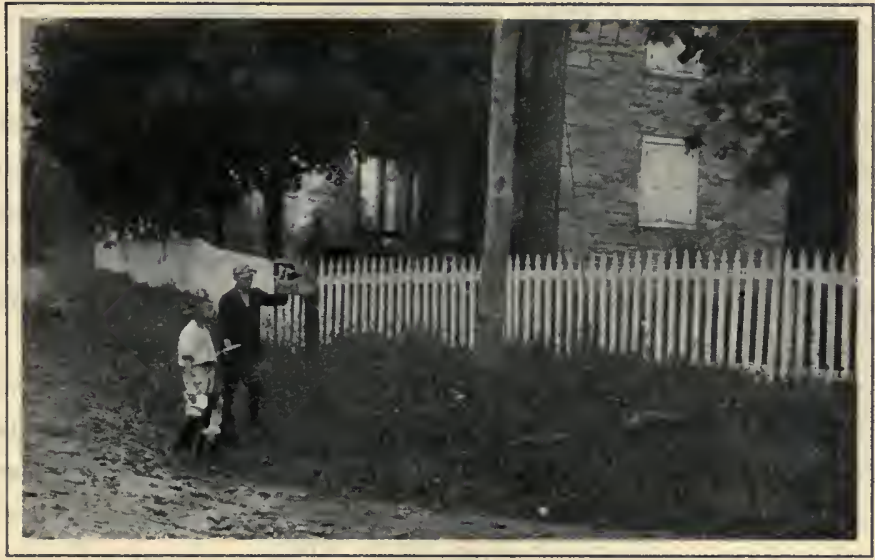

Getting the Morning Mail.

48. Rural Mail Service. - A very few years ago country folks had no government delivery or collection of mail. To post a letter now and then, or to find out whether one lay waiting at the post office, the farmer himself had to drive to the village - perhaps over many miles of wretched roads. Packages of more than four pounds could be sent or received only by freight or express, and express rates were extremely high. Under such conditions the farmer's family sent little mail and received little. Now the parcel post and the daily rural mail service bring to his door the merchandise of a distant city and the latest news of 
the world; and, in turn, earry lis butter and new-laid eggs to profitable city customers, - all at very cheap rates.

In 1911 , when rural delivery was new, 41,359 carriers served $19,000,000$ country people at a cost to the government of about two dollars apiece. This cost, it was found, was repaid by the increased postal business. In the first two years after "free" service was extended to the country, the general mail matter in one Maryland county increased 90 per cent.

'Then, January 1, 1913, the parcel post was started, and the volume of postal business grew enormously. A year later a new parcel post law made the low rates still lower, and raised the weight limit on packages. ${ }^{1}$ 'The next year (1915) the rural mail service was reorganized and greatly extended, so as to reach nearly all the farms except those in exceedingly isolated and inaccessible districts.

49. The trolley and automobile have taken high places among the farmer's conveniences. The trolley may pass his house and stop at his front gate. With little expense, then, he can take his family to the village or city store, or send his freight to the consumer. The number of automobiles that have been bought by farmers in recent years proves that this convenience is being appreciated. Many farmers now consider the automobile a necessity. A few miles on a good road mean very little to the man at the wheel. The farmer can travel for many miles with speed, pleasure, and comfort, to compare his own work with that of his neighbors, or to do his marketing and to carry light produce to town. The automobile truck, also, for general

1 In 1914 it beeame possible to send by mail almost any package under 50 pounds in weight to any point less than 150 miles distant, and to send 20 -pound packages to any point in the United States. Tliere is a size limit, however, as well as a weight limit on postal parcels. 
delivery purposes, and especially for long hauls, is meeting with high favor among farmers.

50. Good roads are among the foremost conveniences of rural life. Narkets, schools, churches, neighbors, are made more accessible by them. They save labor and time and add value to land and produce. In Chapter IV we learned that a community spirit was necessary in order

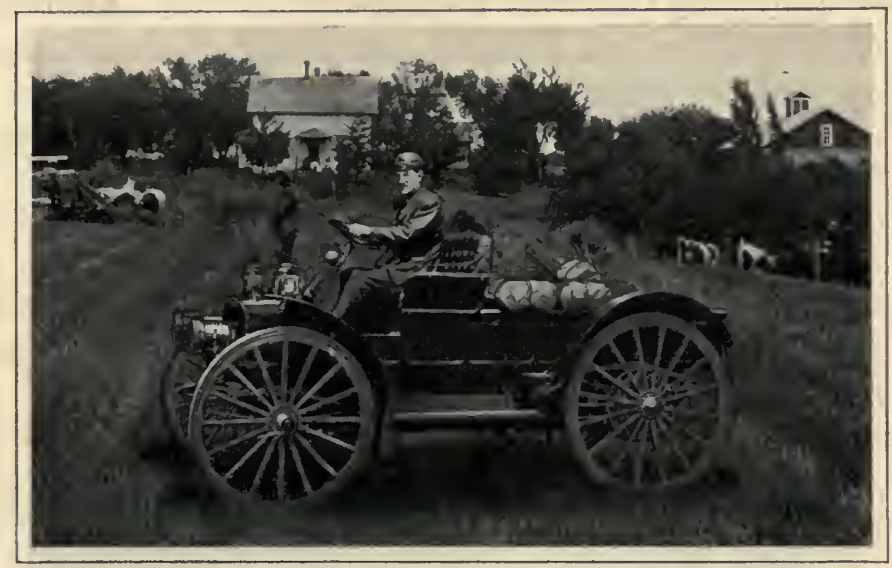

The Automobile on the Farm.

that individual farmers may receive larger returns for their labor. But this community spirit has little chance to develop without good roads.

51. A short history of roads helps us to understand their value. The ancient Romans covered Europe with magnificent paved roads, two thousand years ago, in order to move their armies easily from place to place. But after the Roman Empire fell, these noble highways went to ruin; and for hundreds of years European roads were as bad as America has ever seen. 'The modern good-roads movement began in England, only a little before the time of the American Revolution. Until that time, even England had 
only worn-out dirt roads, over which merchandise had to be carried almost wholly by pack animals, and on which all travel was by horseback or - in favored districts - by a slow coach toiling along four miles an hour behind six horses, with an occasional overturn in one of the many mudholes.

Then, a hundred and fifty years ago, England began to build turnpikes between a few important cities. At first a

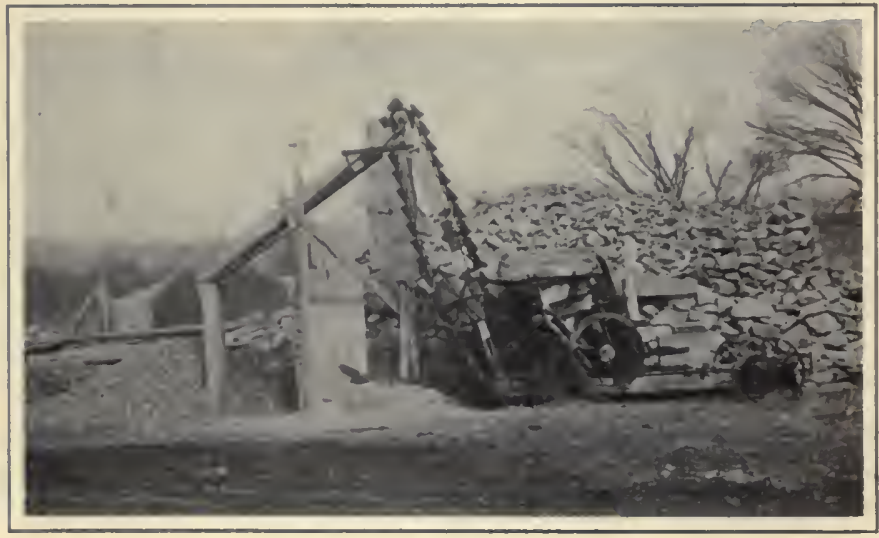

Stone Crusher.

turnpike was merely a dirt road where the earth was turned in toward the middle, so as to "crown" the road and let the rain water drain off quickly into ditches at the side. In places, gravel or crushed stone was added to improve the surface; and new ditches, when needful, drew the water away from the sides of the road. It was found that if water was not allowed to stand on the road or at its side, the surface would not easily be cut into ruts by ordinary travel.

Then, in 1810, John MacAdam, a Scotch engineer, built a few miles of road that made his name famous. He 
placed first in the roadbed a layer of stones about three inches through. These were packed firmly. On this layer he placed another layer of stones about one inch in diameter. These were also rolled or packed firmly. Then a third layer, or surface dressing, of finely crushed stones was placed on top, and likewise packed and rolled. Like the other turnpikes, the road was elevated in the middle and made to slope gradually toward the gutters on the sides, receiving in this way a smooth and hard surface and a gentle crown. The "macadam" road still ranks among the best of-highways all over the world.

Until after 1806 the United States had only dirt roads, from which, at most, the brush, stumps, and rocks had been removed. Even these unimproved roads were few ; and they ran, nearly all of them, east and west - joining some Appalachian district with an Atlantic port.

The first movement in our country for' good roads grew out of the needs for closer union between the eastern Appalachian slope and the Mississippi valley. In 1806 Congress made an appropriation to begin a highway from Cumberland in Maryland to St. Louis; and for thirty years more the government gave many grants of money to complete and repair this famous "National Road," - until its place was more than taken by the growth of railroads.

The present good-roads movement in America is still young. It received its first impulse largely from the new needs of the automobile. Much has been accomplished in the past few years, though we are still shamefully behind European lauds. Perhaps the best result from the movement, so far, is the universal conviction that good roads are vital to the prosperity of any farming district.

52. The further discussion of good roads as rural conveniences will be considered under the heads of economy, construction, and maintenancé. 
a. Economy. Poor roads mean poor economy. The following are the results of an extensive investigation in Europe to determine the average cost of hauling a ton a mile:

Per ton per mile

On earth roads, in poor condition $\ldots \ldots .39$ cents
On stone roads, in good condition $\therefore . .8$ cents

The Department of Agriculture of the United States also made a similar investigation on American roads with the following results :

Per ton per mile

On earth roads, in poor condition .... 25 cents

On stone roads, in good condition .... 10 cents

The results of both investigations show that poor roads are expensive.

b. Construction. In nearly all European countries it has been the common practice to place the construction and maintenance of roads altogether in the hands of expert road engineers, - men who are versed in the technical side of road building. For this reason, European roads are usually in excellent condition. In America, on the other hand, the responsibility for the building and the upkeep of roads is commonly in the hands of men who have never made a special study of the road problem. This is one main reason why our roads are inferior to those abroad.

The essential points to be considered in the construction and maintenance of roads are: (1) grade, (2) foundation, (3) surface, ( 4 ) crown, (5) gutter.

By the grade of a road is meant its rise or fall from a horizontal plane. The ideal grade is one which is practically level. In hilly countries a level grade would cost too much ; but much can be done merely by lowering an elevation here, and raising a valley there, along the level of a road. Often to run the road around the base of a 
hill will be preferable to the shorter distance but steeper grade across the hill.

After the grade has been established, the next thing is to lay the foundation. Turnpikes and "macadam" roads have been explained above. Only à small per cent of American roads, however, are "macadamized." More than $2,000,000$ miles of our roads are "dirt roads." That is, they have no foundation except the natural earth. No

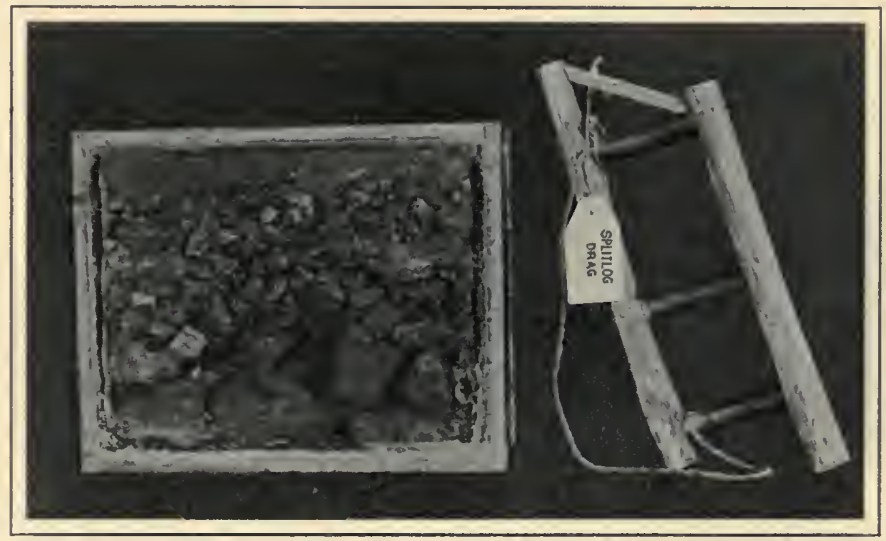

Models Illustrating Road-Building.

Cross-section of macadam road and splitlog drag.

layers of stone are laid down and rolled, to support the smooth surface. The dirt road will probably be for many years the kind used by most farmers. Accordingly it is highly desirable to make it as good as possible.

The dirt road is made by crowning a strip of land from such earth as is found close beside it. If there are gravel pits near by, a little gravel, spread near the middle of the road, improves the surface and helps to preserve the crown. Crushed stone is even better for the surface, but more expensive. Gutters, or ditches, to keep the rain 
water from the road, are even more important than with macadam roads.

c. Maintenance. An ingenious device to keep dirt roads in good condition is the "split-log drag." This eheap and helpful contrivanee was invented, not many years ago, by Mr. D. W. King of Iowa. In its original form the King l'oad drag is simply a heavy log split through the middle, the two pieces being then joined by stout bars of wood about two feet long. This forms a double scraper.

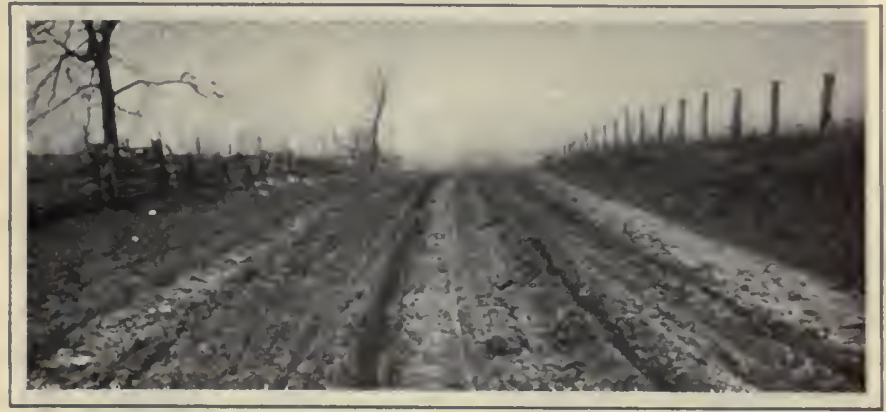

EFFECT OF NARROW TIREs.

Horses are attached to this drag in such a way as to give it a slanting movement. By drawing it along first one side of the road and then the other, especially just after a rain when the earth is soft, the loose dirt is seraped from the side toward the middle. This fills ruts. At the same time, ridges are smoothed away, and the surface is more and more firmly compacted.

This invention is improving thousands of miles of dirt roads. A Massachusetts road official reports an annual saving of five sixths of the road tax by its use. Mr. King's idea has been copied in many kinds of iron drags; and these have generally replaeed the primitive split $\log$. 
53. Conveniences in the House. - Failure to employ modern methods to save labor within the house works a needless hardship upon the farm woman. Houschold conveniences which used to be found only in the city are now often available in the country. Many a farmer's wife finds her life easier and richer thereby ; and many another, who is wasting her energy and impairing her health by struggling and worrying along as her grand mother did, might find great relief in the use of simple and inexpensive conveniences.

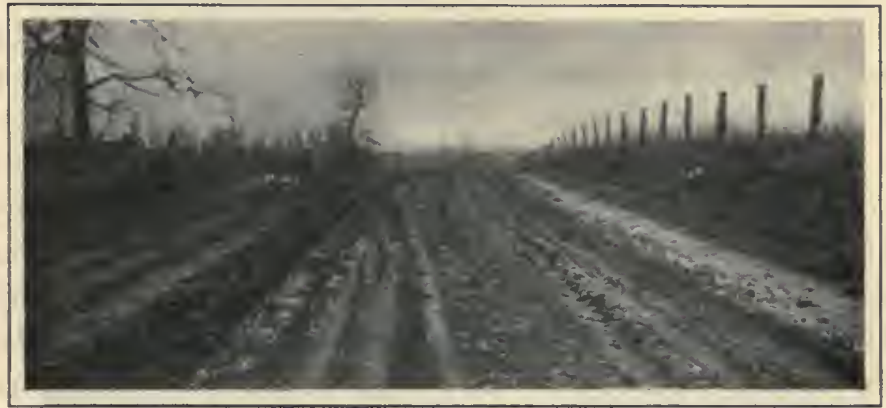

EFFECT OF BROAd TIRES.

This is the same road as in the previous picture. Note the difference in its condition.

a. Running water, hot and cold, both for bathroom and kitchen, saves much drudgery, and means a great deal for the health and comfort and uplift of farm life. Often the house is situated lower than a near-by spring. Under these conditions a few days of labor and a small expense for pipes will bring the water into the house. If it is not possible to use a hillside spring for this purpose, perhaps a hydraulic ram can be installed beside a passing stream to pump water into the house, as is described above ( $\$ 46$ ). And if neither of these simple means is available, then a windmill or gasolene engine will do the work. 
In this last case, an elevated tank for the storage of the water must be built. 'The tank may be placed in the attie, the barn, or an outside tower. Water weighs 62.5 pounds per cubie foot, and a large tank in the attie would hardly be safe. A deseription of the details of construction and operation of such in tank (or of the air-pressure tank that is also used for this purpose) ean be obtained readily from dealers in windmills and in farm water systems. The windmill and tank, and especially the airpressure water system, are somewhat eostly to install. But, like all permanent improvements, they add to the selling value of the property; and if the first cost can be afforded, the subsequent running expense is very small. In any ease, the farmer who provides a windmill for his cattle has no excuse for not extending its use to his wife.

b. Furnace. A furnace in the cellar will heat the entire house. In a large house it does the work of many stoves. Evenness of temperature is desirable in all the rooms that are commonly used. Otherwise the entire family will be likely to live in the warmest room, usually the kitehen. This is not sanitary.

Steam, hot-air, and hot-water heating systems have each their advocates. For a large building with a good flue, steam is generally preferred. Steam heating requires a good fire constantly. Hot air and hot water as carriers of heat are more economical in small houses than steam. Whatever system is used, it should be aceompanied by an adequate system of ventilation. Fresh air within the house is strangely neglected in many eountry houses.

c. The kitchen is the workshop of the home. It may be called the eenter of farm activities. It should be well planned, having a convenient pantry, ice box, modern range, and a convenient arrangement of necessary artieles in constant use, sueh as pots and pans. 
The kitchen range is pcrhaps the most important machine on the farm. It is used much of every day; and so to buy a poor one is wasteful. A good steel range will last a lifetime and give satisfaction daily. The range should be plain; trimmings and ornaments are hard to keep clean and are not artistic. Steel wool is an excellent and inexpensive material for cleaning the range and the metal ware used about it.

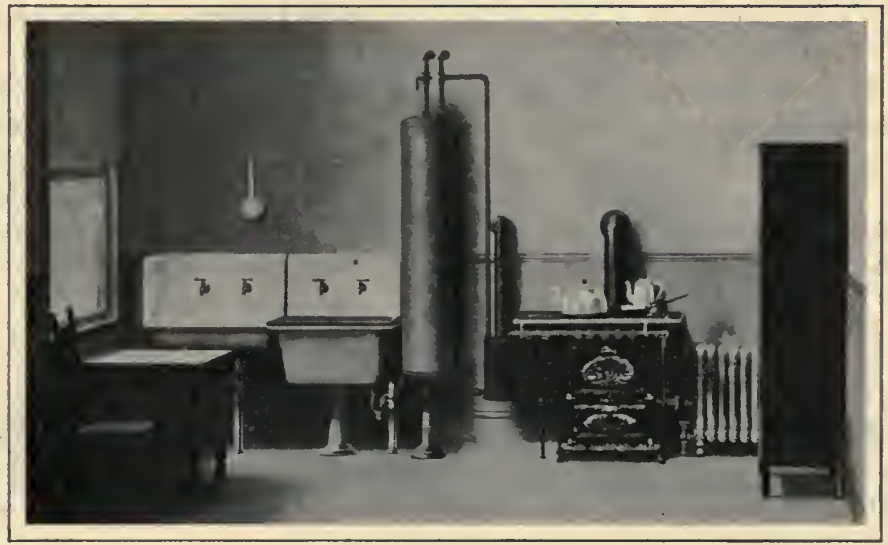

Kitchen Conveniences.

In selecting granite ware, linoleum, rag rugs, ice box, and other necessary articles for the kitchen, there should be harmony in the color scheme. The cost is no more; and such harmony adds much to the attractiveness of the home. A bright and cheerful kitchen, in which convenience, health, and comfort are kept in view, means a great deal in making country life satisfying.

\section{Practical Questions}

1. How does machinery influence drudgery? 2. What is meant by motor power? 3. Name three kinds of work on the farm in which a motor is used. 4. Discuss the use of the gasolene engine. 
5. What farm work night be done by electricity? 6. Discuss the advantage of the rural telephone. 7. Give some facts on the progress mude in installing rural telephones.

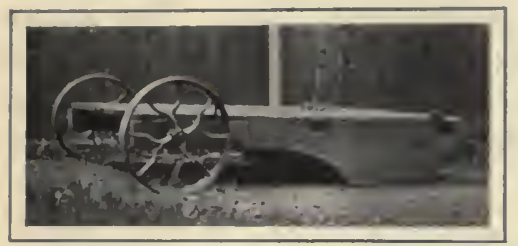

HANDY FARM IMPLEMENT.

This combined sled and wagon is convenient for moving plows, harrows, wood, and so on.
8. In what way is the rural mail service a convenience? 9. How may running water be iptroduced into a rural home? 10. What are some of the advantages of a furnace in the cellar? 11. 1)iscuss five conveniences of the rural kitchen. 12. In what way are good roads conveniences? 13. How do highways of all kinds influence national life? 14. Give some facts showing that good

roads are economical. 15. Describe the construction of a macadam road. 16. What is the "split-log drag" and how is it used?

\section{Home Exercises}

1. Make a list of all the conveniences of your house and harn. Indicate by a sketch the location of all the buildings with reference to the public highway, and indicate on the same sheet where the buildings might have been located with greater regard to present convenience.

2. Draw an outline map of your township, locating the public roads. By using the circumference of a carriage wheel as a unit of measure, estimate the number of miles of highways in the township. Can you find out whether the farm buildings determine the location of the highways or the highways determine the location of the farm buildings? Could the roads be more conveniently located?

3. Let us suppose that it would cost $\$ 100$ to obtain rumning water in the house. Then if your mother's time is worth ten cents an hour, would the labor saved in carrying water equal the interest on the investment?

\section{Suggestions}

1. A trip by the class to some home to study the gasolene engine would be instructive. The name and use of each part should be noted. If this trip cannot be taken, the gasolene engine may be 
assigned to some member of the class whose father has one, as a special desson. A drawing of the parts on the blackboard by this pupil should be expected. But no discussion about the engine in its absence is so valuable as an explanation of it while it is before the class.

2. If possible procure a telephone outfit and explain its construction.

3. Make a model of a macadamized road. This can be done on a board placed on the desk. Place some clay on the board for the bed. Upon the clay arrange different sized stones in layers. On top put a dressing of sand. It can readily be explained how the large stones in

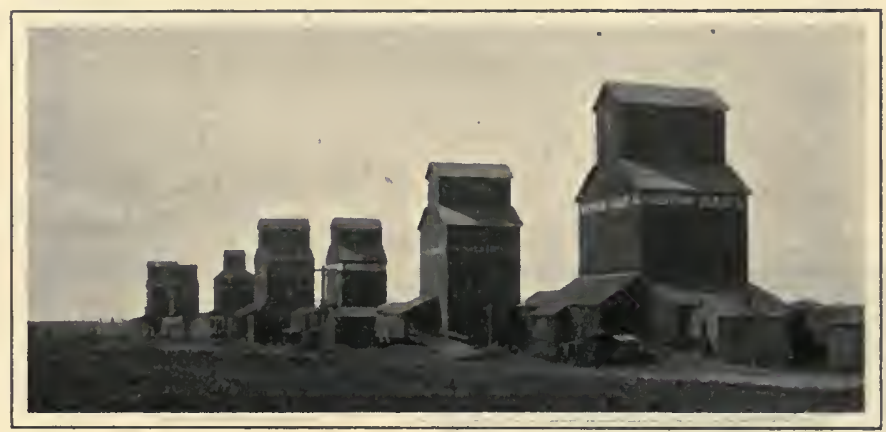

Grain Elevators.

A convenience in the Wheat Belt.

the bottom prevent the rise of water from below and thus keep the road dry and hard. Sprinkle some water on the completed model. In a short time pull apart a section of it. Note the absence of water between the large stones.

4. Make a model "split-log drag" from the description given. Explain its operation on the model road.

\section{REFERENCES}

Constructive Rural Sociology. Gillette.

The Farmstead. Roberts.

Cyclopedia of American Agriculture. Bailey.

Country Life. The Anuals, March, 1912. 
Farmers ${ }^{\circ}$ Bulletins. Washington, D. C.

126. Practical Suggestions for Farn Buildings.

270. Modern Conveniences for the Farm Home.

338. Macadam Roads.

342. A Model Kitchen.

505. Benefits of Improved Roads.

Sexage Disposal for Rural Homes. Wisconsin, No. 34.

Reading Courses for Farm and Farm House. Ithaca, N. Y. 


\section{PART II}

\section{THE SOIL AND ITS IMPROVEMENT}

\section{CHAP'TER VII}

\section{THE SOIL}

A soil, to be fertile, must above all things be light and pliable, and this condition we seek to bring about by the operation of plowing.

- VIRGL.

54. Soil and Life. - The ancients used to say, "The earth is the mother of us all." This statement is literally true. The soil supplies us with the means of life. In great measure, all living beings are organized soil particles. Plants and animals and human bodies are made up of substances which occur in a simple state in nearly every handful of earth. Man cannot use these simple substances directly as food, but plants can and do; and man

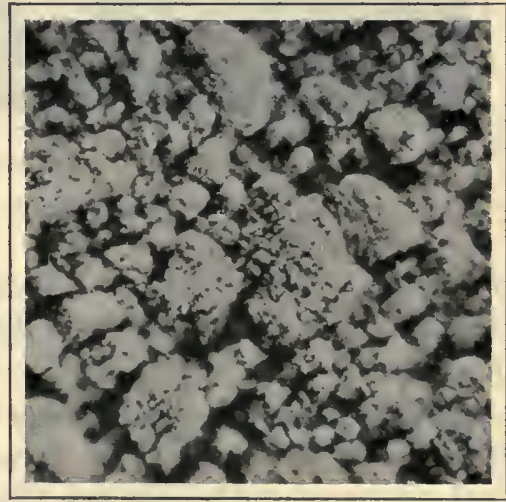

Clod of Soll Magnified.

This soil is said to be not "in good tilth," as the particles are bunched, not loose and granular. and all the higher animals live on plants or on other animals which thrive on plants. 
Not only does the soil supply the materials out of which we build our bodies, but it also produces the substances with which we clothe our bodies, - cotton, linen, silk, and wool. Even such articles of commerce as lumber are gifts of the soil to man. Many articles, too, which are dug out of the earth (not, however, from the "soil," as the farmer uses the term) are useful to us. Iron, coal, paint, building stones, cement are either rocks or their

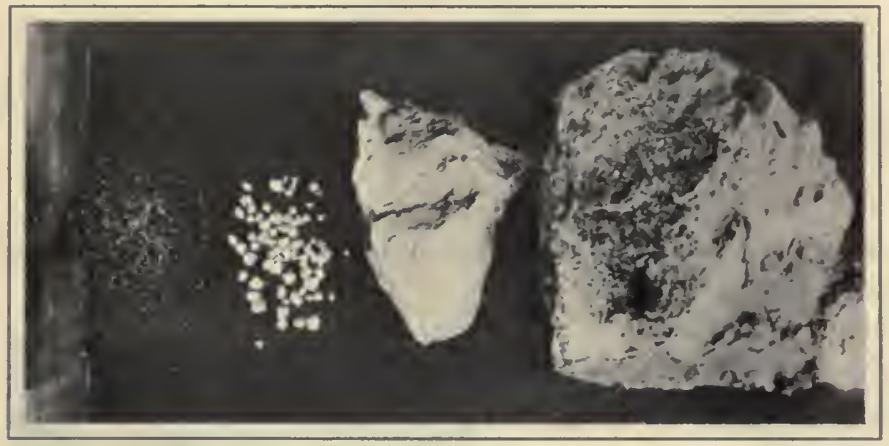

Relative Sizes of Soll Particles.

From left to right: clay, silt, sand, gravel.

products. And rocks, as we shall learn, come in time to form the bulk of the soil. Truly, "the earth is the mother of us all."

55. What Soil Is. - The term soil is used frequently in this book. What is soil? It may be defined as the loose surface material that covers the land and in which plants usually grow. Pick up a handful of soil and examine it. It is made up of many different substances, - little stones, gravel, sand, and, if allowed to dry, of a fine powder. Bits of partly decayed plants and parts of insects may also be noticed if we use a microscope. If we examine the dust with a magnifying glass, it is seen to be composed of par- 
ticles of different sizes, and each particle looks much the same, under the glass, as do the larger ones to the naked eye. The spaces separating the minute fragments are, of course, filled by air or water; and we know that soil contains moisture, because so often it is damp. Soil, then, is surface material, made up of waste or fragments of rocks, of organic matter, and of small particles of air and water.

56. The varying degrees of fineness or coarseness of the soil particles are expressed by the names clay, silt, sand, gravel, and stone.

a. Clay is formed of very small soil particles. They are so small that it would take at least 5000 of them laid side by side to reach one inch. The largest particles of clay, the red

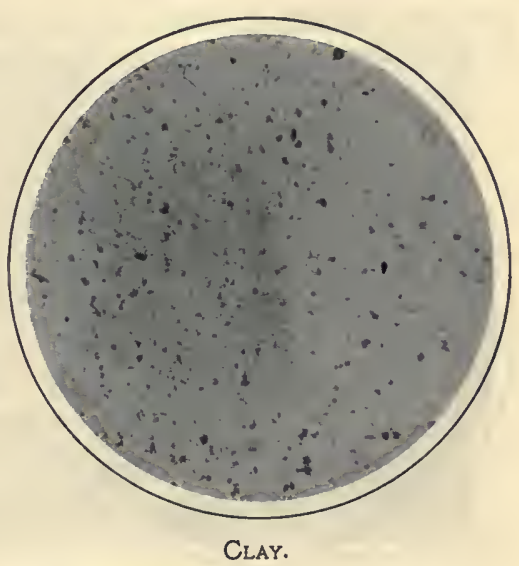

The largest particles of clay are about $3 \frac{1}{300}$ of an inch in diameter. corpuscles of our blood, and the green corpuscles (chlorophyll bodies) of plants are all about the same size. If a bit of moist clay is rubbed between the fingers, it is found to lack grit. A clay soil is hard to drain because its very fine grains will not allow the water to pass through. In drying, clay tends to form a hard, compact mass, through which it is difficult for plant roots to penetrate. If plowed when wet, it becomes puddled, as when a small boy makes marbles out of wet clay. Clay lands are cold, stiff, heavy, and difficult to work, although they hold water well and are unusually rich in plant food. 
b. Silt is a term used to define soil particles next larger than clay. A silt particle is so small that it would require 500 of the largest ones placed side by side to extend one inch. A silt soil is slightly lighter and more porous than a clay soil. Like clay it retains moisture and fertility very well, and is, therefore, well adapted for corn and grain, especially during dry seasons. Both clay and silt if properly worked will beeome granular or open; that is,

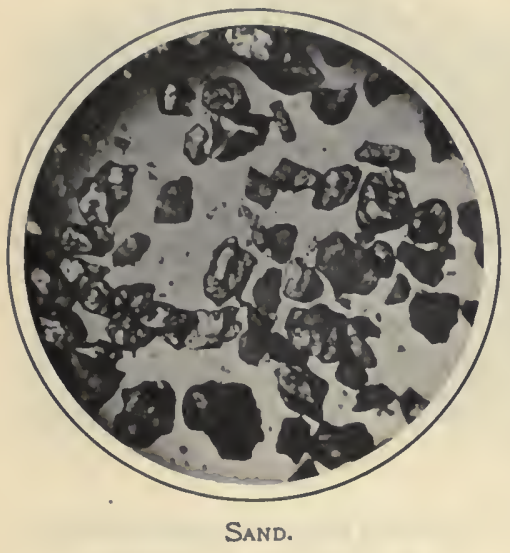

Seen under the microscope. many of these tiny particles unite into little masses or granules and thus resemble sand.

c. Sand. Soil made up of particles larger than those that form silt is called sand. The United States Bureau of Soils recognizes different grades of sand based on the size of the particles. Sand particles run from one twenty-fifth to one twohundredth of an ineh in diameter. Soils containing considerable sand are called light, because they are easily worked. A cubic foot of dry sand, however, really weighs more than a cubic foot of dry elay. Pure sand is mostly quartz (a mineral closely related to glass), and it contains little food ready for plant use.

d. Gravel. Tiny bits of rock between one twelfth and one twenty-fifth of an inch in size form gravel. Gravel differs still more from elay than sand does, and it dries out even faster than sand.

e. The term stone in agrieulture refers to all rock 
masses over one twelfth of an inch in diameter. Very large stones are called rocks. Stones form a surface cover to prevent evaporation from the soil beneath them, and so far they are helpful to farming. A boy sometimes likes to turn over the flat stones in a field to see the insects scamper away from beneath it. 'They had been drawn to the place by the moisture under the stone.

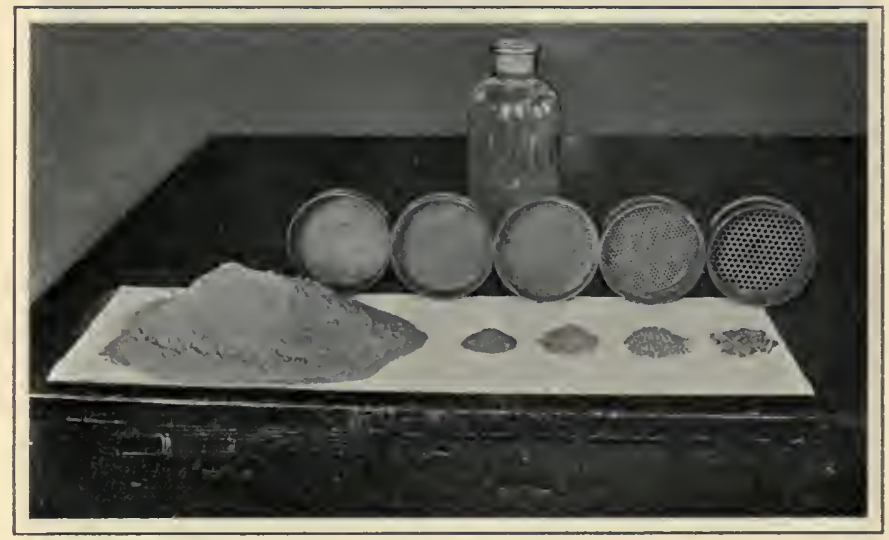

BOTTLE OF SOIL SIFTED.

Each pile is in front of the sieve through which it came.

57. Where Do the Rock Particles Come From? - Except for the size of their particles, there is little difference, as far as appearances go, between sand, silt, clay, gravel and stones. It is possible to go to a ledge, and, detaching a large, rocky mass, to crush it with a hammer, first into stones, then into gravel, next into sand, then into silt, and finally into clay. In fact, when rocks are crushed for road building or concrete work, this is what the crusher actually does. (The crusher, of course, makes all the different sizes at one blow.)

Now there are natural forces that produce the same 
result as the hammer or the road crusher. 'These forces, however, act more silently, and their operation is frequently unnoticed. When the earth was young, there was no soil upon it, but only a hard, rocky crust, like that which often appears on hillsides where the soil has been removed. Silently and slowly, through long periods,

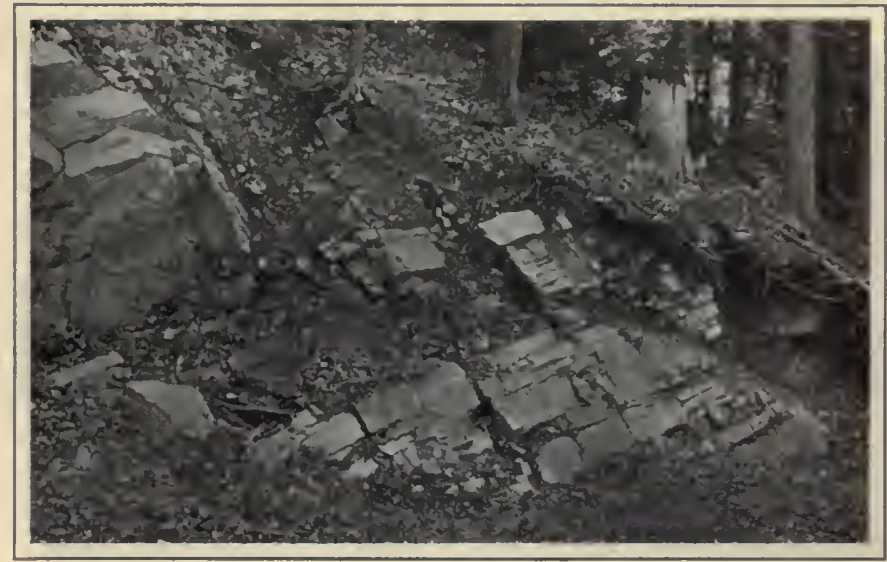

\section{DisintEgRATION.}

A limestone ledge breaking up and forming soil.

nature crushed and refined the outer surface of these rocks by means of two different processes : namely, disintegration and decomposition.

a. Disintegration is a physical process. That is, by it rock particles are pulled apart without their nature being changed. You have perhaps noticed a bottle of water left standing outdoors for a few days during a cold part of the winter. The water froze and broke the bottle. A tremendous force must have been exerted in breaking the bottle. When the temperature of water drops from four degrees centigrade to zero, or the freezing point, it 
expands; and as it expands it exerts enormous power in order to find room for itself. Go to a quarry and notice the numberless cracks, joints, and fissures in the rocks. These openings were formed mainly by freezing water during the winter. Many rock masses are rent asunder by this power. Usually, at the foot of a rocky ledge we

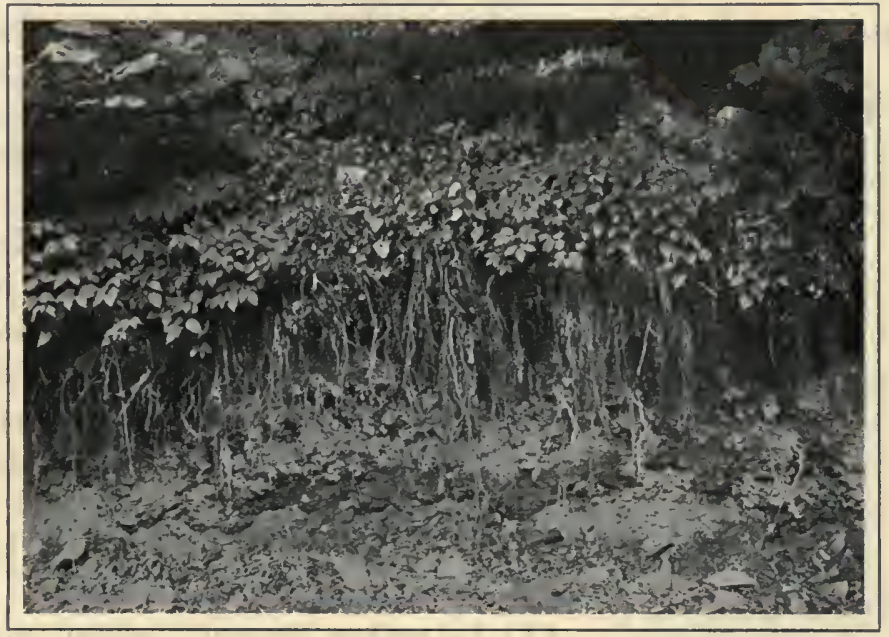

How ROOTS Hold the SOIL.

The soil has been removed from these roots to show how they penetrate and prevent its washing away.

may see large masses of fragments which are the results of this kind of disintegration.

In our science studies we have learned, no doubt, about many other physical forces that break up the solid rocks. We know that glaciers have acted as gigantic plows in breaking loose and carrying away and crushing up enormous quantities of rocks; and we know, too, that erosion is still working, more gently but unceasingly, to the same end. 
b. Decomposition is a chemical process; its work is done by changing the composition of the particles. Rocks rust, as iron does. That is, their surface particles combine with oxygen from the air. Then the powdery rust particles are easily removed. Rocks are also acted upon by certain acids which the decay of organic matter forms in the soil. In this way parts of the rocks are dissolved; and then they are carried away by running water. De-

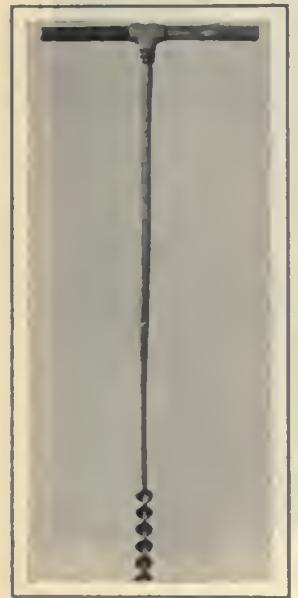

SOIL Auger.

Used for examining soils at different depths. composition and disintegration frequently work together, in this way, on the same rock, each aiding the other in forming soil.

58. Humus. - Humus is partly decayed vegetable and animal matter in the soil. It is found in a pure state around rotten stumps. The greater part of humus comes from plants that have decayed in the presence of moisture and of the oxygen in the air. Humus is a very important part of the soil. It has the following uses :

(1) It makes the soil lighter and more porous, thus improving its condition.

(2) It helps the soil to hold heat and moisture.

(3) It supplies food for growing plants.

(4) It promotes the growth of useful bacteria.

Humus is obtained from roots, stubbles, and manures, which are plowed under and left to decay in the soil. Usually it makes the surface soil darker than the subsoil, or what lies below the reach of the plow. In fact the eolor of the soil is often taken as an indication of the amount of humus present. 
59. The Kinds of Productive Soil. - For farming we do not want the soil to contain much stone or gravel, nor do we want pure sand or pure clay. We want a mixture of sand, silt and clay, with some humus. Such a soil is called loamy. All productive soils are usually loamy.

Loam is a soil that is intermediate between sand and clay. It is not so open and porous as sand, or so stiff and tenacious as clay. That is, it is a mixture of sand,

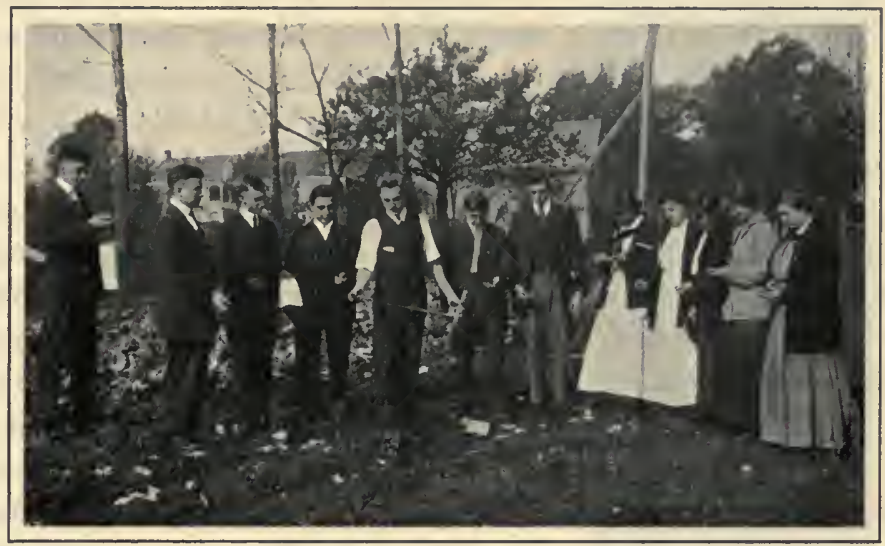

Studying Solls.

Students using the soil auger to get samples of soils.

silt, and clay, together with some humus and of course with air and moisture. The major portion is silt. A sandy loam contains more sand than clay; a clay loam, more clay than sand. For general farm purposes a medium or average loam is preferred, especially if it contains a large amount of humus.

60. Soil Air. - The spaces between soil particles are occupied either by air or water. Both are necessary for plant roots. If we completely submerge, the roots of a potted plant in a pail of water, the plant soon turns yel- 
low and dies. That is because the roots can no longer get air. Low areas in fields that are flooded during the summer show the same result. Trees along the sidewalk often die beeause the pavement shuts off the air from the roots. Certain trees, like willows, thrive beside streams, because their roots can use some of the air in the running water.

Soil in a good state of cultivation has nearly half its volume filled with air and water. Mixed with this "soil air" there is usually more carbon dioxide than is found in the air above the surface. This larger amount of earbon dioxide eomes from the decay of vegetable matter in the soil.

61. Water in the Soil. - Soil is not productive unless it contains water. All other needful ingredients may be present in proper quantities, and yet the soil will give sinall yields if moisture is insufficient. There is an old saying that soil, like a chain, is as weak as its weakest link, and that the moisture is often the weakest link in soil fertility.

Plants use an enormous quantity of water in their growing season. An average crop of corn needs 8 inches of rainfall to mature it, allowing notling for evaporation or percolation. It has been estimated that an acre of cabbage draws from the soil, and throws off into the air, 500,000 gallons of water in one summer, and that an oak tree with 700,000 leaves transpires in this way about 180 gallons of water daily. Plants must have this vast amount of water for a number of reasons. For instance, it is the water within them which transports the food material from the soil to their leaves. In order that a plant may get out of the soil something like an ounce of earthy matter it must absorb nearly a barrel of water for this purpose alone.

Plant substance, too, like the human body, is largely 
water. Nine tenths of the weight of some common plants is water. In a very dry season, or in a dry place, too much of this essential water evaporates from the body of a plant, and the plant wilts. This is because the water was needed to fill out its body, and to give it substance and stiffness.

Water exists in the soil both as free water and as film water. If a tin can is filled with pebbles and water, and if then a small hole is made in the bottom of the can, the free water will run out, and leave the film water eoating the pebbles. So while the free water can be drained off the land, the film water eannot be.

62. Capillary Water. - Film water is often ealled capillary water. The word "capillary" means hair-like, and it refers to the hair-like, irregular spaces between the small soil particles. It is in these spaces that film water, or capillary water, is found. By placing the corner of a blotter in a little water, one can see how capillary water behaves. The water rises through the blotter rapidly at first, and then more

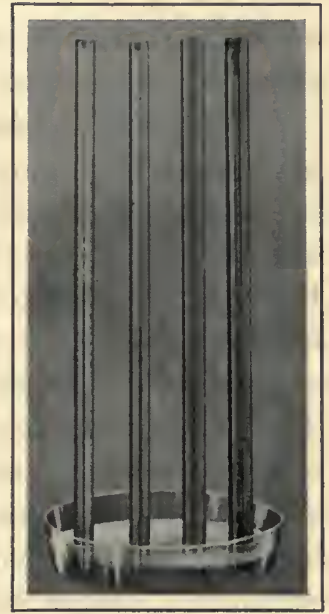

Capillary Attraction.

The height of the water in the tubes varies inversely with the size of the bore.

slowly. The rise is due to the attraction which the paper fibers have for the water films. This is known as film attraction, or capillary attraction. In the soil, capillary attraction tends to transfer water from its moist parts to its dry parts. This transfer may be in any direction, - up, down, or sidewise.

The amount of capillary water which a soil can hold 
depends on the extent of surface of the soil particles. $A$ cubic foot of coarse sand will hold one third its bulk of water. Only a part of this water, however, is capillary water, that is, water which clings to the surface of the grains. We have learned in arithmetic that surfaces increase as the squares of their like dimensions while solids increase as the cubes of their like dimensions. A grain of sand has a greater surface in proportion to its size than a pebble has. Therefore a cubic foot of sand will hold more capillary water than a cubic foot of pebbles.

63. Preventing Loss of Capillary Water. - Farmers give a great deal of attention to preventing the needless escape of capillary water from the soil, since nearly all the water absorbed by plants is of this sort. When the sun shines bright again after a heavy rain, the surface of the soil soon becomes hard and compact, forming a crust. Pick up a small block of such crust and look for air spaces in it. They are exceedingly small. In other words, the soil particles are fine and close together. Such a condition (according to the statements in the last paragraph above) hastens the movement of soil water to the surface, from which it is evaporated and lost to the crop.

The way to prevent this rapid loss is to break up the crust into loose particles with the hoe, harrow, or cultivator. By the use of these tools a dry mulch is formed at the surface of the soil, and the widely separated particles of this mulch draw up the capillary water from below very slowly. Of course, some moisture continues to evaporate; but, by renewing the mulch every few days, the loss can be kept very small. Top dressings of straw or manure, and cover crops like rye and clover, are also effective mulches. Moreover, when plowed under and turned into humus, such substances enable the soil to hold more capillary water. 
64. Free water shuts out the air from the soil. Bacteria must have air ; and so free water hinders the growth of soil bacteria. More heat is necessary to warm a quantity of water than to warm the same bulk of earth; and so free water makes the soil cold. Frequent rains in spring sometimes flood fertile parts of a farm and delay seeding enough to shorten the growing season seriously or even fatally to the year's crop.

In these three ways, then, free water on the soil is harmful to farming. It is capillary water upon which nearly all farm plants depend. But the supply of capillary water is kept up from the free water. A chief problem for many farmers, therefore, is to keep up the proper supply of capillary water by securing enough free water at all times without having too much of it at any one time.

If the water from the clouds would fall in every place at the desirable time in quantities just sufficient to supply the capillary water needed by the crops, there would be no free-water problem. But rains are not always dependable; and some land needs more water than other land close by that gets the same rainfall. So the farmer must often drain lands which are too wet, or irrigate lands which are too dry.

65. Drainage. - There are nearly $75,000,000$ acres in the United States which are unproductive because they are too wet and marshy. "Bottom lands" and swamp lands are common in almost everystate. In many districts, entire cultivated fields, or parts of fields, are drowned during parts of the year. Some of this wet land cannot be drained, because there is no lower place near it to which the water can be carried, but much of it can be drained.

Drainage carries away the useless or harmful water. It lowers the "water table," or the level at which free water stands in the ground. Thus it opens to cultivation many 
districts that could not otherwise be farmed at all; and on old farm lands it corrects the three evils named above due to too much free water. That is, it admits air and bacteria to more soil, and so gives the plant roots more soil to feed in. It makes it easier for the sun to warm the soil. It lengthens the growing time upon certain lands.

Artificial drainage is not needed in an open, porous soil, such as we find in sandy or gravelly regions. It is the hard, compact, clayey soils which hinder the escape of the surplus water and which need to be drained by the farmer. There are two methods of effecting drainage, - the open method and the closed method.

66. Open drainage means the use of open ditches or surface drains as water carriers. These ditches are expected only to remove the surplus water in times of flooding. Their size and cost depend entirely on local conditions. The greater the territory to be drained, the greater must be the capacity of the ditches. In the Central West many miles of these surface drains, extending through many farms, have been constructed by farmers working together. Side or lateral drains run into the mains. The main ditch may be perhaps eight feet deep and twenty feet wide. Large dredging machines are used in digging these large ditches.

The first cost of open ditches is less than that of closed drains; but they take up a good deal of the farm area, cut up the farm inconveniently, and cost much labor and trouble to maintain.

67. Closed Drainage. - The second method of effecting drainage is by closed drains underground. This method has certain advantages over the former. No valuable surface land is used; the farm is not disfigured and cut up; and if the drains are properly made, they last a life time. The most simple kind of closed drain is made by plow- 
ing and shoveling out a deep gutter, as for a surface ditch, and then partly filling it with large stones, which are afterward covered with earth and soil. The water from the soil at the sides drains into this stony space readily, and escapes at the bottom or along the slope.

Where stone is at hand, this kind of drain costs only a little more than the open drain. In time, however, fine particles of earth and soil will work down between the

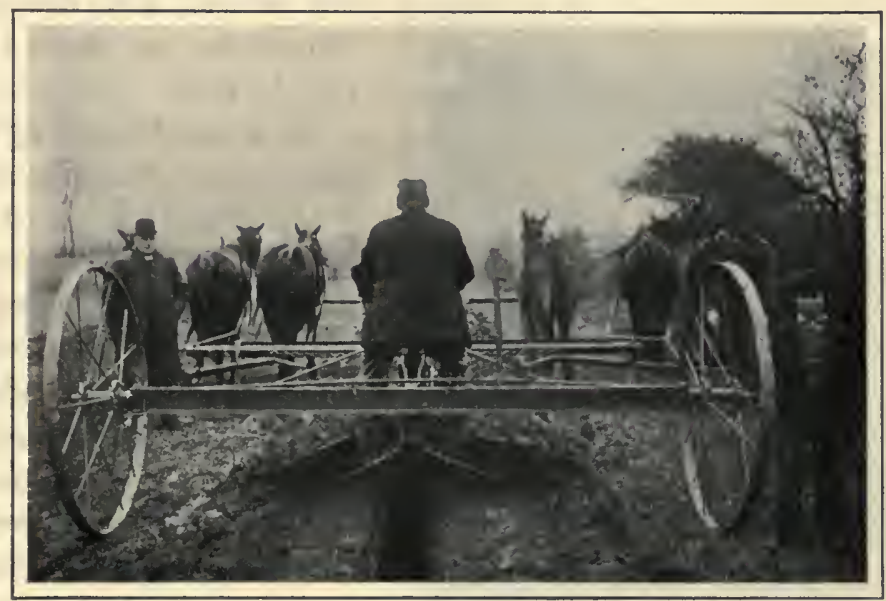

Ditching Machine.

This saves time, labor, and expense.

stones and interfere with the further passage of water. The stone-filled drain is not so lasting as some other kinds of closed drains. Hollow tiling makes a better filling for the drain than stone, and it is now used extensively.

These tiles, made of concrete, are made in sections only two feet or three feet long, and with different diameters. A large main ditch may call for a twelve-inch tiling, if much water is to be carried; but the lateral drains will use smaller tiling. 
68. Number and Grade of Drains. - In heavy clay soils, more drains are needed than in soils where there is an admixture of sand, because in the latter natural drainage is better. In elay bottom it is a good plan to place the side drains about sixty feet apart, while in lighter soil one hundred feet or more is the proper distance. The grade or fall of the main ditch should be at least an inch

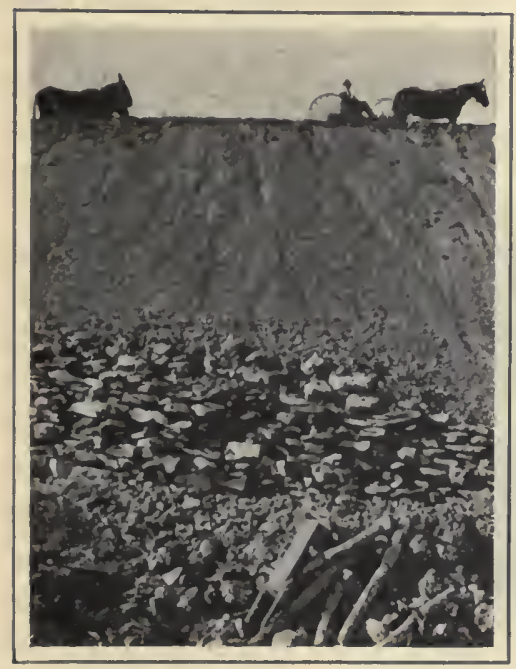

Part of an IRrigation Dam.

to eighty feet, and the fall of the side drains should be an inch to twenty feet.

69. Does Drainage Pay? - The drainage of water-soaked lands yields a large income on the investment. Professor Waid describes some experiments made by the Massachusetts Experiment Station. Ordinary land was used for the test. Before drainage it had produced a rotation of corn, potatoes, rye, and elover. The same rotation was followed for four years after drainage. The seeond four years gave an increased yield of twenty-five per cent, on the average, over the average yield of the four years before drainage. Professor Waid shows that this increase, at market prices, amounted to a profit of forty-one per cent on the cost of drainage.

70. Irrigation is used, as drainage is, to secure the proper amount of soil water; but it is used under conditions just the opposite to those that make draiuage profitable. Irri- 
gation is the process of supplying dry lands with water sufficient to meet the needs of the growing plants.

Irrigation is practiced in certain sections of the West on a large scale. Immense quantities of water are conveyed directly to the farmer by ditches from distant sources, lakes, rivers, or artesian wells, - having suitable elevation. Occasionally it is necessary first to pump the water into large reservoirs to obtain a suitable supply and elevation. Millions of dollars have been spent by the government and by private individuals in installing irrigation plants; and thousands of acres which would otherwise be unproductive are in this manner made to produce luxurious crops.

Water gates regulate the flow of water from the reservoir into the main ditch, which carries it toward the plains below. At proper distances, lateral ditches branch off on either hand, and from these again new laterals, until the land is intersected by a network of canals. Each ditch, large or small, has its water gate, and some ditch reaches each farm in the district. At a given farm, the water is admitted from the public ditch to the farmer's private ditch when needed; and from this ditch it is conducted over the land at will by shallow furrows to be taken into the soil.

A similar system of irrigation is employed, on a much smaller scale, in many ordinary farming districts by the truck farmer. Truck plants are sensitive to drought, and if the trucker must depend on the uncertain rainfall, his profits will often disappear. Irrigation enables him to do away with this uncertainty.

In place of this ditch-and-furrow irrigation, some truckers use an overhead system which supplies the water in imitation of natural rain. Perforated pipes, an inch or tivo in diameter, are erected on supports, high enough to allow cultivation of the soil beneath them, and they are so arranged over the field that by operating a lever one or 
more séries of these pipes will sprinkle water over parts of the garden patches. Except on eloudy days the sprinkling is done during the morning or evening.

\section{I'ractical Qunstions}

1. In what sense is the earth a mother? 2. Name all the different articles obtained from the earth. 3. Can you think of anything more important than soil? 4. Define soil. 5. Of what substances is soil composed? 6. What is soil texture? 7. Explain the terms clay, silt, sand, and gravel. 8 . How is soil formed? 9. Distinguish between disintegration and decomposition. 10. Of what value is humus? 11. How would you show the need of soil air?

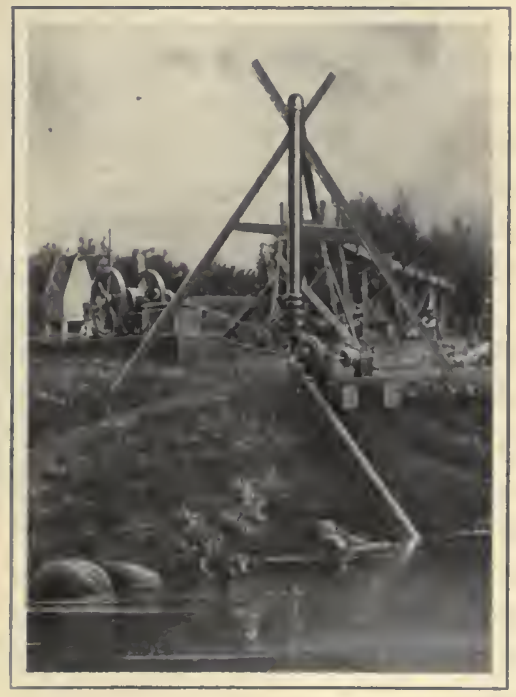

Pumping Water to IrRigate Farm LANDS. 12. How may a needed substance in the soil be the weakest link in soil fertility? 13. Fxplain the difference between film water and free water. 14. How do farmers prevent the loss of capillary water? 15. How does free water injure crops? 16. Explain the purpose of drainage. 17. How does irrigation differ from drainage?

Home Exercises

1. Make a sketch of your farm, or of a farm you know, marking off the fields. Look earefully for differences in the soil texture of the different fields. If you notice any differenees, indicate them on the sketch.

2. Take a sample of the darkest soil you can find on the farm and a sample of the lightest colored. Examine then earefully and note the differences. From what parts of the farm were these samples taken?

3. What is the average thickness of the surface soil on your farm?

4. Does any part of your farm need drainage or irrigation? 


\section{Suggestions}

1. The study of the nature of soils can be made most interesting and profitable, if the pupils are taken on a soil excursion. A spade or soil auger should be taken along. Note which is the lighter in color, the surface soil or the subsoil. Note, too, which contains the greater amount of humus, and how far down the roots of different plants extend.

2. To show the action of capillary water, fill three lamp chimneys, one with fine sand, another with clay, and the third with gravel. Press down the soil somewhat with a stick. Tie cheesecloth over the top of each chimney, and invert them in a shallow dish of water. Note how rapidly the water rises in each. Explain the reasou for this difference.

3. To show that soil contains air, throw a small handful into a glass of water and watch the air bubbles rise. To measure the exact amount of the soil air, fill a quart jar with the soil to be measured. From another jar add water slowly nutil no more will be absorbed. The water takes the place of the soil air. Find the per cent of soil air.

4. To show that soil water contains plant food, take a glassful of clear water from a ditch or poud and evaporate it for several days on a fairly warm part of the stove. Do you notice a deposit on the side of the glass? What is it?

\section{REFEREXCES}

Fertility of the Soil. Roberts.

Soils. Burkett.

Soils and Crops of the Farm. Morrow and Hunt.

The Fertility in Illinois Soils. Bulletin No. 123.

Soils. Minnesota Bulletin No. 41.

IIumus in Its Relation to Soil Fertility. Year Book, 1895.

The Storage and Use of Soil Moisture. Nebraska Bulletin No. 140.

Farmers' Bulletins. Washington, D. C.

245. Renovation of Worn-out Soils.

524. Tile Drainage on the Farm. 


\section{CHAP'TER VIII}

\section{PLANT FOOD}

It is not the land itself that constitutes the farmer's wealth, but it is the constituents of the soil which serve for the nutrition of plants.

- Liebio.

71. The Soil and the Plant. - In the last chapter we studied a few points about the soil, and learned anong other things that the soil is the natural home of plants.

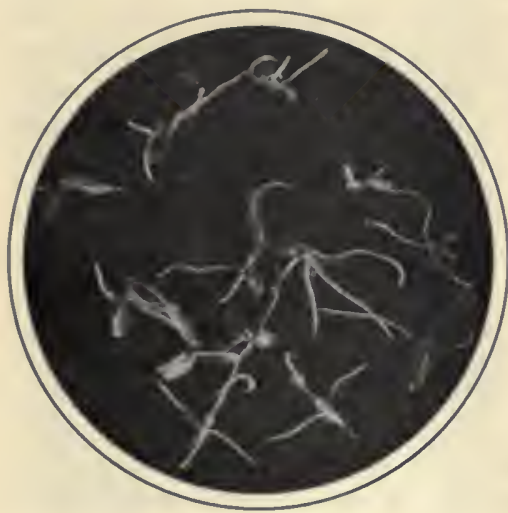

ROOt Hairs on Wheat Roots.

Through the walls of these tiny hairs plant food passes to the root proper.

We will now inquire more especially what the plant finds in the soil to feed upon.

Plants modify a part of their body into what we call roots, to take hold upon the soil and to secure certain kinds of nourishment from it. The roots of plants must extend far enough into the soil to enable their thread-like outgrowths, called root-hairs, to reach the desired nourishment; and the soil should not be so hard as to prevent them from penetrating into it for the required distance.

Nearly all the common farm plants feed from the "surface soil." 'This is the part we plow and pulverize. 
When the soil can be easily pulverized, and contains plenty of organic matter, it is said to be in good tilth. This condition is favorable for root growth. It enables the roots to extend themiselves more readily between and around the loose particles, and it makes easy the

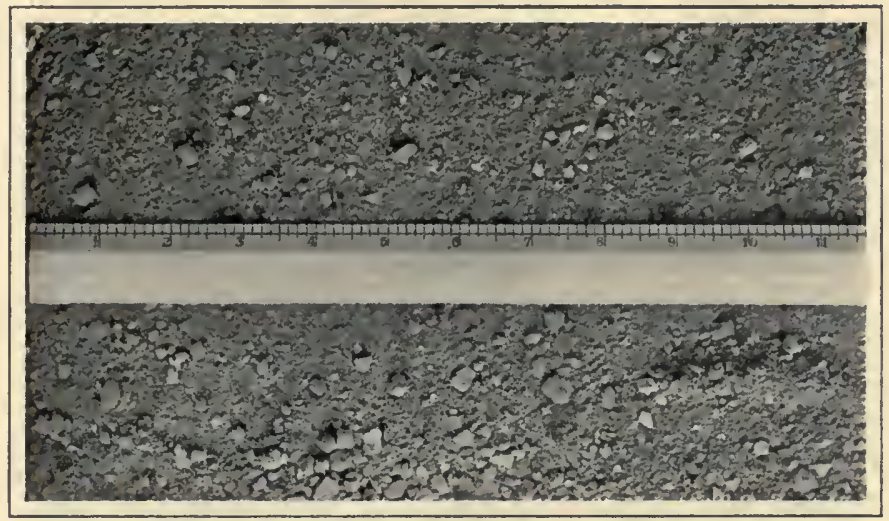

SOIL IN GOOD TILTH.

work of the delicate root hairs through which the plant absorbs its food.

Plants require not only that the soil be in good tilth, but also that it contain such plant foods as they need and that it have these foods in such a state as to be usable. Soil water holds some carbon dioxide (a gas), which comes from the air, and various mineral substances in solution - as water in a cup may hold salt or sugar in solution. Plants absorb soil water through their roots. Most of it they give off again through their leaves - but first they take from it such of the minerals as they can use for food. A fertile soil must have a sufficient supply of soil water and the necessary mineral substances for this water to take up to feed plants. We will now see what these plant foods are. 
72. Plant Foods. - About eighty distinet elements ${ }^{1}$ are known to the ehemist. Thirteen of these are used by plants. The following table names these thirteen and gives some faets about them.

Nitrogen
Phosphorus
Potassium
Calcium
Chlorine
Iron
Magnesium
Silicon
Sodium
Sulphur

These four elements are supplied by the

Nitrogen

Carbon

Hydrogen

Oxygen

These four elements are supplied by the soil, but soil is likely to be deficient in one or more of them, and then the furmer must supply the need.

These six elements also are supplied by the soil. None of these elements need be supplied by farmers.

air and the water. They are always present if the soil is not lacking in water. A combination of carbon and oxygen forms the gas called carbon dioxide; and a combination of lyydrogen and oxygen forms water.

The farmer, then, needs only to attend to the supply of soil water and of the four elements in the first group above. The supply of soil water has been discussed, briefly, and the matter will receive more attention later. The supply of ealeium, the main substance in lime, and one of the four important elements, will be treated in the next chapter. The present chapter will now deal with the other three elements, - nitrogen, phosphorus, and potassium. These are sometimes ealled the three great agricultural elements.

1 An element is a substance which cannot be resolved into different kinds of substances. Air was once called an element, but it is no longer called so, because chemists have found how to separate it into different gases. Each of these gases, however, like oxygen or nitrogen, is an element. 
73. Nitrogen is a gas, slightly lighter than air. It lacks color, taste, and odor. It does not combine easily with other substances, and its compounds break up very readily. It makes up four fifths of the air, and it is probably the most important food element for both plants and animals. Neither plants nor animals, however, can make use of it in its free state, as it is found in the air. They ean take it only from certain compounds, and the compounds of

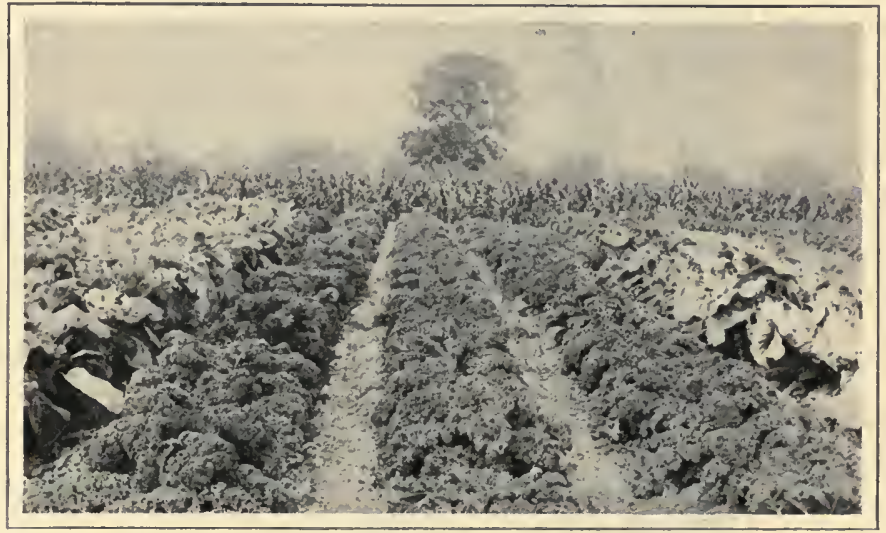

Curly Kale.

The heavy crop shows abundance of plant food in the soil.

nitrogen which are usable by plants are not eommon. Wuch money and effort are expended to get these compounds into the soil.

74. Nitrogen enters the soil to become available for plants in four ways: (1) through the use of barnyard manure; (2) through the deeay of vegetable matter in the soil; (3) through commercial fertilizers plaeed in the soil; and (4) through the use of legumes, such as clover and peas, with eertain bacteria on their roots.

a. Ammonia gas can often be smelled in fresh manure 
piles. This gas contains about eighty per cent nitrogen. The soil absorbs ammonia to a marked degree and changes it to available compounds of nitrogen. Even ammonia itself is slightly available for the uses of plants, but not

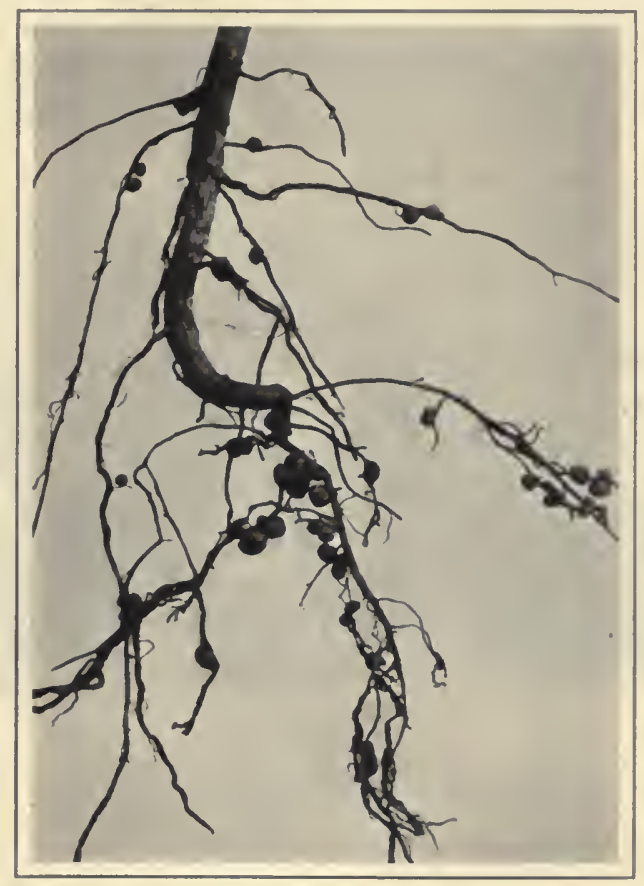

Nodules on BEAN ROOTS.

Where the nitrogen-gathering bacteria grow.

to the extent of other nitrogen compounds, which are called " nitrates."

b. Ammonia is also set free for plant growth when the decay of vegetable matter forms humus. In a general way it may be said that the amount of nitrogen in the soil is in proportion to the humus it contains. 
c. Nitrate of soda, or Chile saltpeter, contains about fifteen per cent nitrogen; and dried blood, tankage, and bone meal carry from three to fifteen per cent nitrogen. These last three fertilizers are products of the slaughterhouse. In all these commercial compounds, nitrogen costs three to four times as much as an equal weight of phosphoric acid or potash in their commercial compounds.

$d$. The best way to get nitrogen into the soil is to grow clover or alfalfa or other leguminous plants in a rotation upon it. The ancient Chinese said, "Beans are good for the ground"; but they did not know why it was so. We know now that plants of the clover family assist the growth of certain bacteria in the soil about their roots, and that these bacteria "fix" free nitrogen from the air into compounds suitable for plants to use. Nearly all crops leave the soil poorer; but clover crops usually leave it richer by the addition of this costly and essential food for other crops.

75. In the world of life, nitrogen is the great builder. All protoplasm, the primary substance out of which all organisms build their bodies, contains this element. Work may go on for a time, or heat may be produced, without nitrogen; but no plant or animal structure can be built up without its aid. It does not build alone, but its presence is always required for building. A little nitrate of soda, scattered on the sod beneath a languishing tree, will commonly tend to stimulate its growth and tint its foliage with a healthy green color.

76. Phosphorus forms the principal element of phosphoric acid, - - a compound of phosphorus and oxygen, one pound of phosphorus forming nearly three and one third pounds of phosphoric acid. Pure phosphorus is a straw-colored solid, having the consistency of beeswax. The whitish smoke which appears when a phosphorus match is first 
lighted is phosphoric acid. As a plant food phosphorie acid is obtained from manure, from phosphate rock, from slag and manure, and from bones and other waste materials of meat-packing houses. Phosphate rock is sometimes treated chemically to reduce it to phosphoric acid before it is used on the land; but sometimes it is merely erushed and then applied directly to the soil. In this second case it is converted into plant food very slowly. Animals separate their food roughly into bones and manure. Bones are rich and manure poor in phosphoric acid. But manure contains potash while bones do not. Hence when we return bones and manure to the soil, we give back to it in a measure what the animals remove from it.

Phosphoric acid aids in the transfer of protein (see Chapter XXVI) in the plant, and is especially necessary for the formation of seeds.

77. Pure potassium is a silvery white metal, tinted with a pale blue color. It ignites when thrown on water, burning with a violet flame. Like phosphorus, it is a deadly poison in its pure state, but it is seldom or never found in that state in nature.

With oxygen it forms a compound called potash, - the form in which we know it best. One pound of potassium forms one and one fourth pounds of potash. Most of our potash comes from Germany. The crude rock is there mined under such names as kainit, carnallit, sylvinit, hartsalz, and steinsalz. These rocks run about twelve per cent potash. Hardwood ashes contain from two to twelve per cent potash, ordinarily averaging about six per cent.

The function of this plant food is twofold: it is needed in the trinsfer of earbohydrates such as sugars, and for the growth of seeds. 
78. Amount of Plant Food in the Soil. - An acre of average productive soil to the depth of $6 \frac{2}{3}$ inches, representing the amount usually turned over in plowing, weighs about $2,000,000$ pounds and will contain nearly 8000 pounds of nitrogen, 2000 pounds of phosphorus, and 35,000 pounds of potassium. This, however, is a rough estimate only. The nitrogen content may vary from 1000 to 35,000 pounds; the phosphorus from 160 to 15,000 pounds; and the potassium from 3000 to 60,000 pounds. In some soils there is scarcely any lime at all; in others the lime runs as high as 20 pericent.

While there are enormous quantities of poteritial plant food in an average soil, 'yet only' a: small fraction of it is liberated as available plant food during an average season of average furming. That is, two

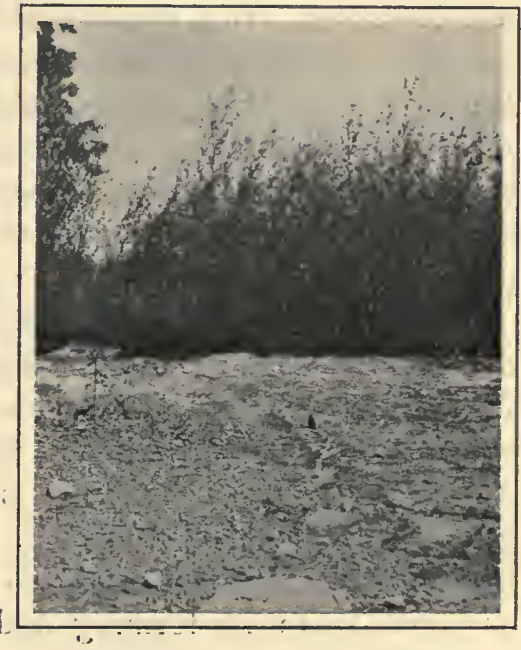

Sweet Clover on Shallow Limestone Soll..

per cent of the nitrogen $(8000 \times .02=160$ pounds of nitrogen); one per cent of the phosphorus $(2000 \times .01=20$ pounds of phosphorus); and $\frac{1}{4}$ of one per cent of potassium $(35,000 \times .0025=87.5$ pounds potassium $)$ is estimated to be liberated in one season. In other words the surface soil to the depth of $6 \frac{2}{3}$ inches should have resources enough to supply the nitrogen for 50 years, the phosphorus for 100 years, and the potassium for 400 years, even were we to ignore all additional plant food from whatever source. 
Let us examine two common crops as corn and clover hay and note to what extent they withdraw fertility from the soil. A 50 -bushel crop of corn removes about 74 pounds of nitrogen, 12 pounds of phosphorus, and 35 pounds of potassium. A ton of clover hay removes about 40 pounds of nitrogen, 5 pounds of phosphorus, and 30 pounds of potassium. By a simple calculation we can determine how many years we could expect these yields if we knew our soil resources. But, unfortunately, the question is not so simple. A soil may be non-productive and yet be very fertile so far as these chemical elements go. That is, there may be an abundance of these elements present, but other substances, acids, alkalies, vegetable poisons, or an excess of free water perhaps, may by their harmful activity render the soil non-productive.

The Germans have a proverb which says, "Kalk macht die Väter reich, aber die Söhne arm." (Lime makes the fathers rich, but the sons poor.) This means in a general way that lime liberates plant food and tencls to exhaust soil fertility. That is, lime is an active substance, as are phosphoric acid and potash. The amount of potential plant food in the soil is not so important as the process at work there in forming and accumulating available plant food.

79. Available Plant Food. - Available plant foods are such substances as can be utilized immediately through natural processes. The foregoing soil analyses tell us the total quantity of plant food in the soil. This knowledge has a bearing upon the permanency of agriculture, but it has little meaning so far as this year's or next year's crop is concerned. The practical question concerns the available supply. How much of what is in the soil is the plant able to get? This problem is taken up in the next chapter. 


\section{Practical Questions}

1. What is the relation of the soil to plants? 2. How does pulverizing the soil aid the growth of plants? 3. Name the elements needed by plants. 4. What are the so-called three great agricultural elements? 5. Give two characteristics of nitrogen; of phosphorus; of potassium. 6. How do plants obtain their nitrogen? 7. What is the function of nitrogen? Of phosphorus? Of potassium? 8. Distinguish between plant food and available plant food.

\section{Home Exercises}

1. Dig up carefully several different farm plants; then measure and draw their roots. Are there any farm plants which send their roots into the subsoil? In case of corn, how near to the surface do the roots extend? Can you see whether roots move to or from the more moist parts of the soil?

2. Is it possible to overfeed a plant? Try it in the garden by adding a large quantity of fertilizer or compost to a plant. Take notes from week to week on the behavior of the plant.

3. Ask the fertilizer man for a small quantity of nitrate of soda, acid phosphate, and muriate of potash. He can obtain these plant foods from dealers at a trifling cost. Add a little of each of these substances to different plants on your plot, and note and describe the results. Write to the county agent for details in working out this exercise.

\section{SugGestions}

1. It would make the subject very real to have in the schoolroom a small sample of pure phosphorus and potassium; a half ounce of each would answer. Supplies of this nature are cheap, and can be bought at any of the supply houses listed in the appendix. The burning of a bit of potassium on water is an especially striking experiment. Phosphorus must be handled with great care.

2. To show that the air contains about four fifths nitrogen, burn up the oxygen contained in the air in an ordinary wide-monthed bottle. Proceed as follows: Take a splint of wood about six inches long. Light this at one end and insert the lighted end into an inverted bottle which is then immersed in water. Measure the quantity of water that arose in the bottle to take the place of the oxygen consumed. What is left in the bottle is mostly nitrogen. What per cent is it? 
3. Pupils usually know much more about the parts of plants above the ground than they do about roots, - the main feeding organs of plants. The reason for this lies in the fact that roots are hidden from view. 'The teacher should demonstrate before the class the complete root systems of common farm plants.

\section{REFERENCES}

Fertilizers and Crops. Van Slyke.

Soil Fertility and Permanent Agriculture. Hopkins.'

Fertilizers. Voorhees.

Chemistry of Plant and A nimal Life. Snyder. Plant C'ulture. Goff.

Farmers' Bulletins. Washington, D.C.

186. Elementary Exercises in Agriculture.

237. Lime and Clover.

245. Renovation of Worn-ont Soils.

257. Soil Fertility.

327. Conservation of Natural Resources. 


\section{CHAP'TER IX}

\section{FERTILIZERS}

It cannot be denied that the use of commercial fertilizers is a source of profit for the farmer, when they are used in the right way.

- Roberts.

80. Why Do We Use Fertilizers? - However well a soil may be irrigated or drained, and however intelligently it may be otherwise cared for, some additions must be made to it

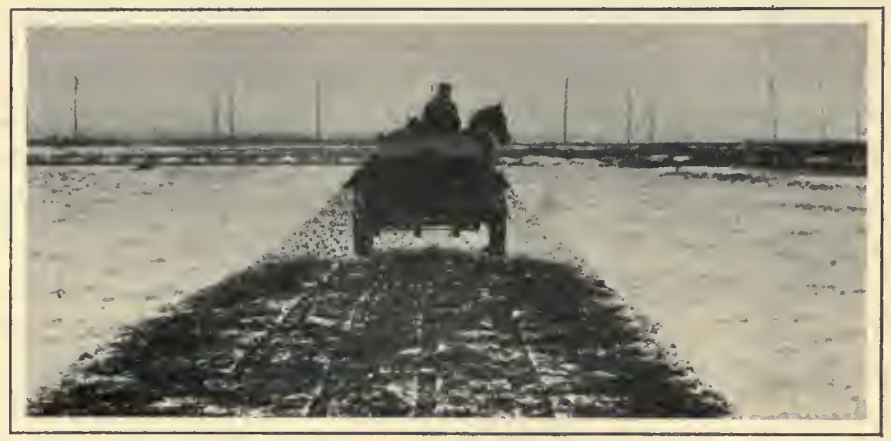

SPREAding MANURE.

The manure spreader separates hard masses and distributes them evenly.

from time to time in the form of fertilizers in order to keep up its producing power. Soils tend to run down. They lose fertility, and become poorer and poorer. Many eastern farms now selling for twenty or forty dollars an acre would be worth three or four times as much if the soil had been eared for properly. These farms have been treated for 
a long time as though crop after crop could be removed without injury. Often, in such neighborhoods, one farmer produces twice as much to the acre as another close by. This difference was not noticeable a century ago. One soil has been abused; the other has been cared for. It is just as reasonable in the long run to work a horse day after day feeding it no grain, but only hay or straw, as to work the soil season after season without supplying it with plant food.

81. Kinds of Fertilizers. - A fertilizer is any substance added to the soil to maintain or to increase its power to produce crops. Fertilizers are either direct or indirect. A direct fertilizer is one that supplies available plánt food directly to the soil. Nitrate of soda is a common example.

An indirect fertilizer, such as lime, is one that benefits the growth of plants through its effects on the soil by improving texture, preventing sourness, promoting the growth of helpful bacteria, or by converting unavailable plant food into available food, but not by furnishing substances to plants directly.

A complete fertilizer is one that supplies nitrogen, phosphoric acid, and potash, all three. One that furnishes but one or two of these plant foods is termed an incomplete fertilizer.

Commercial fertilizers. The question of fertilizers has become so important that large industries have been developed in the United States to manufacture certain kinds of them. Nearly six hundred manufacturers are selling more than $\$ 150,000,000$ worth of fertilizers to Americin farmers yearly. Such manufactured products are called commercial, or artificial, fertilizers to distinguish them from those like manures, which are produced by nature. The manufacturers gather the raw materials from widely. 
different sources, as was noticed in the last chapter. They then treat these materials in many different ways and compound the products into various combinations to meet the varying needs of farmers.

82. Fertilizer Formulas. - The composition of commercial fertilizers is expressed by formulas. If we say the formula for a certain brand of fertilizer is $2-8-10$, we mean that

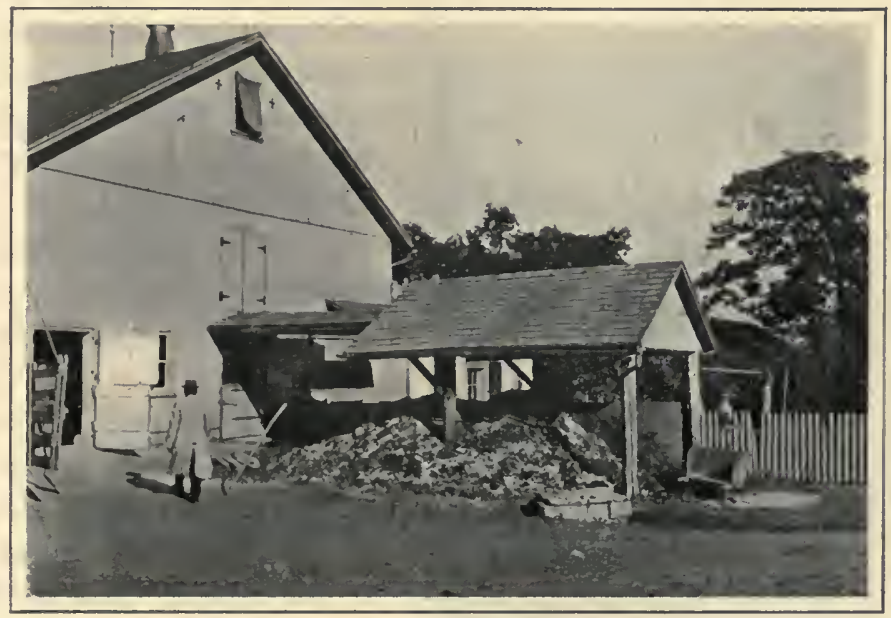

Proper Care of Manure.

Note the location of the pile under a shed.

the minimum guarantee for the fertilizer is 2 per cent nitrogen, 8 per cent phosphoric acid, and 10 per cent potash. This order, you will notice, is the alphabetical one. In the general trade, nitrogen is usually expressed as ammonia, fourteen seventeenths of which is nitrogen.

83. Barnyard manure consists of the solid and liquid excreta of the farm animals, together with the absorbents employed. Its most valuable fertilizing influences are in direct. The large amount of vegetable matter in it be- 
comes humus, and makes the soil looser in texture, more able to hold moisture, and better able to turn its plant food into available forms.

Manure is also highly useful as a direct fertilizer. Its composition varies with the animals, their bedding, and with the kind of food they have had. A ton of average barnyard manure supplies from 10 to 15 pounds of nitro-

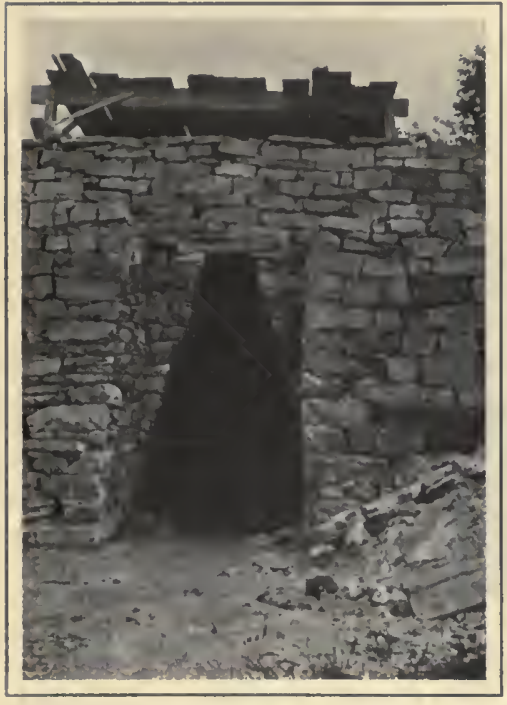

A Lime KILN. gen, from 4 to 9 pounds of phosphoric acid, and from 9 to 18 pounds of potash. Thus, though low in its proportion of phosphorus, it contains all the substances that soils are most likely to lack. It is a "complete fertilizer."

Fresh manure, however, decomposes rapidly if exposed to the air, and so loses much of its value. The care and use of it, therefore, are of vital concern. The nitrogen and the potash are the elements most likely to be lost. The best way to prevent this loss is to spread the manure on the land as soon as possible. The three direct fertilizing elements are found mainly in the liquid manure. Care should be taken to provide bedding enough to absorb and hold this, and in this way to apply it directly to the soil. The farmer should see that it is not allowed to drain off into a passing stream.

84. Green Manure. - Green clover, cowpeas, and rye are 
frequently plowed under for humus. However, the practice is growing of feeding a part of these crops to the stock and then using the manure on the land. In some localities, a profit in fattening beef cattle can thus be made as a by-product. Three fourths of the nitrogen and phosphorus and one third of the organic matter of feeds on the average live-stock farm is recovered in the manure.

85. Lime, we have already said, is valuable mainly as an indirect fertilizer. As such, it works in five ways:

$a$. It liberates plant food that is held in insoluble compounds in the soil, by combining with them into new compounds which are soluble in the soil water.

$b$. It hastens the decomposition of vegetable matter into humus and makes available the fertility it contains.

c. It aids the action of manure. The full benefit of manure or other fertilizers will not be realized in soils deficient in lime.

d. It mellows clay soils, making them more granular, friable, and loose.

e. It "sweetens" the soil. This is the most important use of lime. Decomposing vegetable matter leaves ceitain acids in the soil. These aid in making the soil sour, so that needful bacteria cannot flourish. Lime corrects this sourness, by combining with the acids into harmless or helpful compounds.

86. When Should Lime Be Used? - Litmus paper (to be had at drug stores) shows whether the soil is sweet or sour. Its use is a simple matter. Place a red and a blue strip in a hole several inches below the surface. If the blue paper reddens after remaining in contact with the moist soil for an hour or less, lime is needed; if the red paper turns blue, no lime is required. The presence of plaintain and sorrel is commonly taken to indicate a sour soil or a soil in need of lime. 
The failure of elover on soils where it onee grew is a good indication of the need of lime, provided the failure is not due to plant diseases or to a bad season. On the other hand, a good stand of clover indicates positively that the soil is sufficiently sweet.

87. Forms and Application of Lime. - Lime is obtained from limestone roek. This rock is sometimes ground into

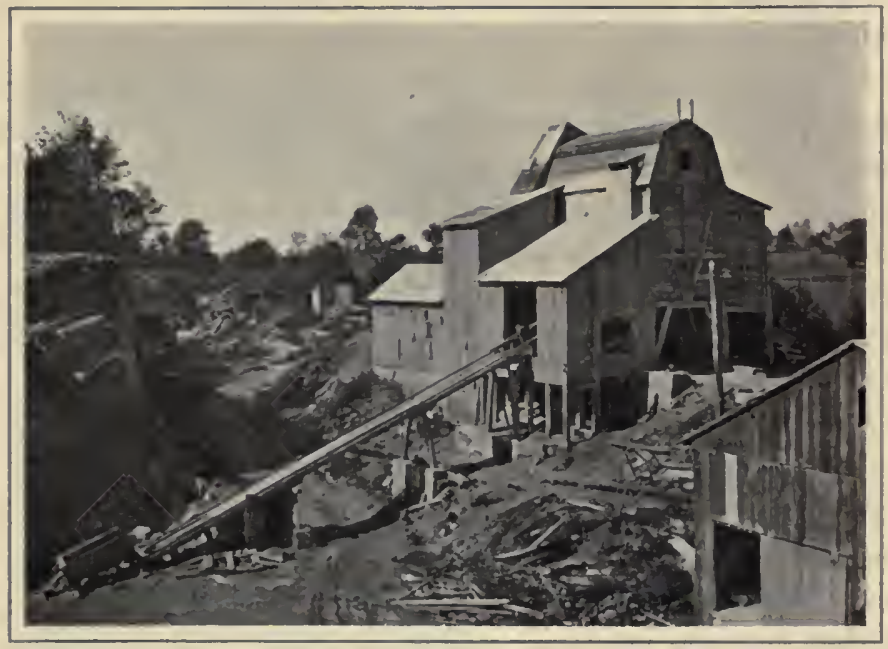

Preparing Stone Lime.

Pulverized natural limestone is taking the place of other forms of lime as a fertilizer.

fine particles, and then applied to the land. The fine division of the rock is needed to spread it evenly and to increase the relative surfaces of the particles in order to hasten its action. But even in this ground form, limestone rock acts very slowly, beeause it must first be dissolved in the soil. Often, therefore, limestone is heated in a kiln, to drive off its carbon dioxide, and so ehanged into quicklime. This is then slacked by air or water. When 
water-slacked, quicklime is caustic and acts swiftly. In the air-slacked form, the lime has been changed back toward its original state, except that it is no longer in stony masses but in very finely divided particles. In either form, however, especially in the first, quicklime is apt to decompose some of the humus in the soil. For this reason,

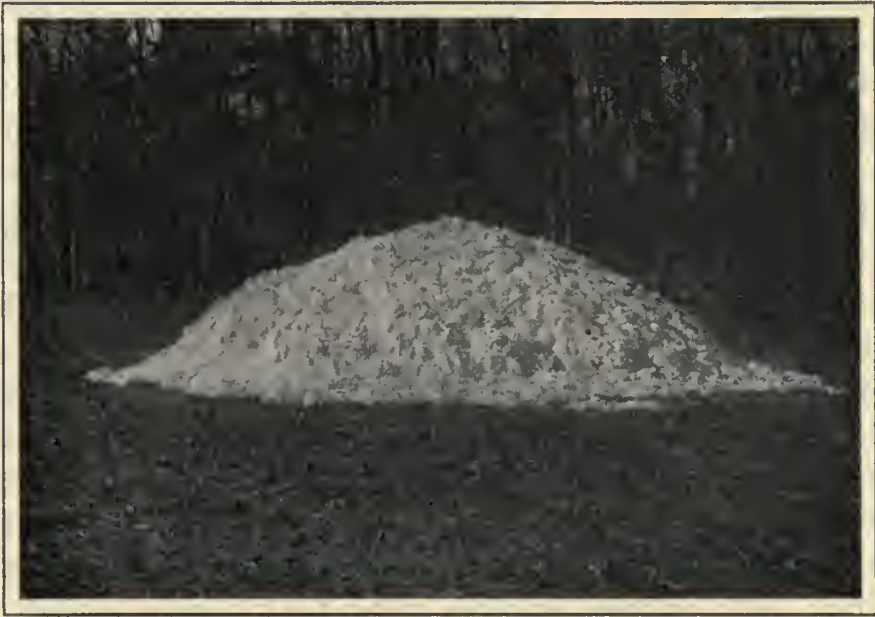

A Pile of Slacked Lime.

many farmers are coming to prefer the slower but more beneficial action of the limestone rock.

Pennsyluania Experiments witi Lime Yields per Acre during Tinenty Years.

\begin{tabular}{|c|c|c|c|c|c|c|c|}
\hline \multirow{2}{*}{ Treatment } & \multicolumn{2}{|c|}{ CorN } & \multicolumn{2}{|c|}{ OATS } & \multicolumn{2}{|c|}{ Wheat } & \multirow{2}{*}{$\begin{array}{r}\text { HAY } \\
\text { Tons }\end{array}$} \\
\hline & $\begin{array}{c}\text { Grain } \\
\text { Bushels }\end{array}$ & $\begin{array}{l}\text { Straw } \\
\text { Tons }\end{array}$ & $\begin{array}{c}\text { Grain } \\
\text { Bushels }\end{array}$ & $\begin{array}{l}\text { Straw } \\
\text { Tons }\end{array}$ & $\underset{\text { Bushels }}{\text { Grain }}$ & $\begin{array}{c}\text { Straw } \\
\text { Tons }\end{array}$ & \\
\hline None . . & 819 & 18.8 & 678 & 14.3 & 279 & 13.2 & 24.9 \\
\hline Burned Lime . . & 699 & 16.5 & 617 & 17.8 & 318 & 14.6 & 23.6 \\
\hline Ground Limestone & 798 & 18.6 & 732 & 20.4 & 331 & 16.6 & 29.2 \\
\hline
\end{tabular}


This experiment shows in the most convineing manner the tendency of burned lime to destroy fertility. In every ease it is noticed that the limestone rock produced higher yields. This experiment incidentally shows that it often takes a long time to bring even the most careful work to any conclusion that will stand the severest tests. Farmers should therefore be cautioned against arriving at conclusions from their home experiments carried on for a brief period only.

Too much lime is harmful. The best practice is to make small but frequent applications ; it is not well to try to add enough lime at one time to last a generation.

88. What Fertilizers to Apply. - A few years ago nearly all farmers believed that the sole purpose of fertilizers was to supply a plant food exhausted from the soil. They reasoned as follows: "Fifty bushels of corn remove from the soil about 74 pounds of nitrogen, 12 pounds of phosphorus and 35 pounds of potassium. Growing corn on the same field for a few years, then, must exhaust the supply of these food elements; and so fertilizers must be supplied to make good the loss." While men argued in this way, they thought that a chemical analysis of the soil was all that was needed to show what fertilizers should be supplied.

But now we have learned (Chapter VIII) that in an average soil there is enough of all these plant foods to last for two generations of yearly cropping. We have also learned, however, that only a small part of this food is available. That is, only a small part of it at any one time is soluble, or in a form that can be used by plants. The addition of a little fertilizer, however, may cause a marked increase in a erop yield. This is because the fertilizer may not only add plant food directly to the soil, but may also release for use some of the store before imprisoned in the soil in unusable forms. 
Soil analysis, therefore, is not enough to tell us what fertilizer to use. It is helpful, particularly if it shows the absence of some important element; but for the average farm it is less instructive than experiments with different fertilizers. Experiment stations make these experiments on the different types of soil in their respective districts. They keep careful records of the kinds and quantities of fertilizers used on different fields, and on sections of the same field, and they measure carefully the crop yield through a period of years before and after this fertilization. Then they publish the results, and suggest allowances to be made for variations in rainfall or in other climatic conditions.

It is usually safe for the farmer to adopt the advice of a station, based upon such experiments; but it is well for him at least to confirm the experiment himself by keeping records and observing carefully whether the results secured by the station are secured also upon his land. And if there are no records of satisfactory government experiments in his neighborhood, or upon his kind of soil, it need not cost the farmer much money or time to experiment for himself. Two or three kinds of fertilizer added to as many strips through a field will give a useful basis, at the close even of one season, for comparing the results of the different fertilizers with one another and with the absence of any fertilizer on the rest of the field. The fertilizer that brings the best returns upon a particular soil and for a particular crop is the one to use for that soil and that crop. It is well worth while to find out what this one is.

\section{Practical Questions}

1. Define the four different kinds of fertilizers. 2. Discuss barnyard manure as a direct and indirect fertilizer. 3. What crops 
are used to furnish green manure? 4. State five uses of lime. 5. How can a farmer tell the need of lime? 6. What different forms of lime have you seen? 7. If a man desires to plant an acre of potatoes, what fertilizer should he use?

\section{HoMe FXarcises}

1. Hunt up all the fertilizer sacks you can find and copy the formulas on them. Bring these formulas to school and compare them with those brought to school by other students.

2. Do you know of any farmers who mix their own fertilizers? Does it pay?

3. Visit a limekiln and find out all you can about it; then write up a report on burning lime.

4. Get the selling price of inanure and of the commercial fertilizers. Which does the greatest amount of good, considering cost?

5. Keep a careful record of the cost and action of fertilizers used on your father's farm.

\section{Suggrstions}

1. A way of making the study of fertilizers very practical is to ask the pupils to report their home experience on the kind of fertilizer used and the crop yields. It is not so much, however, a question of getting infornation that counts, as it is the carrying out of a few simple ideas for improving farm practice. When possible, a little land should be used by the pupils theinselves for this work.

2. Many interesting and instructive experiments can be made with a bit of limestone. Pour hot vinegar on it: carbon dioxide, a common gas, escapes. Throw a piece in the stove, and even when cooled, it may burn the fingers, because it has been changed to a weak alkali. Place a bit of the burned stone in a glass of water and blow your breath into the water through a straw; the water turns milky, showing that you exhale carbon dioxide.

\section{REFEREXCES}

Soils and Fertilizers. Snyder.

Fertilizers. Voorhees.

Farming with Green Manures. Harlans.

Talks on Manures. Harris. 
Farmers' Bulletins. Washington, D. C.

44. Commercial Fertilizers.

77. The Liming of Soils.

192. Barnyard Manure.

237. Lime and Clover.

259. Use of Commercial Fertilizers.

273. Leguminous Crops for Green Manuring. 


\section{CHAPTER X}

\section{SOIL MANAGEMENT}

Ye rigid Ploughmen! bear in mind Your labor is for future hours. Advance! spare not! nor look behind! Plough deep and straight with all your powers.

89. What is Soil Management? - We have said that the soil is our most valuable natural resource. All the wheels of industry would stop, and even our lives would soon end, if the soil did not produce food for man and beast and supply materials for man's industries. But, like other useful things, the soil must be used intelligently. Careful planning is necessary to get the best results from it. Many farmers fail to secure large erops, not because the soil is at fault, but because the farmers are. Too often they abuse and injure the soil, just as some ignorant men abuse and ruin a horse.

Farmers should look upon the soil with great respect and not think of it as mere dirt. Scientists who have been studying the soil for the greater part of their lifetime say that they have found out only a little about it. IVe ought not to have a low opinion of anything that is the abode of so much that is still unknown.

Many useful facts, however, have been discovered with regard to managing the soil; and if all farmers would apply this knowledge, they would greatly profit both themselves and the rest of the world. One point in particular 
should be kept in mind whenever we have anything to do with the soil: we should each see to it that the soil is as fertile and productive when we pass it on to our children as it was when we received it from our parents. More people will have to be fed from the soil in the future than in the past; and it is not fair to the coming generations for us to handicap them

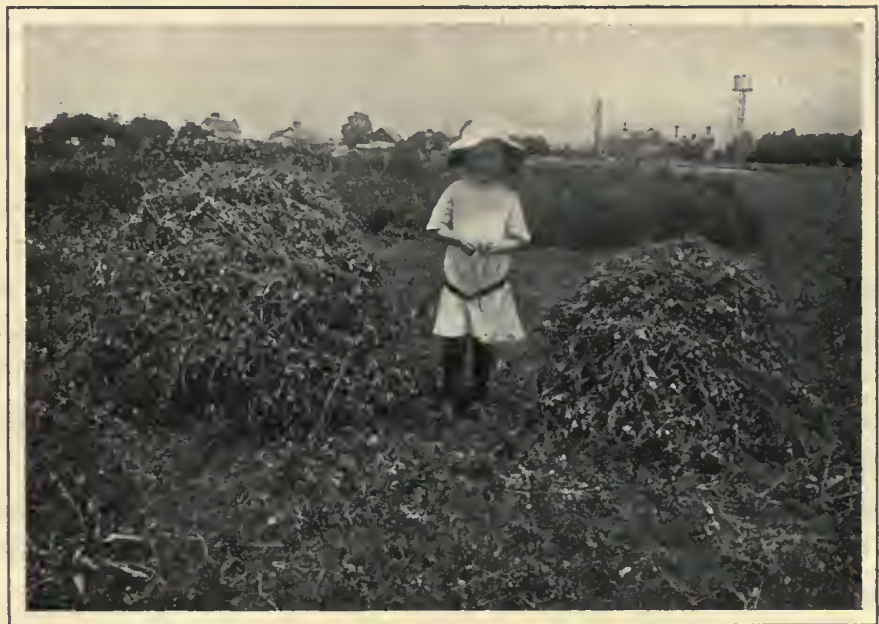

EFFect of Tillage.

The alfalfa at the left was grown in soil more carefully prepared than that at the right.

by lowering the producing power of the soil. Rather, it is our duty to increase that power.

Proper soil management, then, is the handling of the soil in such a manner that it will produce year after year the largest possible yields of valuable crops, at the lowest possible cost, without lowering its productive power for the future.

90. Tillage. - No one knows who first conceived the idea that before a crop is planted the soil should be prepared 
to receive it. We call this preparation tillage. Its origin takes us back from the modern plow and harrow, past rude implements still in use by barbarous peoples, to the days of the crooked stick of the savage. From the very earliest times, men stirred the soil before planting the seed, not knowing exactly why, but believing that they would obtain larger erops by doing so. Civilized man has found out several reasons why tillage is beneficial. We will now note some of them.

a. Tillage, we have already said, breaks compacted soil apart and pulverizes it. Soil lying untouched for a year or two becomes compact chiefly by the force of falling rain, by the action of the water and ice within the soil, and by the pressure of the upper soil layers. This shuts out air from the soil. But we have learned that plant roots need air. Tillage ventilates the soil, driving out foul gases that it may contain, and making open spaces, or pores, which take up fresh air.

b. Tillage conserves moisture. In the last chapter it was stated that soil moisture is perhaps the most important point for farmers to watch in connection with their soils. This was why so much space was devoted to the study of drainage and irrigation. Capillary water escapes from the soil either by direct evaporation or by being absorbed by plant roots. It is the loss by evaporation that needs to be regulated by tillage.

In this matter the first thing to see to is to be sure that the deeper layers of the soil store up all the water they can hold. To help this process, where needful, the farıner loosens up the under erust, sometimes by dynamite, but more commonly by deep fall plowing. The idea in mind is to get many open spaces for water storage deep in the soil.

Surface or shallow tillage is next resorted to in order to 
conserve this deep soil water by preventing it from moving upwards too rapidly and escaping by evaporation from the surface. In a previous chapter (page 104) we have described the way in which this is done by shallow tillage.

There is an old but truthful saying that it is possible to water the garden with a rake. The dust mulch formed by the rake makes the water below it last longer, so that it does as much good as more rain from above.

c. Tillage cleans the soil. A farmer must always keep on the lookout for injurious agents like insects and weeds.

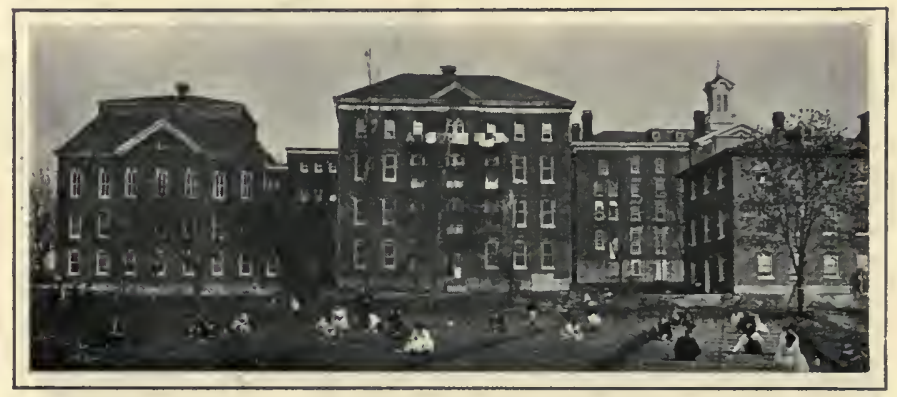

A SchOOL GaRden.

Students making practical tests of soils.

He must try not to allow them to become established in his land. Many harmful insects pass the winter in the ground on account of the protection it affords. During the late fall, when these pests are at rest in fancied security, the farmer may plow them up and leave them exposed to the winter weather and spring birds.

Weeds likewise are destroyed wholesale by tillage. When the weed roots have become established in the soil, the farmer inverts it by plowing, thus smothering the stems of the weeds and exposing their tender roots to the dry, withering air. And as this deep tillage kills mature weeds, 
so frequent shallow tillage keeps new weeds from starting or from becoming firmly established.

d. Tillage serves many other useful purposes. It enables the farmer to mix fertilizers of different kinds uniformly in the soil. It makes it easier for him to plant his seed and cover it. (Probably this was the only benefit from tillage that early farmers knew.) It brings different

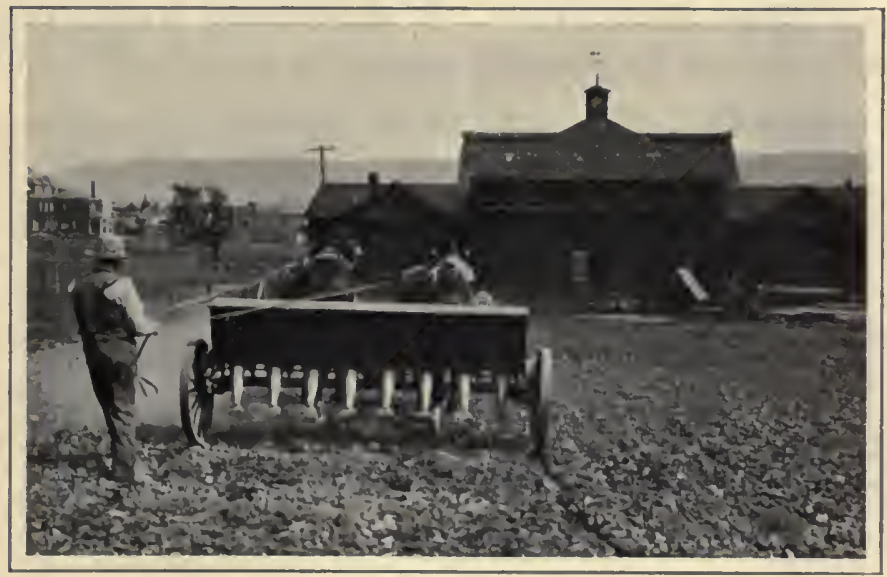

\section{SPREAding Lime.}

This spreader distributes the lime more evenly than if it is shoveled from a wagon.

particles of soil at different times to the surface where they can be cleansed and made more usable for the plant.

To sum up briefly: tillage helps the farmer get seed and fertilizers into the ground. It kills countless enemies of the growing plant before and after it starts, and brings new food within its reach. It brings to the plant's rootlets indispensable air which otherwise would be shut out, and it keeps in for those rootlets much indispensable water which would otherwise escape. 
91. Story of the Implements of Tillage. - Many of the improvements in the tillage implements of to-day have been made in quite recent years. When the famous Minute Men of the Revolution left their plows standing in the furrows to rally for the defense of their country, they left a clumsy wooden "bull plow," which was about as crude and primitive as the plows used by the Egyptians when the pyramids were building, fifty centuries before. So, too, of other farm tools of that time. There had been little improvement in them for five thousand years. Even a generation later, when Thomas Jefferson became President, the farmer in America and elsewhere still plowed with this bull plow, which at best could only scratch the ground, sowed his grain broadcast (by hand), cut it. with the prehistoric sickle, and threshed it on the barn floor with the flail of prehistoric times - if he did not tread it out with cattle, as the ancient Egyptians did.

The first threshing machine was invented in 1785 , but for many years it did not come into use. The only farm "machinery" to be drawn by horses in 1800 was the bull plow, an equally clumsy, wedge-shaped, wooden harrow, and a cart. The sickle, scythe, flail, fork, ax, spade, hoe, and rake complete the list of farm implements of that day; and, except perhaps the ax and scythe, all these were awkward in shape and heavy. The first cradle scythe a hand tool, but a vast improvement on the old sickle for harvesting grain - was patented in $1803 .^{1}$

In 1800 , the era of rapid change in farm machinery was just at hand. A large part of the new machines of this age have to do with the crop at harvest or after it. Some of this machinery will be treated in later chapters. This chapter will now treat of the implements of to-day that

1 The brief historical statement of the last two paragraphs is taken mainly, with permission, from West's American History and Government, pp. 390, 391. 
concern the preparation of the soil and its care while the crop is growing.

92. The plow has often been called the most important instrument ever invented. Its pictures decorate the coat of arms of many of our states. 'Two great classes of plows are now in use:

a. The disk plow has a rolling motion, and is used mainly in dry soil.

b. The moldboard plow slides along through the ground. By varying the shape and slope of the moldboard, we get varieties of this kind of plow, - the stubble plow, the

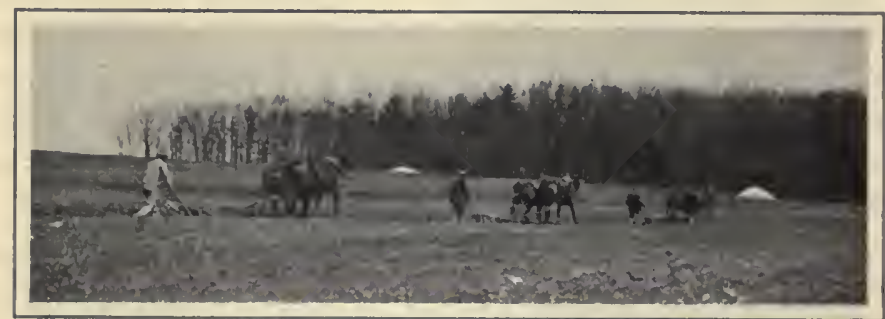

The Common Plow.

Here the plowman walks behind.

breaking plow, the black-land plow, and so on. These varieties are used for the purposes that their names indicate.

93. Stages of the Plow. - In very early times, and in some backward countries to this day, the plow was literally a crude tree crotch, which was drawn by slaves or cattle. It took centuries to make the improvements that are now so well known. The iron share, in some form, must have been in existence 1100 years B.c., because the Bible relates that the Israelites went down to the Philistines "to sharpen, every man, his share and coulter." About 1800 A.D. the cast-iron plow appeared; but farmers long 
declared that its use poisoned the ground, and it did not fully replace the bull plow until about 1825 . Then the better plowing it made possible created a new era in farming. Thomas Jefferson had had much to do with this improvement, by his experiments upon various forms of moldboards, and Daniel Webster also had a hand in the movement.

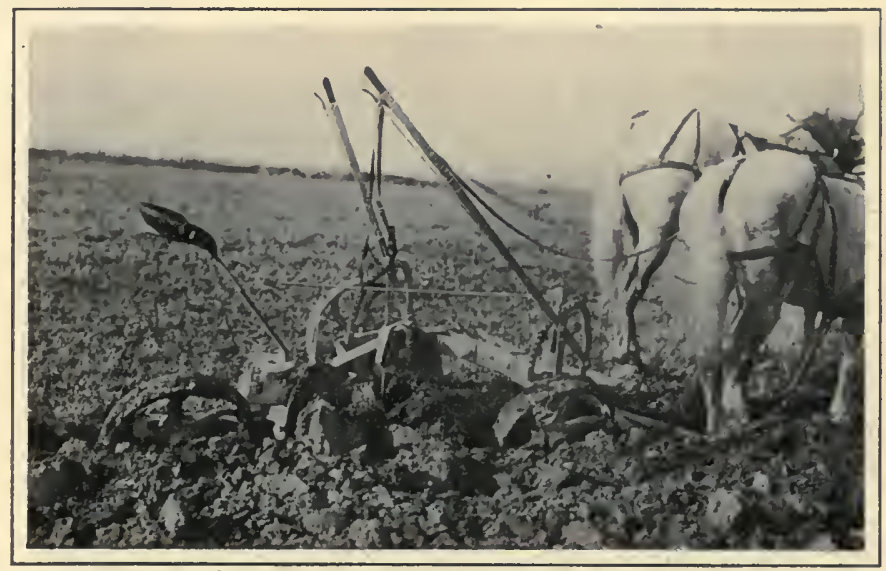

The Spaulding Plow.

Here the plowman rides and can adjust the plow from his seat.

On even ordinary farms in the prairie states of the West it is rare indeed now to see a farmer walking behind a plow. The usual plow there is the "gang plow." This consists commonly of three distinct moldboard plows fastened together, one a little to the rear and to the left of the one before it, so as to turn three furrows at once. This gang plow is drawn by five horses, and the driver rides. One man and five horses, in this way, do much more work than three men and six horses with single plows. 
The growth of the "age of steam" made possible still further development in the plow. To-day, on large farms free from stumps and stones, the 110 horse-power traction plow moves as fast as a man can walk, eovering a strip 30 feet wide at one time. This machine plows, harrows, and seeds at the same time, and treats 80 or 100 acres a day.

94. In plowing, we must consider the depth, the time, and the manner of turning the furrow.

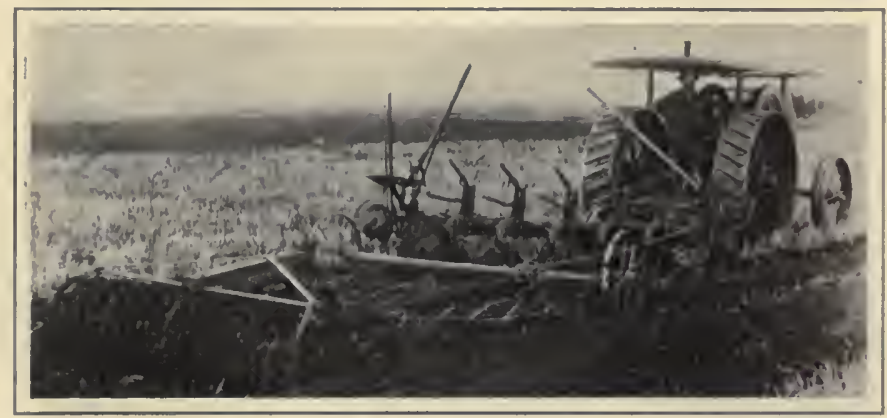

Traction Plow aNd DisK HaRRow.

Note the width of land plowed and harrowed by. one man.

a. Depth. It pays to plow deep. Said a wise man to a farmer who eomplained that his land was poor: "There is much wealth in the farm under the one you have been tilling: plow up that wealth."

It will not do, however, to bring up a large amount of new subsoil at any one plowing, because that undersoil lacks humus and cannot get much of its plant food into available forms in the first season it is tilled. About one inch deeper than previous plowings is as deep as the plow should go at one plowing. Deep plowing should be secured gradually.

Deep plowing is especially necessary in dry regions and 
on worn-out lands (on lands, that is, where the surface has been worn out), and it is always advisable for root crops. On the other hand, some small grains, like oats, thrive well on shallow plowing because their roots feed near the surface. In a rotation of corn or potatoes, small grain, and clover, it is often well to plow deep for the corn crop, and then plow shallow the next year for the oats.

b. Time. Clay soils should not be plowed when wet, because they are likely to "puddle." This compacts

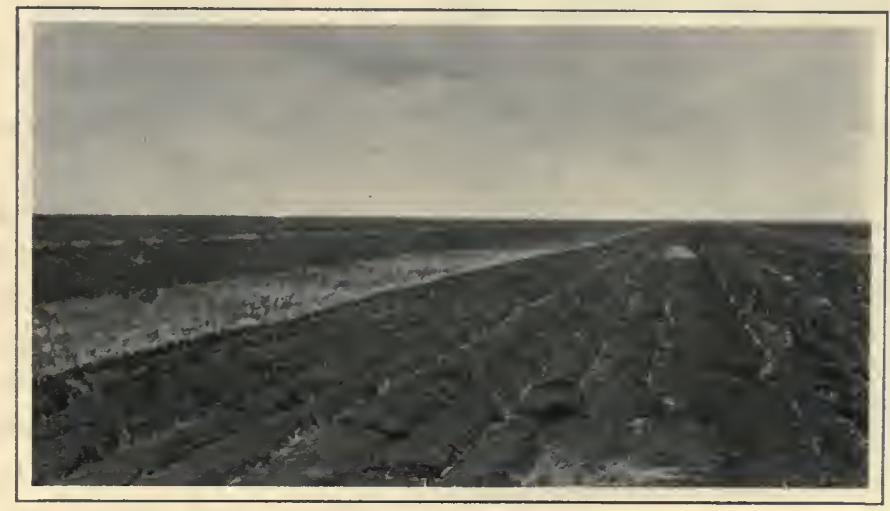

FurRows PROPERLY TURNED.

them, and makes it hard for air and roots to get into the soil. Fall plowing is best in regions of scant rainfall and clay soils, because more of the winter moisture can then sink into the ground, instead of running off. On hillsides, where the winter rains are apt to wash the lands, spring plowing is to be preferred.

c. The furrow. There are two objections to turning the furrow slice of sod completely over, so as to make it lie flat in the bottom of the furrow. First, the capillary connections between the sod and subsoil will be broken more 
than necessary; and, second, the ground will not pulverize well. It is better to have each furrow slice lap slightly upon the preceding one.

95. The Harrow. - The first harrow was probably a tree limb with projecting branches. The purpose of the harrow is to crumble the soil and to give it good tilth, or fineness. After plowing,

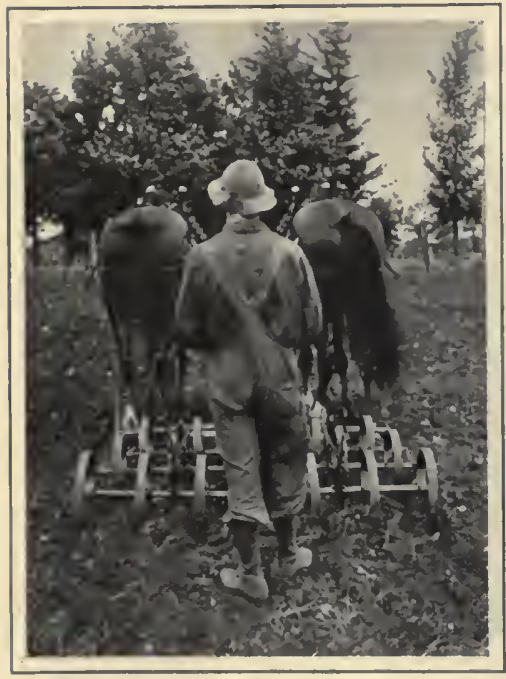

SPRING-TOOTH HARROW.

This is especially effective in leveling and breaking up the surface soil. the surface of the ground should not be allowed to dry out before harrowing, since it is then more difficult to break up the clods.

There are three common types of harrows:

a. The spike-toothed harrow is made of spikes fastened in a wooden or iron frame. This type is especially useful in forming a dry-dust mulch. It is used to follow the plow, and sometimes, again, with crops like coln and potatoes, after planting but before the plants sprout. In this second ease, the teeth are slanted back, so as to stir the soil very lightly.

b. Each tooth of the spring-toothed harrow is a broad spur extending from a strong half coil of steel. When these teeth strike an obstruction that they eannot tear up, they "spring" back and release themselves. This kind of harrow, therefore, is suited to stony fields and to orchards 
where roots abound. For a like reason it is useful in many new lands.

c. The disk harrow cuts the clods and the surface soil. It is very effective in pulverizing the ground and in destroying weeds. 'To prepare corn stubble land for oats, the disk harrow is often used in place of the shallow plowing that was discussed a little above.

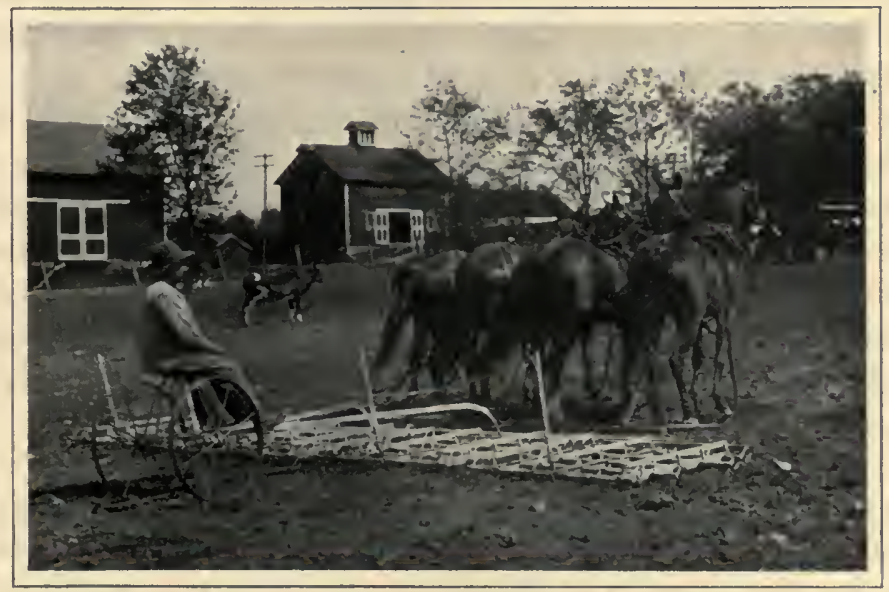

EXTENSION HARROW.

A labor-saving device for level fields.

96. The cultivator is used for intertillage, or tillage between the rows of such crops as grow in rows. It may be used after planting, before the plants appear, if the rows are so marked that they can be seen; but its main use is between the rows of standing crops.

In small gardens a hand cultivator (pushed by hand) has great advantages over the hoe; and it finds an important place also in truck gardening on a large scale if land is so valuable that it is desirable to plant in rows too near together for the use of a horse. 
For larger crops, horse cultivators are necessary. These, if drawn by two horses, are usually also riding cultivators. Like "sulky" plows, these " riding cultivators" make the work more rapid, easy, and interesting.

97. The roller and the planker are compacting and smoothing tools which are often used after plowing and harrowing. Some soil moisture is sacrificed by their use; but without them many elods in some soils can hardly be broken up. Small seeds, too, germinate more quickly and strongly in soil that is pressed tightly about them.

98. Crop rotation is quite as important to the welfare of the soil as is fertilizer or tillage. Crop rotation means the growing of a series of different crops on the same field in a definite order through a series of years. A field that grows corn this year may perrhaps grow wheat or orats next year, clover the year following, and then begin with corn again the next season. This is an examplc of a threeyear rotation.

In a case like the above the farmer probably wants to raise some of all three crops each year; so he divides his tilled land into three nearly equal fields. Each of these fields has one of the three crops; and just as the three crops are rotated on each field through the years, so is each crop "rotated" through the three fields. The important side of crop rotation, however, is the side mentioned first, - the change from year to year in a given field. Let us see why this change is necessary.

99. The Need of Crop Rotation. - A farmer and his teams may work hard to prepare the soil for seeding; the soil may hold an abundance of plant food; the seed may be good, and the season favorable; and yet the crop may be poor because the same kind of crop has been grown on the field for too many years in succession.

Each kind of plant takes its particular kind of food 
from the soil. Potatoes remove large quantities of potash; timothy takes nitrogen; small grains take phosphoric acid. If any one of these crops be grown year after year on the same field, the soil there will lose most of the available food for that kind of plant.

But though the land that has grown potatoes for three or four years gives only decreasing crops of that plant, it may give excellent grain crops. An "exhausted" soil often is exhausted only for a particular crop. Nearly all plants, however, require at least a small amount of each kind of plant food; so if exhaustion of any sort goes too far, it becomes difficult to use the land profitably at all until its fertility has been built up again by slow and costly processes.

In colonial times tobacco was raised on the rich lands of Virginia and Maryland each season until field after field was exhausted and abandoned. A little later, in the central West, and later still, in the more distant West, a like sin against the soil was committed with wheat.

Of course some attempts were made on the colonial tobacco lands and on the western wheat fields to supply the needed plant food by fertilizers. But it was found, to the surprise of the farmers, that this checked the decrease in crop returns only partially. As will be more fully explained a little further on, the fact is that food exhaustion is not the only evil that follows from using the soil continually for the same crop.

It is possible, however, to grow crops on the same land every year for centuries, and at the same time to improve its condition steadily instead of exhausting it. To do this requires fertilizers, but quite as much - even more -it requires that successive crops vary in kind. That is, it requires a wise crop rotation. In a rude way, even some barbarous peoples have learned the need of a "rota- 
tion" in crops, while European farmers and the better American farmers have practiced some kind of crop rotation for a long time. Of late years nearly all farmers have adopted the practice, because at last they have found that it pays. And quite recently a great deal more has been learned about why it pays, and what kinds of rotation pay best.

100. Five reasons why crop rotation pays will be noted here.

a. Rotation varies the demand for soil-food from year to year; thus it enables the natural forces in the soil to accumulate a new supply before it is again especially demanded. This was the first beneficial result that men learned, but it is not the most important.

b. Rotation avoids the collection in the soil of certain poisonous substances known as root excretions. Our knowledge about this is very recent and rather theoretical. The roots of a plant, we now know, throw off waste matters as we do in perspiring. These excretions cannot escape freely from the soil; and so, if the same crop is grown on a field for several years, the soil there accumulates so much of the excretion of this particular plant as to poison future crops of it. The roots of another variety of plant, however, will not be injuriously affected by this poison. Plants are rotated, then, to avoid the effects of their own excretions. After three or four years, natural forces in the soil destroy the excretion, and then the first plant may be grown again.

$c$. Rotation permits the use of different layers of soil by alternating deep and shallow rooted crops, like corn and wheat.

d. Rotation makes it easier to distribute farm labor more evenly through the year. One of the problems of the farmer is to keep his help busy at profitable work. Farmers who grow wheat only, or cotton only, have little 
to do between seed time and harvest. They cannot afford to keep regular help; and so when harvest comes, they often have difficulty in securing all the labor they need. Farming, too, will be a better business, and the farm will be a better place to live, when the farm laborers have a regular lome upon it instead of coming and going as tramps.

$e$. Rotation keeps down pests, like certain insects and weeds. Different pests live upon different crops. By changing the crops from time to time we can more easily exterminate the pests.

The best order of rotation depends upon the kind of farming and the products of the district. Some districts find a good five-year rotation in corn - oats - wheat or rye - clover and timothy - timothy - corn. This rotation is practiced by many eastern farmers. Timothy is drilled in with the fall wheat or rye, and the clover is broadcasted early the following spring. The common red clover usually dies out at the end of the second year, but the timothy thickens up to take its place, and the land is left in grass for two years. Manure is spread on the sod, to be plowed under for the coming corn crop; and mineral fertilizer's are drilled in with the wheat. Some farmers spread much of their manure on the oat stubble. This practice is not as good as the other one mentioned, since the manure generally lies in the yard until after the oat harvest and so loses much of its value.

A good three-year rotation for a potato section or a dairy section is potatoes or corn - wheat or oats - clover.

In alfalfa regions the alfalfa is usually allowed to stand for four or five years; then corn is planted for two seasons; finally wheat, rye, or oats; and then alfalfa again. 


\section{Practicala Questions}

1. What is meant by the phrase soil management? 2. In what ways may a soil be abused? 3. Define tillage. 4. How did the ancients till their land? 5. How does tillage conserve moisture? 6. Discuss tillage as a means of ridding the soil of insects and weeds. 7. What is the most important purpose of tillage? 8. Describe the plow. 9. State some facts on plowing. 10. Describe the work of the different types of harrows. 11. In what sense are crops "rotated"? 12. State three benefits of crop rotation. 13. Give a good order of crops for a five-year rotation.

\section{Home Exercises}

1. Make a drawing of your farm or one you know, as at the close of the last chapter, showing the exact size and location of the different fields. Mark on each field the name of its crop for this year, last year, and for the last five years. Does your rotation correspond with any of those given in the text?

2. Ascertain the yield per acre of all your leading crops. What was the cost of the fertilizer, and how many dollars worth of produce were sold?

3. How is your manure kept? Is it placed under cover or stored in the yard? How many loads of manure do you apply to the acre? Is the manure spread on the sod or on oat stubble? If on neither of these, where is it spread?

4. If there are any poor or run-down farms in your neighborhood, what is this condition due to?

5. Does your father turn the furrow over completely in plowing?

6. Write a description of all your home implements of tillage and the care that is given them.

\section{Suggestions}

1. Get a good manual or bulletin for detailed directions on how best to illustrate the topics discussed in this chapter.

2. A member of the class may be given the problem of studying the different methods of tillage as practiced in the different countries. Histories, geographies, encyclopedias, and other books likely to contain information on this point shonld be used. A few days should be allowed for this work and then an oral report should be presented.

3. A Club study on soil managenent under the direction of the 
county agent will be appreciated by the older boys. This study may be combined with others, such as grain raising, baby-beef production, or the growing of forage crops. It would be well if a number of pupils were to work together in a coöperative group, using a short rotation of crops. The members undertaking this work should be organized into a club. This adds zest and develops the spirit of sympathetic helpfulness, in place of that selfish rivalry which is often the fruit of contest between individuals. The basis of the award may be as follows :

a. The plan and management of rotation . . . . . . 20

b. The average yield per acre . . . . . . . . . 20

c. The net profit on investment . . . . . . . . . 20

d. The fertile condition of the soil at the time of rotation . . 20

e. Soil and crop records, with written report . . . . 20 Total score . . . . . . . . . . . . . . 100

\section{REFERENCES}

The Soil. F. H. King.

Physics of Agriculture. F. H. King.

Farmers' Bulletins, Washington, D. C.

245. Renovation of Worn-out Soils.

320. Management of Soil to Conserve Moisture.

406. Soil Conservation. 


\section{PART III}

\section{CROPS}

\section{CHAP'TER XI \\ THE NATURE AND WORK OF PLANTS}

Plants exercise two sets of functions, - growth and reproduction. The higher plants may be said to have three sets or classes of organs : those that have relation with the soil; those that have relation with the atmosphere and sunlight; those that are concerned with reproduction. - BAILET.

101. Why should farmers be acquainted with plants? It is not possible to grow planits successfully unless we know something about their eharacter and habits. It is true that one may obtain fair results by rule-of-thumb methods when working under the direetions of other people; but the highest rewards come to those who know why they do things. We have already studied about certain foods which plants must have. Every one knows that plants must have water. But why do they need it? What purpose does it serve in erop growth? Why must we supply the other speeial needs of plants? The man who knows these why's not only supplies the needs more intelligently, but also finds greater joy in doing so.

So even the average farmer is better off for knowing a little about cells and protoplasm. It will not do to say that such subjects belong only to the scientists.

Many common activities of plants cannot be understood without this knowledge. Perhaps a boy has learned how 
to graft apple trees; if he wants to learn why the process works, a book will tell him that the cells of the one plant unite with those of the other, and that the protoplasm of thesc cells multiplies rapidly until a perfect union is effected. But what do these terms mean? Farm papers and farmers' bulletins, in trying to explain important matters, are compelled to use many other such terms. The farmer who cannot understand them is shut out from the cheapest and most accessible information about his work.

102. Plants and Animals. - Any one can distinguish a horse from a tree, or even a worm from a root. The horse grows to a definite size, moves from place to place, and has special organs for the taking in of food and air. In a

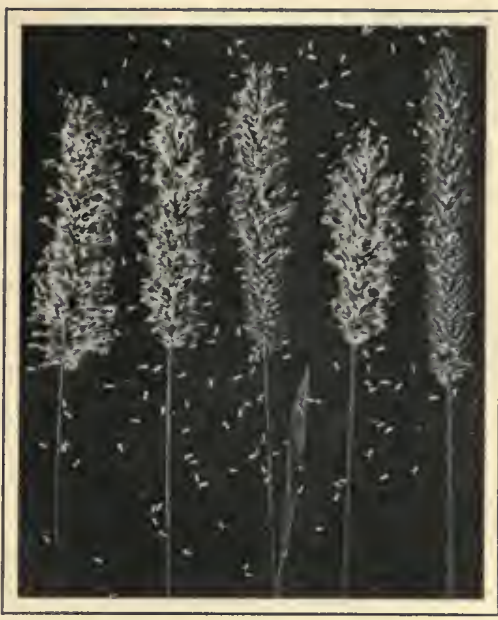

TiмотнY IN BLOOM.

Note the falling anthers. word, it has a complicated body whose many parts have widely different structures and uses.

A tree must stay where it has been planted; its limbs may sway, its leaves may flutter, and its roots advance into the dark soil, but it cannot move away. The body of the tree, too, is made up of parts that show differences of structure and use, but these parts are few in number and simple in their relation to one another. No central station like the brain of the horse controls all the other parts of the tree's body. Each organ of the tree does more 
different things than single organs of the horse do. The tree does not have so many separate organs, each for a distinct purpose, as the horse has. It has no eyes, no ears, no teeth. Its structure is simpler than that of the horse.

When, however, we go down the scale of life and compare the simpler plants with the simpler animals, it grows harder and harder to tell plant from animal. The sponge that may be seen in the ocean, and even in some farm brooks, cannot move from place to place although it is an animal. - On the other hand, certain low plants, like the pond scums that may grow beside the sponge, have much freedom of motion.

The difficulty becomes still greater when we coine to bacteria, For more than a century after they were discovered, they were taken to be little animals. Now, however, they are regarded as plants.

103. Protoplasm. - The white of an egg is a substance familiar to all of us. It is jelly-like. It lacks stable form; and, if pressed between the fingers, no grit is felt in it. It is thicker than water, of which it is mostly composed. If heated, as is well known, it coagulates; that is, it becomes white and opaque. Certain chemicals also, like alcohol, will coagulate it. A lump of sugar can be kept, at ordinary temperatures, for any length of time, without decomposing. But the white of an egg, unless carefully preserved, soon spoils and gives off an offensive odor.

This white-of-egg substance we call albumen, or protein. Now protein is a large part of protoplasm, about which we wish to learn. Chemists tell us that protoplasm is exceedingly complex. Huxley, a great English scientist, called it "the physical basis of life." It is present in all the growing parts of plants and animals, and, under a powerful microscope, it has exactly the same visible char- 
acteristics, whether it is found in the finger of man or in the twig of a tree.

The word "protoplasm" means first formed. Every part of plants and animals was made from it. In reality, it is the only part of an organism that can grow. Only a small part of a tree is really alive, since only that small part contains protoplasm.

104. Cells. - Protoplasm does not usually occur in large masses, but in tiny lumps, each separated from the next by a more or less distinct wall. It is these walls that give the plant strength. Each separate lump, with the wall about it, is called a cell. If one had eyes sharp enough to see all the cells of a stalk of corn at one time, the stalk would resemble a tall, oddly shaped building, whose outside walls would appear composed of irregular masses cemented together, not unlike the stones in the wall of an

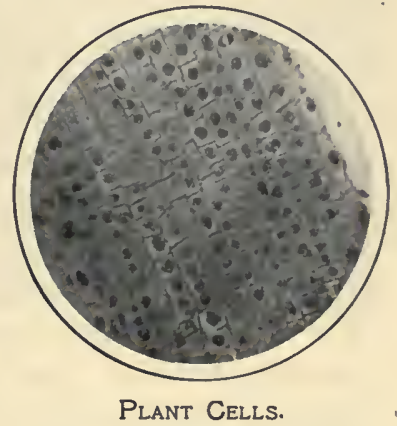
As seen in a growing onion root. ordinary house. Within the stalk, long, hollow, cell-like pipes could be noticed; and around the pipes, separating them from one another, countless round bodies (the pith cells) might be observed. The cells of the cornstalk have many different shapes, just like the parts of this imaginary building. Some cells are as irregular as the cornstalk itself; others have the shape of cubes, wedges, plates, or strings.

105. How Plants Grow. - Floating in the protoplasm of each live cell is a small rounded body known as the nucleus. This nucleus is an important agent in the growth of new cells. Cells, as we have said, never attain 
a large size, although they may grow rapidly. If well nourished, each nucleus quickly divides into two nuclei. ( $N \ddot{u}^{\prime} c l e \bar{\imath}$ is the plural of $n \ddot{u}^{\prime}$ clè us.) A new wall appears between these nuclei, forming them into two cells. When either of these has enlarged to the size of its parent, it is ready to divide again, and so on. When we speak of plants growing, we mean that their cells are multiplying in this way.

Cells take in food through their surfaces, and the amount of food that can enter them depends in part on the extent of their surfaces. Just as a pea has a greater surface in comparison to its bulk than an orange has, so a small cell has more feeding surface relatively to its needs than a large one has. This means that the larger cells become, the greater their chances of starving. Cell multiplication, then, is a means of saving the life of plants, as well as a process of growth.

106. Plants as Storehouses of Food. - Every plant has some part which it uses for a storehouse. Plants do not use up for their own growth all the food that they gather. They do so for a while, it is true, until they secure a season's growth. Then they begin to store up the plant food - in seeds or roots or tubers - for their offspring the next season. The farmer takes this stored-up food for his own purposes, just as a bee farmer takes the food his bees have stored away.

Food stored in the plant always contains both albumen (protein) and starch, but different plants store these things in very different proportions. Some, like beans, are rich in albumen; others, like corn, in starch. Albumen is the tissue-building part. Starch furnishes heat, or energy. The albuminous foods, or proteins, contain nitrogen (Chapter VIII); the starch is carbon, hydrogen, and oxygen. It is called a carbohydrate. Another carbohydrate is 
sugar, which, in composition, is almost the same as starch.

107. The storing process is exceedingly interesting, and the farmer ought to understand it. Starch is formed mostly in the leaves. The sunlight and the green substance of the leaves (chlorophyll) manufacture it out of carbon dioxide and water. ${ }^{1}$ The rest of the process varies in different plants. In the potato plant the starch is next turned into sugar. The sap then dissolves this sugar, ${ }^{2}$ and carries it to the underground tubers, where it is turned back into starch and stored away. In some plants, during these parts of the pro-

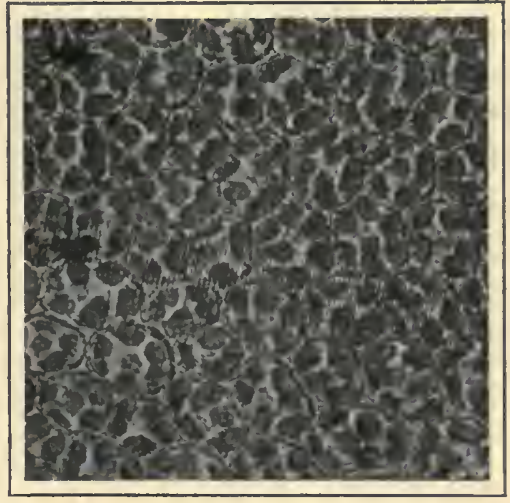

ChLorophyll Bodies of a Leaf.

Note the separate cells, each containing about half a dozen chlorophyll bodies.

cess, deposits of sugar itself are formed. Other plants form deposits of gums, - which are always nearly like starch and sugar in composition. Still other plants deposit fatty substances that we call oils. Vegetable oils are found especially in the olive, in cotton seed, and in nuts. The coconut is an extreme instance of an oily food deposit. Fats, like carbohydrates, furnish heat.

1 In this part of the process, some oxygen is thrown off into the air as a by-product. Plants breathe through fine pores usually on the under side of their leaves, much as the higher animals breathe through their nostrils. But animals take the air for the sake of its oxygen, and their lungs throw off into the air carbon dioxide. Plants breathe largely to get this carbou dioxide, and throw off some oxygen. However, plants do consume some oxygen, and in this respect they resemble animals.

2 It cannot well dissolve starch. 
108. The plant is a factory which works only by daylight. No staruh can be made without sunlight. Sunlight may be looked upon as the power that runs the factory, as steam runs a mill.

We may' carry this comparison further. A shoe factory, besides its power, needs a variety of materials, - wood, leather, nails, and so on. If the supply of shoe pegs has been allowed to run out, all the work must stop, though everything else is ready at hand. So, too, the absence of only one of the things needed by the plant factory may cause it to suspend work and die. Sunlight, warmth, water, the various plant foods in available forms, all must be secured in the degree needful. A lack of any one will damage or destroy the crop.

\section{Practical Questions}

1. Distinguish between plants and animals. 2. What are the characteristics of protoplasm? 3. Name three parts of a cell. 4. Compare the parts of a building with the parts of a plant. 5. Explain how cells are useful to plants. 6. Why do cells divide? 7. Explain how a plant may be likened to a factory. 8. Of what advantage to the plant is it to store up food or energy? 9. Explain how man profits by the tendency of certain plants to store up food. 10. Review the uses of water to a plant. 11. Name three gases useful to plants. 12. How do plants breathe? 13. Naune six mineral substances found in plants.

\section{HOME FXXRCISES}

1. Make an estimate of the number of different plants you can find on your farm. You can readily determine the area of the different fields, and you can count the number of plants. in an average square foot of each field. A simple calculation would give you the entire number.

2. Collect as many different kinds of wood as you can and conpare their hardness, stiffuess, and readiness to split. How does the nature of wood determine its uses for handles, spokes, flooring, and so on? 
3. Compare a piece of meat with a tip of a growing plant. In what ways do they differ?

\section{Suggestions}

1. Make a list of some of the characteristics of a tree and another list of those of the horse, and underscore those that are common to both.

2. Procure an egg and open it in a small dish. Note the absence of grit when a bit of the albumen is rubbed between the fingers. Place a small quantity of the albumen in water to see if it sinks. Then boil the water and note the effect. Vinegar or alcohol poured on some of the albumen will produce the same effect. Try it.

3. Take a bit of moist clay the size of a walnut. Into the soft mass press a pebble the size of a pea. Procure a small box just large enough to hold the mass. Mold the mass to the form of the box and place it inside. The box represents the cell wall; the clay represents the protoplasm; and the pebble, the nucleus of a cell. Old cells may lack the nucleus and protoplasm, and an empty box of any form would therefore represent them, except that usually the sides of a "dead" cell are packed closely together.

4. Coat a small plant with a thin smear of vaseline, and note the effect. The vaseline prevents the loss of water, and the entrance and exit of gases.

5. Burn a match. What remains is mineral matter.

\section{REFERENCES .}

Some good textbook in Botany.

Hand Book of Nature Study. Comstock.

Plant Culture. Goff.

Study of Corn. Shoesmith.

Farmers' Bulletins. Washington, D. C.

195. Simple Exercises Illustrating Some Applications of Chemistry to Agriculture.

218. The School Garden.

408. School Exercises in Plant Production. 


\section{CHAPTER XII}

\section{HOW NEW PLANTS ARE STARTED}

In the morning sow thy seed, - Ecclesustes xi. 6.

109. A plant is born, grows, and finally dies, much like an animal. Like animals, too, each kind of plant has a quite definite term of life. A grain of corn may be planted in May, and by October the plant will die. A turnip may

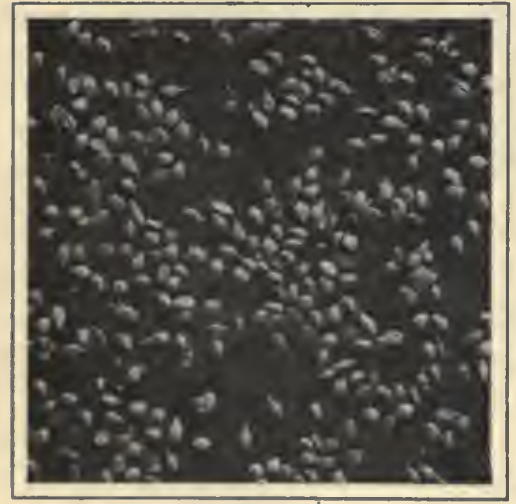

Millet Seed.

By which the plant is "propagated." start to grow in April and live through the second summer. Within an apple blossom a new apple tree begins a life that endures perhaps for a century. Many trees of the forest live for several centuries; but for each one, under even the most favorable conditions, a certain period of growth is followed by a period of decay and finally by death.

110. During its lifetime, each plant is busied largely in reproducing itself in new plants. Its whole character is adapted to the particular way in which it "propagates" itself, or extends its life around it and into the future. But man needs many kinds of plants in greater numbers 
than could be found if they were left to their own efforts in this matter. A chief part of the farmer's work, therefore, in field, garden, and orchard is to help useful plants propagate. 'To do this best, he needs to know the methods

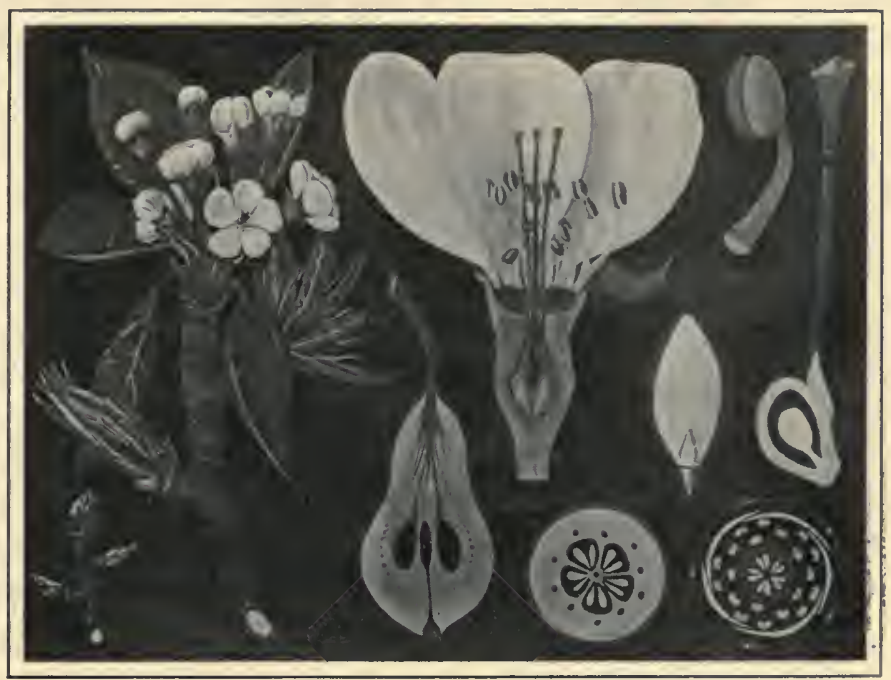

The Life Story of a Pear.

Twig, bud, blossom, and fruit.

by which plants work by themselves. First of all he must understand their flowers.

111. Flowers. - Most plants, including nearly all found in our fields, reproduce themselves through seed. Seed is always formed from parts of a flower. Hlowers are not always showy and fragrant, like the flower of the rose. The blossoms of wheat, oats, timothy, or other grasses are very small and have little color. Still the wheat flower is more important to the wheat plant than is the rose flower to the rose plant - and much more important to us. 
112. Flower Parts. - In the blossom of the common pear ${ }^{1}$ you can easily notice four whorls, each of a distinct kind. (1) The outside whorl is made up of five green leaves. (2) Next within is a whorl of five large white leaves. The outside whorl is the calyx, and each of its leaves is a sepal. The second whorl is the corolla, and each of its leaves is a petal. (3) The base of the calyx

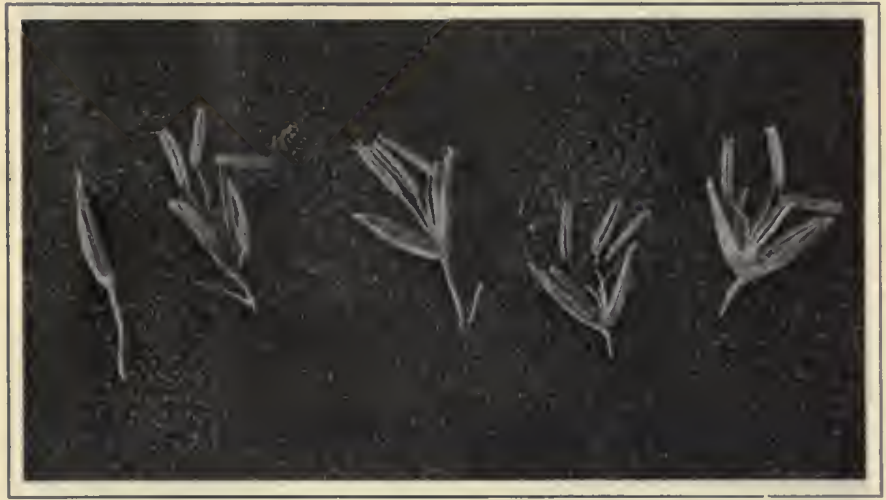

Staminate Flowers and Pollen of Corn Plant.

supports a third whorl of several thread-like parts. These are the stamens. Each stamen has at its tip a little sac called the anther. (4) At the center of the blossom are the pistils, three to five of them. They resemble the stamens. Their stalks or styles all come from one point at the center of the flower, but laek the brightly colored heads or anthers, and have green heads, or stigmas, instead. Were we to pull apart the urn-shaped base of the calyx, we should find the pistils extending to the center of the

1 If the pear blossom is not available for this examination, the teacher or class can easily find some other flower that shows sepals, petals, stamens, and pistils, though the number of parts may differ from those of the flower described here. 
urn, where they unite into a central mass known as the ovary; the ovary will form the core of the pear and the calyx the soft pulp outside the core. The calyx also serves as a fleshy wrapper to the delicate ovary.

113. What is the work of each of the flower parts? The calyx protects the bud when starting, and, later on, it furnishes some starch to the growing seeds. The corolla is needful to attract insects. Grains of the fine flower dust called pollen are produced in the stamen's anther. When pollen falls upon the pistil's stigma, that organ absorbs it, and passes it down through the style to the ovary, where there are already minute egg-like bodies called ovules. The pollen fertilizes these ovules; that is, it joins with them to make them grow into seeds. No seed can be formed without this union of pollen and ovule.

114. The stamen and pistil, accordingly, are the essential parts of the flower. Both are absolutely necessary to the production of seed, which is the purpose of flowers. Calyx

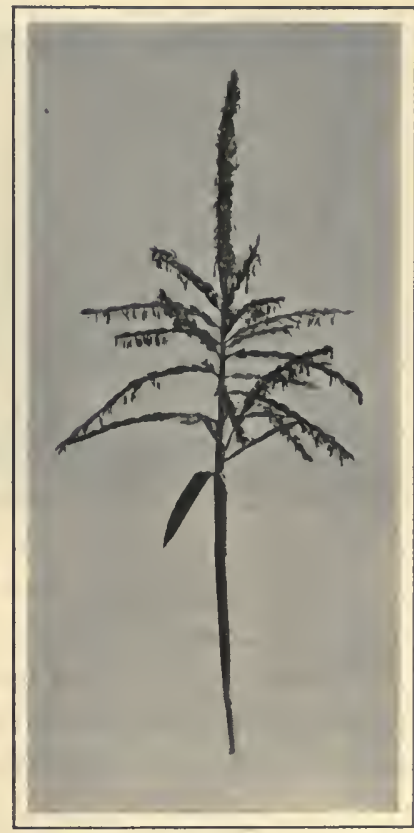

CORN TASSEL.

Staminate flowers. and corolla may assist in one way or another, but they are not essential parts. Many kinds of flowers do not have them. The cornflower does not, but it produces much seed.

Indeed, no one cornflower has both stamens and pistil. The tassels at the top of a stalk are clusters of staminate 
flowers (flowers with stamens). ${ }^{1}$ If you shake a stalk of corn when the anther saes have the pollen ready, a cloud of yellow powder will fall from the tassels, looking like a shower of sulphur.

The pistillate eornflowers grow lower on the stalk in one or more bunehes, or "ears." If you pull away the

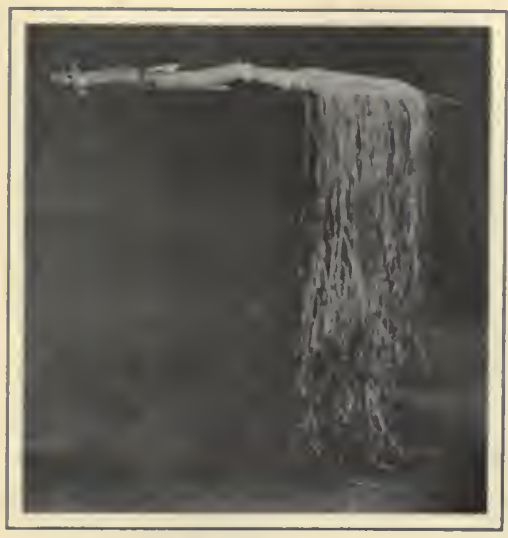

CORN SiLK.

Pistillate flowers.

husk from a young ear soon after the silk begins to show, you will see that each of the many silk threads ends in a kernel. This kernel is an ovary; each thread of silk is both style and stigma ; kernel and silk together form a pistillate flower. The pollen from some tassel flower at the top falls upon the many silk stigmas of each ear and is earried down to the bunch of ovaries. ${ }^{2}$

Flowers that contain both stamens and pistils are called perfect flowers, whether ealyx and corolla are present or not. Flowers that lack either stamens or pistils are im-

1 These flowers are very small. They grow along the spikes of the tassels, in conplets. Each flower is nearly inclosed in a hard, ribbed covering ealled glume. If this is pressed aside with a pin, one can see three stamens, partly surrounded perhaps by an inner wrapping. Usually only one flower of each conple prorluces pollen.

2 The pistillate cornflowers in the ear have interesting likenesses to the staminate flowers of the tassel. Thus the flowers on the ear, too, grow in couples. If we examine the young ear with great care, a sterile grain will be found under the fertile one. And each grain of the couple is inclosed in onter and inner wrappings. These show on the cob when the ripe corn has been shelled. 
perfect flowers, even if they have both calyx and corolla. The pear blossom that was described above was a perfect flower; each kind of cornflower is imperfect.

115. Cross-pollination. - Even in some kinds of perfect flowers the pistil often gets its pollen from the stamen of another flower instead of from its own stamen. All clover blossoms have both stamen and pistil; but the pollen and ovules of the same blossom do not readily unite. The

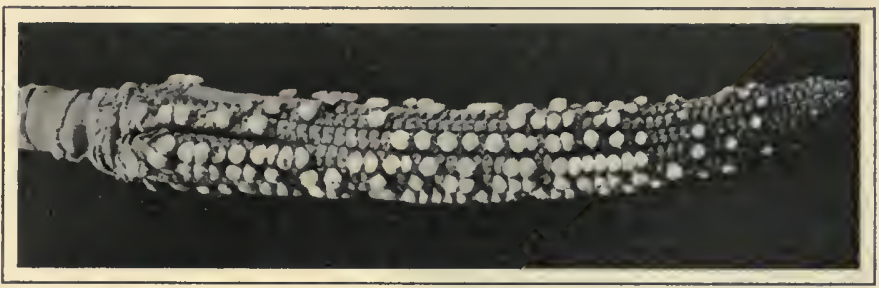

EfFect of Poor Pollination.

pistil uses pollen brought to it from another blossom. This is cross-pollination.

With farm plants, cross-pollination is far more common than self-pollination. Nature seems to have found out that cross-pollination gives more vigorous plants. Charles Darwin, one of the world's greatest scientists, proved by experiments that when cabbage flowers used their own pollen, they grew heads only a fourth as heavy as when they used pollen from another cabbage.

116. In cross-pollination how is the pollen carried from plant to plant? 'The wind carries corn pollen. Most of it falls on the ground or on other plants; but each stalk produces a large amount, and its high place on the plant helps the wind to distribute it well, so as to powder nearly every bunch of corn silk with it. ${ }^{1}$

1 If the corn silk receives pollen from the tassel of its own stalk, the pollination is not cross-pollination, because both flowers belong to the same plant. Corn uses both self-pollination and cross-pollination. 
The wind, too, is one agent in transferring the pollen of other plants from flower to flower, but many plants would fail to produce seed if nature lid not also use other less wasteful devices. In a field of red clover in blossom, bumblebees are usually busy visiting flower after flower. Commonly, the yellow pollen can be seen sticking to parts of their bodies. When a bee enters a flower, he brushes

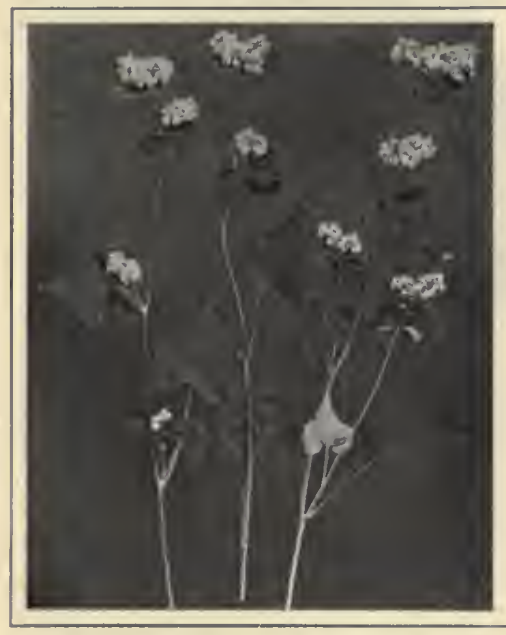

Buckwheat Plant in Blossom. off upon it part of the pollen he brings with him; and, before he leaves, his body collects some fresh pollen to carry on to the next plant.

The clover blossom and the bumblebee are especially suited to each other. The long tongue of the insect just reaches the nectar of the flower ; the blossom has the tint of red which, experiments show, is particularly attractive to the bee, ${ }^{1}$ and the clustering of many small flower's in one head makes it easy for the visitor to carry pollen to them all with little loss of time.

Red clover gives two crops in a season: one early in the summer; the other in the late summer or early fall. Even if the first crop is allowed to stand, it produces little seed, though blossoms have been abundant and vigorous. On the other hand, the second crop, if permitted to ripen, is

1 Probably, however, the bees like this color only because it is the color of the flower where they usually find food. 
usually profitable for seed. Farmers have known these facts for a long time, but only recently have they known that the difference between the two crops is due to the habits of the bumblebee. In the spring, when the first crop is in blossom, bunblebees are rarely seen; and the few that have survived the winter can cross-pollinate only a small proportion of the flowers. But by the time the second crop is in blossom, the colonies of bumblebees have multiplied, and many more of the flowers are crosspollinated.

The honeybee has a tongue too short to reach the nectar of the red clover, but for multitudes of other flowers it is a most efficient pollen carrier. Butterflies, some moths, and humming birds help in a like way. Usually a study of any one of these creatures and of the flowers it visits most will show some striking way in which the blossom and its helpful visitor are suited to each other, as bumblebee and clover are.

117. Other Methods of Propagation. - Many plants propagate themselves in other ways besides by seed. This used to seem very strange. Some years ago, however, August Weismann, a famous German scientist, advanced the theory that all life comes from a certain form of protoplasm which he cilled germ plasm. In the higher animals this germ plasm is found only in the organs of reproduction; but in plants it is more or less distributed through all their live tissue. This is why we can propagate some plants from shoots or by grafting and budding.

Many plants, to be sure, have little germ plasm except in the flower. Such plants can be propagated to advantage only from their seed. In other plants, the germ plasm permeates the entire structure, or at least various parts besides the flower. Many plants reproduce themselves underground by tubers, like the potato, or by new shoots 
from the germ plasm in the roots, as shrubs and trees will do. The willow will produce offspring from its twigs, if they are cut off and placed in the ground properly. The

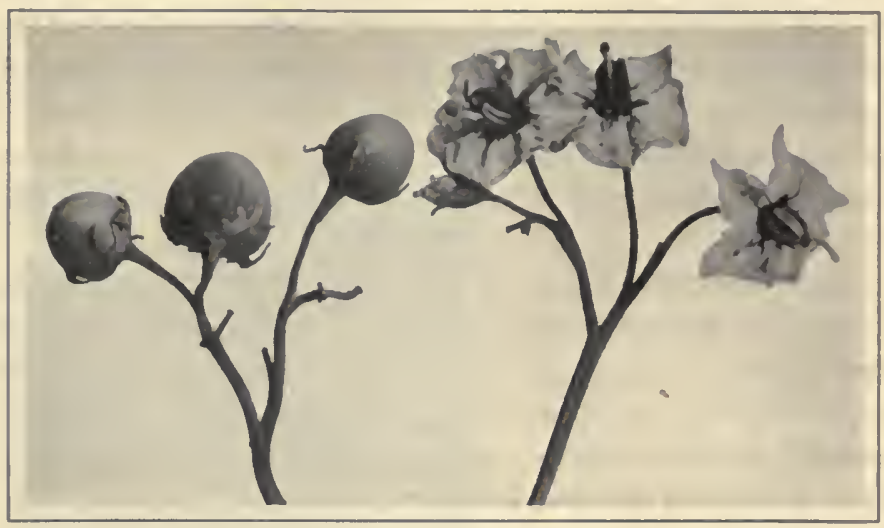

Seed Balls and Flowers of the Potato Plant.

begonia and other similar plants have the reproductive power even in the leaf.

118. The Two Great Ways of Propagating Plants. - All these various methods of propagation are classed under two heads, sexual and asexual (non-sexual).

a. The seed method is sexual. Stamens and pistils are sex organs of plants. The pollen from the stamen contains tiny particles of male protoplasm; the ovules of the pistil eontain female protoplasm. The union of the two kinds produces an active germ plasm in the seed.

b. Propagation from roots and cuttings, and indeed by all methods except by seed, is asexual. The new plant may be said to have a mother but no father. The tendeney to likeness between offspring and parent is much stronger in this kind of reproduction than in reproduction by seed. 


\section{Practical Questions}

1. What are flowers, and what is their purpose? 2. What is meant by reproduction? 3. Do all flowering plants reproduce by seeds? 4. Describe a pear blossom or any other blossom. 5. How many parts are there to a pear blossom? 6. Give the function or use of each part. 7. Define self-pollination and cross-pollination. 8. How do plants secure cross-pollination? 9. In what ways are the bumblebees and the blossoms of the red clover suited to each other? 10. Account for the small amount of seed in the first crop of red clover. 11. Have you ever noticed any insects besides bees visiting flowers? 12. Distinguish between a perfect and an imperfect flower. 13. Describe the two kinds of flowers borne on the cornstalk. 14. Will the grains of corn develop without pollen? 15. How do you account for cobs only partly filled out with corn?

\section{Home Exercises}

1. Ascertain how each farm plant reproduces. Have yon ever seen flowers on potato plants? Examine a head of wheat shortly after the flowers have appeared. Is the pollen carried from head to head?

2. Collect all the different farm flowers that you can find, and describe those of the leading crops. Bring report along to school.

\section{Suggestions}

1. In learning the names of the parts of a flower care should be taken not to select flowers for study that belong to the daisy family or that are very small. Large, simple specimens should be selected.

2. The flower selected should be pulled apart, and its parts carefully noted and described.

3. An effort should be made to determine which flowers are visited by insects and which are not. This work must be done in the field. The kinds of flowers visited should be noted. It is interesting to determine whether showy and fragrant flowers are more frequently visited than other kinds.

4. Bring to the schoolroom a few red clover blossoms. Count the number of flowers in each head, and look for the nectar glands. An interesting exercise would be to study the red clover blossoms in the field for the kinds of insect visitors. 
5. Dissect and draw the parts of the two kinds of flowers borne on the cornstalk.

Botanies.

\section{REFEREACES}

Familiar Flowers of Field and Garden. Matthews.

Practical Floriculture. Henderson.

In God's Out of Doors. Quayle.

Cornell Nature Study Quarterly, No. 2. Ithaca, N.Y. 


\section{CHAPTER XIII}

\section{MORE ABOUT STARTING NEW PLANTS}

Contact with nature affords a better tonic and nervine than the pharmacist can compound. - GARD.

\section{REPROIUUC'TION}

To start plants to the best advantage, we should know more about them. First we will consider some more facts that concern reproduction by seed.

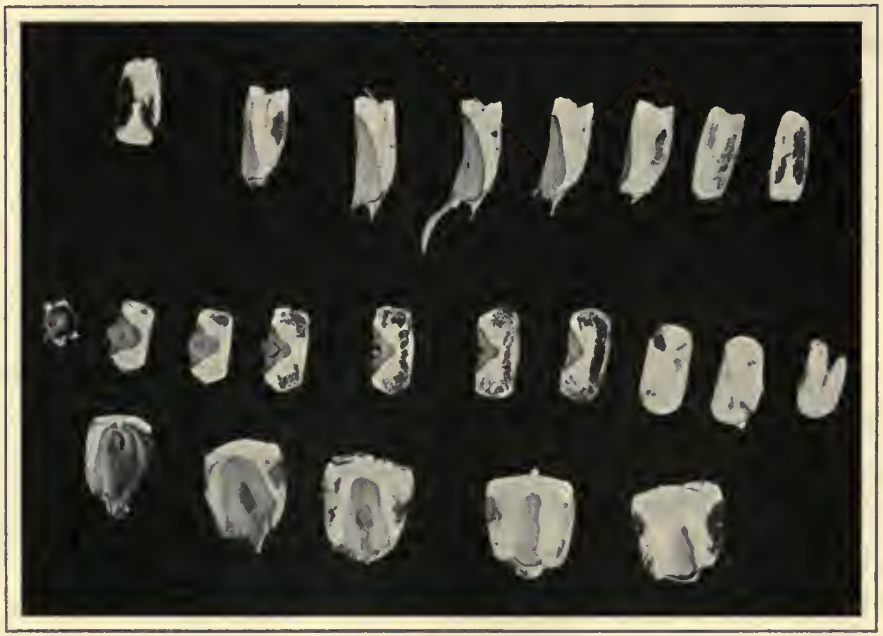

Sections of CoRn Kernels.

In the top row the kernel is cut lengthwise; in the middle row, crosswise; in the bottom row, flatwise. The white part is starch; the gray part, germ. 
119. Seeds and Embryos. - Two eommon types of seed are represented by the benn and the corn.

a. $A$ bean seed can easily be split into two equal parts, ealled cotyledons. Attached to one end of the seed, between the cotyledons, are a pair of miniature leaves called the plumule, and a short root sprout known as the

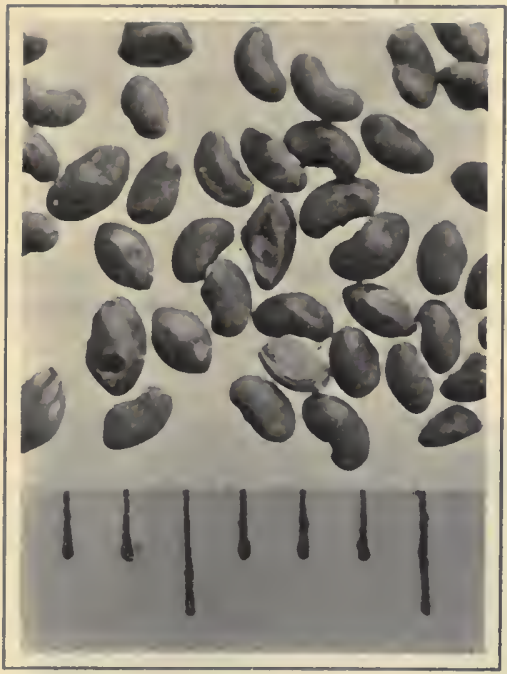

Poor Alfalfa Seed.

Before testing.

radicle. The three parts together form the embryo. This contains the germ plasm that was formed by the union of pollen and ovules.

Plants whose leaves are net-veined and which bear flowers having usually four or five divisions to their caly $x$ and corolla produce seeds of the bean type.

b. A grain of corn cannot readily be split apart into halves. A eross section of the kernels, especially if the seed has been soaked in water, will show the embryo at the base. This embryo or germ consists of one irregular cotyledon, a plumule made of sheathing leaves, and a radicle. Oecupying the broad end of the grain is the endosperm, - a material that is mostly stareh, to feed the embryo when it sprouts.

This corn type of seed is found in plants that have parallel-veined leaves and that bear flowers with the parts commonly arranged by threes or by sixes. 
120. Seed should be tested to determine what per cent of it will sprout and to find out whether it contains impurities such as dirt, weed seeds, and chaff. Farmers often lose heavily by using poor seed. The Iowa Experiment Station at one time tested 3300 samples of seed corn and found only sixty per cent of the samples good enough to use. Under the most favorable conditions this seed as a whole would produce but little more than half a crop.

121. The quantity of seed to sow to the acre varies somewhat with the character of the soil and with its preparation.

The following table of a few common kinds of seeds shows the quantity of each that has been found most profitable for an acre of average land in good tilth.

\begin{tabular}{|c|c|c|c|c|c|c|c|c|}
\hline & & & & & & & & \\
\hline & & & & & & & & \\
\hline alsike) & & & & & & & & 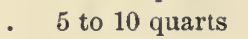 \\
\hline red) & 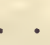 & & & & & & & \\
\hline & & & & & & & & \\
\hline or silage) & ) & & & & & & . & 9 to 1 \\
\hline , & & & & & & & & \\
\hline • & . & & & & & & & Po \\
\hline & & & & & & & & \\
\hline . & & & & & & & & \\
\hline & & & & & & & & 8 to 10 \\
\hline
\end{tabular}

122. Needs of the Seed. - A seed is a plantlet asleep, or in its resting stage. It may live a long time without change, if kept cool and dry; or it may awaken to activity in a few days, if kept warm and moist. Good seed will not sprout well in an ice chest, even with plenty of air and water; nor will it do so in a well-corked bottle with sufficient water and the proper degree of heat; nor in a dry room with warmth and air. Warmth, air, and moisture, all three, must be present in the soil for the awakening of the seed. 
123. The Seedling. - A young plant that eomes from a

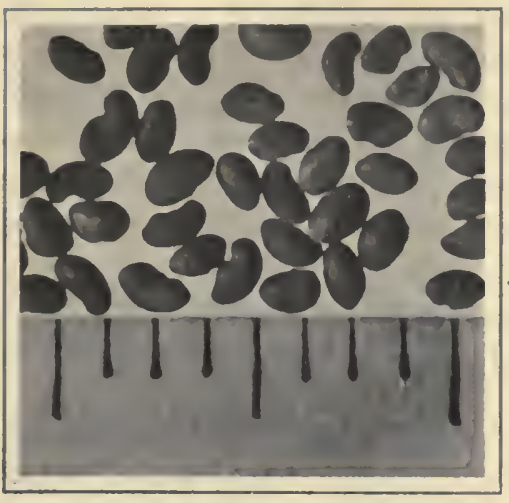

Good Alfalfa Seed.

Before testing.

seed is called a seedling. This name is likewise applied even to many mature plants started from seeds, if such plants are commonly propagated in other ways also. The term seedling apple, for example, distinguishes an apple plant started from the seed, from a plant started froin shoots.

A young seedling at first depends for food on the material stored up within its seed coats. A critical period in its early life comes when it has exhausted its own food material, and has not yet formed enough leafage and rootage to supply fully the demands of its growth. During this period - a few days or longer - the seedling is ver'y tender and delicate. If planted too deep, it may find the soil around its roots too cold or lacking in fresh air. If planted too near

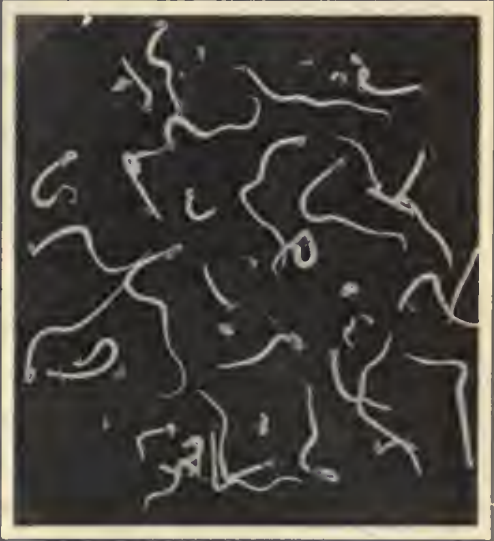

Alfalfa Seeds After Testing.

Note that some have not sprouted at all, while others have sprouts an inch long.

the surface, it may suffer from lack of moisture. The 
farmer, then, should be careful not to bury the seeds too deep nor to plant them too near the surface. He should be especially careful also to have the seed bed warm, moist, and mellow, so that the seed may germinate quickly and shoot up rapidly, and so get through its critical stage in as short a time as possible.

124. Roughly speaking, the depth at which a seed should be planted depends upon its size. Large seeds need deep planting; small seeds require shallow planting. It is a common practice to broadcast clover seeds on the winter wheat in early spring (Chapter $\mathrm{XXI}$ ), and trust to spring rains or to the freezing and thawing of the ground to cover them sufficiently. Lettuce seeds are sown on

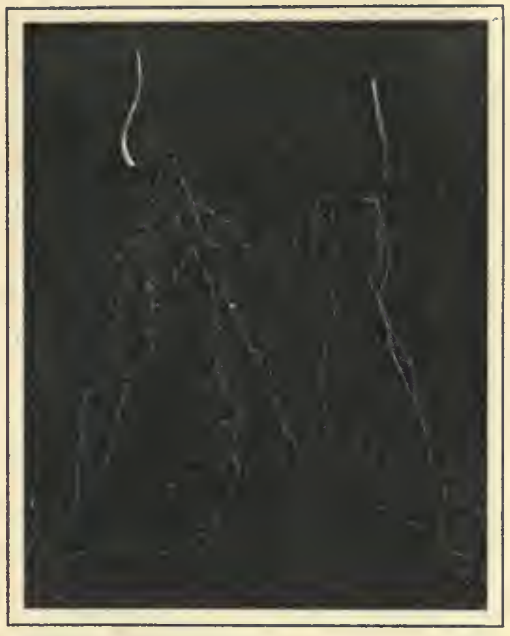

Roots of Wheat SeEdlings.

The one on the left was grown in sand; the other, in water.

the surface and pressed in slightly with a board. In one series of experiments, wheat planted at the depth of one half inch required eleven days to come up; that planted three inches deep required twenty days, and that planted six inches, twenty-three days. Moreover, only one third of the seeds planted under six inches of soil grew, while three fourths of those planted under three inches of soil grew and flourished. Such experiments have been made upon many kinds of seeds, and it is worth while for farmers to know the results. 


\section{NON-SEXUAL PROPAGATION: PARTS OF THE PLAN'T CONCERNED}

To understand better the non-sexual propagation of plants it is necessary to know more about their stems, roots, buds, and leaves, the parts by which they are propagated.

125. Stems. - Most farm plants have one or the other of two kinds of stem. One kind is illustrated by the pear tree ; the other, by corn.

a. An examination of a stem of a pear tree ${ }^{1}$ will show three distinct groups of tissue in it: the bark; the cambium; and the wood.

(1) In the bark, especially in the bark of new stems, numerous openings may be seen, about as large as ordinary pinheads. These are breathing pores for the deeper layers of bark. 'The bark serves mainly to protect this next group of very tender, liquid-like tissue.

(2) This middle group of tissue, between bark and wood, is the cambium. From the viewpoint of growth and reproduction, it is the vital part of the stem. Its cells contain protoplasm in a more active form than in those of any other part of the stem; and some of this is germ plasm and may create a new plant.

There are two layers of cambium cells: one adhering to the inside bark; the other, to the outside wood. The two together are about as thick as a leaf of the paper in this book. A boy often sees the two cambium layers of the willow when making willow whistles in the spring. After hammering the bark to loosen it, he pulls it away from a piece of the stem; then sometimes he scrapes away loose, moist particles that cover the surface of the wood. These particles are the inside layer of cambium. Perhaps

\footnotetext{
1 Such an examination can be made most easily in the spring when sap is starting.
} 
he has been unlucky enough to split the cylinder of bark; if he looks at the inside face of it, he will see other moist particles. These are the outside cambium layer.

Bordering each layer of cambium, many of the cells are arranged in long strings, or pipes, much as our blood vessels are. Through these pipes the sap of the plant circulates, rising from the roots to the branches through the outer wood, and returning to the roots in the inner bark. ${ }^{1}$

(3) The wood of the stem supplies strength and firmness to the tree, as bones do to animal bodies. In an old tree the heart or center wood is merely a mass of dead cells, and serves no use except to give strength. But the sap wood, or that nearest the cambium, in addition to affording stiffness to the tree and to providing pipes for the rise of sap,

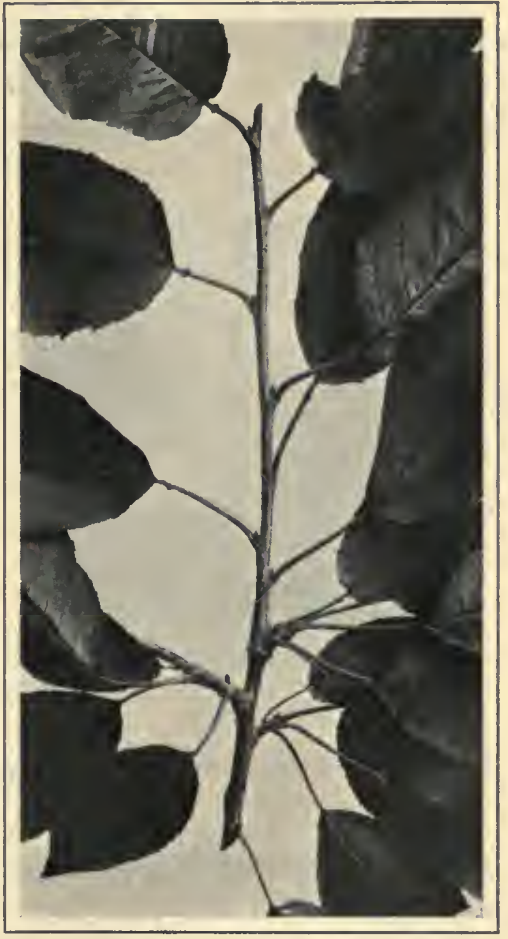

BUdS in the AxILS of Leaves.

Branch of a cherry tree in July.

serves as a storehouse where the sap may store surplus food for the next season's growth. Each year a layer of

1 A stem of any rapidly growing plant placed in red ink will show in a most striking manner in what part of the stem the sap rises, and the rate at which it moves. 
light wood in the spring, and usually of darker wood in the summer and fall, is formed by the cambium, so that the age of a tree can easily be determined, when cut down, by counting these pairs of rings.

b. The stem of the cornstalk consists of a series of nodes, or swellings, which are separated by internodes. Each internode is made up of a hard outer rind, or bark, and a soft interior structure composed of numerous hollow fibers

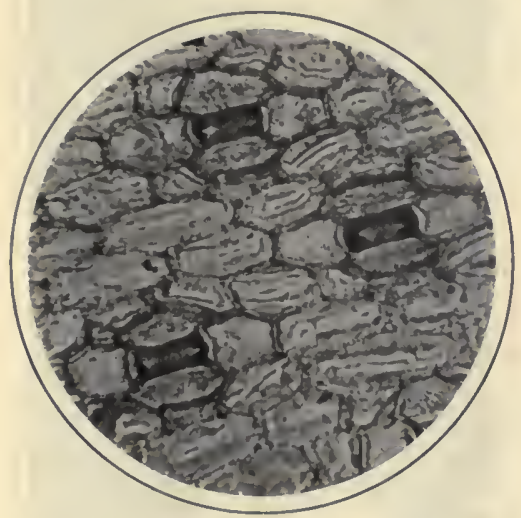

Breathing Pores of a Leaf.

The three dark spots are open breathing pores. and pith. The fibers are thread-like and are embedded separately in the pith. They correspond rather elosely to our blood vessels, in that they are the bearers of the sap of the plant. They run upward in each internode, leaving the stem at the nodes to enter the leaves.

126. Roots have much the same structure as stems. They are less firm, however, and they have one important feature that stems do not have. This is the growth of hair that densely clothes new roots.

These hairs are each about a fourth of an inch long and as fine as the threads of a spider web. They grow out of surface cells on the roots. They are very delicate, and are casily destroyed. Without them a plant cannot grow, for it is through them that food enters the plant in solution in the soil water. In transplanting plants, special care must be taken not to pull off or destroy too many of these root hairs. 
127. Buds. - If we observe buds on a shrub or orchard tree from time to time in the early spring, we notice that some buds grow into shoots that bear leaves only; others, into shorter shoots that bear both leaves and flowers; and some into still shorter shoots that produce only flowers. Accordingly, we speak of three kinds of buds, - leaf buds, mixed buds, and flower buds.

The buds of trees and shrubs are formed during summer and fall, and must be protected from freezing during the winter. This protection is afforded largely by a covering of scales, cemented together by a kind of wax.

128. The leaf is the factory of the plant. In it are manufactured its starch, protein, and oil. The framework of the leaf is largely a collection of veins, which branch more and more on entering the blade or flat part of the leaf. These veins give stiffness to the leaf, and distribute the solids in solution. The tiny openings in the skin of the leaf (mainly on its under side) are its breathing pores. They are about one tenth as wide as the thickness of this paper. It has been estimated that there are about $13,000,000$ of these breathing pores in a sunflower leaf.

\section{METHODS OF NON-SEXUAL PROPAGATION}

We have described briefly stem, root, bud, and leaf, because these parts, one or more, are used in propagating some plants asexually. Next we will consider the five chief ways in which these parts are used for this purpose: (1) by cuttings; (2) by using certain modifications of the stem which, in some plants, are especially suited for this purpose ; (3) by layering; (4) by grafting; and (5) by budding.

129. Cuttings are detached parts of a plant's body. A piece of a stem, or of a root, or of a leaf of some plants may be placed in the soil in such a manner as to develop roots at one end. Roses, grapes, currants, gooseberries, and ornamental shrubs are commonly propagated in this 
manner. Pieces from such plants form hardwood cuttings, as distinguished from the green cuttings of "soft" plants like the geranium and begonia.

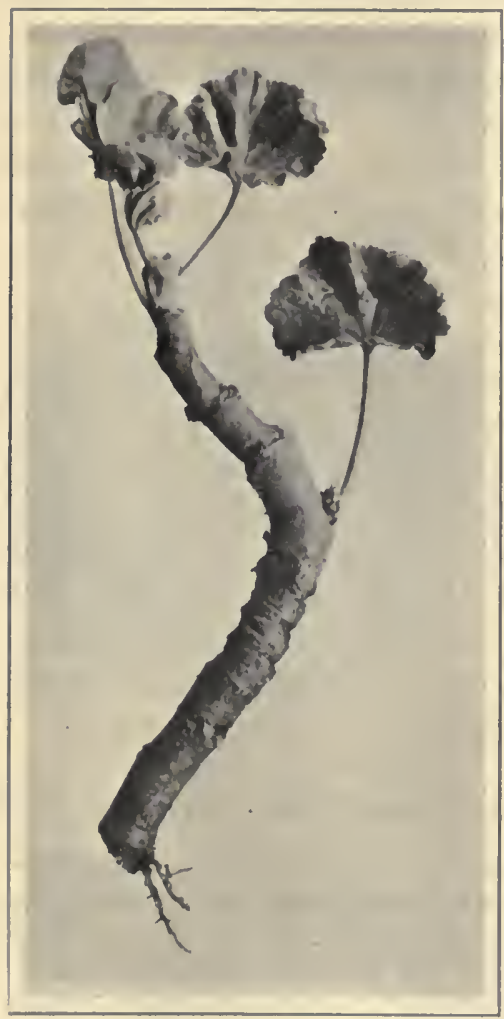

Geranium Cutting.

Note the two roots just starting.

Roses are among the easiest plants to propagate. In early fall, cut off a part of a rose stem about six inches long, allowing a leaf or two to remain on the cutting. The cutting should be brittle enough to snap off if bent quickly, and so the most rapidly growing shoots are not suitable. Place about one third of the cutting in the ground, which must then be firmly pressed about it. Cover the eutting with a glass jar to prevent excessive evaporation. Roots should appear in a few weeks, and by spring the young rose stalk is ready for transplanting.

The stems of grapes, currants, and gooseberries are also cut about six inches long, and each should have at least one eye or bud above the ground when planted, and at least one in the soil.

Cuttings of ornamental shrubs, like dogwoods and mock 
oranges, are usually made in early fall. Healthy, vigorous branches are cut into pieces with two or three eyes or nodes apiece. These slips may be tied together, some twenty-five in a bundle, and kept in a cool place through the winter, to be started in the field in the spring whenever the soil and weather are favorable. Or they may be planted at once in the fall, in moist sand, and kept warm by decaying compost. The temperature should not rise above $80^{\circ} \mathrm{F}$. The sand must be kept thoroughly moistened, but not wet, and must be well pressed down around the cuttings. After they have taken root they should be transplanted to small pots, and then should be partly buried in sand. As soon as the pots are filled with the roots, larger pots must be provided.

Green, leaf-bearing cuttings - from the geranium, for instance-

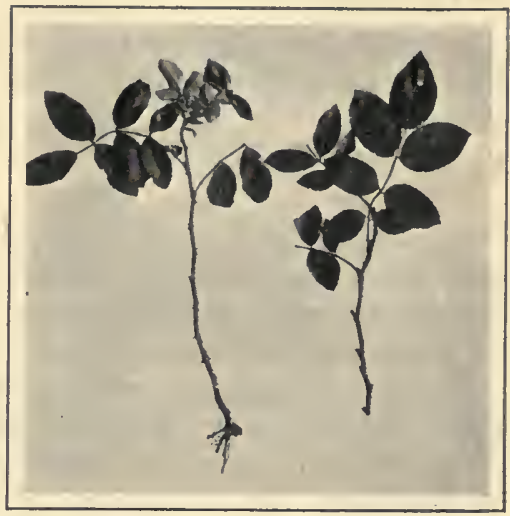

Rose Cuttings.

The one on the left has already sent out rootlets; that on the right has not been planted.

are propagated in essentially the same manner. The foliage should be trimmed off before planting, to retard evaporation.

Root cuttings made from the plum, blackberry, and red raspberry are given much the same treatment as that just described for ornamental shrubs. The temperature of the bed of cuttings must be kept down until towards spring. Sweet potatoes are roots, and are occasionally cut into pieces for planting. Or they may be started in hotbeds; 
then the shoots which come up may be pulled off and planted.

With a few common plants, notably the begonia, only a portion of leaf may be used for a cutting. Perhaps one half of the leaf is first removed, the remainder is then placed in moist sand, its stem being partly embedded. The leaf should not be allowed to dry up. Roots should soon start, and after they have made a good growth, the cutting may be transplanted.

Tubers, like potatoes and artichokes, are stems, although they grow underground. The "eyes" are the buds on these stems. In reference to potato cuttings, Professor Fraser of Cornell says :

Early varieties do not do as well when cut; and varieties with white flowers seem to be softer in texture and more liable to failure, if cut, thau those with purple or colored blossoms. Some varieties cannot be cut with profit, owing to lack of bud-producing eyes.

The labor of cutting is often greater than the cost of extra seed. When seed is expensive, as when a variety is new, it is wise to cut as far as possible to secure the largest possible yield in the least time, but this course must be followed by selection, or rapid deterioration of the variety will result. A potato cut into single eyepieces, and each piece planted in a hill, would give a greater yield than it would had it been planted whole.

130. Modified Stems. - In the preeding paragraph the potato tuber was called a stem. The plant modifies its stem into this form in order to store food and grow plasm for reproduction. The farmer meets many other peculiar stems that have also been modified for the same purposes.

a. Bulbs are scaly and fleshy stems. Certain common members of the lily family, including the onion, are propagated by bulbs.

b. Corms are solid bulbs. The gladiolus is grown from corms. 
c. Rootstocks are also underground stems. Many grasses produce branches that burrow into the ground. These branches show regularly arranged nodes and internodes. The leaves of these underground branches have been reduced to whitish scales or have entirely disappeared. Many plants keep alive through the winter

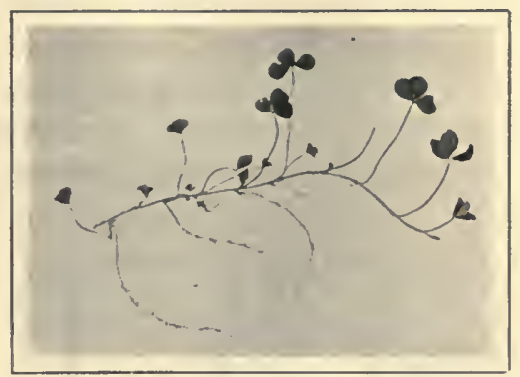

Stolons of White Clover.

A leaf appears at each node. through their rootstocks. The part of the plant above the ground is killed; but the underground stem remains

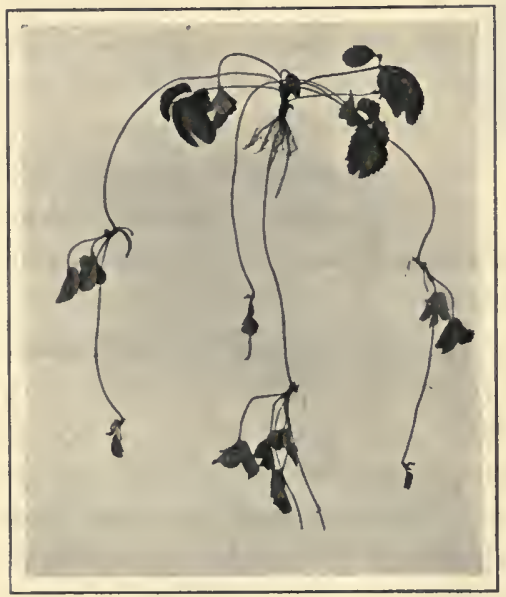

STRAWBERRY RUNNERS.

Four runners have started from the plant at the top.

alive because of the protection afforded by the ground. In the spring, a shoot, or new plant, may be sent up from any of the nodes. This is why the farmer may have a permanent pasture without replanting, and why he is troubled by quack grass and Canada thistles.

d. Stolons are creeping stems, like those of the strawberry, dewberry, and currant. After creeping on the ground for a few inches or a few feet, a stolon bends over, strikes root at the tip, 
and develops a cluster of leaves. From this new plant, the main stem continues to ereep further and again strikes root, and so on.

a. Suckers are vigorous branches that spring up from roots or from stems near the surface of the ground. Plums, white poplars, and lilacs form suckers freely. The prop-

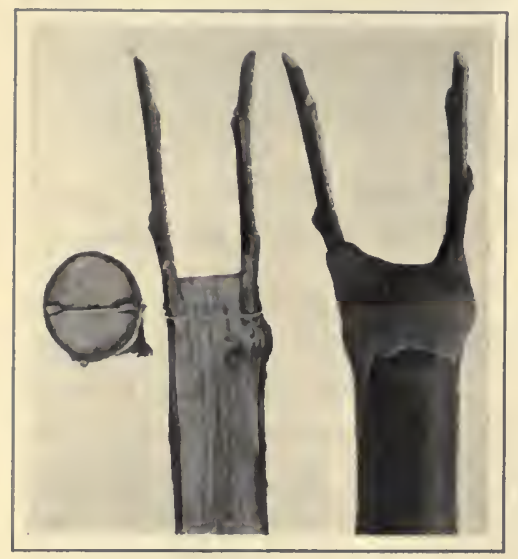

Cleft Grafting.

agator euts off the root connection, and transplants the sucker to start a new plant.

131. Layering is another kind of propagation by stems. Certain plants, like the black raspberry, can be made to take root at the tip of the stem if the stem is bent over and the tip covered with moist soil. This is layering. When the new roots are of fair size, the connection between the old plant and its offspring is cut, and the young plant may be transplanted.

132. Grafting is the art of uniting parts of two different plants. The part to be propagated is ealled the scion, and the part of the other plant to which the scion is to be united is known as the stock. The union is effected by the rapidly multiplying cells of the cambiums of seion and stock. These cells must be kept moist in order to multiply. There are two common kinds of grafting, cleft grafting and tongue grafting.

a. Cleft grafting is performed usually on limbs about the thickness of a man's wrist. From the stock a limb is sawed off smoothly, and the stump is split with a knife or 
chisel. From the other plant two scions, a few inches long, each bearing a bud or two, are cut at the base to a wedge shape. These scions are now inserted in the cleft, one at each side, in such a manner as to bring the cambium layer of each in contact with that of the stock. To insure this contact it is best to spread the scions slightly. Grafting wax is then worked over all the cut surface. This wax prevents the evaporation of moisture from the growing cells and also helps to hold the scions in place.

b. Tongue grafting or whip grafting is a more difficult operation. A scion and a stock must each be about as thick as a pencil, and from two to four inches long. A slanting cut is made at one end of each. This cut end is then split down a short distance with a knife. The two split ends are now fitted into each other in such a way as to cause their cambiums to meet at the surface. The scion and stock are usually held in place by a waxed cord.

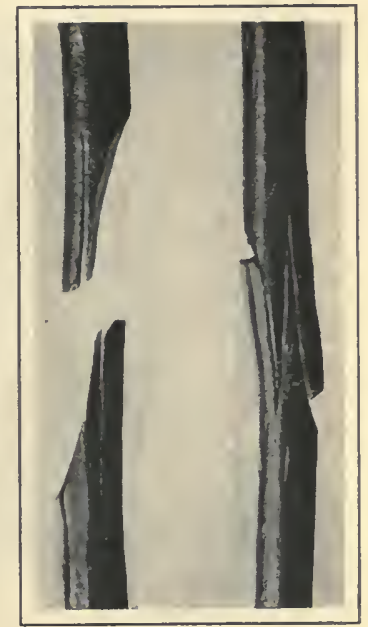

Tongue Grafting.

Apple trees are started in this manner. The seedlings at the end of the first season are dug up, and their roots are cut into pieces for stocks. A section of a one-year-old twig from a tree of the desired variety furnishes the scion. They are then buried in sand and placed in a cool cellar until spring. The plant that grows from this union will resemble the scion plant.

133. Budding is a form of grafting. A T-shaped cut is made in the stock, and a bud from a desired variety is 
inserted beneath the bark and is held in place by raffia or occasionally by a common string.

Peaches are usually propagated by budding. Peach stones are allowed to freeze during the winter. In the spring they are planted, and before winter the shoots are ready to use. A bud is inserted upon each shoot near the ground; and after it is well started, the shoot above the

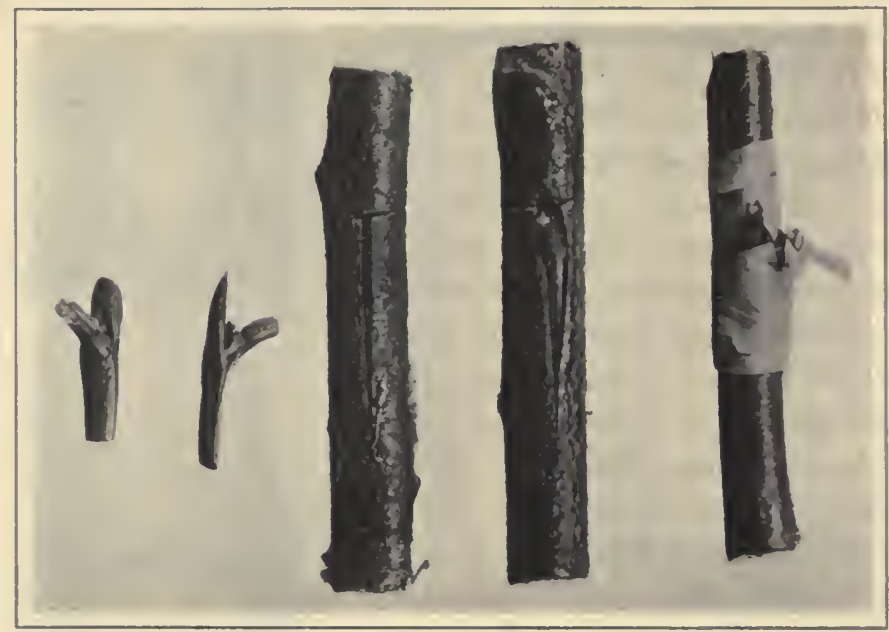

BUdDING.

Four stages of the operation are shown from left to right.

bud is cut off. Other stone fruits, like cherries and plums, are propagated in a similar way.

134. Stock and Scion. - In all forms of grafting, including budding, the seion is really a transplanted plant. The new growth, above the graft, resembles the scion plant. ${ }^{2}$ The stock does little except to furnish nourishment to the

1 If branches are allowed on the stock plant below the graft, those branches will resemble the original stock. An apple tree may be so grafted as to bear several different kinds of frult on different branches. 
transplanted scion. This it does in a remarkable degree; so that one purpose in grafting is to secure quicker growth. An apple seedling will not bear much fruit until seven or eight years old; but if a scion from it is early grafted upon some mature root, fruit may be secured some years sooner.

In certain cases, the stock exerts some other slight influence on the scion. Sweet-apple scions on crab-apple stock bear sour fruit. A quince stock will dwarf a pear tree scion; and in like manner the influence of a dwarf apple tree will retard the growth of scions from a large apple tree.

\section{Practical Questions}

1. What is propagation? 2. Explain the statement that all living things have a period of life. 3. What is germ plasm? 4. Name all the parts of a plant that may contain germ plasm. 5. What is the sexual method of plant reproduction? 6. How does the asexual method of reproduction dif-

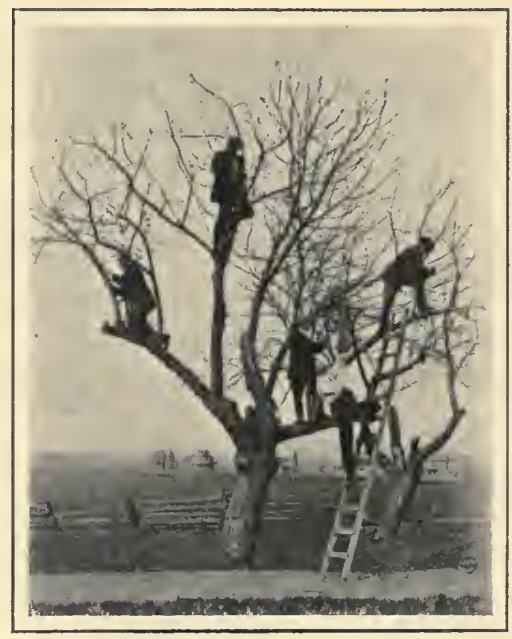

Grafting EXERCISE.

The boys are renovating an old apple tree by cleft grafting. fer from the sexual? 7. Describe a bean seed. 8. What are some of the general characteristics of plants which produce seeds? 9. Describe the structure of a grain of corn. 10. Discuss the value of seed testing. 11. Explain how clover seed may be tested. 12. In what sense may a seed be spoken of as a plantlet that lias fallen asleep? 13. How do farmers awaken seed to activity? 14. Define a seedling. 15. What is the most critical period in the life of a plant. 16. What is the best depth for planting wheat and tobacco? 17. Describe the 
structure of the pear stem. 18. Discuss the structure and function of the cainbium. 19. Compare the structure of a corn stem with that of a pear stem. 20. Describe a root hair. 21. Give the function of a leaf. 22. What are cuttings? 23. What plants are propagated by cuttings? 24. Name three different kinds of cuttings. 25. For what purpose are certain stems modified? 26. Define rootstock, tuber, corm, bulb, sucker, and stolon. 27. Fxplain the art of cleft grafting. 28. Distinguish between a scion and a stock. 29. Explain how certain plants are budded. 30. Discuss the effect of the stock on the scion.

\section{Home Exercises}

1. See how many grafts you can get to grow in your home orchard. As soon as you see that you are successful, you should make an effort to improve some plant by grafting.

2. Test your father's clover, alfalfa, and grass seed according to the inethod suggested on page 225. Report in school the per cent of germination for each kind.

3. After some one has shown you how to start cuttings, propagate several at home and report.

4. How much seed per acre does your father use for his different crops?

5. Start a fruit tree from the seed according to directions given in the text.

\section{SUgGestions}

1. Demonstrate the propagation of a rose cutting. A school garden is convenient for this purpose.

2. The mechanical side of budding and grafting should be demonstrated by the teacher on material brought to the classroom. Each pupil should then be given some practice and be required to insert a bud and make a graft. The details of all the points should be explained from this material. After a little skill has been acquired thus, real work should be attempted on the outside or at home. The pupils should be graded on the number of successful operations performed.

3. Beans and corn should be soaked for a few hours, and their parts then dissected, drawn, and labeled.

4. Procure some small seed like alfalfa and clover. Determine the per cent of germination. If no balance is available, give each pupil a 
thimbleful of seed and ask him to separate the seed and the dirt into piles. In a rough way the per cent of dirt may thus be estimated.

5. Determine the needs of a growing plant, - air, moisture, heat, and light, - by simple experiments such as those suggested in the text.

6. In a large glass jar containing soil, plant different seeds at different depths. Place the seeds agaiust the glass in order that their attempts to rise to the surface may be noted. This experiment is very simple and instructive.

7. Ascertain, if possible, how the farmers of the neighborhood start their plants, and where they obtain their seed.

\section{References}

Botanies.

Nursery Book. Bailey.

Pruning Book. Bailey.

Systematic Pomology. Waugh.

Farmers' Bulletins. Washington, D. C.

113. The Apple and How to Grow It.

134. Tree Planting on Rural School Grounds.

154. The Home Fruit Garden : Preparation and Care.

157. The Propagation of Plants.

181. Pruning.

213. Raspberries.

428. Testing Farm Seeds in the Home and in the Rural School. 


\section{CHAPTER XIV \\ MAKING BETTER PLANTS}

It has been clearly demonstrated that it is possible to increase the product per acre of the average farm up to 40 per cent simply by the use of improved strains of seed developed on the farm itself, at the cost of a little well-directed effort on the part of the farmer.

- Tracr.

I. THE SCIENCE OF PLANT BREEDING

135. A New Science. - About fifty years ago a new science was born. It is called the science of plant breeding. Already it has created many neiw, highly desirable plants, and improved many other old plants in a most astonishing degree. It has established the principles of an art that have enabled an expert to produce a seedless orange; to introduce better flavors into many fruits; to create plums of unusual size and texture; to grow a blackberry plant that bears a bushel or more of berries; to produce a peach-plum that hides the twigs with its fruit ; to increase the size of many cultivated roots and tubers and at the same time to decrease the amount of woody fiber in them; to make potatoes, prunes, almonds, lettuce, and apricots of larger size and better quality than were known before; and to improve many other fruits, regetables, flowers, and trees.

136. The leading plant breeder in the world is Luther Burbank, who now lives at Santa Rosa in California. He was born in Massachusetts, March 7, 1849. As a boy he was a great reader of good books and a close observer of 
nature. This habit of observation gave him passionate delight, and finally started him, while he was yet a youth, upon his great work.

While hoeing in his potato patch one day, he noticed an unusually interesting seed ball on a remarkably vigorous potato vine. This hill of potatoes he guarded carefully, and when the seed was ripe, he gathered it. From this seed he produced the celebrated "Burbank" potato. It is said that a local seedsman paid the young man $\$ 150$ for the right to use this discovery. High authorities declare that the dissemination of this variety of potato has enriched the farmers of America to the extent of $\$ 20,000,000$.

Better still, it showed how to go to work to obtain other varieties, and since that time there

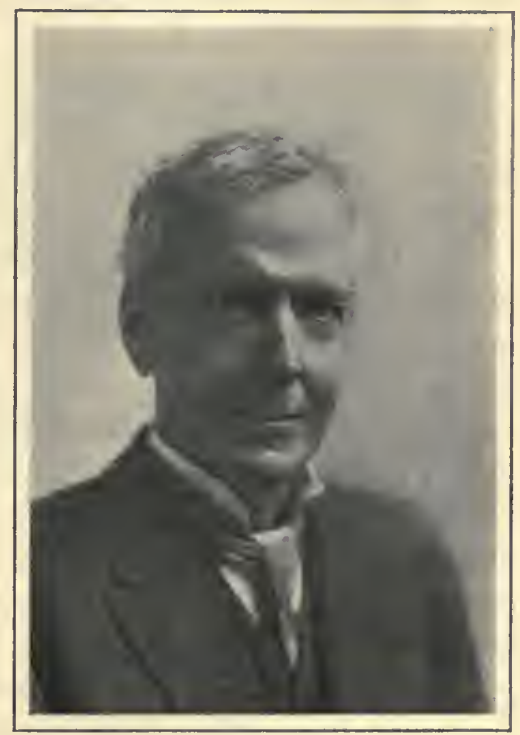

LUTHER BURBANK. have been developed, from promising seed balls, several kinds of potatoes even more valuable than the Burbank. Best of all, the creation of the Burbank potato started young Burbank upon a new career that has benefited the world beyoud all computation. On his extensive experiment grounds in California he has worked miracles in plant creation and improvement. All the marvelous plant work mentioned in the first paragraph of this chapter was done there by him and his little army of trained assistants. 
With good reason Luther Burbank is called "The Plant Wizard of the West."

137. The plant breeder produces new kinds of plants and improves old ones, by crosses. He does not leave Nature to produce crosses unaided. He experiments in new crosses, such as Nature, left to herself, would perhaps never secure. The genius of the breeder is shown mainly in selecting the plants to cross.

After the selection has been made for any one experiment, the work itself is relatively simple. It is merely a matter of cross-pollinizing the two plants and listing the results.

138. In cross-pollination the breeder is concerned mainly with stamens and pistils. He must take the pollen from one plant to fertilize the pistil of the other, - and he must see to it that that pistil is not fertilized in any other way, or he would not know what factors produced the result which he finally obtains.

First the plant whose pistil is to be fertilized is stripped of most of its flower buds, so that the remaining ones may develop vigorously. The remaining blossoms are deprived of their stamens, by the use of fine scissors. This is done before the blossom fully opens, so as to make sure that the anther shall not have already shed pollen on the pistil. Great care is taken, of course, not to injure the pistil when cutting away the stamens; but the calyx and corolla may be cut away also if they are in the way. The remaining pistil is at once covered with a small paper bag, tied on the flower stalk, so that neither bees nor breezes may deposit undesired pollen there. Insects, to be sure, are not likely to visit a mutilated flower; but it is necessary to be absolutely sure, or the experiment is worth little.

The breeder next takes pollen from the stamen of the 
other plant selected, and applies it to the prepared pistil with his finger or with a brush. Usually he first moistens the stigma slightly, to make the pollen adhere to it better.

139. Testing the Result. - After all this work, the pollen may not fertilize the ovules, and no seed may be formed. That is, these two plants may refuse to breed together. In a vast number of experiments this is the case.

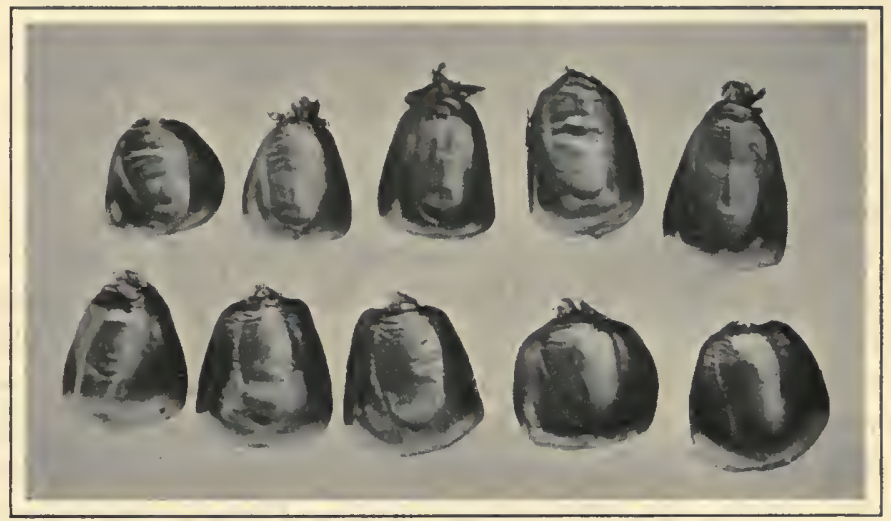

Variation in Plant Breeding.

Note the differences in size and shape among these kernels of corn.

If the ovules are fertilized, seed is formed, and this seed will produce a plant different from its parents. But until this new plant matures, it is impossible to tell whether the plant is an improvement or not. From thousands of crosses the breeder selects only a few to preserve. In some cases it takes years before the breeder can tell whether his new cross is worth preserving. If he has been working with apples, he must wait until the new plant produces fruit; and then if the result is disappointing, he must begin over again. It is fortunate, therefore, that he can hasten results with such plants by grafting. If a sprout for the new apple tree, when a year old, is 
grafted upon an old tree of almost any sort, the new variety of fruit may be secured and tested in the fourth year from the time the experiment began, while if the seedling is left to develop by itself, many more year's will be required. At the best, it is plain that one human life is hardly long enough for complete experiments upon the longest lived plants. Plant breeding is still an infant science; and even more wonderful results are to be looked for from it in the future than those so far secured.

\section{SOME RESULTS ALREADY SECURED}

140. Corn, a leading crop in the United States, has been much improved both in yield and in quality.

a. Increasing the yield. The average yield of corn in the United States is still less than 30 bushels to the acre. In Corn Club work, however, Walter Lee Dunson of Alabama during the summer of 1913 grew 232.7 bushels of corn on his acre of ground, at a cost of 19.9 cents a bushel. Jerry Moore, another southern boy, is said to have raised 228.7 bushels of corn on his acre. These results were secured partly by superior tillage, partly by selecting superior seed. The latter factor is the only one of the two which has a bearing upon plant breeding.

In the average field of corn there are many stalks with only poor ears or with no ear whatever. These barren stalks usually produce an unusual abundance of pollen. Their reproductive energy goes wholly to this. Since the pollen grains from the barren stalks are more numerous relatively than those from productive ones, the tendency to barrenness inay increase. A corn breeder counteracts this tendency by removing the tassels of the barren stalks before their pollen can reach the silk of the productive stalks. This operation does more than counteract the evil tendency: it positively strengthens the opposite good 
tendency, because the ears are then fertilized only by pollen from stalks more productive than the average. The seed from a crop that has been treated in this way will be, not only not worse, but decidedly better, than the seed that produced that crop. Every farmer who saves his own corn seed - as all corn raisers should do-ought to be a breeder of corn at least as far as concerns this simple and profitable operation upon his seed plot.

There are other still more important methods of breeding corn for increased production. These will be discussed in Chapter XIX. Some of them, too, are suitable for practice on any ordinary farm when corn is raised at all,

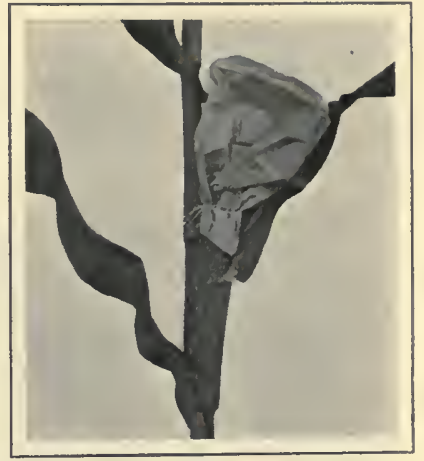

CORN BAGged.

To keep off inferior pollen. and their more general adoption would add enormously to our national wealth. If our average corn yield on the present acreage were increased only from 40 bushels to 50 bushels, the increase would be worth half a billion dollars each year. This would pay all the expenses of our school system, from the kindergarten to the university.

b. Improvement in quality. An average bushel of corn, weighing 56 pounds, contains approximately

36 pounds of starch

7 pounds of gluten

5 pounds of bran

4 pounds of germ

4 pounds of worthless matter including water.

Glucose manufacturers desire corn with high oil value. Feeders of bacon hogs demand corn with low oil value. 
About 40 per cent of the average corn germ is oil. But at the Illinois Experiment Station, two new kinds of corn have been bred: the germ of one contains about 20 per cent, and that of the other about 80 per cent of oil. Both the glucose and the bacon men, therefore, have now a grade of corn that suits their needs much better than the older kinds did.

In a similar manner the other ingredients of corn have been increased or climinished by the breeder according to

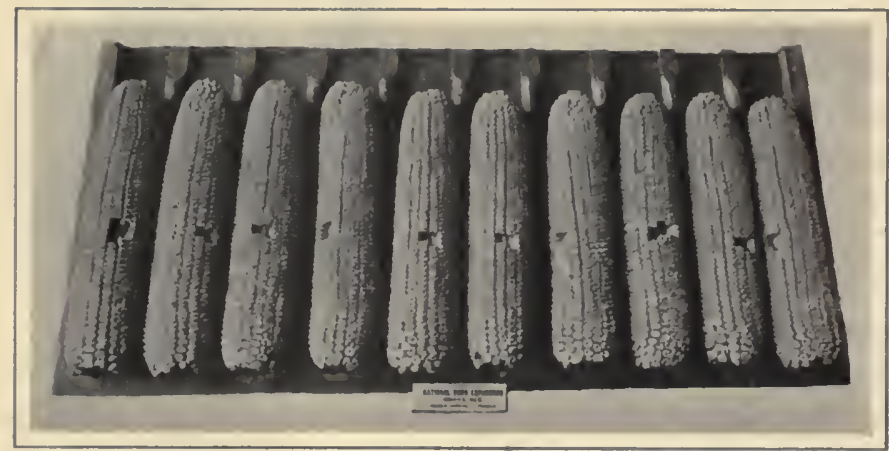

Prize CORN.

Can you find any imperfection in any of these ears?

the demands of the market. The protein which is found mainly in the gluten and the germ has been increased in certain varieties from the old average of about 10 per cent to 14.26 per sent; while in other varieties it has been decreased to 8.60 per cent. So, too, varieties have been produced that have particularly hard, bright, shapely kernels. Other new varieties excel in the shape and size of the ear. Other's have special power to resist disease or drought, or frost.

Breeding for this last quality is especially important. It has already widened the corn belt by several degrees of 
latitude, and is still pushing its northern limit farther and farther north. This, in effect, adds a new food grain to a large part of the world.

141. Tomatoes, only a few generations ago, were known as "loveapples" and were grown only as curiosities. The fruit was unfit to eat: it was tasteless, small, and full of bitter seeds. By cross-pollination and selection, however, the fruit has been increased in size, given a finer texture, flavor, and color, and made to mature early or late, so as to supply the market through a long season.

142. Wheat has been improved in the last twenty-five years more than during the previous four thousand. Many new varieties of wheat

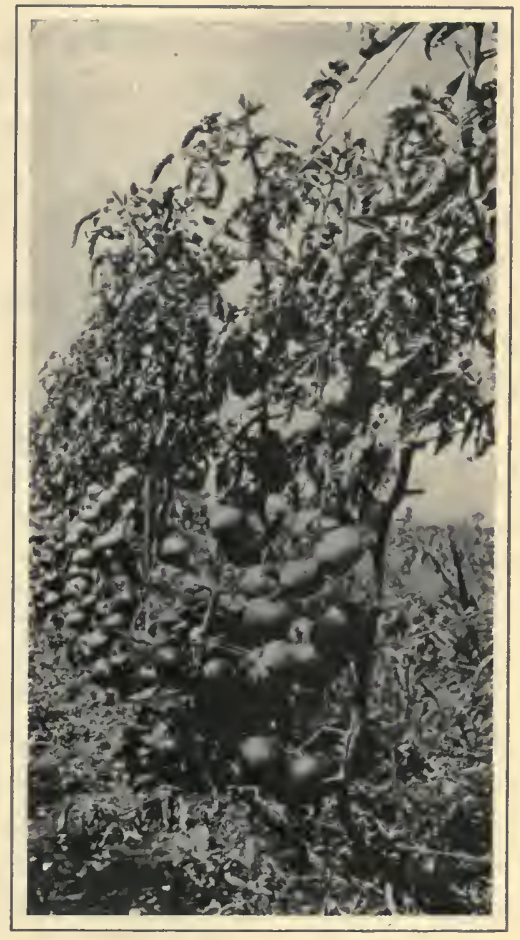

TOMATOES. have been produced by scientific breeding. These new varieties, compared with the old ones, have a greater power to resist rust and drought, produce a larger yield per acre, and contain a higher per cent of gluten or protein. No one variety combines all these advantages, to be sure; but each improved variety is suited to some locality or to some demand of the market. And scientists are trying to improve wheat still more. 
III. HEREDITY AND VARIATION: AND THEIR PLACE IN PLANT BREEDING

143. Nature, too, breeds new varieties of plants, and she has been in the business much longer than man has. For countless centuries she has been developing the myriad kinds of plants that we know from a smaller number of simpler forms. Doubtless even more myriads were started, but failed to survive.

144. Nature and the Human Plant Breeder. - Nature is still at work in the same way; and still, too, when she produces a plant fit to become the mother of a new variety, it often dies out without doing so, or loses its best qualities by unfortunate crosses. The human plant breeder, and indeed the ordinary farmer, sometimes stumbles upon a new sort of plant that Nature has just produced unaided. If the plant is useful, the man's part is merely to protect it and to propagate a new race of plants from it.

This is what the youthful Burbank did with his famous potato. He had some other special merit in that case, however. He noticed a possibility of merit when a less observant man would have seen none at all; and he took the trouble and time to try out the plant and prove its value. Other men have sometimes made like discoveries more purely as a result of chance, so far as their own merit is concerned. A famous instance of such a discovery is lescribed in the next paragraph.

145. The Concord Grape. - In 1843 Ephraim W. Bull planted in his yard at Concord, Massachusetts, a few seeds of the wild fox grape. The grape whose seeds he planted was not unusually attractive to the sense of taste, or sight, or smell. He had no reason to suppose that from these seeds he would obtain a vine which would bear any more attractive grapes. Indeed, he expected to secure only 
ordinary wild grapes. In this, however, he was mistaken. The grapes on the new vine were very superior in size, color, texture, and taste to those borne on the parent vine. They became famous rapidly. The new grape appeared in 1849. Only four years later, in the records of the Massachusetts Horticultural Society, this statement occurs: "E. W. Bull exhibited his new seedling grape, which, under the name of Concord, is now so generally cultivated throughout the country."

146. "Sports." - The Concord lias made the name of Ephraim Bull famous. But Mr. Bull was not a plant breeder. He did not experiment, wisely or unwisely. Nor did he deserve any special credit for planting wildgrape seeds in his garden. Many of his neighbors had done that, and so

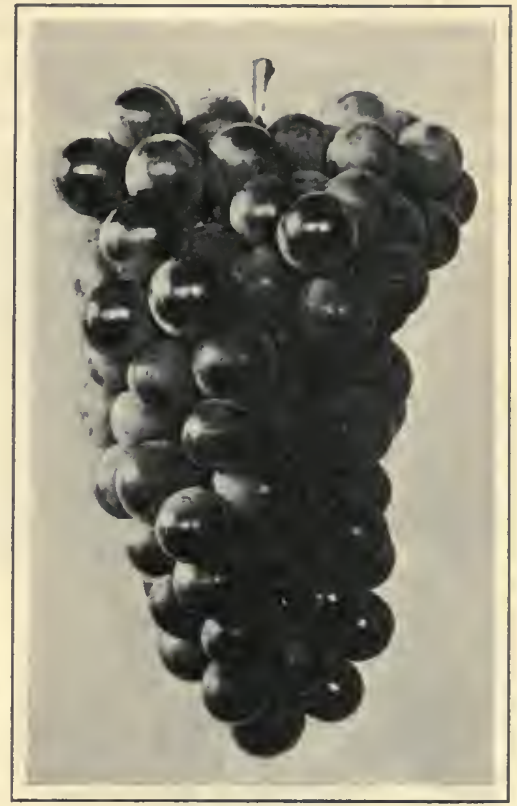

Niagara Grapes.

A cross of the Concord and the Cassady. have thousands of other people before and since, and the vines that grew up have been merely the fox grape.

By a happy chance (so far as man's part goes) the seed in Mr. Bull's garden produced " "sport." A "sport" among plants is a plant which, purely from natural causes, departs widely from the parent type. Sports occur also in the animal world, and perhaps even more in the human 
race. A six-fingered child is a "sport." So is a giant or a dwarf.1 The higher and more complex the kind of life, the more likely it is, apparently, to produce "sports" in its offspring.

147. Heredity. - A "sport" gives us a shock of surprise at first, because we expect offspring to resemble the parent closely. The only reason that most of us have for expecting this likeness is that offspring usually do resemble the parent. When we wish to speak of the force in nature that causes the offspring to tend to repeat the character of the parent, we call it heredity.

148. Variation. - But happily in all natural organisms there is not only this force of heredity, or a tendency to

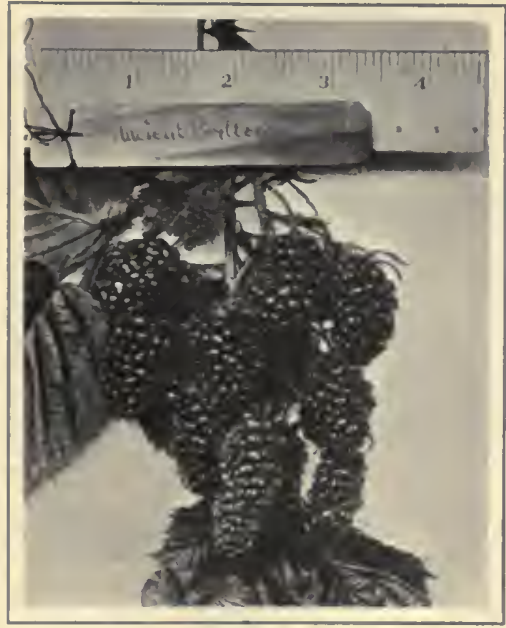

IMPROVED BLACKBERRY. repeat the parent, but also an opposite tendency which we speak of as "the tendency to variation." If it were not for this second force, neither nature nor man could much improve either plants or animals.

149. These two great forces, heredity and variation, work together in all living organisms. Heredity secures a general likeness in each variety, but there is always some variation. In a corn-

field, even if all the seed came from one plant, the stalks differ from one another, and some differ a good deal from the average. Once in a long while, one stalk may

1 Unless the dwarfing has been caused by treatment after birth. 
differ so far from the average as to deserve the name of a "sport." A certain race of men have, let us say, 5 feet and 8 inches for their average height. Of tein thousand men of the race not very many have precisely that height, but almost all are near it, varying only two or three inches on one side or the other. A very few individuals of the

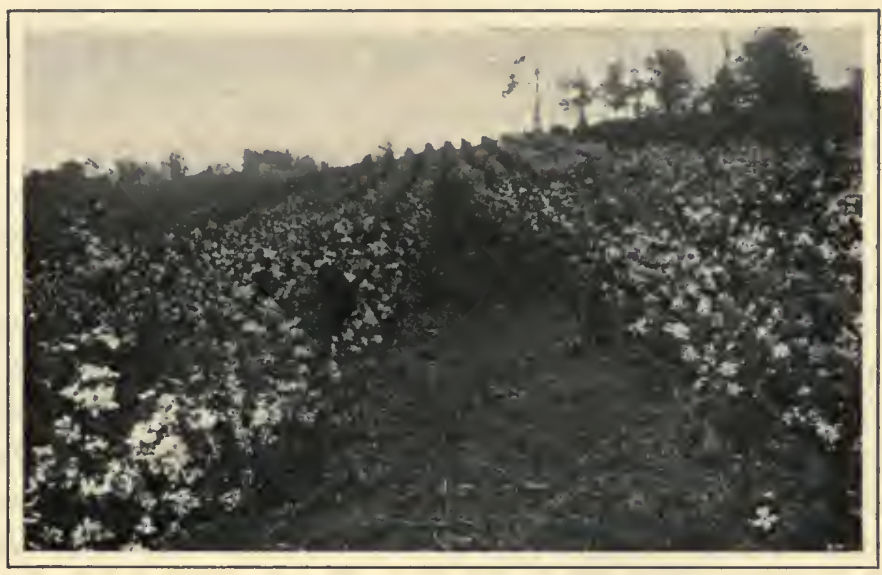

BLACKBERRY Field.

ten thousand, however, will probably be almost seven feet high, and a very few others may be not much over four feet. These extreme individuals are "sports." 1

150. The student should now be able to understand somewhat better the work of the plant breeder. (1) The breeder studies the variations in the offspring of a germ plant, and tries to preserve and propagate the variations that seem most useful for man, - for instance, the most productive stalk of corn in a field. (2) He takes advan-

1 There is a like natural variation in other qualities. Among men, for instance, there is a general average of mental ability. Most men vary only a little from this average; but in a million there will be a few natural geniuses and a few natural idiots. Both these classes are "sports." 
tage, especially of extreme variations, or "sports," if their character is promising, becuuse here Nature has done more of his work for him. (3) He experiments with new crosses to secure types that Nature of herself has not produced - or which at least she has not preserved.

151. The Perpetuation of a New Variety. - We have just mentioned three distinct ways in which the breeder secures new kinds of plants. In all three, he works with the natural tendency to variation. But in all three, too, in fixing and perpetuating the new variety he relies upon the force of heredity to aid lim.

To use this force, however, the breeder must know a little more about it. At first any one of his new varieties consists of very few plants, - perhaps of only one chosen plant. Now, in all forms of life, the offspring inherits its character not merely from its immediate parents, but also, through them, from more distant ancestors. Accordingly, there is a strong tendency in the offspring of the first plants of a new variety to return ("revert") to the average character of the older variety from which the new one was developed. This tendency is strengthened still farther, in a wild state, by crosses between the new variety and the old one. The offspring of such crosses, as a rule, are more like the old variety than the new one, because the character of the old has been fixed longer and more firmly.

If the grape "sport" that appeared in Mr. Bull's Concord garden had appeared instead in the forest, it would itself have produced "Concord" grapes; but most of the plants from the seeds of those grapes would probably have "reverted" to the character of ordinary wild grapes, and, in time, at best there would have been merely a few vines in the neighborhood with slightly better fruit than the average fox grape. Mr. Bull saved the new variety by propagating it, not by seeds, but by slips. In this kind of 
propagation there is little chance for reversion; as we have said in Chapter XII, the offspring resemble the immediate parent much more surely and fully than in propagation by seeds. Mr. Bull did not have any part in producing the first Concord, but he did have an essential part in preserving and propagating it.

We are ready now to see the three different ways in which the plant breeder makes heredity aid him in propagating a new plant that he has produced.

(1) He must guard his new plant carefully against cross-fertilization with plants of the old variety from which it came. Every corn breeder knows the need of this care.

(2) He must watch several generations of the new variety, - if it is propagated by seed, - selecting from each generation, for further propagation, only those individuals that are true to the new type, and destroying those that show a "reversion" to the old type. This work, too, is part of the work of every corn breeder, and of every farmer who tries to improve his seed. After a few generations of plants, such care is less necessary, because

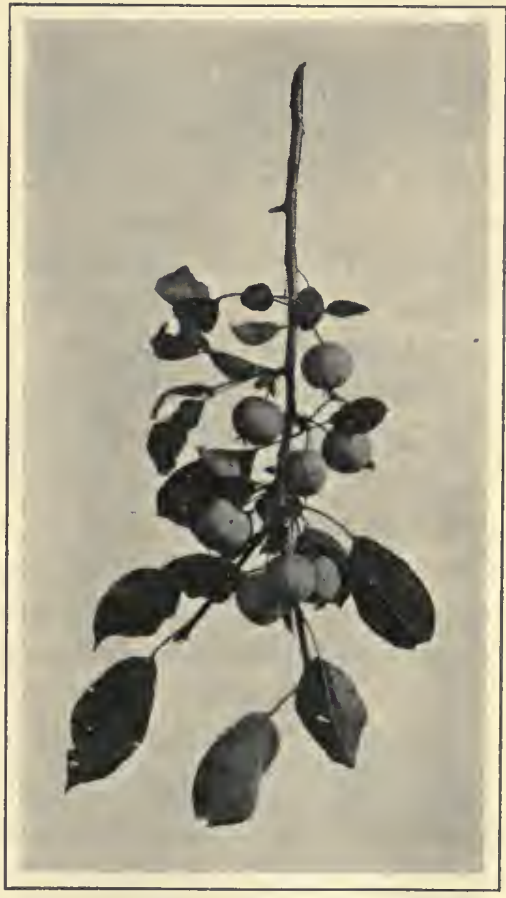

IMPROVED CRAB APPLE. 
the new type has beeome "fixed." This is beeause offspring, as a rule, inherit more from the immediate parents than from grandparents, and more from grandparents than from great-grandparents, and so on.

(3) If the new plant can be propagated asexually, the breeder will of course use this method. One illustration of its advantage has been given. The propagation of new kinds of apples offers another familiar illustration. New varieties are first obtained as seedlings. But, besides the time involved, the seeds from these seedlings cannot be trusted to resemble the new type. They show a remarkably strong tendency to variation as well as to reversion. Now and then a seed may produce a valuable and still newer variety; but, to perpetuate the chosen one, the breeder propagates it by grafting.

152. What Mendel ${ }^{1}$ Taught Us. - Mendel found that plants were made up of what he ealled unit characters, such as height, color, and shape. Assuming that a young plant had 100 unit eharacters, he discovered that 50 came from the pollen parent and 50 from the pistil parent. He found also that in hybrids, or crosses between two different but elosely related kinds of plants, these unit charaeters appear according to a mathematical law. When he took the pollen from white-flowered peas and placed it on the pistil of red-flowered peas, he found the next season that the hybrid bore only white flowers. The influence of the red-flowered parent was suppressed as far as the color unit of the flower was coneerned. But when he planted

1 Mendel, an Austrian monk, was born in 1822 and dier in 1884. His simple experiments in the garden of his cloister, especially with peas, have thrown a flood of light on Nature's great princlple of heredity. His scientific work was not generally appreciated during his life-time; its significance was not then understood. In 1900, however, his papers were "rediscovered." The uature of his researches was then made known to the scientific world, and Mendel and his great work began to be rated at their proper value. 
the seeds of this hybrid, they produced white-flowered plants and red-flowered plants in the proportion of 3 to 1 . In the future, the one fourth that were red continued to produce only reds; but of the three fourths that were white, only one third produced whites in succeeding generations. The remaining two thirds of the whites (or one half of all) were hybrids which behaved in following generations precisely as the first hybrid did. There were 110 red and white peas. The colors did not blend. So, too, in crossing very long and very short stemmed peas, Mendel found that the hybrids were longer than the long-stemmed parent; but in the next generation forms appeared that were shorter than the short-stemmed parent, and the short and long stems were always in a definite proportion. Crossing did not blend the length and shortness of the parent plants, but it did show how to intensify the original qualities.

These experiments have had a remarkable influence on recent methods of making improvements in both plants and animals. As soon as the breeder has determined what is a unit character in the plants he is working with, he may feel sure that crosses will not produce blends in it, and he will see a possible way to intensify it.

\section{Practical Questions}

1. What is plant breeding? 2. What are some of the things that plant breeding has accomplished? 3. Give a short account of Luther Burbank. 4. What part in the making of new plants do the stamens and pistils play? 5. How may undesirable pollen be kept from a flower? 6. What effect does the removal of a few flowers have on those remaining? 7. Give one way in which a breeder can increase the yield of corn per acre. 8. Suppose there is an increased yield of corn in the United States equal to five bushels to the acre, to what extent would it enrich our farmers? 9. Give the composition of an average bushel of corn. 10. Why is corn 
bred for quality? 11. In what way has the plant breeder improved wheat? 12. Describe the work of Ephraim Bull. 13. Distinguish between variation and heredity. 14. Explain the results that Mendel obtained by crossing peas. 15. What did Mendel mean by a "unit character?"

\section{Home Exercises}

1. The method of plant breeding should first be demonstrated by one who knows. 'The demonstrator may be the teacher, the county agent, or a local expert gardener. Try out the suggestions given at school on your own farm or on a special plot. Do not stop with the explanation, but put theory into practice. Take different kinds of corm, truck crops, or orchard fruits. The practice of breeding is a fascinating art.

Do not attempt to cross everything and anything. Confine your work first to crosses that are known to take. Report the results at school.

2. Determine the name of every breed or strain of plants cultivated at home.

3. Go into the field and select the best stalks of corn or into the garden and pick out the best vegetables of any kind. Bring them along to school and tell why you believe them to be the best.

\section{Suggestions}

Demonstrate the following :

1. Open a flower bud and remove the stamens. Tie a small paper bag over the flower for a few days. Remore the bag and tie a label to the stem of the flower. Note whether any fruit develops or seed is produced without pollen. Large blossoms, such as those of the cherry, apple, and pear, are suitable for this experiment. Each pupil can do this work at home. It should be tried upon at least half a dozen different blossoms.

2. Repeat the first experiment without tying on the bag and wait for results.

3. Repeat the first experiment but add a litle pollen from the stamens of another flower.

4. As the corn silk is just emerging from the husks, tie a bag over the ear and silk for a few days. Gather some pollen from another variety of corn, and removing the bag, dust it on the silk. Tie the 
bag on the ear again for a few days longer. Describe the corn when mature, and plant the grain the next year to find out the result of the cross.

5. 'Try to cross-pollinate an apple on a peach, pear, quince, or cherry. It is possible for a failure to be as instructive as a success.

6. Label a few clusters of apple blossoms. Count the blossoms. Later, count the blossoms that produce fruit, and determine the per cent.

7. Remove all the blossoms of an apple cluster except one. Note whether the fruit is better than those borne by the other clusters.

\section{References}

New Creations in Plant Life. Harwood.

Plant Breeding. Bailey.

Principles of Breeding. Davenport.

Plant Breeding. De Vries.

Cereals in America. 'T. F. Hunt.

Farmers' Bulletins. Washington, D. C.

317. Increasing the Production of Corn.

334. Plant Breeding on the Farm.

342. Potato Breeding.

The Art of Seed Selection and Breeding. Year Book 1906.

Sugar-beet Seed Breeding. Year Book 1904. 


\section{CHAPTER XV}

\section{OOMMON DISEASES OF OROPS}

\section{Diseases desperate grown}

By desperate appliance are removed, Or not at all.

- SHAKEgPEa RE.

153. What Is a Plant Disease? - Plants liave to contend not only with excessive heat and cold and wet and drought, but also, like every living creature, with living enemies. When, however, a young squash plant is killed by a cutworm, or when a potato plant is injured by potato bugs, we do not usually speak of the plant as afflicted by disease. But we do so speak when the plant's enemy is some minute form of life that exists within it or only in connection with it. A plant disease is any weak or backward condition due to parasitic plants like bacteria and fungi.

154. Bacteria. - Just as a man is likely to be afflicted with tiny plants called bacteria, which cause such diseases as typhoid fever and tuberculosis, so field and garden crops are liable to suffer from certain other kinds of baeteria. Cabbage leaves occasionally show "burnt edges," the work of these germs. Turnips, cauliflower, kale, and other members of the cabbage tribe may be affected in a like way. The leaves of sweet corn now and then wilt and dry up because their water supply is cut off by the work of bacteria in diseased tissue. On the leaves or twigs of the common pear a "fire blight" often breaks out. The wilting of cucumbers and the soft rot of carrots and other 
vegetables are other instances of the destructive work of bacteria.

155. How Bacteria Multiply. - Bacteria thrive and multiply under proper conditions of food, heat, and moisture. With a strong microscope they may be observed to elongate somewhat. A deepening groove, extending crosswise near the middle, begins to appear in the individual bacterium. In a half hour, if the conditions are favorable, the groove may have deepened to the center, so that the parts will move apart and form two bacteria. At the end of another half hour, each of these may have divided again, and the process may continue indefinitely. The more bacteria, however, the greater the demand for food; and since the available food supply may be limited, the

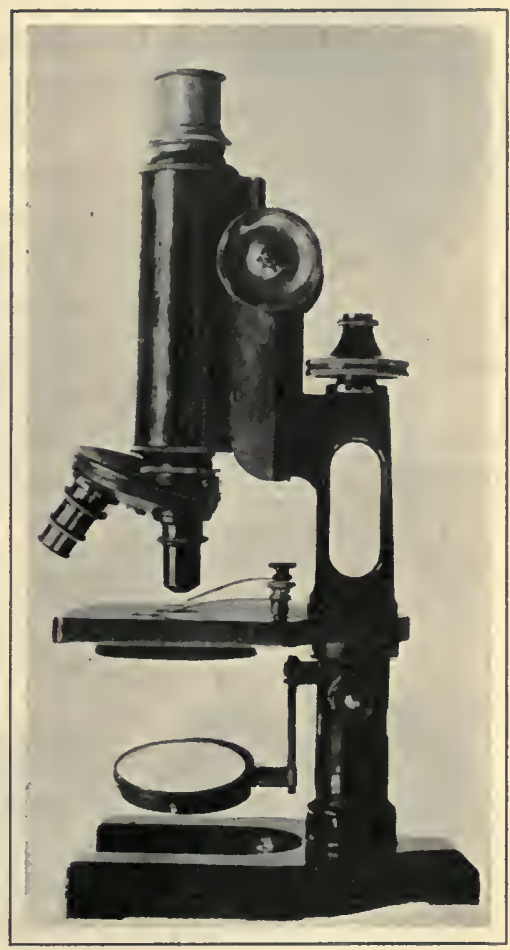

Compound Microscope. Used to detect minute objects. growth and multiplication of bacteria find natural limits.

When subjected to unfavorable conditions of food, heat, or moisture, certain kinds of bacteria surround a portion of their bodies with a thick waxy coat, which enables them to withstand the rigors of freezing weather indef- 
initely, and to endure the temperature of boiling water for perhaps twenty minutes. The parts so protected are

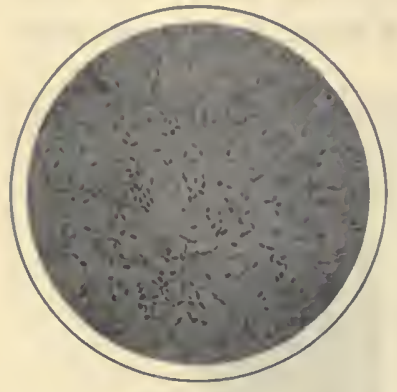

BACTERIA.

Note those which are dividing. called spores. The few kinds of bacteria that produce diseases in man do not, however, form spores, and are therefore more easily killed by heat.

156. Control. - The parts of farm plants afflicted with a bacterial disease should be eut out, or pruned away, and then burned, because they eannot be cured. It is often necessary to destroy an entire plant. Care must be taken to prevent diseased tissue from touching healthy parts, beeause diseases of this nature are conta-

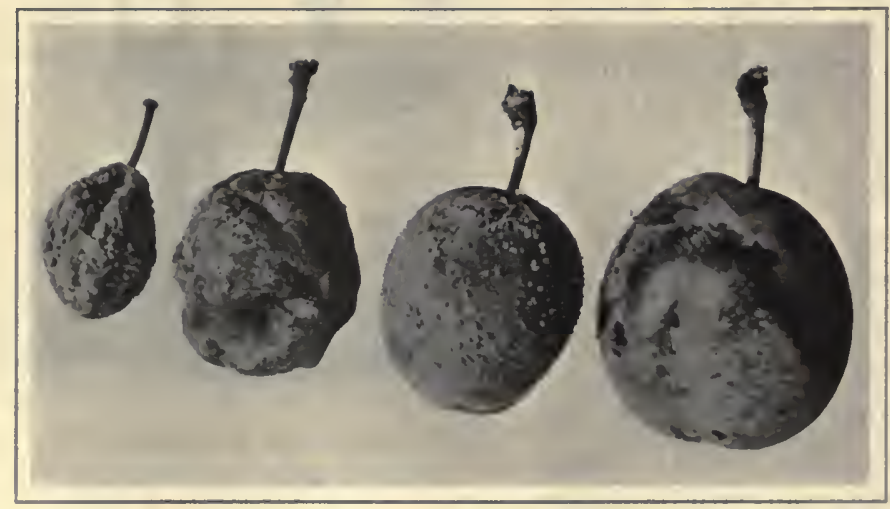

PLUM Rot.

Showing four stages from right to left. It is caused by a parasitic fungus.

gious. Crop rotation is often an effective means of keeping down a baeterial disease, since the germs in the soil 
are likely to die during the absence of the particular plant on which they are accustomed to feed.

In considering the best treatment for plant diseases, a question may arise as to whether the trouble is really of bacterial origin. Often this is difficult to determine without the aid of a good microscope. 'This difficulty, however, is of little practical importance to farmers. It is desirable to use knife and fire to destroy the diseased

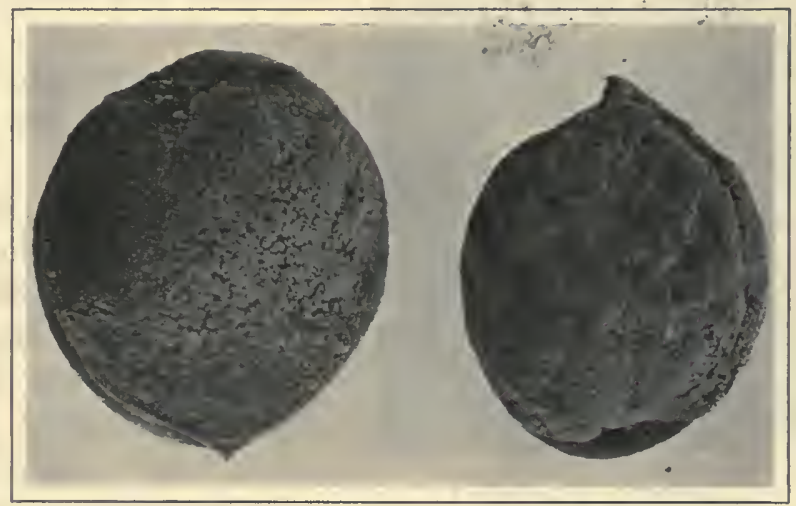

PEACH Rot.

Each eruption is made up mostly of thousands of germs, called spores.

parts of plants affected seriously by any sort of blight, soft rot, or gall growths; and when a field crop has been diseased, it is wise not to sow it again in the same field for three or four years. The Bordeaux Mixture which will be described in $\S 158$ is supposed only to protect healthy plants, not to cure diseased parts.

In fighting plant diseases we should remember that we ought to strive for prevention rather than cure. The reason we destroy plants or parts of plants with contagious diseases is in line with our practice of quarantining people afflicted with scarlet fever, and with the practice 
of isolating or killing cattle affected by the foot-and-mouth discase. Human beings, of course, are taken care of, and cured if possible, but under such conditions as not to be a menace to healthy people. Valuable cattle are killed, if needful, to check the spread of their disease. And as

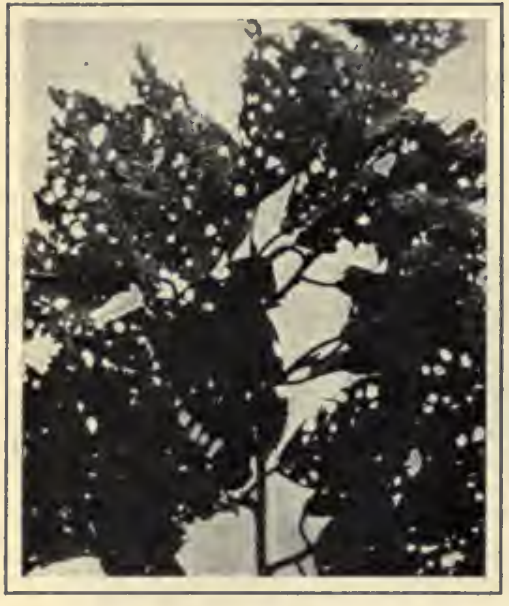

Shot-hole Fungus on Apple leaves.

This fungus is spread by tiny threadlike germs, exuding from little swellings on the leaf.

healthy people are vaccinated as a prevention against contagious diseases like smallpox, so healthy plants are sprayed with certain chemicals to ward off disease germs.

157. Fungi are plants of very low organization, for they produce neither roots, leaves, nor flowers. The most familiar examples perhaps are toadstools. Like bacteria, fungi cannot manufacture their own food directly from the soil, but must depend on other organisms, either living or dead, to support them. Before studying about certain fungi that cause diseases in crops, a few words may be said for them, and for their close allies, bacteria, in that part of their work which befriends the farmer.

The farmer is greatly indebted to these fungi. Without their aid, the surface of the earth would be choked up with old undecayed organisms, and much of the food that has once been taken from the soil by living beings would not be returned to it again. Like bacteria, 
fungi are great destructive agents. Often they destroy - substances useless to man and at the same time convert part of those substances into useful products. The work of converting organic matter into humus is an instance.

The chief reason, however, why we are interested in fungi is on account of their work in destroying useful crops. Of such harmful fungi we have space to notice in detail only mildews, smuts, rusts, scabs, and molds.

158. Mildew is a fungous disease to which all the higher plants are subject. The wellknown "potato blight" may be taken as a type of the mildews. This disease is found over the entire world wherever the potato is grown, and in America alone it causes an annual loss equal to several millions of dollars. In Ireland, in 1845, its complete destruction of the potato crop caused a terrible famine.

When first attacked by mildew, the edges of the potato leaves appear water-soaked, and have a faint purplish tint. As dry weather comes on, the

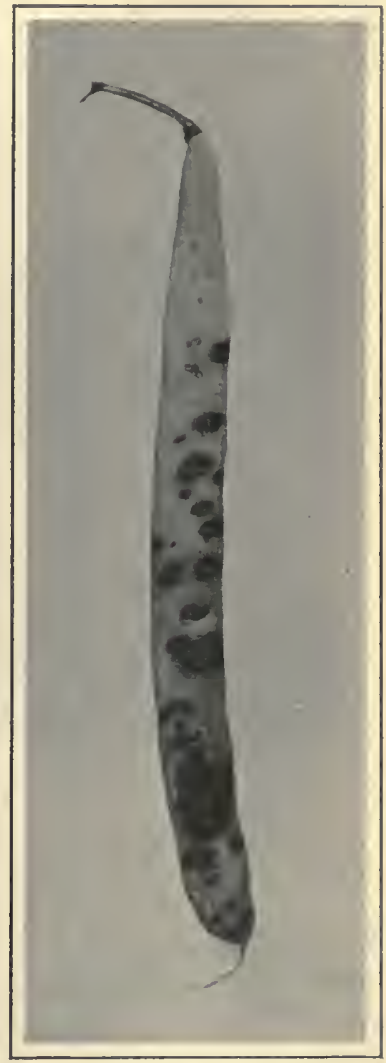

Anthracnose on Bean Pod.

A fungus blight. affected parts turn brown. Later, the entire leaf becomes affected. Mildew spores, which correspond to seeds among the higher plants, are developed in great numbers. These 
fall to the ground and infect the tubcrs, producing a dry rot, - which may be followed by the wet rot, induced. by the action of molds or baeteria.

The main prevention of all fungous diseases is by spraying the erop with Bordeaux Mixture. 'This is made in various strengtlis, but generally from the 5-5-50 formula. Five

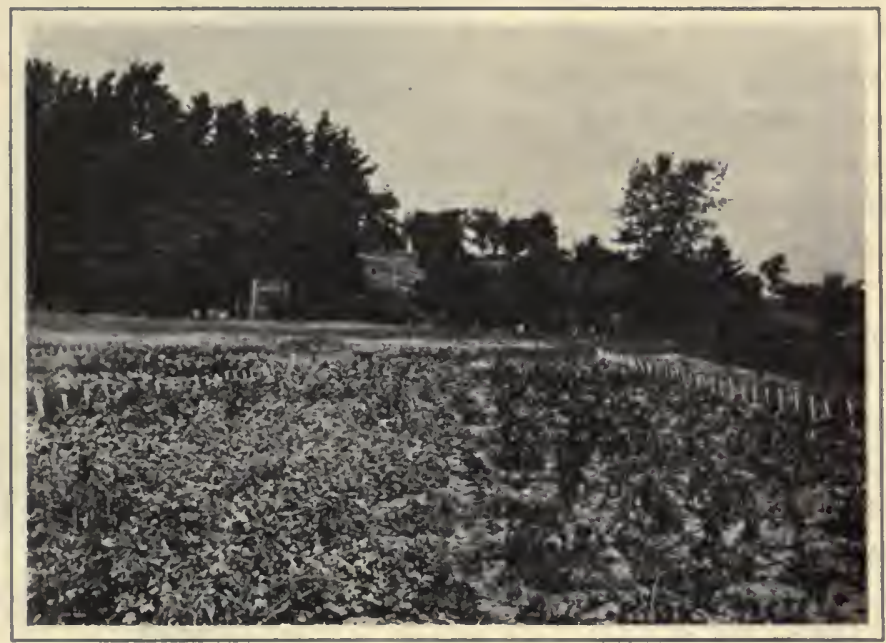

Potato Blight.

The vines on the left were sprayed with Bordeaux Mixture; those to the right were unsprayed.

pounds of lime are slacked in a barrel containing $25 \mathrm{gal}$ lons water, and five pounds of bluestone are dissolved in another barrel containing 25 gallons water. When the bluestone is in solution, it is mixed with the lime, and stirred vigorously, as the mixture takes place.

In case of danger of potato blight, the plants should be sprayed when. no higher than six inches. 'Two weeks later a second application should be used; and two weeks later still, a third application. Clean "seed," crop rota- 
tion, and spraying will enable potato growers to control this blight.

159. Smut is a fungus that attacks such grains as oats, wheat, barley, and corn, producing upon them a foulsmelling, black powder, which is a mass of spores. On corn, smut begins to appear when the plant is half grown. At first it forms small, whitish, wrinkled spots on the surface of the leaves. Later, pustules, or small swellings, may begin to show on the tassel and ears. These develop into large growths with a soft, silvery luster. When mature, these growths break open and discharge millions of black spores, which spread the disease.

While the losses due to diseases are difficult to estimate properly, experts claim that corn smut causes a loss of $\$ 2,000,000$ annually in the United States. The loss from oat smut is placed at $\$ 18,000,000$

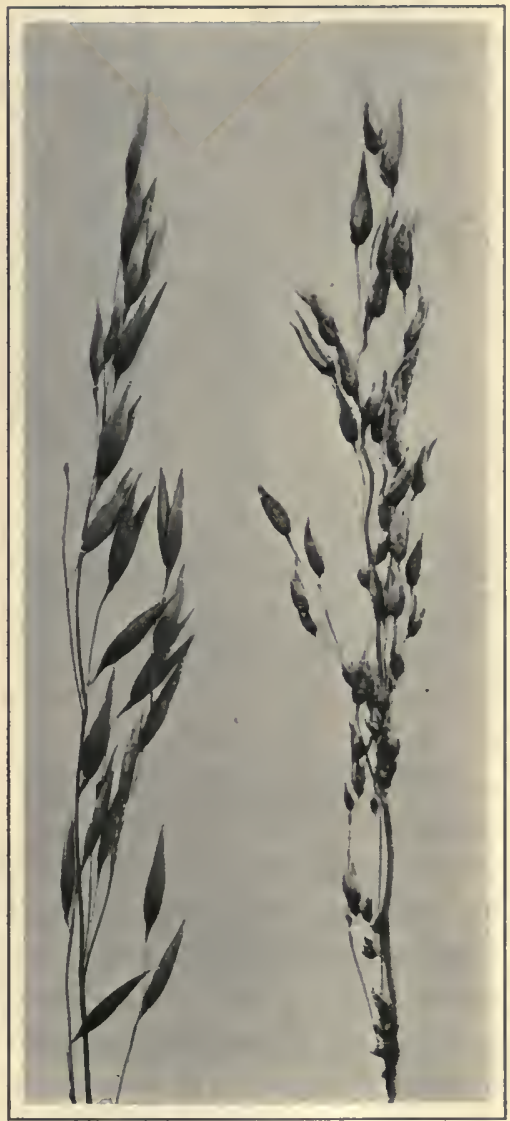

Clean and Smutted Oats. yearly. The amount of damage done to the other grains is very large. Much attention, therefore, has been given 
to finding the best methods of combating these fungous growths.

'To control smut upon corn, it is best to rotate the crops and to destroy the affected stalks before the silvery membrane about the spores breaks. Seeds of small grain, like rye, barley, wheat, and oats, should be dipped in a solution containing thirty gallons of water to one pint of formalin. The grain may be placed in a sack for this purpose, and

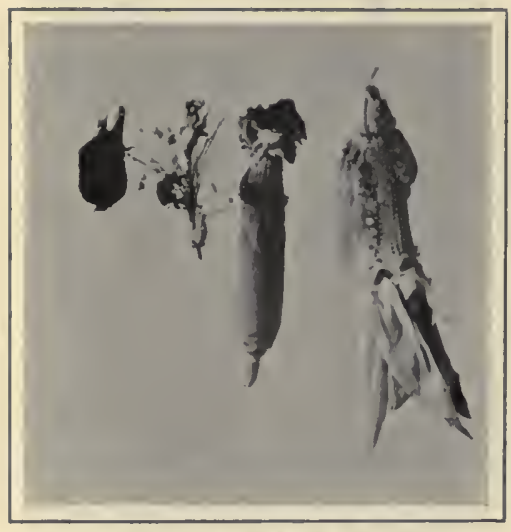

CORN SMUt.

This affects stalk, tassel, silk, husks, and kernels. soaked for about ten minutes. The seed must then be dried immediately. The cost of this treatment is very small in proportion to its benefits.

160. Rust, one of the chief kinds of fungous growth, gets its name from the fact that it has somewhat the appearance of iron rust. The most important varieties of rusts are those that attack clover, beans, wheat, and roses. Although the number of species runs up into the hundreds, and although they affect a great variety of plants, both wild and cultivated, their presence often escapes notice. Wheat rust produces yellowish patches on the stem and leaves; and while it does not destroy the plant, it reduces its vitality to such an extent that there results a considerable falling off in the wheat yields. Other rusts act in a like way upon their respective plants.

No satisfactory method of fighting this trouble has been 
worked out. Several rust-proof plants are widely advertised, and it is hoped that relief from the pest may finally be found by developing for each cropa rust-proof variety. An excess of manure and nitrogen in the soil, low and poorly drained land, and late planting (so that crops mature late) are conditions that favor the ravages of the disease. These conditions the farmer can partly control.

161. Scab is a fungus

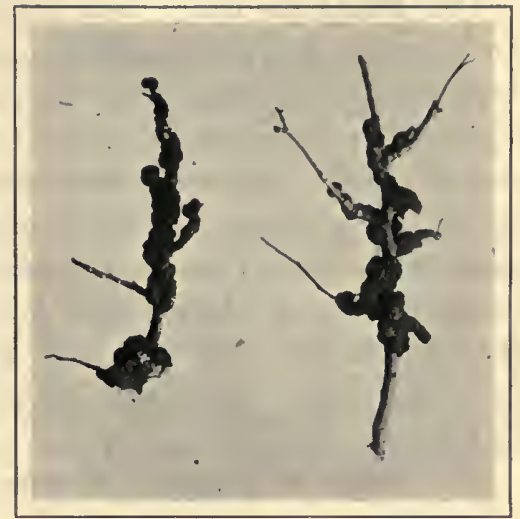

Black Knot on Plum Twigs. known best in the form of "potato scab." The surface of the common potato often shows reddish or brownish spots, early in the season of growth. The growth soon develops in a corky crust.

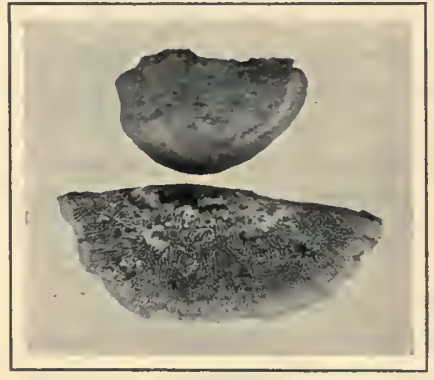

A WoOd-destroying Fungus.

The only way to control potato scab is to use clean seed and clean soil. Clean seed may be insured by treatment with formalin, in a way similar to that described for small-grain seed, but soaked for two hours instead of ten minutes. Clean soil may be secured by crop rotation. Potatoes should not be raised upon a given field oftener than once in three or four years. Scab may also disfigure apples and pears and reduce their market value by causing brownish blotches on the fruit. The most effective remedy 
is to spray the trees, before they blossom, with Bordeaux Mixture or with a weak solution of lime and sulphur.

162. Molds are fungi that not only affect farm, orchard, and garden crops, but which also concern the housewife, especially in canning and baking. When a plant substance has died, molds destroy its body by producing decay. Molds are everywhere present, especially in damp, warm, dark places. This is why food soon "spoils" in such places. If fruit or vegetables are to be preserved a long time, they should first be sterilized by boiling for thirty minutes, then sealed in air-tight vessels, and kept in a cool place. We shall learn more about this subject in Chapter XVII.

163. Names of Fungous Diseases Attacking Common Crops.

Apple

Anthracnose

Black Rot

Blight

Brown Rot

Canker

Crown Gall

Leaf Spot

Powdery Mildew

Rust

Scab

Shot Hole Fungus

Corn

Damping off

Downy Mildew

Smut

Wilt
Bean

Anthracnose

Blight

Damping-off

Powdery Mildew

Rust

Potato

Farly Blight

Late Blight

Dry Rot

Scab
Cherry

Black Knot

Brown Rot

Crown Gall

Witches' Broom

Leaf Spot

Powdery Mildew

Scab

Shot Hole Fungus

Practical Questions

1. What are the main agents causing diseases in plants? 2. Name three plant diseases produced by bacteria. 3. What conditions are most favorable for the multiplication of bacteria? 4. State two ways 
of controlling bacteria. 5. Is it always necessary to know the name of the agent whicl caused the disease in order to prevent it from spreading? 6. What is the potato blight, and how is it controlled? 7. In what way can the smut on oats be controlled? 8. Name three important rusts. 9. What damage is often done by scabs?

\section{Home Studies}

1. Try out the formula in the treatment for scab. In the fall bring to school potatoes showing the effect of treating the seed in this way. You may be able to save many dollars in a bad scab year.

2. Keep on the lookout for plant diseases in your own plot. If any disease appears, and if no one near by can tell you what to do to control it, send a specimen at once to your experiment station. Follow the directions you receive from the station, and then report the benefits of the treatment.

\section{SugGeStions}

1. As a class demonstration showing the contagious character of nearly all the disease agents, take a clean apple and a partly decayed one. Rub the two together gently, and place them away to note the results a little later. Rub two healthy apples together, and compare the effect with that of the first experiment. The results should give an important lesson on the necessity of destroying diseased tissues.

2. An effort should be made to gather a school collection of diseased material that is of importance locally. In corn sections every boy should be able to recognize corn smut, and know how to control it. In potato sections he should have a like knowledge of early and late blight, dry rot, and scab. Teachers should go into details on such questions of local interest.

3. A detailed discussion on the complete life history of an important plant disease should be given. It is best to have the material in school so as to show every stage. For this work a compound microscope is very helpful. A glance at fungus spores under a microscope makes a more lasting impression on the pupil's mind than a half hour's lecture.

4. In many freshly diseased plants, as in the twig blight of the pear, it is often possible, by breaking the twig, to show masses of bacteria oozing out. 


\section{REFERENCES}

Bacteria in Relation to Country Life. Lipman.

Fungous Diseases of Plants. Duggar.

A Text Book of Plant Diseases. Massee.

Diseases of Economic Plants. Stevens and Hall.

Farmers' Bulletins. Washington, D. C.

91. Potato Diseases and Treatment.

243. Fungicides and their Uses in Preventing Diseases of Fruit.

250. The Prevention of Wheat Smut and Loose Smut of Oats.

267. Apple Bitter Rot.

440. Spraying Peaches for the Control of Brown Rot, Scab, and Curculio. 


\section{CHAPTER XVI \\ THE FARM GARDEN}

Who loves a garden, loves a greenhouse, too. - CowPER.

164. The Purpose of the Farm Garden. - In the country, where grocery stores are widely separated, fresh vegetables for the table are often difficult to obtain. Even if this were not so, their cost at a store would mean a heavy drain

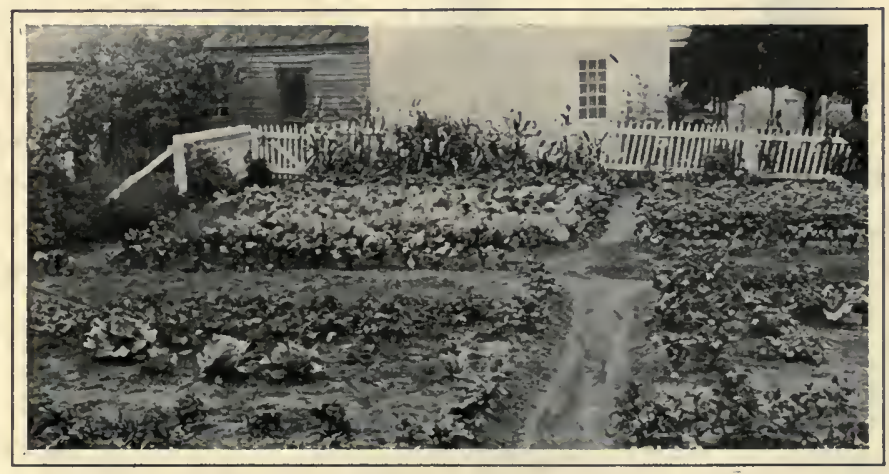

A FARM GARDEN.

on the family purse. A kitchen garden is designed to meet these difficulties by supplying fresh produce for the table throughout the season at little cost.

165. Planning the Garden. - The garden should be conveniently located with reference to the house, because the busy women of the household have to visit it for vegetables nearly every day through a long season. It should be 


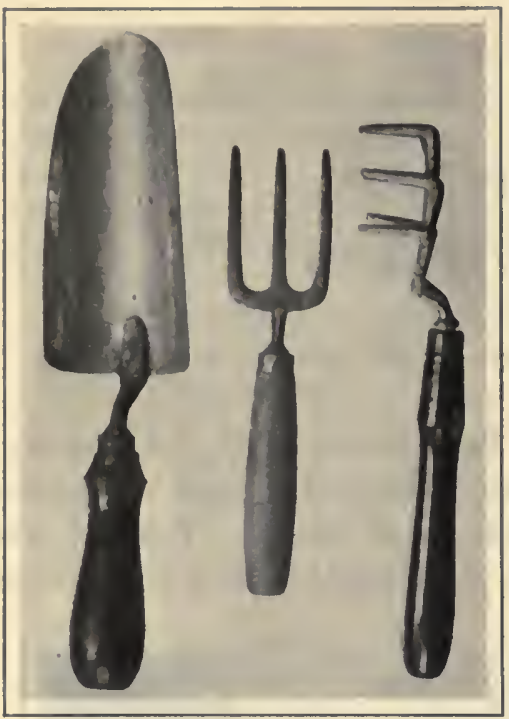

Handy GaRden Tools.

well - drained. Preferably, it should have a southern exposure. The soil should be a rich, sandy loam, beeause vegetables grown on a sandy soil are finer in texture than those produced on a clayey soil. The desirable size depends on the family to be supplied. Where plenty of land is available, there is a considerable advantage in having it of ample size, so that the beds may be prepared and worked with the horse and cultivator; and so that an abundunce of produce may be raised.

Perennial crops, such as rhubarb, currants, gooseberries,

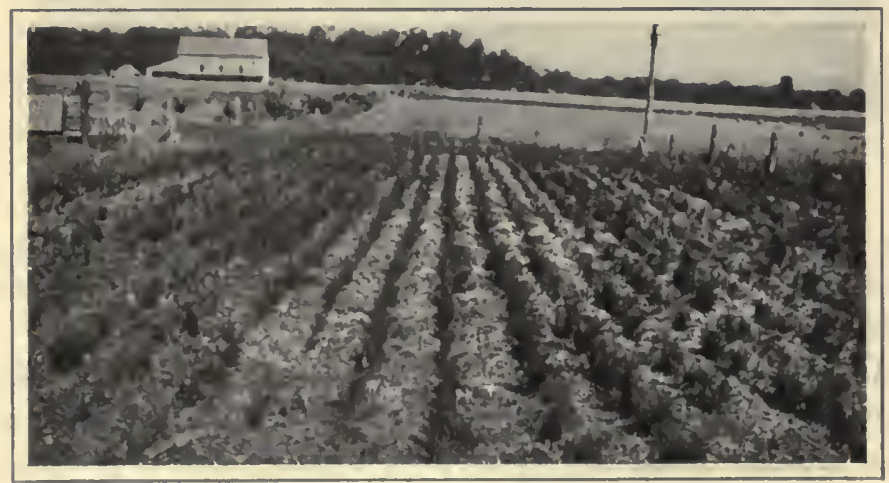

Asparagus Plot. 
and asparagus, should be placed beside the fence so as not to interfere with the tillage. Coarse vegetables, such as

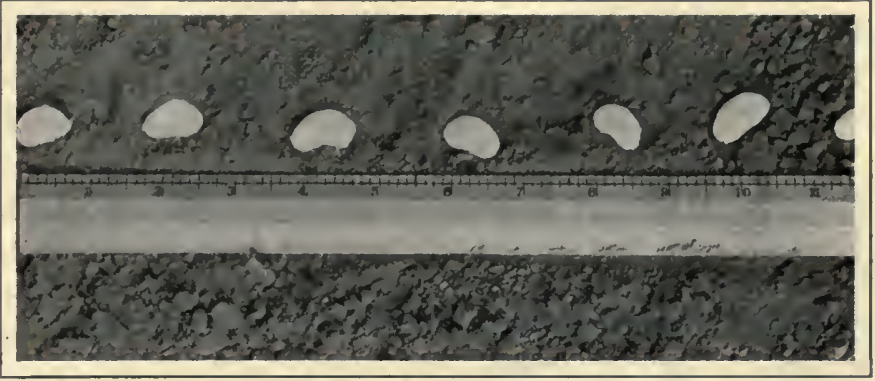

Bush Beans Ready to Cover.

beans, peas, tomatoes, cabbage, cauliflower, potatoes, and the like, are best planted in rows 30 inches apart, if a horse cultivator is to be used. For onions, lettuce, parsnips, carrots, and beets, hand cultivation is preferable, and the rows need not be more than 12 or 15 inches apart.

166. Companion Cropping. - It is often convenient where space is limited to allow an early maturing crop and a late maturing one to occupy together the same space of ground. This is what is meant by the term companion cropping. Cab-

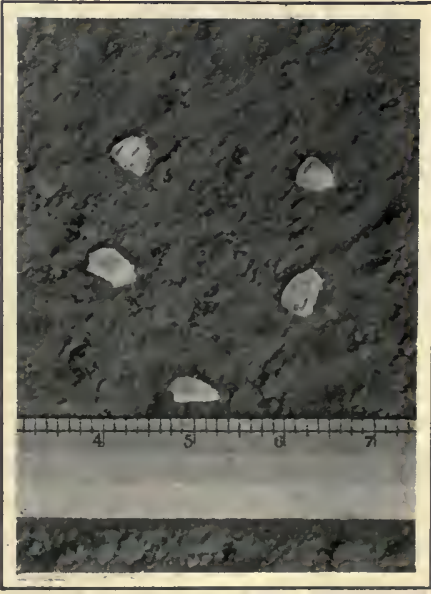

Hill of Sweet Corn. bage and lettuce, for example, are planted in alternate rows, only about half as far apart as the cabbage rows would have to be if they alone were planted. This ar- 
rangement will give the cabbages plenty of room while they are young; and before half the summer has passed the lettuce can be gathered. Then the growing cabbage will have the entire space to itself. By this plan, the lettuce costs no space and little extra work. Another form of companion gardening is to sow radishes in the

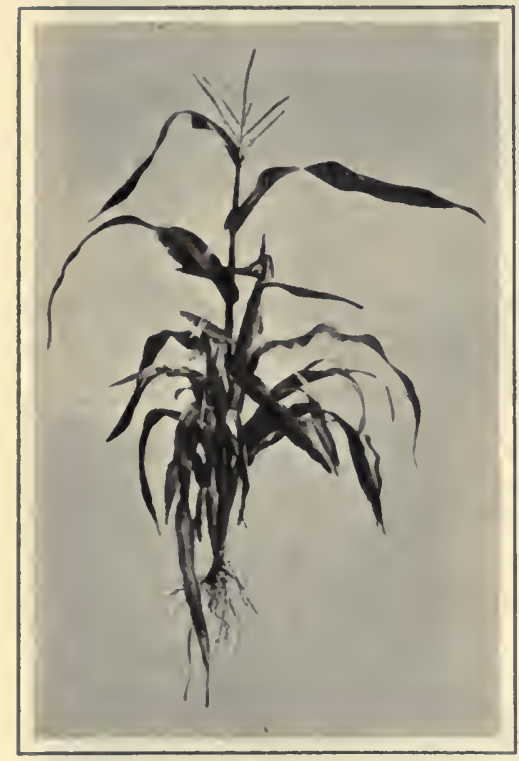

Bantam Sweet Corn. rows of parsnips, carrots, or parsley. The radishes mature early, and pulling them thins the rows as more space is needed for the slower plants.

167. Succession cropping is another way to economize garden space. Turnips and celery are used to "succeed" radishes, lettuce, onions, spinach, early potatoes, and like crops that mature in time to be replaced by others. In places with a long season beans may follow early sweet corn, and late sweet corn may succeed early potatoes. Succession cropping does not require the use of the smaller hand tools to the extent that companion cropping does, and in general demands less care and attention.

168. Seeds. - To use poor seed is to waste time, energy, and money. Most seed firms publish an annual illustrated catalog in which seeds and plants are listed, described, and priced. They also carry on a mail order service. A firm 
of this kind, with a good reputation, can usually be trusted to supply good, pure seeds with strong germs. Seeds put up in small packages and sold at stores are usually acceptable if they are fresh. The following table from Green's $V e g e t a b l e$ Gardening shows the average life of common seeds under ordinary conditions of storage.

\begin{tabular}{|c|c|c|c|c|c|c|c|c|c|}
\hline Kind & & & YeAts & Kixd & & YEARS & KIND & & YEARS \\
\hline Bean. . & • & & 3 & Endive. & . . & 10 & Pepper . & . . & 4 \\
\hline Beet . . & 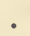 & & 6 & Kohl-rabi & . . & 5 & Pumpkin & . . & 4 \\
\hline Kale . . & . & - & 5 & Lettuce. & . . & 5 & Radish . & . . & 5 \\
\hline Cabbage . & • & • & 5 & Corn. . & . . & 2 & Rhubarb & . . & 3 \\
\hline Carrot & . & - & 4 & Muskmelon & & 5 & Salsify . & . . & 2 \\
\hline Cauliflower & . & . & 5 & Onion . & . . & 2 & Spinach & . . & 5 \\
\hline Celery & . & . & 8 & Parsnip. & - . & 2 & Squash . & . . & 6 \\
\hline Cucumber & . & . & 10 & Parsley. & - . & 3 & Tomato & & 4 \\
\hline Egg Plant & . & . & 6 & Pea. & • & 3 & & & \\
\hline
\end{tabular}

The seed for the most important garden crops should be tested even though they seem fresh. To do this, count one hundred seeds (Chapter XIV), and place them between moist blotters that are inclosed between two table plates. ${ }^{1}$ Keep the parcel warm and moist, and examine it daily. If 75 per cent of the sample have not sprouted well before the end of a week, it is poor policy to plant the seed. However, celery, parsnips, and other members of the parsnip family may be allowed more than a week, because their seeds germinate slowly.

169. Hotbeds, cold frames, and forcing boxes are important aids to a garden. There are three parts to a hot-

1 Common Petri dishes (low flat dishes) used in laboratories for raising bacteria are excellent dishes for testing small seeds. 'These dishes cost, however, about fifteen cents a set. Moist blotting paper is placed in the lower dish. 
bed: the pit, the frame, and the eover. It is best to run the pit east and west and to make it at least 2 feet deep. Inch boards, extending about 12 inches above the ground on the north side and about 6 or 8 inches on the south, constitute the frame. This gives a good southern slope. The width of the frame depends on the sash or cover at hand. Manure which has just begun to ferment

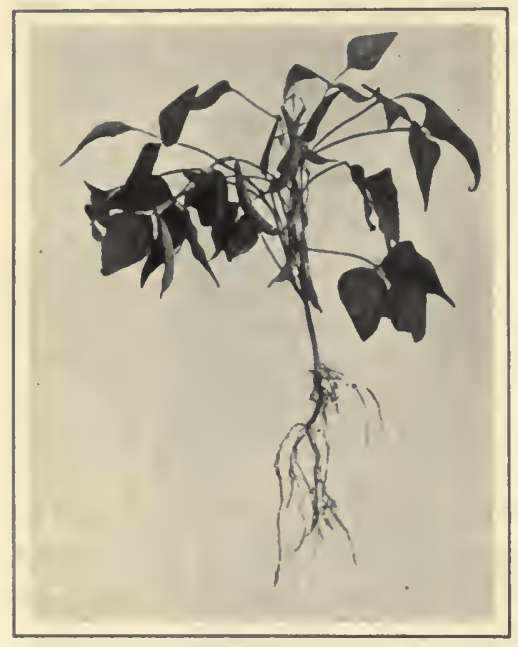

Bean Plant.

The large nodules were broken off in pulling. is placed in the pit. On top of the manure there should be a dressing of 5 or 6 inches of loam. Around the outside it is well to bank up more manure. The fermenting of the manure supplies heat sufficient for early growth.

No pit or heating material is used for a cold frame. Plants transplanted directly from the hotbed to the garden are not sufficiently hardened; that is, not accustomed to the cold. The cold frame, therefore, is used to harden plants started either in the house or hotbed and also to start plants late in the season.

Forcing boxes enable the farmer to get plants like asparagus and rhubarb several weeks earlier than these vegetables could be grown without them. Considering the high price of early vegetables, foreing boxes are very desirable. Forcing is a simple process. In late fall, ordinary boxes are placed over the plants. Around the 


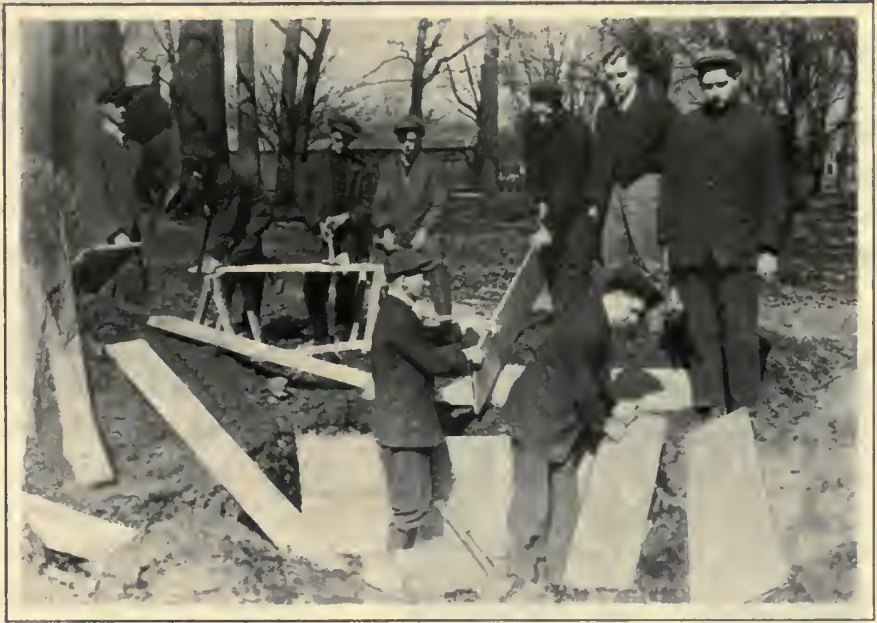

MAKING A HOT-BED.

The work of a high school class in Vegetable Gardening.

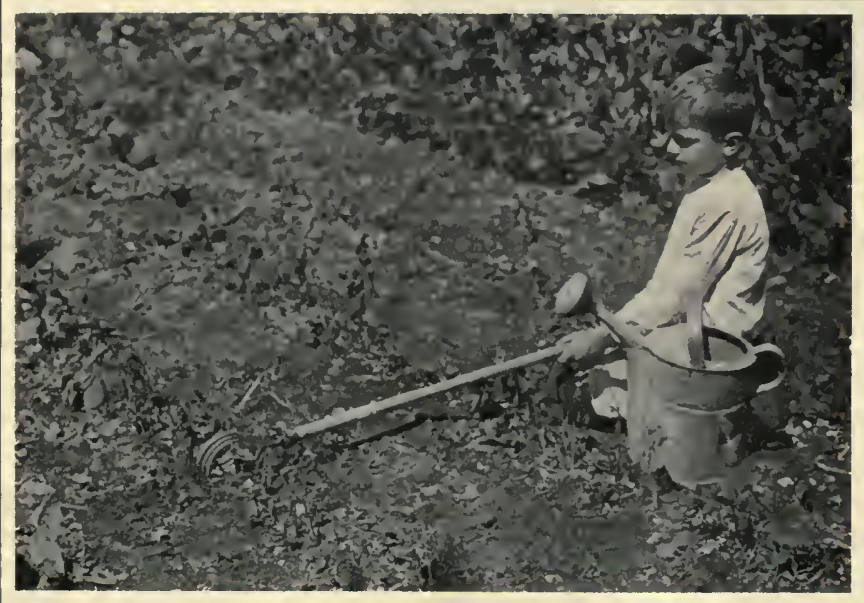

A BeAN PROJeCt.

Ruined by too much Paris Green. 
boxes stable manure is banked to furnish enough heat to keep the soil warm and to prevent freezing. The plants will be kept more or less active, through a considerable part of the winter, and they may be made ready for the market very early in spring.

170. No special directions for raising the different sorts of garden produce are given here. The best seed houses

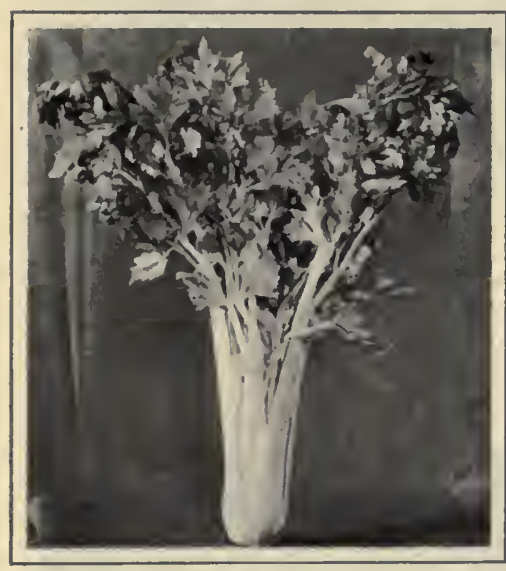

Celery. usually distribute free, with orders for seeds, admirable little booklets giving directions much fuller than could be put into a textbook for the planting and cultivation of all kinds of fruits and vegetables. Here it need only be added that the garden should contain a great variety, and an abundance of each sort that is planted. By all means there should be a series of plantings of such vegetables as peas, lettuce, sweet corn, and beans, so as to have these eatables in the best condition through a long season. Any surplus need not be wasted. Directions for its use will be given in the next chapter.

\section{Practical Questions}

1. State two purposes of a farm garden. 2. Name three things a farmer should consider in selecting a site for the garden. 3. What is meant by companion cropping? 4. Name as many early and late vegetables as you can. 5. In what three ways may seed be poor? 6. How would you test the sprouting power of radish seeds? 7. Explain the making of a hotbed. 8. How is the heat produced in a hotbed? 


\section{Home Exercises}

1. Select one of the many home projects for the raising of small fruits or vegetables that are provided by the United States Department of Agriculture or by your State College of Agriculture. With the aid of the teacher or of the county agent, decide on the raising of some garden fruit or vegetable, and then assist in the organizing of a club, if there is not one already in existence, and compete for the prizes offered.

2. Make a hotbed and a cold frame according to the directions given. As soon as the vegetables are ready for table use, bring a few specimens to school, with a report on how the work was done. The teacher will, no doubt, allow credit for such practical work.

\section{Suggestions}

1. If sufficient land cannot be secured for a school garden at or near the school building without reducing the size of the playground, it is best for pupils either to have a separate home plot or to work jointly with their parents in the home garden. Vegetables, it is true, may be grown with some success in window boxes, and many interesting and instructive facts may be learned in this way. It is always best, however, to carry on experiments as nearly as possible under natural conditions. Neither the schoolroom nor the ordinary school garden supplies these. For demonstrating seed testing, however, there is no place better than the schoolroom. The process, too, is simple, and it presents many opportunities for a little manual work and for gathering material for problems in farm arithmetic.

2. In many parts of our country, parents set aside about a quarter of an acre or more for their children to use, as a little farm or garden. Suggestions as to how and what to plant may be given in school. Occasionally, the teacher may visit these little farms. Exhibitions may be made in the fall. A careful record of every operation should be kept: the cost of plowing, cultivating, and harvesting; the price paid for seeds; the money received for produce; and the profits or losses. The Club idea gives greater purpose and meaning to the work. Credit should be allowed for work of this nature done out of school.

3. Pupils, however, should be taught to coöperate as well as to compete for prizes. 


\section{References}

How to Grow Vegetables. French.

The Practical Garden Book. Bailey and Hunn.

Farmer's Bulletins. Washington, D. C.

154. The Home Fruit Garden: Preparation and Care.

198. Strawberries.

220. Tomatoes.

254. Cucumbers.

255. The Home Vegetable Garden.

Tomato Growing as Club Work. Washington, D. C.

Tomato Growing. Washington, D. C.

Agricultural Contests. Ithaca, N. Y.

Home-garden Planuing. Ithaca, N. Y.

Vegetable Gardening. Ithaca, N. Y.

A Farm Garden. Columbus, Ohio. 


\section{CHAP'TER XVII}

\section{KEEPING THE GARDEN PRODUOE}

Every housewife may run a miniature canning factory in her own kitchen, and on the farm this is especially economical and desirable, the economy being less pronounced in the case of city dwellers, who must buy their fruits and vegetables. - BreazeaLE.

171. The Need. - Every child knows that raw fruits and vegetables do not keep well unless properly cared for. The garden, perhaps, has produced a crop much too large

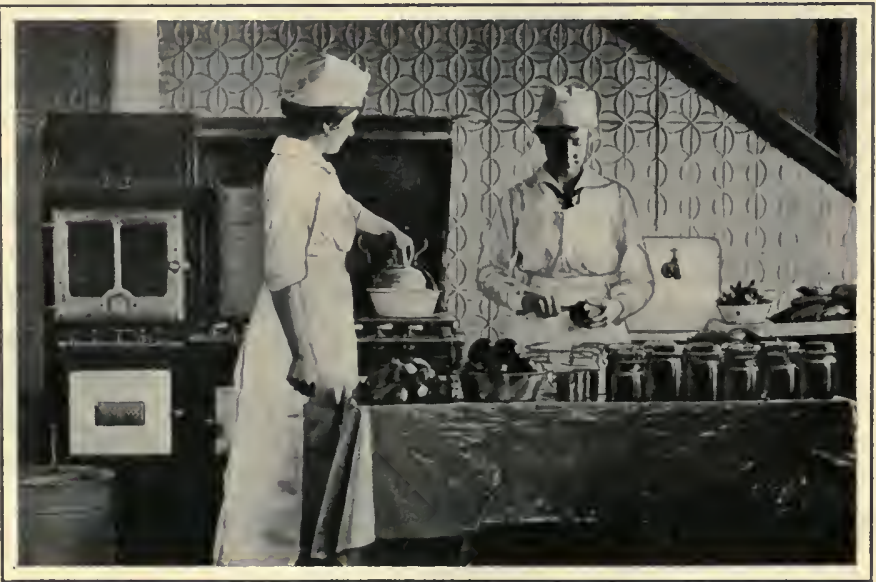

Kitchen Canning.

for immediate table use or for the demands of the market. Are we willing to allow the surplus that we cannot eat or sell to spoil or go to waste? This would not be good 
management. Yet it is claimed that in many states half of such surplus garden produce does go to waste. And during the long winter months when jellies and canned vegetables would relieve the sameness of the table fare and would make the meals more appetizing and wholesome, farmers are often obliged to go without these things or to pay a high price for them.

Often the result is too large a use of meat. Meat at nearly every meal may not be injurious if it is accompanied by a liberal supply of plant produets, but it is a common

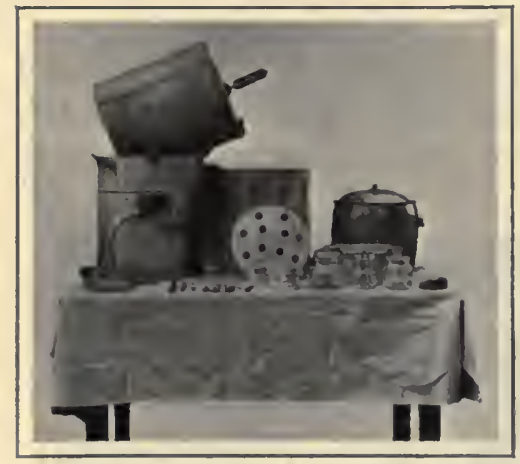

Home Canning Outfit. practice on farms to serve too much meat in proportion to the amount of vegetables. The practice is extravagant, as well as harmful to health. Now most of the surplus garden produce - even very perishable kinds of it ean easily be kept for winter use in forms that are both wholesome and toothsome. The chief ways of doing this deserve attention. Jelly making, canning, and preserving are slightly different ways of keeping perishable fruits and vegetables. Some produce is best suited to one of the three methods, some to another.

172. To make jelly in the best and most attractive form, a. Select only perfect fruit, or perfect parts of the fruit.

b. Wash it thoroughly, having first removed the stems. If one is making a large quantity of jelly, however, it takes much time to remove stems from such fruit as grapes and currants, and to let them remain will make hardly any 
perceptible difference in the result. Large fruits, like apples, should be cut into small pieces.

c. Place the fruit in a saucepan or in a large kettle, according to the quantity. The utensils should be porcelain lined, or made of granite iron, or of some other substance that is not easily affected by fruit acids.

d. Add a little water unless the fruit is very juicy. Raspberries need none, or very little; currants need only about half a cupful to four cups of fruit, and much less will do if the fruit at the bottom of the kettle is

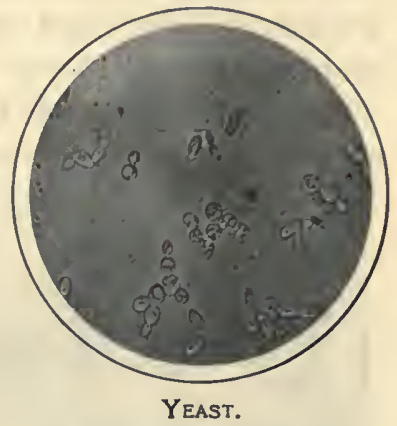

Note the "budding," or reproducing. Yeast ferments sugars. mashed; apples and quinces need to be nearly covered with water.

e. Cook slowly, with frequent stirring. When the fruit

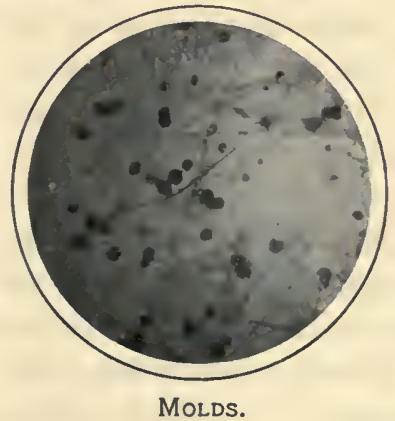

Each black spot is a mass of germs or spores. begins to simmer, crush it with a masher. Continue cooking until the mass is cooked through.

$f$. Strain through sterilized cheesecloth bags. Suspend the bags over bowls, and allow the juice to drain for half an hour. The bags may be squeezed lightly, to assist this process. At the close of the half hour, the bags may be squeezed until no more juice can be pressed out, but this "second juice" should not be mixed with the first. It contains less of the gummy substance known as pectin, and it holds more pulp. 
It may be made into a second grade of jelly by itself, or it may be used in marmalades, fruit butters, and so on. Instead of squeezing the bags, the contents may be covered with water, and, often standing over night, boiled again for a "second jelly," and the process may even be repeated again for a "third jelly" with currants and grapes.

g. Boil the first juice from ten to twenty minutes, according to the fruit, skimming away any scum that may form. $h$. Then add sugar. Raspberry or currant juice needs

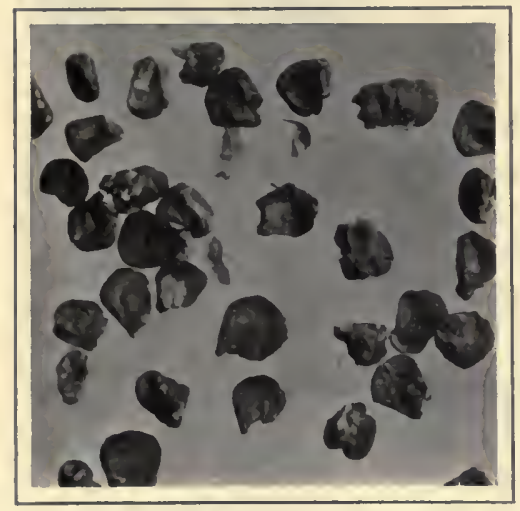

DRIED CORN. an amount of sugar equal to its own bulk; apples or plums need a little less. The sugar should first be heated, so as not to cool the juice needlessly, and it should not be added faster than the juice can dissolve it. Stirring will help to keep the sugar from burning on the bottom of the kettle. If the sugar is added too soon, it loses much of its sweetness in the necessary boiling, and a larger amount is required.

$i$. Continue to boil until the juice "jellies," or thickens slightly. This eighth step is the critical part of the whole process. The addition of the sugar makes the juice liable to boil over unless it is watched closely; and if the boiling is allowed longer than necessary by only a few minutes, the jelly will be more solid than desirable. The jelly maker learns to know the point at which to stop by observing the behavior of the juice when a little is dropped from a spoon or when it is left for a few seconds 
to cool in a small plate. Usually five minutes is long enough, unless too much water was added at first.

$j$. Clean tumblers should first be sterilized by sealding out with water or by being placed in a hot oven for ten minutes. While being filled with the hot juice, they should be placed upon a cloth that has been wrung out in water, or in a pan with a little water in the bottom, to guard against breaking. Pour the jelly into tumblers and set it aside to harden.

$k$. The following day the glasses must be covered. A little melted paraffine may be used to cover the jelly in each glass; or a thin paper wet in alcohol or brandy may be used. The purpose, in either case, is to shut out all air from the surface. After this, the

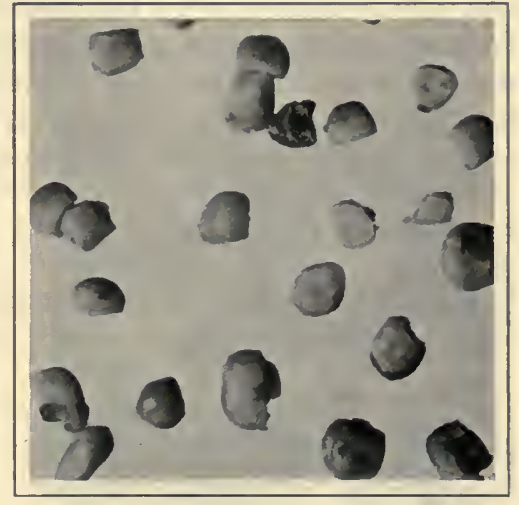

Canned Corn. glasses themselves are covered, either with tin caps. or with papers tied firmly upon them.

There is a great saving of time in making large quantities of jelly in one operation. If the fruit can be secured, it does not take much longer to make a hundred glasses in one day than to make twenty. This matter is especially important to the ever-busy farm housewife.

The best jellies are made from currants, grapes, raspberries, apples, crab apples, plums, and quinces, or by some mixture of these juices. Raspberry jelly has perhaps too strong a flavor by itself, but some raspberry juice, added to currants or apples, imparts a very delicate flavor to the compound. So, too, crab apples, plums, or 
rhubarb are used, not only to dilute raspberry juice, but also to make it " jell" more readily.

Almost any cook book contains full direetions for making each kind of jelly. The ideal product ealls forth high praise both for its food value and for its beauty.

"The jelly should be a beautifully colored, transparent, palatable product, obtained by so treating fruit juice that the resulting mass will quiver, not flow, when removed from its mold; a product with texture so tender that it cuts easily with a spoon, and yet so firm that the angles thus produced retain their shape; a clear product that is neither sirupy, gummy, sticky, nor tough, neither is it brittle, and yet it will break, doing this with a distinct beautiful change that leaves sparkling characteristic faces. This is that delicious, appetizing substance, a good fruit jelly."

173. Canning is somewhat more diffieult than jelly making, but it is eheaper, and it preserves more of the

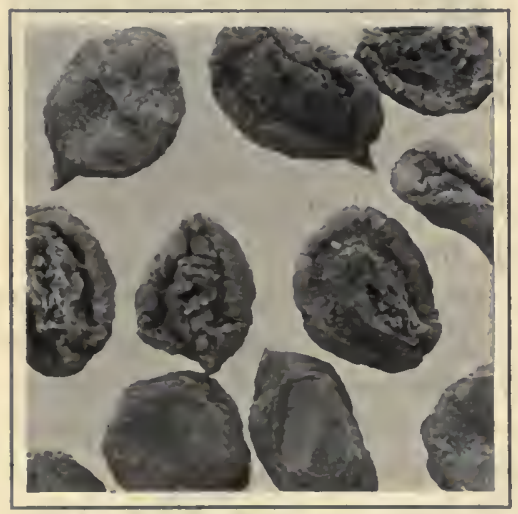

Dried Peaches.

Bacteria cannot destroy these, because germs need water. produce. Each farm home should get from Washington a free copy of Farmers' Bulletin, 359 , which contains a description of many of the newer canning devices and utensils. Other free circulars give detailed accounts of the handling of all common garden produce. Accordingly, we give here only general directions for canning one common fruit, one easy vegeta-

ble, one green, and one difficult vegetable.

a. Tomatoes. Select ripe tomatoes, but not over ripe, 
and see that they are free from taints and spots. They should be graded as to quality, size, and ripeness, and each kind should be canned by itself. Place the tomatoes in a vessel and scald them thoroughly. This loosens up the skins, which should now be removed. If the jars are large enough, the tomatoes should be packed in them whole; if necessary, cut them before packing. Add a little salt to the can. Close the top loosely, and sterilize for thirty minutes in hot water or steam. Remove the jars, and tighten the tops. It is well to place the jar upside down to see if it is closed tightly. If tin cans are used, care must be taken to see if they are properly capped and tipped.

b. Eggplant. Eggplant should also be scalded thoroughly and then plunged into cold water to make it easy to remove the skins.

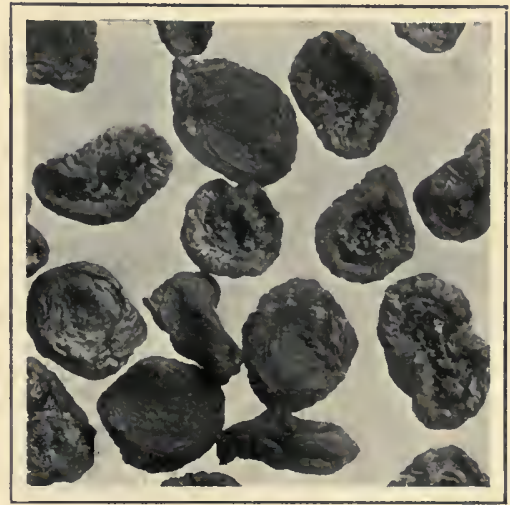

DRIED APRICOTS.

Being larger than tomatoes, the eggplant must be sliced before being packed in the jar or can. Boiling water containing a little salt is now poured on the vegetable in the container. Sterilize for one hour in hot water, after which the containers should be tightly covered, and inverted.

c. Spinach. Spinach, like eggplant, is a vegetable, but is commonly called a green. Scald for a few minutes in boiling water for blanching, and then plunge in cold water. Boil the greens in a pan for a half hour to shrink them. Pack them in the jar or can, and add hot water containing 
a little salt. Sterilize for one hour, and then tighten the covers and invert while cooling.

d. Peas are an example of a vegetable that calls for more sterilizing than the kinds so far deseribed. Shell and wash young peas as for cooking. Pack them in glass jars with their rubber's ready for sealing. Pour in cold water, as much as the jar will hold. Place the jars in a steamer and sterilize for an hour. Seal the jars. The next day, loosen the tops of the jars and sterilize again for

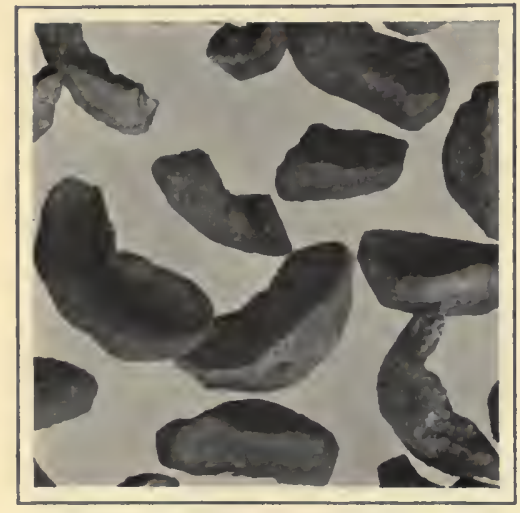

DRIED APPLES.

The drying of apples has become an important industry.

an hour; then seal the jars again. Repeat this process a third time on the next day. Then the jars may be put away. The first day's sterilizing will kill all the bacteria, but the second and third day's sterilizing is needed to kill the seeds which otherwise might grow into bacteria. Sweet corn and beans are treated essentially as peas are.

With other materials, the prineiple of eanning is the same. See that the material is in good eondition. Diseard skins, cores, and stems, if they detract from the appearance and value of the canned product. Some people add considerable sugar when canning peaches and pineapples: others do not. Some prefer to leave the stones in peaches: others remove them.

174. The main differences between canning and jelly making are two. In jelly making, more sugar is used, and less 
of the fruit or vegetable substance is kept. Both these differences are reasons why jellies are less liable to attack by bacteria and fungi than canned products arc. In both processes, all bacteria are killed by heat; but in canning, it is absolutely essential to see that the jar is filled to the top, so as to drive out all air, and that it be covered, while still hot, in such a way as to make it absolutely air-tight. Jellies contain so much sugar that bacteria and fungi cannot thrive on them. Jelly, therefore, will keep a long time without an air-tight covering.

175. "Preserves" are intermediate in character between jellies and canned goods. The whole fruit is used, or a great part of it, not merely the juice; and it is cooked with at least three fourths its weight in sugar. Preserves keep more easily than canned fruits, but they do not retain so well the natural flavors. Both jellies and preserves are indigestible, in large quantities, because of the large amount of sugar in them, while canned goods are perfectly wholesome, if the canning is properly done.

176. "Curing." - The three processes so far described all preserve the juices of fruits and vegetables in a more or less liquid state. Some crops, however, may be kept conveniently by the simpler work of merely drying the water out of their juices. This method is workable because bacteria and fungi cannot thrive without moisture. Apples, peaches, cherries, beans, peas, and sweet corn are preserved in this way. Large fruits, like apples, must first be cut into slices. The principle in "curing" vegetables is the same as in "jerking" meats or in smoking hams. Unfortunately some of the natural flavor is usually lost in the process.

177. Still simpler methods keep many garden crops through the winter. These simple methods apply where it is 
necessary, not to kill bacteria to begin with, but only to prevent their too rapid growth in the stored produce.

Potatoes, we all know, need only to be stored in dry bins where they will not freeze and where the temperature will be between forty and thirty-three degrees Fahrenheit.

Onions need only a little more care. They would spoil if piled up in deep bins, like potatoes; but they will keep if spread in thin layers on a garret floor, or if stored in

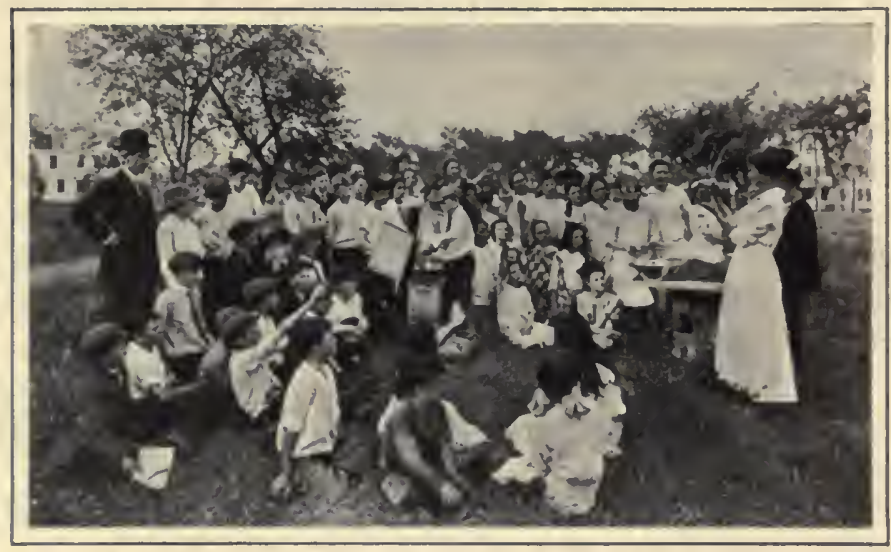

Meeting of a Tomato Canning Club.

shallow boxes that are piled up in any dry cool place in such a way as to let the air circulate a little through the contents.

Cabbages need to be placed so that they will not touch one another, and then to be covered with a few inches of dry straw or dry sand. Freezing is not hurtful, if there is not too much thawing and freezing; and so, in cold regions, if room is lacking in the cellar, this vegetable may be kept in the way just described in shallow trenches outof-doors, for use the following spring. For winter use, it is usually enough to wrap the heads in dry paper and pile them up on cellar shelves. 
Celery should be taken from the garden in the fall and planted in close rows in the cellar, and then watered occasionally. The absence of light will bleach the stalks and make them tender.

The cellar, mentioned so often in the paragraph above, is the most common storage place for vegetables for family use. Its temperature for this purpose, however, must be kept only a little above freezing. Thus, in moderately warm climates, an outside excavation is often preferable.

\section{Practical Questions}

1. Why should we make an effort to make some of our table produce last for the winter? 2. What is meant by the terms canning and preserving? 3. Why is more produce canned than preserved? 4. What causes certain foods to spoil? 5. Can you distinguish between a condition and a cause as applied to the decay of foods? 6. Explain the steps of making jelly. 7. What would you call good jelly? 8. How may cabbage, apples, and currants be kept for the winter?

\section{Home Exercises}

1. Join a canning club. Full directions can be obtained by writing to the State College of Agriculture, or to the Bureau of Plant Industry, Washington, D. C.

2. Write a report on

(a) what part of your home garden produce is kept for the winter;

(b) the quantity of each kind of produce kept;

(c) the different methods used in keeping it;

(d) the profits or losses in this work when compared with the purchase price of similar articles.

\section{Suggestions}

1. Place a slice of moist bread under a plate for a few days. Examine the molds - a fluffy growth darkened here and there - and the colonies of bacteria, which are smooth growths. If the bread is kept dry, no germs will develop.

2. Place two apples on the desk. Prick the skin of one at several places with a pin. Observe them carefully from day to day to see 
where rotting first begins. The result suggests why nature protects such perishable objects with a skin.

3. If heating facilities can be obtained in the schoolroom, demonstrate the principle of cauning as an aid to the home work.

\section{REFERENCES}

Farmers' Bulletins :

359. Canning Vegetables in the Home.

426. Canning Peaches on the Farm.

521. Canning Tomatoes in Clubs and for Market. 


\section{CHAPTER XVIII}

\section{POTATOES}

Among the vegetables, the potato, in this country at least, is the most generally used. It has of late been decried as having no good value. This is far from true. - Alice NortoN.

178. Importance and Origin. - If all the land of the United States devoted to the growing of potatoes were combined into one field, it would cover an area of about five thousand square miles, or the entire state of Connecticut. Our main potato belt extends from Maine southward to Maryland and westward to Kansas.

The potato is native to America. Sir Walter Raleigh introduced it into Europe in the year 1584. It became popular there at once, and to-day it is grown even more extensively abroad than in this country. About one tenth of the world's supply is grown in the

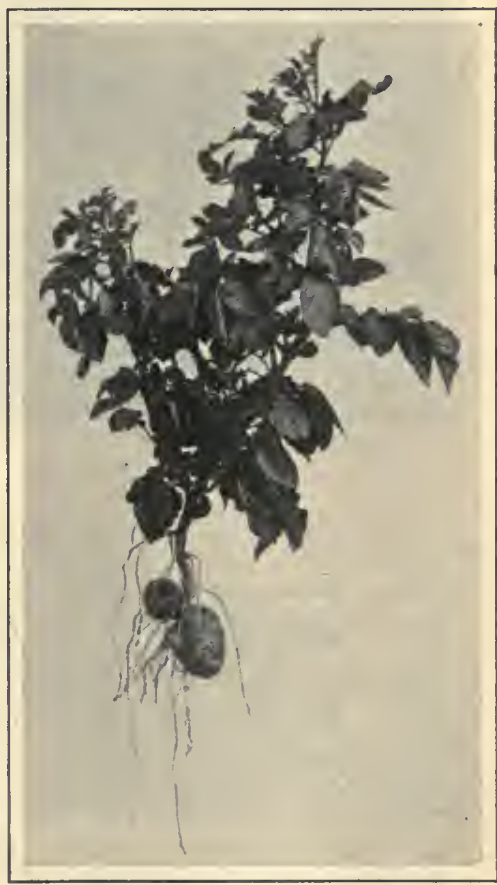

Young Potato Plant. 
United States. The total yearly production is about five billion bushels. See Appendix A, Chart IV, page 468.

179. The potato is a store of starchy food put away in a modified stem, or tuber. It is not a root. This has been explained in Chapter XII. The "eyes" are buds on the enlarged stem. A cross section of the tuber shows the same arrangement of bark and pith that the stem has above

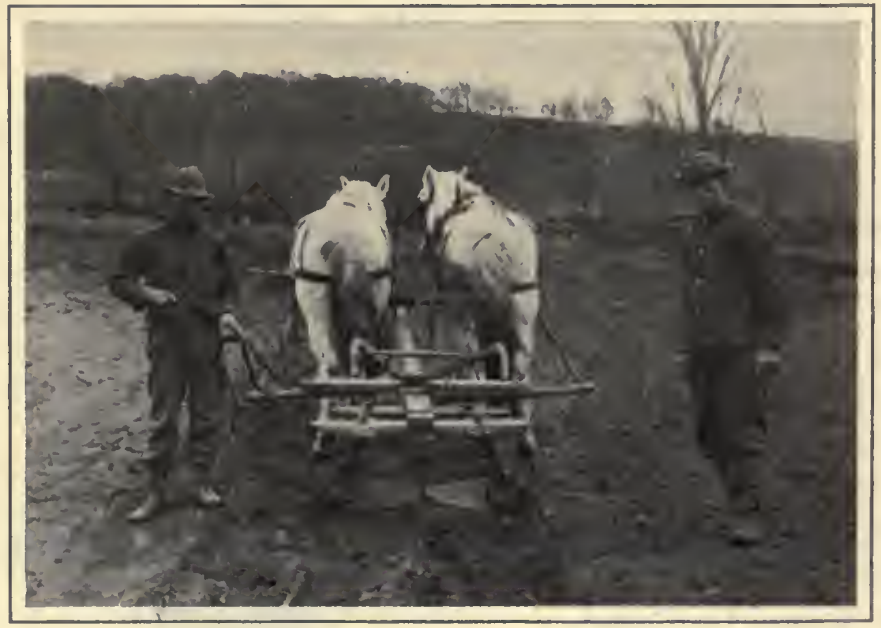

Covering Potatoes with a Two-winged Plow.

ground. And the tubers do not have the small rootlets that can be found on the true potato roots.

180. Variety. - A bout the first thing to be decided by the potato raiser is the variety of potato that he shall grow. Several matters are concerned in this decision, such as yield, resistance to disease, cooking qualities, shape, eyes, leaves, color, and the practice of neighbors.

a. Early varieties usually yield less than late ones.

b. Certain varieties, like the Carmen No. 3 and the Rural New Yorker, have great power to resist common diseases. 
c. When baked or boiled, the potato should be dry, mealy, and floury, - not wet or soggy. Nor should it have an earthy flavor.

d. A long, pointed, or irregular shape, in a variety not naturally so, may indicate lack of vigor. Rounded or oval tubers, too, are easier to handle, suffer less waste in peeling, and are usually cleaner.

$e$. Deep eyes cause waste in peeling. They also hold moisture, which promotes decay.

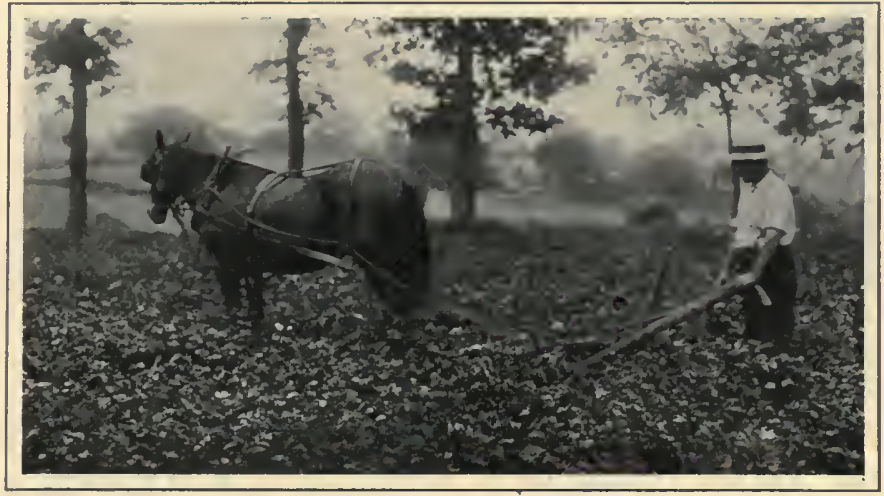

Cultivating Potatoes.

When potatoes are cultivated as late as this, too many roots are likely to be cut.

$f$. The foliage should be ample. A thick, high leaf resists unfavorable conditions of climate.

$g$. Some markets prefer white potatoes; some, red. The farmer must follow the demand of his market.

$h$. Neighborhood agreement is important. If the farmers of a locality raise, in the main, the same variety, they will find it easier to market the produce, and they will get a better price for it.

181. Seed selection is the second part of the grower's work. Neither very large nor very small potatoes should 
be used. An average-sized tuber, true to type in shape, is preferable.

Hill selection, that is, picking out seed potatoes in the field from large hills, is better than bin selection. The potatoes in one hill may weigh twelve ounces, and those in another eight ounces, though the better ones in the two hills may look just alike. The potatoes of the better hill will tend to transmit to the next generation their high producing

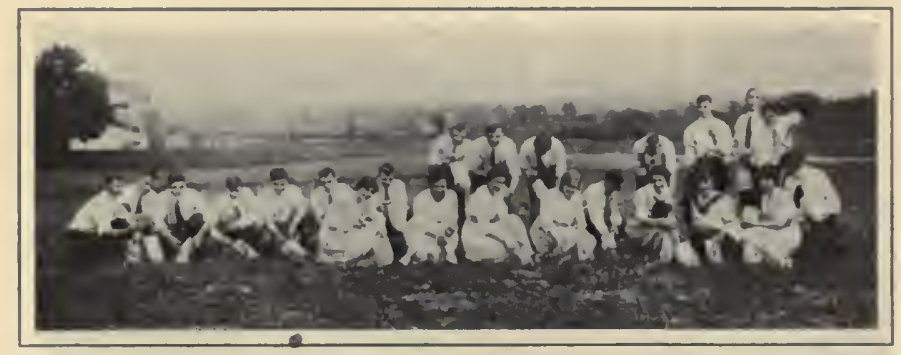

Class Selecting Seed Potatoes.

quality. In seleeting seed from the bin, one could not tell whether the seed came from a high or low yielding hill. 182. The soil should be of a sandy or gravelly loam, if possible. Potatoes are less likely to be attacked by rot in sandy soils than in clayey ones. In crop rotation, potatoes best follow clover. In selecting a commereial fertilizer, one strong in potash is best; and unless nitrogen has been supplied to the soil by clover, that costly element also must be secured in the fertilizer. In clayey soils, however, where manure poor in phosphoric acid has been applied, some fertilizer rich in phosphoric acid should be applied directly to the crop, or elsewhere in the rotation. See Bulletin 187, Geneva, N.Y. Potato planting should be preceded by deep plowing.

183. In planting we must consider the distance apart at which to place seed, and the depth. 
a. Early varieties are planted as close as $12 \times 27$ inches; the latc ones which spread more are placed somewhat farther apart.

b. The two kinds of culture govern the depth of planting. In level culture, planting potatoes three to four inches below the surface is the prevailing practice. Where the

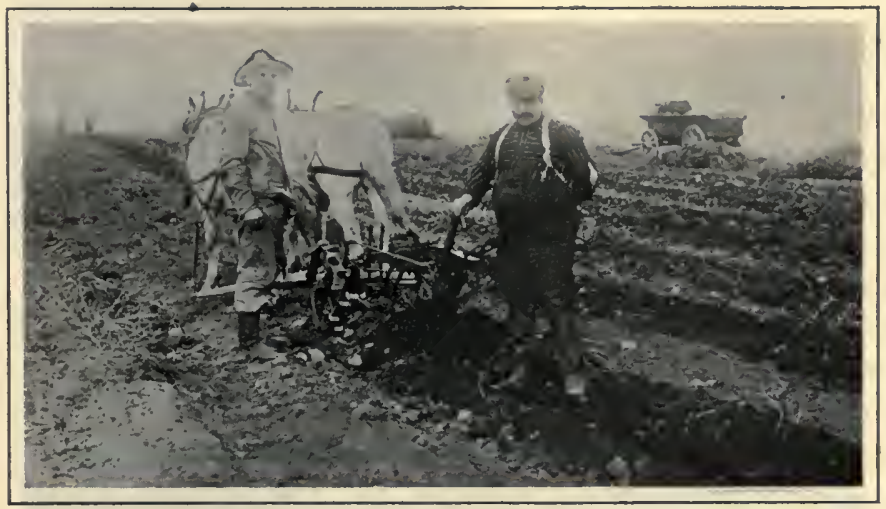

Potato Digger.

soil is heavy and the rows are "ridged," planting them two to three inches deep is sufficient.

184. Cultivation. - A week after planting, the field should be gone over in both directions with a spike-toothed harrow, to loosen up the ground and to destroy weeds. As soon as the rows appear, intertillage may be started. The first cultivation should be deep, especially if the ground is weedy; but as the vines grow, cultivation should become more shallow, and be kept farther and farther from the rows, so as not to destroy the feeding roots. When the land is worked the last time, some soil may be thrown toward the plants by the lateral shovels. This will smother some weeds and increase the bearing surface. 
185. Harvesting. - Potatoes are harvested by fork, spade, plow, or by the riding digger. As soon as early potatoes are of marketable size they may be harvested. For the late varieties it is well to wait until the vines are dead. The tubers will then break off readily without rubbing. Digging is best done when the soil is fairly dry, as less

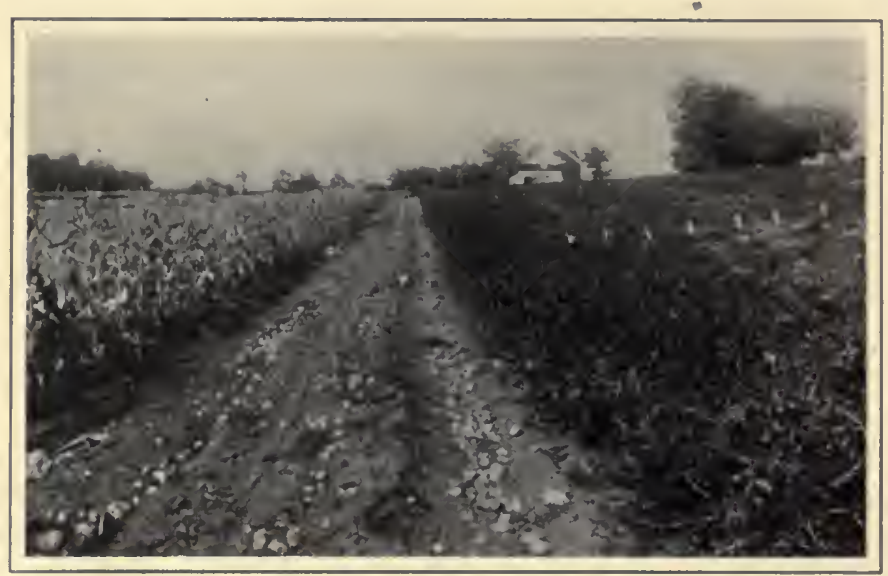

A Good Potato Crop.

dirt will cling to the tubers. They will then dry off better, and hence be less likely to rot.

186. Storing and Marketing. - Good ventilation and a cool temperature retard rotting. A common practice is to store potatoes in the open in piles covered with straw and soil, or in cellars. Either method nay be good, provided the proper conditions of temperature and ventilation are secured. The temperature, however, should not be allowed to fall below $33^{\circ} \mathrm{F}$. It is wise economy to use a thermometer in the potato room, and, if necessary, to run an oil stove there during the coldest nights. 
Before marketing, potatoes are graded as to size, shape, second growth, and color. 'Two markets are available, the local and the distant. Eastern-shore farmers sell their produce through selected receivers who charge about 8 per cent commission. The receivers pay an agent 3 per cent for buying and for in-

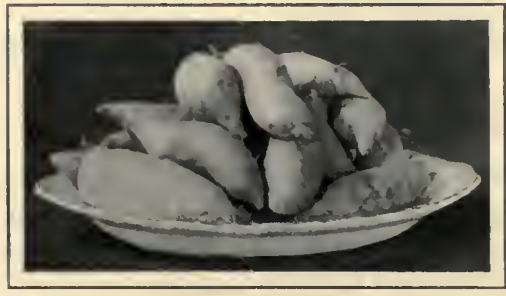

Sweet Potatoes. structing the growers in methods of grading, assorting, and packing.

187. Sweet potatoes are true roots. They are grown in nearly all the states, particularly in the South. The best quality is produced in warm, well-drained, sandy soils. It is a common practice to use a complete fertilizer, high in potash, for sweet potatoes. The vines make rapid growth, and when a foot or more long may be trimmed. The cuttings so obtained may be used for further planting.

\section{Practical Questions}

1. Where is the potato belt of the United States? 2. What is meant by "potato seed"? 3. Name four points to be considered in seed selection. 4. Explain why a potato tuber is not a root. 5. What facts are to be considered in planting potatoes? 6. Discuss methods for cultivating and harvesting. 7. Name two conditions that promote rot.

\section{HoMe Exercises}

1. If potatoes are a leading local crop, a potato club should be formed. Write to the State Agricultural College or to the Bureau of Plant Industry, Department of Agriculture, Washington, D. C., for blanks similar to those spoken of at the close of the last chapter. An eighth or a quarter of an acre may be used for the club work. A report should be made on the preparation of the plat, the planting, 
the seed, the cultivation, the treatment for bugs and diseases, and the grading and marketing. The basis of award should be as follows :

(1) Yield . . . . . . . . . . 30 points

(2) Net profit on investment . . . . . 30 points

(3) Exhibit of produce (fresh and cooked) . 20 points

(4) Crop report and story . . . . . . . 20 points

Total score . . . . . . . . . $\overline{100}$ points

2. Write a connected story on how your father handles his potato crop.

\section{Suggestions}

1. Demonstrate the difference in loss of weight between a pared and an unpared potato. Expose both the pared and the unpared, after weighing, to the air of the schoolroom for a month and then reweigh. Explain the reason for the difference in weight.

2. Take two tumblers. Place a potato in each, the one having the stem end down, and the other the stem end up. Add water to cover the bottoms of the potatoes in the tumblers. Is there any difference in the growth of the sprouts? Fxplain.

3. Cut a potato. How many different parts do you notice? Make a thin slice and hold it to the light. Draw the section. Label outer bark, inner bark, and pith.

4. Preserve a scabby potato in formalin, and dry a leaf affected with late blight between blotters for a schoolroom specimen.

\section{REFERENCES}

The Potato. Samuel Frazer.

Farmers Bulletins. Washington, D. C.

35. Potato Culture.

91. Potato Diseases.

324. Sweet Potatoes.

407. The Potato as a Truck Crop.

533. Good Seed Potatoes and How to Grow Them. 


\title{
CHAPTER XIX
}

\author{
OORN \\ But let the good old crop adorn \\ The hills our fathers trod; \\ Still let us for his golden corn \\ Send up our thanks to God.
}

- Whittier.

188. Our Yearly Crop. - Corn is our most valuable crop. Four fifths of our farmers raise it. See Appendix A, Chart III, page 468. The yield in the United States for 1912 was $3,124,796,000$ bushels. This crop alone enriched the farmers that year to the extent of $\$ 1,520,454,000$. These figures are overwhelming. Loaded on wagons, a ton to each, the crop would form a procession twenty wagons wide extending around the globe. As many drivers would be needed in the procession as there are inhabitants in the United States. Converted into silver dollars, it would take over four thousand teams, each hauling a ton, to take the crop to the bank. The value would support our public schools for five years.

189. An American Plant. - In the Bible we read how "Joseph's ten brethren went down to buiy corn in Egypt." The Psalmist, too, says: "The valleys are also covered over with corn; They shout for joy, they also sing." But in these quotations the word "corn" is used in its old European sense, referring to any hard grain, like wheat, rye, or barley. Strictly speaking, in the usage of 
to-day, "corn" is maize, and was unknown to the people of the Old World until America was discovered.

The Indians cultivated maize from Canada to Argentina. In Mexico there was a maize goddess whom the

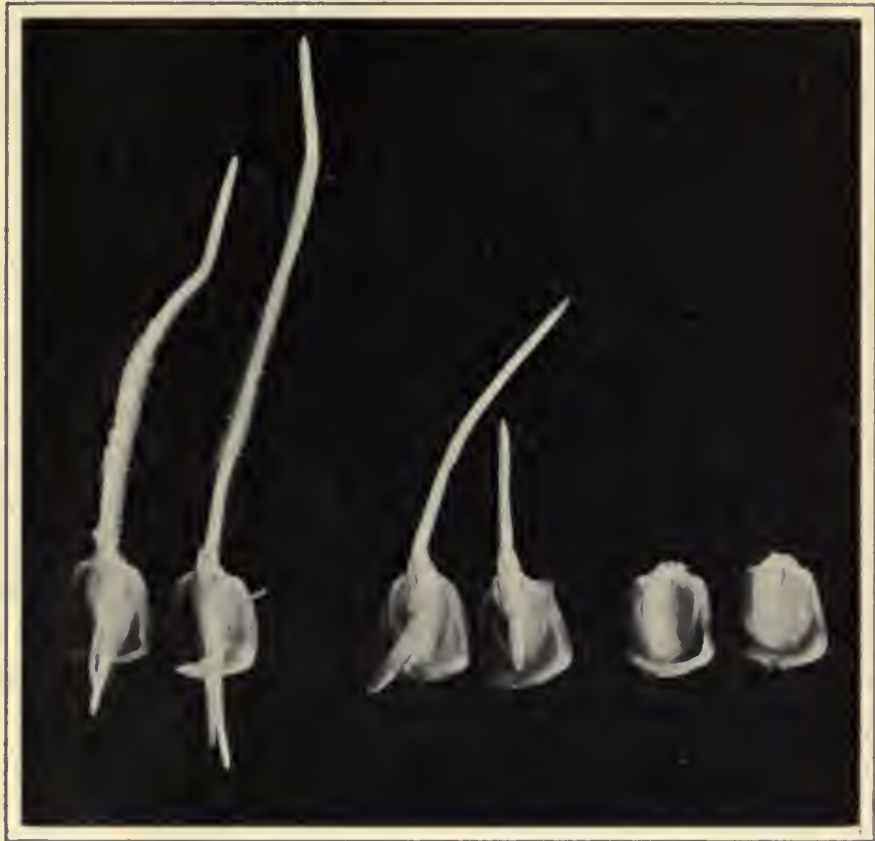

GoOd ANd BAd SEed.

These six kernels were under exactiy the same condition in the germinator.

natives worshiped. The plant is still sometimes called "Indian corn." The Indians taught the early European settlers how to grow it." At times the settlers would have

I In his " History of Plimouth Plantation" Governor Bradford states that the settlers "began to plant their corne, in which service Squanto (an Indian) stood them in good stead, showing them both the manner how to set 
starved, had it not been for this native plant, and finally they gave it especially the general name then in use for grain.

190. The Selection of Seed. - Farmers use eorn for both grain and fodder; and therefore both stalk and ear are to be considered in selecting seed. For this reason it is best to begin the selection in the field before harvesting. Ear's should be preserved only from those stalks that have

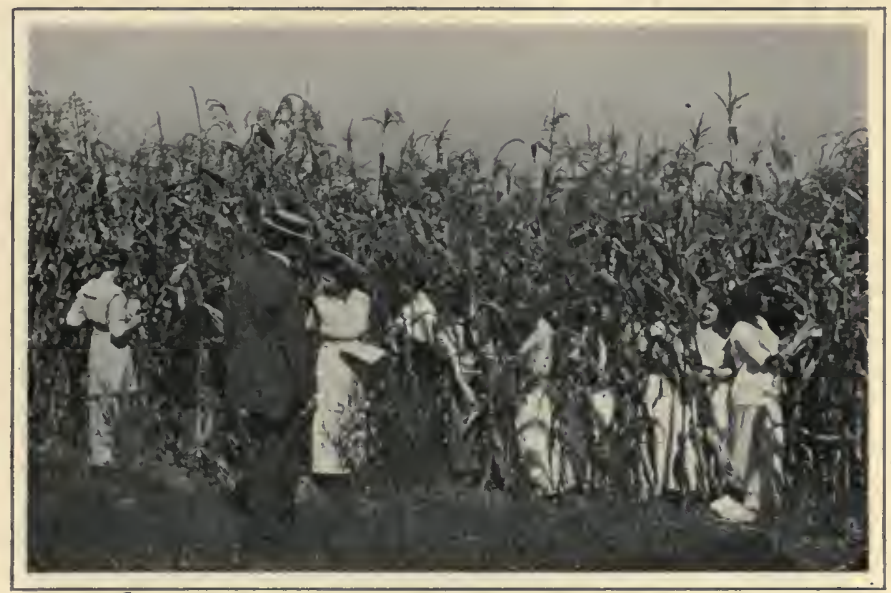

Class Selecting Seed Corn.

ample foliage and vigorous growth, and that produce one good, well-developed ear, two ears apiece, if two ears are customary in the variety. The ears should hang over somewhat and should be placed neither high nor low.

The points to be secured in ear selection are vitality, yield, and maturity.

it, and after how to dress and tend it. Also he told them axcepte they got fish and set with it (in these grounds) it would come to nothing; and he showed them yt in ye middle of Aprill, they should have store enough come up ye brooke by which they begane to build and taught them how to take it." 
(a) Vitality. A good germ is needed,-one that is large, bright, and plump. But it will not do to trust to looks. To determine whether the kernels have life, a germination test should be made shortly before planting. Several inexpensive devices for this purpose are in use.

Professor H. D. Hughes of the Iowa Experiment Station has invented a simple contrivance, which he calls the "rag doll " outfit.

A few yards of good sheeting are torn in strips, 8 inches wide and from 3 to 5 feet long. A line is drawn lengthwise with a pencil through the middle of a strip, and then cross lines are made about

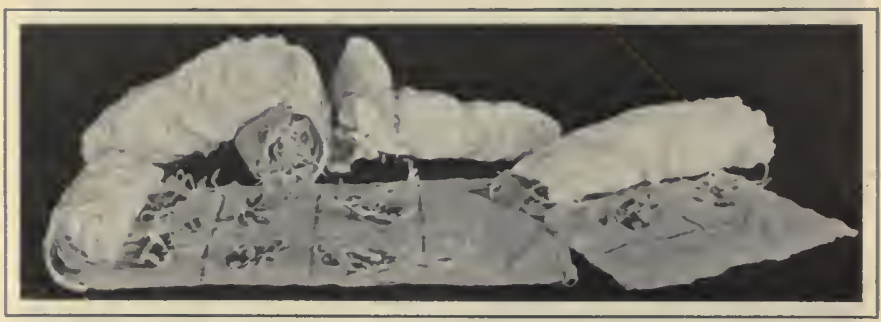

The "RAg Doll" TEST.

every three inches. This divides the cloth into squares, which are numbered.

A marked strip is now wetted and spread out before the ears to be tested. Six kernels are taken from an ear marked one, and are placed in the number one space; six are taken from an ear marked two, and are laid on the space marked two, and so on. The six kernels from each ear should be taken from different parts of it.

When the spaces have all been used, the cloth is rolled up carefully. The moisture present will prevent the kernels from slipping ont of place. A string is now tied loosely around each end, or a rubber band may be used. From 30 to 50 ears can be tested on each piece of sheeting.

When this part of the process has been completed, the rolls are placed in water from 8 to 12 hours; they are then put into an ordinary box or under a bucket upside down for about tive days, but placed so as to get air. 
The cloths are then unrolled, and the sprouted and unsprouted grains carefully examined. An ear is discarded if all the six kernels do not show strong germination. The numbers of ears, of course, must be recorded in some convenient way.

(b) Yield. The average corn yield of the United States is nearly 30 bushels per acre. A boy in South Carolina grew 228 bushels of dry shelled corn to the acre. It is needful to consider, however, not only the number of

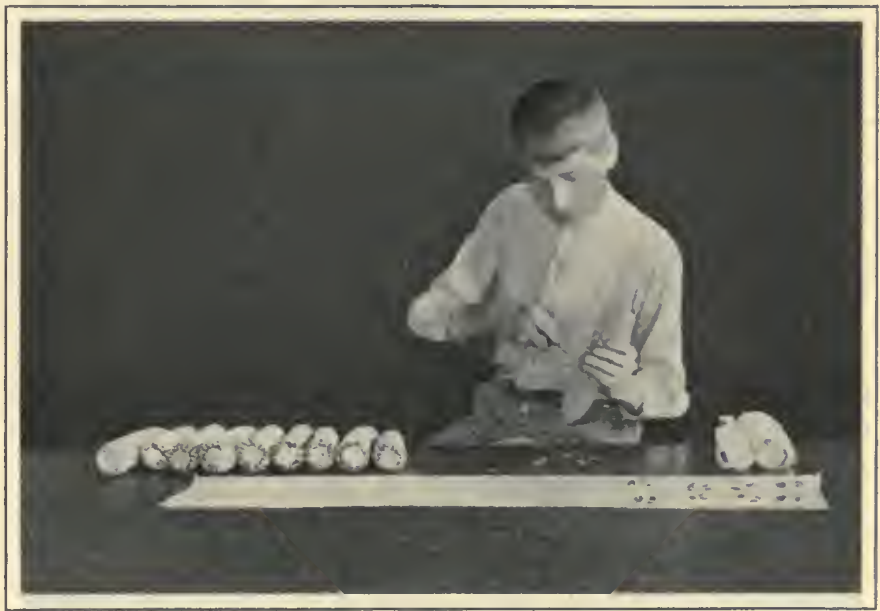

Removing Seed for Testing.

bushels of corn to the acre, but also the cost of producing them. The southern boy grew his corn at an enormous expense. A slight expense will commonly do much to increase the yield.

If one counts the stalks in one hundred hills as they come in an average cornfield, he will probably find that the stand represents less than 75 per cent of the seed; and if he subtracts the number of barren stalks from his count, this per cent would be reduced still more. Much 
can be done to improve such yields by seed selection alone. A farmer should not only select the best corn in his own field for seed, but sliould also get into touch with corn breeders' organizations, his Experiment Station, and

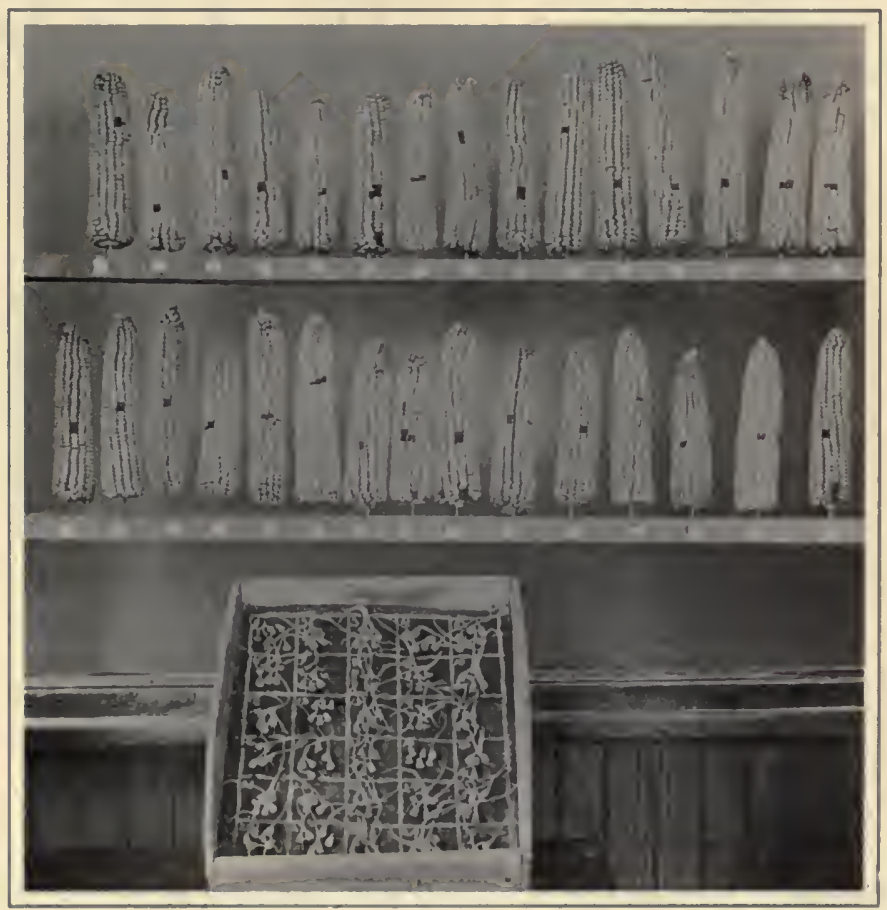

Box Method of Testing Seed.

the best corn growers in the neighborhood. A pint of high-yielding seed corn, secured from any of these sources, may yield such an increase in bushels per acre in a few years as to pay all the farm taxes.

(c) Maturity. Early maturity will permit thorough drying-out before freezing weather arrives. The moisture 
should have time to evaporate from the ear before it is stored. Otherwise, molds may develop and the germs be killed. Seed corn, therefore, should not be soft and spongy on the cob.

191. The "Ear-to-Row" Experiment. - When ears of seed corn have been selected as described above, if the seed tests well, it ought to produce a stand much above the average, and, by following up the process for a few years, marked gains should be secured. But it is possible, at no

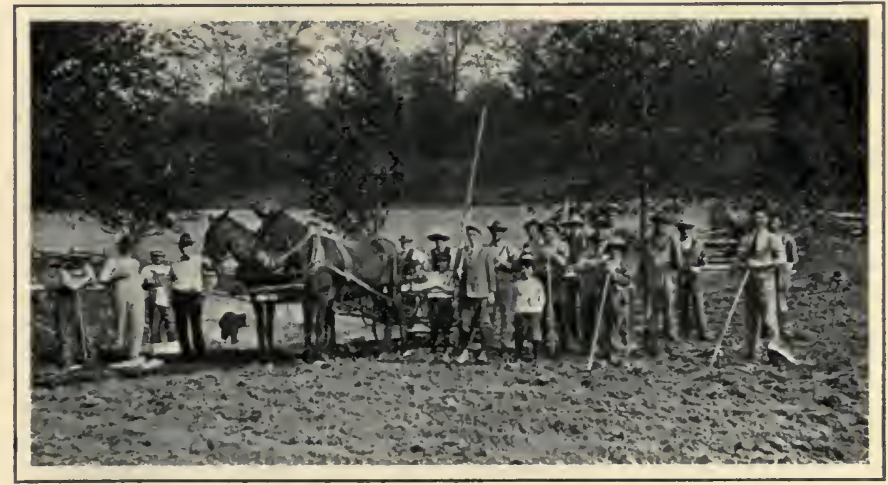

Starting a Corn Variety Test.

great expense of time and labor, to carry the selection a step further - by the "ear-to-row" method.

For this, the farmer must have a special seed plot. A certain number of the most promising seed ears are selected, one or two hundred. These are numbered. Then the seed of No. 1 is planted in row No. 1; the seed of ear 2 in row 2 ; and so on. The ears probably all promised well and looked much alike; but the rows will probably show an amazing difference in productivity. Some rows may produce two or even four times as much corn as other rows. Seed for the next year will be selected 
from the best rows, and the experiment may then be repeated. Soon the whole crop will come from high-produeing ears.

192. Kinds of Corn. - Dent Corn is the sort most extensively grown in the United States. It derives its name from a depression or "dent" in the grain due to drying.

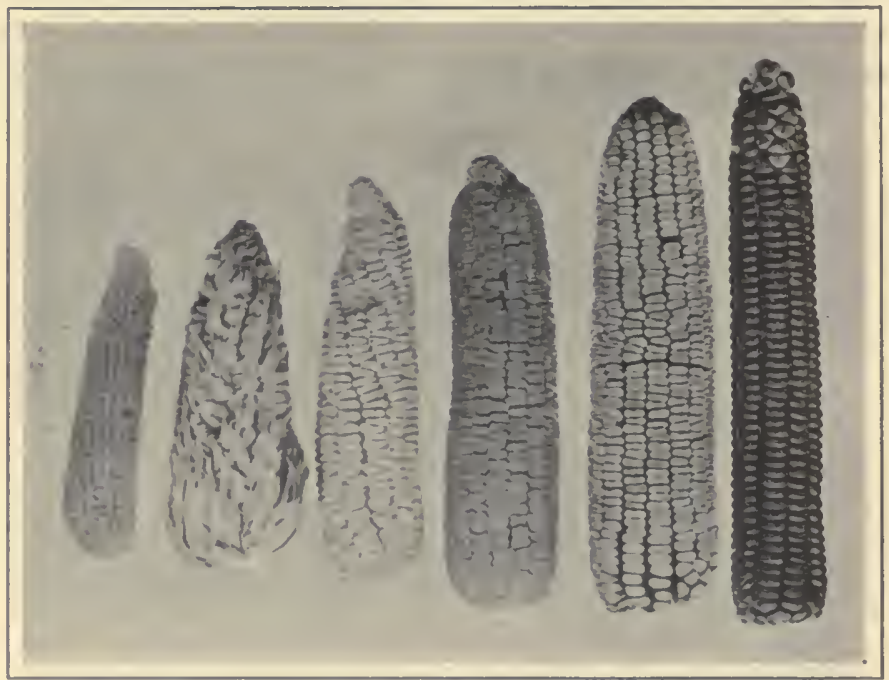

SIX TYPES OP CORN.

Pop, pod, soft, sweet, dent, flint.

Flint Corn is smooth, yellowish, reddish, or white in color. The cob is large and slender, bearing 8,10 , or 12 rows. It matures carly, and is grown mostly in New England and Camada.

Pop Corn is grown widely but sparsely. Its inclosed moisture expands, when highly heated, turning the broken and enlarged contents inside out.

Sweet Corn is grown mostly for table use on the ear and for eanning. When dry, it presents a shriveled appearance. 
Pod Corn is supposed to be the most primitive type of corn. However this may be, it is certainly an interesting type, although not common. Each kcrnel is inclosed in a pod which resembles the husks surrounding the entire ear. It is interesting also to note that occasionally we may find a few podded grains on our common corn, which fact suggests a reversion to the pod or earlier type. Pod corn is thought to have originated in Argentina, South America.

Soft Corn is characterized by the entire absence of horny endosperm (the part outside the germ). Like pod corn it is mostly a curiosity with us. However, it is grown somewhat in Chili and Peru.

193. Culture. - After the seed corn and its variety have been selected, the work of the season runs on from preparing the seed bed to harvesting.

We must not forget that corn is a tropical plant and that the seed should not be planted before the soil is warm.

In the preparation of the soil, the increase of its waterholding capacity and its available food supply are the objects desired. The soil particles should be made fine, to enable the root hairs to absorb nourishment readily. Late fall or early spring plowing of soct is the best farm practice. The plowing should be deep. One to two inches is the average depth for planting the kernels. This will enable then to get the benefit both of the warm surface layer and the interior moisture.

As soon as weeds appear, which may be in a few days after planting, a weeder or cultivator is run over the ground to kill them, and also to let air into the soil, and to prevent the loss of moisture. Shallow cultivation is best. Later in the season, when the stalks are a foot or two high, the feeding roots spread widely, and only the 
finer cultivator teeth should be used for the shallow eultivation and for securing the least soil muleh.

194. Judging. - The "judging" of corn is for the sake of comparing different seed ears of a givell variety, in order to determine their relative value as seed. Beginners generally use a "score eard" for this purpose. The table

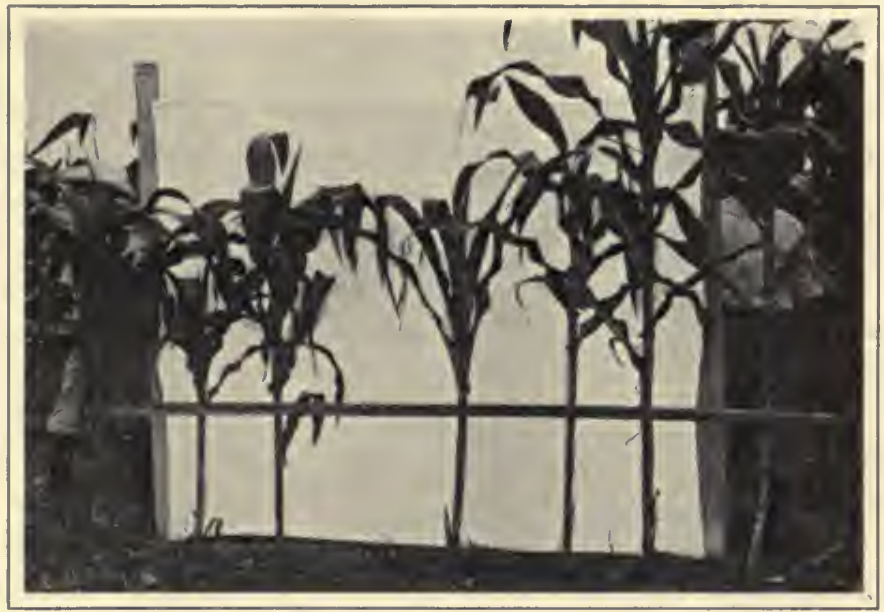

Result of Not Testing Seed.

Had these boys tested their seed, they would have had six healthy plants in the place shown instead of five.

on the following page is an example of a score card for dent corn.

A little explanation may make it easier to use the following card. Usually, ten ears are placed side by side on a table, the tips pointing in the same direction. In exhibits the ears should be laid together, so as to give them an even and uniform appearanee, the best ears being to the left. The terms used in the seore eard may be explained briefly. 


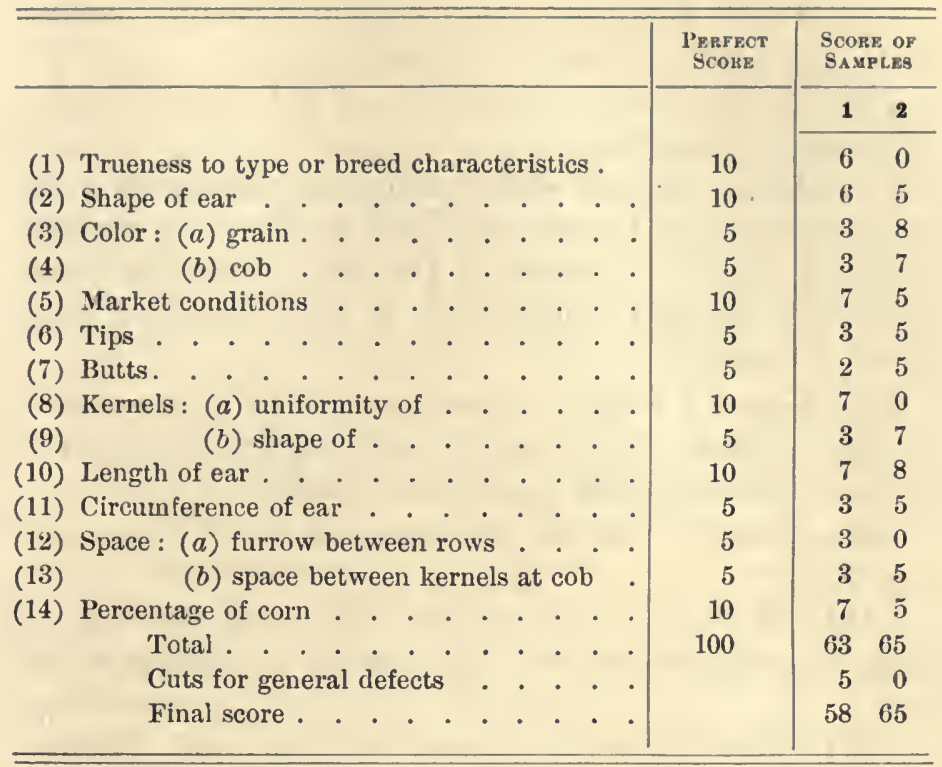

\section{Name}

(1) Trueness to type. A mental picture of a perfect ear must be kept in mind. Mark down the per cent of the ears judged, if they vary from this in form of kernel, shape, color, and indentation. Ten points are allowed if the ear is perfect. To the first sample in the card above, only six points were given, and to the second, none. These two ears, then, were imperfect, as regards trueness to type. The second departed too widely from the type to merit a single point.

(2) Shape of ear. Ears should be nearly cylindrical, not crooked or tapering.

(3) The color of grain should be uniform.

(4) The color of cob should be cherry red for yellow corn, and glistening white for white corn. 
(5) Market condition: Corn should be mature, sound, solid, and free from injury or decayed spots.

(6) The tip of the ear should be filled out to the end, or completely covered.

(7) Butts. Kernels should run up evenly to the shank in regulat rows. 'The eavity should be elean and concave.

(8) Kernels: Uniformity. The kernels must not only conform to an ideal standard, but be uniform among themselves in shape and eolor.

(9) Kernels: Shape. Kernels should be wedge-shaped, but not pointed. The length of each grain should be about one and one half times its greatest width.

(10) Length of ear should correspond to the standard selected.

(11) Circumference of the ear, one third the way up from the butt, should be three fourtlis the length of the ear.

(12) Space (a) refers to space between rows. Furrows should be straight and uniformly narrow, but not elosed.

(13) Space (b) refers to space between kernels close to the cob. The grains at the tip should touch one another.

(14) Percentage of corn. Well-matured corn shells 85 pounds of eorn to 15 pounds of eobs. The cob, however, should be of medium size. As its size becomes smaller the number of rows on it decreases. Chaffy and immature cobs indieate a low percentage of grain.

\section{Practical Questions}

1. What is the size of our corn crop? 2. What is meant by the word corn? 3. Where would you begin in the selection of seed corn? 4. What is meant by the term vitality? 5. How can the corn yield per acre be increased? 6. Name and describe three kinds of corn. 7. What are some of the points to be considered in corn culture? 8. Of what value is a score card for corn? 


\section{Hone Exkrcises}

1. Start or maintain a corn club. No crop lends itself more readily to club work than corn does. Send to Washington for Farmers' Bulletin No. 415, on "Seed Corn"; Farmers' Bulletin No. 617 on "School Lessons on Corn" also; circular No. 104, on "Special Contests for Corn Club Work," aud for the circular entitled, "Organization and Instruction in Boys' Corn Club Work." With the aid of the County Agent, of the Superintendent of Schools, or of the local teacher, the elub should easily be organized. The basis of award in corn club work may be:

(1) Greatest yield per acre . . . . . . 30 points

(2) Best showing of profit on investment . . . 30 points

(3) Best exhibit of ten ears at county, district, or state fair . . . . . . . . . 20 points

(4) Crop report record and story of club work $\quad 20$ points Total Score . . . . . $\overline{100}$ points

2. In addition to the corn club work many simple and original experiments can be worked out at home.

In early fall a pupil may determine the number of bushels of corn to the acre on his home farm as follows: Along the edge of a corn field, by pacing, or using a string, measure off 209 feet, the length of a side of a square acre. Then measure the same distance on the adjoining side of the corn field. Count the rows included in this distance, and the average number of ears in three rows. Fill a bushel measure with unshelled corn, then count the ears, and assume that it takes two bushels of corn on the ear to make one that is shelled. Estimate the number of bushels per acre from these figures. See how nearly your estimate holds out when the crop is harvested.

\section{SugGESTIONS}

1. Demonstrations made directly on the corn plant in the schoolroom make the subject real. Gather some tassels before the pollen has fallen; place them on a dark paper, and in an hour or two the pollen bags will have discharged their contents. These pollen grains can readily be seen with the naked eye. Blow on the paper to see how easily they float in the air.

2. Remove the husks from an ear as the silk is coming out. Follow each silken thread to the grain that produced it. Are there 
as many silks as grains? Which silks came out first, - those from the butt or those from the tip of the ear? The silk catches the pollen. Can you see any tiny hairs on it near the tip? Is it sticky? Why"?

3. Score a ten-ear exhibit. Send to your college of Agriculture for the score card for your state. Full explanations will be given. Remember that we are not merely studying a textbook, but a subject. Agriculture is an informal subject. Arrange for a Corn Show and a Corn Festival.

4. It is well to try an "ear-to-row" experiment with corn, either in the school garden or at the homes of some of the pupils.

5. A corn variety test also, under the direction of the County Agent or Agriculturist, is an instructive piece of work to follow. When the best variety has been studied by the variety test see that a specimen of it is brought to school.

\section{REFERENCES}

Corn Plants. Sargent.

Corn. Montgomery.

Siceel Corn. A. E. Wilkinson.

Farmers' Bulletins. Washington, D.C.

253. The Germination of Seed Corn.

313. Harvesting and Storing Corn.

414. Corn Cultivation.

499. Corn Growing.

537. How to Grow an Acre of Corn. 


\section{CHAPTER XX}

\section{SMALL GRAIN OROPS}

Except a corn of wheat fall into the ground and die, it abideth alone; but if it die, it bringeth forth much fruit. - ST. JoHs xil. 24.

195. Wheat is our leading small grain. Like all the other small grains, and like corn also, it is a cultivated grass. The Chinese records show that people cultivated wheat as far back as 2700 B.c. It was known to the Lake Dwellers of Switzerland in the Stone Age, perhaps 50,000 years ago. No one, of course, knows much about the antiquity of wheat. Not even the name of the country in which it was first grown is known with certainty. It is probable that it originated in the fertile valley of the Euplirates.

Wheat is now grown in every civilized coun-

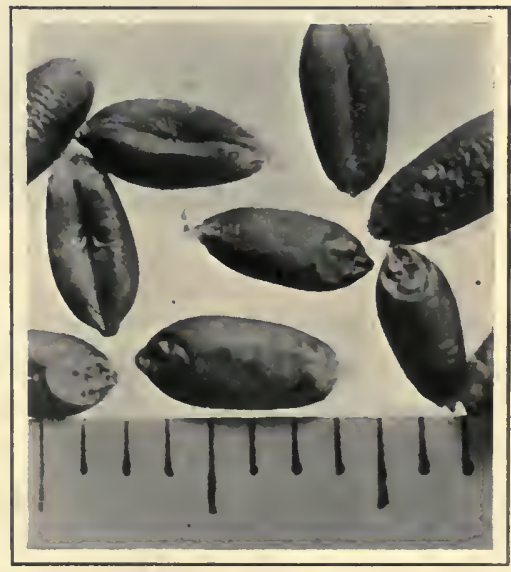

WheAT Grains.

The divisions in the ruler are $\frac{1}{16}$ of an inch.

try. Since the invention of the reaper, however, the number of acres devoted to wheat culture has been 
increasing by leaps and bounds. The reason for this lies in the fact that the wheat grains drop from the heads and are lost unless harvested within an week or two after ripening. The number of acres to sow depends largely on the ability of the laborers to harvest the erop. 'The reaper has multiplied this ability many fold, and so has made possible a vast increase in wheat acreage. One man with

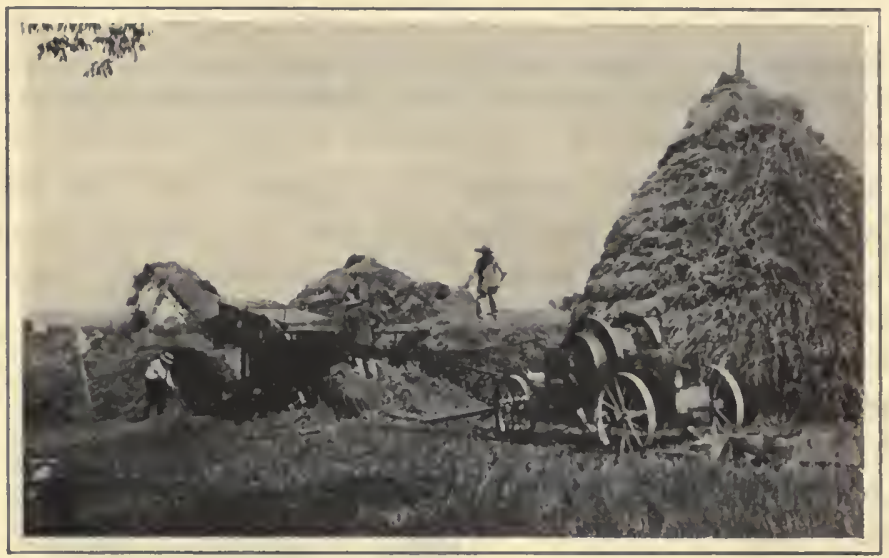

THRESHING $\cdot$ WHEAT.

a reaper is able to harvest as much grain as many men by the older methods. See Appendix A, Chart I, page 467. Wheat is a luman food, not a stock food. Not that it is not good for the stock; but man lias learned to esteem it too highly to leave any of it to lower animals. Bread made from rye, barley, or millet differs very little in nourishing qualities from that made from wheat; but whent bread is whiter in color, more nutritious and more attractive.

It is interesting to know that farmers are harvesting wheat somewhere during every month of the year. The list below names a harvesting eountry for each month : 


$\begin{array}{ll}\text { in January, } & \text { Australia harvests; } \\ \text { in February, } & \text { Egypt; } \\ \text { in March, } & \text { India; } \\ \text { in April, } & \text { Mexico; } \\ \text { in May, } & \text { Central Asia; } \\ \text { in June, } & \text { Italy; } \\ \text { in July, } & \text { the United States ; } \\ \text { in August, } & \text { Canada; } \\ \text { in September, Scotland; } \\ \text { in October, Norway; } \\ \text { in November, Peru; } \\ \text { in December, Argentina. }\end{array}$

196. Seed selection is important. As in the case of corn, the peculiarities of the wheat plants in the field are valuable points to consider in selecting seed. Look at the straw to see whether it is stiff or has a tendency to fall down; whether there is considerable rust present, or insect damage; whether there is uniformity in height, and in time of ripening; whether the heads are compact, so as to retain the grain well. Notice also the presence or absence of weeds in the field.

When the seed has been selected and thrashed, it is well to winnow out the weed seeds carefully, and also the small wheat grains. This will leave for seed only the plumpest and most shapely kernels, and will increase the crop the following year.

197. Types of Wheat. - Wheat is of two general types. Winter wheat is sown in the fall. Spring wheat is sown in the spring. Under each type three varieties are noted:

\section{Winter Wheat \\ 1. Soft \\ 2. Semi-hard \\ 3. Hard}




\section{Spring Wheat}

1. Soft

2. Hard

'3. Macaroni, or durum

Wheat grown in moist regions is soft, and that grown in dry regions is hard. The best flour is made from hard wheat. The macaroni wheat is a variety whose seed was recently introduced into the United States from the dry

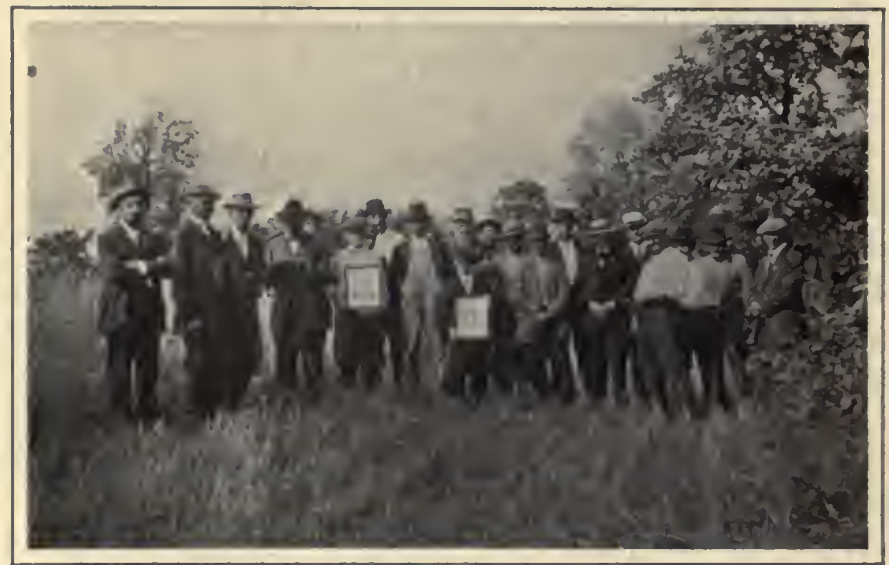

A Wheat Variety Test.

lands of Russia. It is now extensively grown in the semi-arid regions of the southwest. It is the hardest of all the whents.

198. Culture. - A rich soil is necessary for a good stand of wheat. Plenty of humus is desirable. This is why in the early days the virgin soils of our country were so profitable for wheat raising.

The soil must also be prepared carefully before planting. In corn culture, cultivators are used after planting the seed; but this is not possible with wheat, and so 
spécial care must be given to the soil before seeding, in order to have it well fined and free of weeds.

Before machines were invented for drilling in the wheat, it was sown broadcast, and this method is used by some farmers to this day. But broadcasting (which is simply throwing the grain around by hand) is very wasteful. Its wastefulness points the moral to a well-known parable

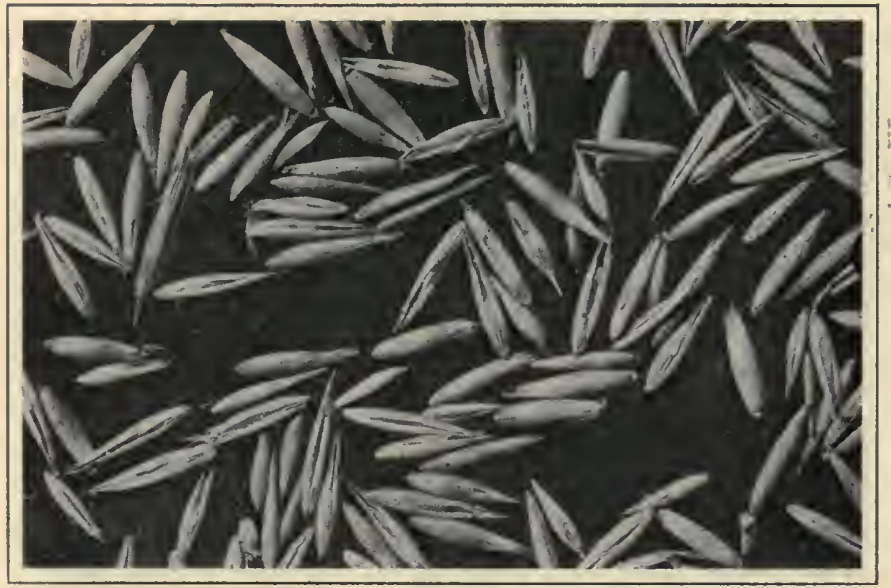

Oats - Natural Size.

in the Bible. According to the parable some good seed fell on shallow ground, some on stony ground, and only a part fell on good ground.

In order to sprout well and to produce a thrifty growth afterwards, the grain should be planted from one to two inches deep. The drill can be set in such a manner as to secure not only the proper depth for the seed to grow best, but to make the amount of seed planted in a given space equal to that planted in any other equal space. This cannot be done by broadcasting, no matter how carefully the seed is afterward harrowed.in. Some seeds 
will lie on the surface for "the fowls of the air" to pick up; others may be covered too deeply, and not:sprout well. Then, too, the little furrows made by the drill, if extending east and west, will protect the roots somewhat from the effects of thawing and freezing, each east-towest row being shaded sufficiently to prevent frequent thawing.

199. Gathering the Harvest. - A field of golden grain ready for the harvest is a sight to inspire a poet. A

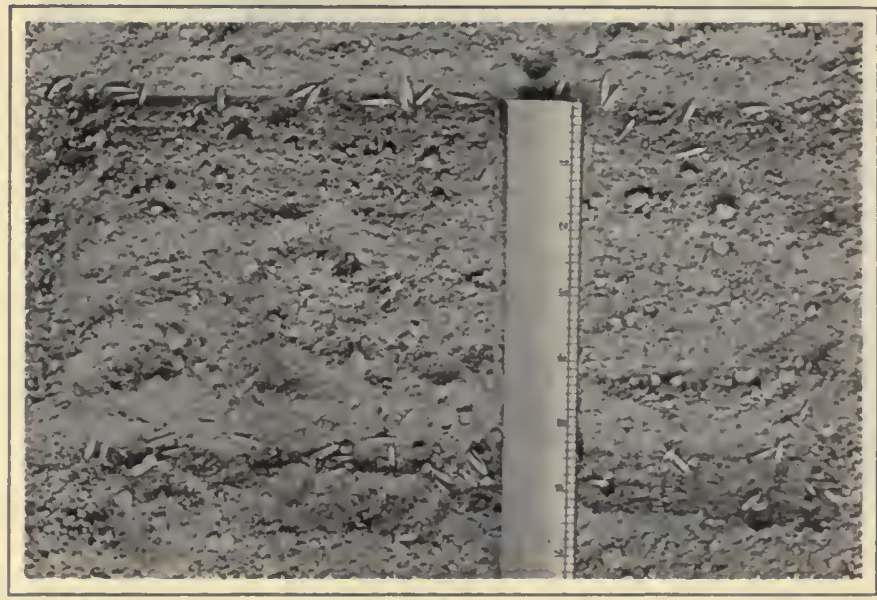

Oats as Planted in Drills.

practical farmer may draw the same joy from the sight, but he will wish also to know whether the grain is getting too ripe. It is important to know the earliest moment when the grain can be cut so as to avoid scattering. When the stalks are beginning to have a rich, golden hue, and while the grains are yet soft enough to crush between the fingers, the harvest time is at hand. However, if the thrashing and cutting is done at one time by what is called a eombination harvester and thrasher 
drawn by an engine or many horses, the grain should be left to become fully ripe and hard before cutting. The riper the grain, the easier it will shell out.

200. 0ats. - If we examine the crop statistics for the United States, we shall find that in number of bushels corn stands first, oats second, and wheat third; and the order for the money value of these crops is corn, wheat, and oats.

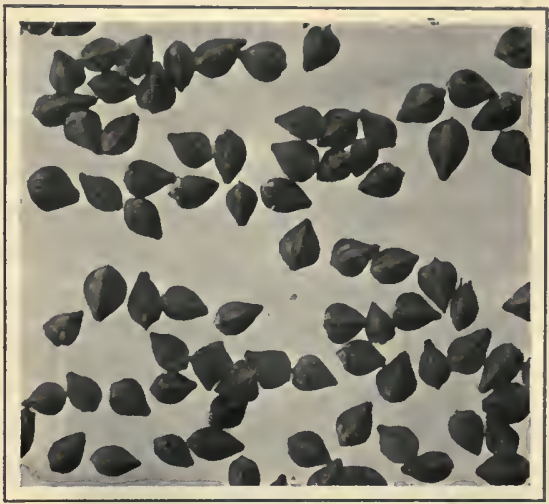

Buckwheat - Natural Size.

The grain of the oat plant is used chiefly as a food for horses and to make a preparation known as oatmeal.

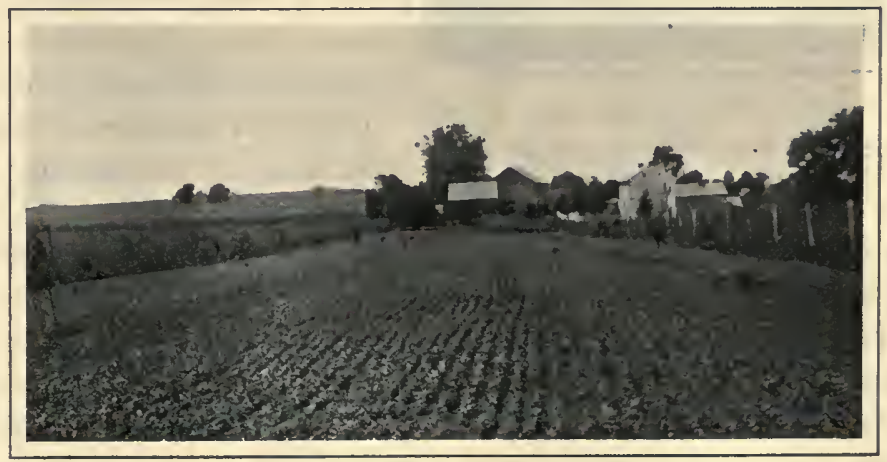

Buckwheat Planted in Drills.

For many years oatmeal has been a popular breakfast cereal. It is one of the cheapest sources of protein, a tissue-building food. 
The oat plant does not thrive well in warm climates, but its yield gradually increases from eighteen bushels in our southern states to fifty or seventy-five in the northern states. In Canada, Montana, and North Dakota it is not uneommon for the yield to exeeed one hundred bushels per acre. See $A$ ppendix A, Chart II, page 467.

The Experiment Stations of Minnesota, Ohio, and Kansas have been giving considerable attention to oats in

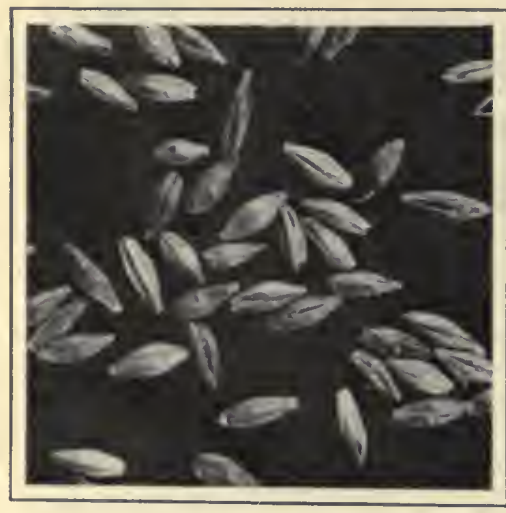

Barley Grains.

Compare these in size and appearance with wheat, oats, and rye.

the hope of improving the yield and quality. They have found that large, heavy seeds produce better yields and a better quality of grain than the lighter and smaller seeds. They have also found that drilling gives better results than broadcasting, and that there is a marked difference in the different varieties of oats in respect to resistance to disease and drought.

Some farmers do not consider oats a profitable erop. This may be true under certain eonditions. A low estimate of the cost of raising and harvesting an aere of oats, including the rent of the land and the thrashing bill, is ten dollars. A yield of twenty bushels at forty cents a bushel wonld mean a gross income of only eight dollars, or a loss of two dollars per acre. This, of course, would not be good farming. A yield of fifty bushels, on the other hand, would give a profit of about ten dollars. 
Oats are planted very early in the spring, and they are harvested after wheat and before corn. In this way work on the oat crop aids in filling in the time of farm labor. This is an important consideration, and together with the high food value of the crop, it makes the growing of oats, on the whole, very popular.

\section{Barley and Rye.-} In the number of bushels of the leading cereals grown by American farmers, barley follows oats and rye follows barley. Barley and rye are raised more extensively in Europe than in the United States. Formany centuries barley was the chief bread-plant of the world. This was true, even as late as the sixteenth century. It is now largely used in the

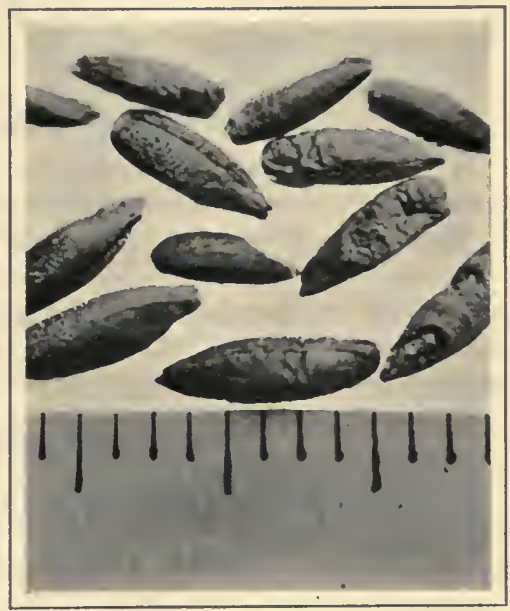

Rye Grains.

The divisions in the ruler are $\frac{1}{16}$ of an inch. making of malt for the manufacture of beer. In general appearance and habit of growth barley resembles wheat, but it is somewhat shorter, and its heads are more often "bearded" with needle-like appendages. These appendages make the handling of the barley crop annoying, and for this reason the United States Department of Agriculture has undertaken to "breed off" the needles. The new beardless variety will probably soon take the place of the older varieties.

Russia produces one half of the world's rye crop. In its general features rye resembles wheat. It is, however, 
considerably taller, and lighter in color, and it produces a smaller grain. Rye straw is extensively used for the making of baskets, fans, boxes, mats, and paper. Little attention has been given to improving rye. Naturally hardy and vigorous, rye is much grown as a cover crop and as a winter pasture. In these eases the grain is not allowed to mature.

\section{Practical Questions}

1. What can you tell about the history of wheat? 2. What qualities does wheat possess which make it a desirable human food? 3. Can you tell why wheat can be harvested somewhere during every month of the year? 4. How should seed wheat be selected? 5. Explain the preparation of the seed bed for wheat. 6. Describe the raising of oats. 7. In what ways do barley and rye differ from wheat?

\section{Home Exercises}

1. Determine whether the growing of wheat is as profitable to your father as the growing of corn. Include every possible item, as cost of seed, fertilizer, and harvesting. If you discover, for instance, that wheat is the better money crop, would it be advisable to increase the wheat acreage at the expense of the corn acreage?

2. Gather up all the home data you can on the culture of any one of the sinall grains. Start with the selection of the seed and carry the work through to the point where the grain is taken to the mill. Write a concise, logical, and complete account of this work in your school notebook.

3. What insect and fungus pests have reduced the profits on sinall grains in your region?

\section{SugGestions}

1. The small grains lend themselves very acceptably to schoolroom exercises. Supply each member of the class with sereral heads of wheat. Count the grains in each head. In what part of the head do you find the best grains? How are the grains supported on the head? Can you separate all the parts of one flower? Can you find the names of each part? Are the wheat flowers "perfect?" If this 
work can not be done on fresh material, heads must be collected and be preserved in mice-proof boxes. If there should be an increase of a single grain in every wheat head in a ten-acre field, how much money would that increase mean?

2. Throw a few of any one of these common grains in the fire and watch them through a thick blue glass as they burn away. You will notice a beautiful lavender flame due to the potash present in the grain. You will find more potash in the bran than in the white part. Burn a little bran and white flour. Note the intensity of color produced by each. Explain that we need mineral matter and that whole wheat bread is, for this reason among others, often preferred to white bread.

3. Correlate the study of grains with geography, history, botany, and arithmetic. Formerly, grains of wheat were used as a measure of weight. These grains were selected from the middle of the head and well dried. Do 5760 of these grains equal a pound 'Troy? Do 7000 of them equal a pound Avoirdupois? Verify as a class exercise. It night be well to have the smaller pupils count out this number as an exercise in number work, the weighing being done by the students of Agriculture.

\section{REFERENCES}

Cyclopedia of American Agriculture. Bailey.

Cereals in America. T. F. Hunt.

Forage and Fiber Crops in America. T. F. Hunt.

Farmers' Bulletins. Washington, D. C.

420. Oats: Distribution and Uses.

424. Oats: Growing the Crop.

443. Barley: Growing the Crop.

534. Durum Wheat.

616. Winter Wheat Varieties for the Eastern United States.

678. Growing Hard Spring Wheat. 


\section{CHAP'TER XXI}

\section{FORAGE OROPS}

To-morrow to fresh woods and pastures new.-Mıтos.

202. What is Forage? - In the last chapter we have studied about certain crops which are raised mostly for

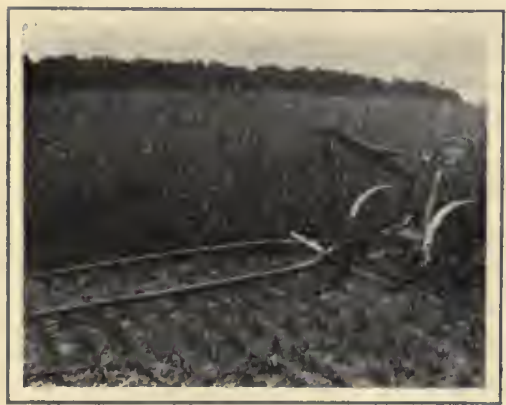

Cutting Forage. their grain or seedls. We will now take up a few plants whose stems and leaves are especially valuable to farmers. The stems and leaves of nearly all farm and garden plants except celery, rhubarb, lettuce, and turnips are fibrous and coarse, and are not relished as human food.

But animals have stronger powers of digestion than men, and they are very fond of the stems and leaves of many coarse plants. 'These plants are ealled forage plants, or merely forage.

203. Kinds of Forage. - If forage is gathered fresh by animals themselves, as in grazing, it is ealled pasture. If cut and allowed to cure or dry, it is known as hay, straw, fodder, or stover. If cut and fed green, without euring, it is known as a soiling crop. If stored in silos while still 


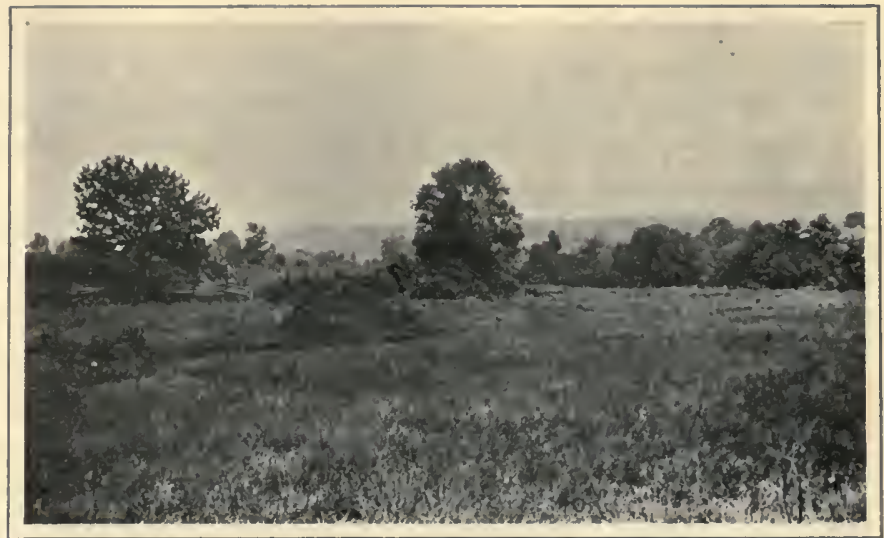

A Typical Meadow.

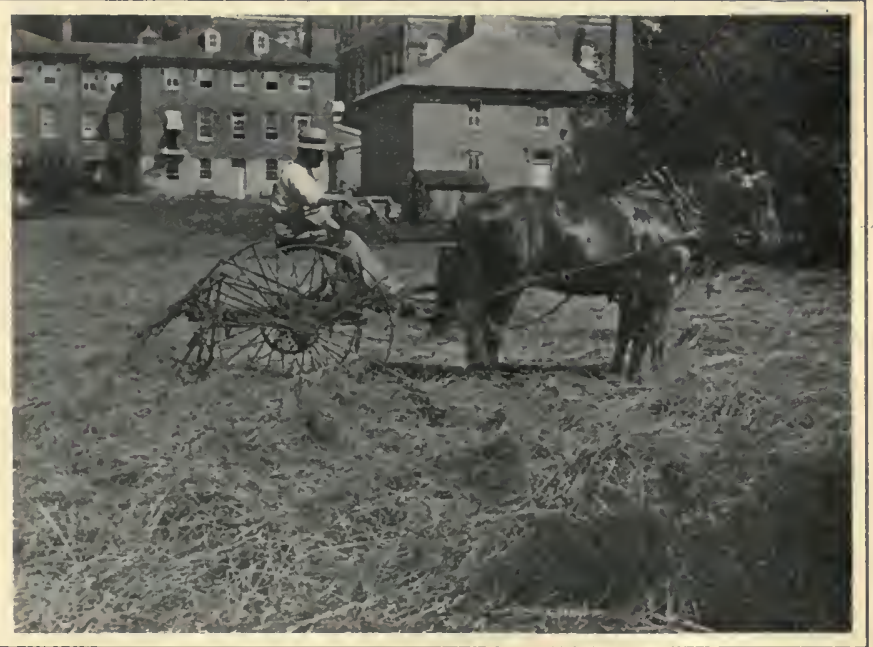

HAY TEDDER aT WORK.

The tedder hastens curing by raising and loosening the hay. 
fresh and green, so as to keep in this state, it is called silage.

204. Pasture. - Much of our land is not farmed, because it is too hilly, too wet, or too rough to cultivate. Such lands, nevertheless, may be used for pasturage and may provide a cheap means of maintaining animals. Wet pasture lands are known as meadows. Meadows usually require little attention. In most districts they will pro-

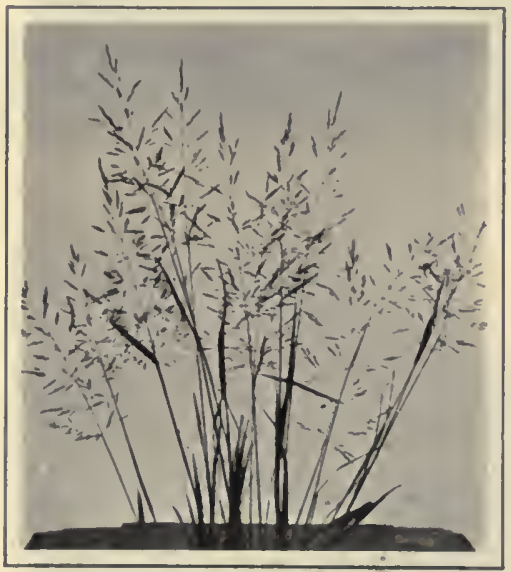

RED TOP. duce two erops of hay each season, or they should provide a permanent pasture throughout the summer. It is necessary to fence them if they are to be used as a permanent pasture. In the meadow we often find a fine quality of grass nourished by unfailing springs or creeks. The abundance of accessible water with rapidly growing and nourishing grasses makes meadows well-nigh ideal pasture grounds. In time, however, such pastures may be cut up badly in wet places by the eattle, and the nourishing grasses may be displaced by coarser varieties or weeds. It is then a good practice, when the soil is in proper condition, to plow and fertilize the meadow and start a new pasturage.

It is often possible to reënforce the regular pastures from other sources. Thus, after a crop has been harvested, the field may sometimes profitably be thrown open for the cattle to glean what has been left along the fences, 
around the trees, and in the open. The wood lot also may contain some suitable pasture plants, and if it adjoins a meadow, it is convenient for use by the cattle.

205. Hay. - In value our hay crop ranks second only to corn. For the last fifty years in the United States there

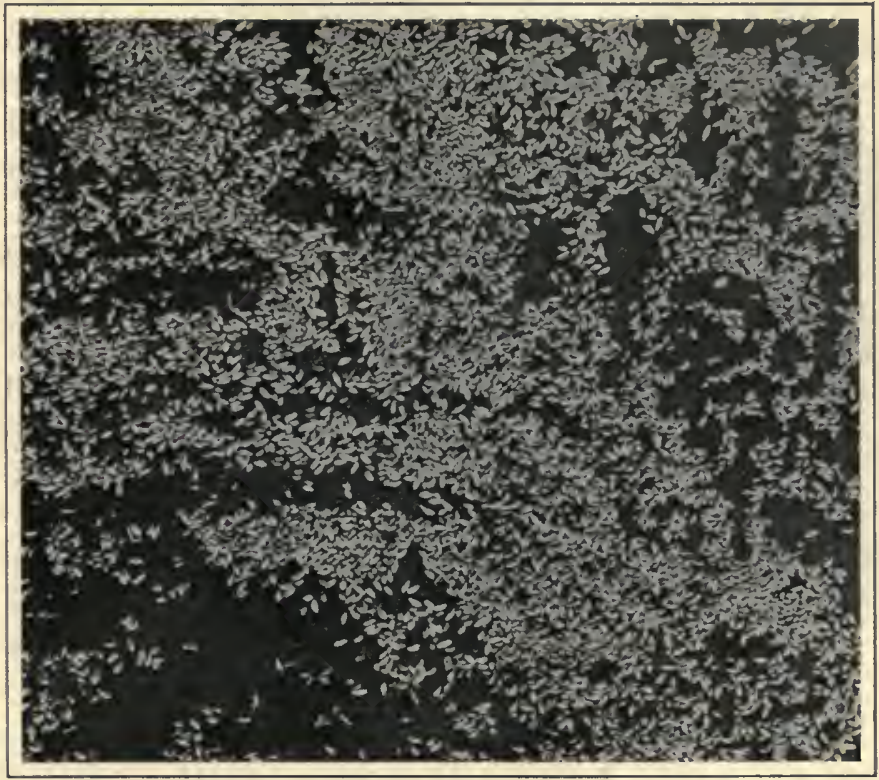

Timothy Seed.

has been a slight but gradual increase in hay tonnage, in cash value, and in the average yield per acre. We now produce about a ton and a half of hay to the acre. See Appendix A, Chart V, page 469.

Hay is any crop cut and dried for feed. Fodder, the cured stalks of corn, is a coarse form of hay. Grasses, however, because they are readily cured, furnish most of our hay, although the clovers, alfalfa, and cow peas, which are not really grasses, form a large part of the crop. 
206. Timothy ranks first among hay plants. For years, either unmixed or mixed with elover, it has found a ready market in cities at high prices. It is adapted to various soils and is easily grown. It lives longer than two years, though after three or four it usually runs out rapidly.

207. Kentucky blue grass, so called because of the peculiar richness of its color, is unexcelled for lawns, pastures, and hay. It attains its best growth in sections rich in lime-

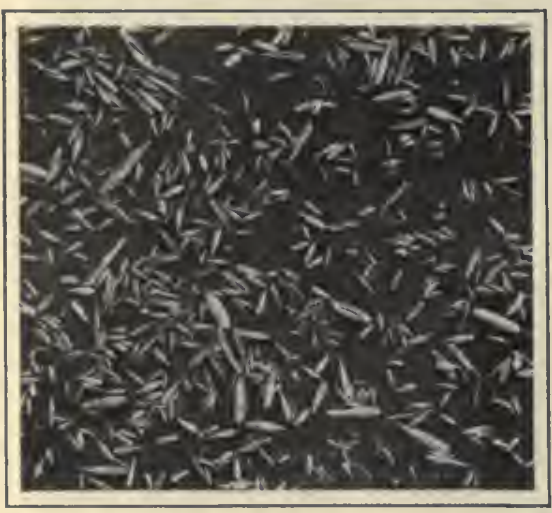

Seed of Kentucky Blue Grass. Larger bodies are chaff. stone, notably in the "blue-grass" regions of Kentucky. As a pasture, it seems to improve with age. It needs several years to get a good sod; but, once established, some blue-grass pastures have supported grazing animals successfully for over tifty years, and have not run out.

208. Alfalfa. - It has been said that in America corn is king, and alfalfa, queen. As a forage plant, alfalfa was grown in Europe before the Christian era. Its merits, however, have only lately appealed to American farmers. Over 2,000,000 acres are now devoted to its growth. See Appendix A, Chart VI, page 469.

Alfalfa will not sncceed well if the soil is not sweet, porous, and well drained. It is very sensitive to soil acids, and most of the eastern soils need liming for good results with alfalfa. Nor can alfalfa be pastured heavily, and not at all the first year. When young, it is very tender, and it does not thrive well if sown with other plants. 
The conmon causes of failure to get a good alfalfa stand are: (1) seed is not sown at right time; (2) the soil is too weedy ; (3) the plants winter kill; (4) the soil lacks lime; (5) the soil is poorly drained; (6) there has been no "inoculation" with alfalfa bacteria.

Alfalfa roots break readily during freezing and thawing weather. In certain sections this trouble is the most difficult one to contend with. Where the land is light and

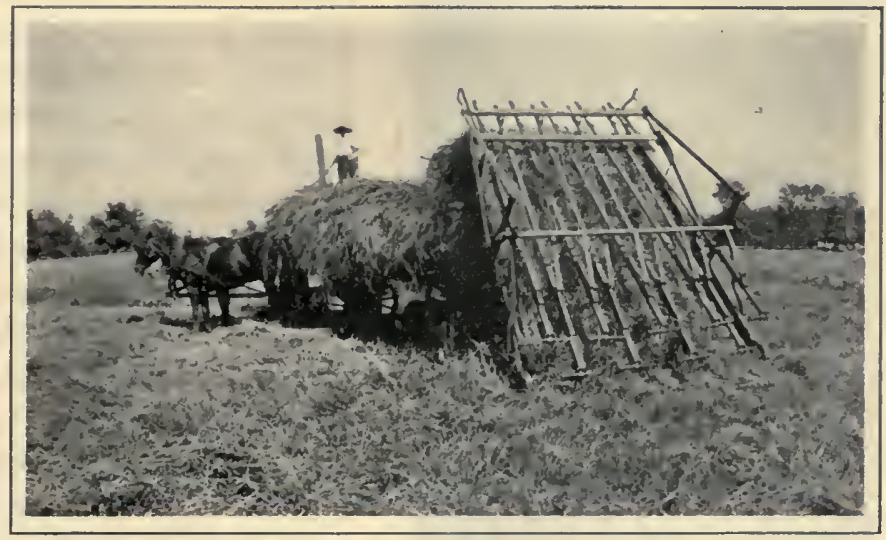

HAY LOADER.

without a subsoil of clay, alfalfa is not likely to be injured very much by winter killing. Alfalfa needs a good start by fall, and it is best to sow it early if witch grass, wild mustard, shepherd's purse, or any other common weeds are liable to choke it out before winter starts. Usually it is necessary to inoculate the seed bed. That is, it is necessary to bring soil from an old alfalfa field and scatter it over the seed bed at the rate of 200 or 300 pounds per acre, just before seeding. In this old soil there are countless numbers of bacteria that produce little swellings on the alfalfa roots. These bacteria then gather 
nitrogen from the air, and make a compound of it that is available for the plant.

209. The Value of Alfalfa. - "For filling a milk can, an alfalfa-fed cow is equal to a handy pump," says a western farmer. Primarily, alfalfa is a dairy feed. It is rich in protein. It is claimed that five acres will furnish enough

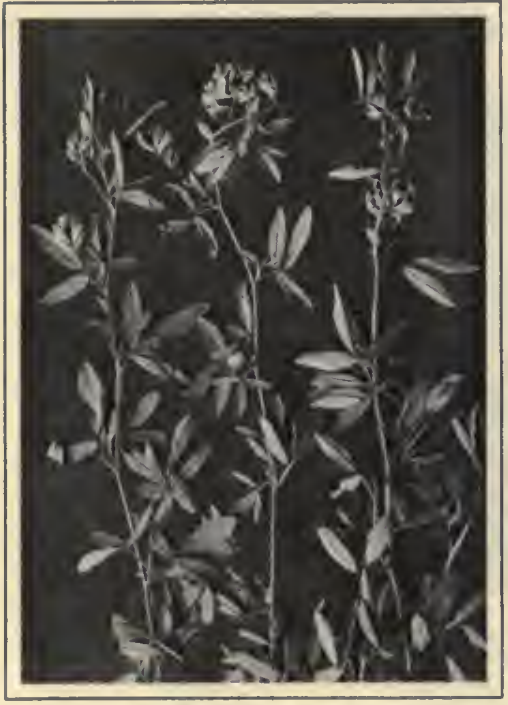

The Alfalfa Plant. green feed to sustain a herd of twenty cows from June to October, if only a little is cut at a time. As a pasture for fattening hogs, little more can be desired than a flourishing alfalfa stand. Alfalfa hay, weight for weight, contains as much nutrition for milk cows as bran does.

The plant is a deep feeder : its roots extend far into the subsoil and bring thence to the surface some potash and phosphoric acid. This improves the soil. An alfalfa field is commonly cropped three times a season, and sometimes four crops in a season are taken. The plant, too, is a perenuial.

Alfalfa, being a legume, to which family also belong the clovers, beans, peas, and vetch, is, like the other members of the family, a nitrogen gatherer. The free nitrogen of the air is combined with the oxygen of the air and earthy matters of the soil to form nitrates, which are tissue-building plant foods. The factory where this transformation 
takes place is in the little nodules or swellings on the roots. The agents which work the transformation are bacteria. These bacteria form with the legumes a close, mutually helpful relationship called symbiosis.

210. Clover. - Four kinds of clovers demand notice, - the red, the crimson, the white, and the alsike.

a. Red clover can be

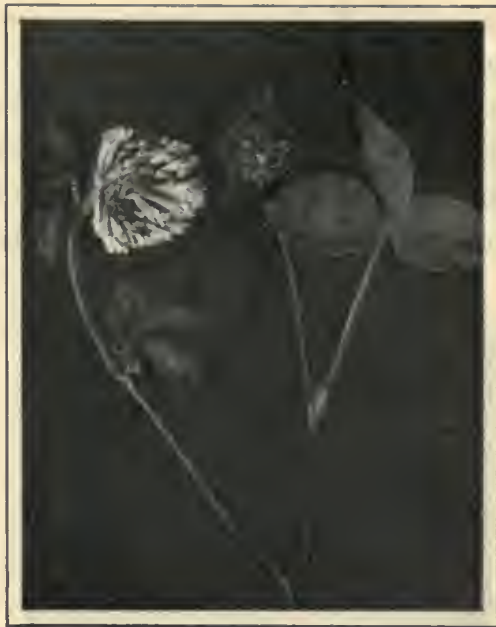

Red Clover. recognized by a pale spot on the face of the leaflets. Two kinds of red clovers are grown, the "medium" and the "mammoth." As a rule, "red clover" means the "medium red." In the eastern part of the United

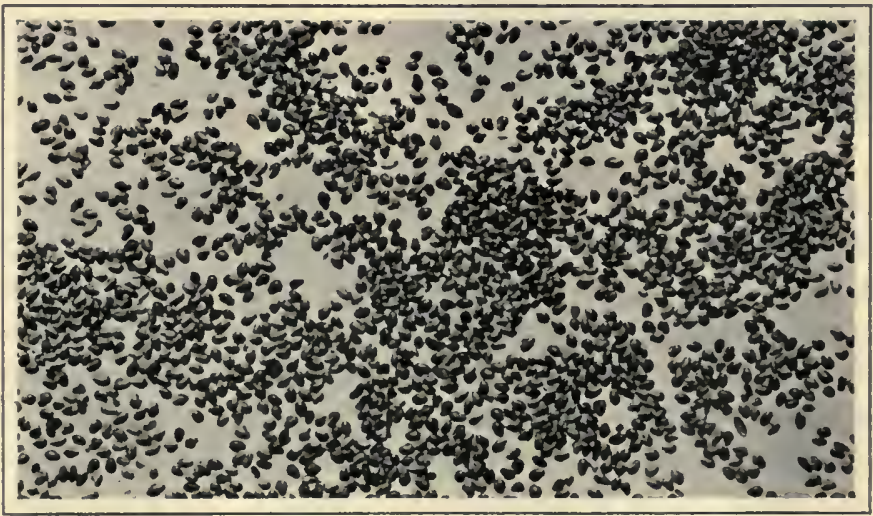

Red Clover Seed. Natural Size. 
States, red clover ranks next to timothy as a hay erop. It is sown broadcast in early spring on winter wheat or rye. Timothy, perluaps, has been seeded in with the grain. The elover and timotlyy get a good start in the fall, after the grain has been removed, and the next year there should be two good hay crops. The second of these, even if timothy

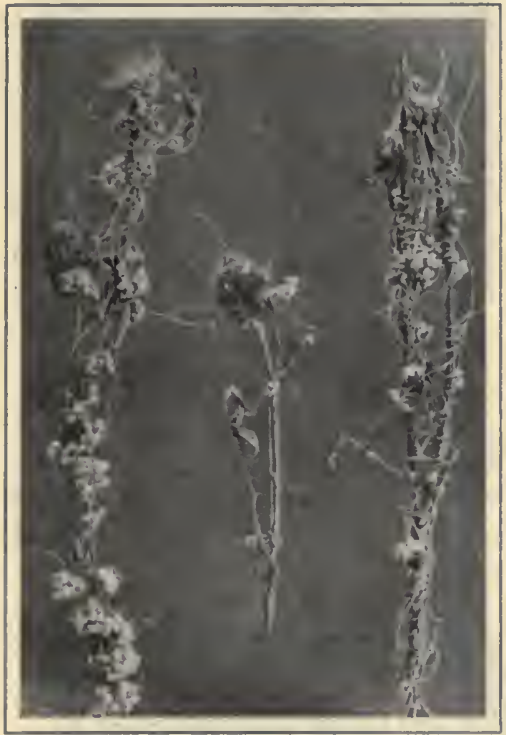

Dodder, a Parasite on Clover. also was sown, will be wholly elover. If the field remain "in hay" another year, the red clover will have run out - unless the second erop of the year before is allowed to seed itself back on the land. 'The timothy, however, will have thiekened, to take its plaee. In many dairy distriets a large part of the elover is raised without any admixture of timothy, because clover hay is preferable for dairy eattle. In city markets, pu, timothy brings the highest price, and the timothy and clover mixture is in high favor. The beneficial effect of clover upon the soil has been noted in Chapter VIII.

b. Crimson clover is an annual and a native of Europe. Its heads are long and crimson. Farmers usually sow it in orehards and with corn to enrich the soil.

c. White clover produces white flowers ; it is a perennial, living more than two years. It is a low-growing plant, 
of no value for hay purposes, although for pasture it takes high rank.

d. Alsike clover thrives well even on soil slightly acid, and is little subject to diseases. The flowers are rose-tinged. It thrives evell on wet soils where it is impossible to get a stand of red elover. Alsike grows later than red clover, and usually gives only one crop in a season. It is a perenuial, however; and in feeding value for dairy cows, weight for weight, it excels red clover by about one sixth, ranking about halfway between that plant and alfalfa. It is much easier to cure than red clover, and the stems are less woody. In many sections it is steadily growing in favor.

\section{Soiling Crops.}

The term soiling crops has been explained a little above. 'The word "soiling" in this phrase does not refer to the

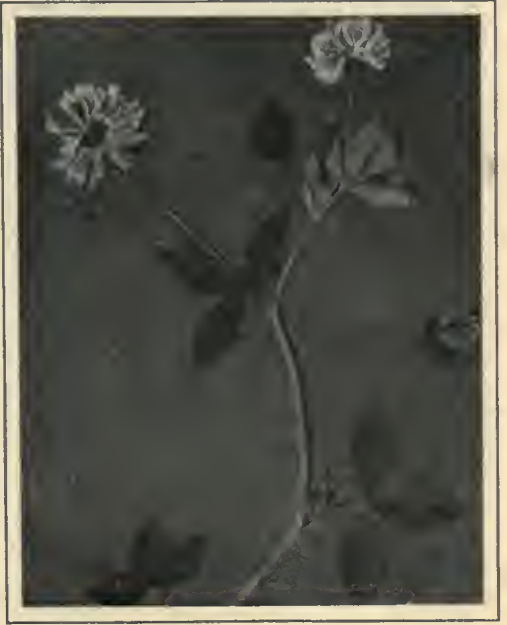

Alsike Clover.

soil, as wa commonly use the word. During the dry summer months, pasturage is likely to be poor, and flies torment the cattle. When these conditions begin, the milk flow falls off quickly. To prevent such loss, the dairyman needs to keep his cattle in the barns, during much of the day time, at least. He cannot well depend upon hay and dry feed for them, however, when they have just been on grass. So he needs soiling crops.

The dry season varies somewhat from year to year; and 


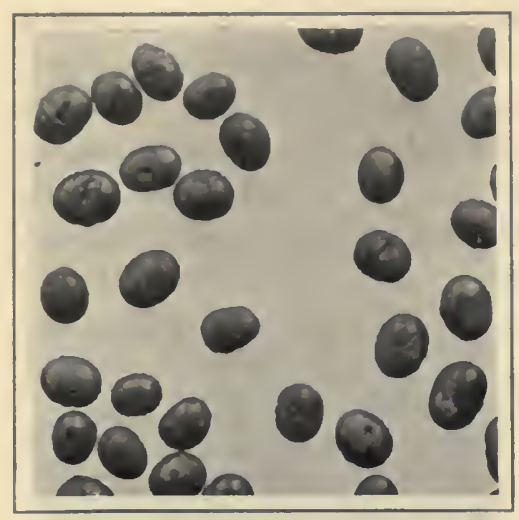

Sor BEANS.

Natural size.

the wise dairyman prepares for such variation by growing a series of different soiling crops. Oats, corn, cow peas, soy beans, clover, vetch are all suitable; and two or three of them may be planted in such order as to provide green forage through the dry period. Millet is often sown for this purpose in May, and is ready to use for soiling in six weeks. Rye, planted in the fall, may be used the following summer even earlier than millet. When any part of these crops is not needed for soiling, it can always be cured for hay, or, if a grain crop, it may be allowed to mature for harvest.

212. Silage - Fresh forage is better than dry for producing both milk and beef. Soiling crops, we have seen, provide fresh forage during the grass-growing season. Silage provides it during the rest of the year; and even for July and August a summer silo on many farms now takes the place of soiling.

A green crop is made into silage by being cut fine and then packed "way in a "silo." Silos are built of wood staves, of brick, of cement,

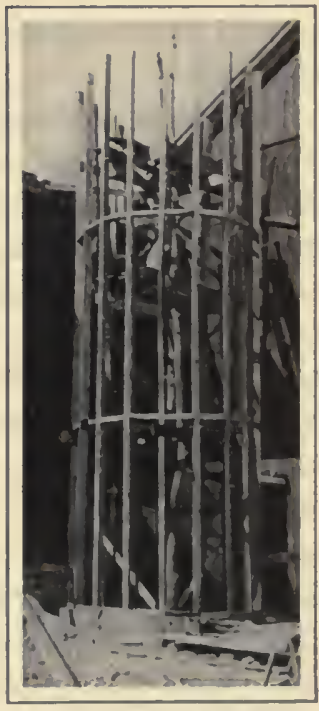

Building a Cheap Silo. 
or of clay tiles or blocks. The important points are that the walls be air-tight, and smooth on the inside, and, in cold climates, that they keep the silage from freezing unduly. The inside surface of the wall must be smooth, and free from needless corners, so that the silage can be packed without leaving air spaces in it. A layer of the silage at the top will spoil, from air contact, unless the farmer begins to use it as soon as it is stored ${ }^{1}$; and, after use begins, about two inches of depth must be fed each day, to prevent too long a contact of any part with air.

The principle of silage making, then, is that of "canning" the green forage with all its juices in it. The bacteria already 'in the substance, however, are not killed

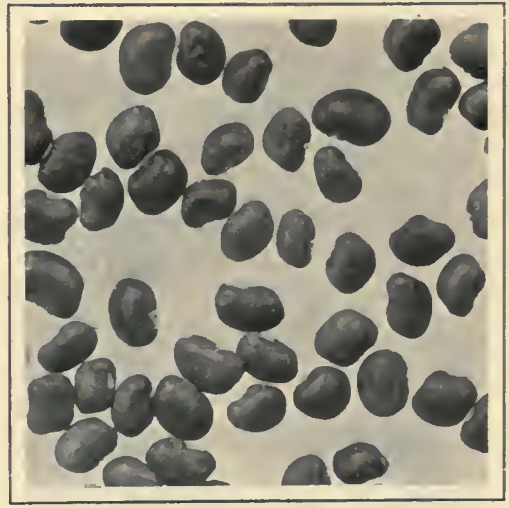

Cow PEas.

Natural size. by heat, as in most canning of vegetables. ${ }^{2}$ Sourness or acidity is produced by cellular respiration which continues until all the free oxygen is exhausted. The acids so produced protect the ensilage from harmful bacteria. The sourness is neither objectionable to cattle nor harmful to them. If air reaches the silage, however, so that molds form, it is unfit for any animal, and sometimes fatal to horses.

1 This spoiled top layer - a foot or so in depth - will protect the silage below for a long time. Sometimes, too, if the silage is not to be used for some months, the farmer wets the top and sows oats or barley upon it. The thick green growth that results effectually "seals" the silo top.

2 Some vegetables, like rhubarb, can be canned without heat. 
Almost any juicy green erop may be turned into silage. Clover, cow peas, vetch, and even clean beet tops, are often used. The best silage, however, is made from corn. Only a few years ago eorn silage was usually made from immature "fodder" corn, grown thickly in the drills, with only nubbins for ears. But experiments have proved that a large part of the food value is lost if the corn is cut much before it is ripe. 'The approved practice now is to sow in

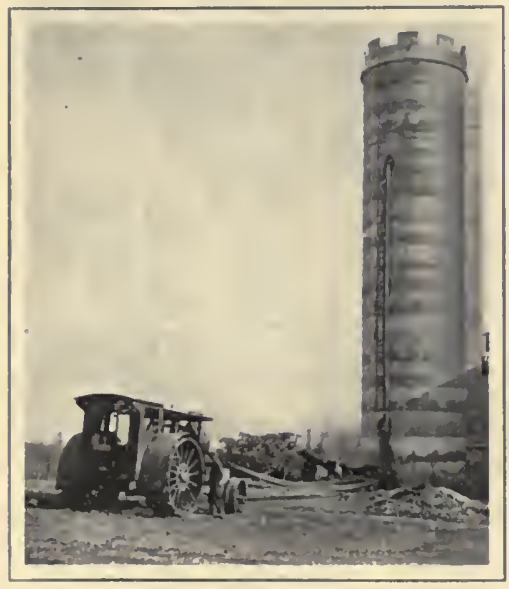

A Cement Silo. such a way as to develop a fair proportion of ears, and to cut the crop only a week or so, at most, sooner than if it were being eut for grain. Corn silage made in this way is not only much higher in food value than the older sort, but it is also less likely to spoil, and it is almost wholly free froin the odor that has in the past been associated with silage feeding. This is because the sugar of the sap has had time to turn into starch. In less mature corn the sugar ferments the silage.

A silo "entter," driven by an engine, receives the corn bundles from the field, cuts stalks and ears rapidly into half-inch or quarter-inch pieces, and elevates these shreds, by a carrier or a "blower," ten, twenty, thirty, or even sixty feet, to the top of the silo. As the corn falls within the silo it is trodden down or in some other way packed thoroughly by two or more men.

The total cost of a ton of corn silage (including all fac- 
tors, like land rent and interest on cost of silo) should be under $\$ 4$. At a much higher figure it would still be the cheapest winter forage for dairymen. With good corn - silage (made from ripe corn, ears and all), and with good clover or alfalfa hay, milk cows can go through the winter profitably with little more grain than when on pasture and with about as high a flow of milk. No dairy farmer with as many as ten cows can afford to be without a silo.

\section{Practical. Questions}

1. Define forage. 2. In what way does forage differ from table vegetables? 3. What are the characteristics of a good pasture? 4. What is hay? 5. Why is timothy a valuable hay plant? 6. State some of the reasons why some farmers fail to obtain a good stand of alfalfa. 7. Why is alfalfa a valuable crop? 8. Describe three clover plants. 9. For what purpose are soiling crops used? 10. What is silage? 11. What is the relation of silage to soiling?

\section{Hone Exercises}

1. How many tons of forage are raised on your home farm? Is its market value equal to that of the grains?

2. Since roots are just as important to plauts as stems, and since roots grow in the ground out of sight and for this reason are less known than stems, roots of the common forage plauts should be carefully dug up in order to study their main peculiarities. Do you notice any difference between the roots of the clovers and those of the timothy? On which are swellings found? Make a sketch of these roots and bring it to school.

3. Test your father's seeds for germination according to the method given for garden seeds. Report.

4. Collect specimens of all the insect and fungus enemies to the forage plants. Bring the specimens along to school and send samples of them to your Experiment Station for identification and for best methods of control.

\section{SugGestions}

1. Teachers should study local conditions carefully before home exercises are assigned to the pupils. 'This of course applies to all home exercises. In educational work the home has been too often neglected 
as a center of educational activities. A tendency may arise, however, to expect certain work to be done at home which can be done better in school. It is better, for some pupil, or the teacher, to bring to school specimens of the alfalfa plants for study as a class exercise than to have the pupils study the plant at home. The pupils are all together in the class, and the teacher is present to instruct and to inspire them.

2. Pupils should be tanght to draw, measure, and describe accurately such plant material. It is better to get a little definite first-hand knowledge of a few things than a smattering knowledge of many things obtained through the eyes of other people.

3. Take the class into a neighboring field in which leguminous plants are growing. Dig up a specimen of alfalfa, clover, or beans. Show the tubercles or nodules on the roots and explain their function.

4. Sprout about a dozen alfalfa seeds in a Pasteur dish or by some other method. When the roots are an inch long insert them into the meshes of a piece of fly-netting and allow them to hang in the water of a wide mouth bottle. Add a few drops of phenolphthalein to the water and enough weak limewater to give the solution in the bottle a marked reddish tint. Examine in a few days. Does the color of the water fade out? Explain.

Sprouting seedlings of any kind thrown into a weak solution of limewater, colored red with phenolphthalein, will decolorize the water in a short time. This is a most striking experiment to prove that roots in activity throw off acids.

\section{REFERENCES}

Farm Grasses of the United States. Spillman. Forage and Fiber Crops in America. T. F. Hunt. Farmers' Bulletins. Washington, 1). C.

66. Meadows and Pastures.

72. Cattle and Ranges of the Soutliwest.

237. Lime and Clover.

278. Leguminous Crops for Green Manuring.

318. Cow Peas.

339. Alfalfa.

372. Soy Beans.

458. The Best Two Sweet Sorghums for Forage.

578. The Making and Feeding of Silage.

485. Sweet Clover.

508. Market Hay. 


\section{CHAPTER XXII}

\section{WEEDS}

An ill weed grows apace. - CHAPMAN.

213. What plants are weeds? Weeds have been called "plants out of place." It is true that the vilest weed may be of some use in the right place. Beside the edge of a torrent a Canada thistle may check the cutting away of the soil by the stream. On the other hand, a wheat plant may be as troublesome in a potato patch as mustard would be. Most plants, however, that bother a farmer are plants that are never, or hardly ever, cultivated by man. Some of them perhaps are "only plants whose use has not yet

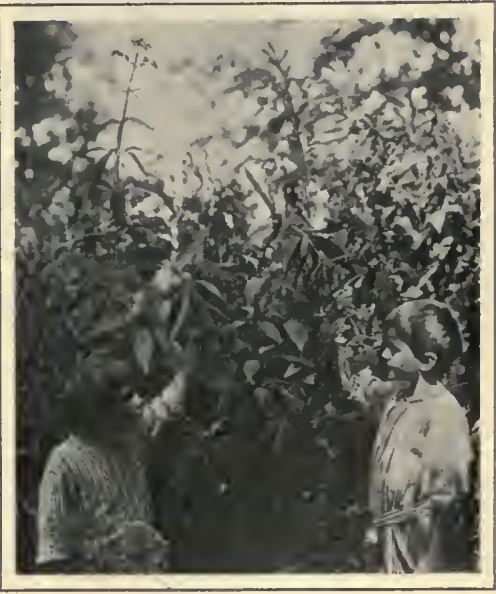

Joe Pye Weeds.

A perennial common in wet places. been found." But for practical purposes, weeds may be defined as useless plants that interfere with regular crops. 214. Like useful plants, weeds are annuals, biennials, or perennials.

(a) Annuals grow from seed only. The seed germinates 291 
in the spring and dies the same season. Familiar examples are: dodder, pigweed, bindweed (wild morning glory), wild mustard, ragweed, Russian thistle, shepherd's purse.

(b) Biennials in the first season produce only a short stem, leaves, and a thick root. From this root, in the seeond year, the plant sloots up, flowers, prorluees seeds, and then dies. The eommon thistle, dandelion, moth

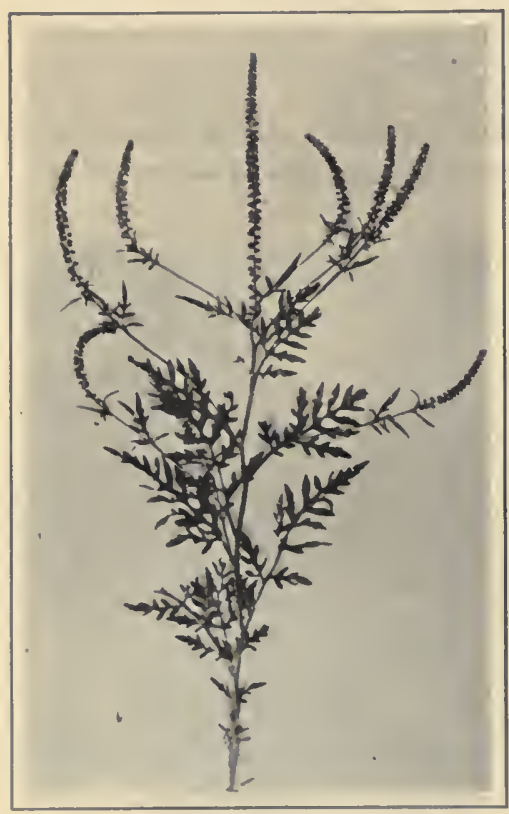

RAGWEED. mullein, teasel, carrot, and wild parsnip are biennials.

c. Perennials live on from year to year, the underground part surviving the winter. "Live-forever," Canada thistle, quack grass, Johnson grass, plantain, oxeye daisy, sorrel, and toadflax are common perennials.

A few plants may belong to two classes, aceording as the conditions are favorable for their growth. The dandelion, for instance, may be either a biennial or a perennial.

215. How to Get Rid of Weeds. - Two points must be borne in mind when one wishes to destroy a weed: First, to which of the three elasses does it belong, or how long does it live? Second, how does it reproduce and spread?

Annuals need only to be prevented from flowering and going to seed. Nature will kill them at the end of the 
season. If, however, a farmer wishes to destroy them earlier than their flowering time, he uses the same methods that are necessary for biennials. It is possible to get rid of annuals or biennials (1) by thorough tillage; (2) by cutting 'and pulling; (3) by using chemicals; (4) by rotation of crops; or by combining two or more of these methods.

To rid the farm of perennial weeds, the most approved methods are: (1) thorough tillage; (2) rotation of crops; (3) using chemicals; (4) summer fallowing; (5) using a smothering crop.

Tillage and erop rotation were mentioned in Chapter $\mathrm{V}$ as means of destroying weeds. The cutting and pulling methods are used when weeds are few in number, or are seattered here and there along fences and

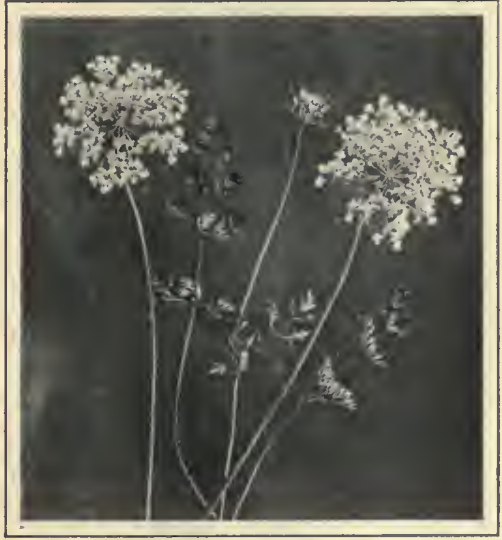

WILD CARROT. roadsides. If the flowers are mature, however, there is often sufficient vitality left to ripen the seeds, even after the plant has been cut or pulled. Therefore weeds in flower had better be burned.

If annuals and biennials have spread thickly and widely over an entire field, tillage and crop rotation are the best means of eradicating them.

Some plants, like wild mustard, when growing among oats or potatoes, may be killed by an iron sulphate spray. The ehemical kills the weed but does not harm the oats or potatoes. The 100-12-50 formula is used; that is, 
100 pounds of iron sulphate and 12 pounds of bluestone are dissolved in 50 gallons of water. The liquid is then applied thoroughly to the weeds by a field sprayer.

Common salt, gasolene, or earbolic acid may be applied by hand to scattering perennials. A little on the root of

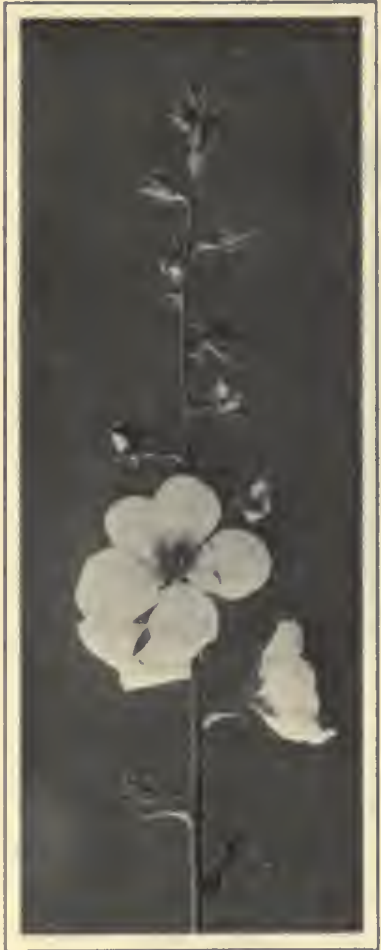

Moth Mullein. each plant after the top has been grubbed off is usually enough. This remedy, however, makes the soil less fertile for a year or two in the spots where it has been applied.

Summer fallowing means the cultivation of a field without a crop. The land must be kept bare by frequent and thorough cultivation. Then the underground parts of a plant are starved out because they are not allowed to send up stems and leaves to make starch.

Sometimes buckwheat is sown to smother perennials that are not easily subdued by other methods. Buckwheat itself has some weed characters. It resists drought, grows rapidly, thrives on poor soil, and tolerates shade.

Two particularly troublesome weeds we will discuss in detail.

216. The Canada Thistle may be regarded as the "Prince of Weeds." It came originally from Europe, where it is called "Creeping Thistle." It is a perennial, and each plant develops vigorous rootstocks from which there grow 
upward stems from one to three feet tall. The leaves are bright green above, white-woolly beneath; the edges are curved or wavy, deeply cut, and bear many sharp stiff spines; the flowers are rose-purple, about an inch long, and are armed with weak prickles.

The seeds are distributed chiefly by water (creeks, rivers, irrigation canals, etc.); by ship-

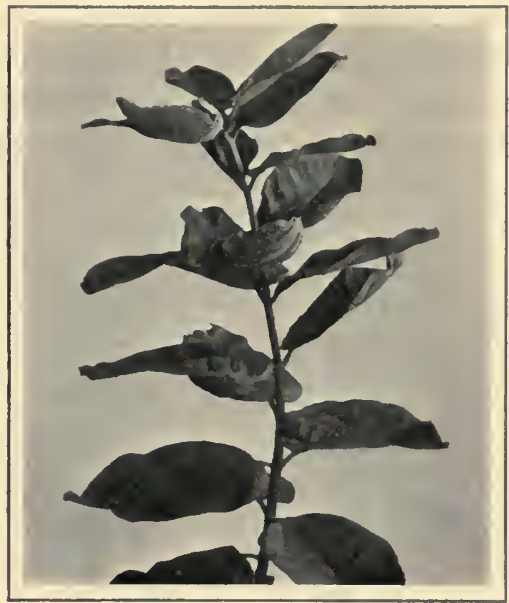

MiLKWEED. ments of hay, grain, clover, or grass seeds; and by the wind. They seldom ripen in cultivated fields, because they

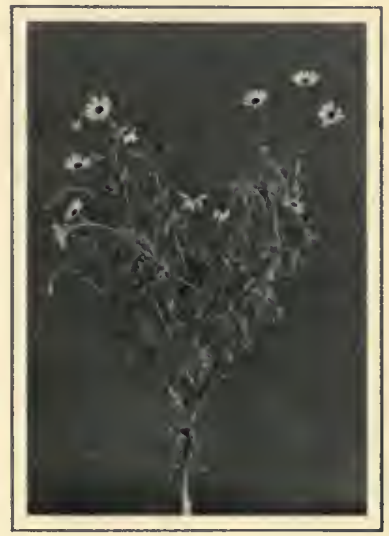

FENNEL. mature late; but along the roadsides, and in pastures and vacant lots, where they can acquire energy enough, a considerable number of seeds are produced. Moreover, the plant spreads in another way. In cultivation, the implements of tillage tear up the roots and spread them over the field, and then these rootstocks or underground stems reëstablish themselves where they have been left to lie.

The most effective remedies for the Canada Thistle are as follows :

(a) On large areas, late plowing in the fall, without 
harrowing, exposes the rootstocks to the winter frost. This will kill most of them. There should follow in the spring, cultivation thorough enough to keep leaves from appearing above the ground. Without leaves (the breath-

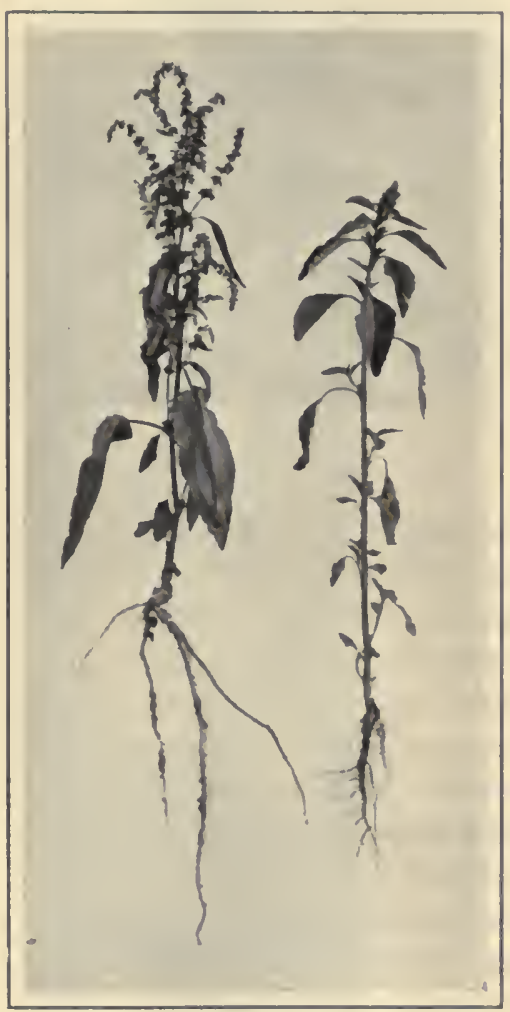

Two Kinds OF PIGWEed. ing organs) the roots must soon die. In the summer, hemp, millet,

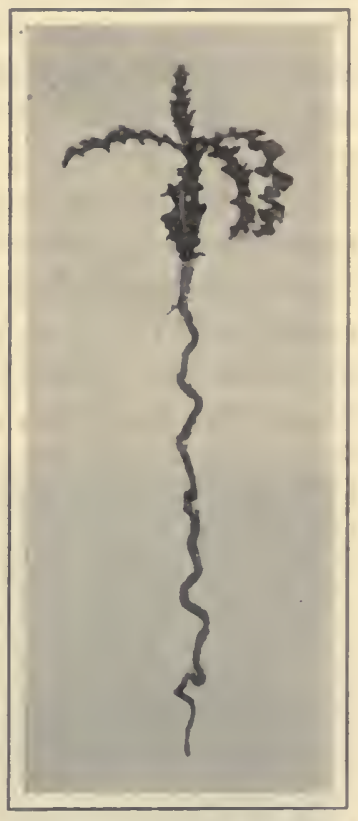

Canada Thistle.

Note length of rootstock.

or buckwheat may be sown as a smothering crop to complete the eradication.

b. Scattered plants, or small patches, may be covered with tar paper or other heavy paper. The paper excludes the sunlight. Or the plants may be kept cut close with 
a hoe. After cutting, it is well to apply a handful of salt, or a pint of strong brine, to each root. Gasolene and carbolic acid are good substitutes for salt.

217. Quack grass is also a perennial. It may grow as high as five feet. Its roots are botanically fibrous rootstocks. Its leaves are rough above and smooth below. The plant ripens its seeds in July. If mowed and taken in with the hay, the seeds may reach the manure pile, to be scattered later over the farm. Quack grass seed is fairly common in the seeds of clover, timothy, and alfalfa. It may also be blown about by the wind.

When once established, a small patch spreads rapidly, not merely by the seeds, but even more by the long, thick, many-jointed, white rootstock, each joint of which sends up a new plant. Ordinary tillage merely scatters

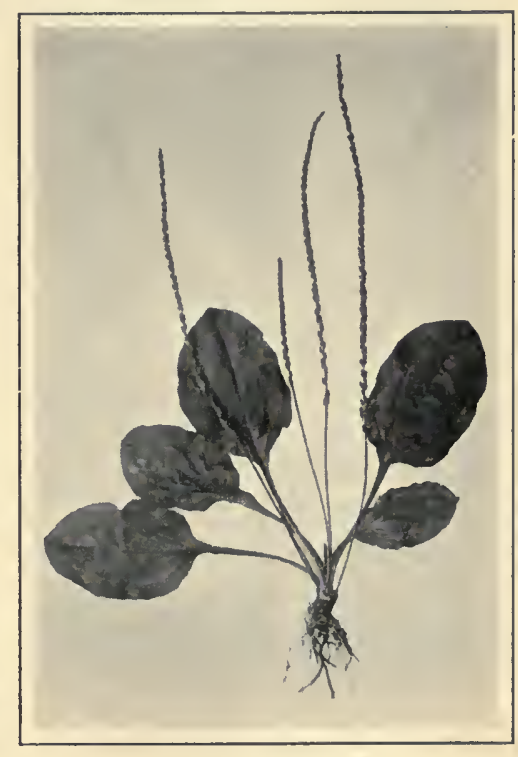

Plantain.

and multiplies these roots, even more rapidly than it does those of the Canada Thistle.

For both these pests prevention is better than cure. Every precaution should be taken to prevent the presence of seed; and if small patches of the plant appear, they should be destroyed at once by some of the methods described under the treatment of the Thistle. For Quack grass, on a large scale, such methods are especially diffi- 
cult and costly; and there are many so-called "Quack grass farms" which have been made almost worthless by leaving this weed too long uncontrolled.

218. Coöperation in Weed Control. - A clean farm, some one has said, is as important as a clean conscience. One

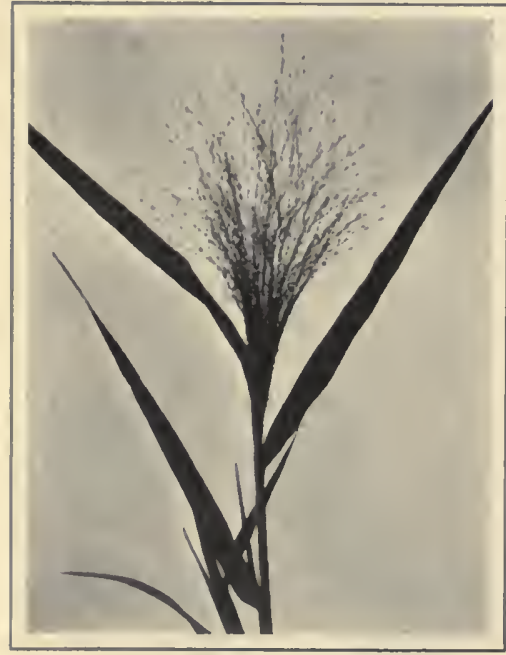

TUMBLE GRAsS.

So called because the top breaks off and blows about in the wind. abandoned or neglected farm may supply enough weeds to stock the neighborhood. The public highways, too, are often an annoyance to farmers who desire clean farms. Weed control provides an excellent opportunity to show community spirit. The task of eradicating weeds is sufficiently difficult when every one in the community works with a common purpose ; it is well-nigh impossible if a few of the farmers neglect or refuse to cooperate with their neighbors in this matter.

\section{Practical Questions}

1. In what sense are weeds a tax? 2. Define a weed. 3. May a weed have any good qualities? 4. Name the three great kinds of weeds, and give two illustrations of each. 5. Why is a perennial weed often harder to destroy than an annual or biennial ? 6. How can weeds be destroyed by tillage? 7 In what way may dandelion or plantain be eradicated from the yard? Explain how one plant can sinother another. 9. Describe the Canada Thistle. 10. Discuss the best methods of destroying it. 11. Is a "clean farm" as im- 
portant as a clean conscience? Can a farmer have the first without the second? 12. Why should farmers coöperate in weed control?

\section{Hone Exercises}

1. Ask your father for a description of all the different methods he uses to destroy his weeds. Which weed does he think is the worst one on his farm? Why is this weed so objectionable? How does it multiply, and how do you think it can best be controlled?

2. Write a short account on "How I kept my Plot Free from Weeds."

\section{SugGestions}

1. Pupils should be asked to bring to school a few of the worst weeds on the farm. It is no discredit if the teacher does not know the names of all of them. There are over 200,000 different kinds of plants known, and no one can recognize them all. A good plan would be to send those plants whose correct names are not known in the community to the State College, for identification and

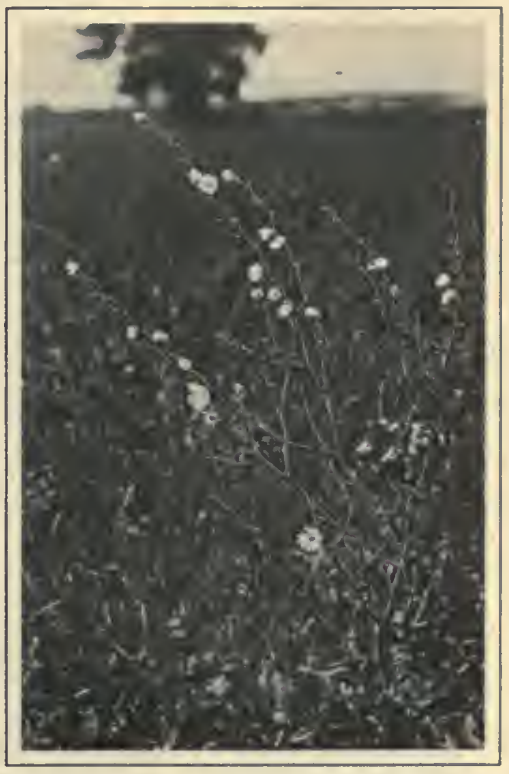

ChICORY IN OATS. for special information on how to get rid of them.

2. There should be some practical work done in the eradication of weeds. The effectiveness of the various methods outlined in this chapter can be demonstrated on common weeds by the teacher.

\section{REFERENCES}

Weeds and How to Eradicate them. F. Shaw.

Farmers' Bulletins. Washington, D.C.

28. Weeds, and How to Kill Them.

464. The Eradication of Quack-grass.

545. Controlling Canada Thistles. 


\section{CHAPTER XXIII}

\section{THE OROHARD}

Come, let us plant the apple tree

Cleave the tough greensward with the spade;

Wide let its hollow bed be made:

There gently lay the roots, and there

Sift the dark mould with kindly care. - BRYANT.

219. The Farm Orchard. - An orchard is a piece of ground especially devoted to the growth of fruit trees, sueh as the apple, plum, cherry, pear, and peach. Nut-bearing trees,

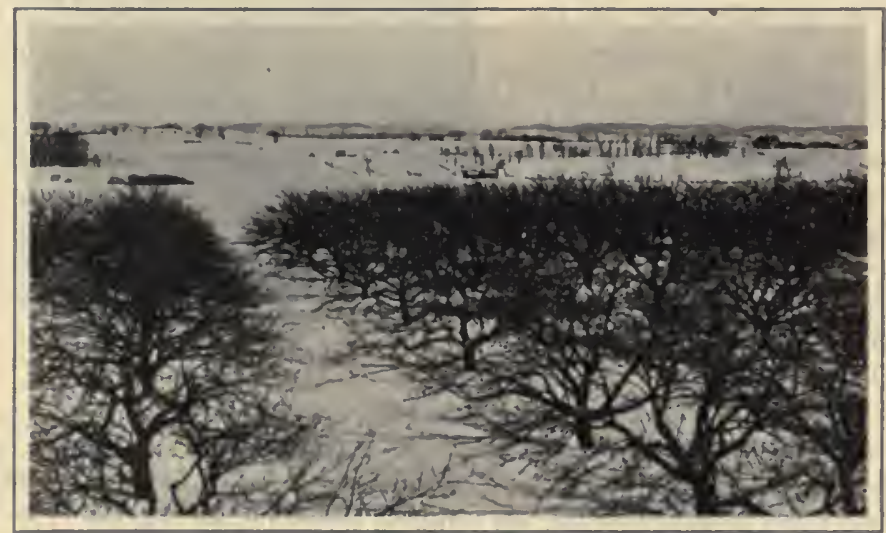

APPLE ORCHARD IN WINTER.

like the ehestnut and the shellbark, form groves, not orehards.

Almost every farmer has an orchard. It may be small, designed to meet the needs of the family only; or it may 
be a "commercial" orchard, covering many acres and occupying the greater part of the owner's time.

Fruit trees become adapted to a wide range of conditions of soil and climate. Consequently, several varieties are grown with some success in nearly every part of the United States. And since fresh fruit is a pleasant and

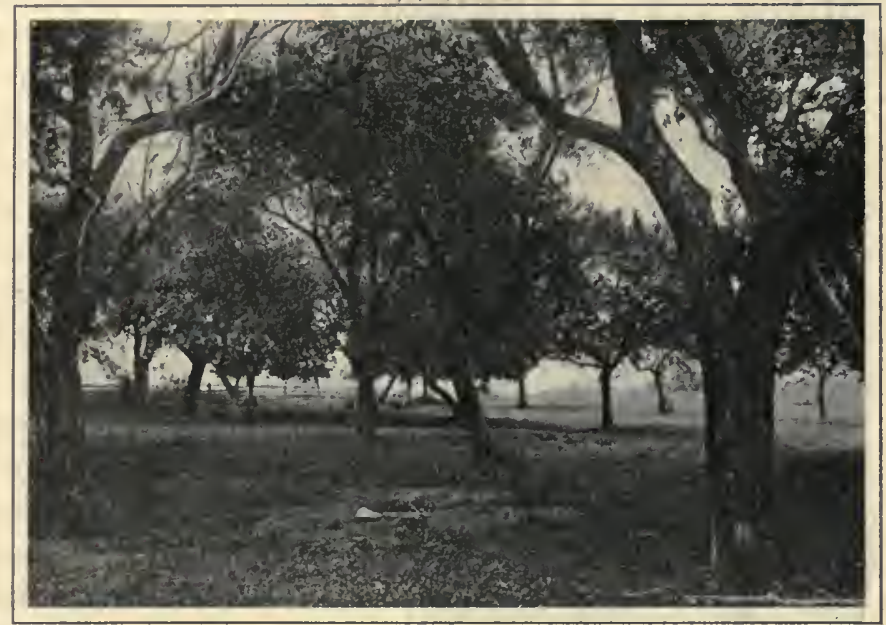

AN Old ORChaRd.

healthy food, and is a good money crop, its production is increasing. See Appendix A, Chart VII, page 470.

220. Selecting a Site for an 0rchard. - In a level country, it is desirable to locate the orchard to the north of the farm buildings, if possible, so that it can also serve as a windbreak. In a mountainous region, however, where slopes and different types of soils are to be considered, the orchard site cannot be so readily determined. If possible; the orchard should slope to the north. This is particularly true of a peach orchard. On a south slope, fruit trees start to bud too early in the spring, and may suffer from 
late frosts. The greater cold of a northern exposure may retard blossoming until the danger of spring frost is past.

Elevated sites, too, are desirable, in order to secure cold-air drainage. Cold air is heavier than warm air, and so drains down into the valleys, foreing the warmer air up the slopes. There is often suffieient difference in temper-

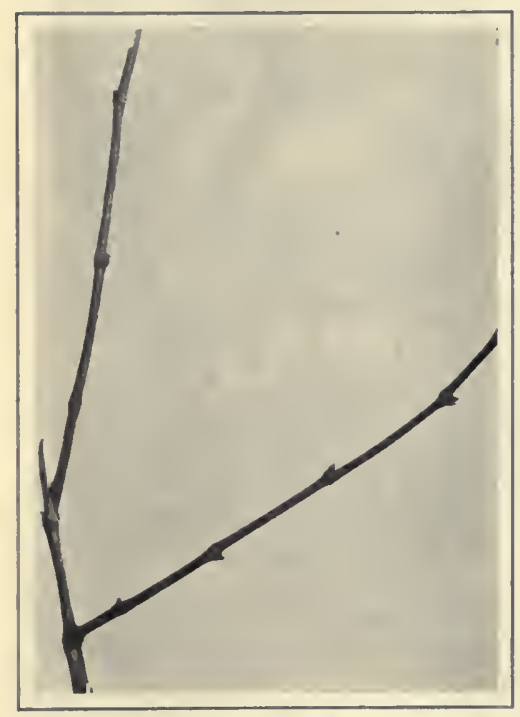

Grape Twigs. ature between the air in a valley and that on a neighboring hill to account for the loss of an entire fruit crop. In the valley, the blossoms may be ruined by a late frost that does not reach those on the lill.

Elevated sites provide also for water drainage. Water drainage is desirable, espeeially for stone fruits, like plums and peaches, which require a well drained and light sandy, or even a stony, loam. Apples and pears thrive best on moist elay loam, but even these fruits respond favorably to the benefits of water drainage.

221. How to Secure Stock. - Chapter XII has described the art and prineiples of propagation. Some fruit-growers propagate their own stock in the manner indicated in that chapter. A larger number, however, buy their stock outright from reliable nurserymen, beeause they find the latter method more satisfactory and economical for their 
needs. ${ }^{1}$ The transfer of stock from the nursery bed to the orchard should mean the least possible change in its environment. Other considerations being equal, then, local nurseries can give better satisfaction than those at a distance.

222. Planting. - Directions for planting usually accompany the shipments. These should be followed. In general, the young trees are planted in rows, for convenience in cultivation afterward. The trees in each row should be about as far apart as the rows are from one another. There is a general tendency to plant fruit trees too close together. This permits the branches to interlock when the trees are

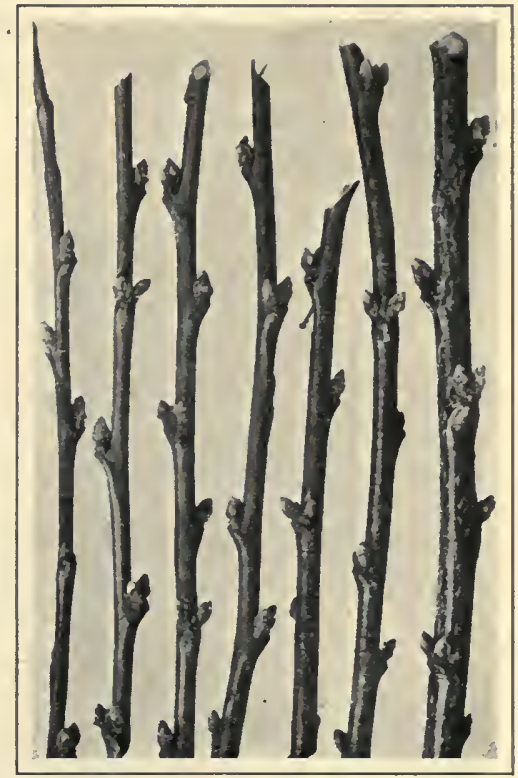

PEACH TWIGS. mature, and it also makes spraying difficult. The following distances are suggested:

$\begin{array}{lll}\text { Apples . . . . } 40 \text { feet } & \text { Pears . . . . } 28 \text { feet } \\ \text { Dwarf apples . . } 15 \text { feet } & \text { Dwarf pears . . . } 20 \text { feet } \\ \text { Quinces . . . . } 16 \text { feet } & \text { Peaches . . . . } 20 \text { feet } \\ \text { Plums . . . . } 20 \text { feet } & \text { Apricots . . . . } 25 \text { feet } \\ \text { Sweet cherries . . } 30 \text { feet } & \text { Sour cherries . . } 20 \text { feet }\end{array}$

1 Such purchases should be made direct from the nursery, even if by mail. Says Waugh, "It should be preached everywhere as a part of the gospel of horticulture, that nobody should ever patronize the traveling fruit-tree agent on any account." The traveling agent is likely to be a representative of an 
A rich, fine loam, not manure, should be carefully worked around the roots in planting, and pressed down with the feet. On top a loose mulch of soil is needed to prevent the loss of soil water by evaporation.

223. Pruning. - After a tree has been planted it must be pruned, or eut back, unless this was done when it was

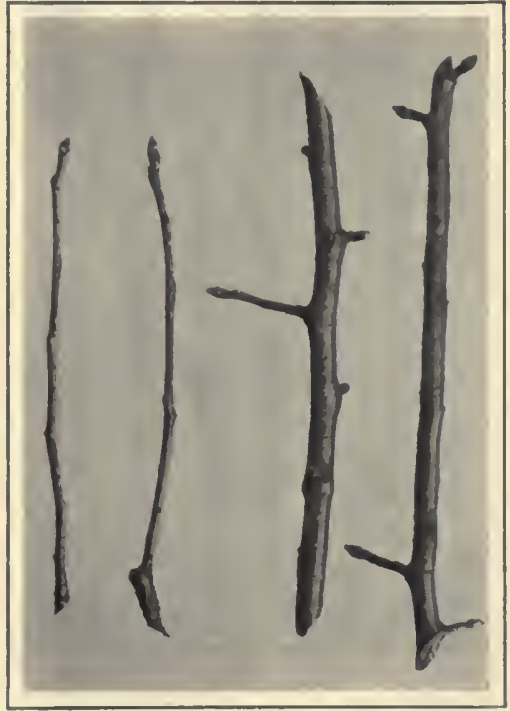

APPLE SHOOTS. taken up in the nursery. There is a natural balance between the root and the shoot of fruit trees before they are dug up in the nursery. By the time the young stock has been transplanted, possibly one half of the stem must be pruned away to balance the root loss.

The first pruning a young tree receives is particularly important. A few cuts may determine the form a tree will take for years. Fruit trees are expected to have a low-spreading habit. Two-year-old or threeyear-old apple or pear stock should be pruned to four or five small limbs, which are then each cut off at an outer bud, a foot from the main stem. The tree will then assume the low-spreading shape desired. Peaches had better be cut tọ a whip about 18 inches high.

Each succeeding spring, the shears should be used on

unreliable nursery, or perhaps a jobber or peddler who disposes of the culls that may have been bought up from firms of good standing. 
the growing trees, keeping them low and open in the middle, so that the sunlight and air can reach the fruit spurs, and so that the fruit will be encouraged to develop toward the base of the larger limbs where its weight will not break down the branches and injure the tree.

Early pruning serves to direct the growth; then there is no call afterward to correct it. Winter pruning stim-

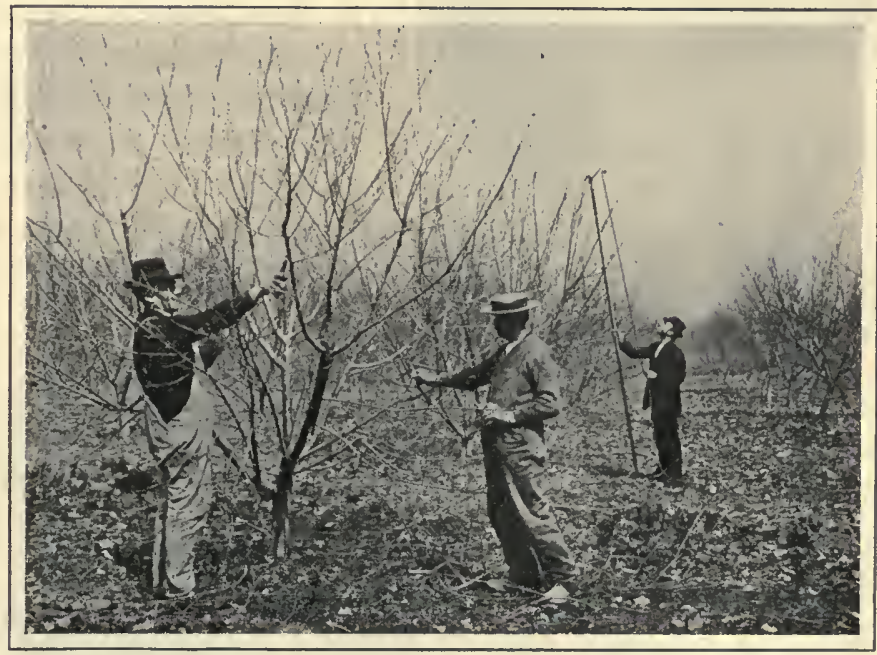

Pruning Peach Trees.

ulates wood growth, while summer pruning stimulates the development of the fruit.

If a branch thicker than one's wrist must be removed, it is best to paint the wound with plain white lead, to prevent the entrance of fungi. The paint is a good antiseptic. Care is necessary to see that the cut is smooth and near the main wood, so as not to leave a stub, otherwise the wound may not heal over. 


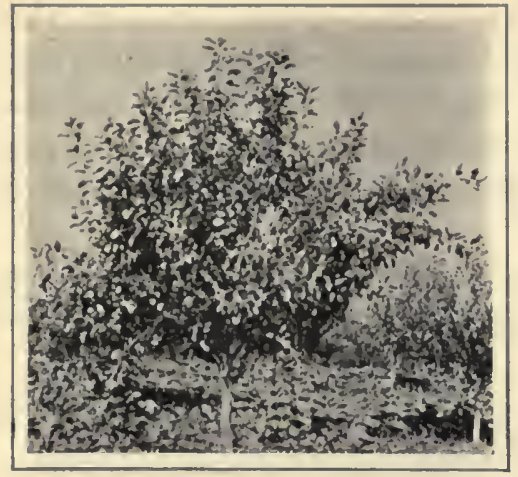

EARLY BEARER.

This apple tree is being injured by being allowed to bear too soon.

224. The management of an orchard includes the cultivating and the spraying of the trees, and the harvesting, storing, and marketing of the fruit.

Many orchards are left in grass, but cultivation is certainly the better practice, except on steep hillsides where sod may be continued for periods of a few years to avoid soil wash. The usual method of cultivation is to plow between the rows in the spring, and to harrow at intervals afterward to the middle of July. Between July 15 and August 1, cow. peas or crimson clover may be sown as cover crops. These grow during the late summer and fall, and are plowed under the following spring to enrich the soil.

The advantages of cover crops are three :

(1) They check undue wood growth, and so stimulate fruit development;

(2) They add humus and fertility to the soil;

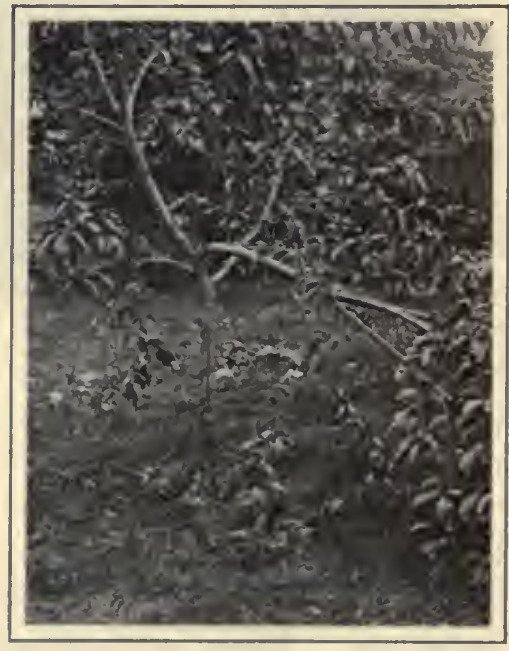

Broken CRotch.

The result of bad early pruning. 
(3) They prevent winter and spring erosion.

Spraying for the San José Scale, where this pest is present and unchecked by parasites, and for the codling moth, rots, and scabs is essential for the best yields of prime fruit. The preparation and use of sprays will be fully discussed in Chapter XXVI.

The harvesting and marketing of the fruit is very simple if it is sold locally; but when the more exacting tastes of distant markets are to be catered to, the problems multiply. Prime fruit must be picked carefully by hand, not shaken from the tree, or pulled or bruised in any way. When fruit is exposed for sale, it brings the best price if it appears neat, sound, attractively graded and packed.

Apples are packed either in boxes or barrels.

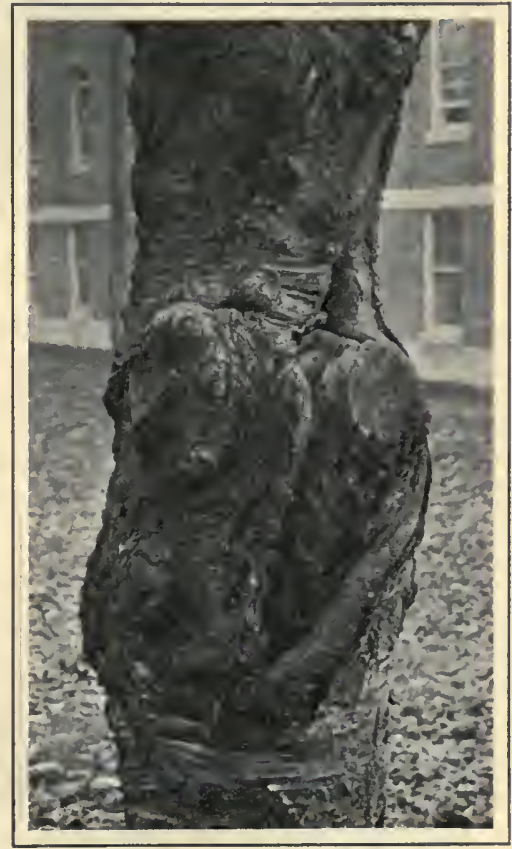

Good and Bad Pruning.

Congress has not fixed a standard size for the packing box as it has for the packing barrel. The usual inside dimensions of the box, however, are $10 \times 11 \times 20$ inches. As the apples are being packed they should be well shaken in order to give them a permanent place and to prevent bruising when handled in shipment. The upper layer is arranged by hand to form a level surface under the head of the barrel 
or box. Barrel or box, too, may well be lined inside with paper to prevent bruising. Apples that are to bring the best price are wrapped individually in soft paper and are

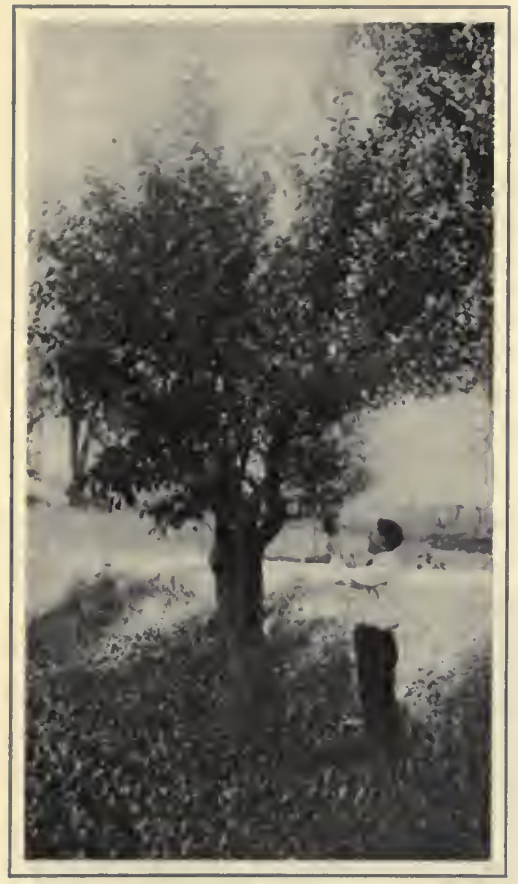

Demorned Apple Tree. packed as evenly and carefully in all the other layers as in the top one.

Our space permits only a few words about each of the common fruits.

225. The Apple. - The Indians never saw an apple until they were shown one by the settlers. There were little wild apples in America, to be sure; but these were so bitter and useless when compared with the "King of Fruits" that only by a generous courtesy do we call them "apples" at all. Today, however, North America leads the world in apple production. More than 100,000,000 barrels are produced here annually. Over 1,000,000 barrels were exported in 1908 .

"Johinny Appleseed" and his work in planting the apple in the Ohio Valley is as interesting at Daniel Boone and his experience in the dark lands of the frontier. "Johnny Appleseed" was a Pennsylvania school teacher whose pay was apple seeds, which the children gathered for him. His boat filled with these seeds, he would start down the Ohio, when spring came, and plant orchard after orchard 
on the open spaces on both sides of the river. When the first settlers blazed their way through the forests, these orchards awaited them. It is said that some of the trees so planted are still flourishing.

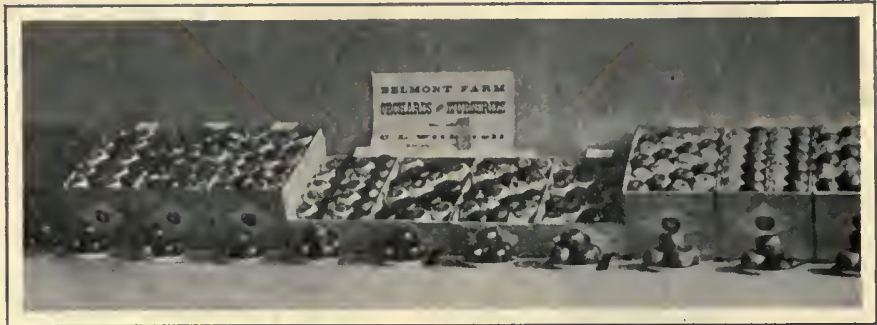

An Apple Show.

226. Pears are grown mostly in New England, in the Central States, and along the Pacific slope. Like apples, they are natives of the Old World, where they are still cultivated very extensively, especially in France and Germany. Some of the varieties successfully grown in the United

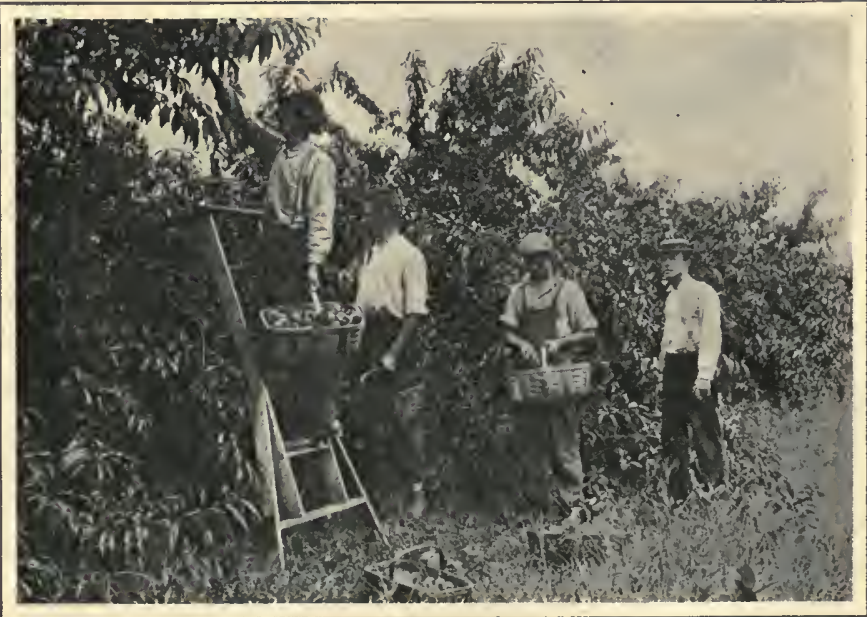

Harvesting Peaches. 
States are the Bartlett, Seckel, Anjou, Sheldon, and Kieffer.

227. Peaches. - Peach blossoms are very sensitive to frost. The hardiest varieties are the Grecusboro, Carmen, Belle of Georgia, and Elberta. The special enemy affeeting the peach is the peach tree borer. Its presence

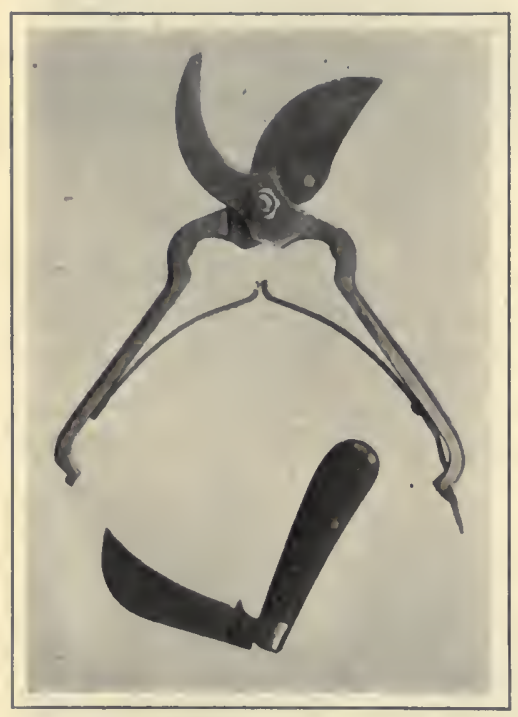

ORCHARD TOOLS. can readily be recognized by the gum and bits of wood exuding at the base of the tree or near the base. This pest can best be controlled by digging it out with a knife. The cuts should be made lengthwise along the burrow.

228. Plums. - A variety of plums introduced into Hungary from 'Turkistan about the year 1461, thence into Germany and France, and finally into Canada by the French colonists, is best adapted to drying. 'This is our most valuable plum, and is known as the prune. ${ }^{1}$ Our other most valuable plums are the Green Gage, Yellow Egg, Red June, Burbank, and Abundance.

229. Cherries are classed as sweet and sour. Sour cherries are the more hardy and more common. The favorite varieties of the sour cherries are the Morello, May Duke,

1 Other plums when dried are sometimes called by this name. 
and Richmond; and, of the sweet cherries, the Oxheart, Governor Wood, Black Tartarian, and Black Heart.

\section{Practical Questions}

1. What is an orchard? 2. Why do not fruit growers generally propagate their own stock? 3. For what reason should a farmer be cautious when buying young trees? 4. Discuss the location for an orchard. 5. What is the purpose of pruning trees? 6. State three uses of a cover crop in orchards. 7 . In what way are apples and peaches harvested and marketed in your community? 8 . Where did the apple originate? 9. Relate the story of "Johnny Appleseed."

\section{Hone Exercises}

1. Each member of the class should plant at least one fruit tree at home, after the proper methods as to planting and pruning have been demonstrated at school. This tree may not yield fruit until the pupil has left school, but a report should be made on its progress at the end of the course.

For practice it would be a good plan to start the tree from the seed, and graft or bud it according to the directions given in earlier chapters.

2. Make a fruit census of the home orchard, giving the number and varieties of different kinds of trees.

3. Draw an outline of your farm, and locate the orchard. Indicate by a cross the place occupied by each tree. Is your orchard located properly? Is it too large or too small? Do you have the best varieties of trees for market purposes? Does the home orchard pay?

4. Explain in detail the entire treatment your father gives his orchard.

\section{SugGestions}

1. Since apples can be brought to the school almost any time of the year, it would be helpful if the pupils would make a formal description of one or two common varieties. The scheme may be as follows:

Variety
Size..+
Shape, - oblong, oblate, flat, conic, etc.
General Color, - striped, splashed, regular, etc. 
Dots on Skin, - few, distinct, numerous, obscure, etc. . . . .

Cavity (the depression at stem), - abrupt, sloping, regular, etc. Eye (the blossom end), - shallow, wavy, deep, narrow, etc.

Flesh, - hard, buttery, granular, fine-grained, etc. .

Flavor, - sour, sweet, flat, etc.

Pupil's Name

School.

Date

This outline may be written on the board or on paper. The adjec. tives following each item are merely suggestive; others may apply.

2. A fruit tree should be planted by the teacher and class; that is, a practical demonstration of a few simple principles of planting, pruning, and spraying should be given on the school grounds.

\section{RefERENCES}

The American Apple Orchard. Waugh.

Progressive Fruit Culture. Sears.

The Apple. Wilkinson.

Principles of Fruil Growing. Bailey.

The Pruning Book. Bailey.

Farmers' Bulletins. Washington, D.C.

113. The Apple and How to Grow It.

134. Tree Planting on Rural School Grounds.

154. The Home Fruit Garden. Preparation and Care.

181. Pruning.

404. Irrigation of Orchards.

482. The Pear and how to Grow It.

491. The Profitable Management of the Sinall Apple Orchard on the General Farm. 


\title{
CHAPTER XXIV
}

\section{TIMBER TREES}

\author{
$A$ song to the oak, \\ The brave old oak, \\ Who hath ruled in the greenwood long! \\ Here's health and renown \\ To his broad, green crown \\ And his fifty arms so strong! - CHORLET.
}

230. Timber trees form a crop, as truly as wheat does. To be sure, this crop does not mature within a year or even within a decade of years; but as it grows it be-

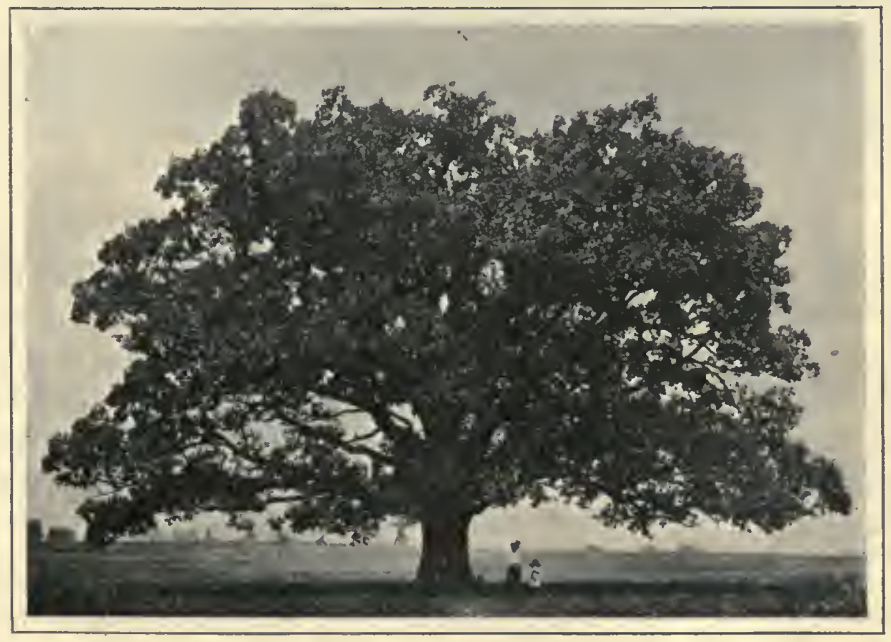

An OAK in an Open Field. 
comes a constantly increasing source of pleasure and profit. Unhappily, this crop is too little grown. Our wood lots are rapidly disappearing, while the demand for timber is increasing. Two and one half times as much timber is annually consumed in America as is grown here.

Trees will grow on hillsides and in rocky places that are unfit for general farming; and, if care is taken to cut

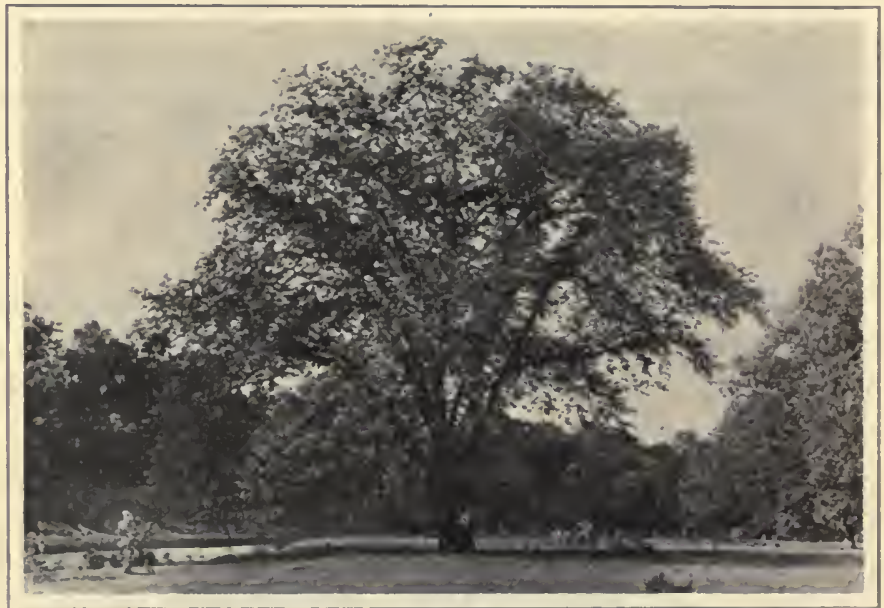

An Elm in an Open Field.

only "ripe" trees and to plant new ones to take the places of those eut, the wood lot on such a part of the farm may give higher returns for labor spent upon it than do the richest acres of the farm. Wood lots are valuable to farmers indirectly as well as directly; and both direct and indirect value varies with the size, composition, and location of the lot.

231. Direct Values. - Timber trees supply shingles, laths, posts, poles, fence rails, railroad ties, staves, barrel hoops, mine timber, firewood, pulp wood, distillation wood, and 
a long list of other articles that are needed on the farm or in the arts. Mr. Fernow, while Chief of the Division of Forestry, estimated that the net yearly income from an acre of ordinary mixed forest would range from $\$ 1$ to $\$ 3$ in the value of the wood products. If we consider how little attention is demanded, and the kind of land from which this income can be derived, it is easy to see that few other crops can show superior net results.

\section{Five indirect values} of timber cultivation may be explained briefly.

(a) Absorption and retention of water. The leaf mold and matted roots absorb and hold back the rainfall. This tends to prevent loss of soil by washing, and the filling up of streams by silt, and the consequent interference with navigation. Forests have little effect on the total amount of the rainfall.

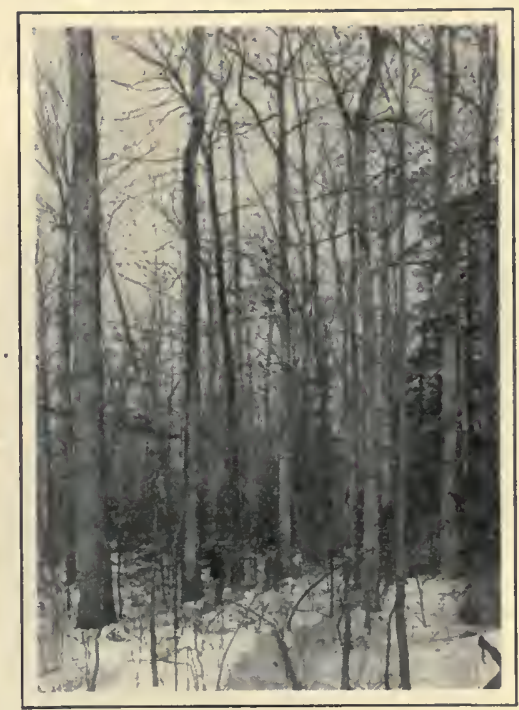

A Mixed Stand of Timber.

Contrast the shape of forest trees with that of trees in an open field.

They do, however, exert a marked influence on the availability of the rainfall for farm purposes. The leaves of trees, and the litter of twigs, branches, and mold in the soil, break the force of the raindrops; and for this reason the soil of the forest floor is not so compacted as a similar soil in the open. The water dripping from the branches, trunks, and leaves soaks into the loose, 
granular soil beneath, instead of draining off quickly into streams. The roots, too, form natural channels for the seepage or entrance of water into the soil. In the winter and spring, also, the forest cover prevents the snow from rapid melting and in this way enables the snow water to penetrate the soil instead of rumning away in destruetive freshets.

And water not only enters the forest soil more easily than that of the open; it likewise leaves the forest soil

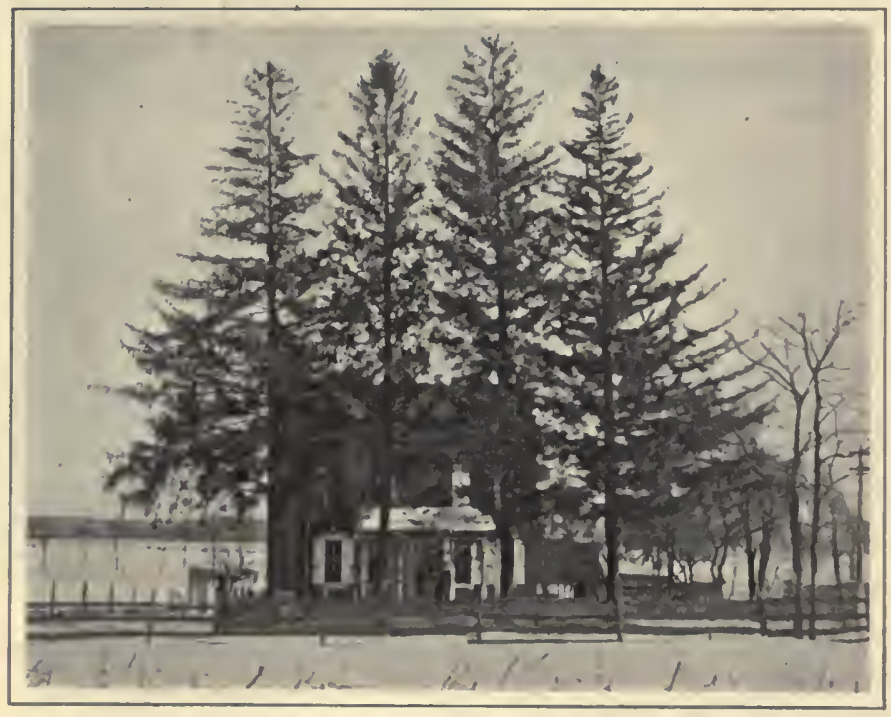

A WINDBREAK.

Show why this is not satisfactory.

more slowly. Evaporation is retarded by the protection afforded by the trees against wind and sunshine. It has been estimated that a wood lot may furnish 50 per cent more available water for springs and subsoil than an open field with the same rainfall. And the subsoil water, 
we know, is the water to be depended on in times of drought.

(b) Windbreaks. A wood lot of timber trees may serve the important purpose of breaking the force of the northern blasts not only for the farm buildings but also for tender crops in the field. Three rows of evergreen trees planted ten feet apart each way, alternated in the adjoining rows, are very satisfactory for this purpose. The outside row should consist of a fast growing variety, like the white pine; the tree of the middle row should be a medium grower, like the spruces. And in the inside row the slow growers (cedars or arbor vite) are very suitable.

(c) Trees help, not merely to shelter from the cold of winter, but

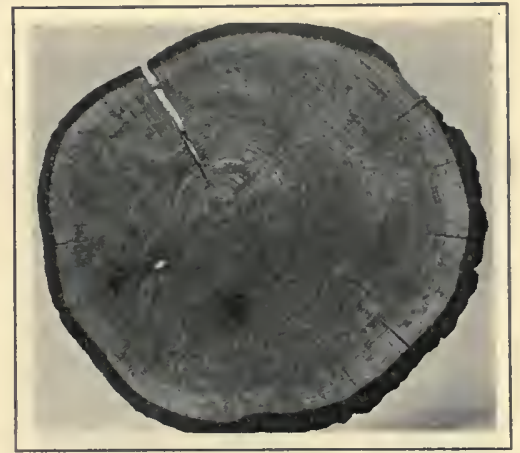

Cross Section of OAK. also, in some degree, to cool the heated air of summer. The evaporation of the vast amount of water from their leaves is a cooling process.

(d) Game animals and insect-eating birds find a natural home in a wood lot. Useful animals of this nature are killed or driven away from a community more by the ax or saw in felling trees than by the gun. Hunters have probably done less to decrease our wild life than have the woodmen.

Any farmer out of whose life there has gone the desire to hunt, fish, or ramble occasionally with boyish abandon, has lost a priceless joy that neither money, position, books, nor human companionship can replace. Wealthy people, 
in foreign countries, especially, buy extensive tracts of land to convert them into game preserves. In America, farmers as a rule have not appreciated the value of diversions and sports as a means of cultivating the manysidedness of their nature. They have assumed too much that happiness comes after wealth has been acquired rather than while it is being acquired.

Birds must have a place in which to build their homes and rear their broods. The erection of bird boxes is a

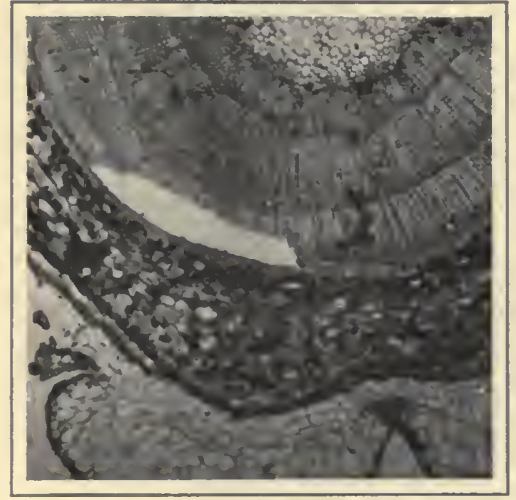

Cross Section of Norway Spruce. city attempt to coax certain birds to take up their abodes near man. In the country, bird boxes are a negligible factor, and will perhaps always remain so, for the reason that they do not attract many of the pest-destroying birds upon which the farmer must depend. Trees and shrubs are necessary in a farnı community to secure the services of the birds most desired.

(e) Rural gatherings. In every rural community there should be a grove suitable for large summer gatherings. A grove for this purpose is not needed on every farm. Nor need the grove belong to the public in order to be suited for public use. However, if the environs of the country church or school are of sufficient size, and are really attractive with shade and beanty, they are to be preferred to those that are private-owned. The presence and adaptability of some grove for rural gatherings is of primary importance : its ownership is of secondary importance. 
233. The Home Timber-tract. - Not many farmers are interested in timber to the extent of selling large quantities of it. Much of the valuable timber that covered our farm land has now been cut, so that there is but little to sell. The small patches that remain here and there, and which could readily be sold to the lumberman at a good price, are more valuable for home use. The small timber tract that is not a commercial venture, but which is designed primarily to meet the needs of the home for fuel and for timber, is appealing more and more to farmers. The starting of a wood lot on land which would be otherwise useless is not only good patriotism but also good business.

234. In the selection of the kinds of trees to plant, several general principles must be borne in mind. 'Trees that thrive well locally are to be preferred to those which may have superior qualities in other respects but which have not been proven to fit the soil and climate. Timber-trees have a wide range. 'That is, one kind of tree may be found growing wild over a considerable part of the country. But still certain combinations of climate, soil, and rainfall are most favorable for its best growth. This question of the adaptation of a particular species of tree to the environment to which its ancestors have been adapted for centuries, must be considered. A farmer desires not a fair oak, hickory, or pine merely, but one of superior merit, one that will reach the highest degree of development under the conditions of his own farm.

Another principle to consider is the uses which the wood is to serve. The home wood lot must serve the greatest possible number of purposes. Certain trees, like the locust, black walnut, wild black cherry, and catalpa lack the general usefulness of the white pine, hickory, tulip-poplar, chestnut, white oak, and ash. Each tree of the first list has special uses in which it excels. For example, the locusts excel for 
posts; black walnut and wild black cherry for furniture. But none of them has the all-round utility of the white pine.

Still another principle of consideration is the value of a mixed growth of trees in the wood lot over what is known as a pure stand, or the growth of one species of timber. A grove of trees of different kinds affords a wider range of usefulness than a grove of any one species, and it is less

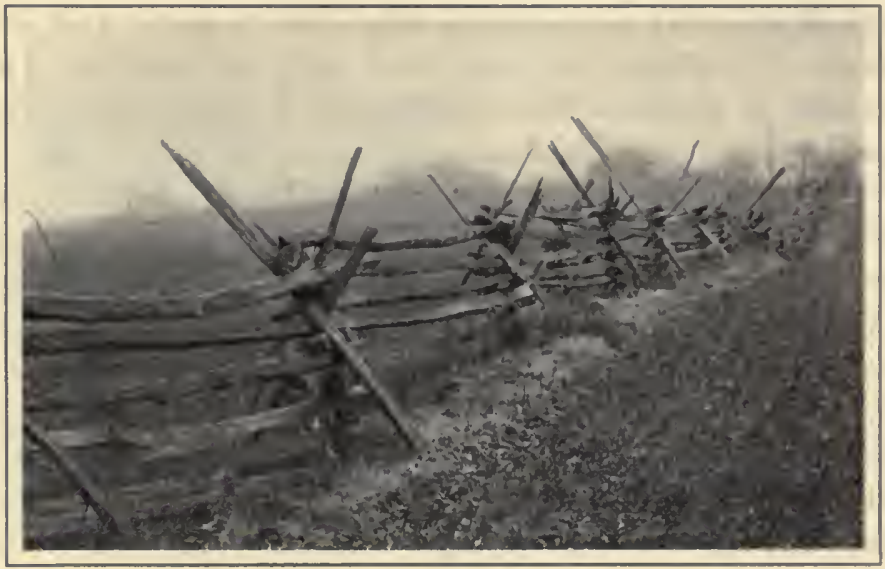

A RaIL Fence.

A common sight when timber was plentiful.

liable to suffer complete destruction from insect depredation. A pure stand of hickory is liable any summer to be destroyed by the bark borer; and the ravages of the ehestnut blight are only too well known in the east.

Certain trees, too, like the wild black cherry, can endure shade better than the white pine. The white pine and the wild black cherry together, therefore, produce a better growth than either alone.

235. The question whether to plant seeds or seedlings depends on the kind of tree and the relative costs of seeds 
and seedlings. The germination of tree seeds, especially those of the evergreens, is so uncertain that it is frequently more economical to buy seedlings from the nursery. Says Fernow, with regard to tree plantings: "In some localities - for instance in the western plains - the germinating of seeds in the open field is so uncertain, and the life of the young seedlings for the first year or two so precarious, that the use of seeds in the field cannot be recommended. In such locations careful selection and treatment of the planting material according to the hardships which it must encounter can alone secure success."

Directions for preparing the soil, for the time and the other details of planting, and for later culture, are usually furnished by the nursery. These directions must

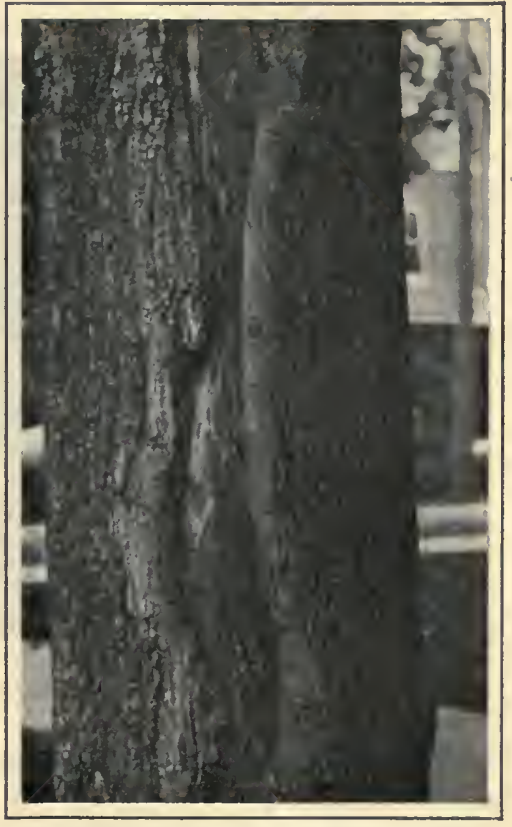

INJURY TO SHADE TREE. be closely followed in order to secure the best results, especially from a combination of species.

236. Care of the Wood Lot. - After the wood lot has been successfully started, a natural thimning process begins. The struggle for existence among the seedlings causes many to die, and at the end of the tenth year comparatively few remain. Attention needs to be given at all 
times to such as are diseased or stunted. These should be removed. If the stand is too dense, in spite of the loss of the numbers that have been killed off by competition, it must be thinned out by hand. Otherwise the stems of the young saplings would soon be too thin to support their crowns. From 300 to 500 trees - the number vary-

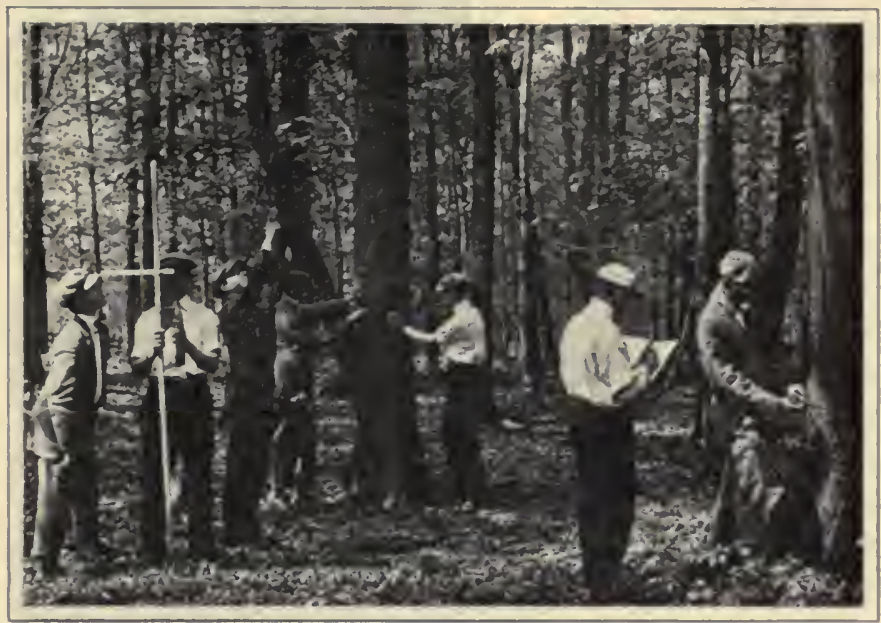

A Lesson in Forestry.

ing with the speeies - should cover an acre when the trees are 50 years old.

237. "Conserving the timber supply" does not mean that timber should not be marketed, or that it should be kept entirely for some future generation, but that it should be used with due regard to the rights of the future. The people living now are already feeling the scarcity of our wood supply and its consequent rising price. It is unfair and unpatriotic to handicap the progress and wellbeing of the farners of to-morrow by depriving them of a necessity. It is a civic duty to see to it that the period 
of reckless waste in this valuable natural resource is stopped.

'The French use 25 cubic feet of lumber each year per capita; the Germans, 37 ; and the people of the United States, 260. We are cutting nemly three times as much timber as is being produced. At the present rate of consumption and reforestation, it has been estimated that our timber supply will last only until 1950.

Dr. Van Hise gives the following suggestions for conserving our timber.

(1) We must reduce waste in cutting.

(2) We must reduce waste in milling and manufacture.

(3) We must reduce loss in turpentining.

(4) We must preserve the life of the timber by preservative treatment.

(5) We must utilize by-products.

(6) We must reduce fire losses.

(7) We must reforest areas burned over.

(8) We must maintain forests or essential areas.

(9) We must maintain areas stocked so as to produce larger growth.

(10) We must battle with insect pests.

(11) We must substitute other products for timber.

(12) We must reform our tax laws.

\section{Practical Questions}

1. In what sense may timber trees be considered a crop? 2. Distinguish between the direct and the indirect value of timber trees. 3. In what way do forests affect droughts? 4. What is the purpose of a windbreak? 5. How does the forest protect game and insecteating birds? 6. State a few advantages of having a small timber tract on the farm. 7. What points should be considered in starting a wood lot? 8. Explain the eare a young wood lot should receive. 9 . What is meant by the phrase "conserving the timber supply"? 10. Give three suggestions from Van Hise as to conservation. 11. Would you be willing to plant a timber tree for the coming generations? 


\section{HOME EXERCISES}

1. Determine the names, and count the number, of timber trees on your farm. To determine the names you should use a book like Apgar's Trees of North America. Which timber tree do you consider the most valuable?

2. Determine the names of all the different kinds of lumber in use at your home, in the barn, house, outbuildings, fences, and machinery.

3. What kind of wood makes the best fuel ? Which splits most readily? Can you estimate the age of your oldest tree?

\section{SugGestions}

1. Arbor Day exercises are helpful in stimulating interest in the value of trees. In nearly every state a day or two is annually designated by some official as Arbor Day. Suggestions for its proper observance are usually furnished free by the state or national government. Care must be taken not to plant too many trees or too much shrubbery around the schoolhouse or home. Too much is perhaps as objectionable as too little.

2. Pupils shonld be encouraged to bring to school the leaves, flowers, and fruit of important timber trees for drawing, identification, and study. It is better to know the value and uses of the different trees than merely their names.

\section{ReFERENCES}

Manual of Trees. Sargent.

Trees of North America. Apgar.

Furmers' Bulletins.

134. Tree Planting on Rural School Grounds.

173. Primer of Forestry.

275. Suggestions for the Management of the Farm Wood Lot.

711. 'The Care and Improvement of the Wood Lot. 


\section{CHAPTER XXV}

\section{ORNAMENTAL PLANTS}

Ihave in mind a garden old,
Close by a little known highway,
Where aster, pink, and marigold
Keep their long summer holiday.
'Mid dreams and vision manifold

Ihave in mind a garden old. - Huтт.

238. Purpose. - Successful farmers are a very busy class of people, especially during the summer. They have so

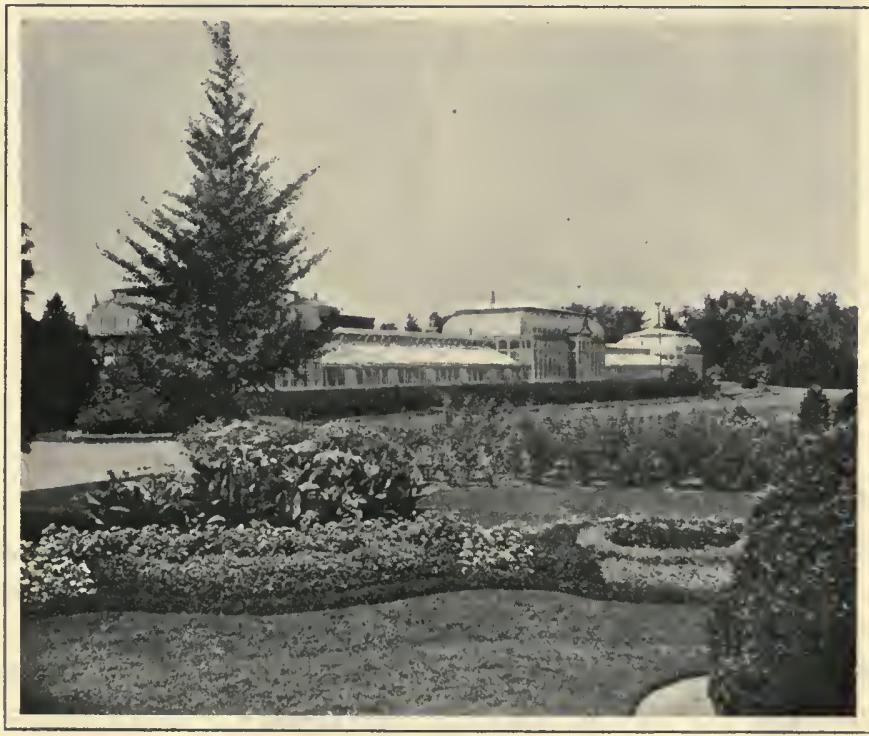

LandsCAPE GaRdening.

Scene in a city park. 
many duties to fill the day that some of them do not stop to think of the supreme value of adding a touch of beauty and charm to the home surroundings. The field may be well-tilled, and the farm generally present a good appearance, but the yard may look neglected and uninviting.

Sometimes, too, this neglect of lawn and landscape has even less excuse. It may be due to a false way of looking

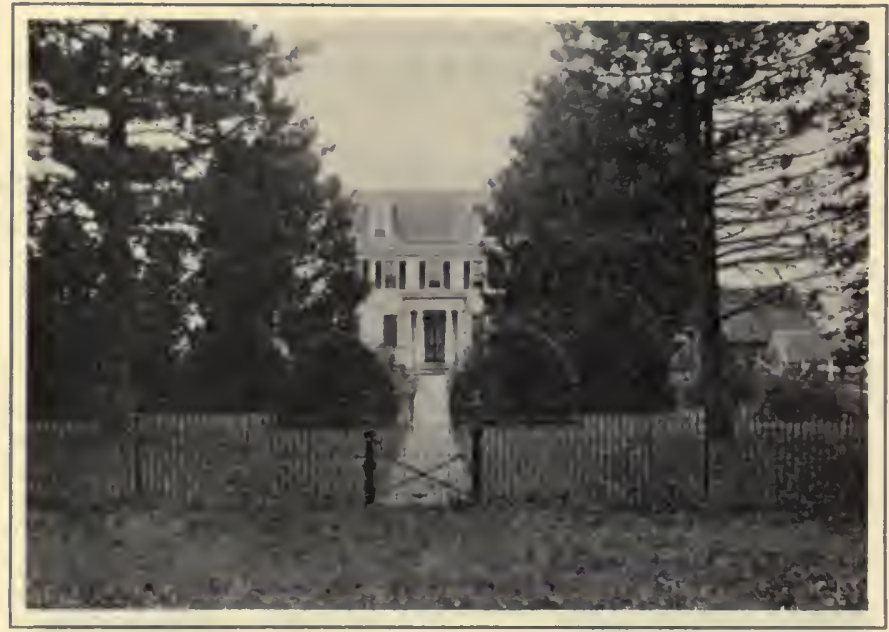

An Attractive Country Home.

at life. The farmer, perhaps, thinks of his home only as a factory whose sole purpose is to put on the market so much hay, fruit, or pork. He regards the house merely as a place in which to eat and sleep, or as a shelter from the heat and cold, and not also as a home around which cluster the tendrils of affection. But even if the farm buildings are viewed solely as the center of an industrial plant, they should not be without a few touches of embellishment. Large business concerns find that it pays to 
enhance the appearance of their buildings by becls of flowers or clumps of shrubbery and a velvety lawn. Surely the farmer should do as much for the farm home.

Ornamental plants do much to make the home surroundings more beautiful and satisfying, and to make the environment of the church and school more in keeping with their high mission.

239. Where to Plant. - To know just where in a yard to place the ormamental plants in order to secure the best effects, may not always be easy to decide. Neither the farmer nor his wife may be naturally artistic, or acquainted with the principles of landscape gardening. The school should give some help by calling attention to a few simple principles and by encouraging the cultivation of ornamental plants as a home exercise.

In general there are two styles of placing plants: the English, or natural; and the Italian, or geometrical.

240. English Style. - The English style, certainly the more suitable for small lawns, is based on nature's methods as seen in the wildwood. Go to the brook and note its graceful curves, and especially the arrangement of trees, shrubs, vines, and herbs, on its borders. Not a straight line can be seen. Visit the bushy stretches on the margin of an open field and note the irregularities in plant arrangement. There is no order, no system of grouping. A clump of alders flourishes here, dogwood there, and willows farther on. Beside them may rise a buttonwood tree. Herbs of many kinds, - grasses, sedges, mints, are huddled in an endless disarray. Each plant is most concerned for its own welfare, and is in competition with all the others. Nature plants her seeds with the most careless indifference to the way the matured plants may appear. 
When planting by this natural method in a yard, the planter must try not only to retain the natural charm of the place, but even to improve on it, by the tasteful use of ornamental plants. Every yard presents a different problem, depending on the time and the money to be expended, and on obstructions, slope, exposure, size, and other peculiarities.

In a general way, the yard to be decorated should be thought of as a large framed picture. All planting should

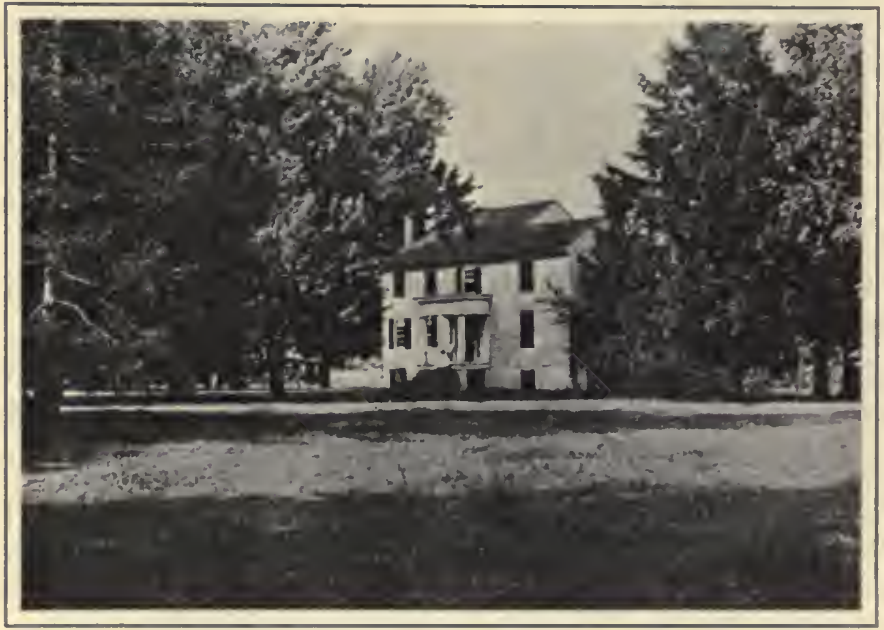

English Style of Planting.

be done in the border of the yard, or the frame of the picture. It is best to keep the center of the lawn open, devoted to plain sod. In the border, as a framework, the larger plants, including trees and shrubs, should be placed to the rear, with a care not to obstruct a distant and restful view, yet so as to screen unsightly buildings. Just as we find an irregular sky-line when looking from a distance over the top of forest trees, so the lawn trees 
should be so placed, by alternating taller and shorter ones, that their sky-line may be broken and irregular.

It is best in most cases to plant the shrubs in clusters or groups. Care must be taken, however, not to mass the clusters so much as to prevent normal growth later on. It is well, too, to mass shrubs in the angles of intersecting paths or beside the entrance to a building, or in the

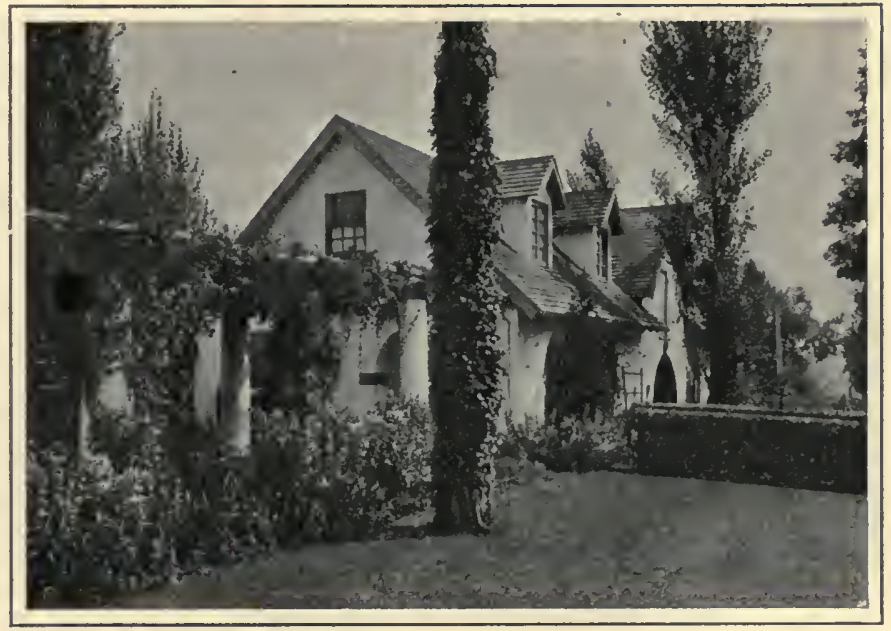

Italian Style of Planting.

curve of a widening pathway, or in some quiet nook which can in this way be made especially attractive and restful.

Without overdoing the matter, there should yet be worked into the decorative scheme a few dainty herbs. The number and variety of appropriate herbs both wild and cultivated is sufficient to meet the most exacting tastes. Shrubbery and trees should form the natural background of the herbs, so that, starting with the greensward in front, the eye may pass easily up over the low 
herbs to the higher ones, then on to the shrubs, the trees, and the blended sky-line beyond.

241. The Italian Style. - According to the Italian style of decorative planting, which is followed in parks and on large estates and driveways, straight lines and geometrical figures are traceable throughout. This style, however, is not suited to small country places, and no discussion of it need be given here.

242. Ornamental plants must be cared for after planting. If left to themselves, much of their beauty will not appear.

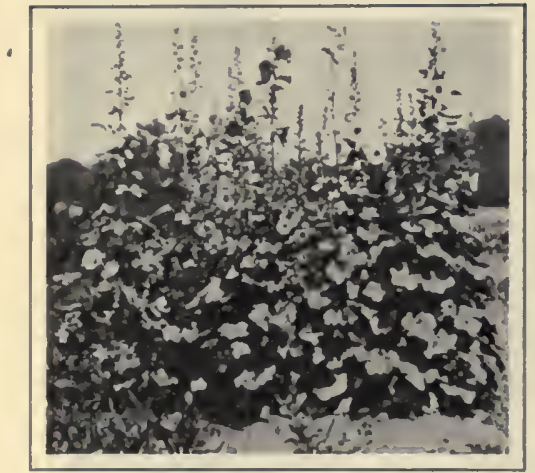

HOLLYHOCKS. This does not mean that severe pruning is needed every year, or that plants are especially liable to be killed by freezing or by pests. It does mean that some pruning is necessary. This is best done as soon as the flowers have fallen. Cut off the tips of the growing branches, and, in the case of flowering shrubs, aim to give the shrubs a compact and symmetrical form. Shrubs are not expected to bear flowers on the inside of the clump, and external shearing not only gives them a better form but increases the flower surface.

Details as to the care of the great variety of plants useful for ornamental purposes must be passed by. A knowledge of such details can be secured readily from the nearest nursery. Each variety needs special treatment for the best results.

243. The Flower Garden. - It is desirable to have a part of the yard devoted exclusively to flowers. Interest in 
flowers is growing. There is a great deal of pleasure in planting, growing, and caring for such comforting and beautiful pets. Every stage of their life is interesting.

After selecting a suitable site for the flower garden, apply a dressing of horse-manure, and carefully spade it under. The soil must then be raked and fined until smooth and level. The seeds of some plants may be sown directly in the garden, the plants being afterwards thinned

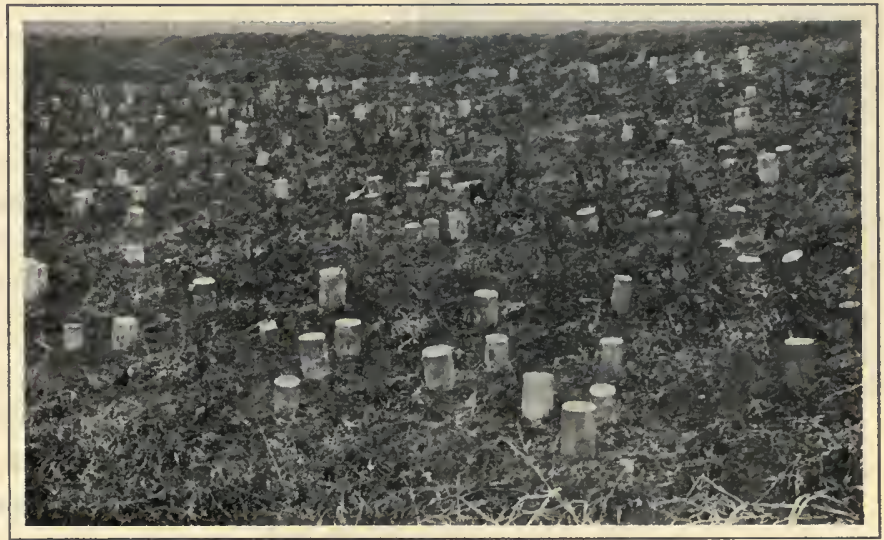

Starting Rose Cuttings.

A school exercise in which each pupil secured a rose cutting and planted it under a glass jar.

to give each plenty of room to grow. Others, like the snapdragon, cornflower, coreopsis, and petunia, are best started in indoor pots or in hotbeds, and then hardened to lower temperature by being transplanted to a cold frame before being finally planted in the garden.

244. The Lawn. - Says Waugh in his Landscape Gardening: "One would not want the furniture in the parlor to take up three fourths of the room. Much less would one want the green carpet of the lawn nearly 
covered with such furniture as trees and flower beds." A lawn dotted all about with flower beds is like a picture spotted with blotches. Few spots in the homestead can

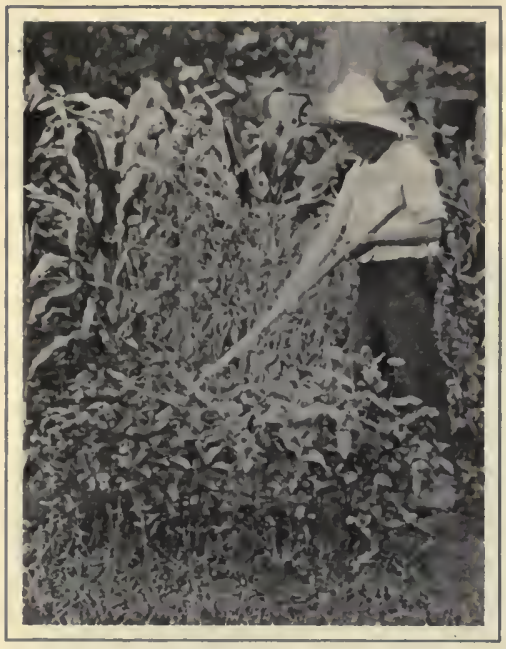

A Flower Project.

Zinnias.

be made more inviting than a clean, well-kept velvety lawn. The grass should be fine, wellmatted and even. Kentucky blue-grass with a sprinkling of white clover will soon form a good sod.if the soil is not too sour. If the sod becomes thin and poor and choked with weeds, it is probably best to turn it down with a plow or a spade, and start anew. In doing so, care should be taken to secure several inches of rich surface

loam into which a thick coating of well-rotted barnyard manure has been worked. It is often advisable to grow a nitrogen-enriching crop, like cow peas or crimson clover, to further enrich the soil. This crop may be turned under in early fall ; and then, after leveling, rolling, and firming the soil, the plot is ready for the lawn seed.

\section{Practical Questions}

1. Why do farmers need ornamental plants? 2. Is it important to know where to place ornamental plants? 3. What is meant by the English style of planting? 4. In what sense can a well-planted yard be compared to a picture? 5. What is the Italian style of planting? 6. What care should ornamental plants receive? 
7. Should a farmer maintain a flower garden? 8. Is it good taste to have the central part of the lawn occupied with flower beds? 9. Explain the care a lawn should receive.

\section{Home Exercises}

1. A home flower garden exercise should be started by the girls. It is best not to use more than a few varieties of flowers. Perhaps one would do. Start a sweet pea, aster, hollyhock, or some other flower-growing contest. Exhibit the flowers. Write a story on "How I kept my flower garden."

2. Make a list of all the ornamental plants that are grown at home.

\section{Suggestions}

1. The teacher should draw a common type of yard on the board and use it to explain the reasons for different types of ornamental plants here or there. It might be helpful if each pupil were to sketch his own yard and garden on the board, and try to indicate the kind of ornamental planting most suitable. Suggestions should be given by the teacher.

2. Pupils should be taught to take notes of the best-kept yards in the community or at places where they may visit.

\section{REFERHACES}

Landscape Gardening. Wangh.

How to Plant the Home Grounds. Parsons.

In God's Out of Doors. Quayle.

Farmers' Bulletin.

134. Tree Planting on Rural School Grounds.

185. Beautifying the Home Grounds.

494. Lawns and Lawn Soils. 


\section{CHAPTER XXVI \\ INSEOTS AND BIRDS}

Sweet is the breath of morn, her rising sweet

With charm of earliest birds. M - Muто.

245. Importance of Studying Insects. - It costs the American farmer more to feed insects than it does to educate his children, says Webster, an entomologist of note. At

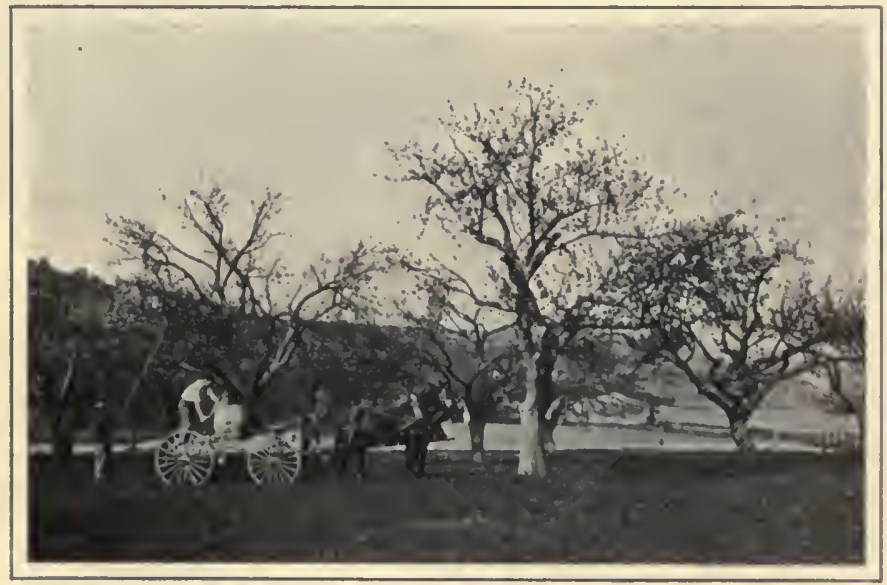

Spraying Apple Trees.

least one tenth of the farmer's income goes to support these vandals. Recent estimates put the loss due to insects in the United States at $\$ 700,000,000$ a year.

246. Two Classes of Insects. - From the standpoint of killing inseets by spraying, there are but two classes to be considered. 
(a) The Chewers, or Eaters, are provided with a pair of hard, side-working jaws, such as can be seen in a grasshopper. Farmers who are not disposed to study the moutl parts of destructive insects may know them by their work. Insects of this sort eat entire parts of a plant. Caterpillars, grubs, and beetles belong to this class.

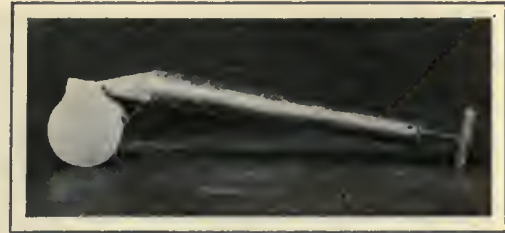

HAND SPRAYER.

For shrubs and vegetables.

(b) The Piercers or Suckers are insects that have their mouth parts formed into sharp, slender, hollow beaks. They live entirely on sap, which they suck up through the beaks, without eating away the plant's body. They merely pierce the skin of a leaf, and suck up its juices. Plant lice, scales, and squash bugs are sucking insects.

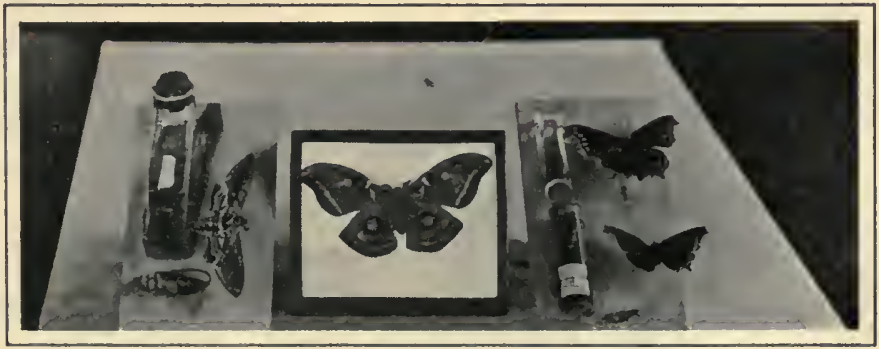

A Method of Mounting Insects.

Tobacco worm moth at left; cecropia moth in center; mourning cloak butterfly at right.

247. Two Corresponding Kinds of Remedies. - The way the mouth parts of insects are constructed, and their method of feeding, determines the choice of materials to be used in spraying them. 
(a) The members of the first elass are killed by internal poisons. Since they eat away parts of the plant, they

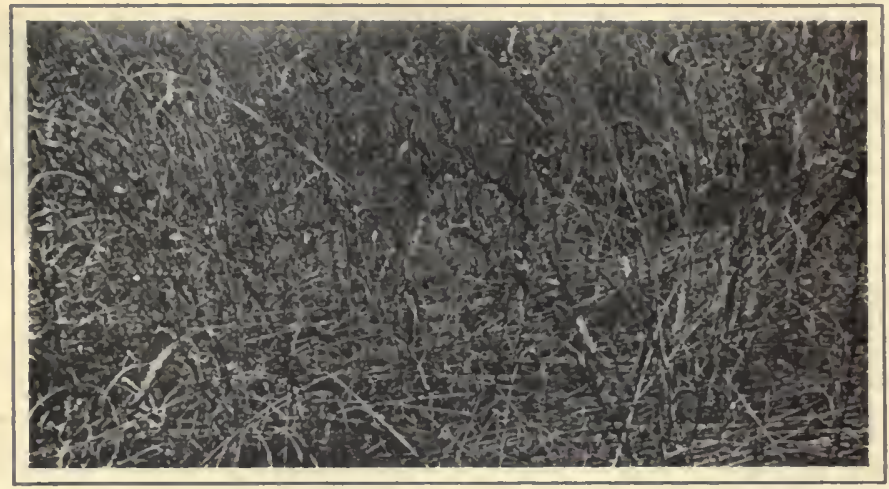

Wheat Partly Destroyed by the Hessian Fly.

can be destroyed much as we destroy rats by putting poison on a piece of bacon for them to eat. As the bacon

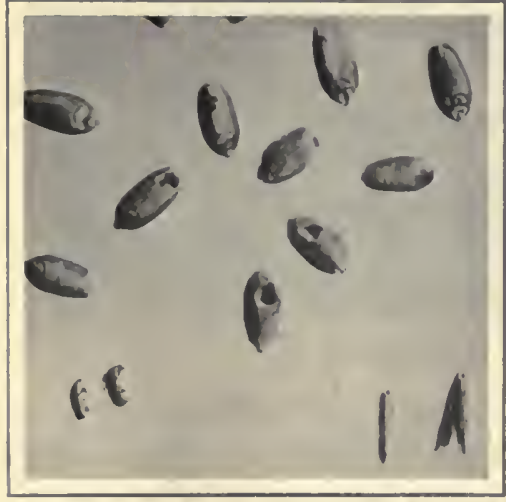

Angoumots Grain Moths and Grain WEEVILS.

Above is the injured grain: below at the left are the weevils; at the right, the moths. is eaten, the poison enters the rat's stomach along with it. So we spray the leaves of plants with a liquid solution poisonous to insects; then, as a part of the leaf is consumed by an insect, the poison upon the leaf likewise enters the body of the pest and kills it.

Two common internal insecticides (internal poisons for killing insects) are arsenate of lead and Paris green. 
(1) Arsenate of lead, if in the paste form, is mixed with water in the proportion of 3 pounds of the poison to 50 gallons of water. In its dry form $1 \frac{1}{2}$ pounds of the poison is enough for 50 gallons of water. The materials should be well mixed and strained before spraying. Arsenate of lead by the hundredweight costs from eight to twelve cents a pound.

(2) Paris green is used with quicklime and water in the following proportions :

Paris green . . . . $\frac{1}{2}$ pound

Quicklime . . . . 1 pound

Water.... . 50 gallons

The Paris green is first made into a paste with a little water; and about a pint of water is added to the lime to slake it. The two substances are then put together, some more water added, and the mixture is strained and made up to 50 gallons. If quicklime is not readily secured, one fourth pound of the Paris green may be mixed with 50

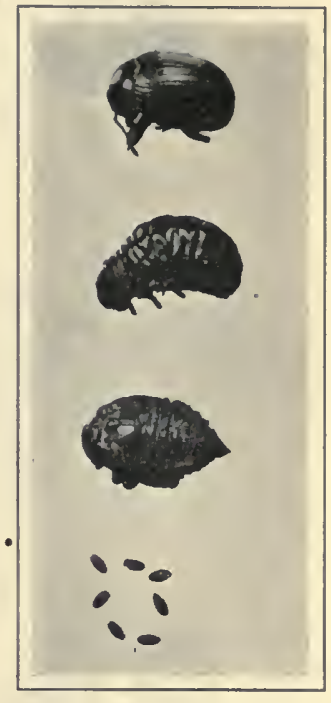

Potato Beetle.

Stages of growth from egg to adult. gallons of water. The purpose of the quicklime is to prevent the Paris green from burning the foliage.

Both insecticides are applied in a fine spray. It is important that the spray mist touch every part of the plant where the pest is likely to feed. Arsenate of lead is very adhesive, and not easily washed off a plant by rain. It is rapidly taking the place of Paris green for spraying. Farmers often use either one or the other of these insecticides in combination with some fungicide (poison for 
killing fungi) like Bordeaux Mixture or diluted limesulphur wash. One spraying then serves two purposes. For large fields there are "horse sprayers"

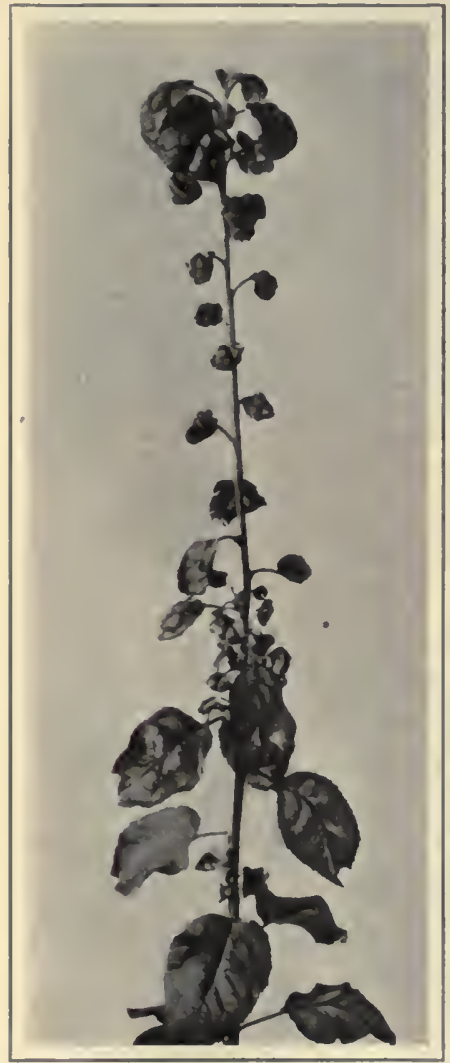

INSECT WORK ON LEAVES. that cover several rows at one time.

Lead arsenate and Paris green are both deadly poisons to larger animals and to man, as well as to insects; and care must be exercised in putting away these mixtures and in cleaning the vessels used in mixing them.

(b) External poisons. Since sucking insects obtain their food from the interior of the plant, and do not eat its tissues, they would not be destroyed by an internal poison unless it were dissolved in the sap. This would injure the plant. 'Therefore an external poison is applied to such insects as are attacking the plants. Two eommon external inseeticides are the following:

\section{(1) Kerosene Emulsion}

Hard soap . . . . $\frac{1}{1}$ pound Hot water . . . . . 2 gallons Kerosene . . . . 2 gallons

The soap is cut into thin slices and dissolved in hot water; and the kerosene is added while the solution is still hot. On dormant trees, without foliage, this solution is diluted with eight times its bulk of water; on foliage, 
with twelve times its bulk. The mixture should be stirred thoroughly before application.

\section{(2) Lime and Sulphur Solution}

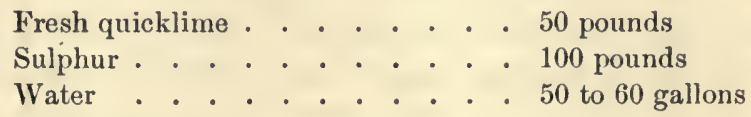

The lime is slaked in a little water, and the sulphur is made into a paste. Both are boiled together in sufficient water in a kettle for one hour. The solution is then strained, and made up to 50 or 60 gallons by adding water.

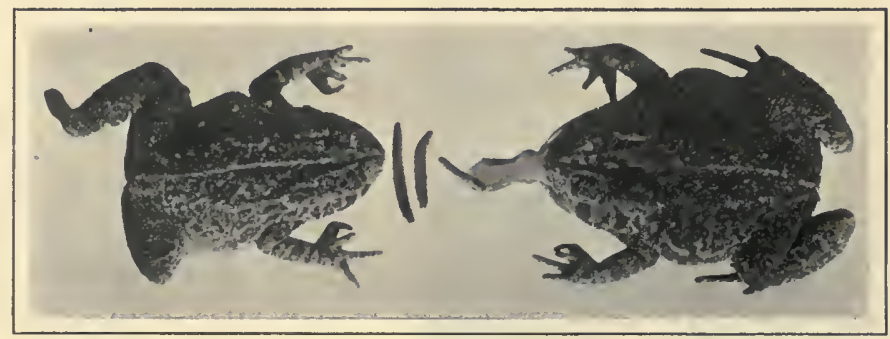

Toads Eating Caterpillars.

When ready for use on dormant trees, as for San José scale, the spray should be diluted with eight times its volume of water or more exactly so that the hydrometer (an instrument to measure densities) reading is 1.03 . For summer control work, that is, when the spray is to be used on foliage as a fungicide as well as a weak insecticide it should be diluted twenty-four times its volume with water, or so that the hydrometer reads 1.01.

These external poisons coat the insect's body with a fine film, and close up its breathing pores. The spraying must be done thoroughly, so as to reach all insects upon the plant. The principle is the same as that of sprinkling chickens with a chicken powder to kill lice. 
248. Some harmful insects cannot be reached by sprays. Cutworms, for instance, do much damage in fields and gardens by cutting off the tender plants. To destroy them, one half a pound of Paris green is mixed with twenty-five pounds of dry bran. The mixture is stirred up in two gallons of water and sweetened with a little

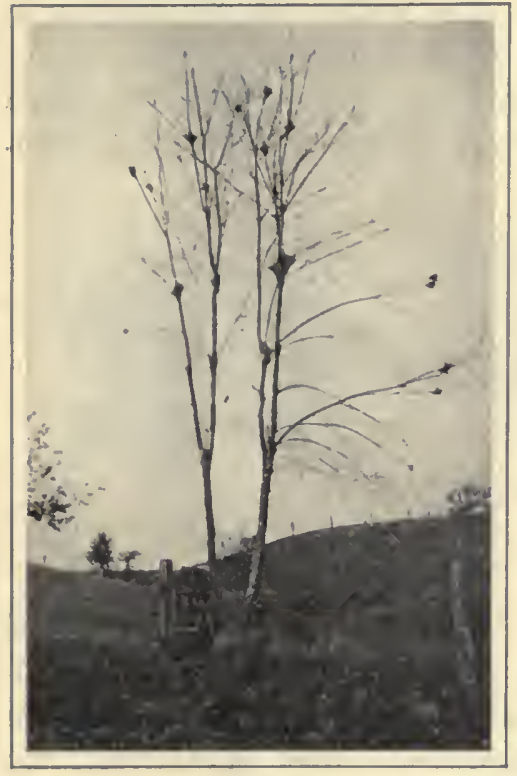

Tent Caterpillars. sugar or molasses. Small quantities of the mash are placed here and there in the soil as the vegetables come up.

Mosquitoes are destroyed by the use of kerosene on the ponds in which they breed, - a pint of kerosene to 250 square feet of water surface. The grain moth is killed by evaporating carbon bisulphide where the grain is stored. The potato vine borer is destroyed by gathering up the vines and burning them. The peach tree borer must be dug out when once in the tree.

249. The Great Variety of Insects. - There are more than 200,000 different kinds of insects known. Only few of these can be found on one farm; but if a man who has made a special study of insects should make a list of all the different kinds which he ean find in one neighborhood, the number would, no doubt, be surprisingly large.

Not all insects are harmful. Some are beneficial; and 
others are of no special interest to farmers in either way. Most of the good work done by the beneficial ones consists in aiding man in destroying the harmful ones by acting as parasites.

250. Common harmful varieties include the clothes moth, bedbug, carpet beetle, cockroach, apple maggot, weevil, chinch bug, corn-root worm, plant lice, currant worms, potato bugs, and the many other pests that exact a heavy toll from the farmers' toil. Three pests will be treated in some detail, - the house fly, the San José scale, and the codling moth.

251. We place the house fly first because it is so well known over the entire globe, not only in the country, but in most cities as well. In Chapter IV we learned that house flies breed in filthy places, and are the carriers of disease germs

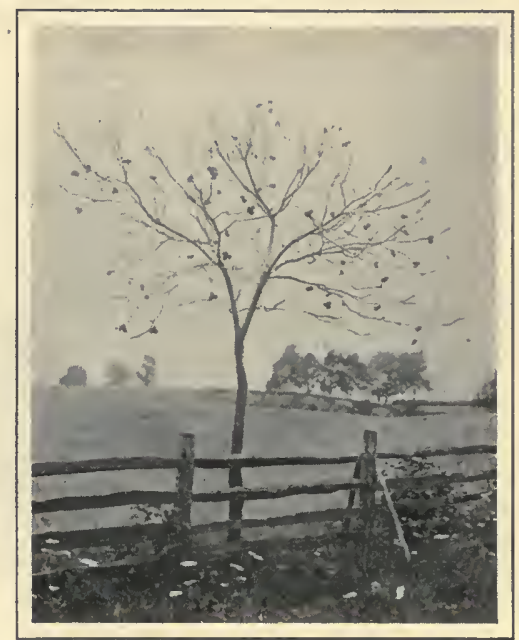

Work of Walnut Caterpillars.

The leaves are eaten but the nuts are left. to man. Dr. L. O. Howard, Chief of the United States Bureau of Entomology, ${ }^{1}$ has made a long. study of the house fly in its relation to disease, and he has shown that typhoid fever germs are carried to healthy people principally by the house fly.

If there is a microscope in the school, place a house fly under it. Look for the hairs on its body and legs, and for the sticky pads at the toes. You will not be able to 
see any germs, perhaps, but you can see thousands of tiny hairs to which germs can cling. When flies come from stables and outhouses, these hairs may be literally covered with dangerous germs; and these may multiply rapidly if allowed to reach suitable food, like milk.

The house fly is one of those insects requiring special treatment. A knowledge of the methods by which it secures its food is of little value. No one would begrudge the little it eats. We must do two things to control flies:

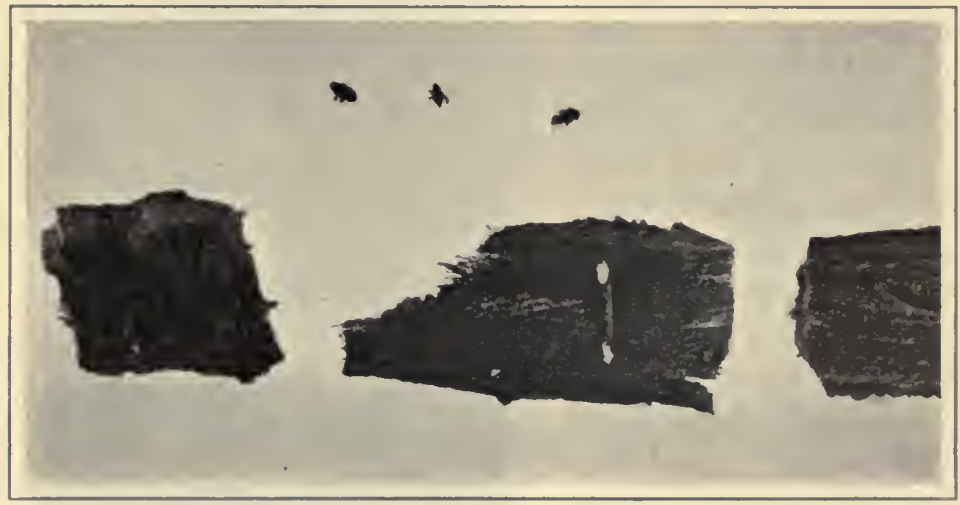

SHOT-HOLE BORER.

Above is the insect - natural size - and below, some of its ravages on peach bark.

(1) keep them from hatching, so far as we can; and (2) keep those which have hatched away from human food.

Farm liomes should have substantial window screens and fly. doors in an excellent state of repair. The common adjustable screen, selling for about thirty-five cents. is easily bent or warped, and hence useless. Permanent screens, to last season after season, ought to be fixed in all the main windows of the house. It is an investment that 
pays. For flies that gain entrance, a liberal use of fly paper is recommended. If many flies have entered the house, it is well to close it up, and disinfect with permanganate of potash and formalin.

For a breeding place, the house fly prefers horse manure, but it likes also any other manure, This is one more reason (see Chapter IX) for removing barnyard manure to the field as quickly as possible. Excretions in outhouses

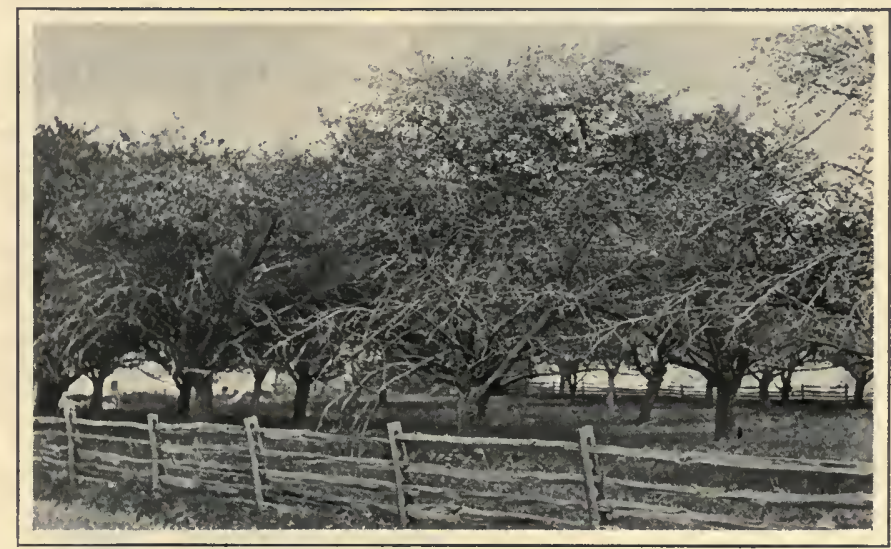

Work of the San José Scale.

Note the many dead branches.

should be covered with lime, ashes, land plaster, or plain earth, to keep away the flies; and, if any member of the family has typhoid fever, the exeretions should be treated with formalin, or some other disinfectant. This treatment should continue for a year after the disease has disappeared.

The power which flies have to reproduce is almost incredible, - as is the case, too, with most other inseets. A fly lays about 120 eggs at a time. These eggs will develop into adult flies in about ten days, and half of 
them will be females, ready to lay more eggs. In one season, if none of the descendants of the first pair were

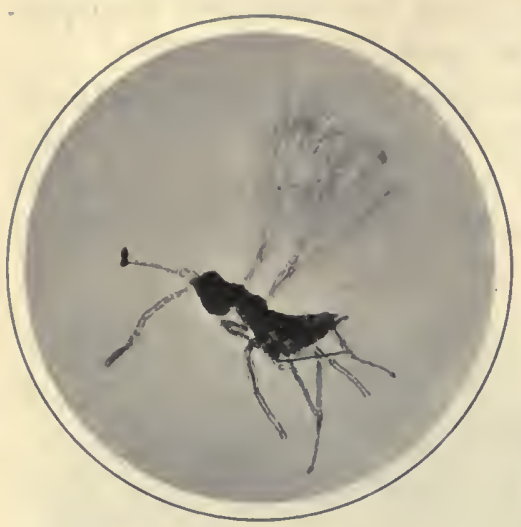

Scale Parasite. destroyed, the offspring would equal the unimaginable number of 2 followed by twenty-three ciphers. One fly "swatted" in the spring means many less in the summer and fall.

252. The San José Scale.

- The house fly is a household pest; the San José scale is a pest of the orchard and garden. And a destructive pest it is. Orchard after orchard has been destroyed by it. Entire neighborhoods have lost nearly every fruit tree. Farmers at first seemed helpless in the presence of its ravages. Many of them had never heard of spraying fruit trees, when this insectappeared in this country, and quite a few did not believe that spraying would be an effective method of controlling it.

No pest, however, has created such in interest in spraying as the San

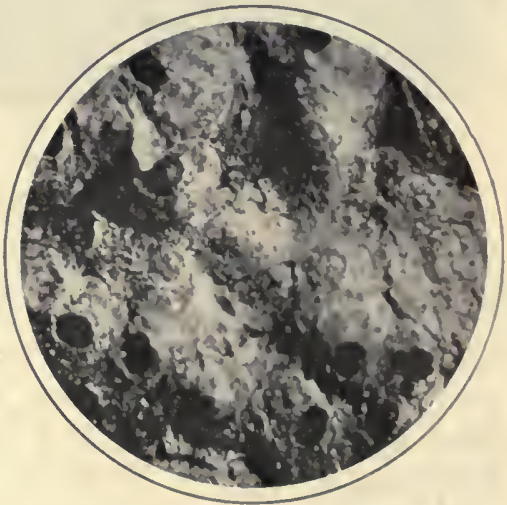

WORK OF the Scale Parasite. José scale has. And in a sense, while its damages have been tremendous, the interest it has aroused in the neces- 
sity of combating pests by scientific methods is part payment for the injuries it has inflicted in farm and garden.

The San José scale comes from China. The name is taken from the town of San José, California, where the insect first appeared in the United States. It is a small sucking insect, a member of the louse family; and it is called a scale because it develops a flat roundish shell, or "scale," over its body. The scale is from a twenty-fifth to a twelfth of an inch in diameter. The insect inserts its beak in bark, leaf, or fruit; and injects a poison which injures the sap for the tree but makes it digestible for itself. This modified sap is then sucked into its body. Thousands of these scales at work at one time on a limb will soon destroy it, or at least weaken its vitality.

The lime and sulphur spray is a most effective remedy. The spray is applied in spring or fall, while the plant is dormant, or in a leafless state. Every part of the affected tree or shrub, especially all new growths, must be thoroughly covered by the spray.

Several kinds of parasites, it has been observed, prey upon the San José scale. So far, these parasites have done more in the way of checking its ravages than all the spraying. But checking pests by parasites, as we shall learn a little later, is not always a dependable method.

253. The Codling Moth. - The word "codling" means an immature apple. However, the codling worm lives not only in the immature but in the mature or ripe apple. Boys have often noticed a pinkish, dark-headed worm in apples. How often have we gone to the orchard and started to eat an apple, only to come upon an ugly worm! One can usually see the hole, surrounded with apple chippings, where the fellow entered. The worm feeds in and around the seed only, and does not destroy the tree itself 
as the San José scale may do. When full grown, the worm leaves the apple and hunts out at secluded spot, perhaps under a bit of bark. There it spins around itself a loose silken cocoon. A small gray moth hatches from this cocoon. Spring cocoons hateh in the summer, and

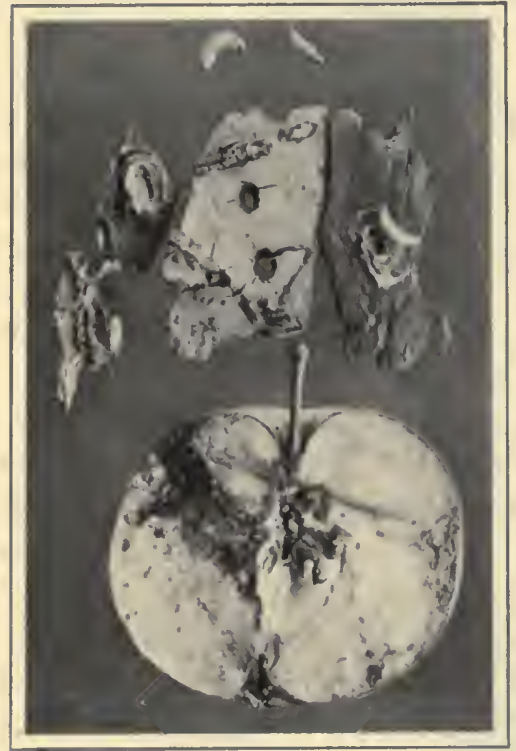

The Codling Moth.

Below, the worms in an apple; above, nests and worms; two holes in center chlp show where woodpecker has robbed the nests. fall cocoons hatch the following spring about the tine of apple blossoming.

The moth ean best be destroyed while in its worm stage. ${ }^{1}$ Since it is a chewing inseet, its destruction is affected by spraying with lead arsenate or with Paris green. The spray should be applied on the young fruit as soon as the petals have fallen, and before the calyx has closed about the pistil. Spray thoroughly into and all around the fruit cluster. The mother lays an egg on or near the flower. In a few days a tiny worm hatches from the egg and by instinct it is guided toward the enlarging ovary. If this has been covered with poison, the worm's first meal is its last. The tree should have a second spray-

1 Insects in their development pass through several stages. In the case of moths the stages are four in number; namely, egg, worm, pupa, and adult. It is the pupa that is inclosed in a cocoon, or silken bag. 
ing about a week or two after the first, in order to make sure that all young worms will be poisoned.

Infested apples frequently fall to the ground. Up to a certain point this enables the remaining ones to increase in size, on the principle that the falling is a thinning out process. Since nearly all the early falling apples are apt to be wormy, they should be gathered promptly and fed to the hogs.

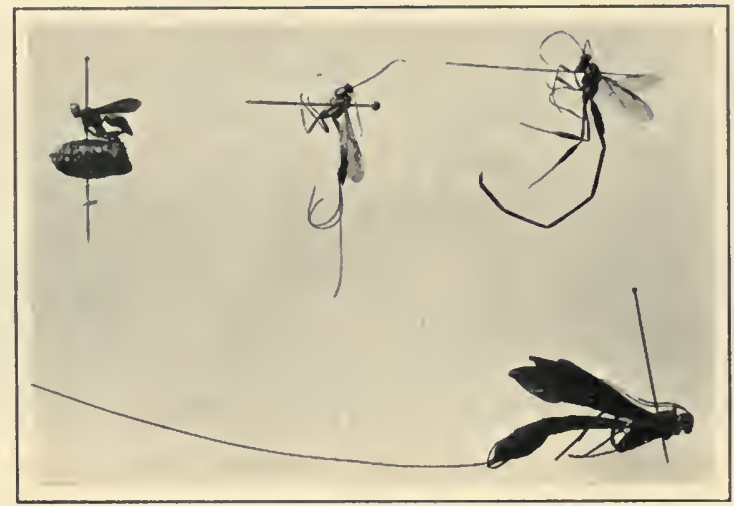

ICHNEUMON Flies.

These are beneficial, as they lay their eggs in harmful caterpillars. The eggs hatch and the maggots kill the caterpiliars.

254. A Few Helpful Insects. - If the farmer were obliged, by himself, to check the ravages of each particular pest, it would probably soon be impossible for him to raise enough food for the world's needs. Fortunately for us, insects are ever waging a bitter warfare among themselves. The moment the numbers of one kind increase above the normal, they are preyed upon and checked by parasites.

255. The Scale Parasite. - A notable example of this warfare by parasites is seen in the gradual decline in the numbers of the San Jose scale. But a few years ago the scale seemed to be destroying nearly every unsprayed 
orchard. Many farmers believed that in time every unsprayed apple, peach, plum, and pear tree would be killed. Here and there, however, some trees were seen to be holding out, showing little damage. It was generally thought that such trees had greater power of resistance to the ravages of the scales. This may be true but cannot be taken as a full explanation of the facts. Unnoticed to the eye of nearly all fruit growers, a tiny worm was at work, within the body of the scale. This worm is hatched from an egg inserted into the seale by a small wasp-like insect about one fiftieth of an inch in length. This parasitic worm, and its near relatives, have now, for the present at least, exterminated the San José seale in parts of the Eastern states.

In the course of time it is probable that this beneficial parasite may be so reluced in numbers on account of the destruction of the food for which it has formed a liking, or, by still smaller parasites living on itself, that the few scales unparasitized may start to increase again at an enormous rate until their parasite can once more multiply to such numbers as to eheck them. So nature maintains her balance.

256. Bees. - When we were studying about cross-pollinating flowers, bees were mentioned as pollen earriers. In this respect they are very beneficial. But bees are also valuable for the honey which they make. Beekeeping throughout the world is a very old industry; and in America thousands of colonies are maintained for this purpose.

As is well known, bees live in colonies. Each colony is made up of workers, drones, and a queen. The workers are undeveloped females, whose business is to gather pollen and neetar. The drones are the males. The queen is the only fully developed female. She lays the eggs. 
The neetar which bees gather from flowers is made into honey, and the pollen into beebread, for the young bees.

Bees are kept in hives. A hive is a box having a top and bottom that can be removed. The bottom projects somewhat on one side to form a platform on which the bees may alight. They can then pass inside through a small hole at the base of the hive. Within the box frames

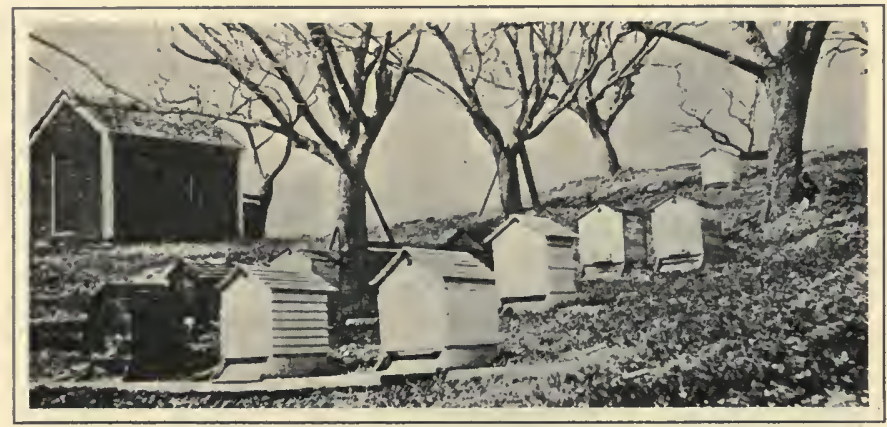

BeEhives in an ORchard.

Bees are useful in pollinating plants.

are arranged in which the honey is to be placed and the young reared.

In the spring, when the eolony has increased in numbers and a new queen is about to appear, the old queen gathers together a large number of workers and leaves the colony. This is "swarming." The swarm usually lights on some object like a tree limb. It is then necessary to collect the swarm in a bag, and place it in a new hive. Bee keepers sometimes clip the wings of the queen to keep her from flying far. Thus they run little risk of losing the swarm.

During the winter, bees need protection from cold. The hive should be placed in a cellar, or shed, or be 
loosely covered with straw or old carpet, according to the climate.

If bees are carefully handled, there is money in them. But one must not neglect them, nor allow diseases, like the foul brood, to enter the hive. Few farmers, however, engage in beekeeping except as a side issue, and for this reason they are likely to neglect the hives except at odd moments.

257. Birds, too, help the farmer to save his crop, beside adding beanty to his life. Longfellow's "Birds of Killing-

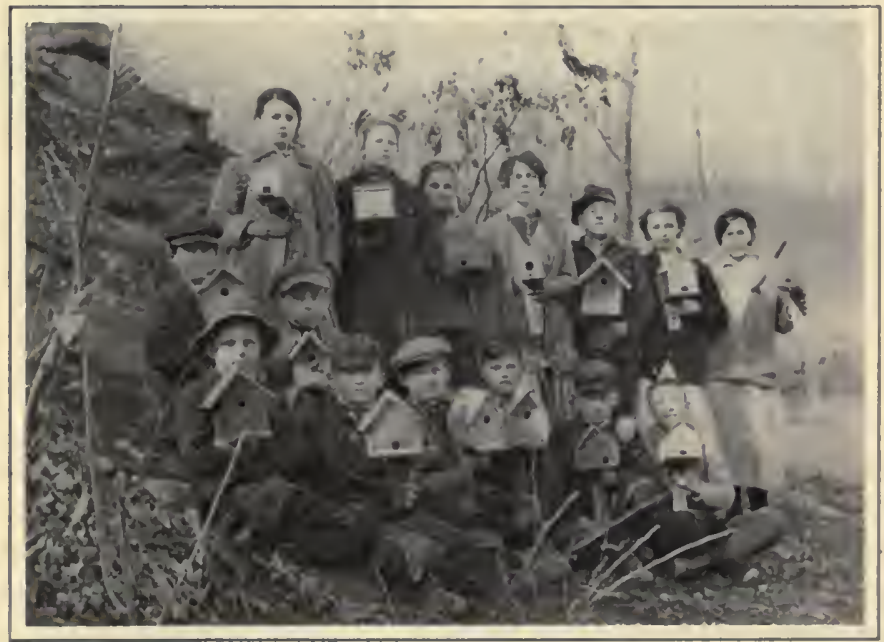

BIRD BOXEs.

worth" contains the following graphic picture of a birdless neighborhood, where the farmers had slain all the birds:

"The summer came, and all the birds were dead, The days were like hot coals; the very ground Was burnt to ashes; in the orchard fed Myriads of caterpillars, and around 
The cultivated fields and garden beds,

Hosts of devouring insects crawled, and found

No foe to check their march, till they had made,

The land a desert, without leaf or shade."

It is believed that if it were not for the birds, successful agriculture would not be possible. They not only check the ravages of many harmful insects, but they also eat up tons of weed seeds.

258. How Birds have been Studied. - It is difficult to follow a bird day after day to watch what it eats. Some may be seen eating caterpillars one hour, and grain the next, so that the good they are known to do may be offset by the damage. Some years ago, in order to have reliable information, competent men, in the employ of the United States Department of Agriculture, undertook to an-

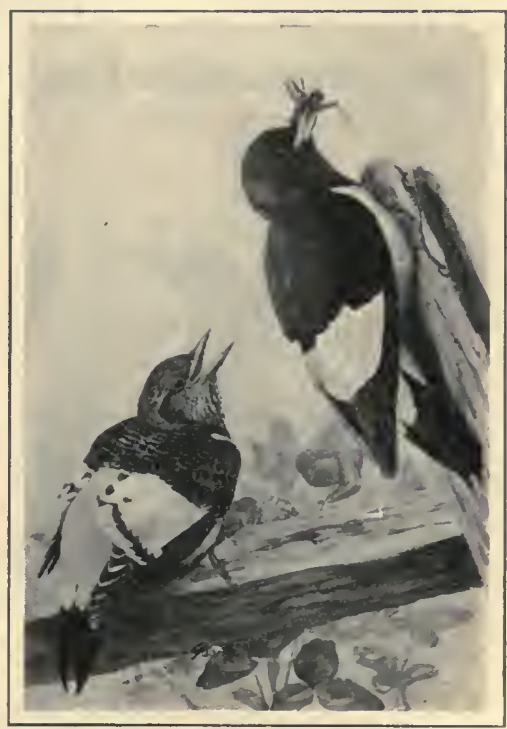

RED-HEADED WOODPECKERS.

All woodpeckers feed on insects harmful to farmers.

alyze the stomachs of many specimens of all the common farm birds. The results of this work have removed all doubt as to the fact that most birds pay well for their board and lodging. The following contents, found in the stomachs of a few of the birds examined, show the main articles of diet of those specimens. 
1 Flicker . . . . 28 White Grubs

1 Nighthawk . . . 34 May Beetles

1 Grackle . . . . 100 Cotton Bollworms

1 Killdeer . . . . 300 Mosquito Larvæ

1 Tree Swallow . . 30 Chinch Bugs

1 Pheasant . . . 8000 Seeds of Chickweed and Dandelion

1 Duck . . . . . 72,000 Weed Seeds

1 Bobwhite . . . 1700 Weed Seeds

1 Yellow-billed Cuckoo 217 Fall Webworms

259. Some Less Helpful Birds. - Except for a few varieties, the value of farm birds is generally granted. Even those

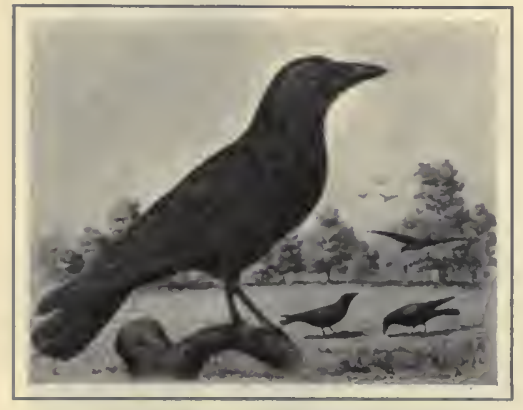

THE CROW. varieties that are usually believed to be harmful have some good points.

Hawks and owls are usually classed as thieves. The truth is that most of them also are the friends of the farmer. In the nest of a barn owl there were found over 3000 skulls of mice and rats. Only An enemy of the corn. three species of hawks are known to be injurious, - the Cooper's hawk, the sharp-shinned hawk, and the goshawk.

An investigation of the food habits of the crow, based on an examination of 909 stomachs, shows that about 29 per cent of its food for the year consists of corn and other grain, the greatest quantity of this being eaten in the winter months. The remaining food consists of noxious insects, wild fruit, and seeds.

The English sparrow is another bird of ill repute. The best that can be said for it is that about 10 per cent of its food is weed seeds. Our native sparrows, such as the 
chipping, vesper, song, field, and grasshopper sparrows, are all beneficial. They look much like the English sparrow and care should be taken to see that they are not killed by mistake.

\section{Practical, Questions}

1. Of what value is the study of insects? 2. Distinguish between chewing and sucking insects. 3. In what way may the structure of an insect determine the kind of remedy to be used in controlling it? 4. Give the composition of an internal and of an external insecticide. 5. Describe the relation of the house fly to man. 6. Discnss the ravages of the San José scale. 7. In what way may parasites be beneficial? 8 . What have you learned about the codling moth ? 9. Speak about the scale parasite. 10. Of what benefit are bees to the farmer? 11. Commit to memory the quotation from Longfellow. 12. How can we prove that birds are an aid to farmers? 13. Have you ever seen any birds doing damage to man? 14. What bird do you consider of least value?

\section{HoMe Exericises}

1. Collect all the insect pests you can find at home. Bring them along to school for study.

2. Select an insect pest of your garden or your father's farm, and give an oral report on what you have done to combat it.

3. Make a careful study of one bird, like the grackle, which may be regarded of doubtful value. Follow it for one hour and report its work.

\section{SugGESTIONS}

1. An endless variety of school exercises is possible with insects, almost any time of the year. In many sections, the milkweed worm is common when school starts in the fall. Its transformation in a tumbler is delightfully interesting and instructive. It passes through the same stages as all the higher insects, - eggs, larva or caterpillar, pupa, and adult.

2. A pest like the cabbage worm or the codling moth, should be brought to school, placed in a tumbler or box, and fed, to get it to pass on to the next stages. Worms should be fed on what they are found eating. Cabbage worms are usually available in September. All that is necessary is a tumbler covered with netting held in place by a rubber band. Collect a few worms and a part of a cabbage leaf 
and place them in the tumbler. Keep the tumbler clean and add fresh cabbage daily. You nay be growing the cabbage butterfly or, if the worm is slightly hairy, a small moth. As in the case of the milkweed worm the transformations take place rapidly.

3. Pupils unay be encouraged to send to the State Experiment Station a specimen of some pest for identification and for information as to the best methods of controlling it. A little practical field study, and a report should then be made on the pest.

4. Get a good bird book, as Chapman's, and learn the names, songs, and habits of the birds. Be kind to the farm birds. Give them food and water when these cannot be secured in winter.

5. Before any bird is condemned, it should be caught stealing or doing some real harm.

6. Concerning bird boxes, do something, even though the boxes are not artistic. Perhaps we can do considerable good in this way even in the country.

\section{REFERENCES}

Birl Life. F. M. Chapman.

Eiconomic Entomolngy. J. B. Smith.

Insects and Insecticides. C. W. Weed.

Injurious Insects to the Farm and Garlen. M. Treat. Farmers' Bulletins. Washington, D.C.

54. Some Common Birds.

127. Important Insecticides.

155. How Insects affect the Health in Rural Districts.

178. In sects.

275. The Gypsy Moth and how to Control it.

442. Treatment of Bee Diseases.

447. Bees.

492. The More Important Insect and Fungus Fnemies of the Fruit and Foliage of the Apple.

493. The English Sparrow as a Pest.

513. Fifty Common Birds of Farm and Orchard.

543. Common White Grubs.

621. How to Attract Birds in Northeastern United States.

630. Some Comnon Birds Useful to the Farmer.

679. Horse Flies.

(The School library inay well contain also Long's School of the Woods and Robert's Kindred of the Wild, two charming books that aid in the understanding of nature.) 


\section{PART IV}

\section{STOCK}

\section{CHAPTER XXVII \\ IMPROVEMENT AND FEEDING}

The lowing herd winds slowly o'er the lea. - Gray.

260. The Importance of Farm Animals. - Man owes much of his progress to live stock. The ox and the horse have

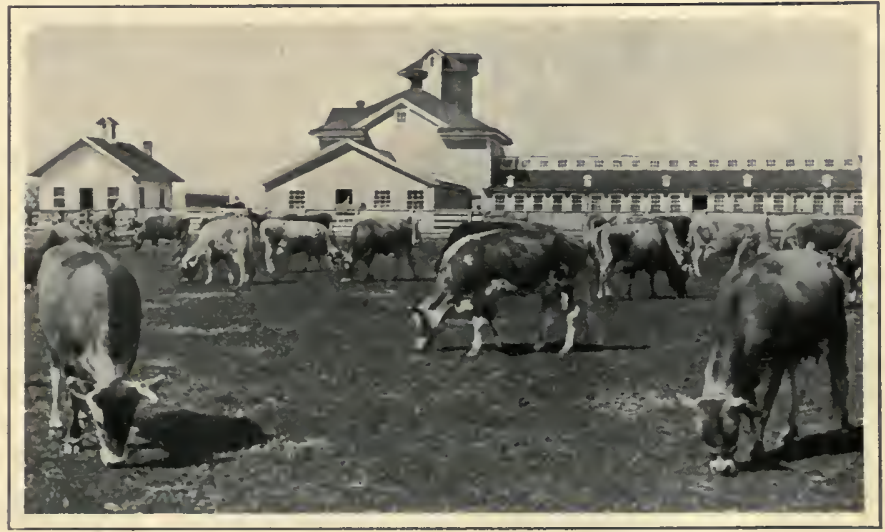

A DAIRY HERD.

made history. Until they were domesticated, our forefathers were not far removed from savagery. Since they became the companions and the helpers of man, their in- 
fluence on him, and his on them, have meant the progress of both. Just when this association was first formed, no one knows. Primitive man left scant records of his doings; and so it is only natural that mystery surrounds the early development of our farm animals.

We do know, however, that our common stock was once wild, and that man domesticated it. He needed the labor of the horse, and at times, the meat; and the milk, flesh, and hides of the cow; the wool and mutton of the sheep; the eggs and meat of the hen; and the manure of all such animals to be spread on the land.

261. How Stock is Improved. - In their wild state, all our farm animals were very inferior to the varieties that we know to-day. The horses lacked speed and draft. The cows furnished enough milk only to supply the needs of their young. Little lard grew on the sides of the swine. The jungle fowl laid no more eggs thm were necessary to keep up the numbers of her offspring. And the wool of the sheep was scant and poor in quality.

Just as man improved wild plants into plants of much higher usefulness to him, so, too, he improved wild animals. The two greater natural forces with which he worked were heredity and variation. These forces we have discussed in Chapter XIV. To-day man understands better how to use these forces than his ancestors did, and recent progress in live-stock improvement has been exceedingly rapid.

Heredity helps the farmer to keep up his standard: variation gives him a chance to improve his standard. The average hen in farm flocks lays about 135 eggs a year. In almost every flock, however, some hens lay more than that. One or two in a common flock may lay 200 eggs. If the farmer can find out which these are (a matter that calls for some time and trouble), and then 
uses only their eggs in raising new chickens, the young hens should, many of them, lay about 200 eggs a year. Those that lay many less should be weeded out. If one or two lay 250 eggs, there is chance for still further advance. By careful "selection" of this kind, chicken breeders in late years have produced whole flocks that average nearly $250 \mathrm{eggs}$ a year, while some 300 -egg hens have been produced. Lady Eglantine, a White Leghorn, of the Delaware station has an official record of 314 eggs for one year. Man's part in this improvement is to select, over and over again, the proper variations that nature offers, and then to protect these selections from going backward toward the old average by mixing with poorer stock.

262. Grading up Live Stock. - Much money could be added to the farmer's income, if his stock had more desirable qualities. For example, the average cow of the United States produces 145 pounds of butter fat yearly. But in 1914, May Rilma, then the champion Guernsey of the world, produced 1058.54 pounds of butter fat-from April 8, 1913, to April 7, 1914; and since then (1915) this record has been beaten by several cows. In all

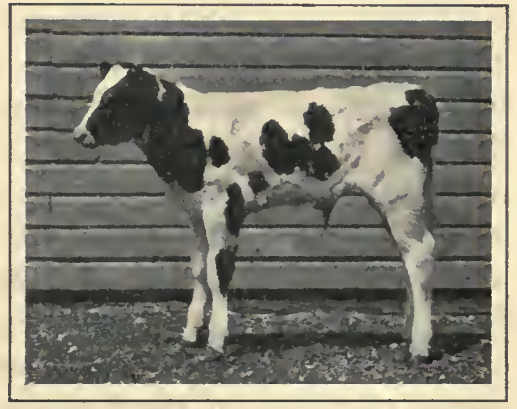

A Holstein Calf.

Sold in Chicago June 5, 1914, for $\$ 20,000$.

herds, there are differences enough in production so that the farmer may "grade up" his herd by selecting only the higher producers for breeding purposes.

Certain terms are in use to express the standing of 
live stock. Pure-bred animals are those which have been bred for particular qualities during a number of generations. To be recognized as "pure," they must have a pedigree, that is, a statement of their ancestry. Grades are the offspring of a "pure-bred" parent and a scrub or another "grade." When more than half of an animal's parentage is pure bred, it is called high grade. If the animal comes from a cross between two different kinds of pure breeds, it is called a crossbred.

Few farmers can afford to stock a farm all at once with pure-bred animals. The cost is too high, desirable as such animals are. As a rule, the best way is to "grade up" the stock. For this, the farmer needs to buy only a pure-bred male for his herd sire. This sire is bred to the best females at hand. Of the offspring, only the best are kept for mothers. By continuing to select and breed in this way, the herd will soon consist of "high grades." If the farmer call afford to buy one or two pure-bred females, along with the sire, he will be laying the foundation for a new pure-bred herd at the same time that he is so "grading up " his old herd.

263. A breeder may aim at any one of a variety of qualities, and, by skillful selection of animals to be bred, he may approach his ideal. Unfortunately, too many breed mainly for qualities that are only ornamental. Until very recently, chicken breeders selected breeding stock more to secure markings of the feathers than to secure high egg production; and prizes at poultry shows have usually been awarded on this false basis. So breeders of Jersey cows have often been in the habit of disearding a good milker if she did not happen to have a black nose and black tongue, while Guernsey breeders discard heifers, otherwise promising, if they do have a black nose.

It is beginning to be understood that such practice is 
wrong. The wise breeder aims at two qualities, - performance and ability to reproduce. The cow that gives a large quantity of good milk is to be preferred, in breeding, to the cow with the most perfect color markings. But even that high-producing cow is of little value to the

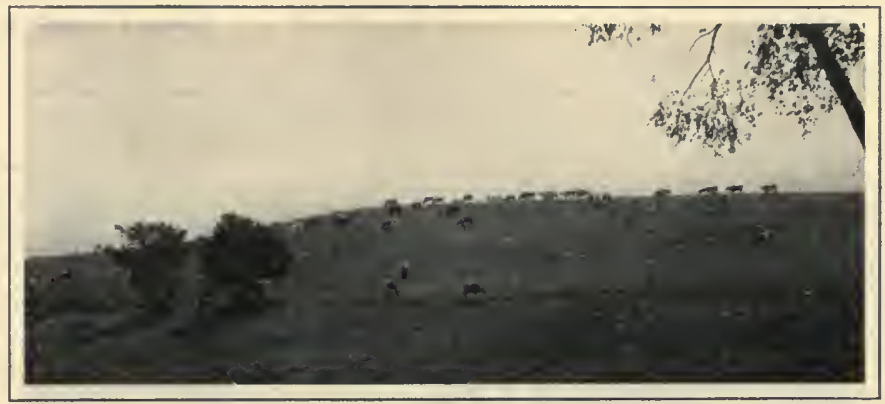

Beef Cattle in Pasture.

dairy world if her calves are few, or weak, or of inferior quality.

264. Feeding. - In getting good results from the farm animals, feeding is next to breeding in importance.

We have learned in Chapter VIII that plants are nourished by such simple foods as nitrates, phosphates, and potash in the soil. Animals cannot make use of these foods directly. It is the work of plants to transform these simple substances into more complex bodies by combining them with other simple compounds like water and carbon dioxide.

265. Three Kinds of Feeds. - In this way, plants form three main kinds of food for animals, - proteins, carbohydrates, and fats. Some mention of these has been made in Chapter XI. In most vegetables and grains, the three are combined in some proportion. But protein occurs nearly pure in the white of an egg; carbohydrate, in 
starch and sugar; and fat, in lard. Stock feeds differ in no way from the vegetable food we serve on the table except in their coarseness, and in the fact that heat is seldom applied in preparing them for eating, and in the further fact that no attention is given to seasoning.

Protein, we have said, contains the important element of nitrogen. Its presence in any feed can be detected by

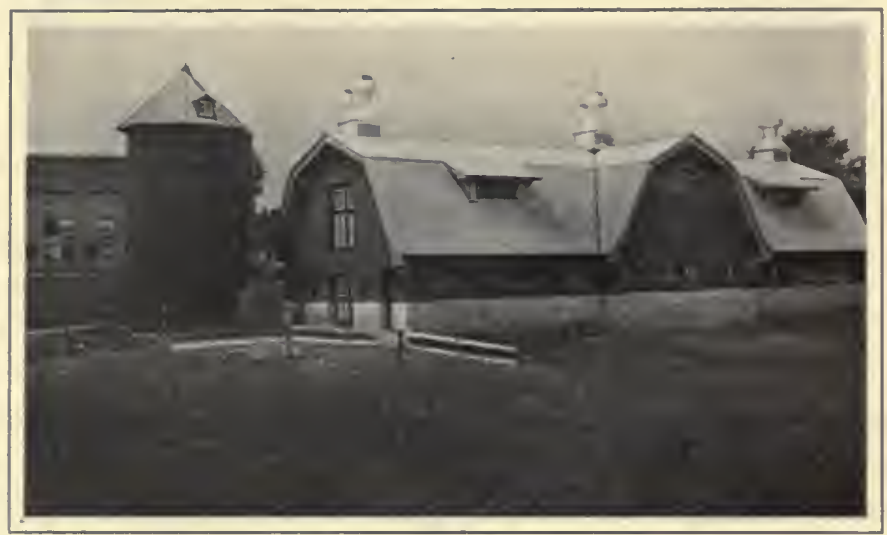

An Elaborate Dairy Barn.

the yellow color produced if a few drops of nitric acid be dropped on it. As found in the white of an egg, it coagulates when heated. Its main work is to build tissues, and to repair those that are wearing out. Recent experiments show that it can also take the place, for a time at least, of earbohydrates and fats, but only at high cost.

Fats and carbohydrates are considered together because their functions in feeding are similar. Both produce energy and yield heat, although fat is two and one fourth times as valuable for this purpose as carbohydrate. Carbohydrate, however, is of particular importance because of its bulkiness and its high per eent of crude fiber. These 
qualities are mechanical aids in digestion. Carbohydrates are readily transformed into fat in the animal's body.

266. The foll wing table shows the per cents, or number of pounds per hundred, of digestible nutrients of dry matter, protein, carbohydrate, and fat, in a few common feeds, together with their nutritive ratios. ${ }^{1}$

\begin{tabular}{|c|c|c|c|c|c|}
\hline 100 Pounis of & & $\begin{array}{c}\text { DRY } \\
\text { MATTER }\end{array}$ & Protein & $\begin{array}{l}\text { CARBOIYY } \\
\text { DRATES } \\
\text { AND FAT }\end{array}$ & $\begin{array}{l}\text { Nutritive } \\
\text { Ratio }\end{array}$ \\
\hline Alfalfa hay & . . & 91.6 & 11.0 & 42.3 & $1: 3.8$ \\
\hline Buckwheat bran . & . . & 89.5 & 7.4 & 34.7 & $1: 4.7$ \\
\hline Clover hay. . & . . & 84.7 & 6.8 & 39.6 & $1: 5.8$ \\
\hline Corn silage . & . . & 20.9 & .9 & 12.9 & $1: 14.3$ \\
\hline Corn grain & . . & 89.1 & 7.9 & 76.4 & $1: 9.7$ \\
\hline Gluten meal. & . . & 91.8 & 25.8 & 68.1 & $1: 2.6$ \\
\hline Linseed meal . & . & 90.8 & 29.3 & 48.5 & $1: 1.7$ \\
\hline Oats, grain & . & 89.0 & 9.2 & 56.8 & $1: 6.2$ \\
\hline Timothy hay. & . & 86.8 & 2.8 & 46.6 & $1: 16.6$ \\
\hline Wheat bran & . & 88.1 & 12.2 & 45.3 & $1: 3.7$ \\
\hline Wheat middlings & s & 87.9 & 12.8 & 60.7 & $1: 4.7$ \\
\hline
\end{tabular}

Nore. If you take any of the numbers in the protein column and divide it into the corresponding number of the carbohydrate and fat column, the second number of the ratio will be found. For example, 42.3 divided by 11.0 equals 3.8. The nutritive ratio then is a method of expressing the protein by 1 and the carbohydrate and fat correspondingly.

It will at once be noticed from the table that there is a wide difference in the composition of foodstuffs. This difference must be taken into account in feeding.

267. Scientific Feeding. - Scientific feeding takes in to consideration the cost, palatability, digestibility, bulk, variety, and composition of different feeds and the effects on the health of the animal. In Henry's feed tables, feeding

I By this phrase, nutritive ratio, is meant the ratio of the weight of digestible protein in any food to the weight of digestible carbohydrates and fat combined. 
standards per day for 1000 pounds live weight are given. Expert feeders follow tables of this nature. Examples of these requirements are as follows:

\section{HeNRY'S Feed TABLe}

\begin{tabular}{|c|c|c|c|c|}
\hline For 1000 Pousds Wright & $\begin{array}{c}\text { DEY } \\
\text { MATTEK }\end{array}$ & P'rotris & $\begin{array}{l}\text { Cario- } \\
\text { IYORATE } \\
\text { AND Fat }\end{array}$ & $\begin{array}{l}\text { Netritivk } \\
\text { liatio }\end{array}$ \\
\hline Horse moderately worked. & $\begin{array}{c}\text { Pounds } \\
24\end{array}$ & $\begin{array}{l}\text { Pounds } \\
2.0\end{array}$ & $\begin{array}{c}\text { Pontnds } \\
12.4\end{array}$ & $1: 6.2$ \\
\hline Cows giving 11 pounds milk daily & 25 & 1.6 & 10.7 & $1: 6.7$ \\
\hline Cows giving 22 pounds milk daily & 29 & 2.5 & 14.1 & $1: 5.6$ \\
\hline Fattening cattle . . . . . . & 30 & 3.0 & 16.1 & $1: 5.4$ \\
\hline Fattening swine . . . . . & 32 & 4.0 & 25.1 & $1: 6.3$ \\
\hline Poultry, for egg production . . & $5 \overline{5}$ & 8.2 & 39.4 & $1: 4.8$ \\
\hline
\end{tabular}

Suppose a 1000-pound horse, moderately worked, were given the following rations daily :

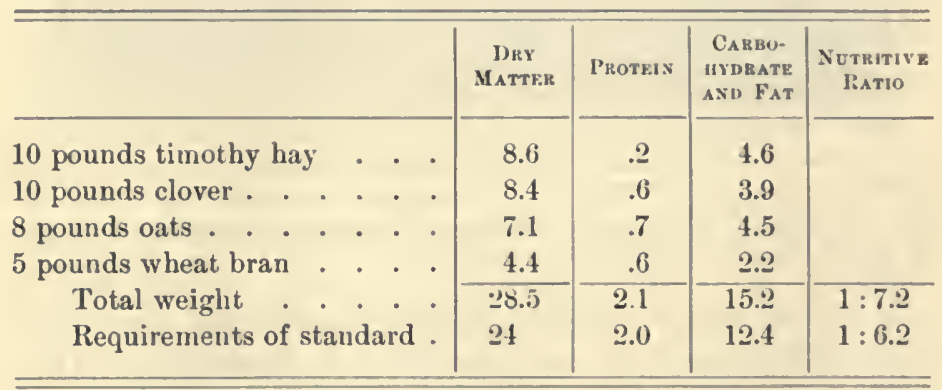

By comparing the total weight with the requirements as stated in the table, it will be noticed that the feed or ration selected contains too much dry matter and carbohydrate and fat and a very slight excess of protein, and that the nutritive ratio is too wide; that is, there is not enough protein for the carbohydrate and fat. A feed, therefore, should be selected with consideration of cost, palatability, 
and varicty, that would supply less dry matter and carbohydrate and fat, and that would bring down or narrow the nutritive ratio to nearly $1: 6.2$. Such a feed would be what is known as a balanced ration.

Let us make another trial ration, dropping the clover hay entirely and substituting linseed meal for wheat bran.

14 pounds timothy hay . . 10 pounds oats . . . . 3 pounds linseed meal . . . Total weight ....

Requirement of standard

\begin{tabular}{|c|c|c|c|}
\hline $\begin{array}{c}\text { DRY } \\
\text { MATrEB }\end{array}$ & Protein & $\begin{array}{c}\text { CARBO- } \\
\text { GADRATR } \\
\text { AND FATS }\end{array}$ & $\begin{array}{l}\text { Nutritive } \\
\text { Patio }\end{array}$ \\
\hline 12.15 & .392 & 6.52 & \\
\hline 8.9 & .92 & 5.68 & \\
\hline 2.72 & .879 & 1.46 & \\
\hline 23.77 & 2.191 & 13.66 & $1: 6.2$ \\
\hline 24.00 & 2.00 & 12.4 & $1: 6.2$ \\
\hline
\end{tabular}

It will at once be noticed that the above proportions satisfy the requirements of the standard ration as to nutritive ratio exactly, and as to the other three requirements very closely. Theoretically, then, other things being favorable, these quantities of feeds may be used. It is quite possible, however, that the first ration would give as good results as the second in spite of its greater variation from the standard. The linseed meal has a marked effect on the digestive action of the bowels and is used mostly to secure finish in a horse for sale or for the show ring, but not above ten per cent of the total feed. If we take one pound of linseed meal and two pounds of wheat bran instead of the three pounds of the linseed meal, we should have, for most work horses, a better ration, although one not as closely balanced as the one just given.

268. From the standpoint of bulk, feedstuffs are divided into two classes, - roughages and concentrates. By roughage is meant coarse materials like silage, fodder, and hay. Concentrates contain more nourishment, bulk for bulk. 
Bran, grains, middlings, chop of all sorts, are examples of concentrates. Good feeding requires in mixture of both roughage and concentrates. Roughage is used mostly for filling up the intestines and for carrying along the more nutritious feeds.

\section{Practical, Questions}

1. How do the improvement and the feeding of stock go together? 2. Which is the most important factor in improvenent, feeding or breeding? 3. Define and illustrate the law of heredity. 4. Is the law of heredity of more practical value to the farmer than the law of variation? 5. What is meant by "grading up" a herd? 6. Contrast a "grade" with a crossbred. 7. For what ideals should a breeder strive? 8. As regards the food consumed, how do plants differ from animals? 9. Give the function of each class of feed for animals. 10. What points are considered in scientifie feeding? 11. Define a balanced ration and a nutritive ratio. 12. Work out a balanced ratio for a cow weighing 1000 pounds and giving 22 pounds of milk daily. 13. Distinguish between a roughage and a concentrate.

\section{IIOME EXERCISE}

1. Give a complete report on the methods of home feeding and compare these methods with those of the standard tables so far as they are given in the table.

2. What pure-bred stock do you have? Ask your father whether pure-bred stock pays.

3. How much money does your father spend each year for feed? If there is an analysis given on the sacks, copy it and bring the analysis to school.

\section{Suggestions}

1. To illustrate the universal laws of heredity and variation, many leaves of a tree, the apple leaf for instance, may be brought to school. Fach pupil may try to find two exactly alike.

2. One hundred leaves should be measured and a graph (like those made in algebra) of then may be placed cn the board. Arrange the graph as follows:

For the smallest leaf, place a dot in the upper right-hand corner above nnmber 1 , aud opposite the number for centimeters (fractional 
parts of an inch, quarters, for example, may be used) appearing on the left side. The numbers on the side indicate the height of the leaf. A mark for the next larger should be placed above number 2, in the upper right-hand corner of the square opposite its height, and so on. Draw a line connecting these points. The horizontal tendency of the line represents the law of heredity; its vertical tendency, the law of variation. ${ }^{1}$

\section{Refirences}

The Feeding of Animals. Jordan.

Feeding Farm Animals. Shaw.

Principles of Breeding. Davenport.

Management and Feeding of Cattle. Shaw.

Farmers' Bulletins. Washington, D.C.

22. The Feeding of Farm Animals.

170. Principles of Horse Feeding.

251. Cheap Dairy Rations.

305. Roots and Cabbages for Stock Food.

1 This statement is not strictly accurate since heredity and variation refer to the likeness or unlikeness between ancestors and offspring. The method of procedure, however, were the materials as available, would be the same as above. 


\section{CHAPTER XXVIII}

\section{OATTLE}

The cattle are grazing, Their heads never raising, There are forty feeding like one. - WовDsw овтн.

269. All boys and girls are naturally interested in cattle. Cattle are beautiful creatures, and in most eases entirely harmless. Watch the cows grazing. They move along

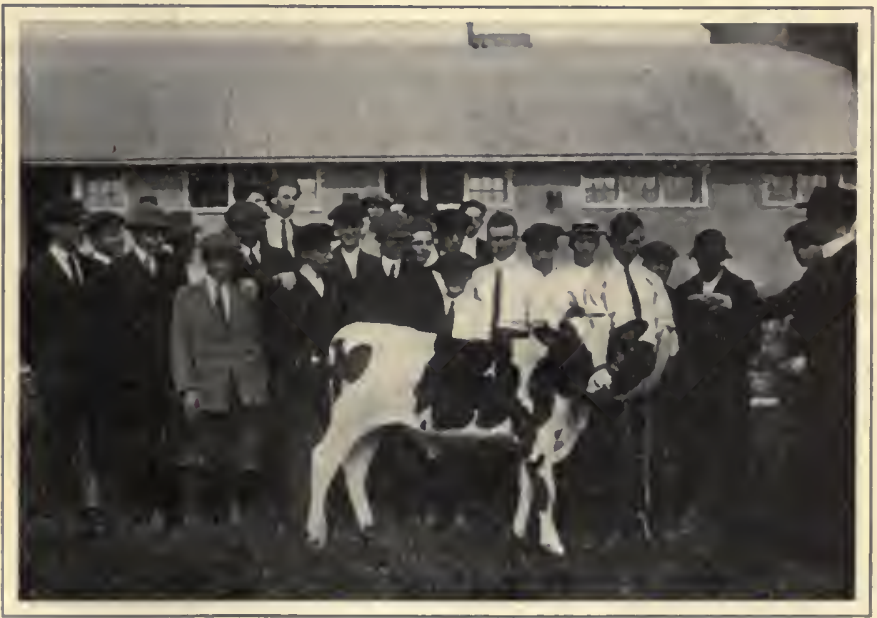

Live-sTOCK JUDGING.

together, facing in one direetion, cropping rapidly and steadily. Watch them at noonday chewing the eud, lying under a spreading tree, or standing knee-deep in a cool 
stream, - a perfect picture of peace and contentment. Then the young calf! What a wabbly creature it is! Because it cannot stand the journey with its mother while she is browsing she hides it, perhaps in a clump of bushes. And for the reason that it must go without food for a long time, it has a large, compound stomach which holds nourishment enough for several hours. The mother, too, feeding her young at such long intervals, needs a large udder to hold the milk supply.

270. Farmers, however, raise cows, not because they are beautiful, or have interesting structures and habits, but because they may be very profitable. There was a time when cattle were the main bearers of man's burdens. They serve that purpose still in China, and, indeed, to some degree, even in some sections of the United States. In our pioneer days, especially when there was much logging to be done, oxen were preferred to horses. Oxen pulled slowly but steadily, and had sufficient patience for such tedious work. As draft animals they even yet are widely used, particularly in foreign countries.

The main reason, however, for our interest in cattle lies in the fact that they supply us with meat, hides, milk, and many useful products of milk, - cream, butter, and cheese, - and that they supply large quantities of manure. We have learned how important it is to keep up soil fertility. Cattle return to the soil as manure nearly three fourths of the fertile elements which they consume as food.

The breeds of farm cattle are classified under two heads, - beef cattle and dairy cattle.

271. Beef Types. - The use to which our forefathers designed cattle determined their type. Beef and the ability to produce just enough milk to feed the calves were the two things wanted in the beef types. The ani- 
mals belonging to that type are low, blocky, compact, broad in the back, and usually poor milkers. The common breeds are: Shorthorn, or Durham, Polled Durham, Hereford, Aberdeen Angus, and Galloway.

(a) The Shorthorns, or Durhams, came from northern England. They were early brought to this country, and are widely distributed and very popular here. Even as a

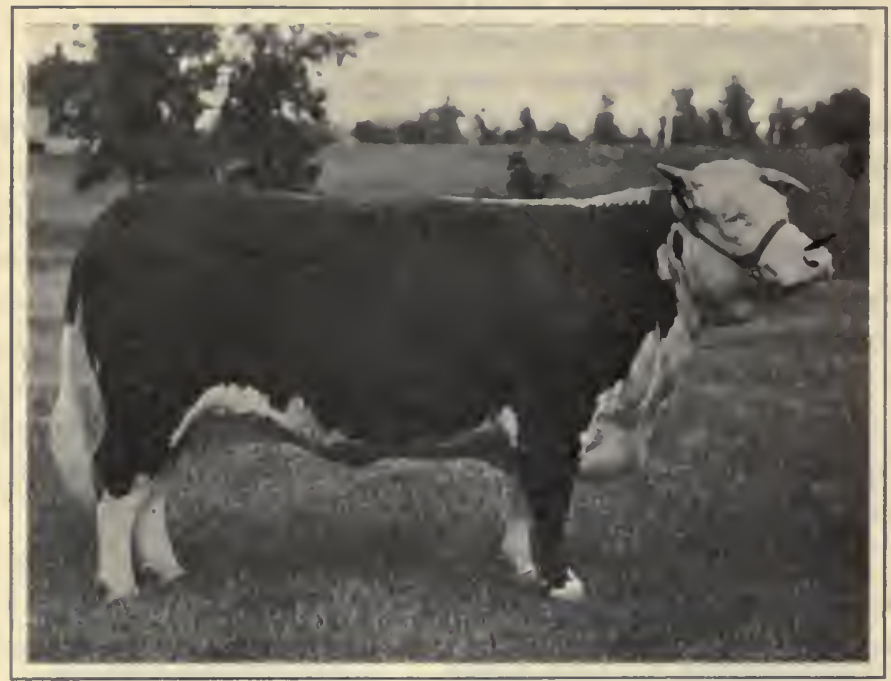

HEREFORD COW.

dairy animal they sometimes take fair rank. In England there is eonsiderable Shorthorn blood in good dairy herds. The horn is variable but always short. In eolor they have a wide range, being pure red, red and white, pure white, or roan. (Roan is a growing together of red and white hair without forming solid patches of either color.)

The Polled Durhams are merely hornless Shorthorns.

(b) The Hereford cattle come from Hereford in the western part of England. They were first imported 
into the United States by Henry Clay in 1817. As a breed, they seem best adapted to level regions. They are found, therefore, chiefly on the plains west of the Mis-

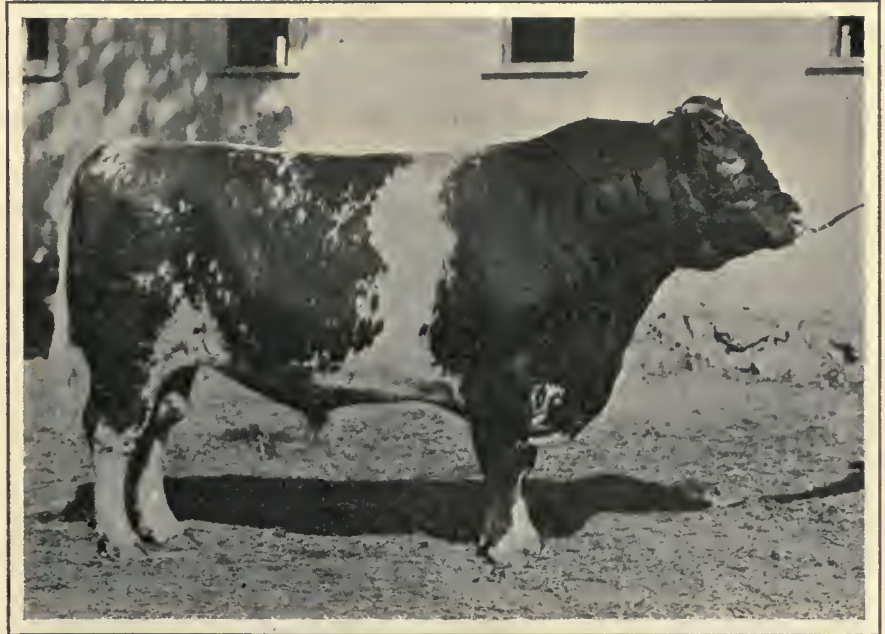

SHORTHORN BULL.

sissippi, and the prairies of Argentina and Australia. Their thick coat of hair and their-strong vitality makes them unusually successful under hard conditions of cli-

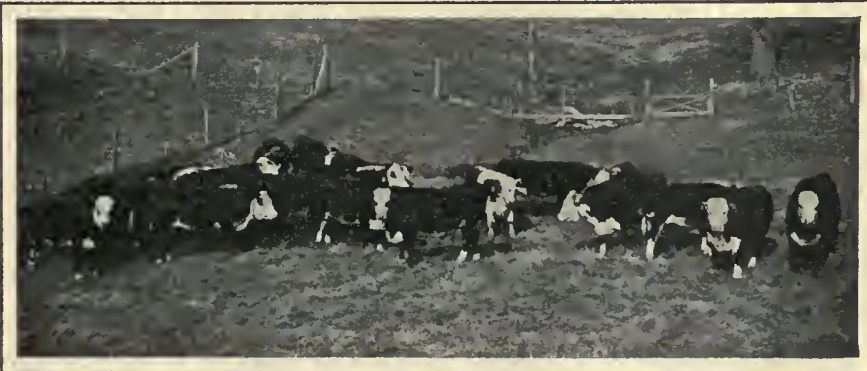

HEREFoRdS AT PASTURE. 
mate. They are occasionally called "white faces," because the white face and underline contrast sharply with the red bodies. The muzzle is flesh-colored, and the horns well-developed.

(c) The Aberdeen Angus. In the northeastern part of Scotland, in the districts of $A$ berdeen and Angus, there was developed an important beef breed which was un-

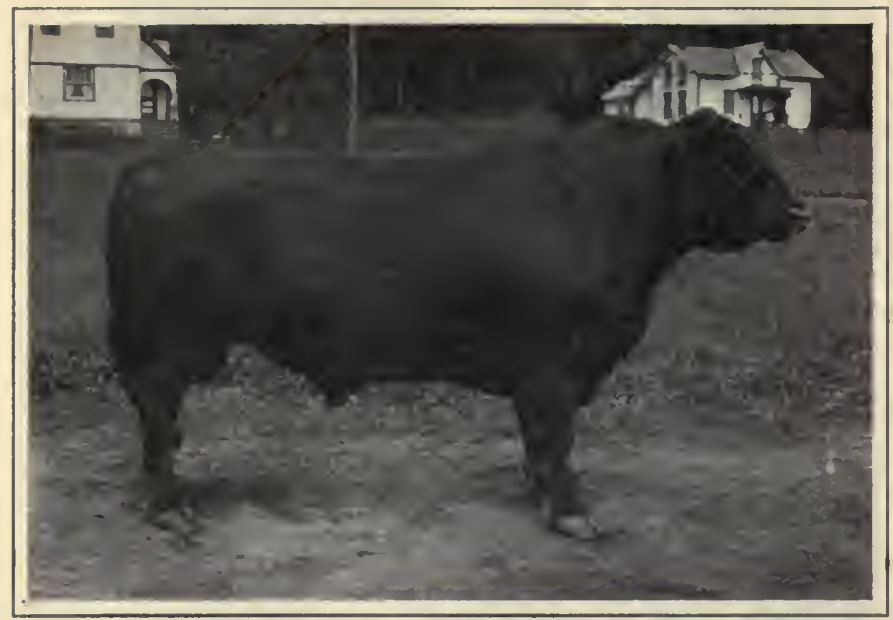

Aberdeen Angus Bull.

known to American cattlemen until the year 1873. Since that date it has met with high favor in all the states of the Union. The cattle are hornless (or polled) and black in color.

(d) The Galloway breed was named after its home, Galloway, in southwestern Scotland. As a type, they resemble the Aberdeen Angus except that the black hair is very shaggy, especially in winter. Since the disappearance of the buffalo, the hide of this animal is much sought for floor rugs, overcoats, and lap robes. Large herds are 
found in Indiana and Illinois, and the breed is not uncommon in other sections. It has marked ability to withstand the rigors of western winters.

272. Dairy Types. - In outline the dairy cow forms, inore or less clearly, three separate wedges. If we look at her from one side, we can see that her upper and under body lines would come together if produced in front of the head. This is the first wedge. Looked at from the top and rear her body becomes wider from the chest to the hips. This is the second wedge. Viewed from the top and front she gradually widens from the withers (the juncture of the neck and back) backward over the abdomen. This is the third wedge. In

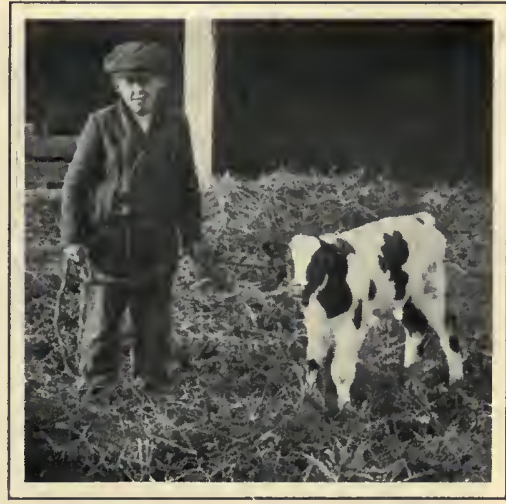

Raising a Holstein Calf. general, while the members of the beef breeds show graceful curves in their bodily outlines, those of the dairy breeds show angles and broken lines. All the other organs of the body seem to radiate from, and to exist for, the udder and the allied structures.

The head of a dairy animal should be lean, with large nostrils, and with a little dish to a broad; intelligent face. The eyes should be calm, clear, and bright. The neck, in the female, should be long and thin. In the male, there should be a heavily muscled chest, well filled out, showing constitution and vigor. The front legs should be straight; the ribs, well arched; the hips, prominent, especially in the female; the thighs, muscular, 
not fatty. Fine hair, covering a soft skin, indicates quality.

When buying a dairy cow, however, the most important part of the body to consider is the udder. When milked dry, this should hang limp and be soft and pliable to the touch, showing good secreting tissue rather than an excess of meaty tissue, and when full, it should form a graceful curve from a point high up in the rear to another well advanced in front. Prominent and winding milk veins, carrying the blood from the udder into the body wall, indicate an ample blood supply.

The common dairy breeds are the Jersey, Guernsey, Ayrshire, and Holstein-Friesian. For dairy cows in the United States, see Appendix A, Chart IX, page 471.

273. The Jersey. - In the English Channel, about fourteen miles from the coast of France, is the Jersey Island,

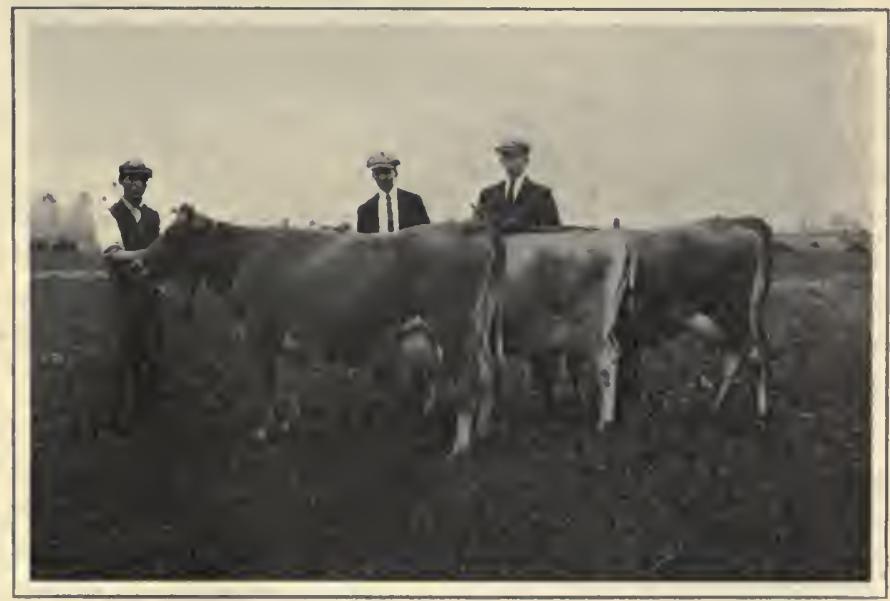

JERSEY Cows.

The cow in front has a record of $7014 \mathrm{lb}$. of milk and $443 \mathrm{lb}$. of butter in a year; the one at the rear, $9656 \mathrm{lb}$. of milk and $613 \mathrm{lb}$. of butter in a year; the one in the middle, $6963 \mathrm{lb}$. of milk and $388 \mathrm{lb}$. of butter in eight months. 
the native home of the celebrated Jersey breed. There are less than 40,000 acres on this island; but it supports about 60,000 people and 12,000 Jersey cattle. In England the cattle from the Channel Islands are called "Alderney," and they were so named for many years in America.

The color, while quite variable, is generally a fawn, although yellowish and grayish Jerseys are sometimes

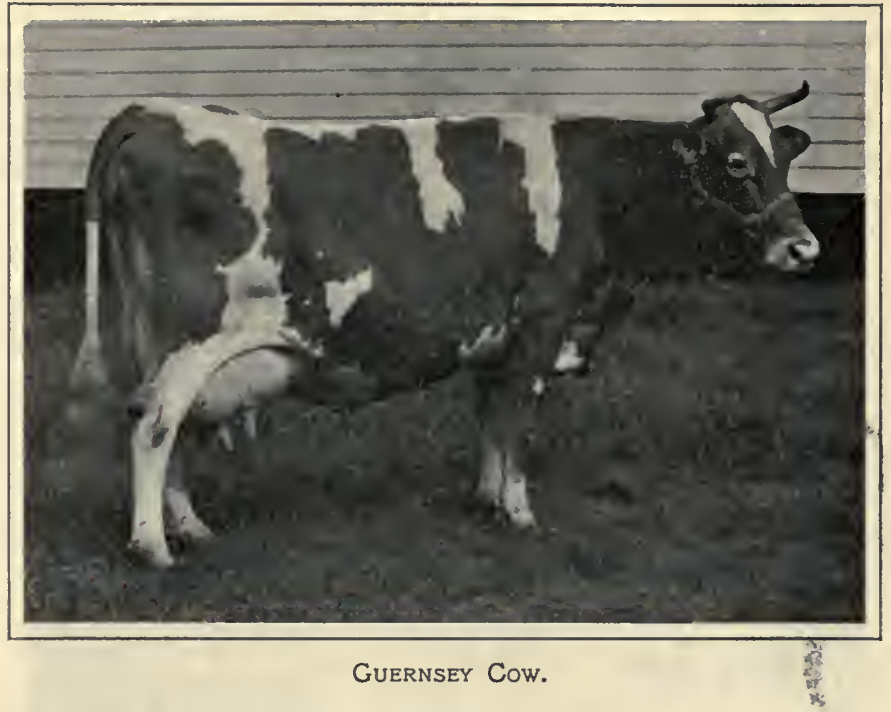

found, and a solid dark brown color is becoming. very common. The hair about the nostrils is grayish or creamy. A black tongue and nose and blackish tips to the amber-color horns are fashionable traits.

High prices have been paid for Jerseys. The bull Eminent $69,631^{1}$ was sold May 30, 1905, at public auction for $\$ 10,000$ and soon after changed hands again at private sale at a still higher figure.

1 Pure-bred cattle are " registered" by numbers. This number, 69,631 , is the registry number of this famous bull. 
274. The Guernsey breed is closely related to the Jersey in history and characteristics. The island of Guernsey, the home of this breed, lies only a short distance from that of Jersey, and contains only 12,600 acres of land. On the average, the Guernsey breed runs slightly larger than the Jersey and is coarser in bone. The color is yellowish, browuish, or reddish fawn, with white marking on the limbs and body. The muzzle is commonly buff, and is encircled by a ring of yellowish hair, as are also the eyes. In quality and quantity of milk, the Guernseys are much like the Jerseys. They are claimed to be the hardier and less subject to disease; and at present (1916) their prices range higher.

275. The Ayrshire takes its name from the county of Ayr, in southwestern Scotland. It was introduced into the United States most likely by way of Canada, and has

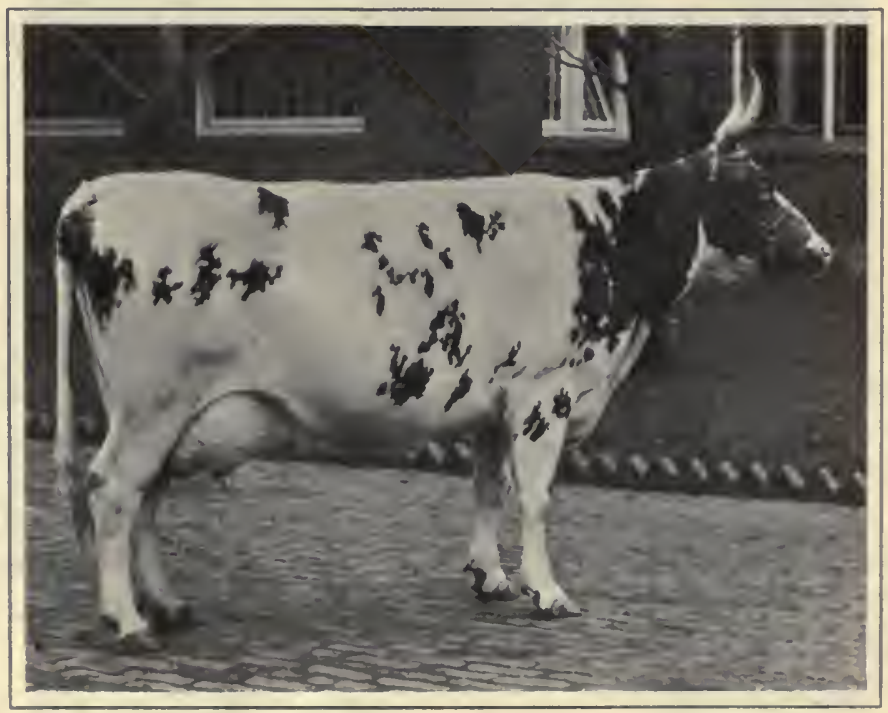

AYRSHIRE COW. 
spread extensively over New England and the eastern states. Because their ancestors were accustomed to the mountains of Scotland, these cattle seem to thrive well on our hillsides. They are medium in size, with a tendency toward beefiness. The color is reddish brown or white, or a combination of the two. The horns are white, up-curving, and black-tipped. The body is large and the ribs well sprung. This breed so far has produced no cows that equal the leading ones of the other three dairy breeds. 276. The Holstein-Friesian. - About forty years ago, cattle by the name of Holstein and Dutch-Friesian were

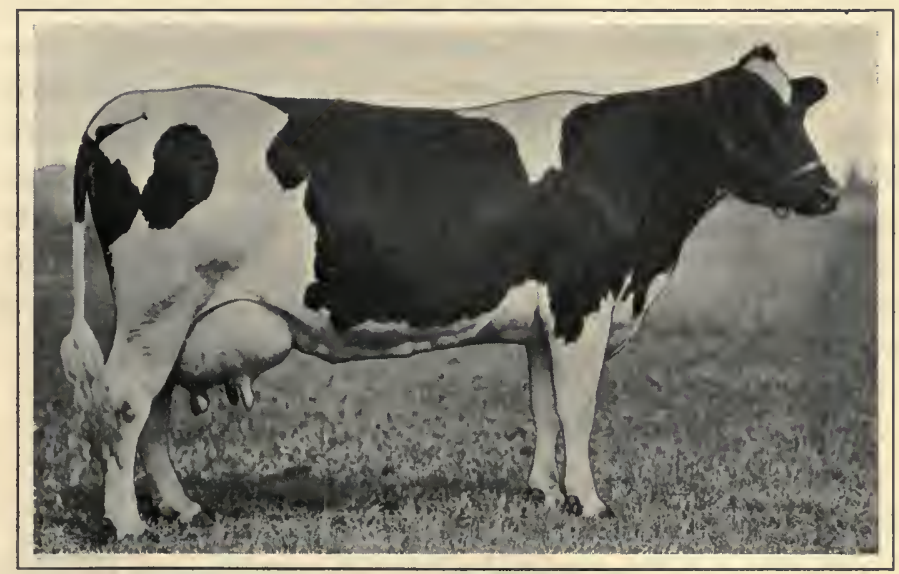

Holstein Cow.

This cow, Johanna Rue, gave $28,403.7 \mathrm{lb}$. of milk in one year.

brought into this country and sold as different breeds. Holstein is a province of North Germany, and Friesland, a district of Holland. The cattle from the two places were similar; and, after considerable discussion, the importers came together and agreed to call them HolsteinFriesian. Recently, the single name Holstein has been used for this breed. 
The Holsteins are now a very popular breed, particularly where milk is sold by the quart rather than on the fat basis. In the Lonisiana Purchase Exposition test, 15 Holstein cows each made a daily average of 53.4 pounds of milk for 120 days, as compared with 41.5 for the Jerseys. A Holstein owned by Powell Brothers of Pennsylvania produced a daily milk yield of $122 \frac{1}{2}$ pounds. A recent California test showed $30,318 \frac{1}{2}$ pounds in one year. Holstein milk, however, is far less rich than Jersey or Guernsey milk. The Holsteins are black and white in color, large in build, with white horns, usually blacktipped, and with a U-shaped udder.

277. Fat in Milk. - Experiments have shown that feeding can affect only the quantity of milk, not the per cent of fat in milk. However, it is known that the per cent of fat (1) increases as the cows approach the period of dryness; (2) as the last portion of milk is being drawn from the udder; and (3) as the time between milkings is shortened. The following is the average per cent of milk fat of several thousand Ameriean cows of the leading breeds :

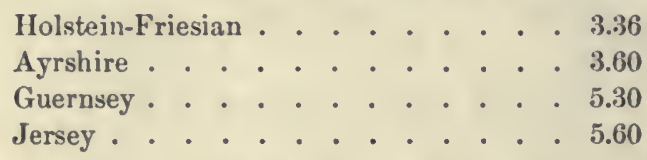

This topic will be treated more fully in the next chapter. 278. Feeding. - When cows are fed, their bodily demands are first taken care of. In other words, they maintain themselves before producing milk or extra fat. Too little feed for a dairy cow cuts down the milk yield, but does not affect the quality of the milk; an excess of feed increases the total weight of the animal, but does not affect milk yields when compared with the result of normal feeding. The following illustrations, given by Van Norman, show this : 
Fed too much

Production

$15 \mathrm{lb} .4 \%$ milk

Maintenance

Production

15 lb. $4 \%$ milk

Maintenance

Fed too little

Fed just enough

\section{Production}

$10 \mathrm{lb} .4 \%$ milk

The different Experiment Stations have been invest1gating the best rations for cattle. The nutritive ratio for a dairy cow should be near 1:6; that is, one pound of digestible protein to six pounds of carbohydrate and fat. The following dairy rations are suggested by the Experiment Station of Indiana,

RATION I

Clover hay . . 18 pounds

Corn . . . 5 pounds

Wheat bran or oats . . . 6 pounds

Cottonseed meal . 1 pound
Ration II Corn silage . . . 30 pounds Cow pea hay . . 10 pounds Corn stover . . 2 pounds Corn . . . . 6 pounds Cottonseed meal . . 1.5 pounds

The foregoing ration is for cows weighing 1000 pounds, giving 22 pounds of milk daily. For each additional three pounds of milk, there should be added a pound of the ground feed mixture. Heavier cattle should have an increase of roughage about in proportion to the increase in weight.

In feeding baby beef (beef cattle between one and two years of age and weighing less than 1100 pounds) it is well to remember that young animals make a greater gain in weight on a given quantity of food than older animals do, and that baby beef has more of a tendency to grow than to fatten, or to "show finish." For this reason baby beef is fed a heavy ration of grain. In the beginning of 
the feeding period, however, considerable quantities of such feeds as clover, cow peas, hay, and alfalfa should be fed. Later, an increase in such fattening concentrate as linseed meal, shelled corn, or cottonseed meal is recommended.

279. Care of Cattle. - Cattle can get along by drinking once a day, but it is much better to give them an oppor-

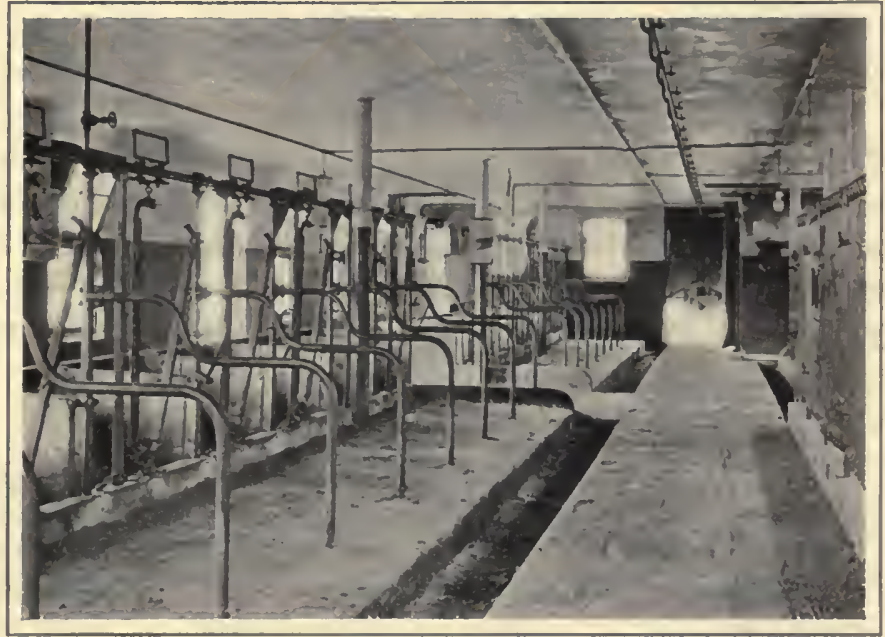

INTERIOR OF DARY BARN.

tunity to drink oftener. Milk cows require about ten gallons of water daily. Cattle exposed to bad weather eat more than those properly protected, and drop in the production of beef or milk. A part of the energy that should go to production goes to maintenance instead.

The stables should be well lighted, and well ventilated, and should be kept clean and sanitary. Unsanitary conditions not only decrease the yields of milk or beef, but reduce vitality and make the stock more susceptible to tuberculosis and other diseases. System, kindness, and regularity in feeding account for much of the profits with 
cattle. When changes are to be made from one kind of feed to another, the new feed should be introduced into the old at first in very small quantities.

\section{Practical Questions}

1. How do cattle serve mankind? 2. What are the characteristics of the beef breed? 3. Name the beef breeds. 4. Describe a beef animal which you may have seen. 5. Deseribe the dairy type of cattle. 6. How does a Jersey differ from a Guernsey? 7. What makes the Holstein a popular breed? 8. Which breed gives the poorest milk? Which the richest? 9. How do you distinguish between maintenance and production? 10. State how your cattle are cared for at home. 11. Does it pay to be kind to animals? Why?

\section{Hone EXercises}

1. Start a baby beef club as recommended by the United States Department of Agriculture or by your local College of Agriculture. Keep all records such as cost of feeding and daily rations. Club members whenever possible should grow their own feed in a distinct exercise. All the details which the club members need to know will be supplied free of charge. The suggested basis of reward is as follows:

(1) Condition of beef at end of period, judged by score card for beef cattle . . . . . . . . 30

(2) Net profit . . . . . . . . . 30

(3) Selection of breed . . . . . . . . . 20

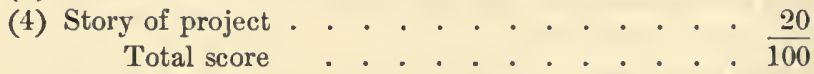

2. In dairy sections it is desirable to start a systematic milk testing exercise for dairy cows. Get in touch with the plans and awards as provided at Washington or elsewhere. Apart from the exceedingly useful practice for the students, this work may be very helpful to the community.

\section{Suggestions}

Score cards for cattle provide interesting and helpful ways for fixing the main points to be looked for. The numbers given under "perfect score" indicate structures that show no defects and unsoundness. After each of these numbers, in the next column, the pupils may place "the score" or number they think the animal deserves.

Scoring should be done in a neighboring barn, if it is not advisable 
to bring an animal to the school yard. This work should be first demonstrated by the teacher before the pupils are given home animals to score.

If other score cards not given in this book are desired, for example, a score card for beef cattle, send to your State Experiment Station for them; also for fuller instructions.

The following is a helpful score card for dairy cattle.

\section{General Appearance}

Form, triple wedge (See Text) . . . . . . 6

Quality, hair fine; skin soft; bone clean . . . 8

Constitution, active, vigorous, healthy . . . . . 8

\section{Head and Neck}

Muzzle, clean-cut; mouth and nostrils large . .

Eyes, bright, large

Face, lean, loug; expression quiet

Forehead, long, slightly dished .

Ears, yellow inside; texture fine

Neck, medium length; throat clean

\section{Fore and Hind Quarters}

Withers, lean, thin. Shoulders, angular not fleshy . Hips, wide apart, not lower than spine

Kump, long, wide, level.

Thighs, thin, long.

Legs, straight, short

\section{Body}

Chest, deep, low; ribs well sprung . . . . . . . 9

Abdomen, large

Back, leall, straight. Tail, long, slim

Loin, broad, level

\section{Milk-secreting Organs}

Udder, large, long, well-curved; teats, evenly placed Milk veins, large, tortuous; milk wells large 


\section{ReFERENCES}

Manual of Farm Animals. Harper.

Types and Breeds of Farm Animals. Plumb.

Farmers' Bulletins. Washington, D.C.

55. The Dairy Herd: Its Formation and Management.

71. Essentials on Beef Production.

106. Breeds of Dairy Cattle.

183. Meat on the Farm: Butchering, Curing, and Keeping.

233. Beef and Dairy Types of Breeds.

350. The Dehorning of Cattle.

473. Tuberculosis.

480. Practical Methods of Disinfecting Stables. Minnesota: Feeding Dairy Cows. Haecker.

(See also the references at the close of the preceding chapter.) 


\section{CHAPTER XXIX \\ MILK AND ITS PRODUOTS}

Such as have need of milk, and not of strong meat. - IIвнве ws v. 12.

280. Milk as Food. - Milk is one of the commonest articles of diet. It contains all the food elements necessary for growth. Milk not only ranks high in nourishing value, but, unlike vegetables, it is almost completely digested. Milk is also a very cheap food. Four pounds of milk (two

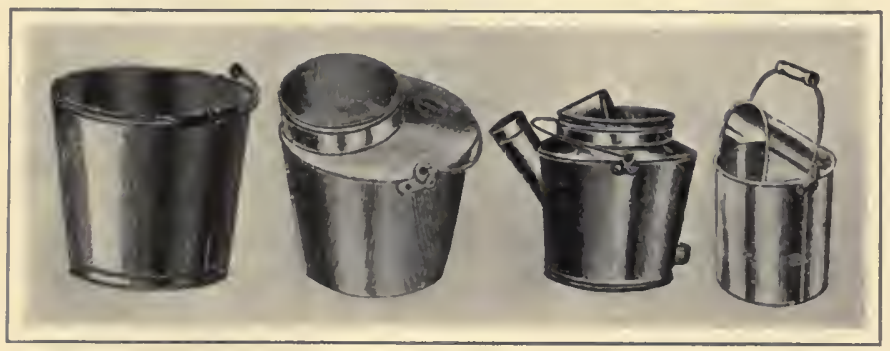

Milk PaILS.

quarts), costing twelve cents, will build the same amount of tissue as one pound of sirloin steak, costing twentyeight cents; and five pounds of skim milk, costing six cents, contain as much nourishment as a pound of the best beef, costing five or six times as much. So far as we know, milk has always been an important human food; and with its products, butter and cheese, it is now a popular food among all civilized people. 
281. The composition of the average milk of 5552 American cows, as compiled by Dr. Van Slyke of the Geneva, New York, Experiment Station is as follows :

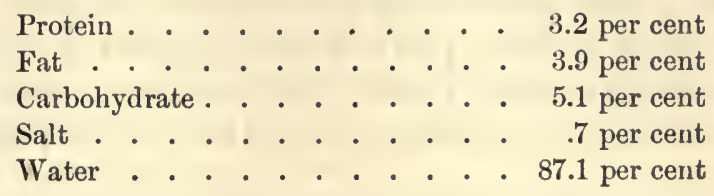

Protein is present in the milk in the form of casein and albumin. Albumin forms less than one fourth of the protein. Casein is the curd formed in milk when it sours. The greater part of cheese is curd. The carbohydrate occurs as milk sugar. Together with the casein it gives skimmed milk and buttermilk their value as foods. Milk sugar is separated from milk by evaporating the whey. The salts supply the minerals needed in bones.

282. Definitions. - Skim milk is what is left after the cream has been removed. Cream is the layer of the milk that rises to the surface on standing; it is rich in butter fat. Evaporated cream has lost a considerable portion of its water by evaporation. Buttermilk is the residue from cream in churning. Pasteurized milk is milk that has been slowly heated to about $160^{\circ} \mathrm{F}$. for about 20 minutes, to kill disease germs, and then rapidly cooled. Sterilized milk is milk that has been brought to the boiling point, to destroy all germs. Condensed milk is a form of milk that has lost considerable water by evaporation. Certified milk is milk which is sold in sterilized bottles and for which a certain degree of purity is guaranteed by the producer. It is produced and bottled under the most sanitary conditions. Butter is the condensed mass of ripened cream containing, in addition to fat, certain other substances, as salt and water. Whey is what is left over after the casein and fat have been removed in cheese 
making. Milk fat, or butter fat, is the fatty or oily part of milk. It is explained more fully two paragraphs below.

283. Quantity of Production. - Some instances of highproducing cows have been given in earlier chapters. The farmer ought to know just how many pounds of milk each of his cows gives each year. It will not do to guess at it. Many a cow gives a foaming pail - too largely foam - at

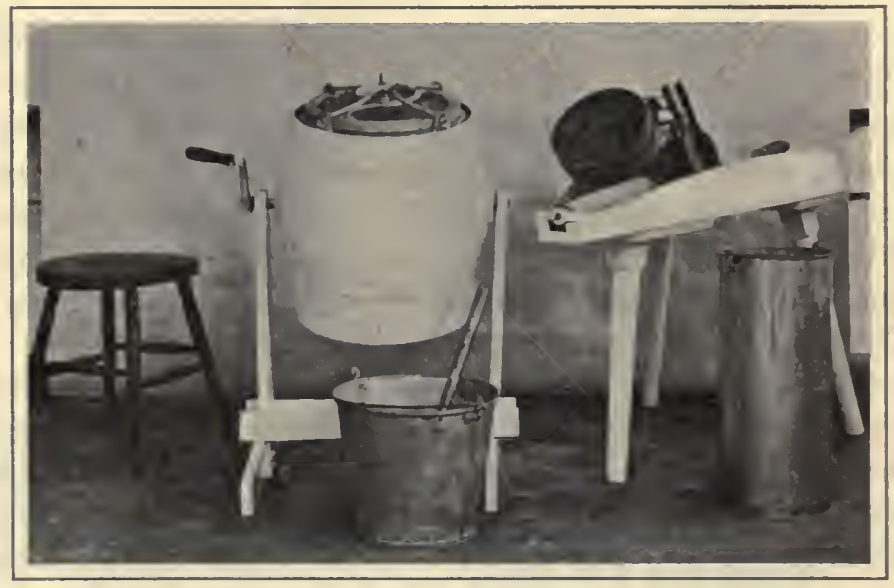

Butter Making OUtfit.

the first of a period, and wins golden opinions, but falls off sooner than the milker notes, or is dry for an unprofitably long period. The farmer should have a set of dairy scales suspended behind the cows, and a "record sheet" fastened to the wall. The best way, thell, is to weigh and record each cow's milk at every milking, and find the totals for each month. The little time needed for this is more than repaid, merely by the added interest taken by the milkers in their work. But fairly accurate knowledge of the cows' yield may be secured, if milk is weighed only once a week, both night and morning, on a fixed day. 
284. The quality of milk varies mainly in the matter of the fat. Milk fat is found in milk as microscopic globules, one drop of milk containing more than $100,000,000$ of them. Eight thousand fat globules placed side by side would reach one inch. The globules are lighter than the other parts of the milk, and therefore rise to the surface or may be removed by the whirling of a separator. About eightyfour per cent of butter is fat.

285. The Babcock Test. - In 1890, Dr. S. M. Babcock, chief chemist of the Wisconsin Experiment Station, in-

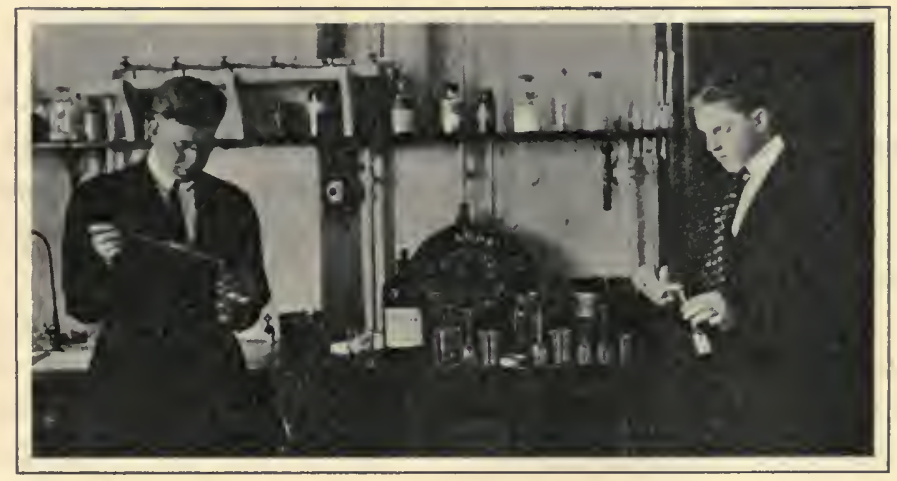

Testing Milk - Babcock Tester.

vented a method of ascertaining the amount of fat in milk and in milk products. The testing outfit consists of (1) a centrifugal machine, (2) two or more test bottles, (3) a pipette for accurately measuring the milk, (4) an acid measure, and (5) common sulphuric acid. A small testing outfit, suitable for school purposes, or for a small herd of cows, can be bought from any dairy supply house for about five dollars.

The following is a brief outline showing the successive steps of milk testing :- 
1) Get milk near $60^{\circ} \mathrm{F}$; mix thoroughly by pouring from vessel to vessel.

2) Fill pipette to the mark with milk.

3) Empty pipette in test bottle.

4) Fill the acid measure to the mark, and pour the acid into the test bottle, washing down any milk hanging to the neck.

5) Shake test bottle at once until the solution has a coffee color.

6) Place an even number of test bottles in the pockets of the machine and whirl five minutes.

7) Add hot water (hot enough to make the fingers uncomfortable) up to the neck of the bottles.

8) Whirl one minute.

9) Add hot water up to mark 7 or 8 on stem.

10) Whirl one minute.

11) Read the fat column at the temperature of about $130^{\circ} \mathrm{F}$.

'There are many details in successful milk testing, which can be mastered by observing the operation in a dairy. Manufacturers of machines, too, inclose minute directions with every outfit they sell. Only a few precautions are given here:

Do not get any acid on your fingers, or allow it to drop on the floor. If some should fall on the woodwork of the schoolroom, or get on the hands, wash with water at once. Practice is needed in using the pipette. Be sure the finger is dry, when allowing the pipette to drain to the mark. In a small machine, espeeially in cold weather, it may be necessary to fill the jacket on the outside of the bottles with hot water. Each division on the stem of the test bottle equals 0.2 per cent fat, but heat expands and cold contracts this column. If white cheesy particles appear below the column of fat, the acid may have been too weak or too little in quantity, or the milk may have been too cold or not properly mixed with the acid. If black partieles appear, some of the opposite conditions must have been present in too high a degree. White bubbles at the top show that the water was too hard. All glass- 
ware should be washed thoroughly as soon as the test is completed.

286. The Value of Testing Milk. - A farmer cannot tell accurately the richness of a cow's milk unless he uses the Babcock test. He is much more likely to be wrong in a guess than even when he "guesses" about the quantity of milk. The amount of cream on the milk is not a safe guide, because some cream contains twice the butter fat that is found in other cream seemingly as rich. Cows, even of the same breed, differ widely in the amount of fat in the milk. We have spoken above of the need of weighing each cow's milk, to know how much she gives. It is equally needful to test each cow's milk occasionally, or to have it tested at the creamery or school, to know what kind of milk she gives.

If a cow in a herd gives 6000 pounds of milk in a year, she is pretty sure to be considered a very good cow. Her milk, however, may test only 3 per cent for butter fat. Another cow giving only 4000 pounds may test 5 per cent. The second is decidedly the more profitable cow.

The farmer, then, who uses the scales for quantity, and the Babcock test for quality, can tell which of his cows pay for their keep, and which are "boarders" and cost more than they return to the milk pail. Many a farmer, by adopting these devices, has learned that he has been paying for the privilege of milking some of his cows 700 times a year. Weighing and testing make it possible to weed out the poor cows and to select the good ones wisely. And weeding ranks with breeding and feeding in the work of grading up the herd.

287. Testing has a Value also for the Farmer's Patrons. The buyer of milk has a sure means of protecting himself against skimming or watering by the milkman. Cities, 
by law, require all milk sold to contain at least a certain amount of fat ( $3 \frac{1}{4}$ per cent to 4 per cent); and milk inspectors stop the milkmen's carts on the street, and take samples to see whether this standard is kept. The creamery, too, is able to be absolutely fair to its patrons, now that it pays for milk and cream on the basis of fat. It can sell different grades of cream conveniently, too, knowing precisely what it does. It is customary to sell a 30 per cent cream (cream of which 30 per cent is fat) for "whipping cream," and a 20 per cent cream for other purposes.

288. Milk-testing associations are becoming common. It is perfectly possible for each farmer to test his own herd; but experience proves that even the best farmers are

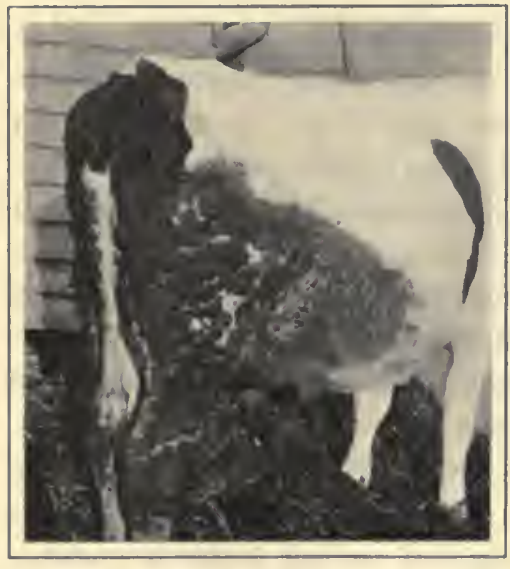

A DiRTY Cow.

It is impossible to get sanitary milk from such a cow. likely to neglect this important work even after having secured the equipment. Accordingly, the enterprising farmers of a neighborhood often combine to employ an expert who shall visit and test each herd at regular periods. Such an expert is often of great service also by his suggestions about the feeding, milking, or other care of cows.

A Testing Association, too, is likely to grow into a Coöperative Breeders' Association, to secure the service of a more costly bull for the several herds than any individual farmer of the group would feel able to buy. 
289. The Care of Milk. - When milk comes from a healthy cow, it is ordinarily perfectly pure; but there is no other food that is so easily rendered unfit for use by carelessness or neglect. Moldy hay, decayed roots, or garlic, fed to cows, will give their taint to the milk. The

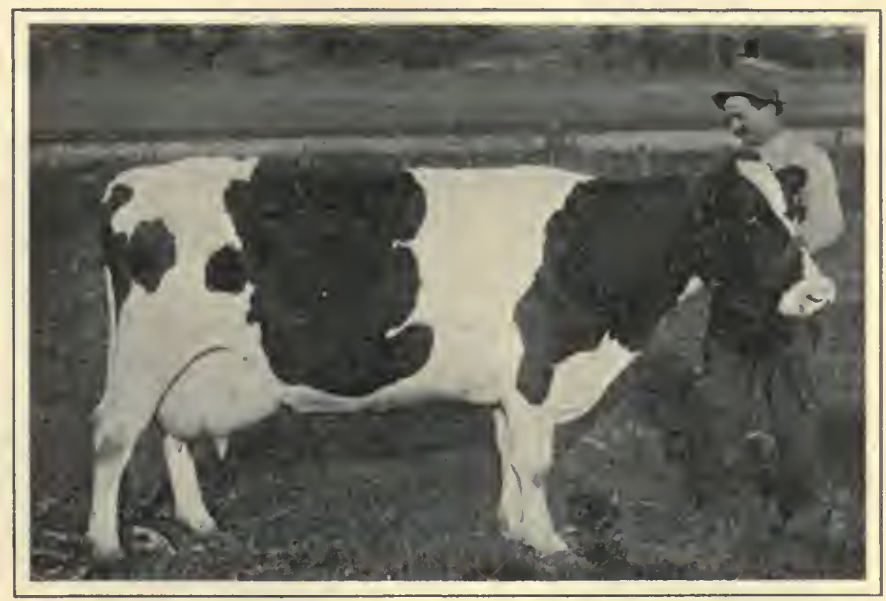

A. Clean Cow.

dairy herd should be free from any contagious diseases, and should have only wholesome food.

But milk also becomes impure from carelessness and ignorance in handling and shipping: We have learned in the chapter on soils that there are countless millions of bacteria living in and above the soil. They also abound in the atmosphere of stables, houses, and creameries. Milk, exposed for a brief time in open vessels, will soon be contaminated by them. Finding this food to their liking, especially if it be warm, they grow and multiply at an enormous rate. These bacteria produce sourness, objectionable flavors, or sliminess. 
Bacteria may enter milk

(1) When milking is done ín unclean surroundings.

(2) When the body and udder of the cow are not cleaned. The flank and udder, before milking, should be wiped with a clean, damp cloth.

(3) When the fore-milk, or first milk drawn from the udder, is not rejected.

(4) When the milker wears unclean clothing.

(5) When milking is done with wet hands. Dirty liquid is almost sure to drop in the pail, if the hands are wet.

(6) When dirty utensils are used at any stage. Milk utensils should be so made as not to have crevices and corners to harbor dirt and thus make thorough cleansing of them difficult.

(7) When wide-flaring milking pails are used.

(8) When the milk is exposed to a dirty atmosphere.

Milk cooled rapidly to a temperature below $60^{\circ} \mathrm{F}$. keeps better than uncooled milk, because bacteria multiply very slowly at that temperature. Many dairymen

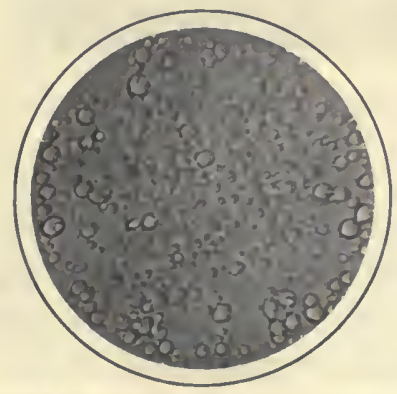

MiLK from the Clean Cow.

When the milk is magnified, only globules of fat appear.

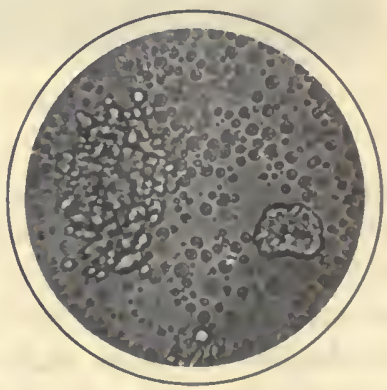

Milk from the DiRTy Cow.

When the milk is magnified, dirt appears in addition to the fat globules.

pasteurize the raw milk. This process kills most of the bacteria ; and the milk will then remain sweet for several days if kept at a low temperature. 
290. Cream Separators. - The old method of placing the milk in stone crocks and allowing it to stand for a day or two for the cream to rise is too slow and tedious a process for a large dairy. A separator was invented to take the cream at once and quickly. A cream separator is what we call a centrifuge - a type of centrifuge which in this case contains a few horizontal disks revolving on an upright axis. Cream is lighter than the rest of the milk.

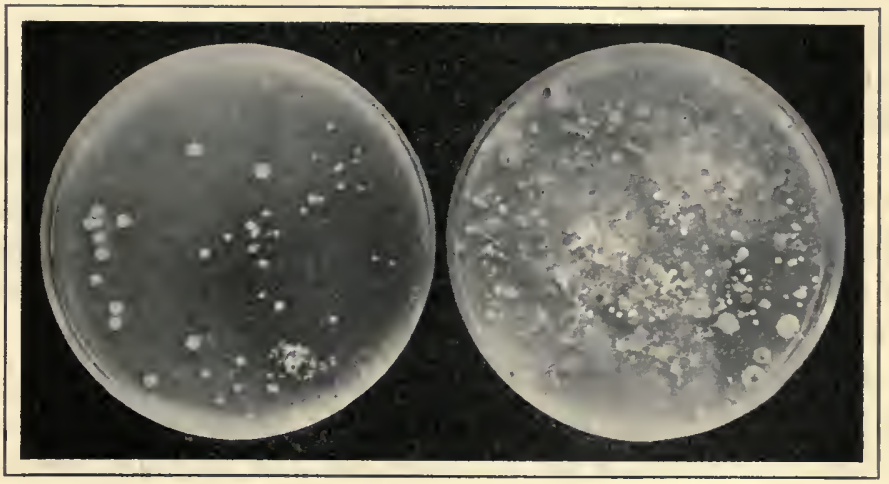

GERMS OF THE DAIRY.

The left-hand dish was exposed out of doors for five minutes; the right-hand dish in a cow-barn during milking for only five seconds. Note the difference in the number of bacteria in each.

As the whole milk enters the separator when that machine is in rapid motion, the heavy part of the milk is thrown toward the circumference of the disks, and the lighter part (or cream) is drawn off near the center. With a modern separator, operated either with an engine or by hand, the cream in several hundred pounds of milk can be quickly and conveniently gathered, under the most sanitary conditions, immediately after the milking.

291. Butter and Cheese. - Cream only is used in making butter. Commonly the cream is first ripened, that is, it 
is kept at a temperature between $60^{\circ}$ and $75^{\circ} \mathrm{F}$. for about 12 hours for the proper bacteria to multiply. At the end of this time, being now slightly sour, thick, smooth, and glossy, it is ready for churning, which condenses the butter fat and parts of the other components into grauules or lumps the size of wheat grains. The butter is now removed from the churn, washed in cold water, salted, worked, and placed in tubs or made up into pound packages for the market. Many of the best creameries have begun recently to make butter from sweet cream.

Skimmed milk, whole milk, or cream may be used in making cheese. To make American cheese, rennet is used to curdle the casein. The milk or cream is then heated in a vat until hardened. After the whey has been strained off, the curd is salted, pressed, and cured. Cottage cheese is merely the curd of milk that has been curdled without the use of rennet. This kind of cheese is eaten fresh.

292. Ice Cream. - One of the valuable products of milk, highly relished by nearly all people, is ice cream. Ice cream, to be sure, is not frozen cream, as its name would indicate, although a considerable part of it should be cream. Ice cream is usually a mixture of milk, cream, sugar, and a flavoring material. To this mixture are often added some eggs, corn starch, or gelatin. The latter substances give better body to the product. Some people prefer one flavor; others, another. Some wish the ice cream "rich" in cream; others do not. Some desire it very sweet; others prefer only a little sugar.

People who make their own ice cream have one advantage. They know its composition and the degree of cleanliness practiced in making it. Sickness occasionally follows the eating of ice cream. The common cause of this sickness is unclean or rusty utensils. Since ice cream is now cousumed in immense quantities in both city and 
country, care must be taken that it is clean, wholesome, and sanitary in every particular.

\section{Practical Questions}

1. Give the composition of milk. 2. Define the following terms: butter fat, cream, sterilized milk, whey. 3. What is the purpose of the Babcock test? 4. What diseases may be transmitted to man by unhealthy cows? 5. Discuss the relation between bacteria and milk. 6. How do bacteria get in milk? 7. Are all milk bacteria harmful? 8. Explain the process of butter making as you have seen it. 9. How does your father dispose of his milk? 10. What is the best way of washing milk utensils? 11. Should the cows be fed during milking time? 12. Why should a farmer keep records of his cows?

\section{Home FXercises}

1. Report on the following -

1. Number of pounds of milk annually produced by the home herd.

2. Number of cows.

3. Number of pounds per cow.

4. Number of pounds of butter fat per cow.

5. Income of the dairy.

2. It is important on the farm to keep careful and exact records. Let each boy of the class take one cow and test her milk for fat once a week for two months, using the school tester if there is none at home. It is better to test the entire milking of one cow thoroughly for a number of successive weeks than to come to quick conclusions on certain members of the herd from one or two tests.

3. Take apart your cream separator and describe all the parts.

4. Describe your own dairy from a sanitary standpoint.

\section{SugGestions}

1. One of the most useful pieces of apparatus for real work in a school is the Babcock tester. Aside from its practical value, the testing of milk is an interesting and fascinating experiment. Milk from different cows may be brought from home, if there is no tester there. As soon as the practical value of a tester has been made clear 
in school, more farmers may purchase them. The school in this way serves the community.

2. Those who are not producers, but only consumers of milk, will be interested in tests for milk preservatives. If a trace of formalin (a rery common preservative) has been added to milk to keep it from becoming sour, pour a little of the milk in a cup together with a few drops of sulphuric acid, having in it a little iron chloride (a teaspoonful of the iron solution to a pint of acid); stir the solution. A purple color shows the presence of formalin.

\section{REFERENCES}

Modern Methods of Testing Milk and Milk Products. Van Slyke. Principles and Practice of Butter Making. McKay and Larson.

First Lessons in Dairying. Van Norman.

Milk and Its Products. King.

A.B.C. in Cheese Making.

Farmers' Bulletins. Washington, D.C.

42. Facts about Milk.

63. Care of Milk on the Farm.

74. Milk as Food.

166. Cheese Making on the Farm.

241. Butter Making on the Farm.

413. The Care of Milk and its Use in the Home.

490. Bacteria in Milk. 


\section{CHAPTER XXX}

\section{HORSES}

A horse! a horse! my kingdom for a horse ! SIIAKEgPEARE.

293. The Story of the Horse. - The horse was domesticated before historic times. Herds of wild horses roamed over Europe before Greece and Rome became prominent in human affairs. "It is a well-known fact," says Professor Marsh, "that the Spanish discoverers of America discovered no horses on this continent, and that the modern horse was consequently introduced from the Old World." Yet America was the original home of the horse. Here from a five-toed animal about the size of a sheep it was evolved.

This was perhaps a million years ago. First, there was an increase in size; second, in speed

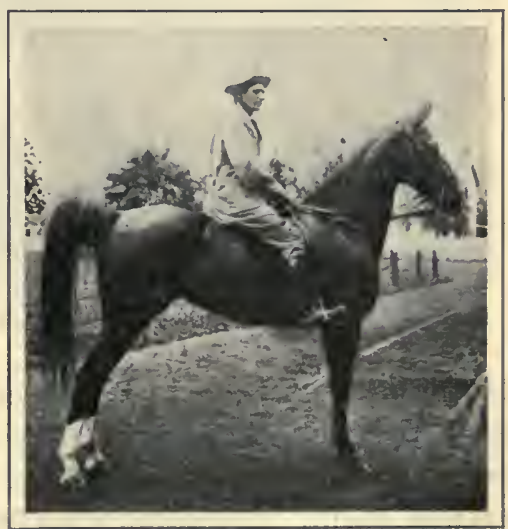

Blooded Saddle Mare. and bone development; and third, elongation of the head and neck. While Alaska and northeastern Asia were still connected by land (these countries being much warmer then than at present), the wild horses migrated across the 
isthmus and finally spread over all the fertile areas of the Old World. The horses that were left in Ameriea died out, meanwhile. Only a few fossil remains have been preserved in places like the old lake-basins of Utah and Wyoming.

According to a legend of ancient Greece, the horse was created by Neptune as a result of a contest between himself and Minerva. Neptune, the god of the sea, and

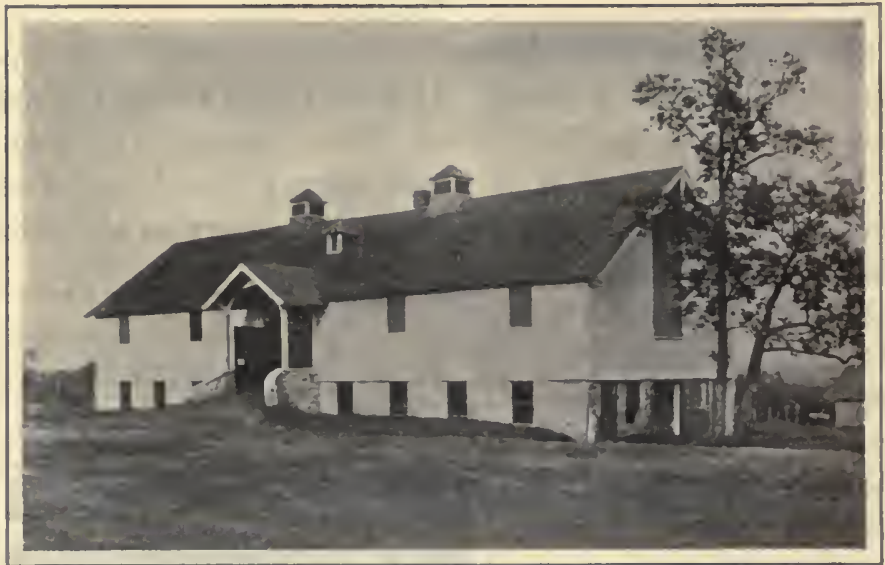

HORSE BARN.

Minerva, the goddess of wisdom, vied with each other to confer the most valuable gift upon mankind. Minerva created the olive tree, which was to feed the hungry over all the world. Neptune, after having studied the needs of man, struck his trident upon the earth, from which there sprang a prancing steed, that would serve its master in pence and war.

294. Origin of the Two Great Types. - The methods of warfare during the middle ages had much to do with forming our present types of horses. During the age of 
heavy armor, when well-armed knights weighed about four hundred pounds, heavy horses were necessary to support them. This was the chief reason for the development of heavy horses. Laws were passed in medieval

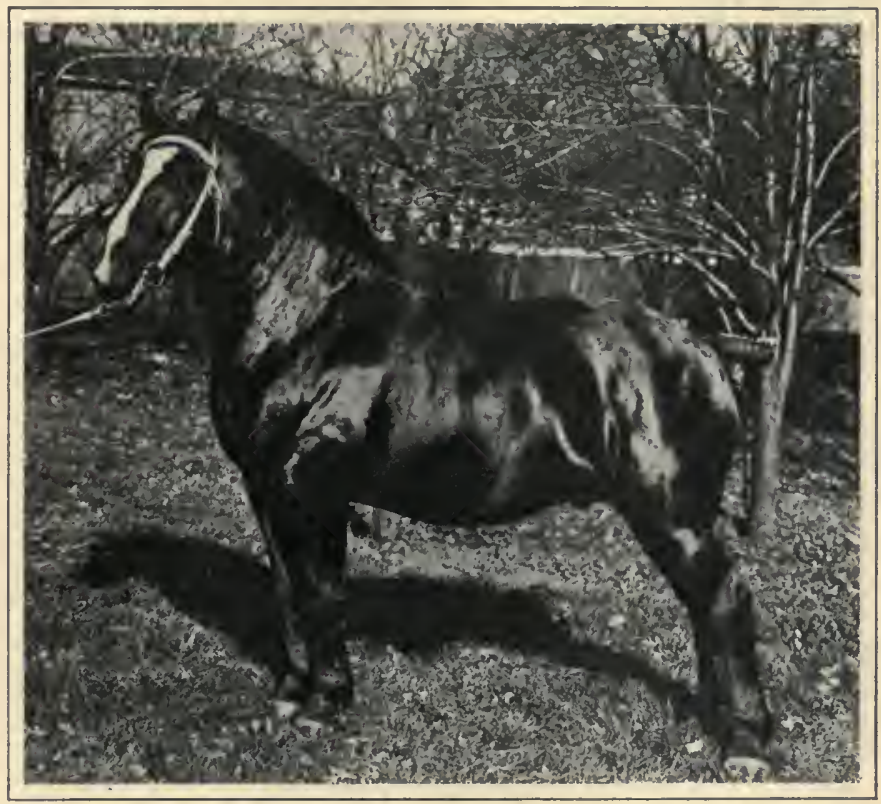

Percheron Stallion.

England condemning all stallions weighing less than 1200 pounds.

But when horse breeders had thus developed an animal of great weight and strength, the invention of gunpowder and firearms made heavy horses relatively less useful in war. Fleetness of foot, quick action, and light weight were now needed. Europe then secured several varieties of lighter horses and began to breed horses of the type more serviceable under the new conditions of warfare. 
Horses to-day serve many purposes, and the breeder modifies their form to suit these purposes; but the two historic classes that.were developed by the needs of war eonstitute still the two general types that persist in city and country.

The main contrasts between the two types of horses are shown in the following table:

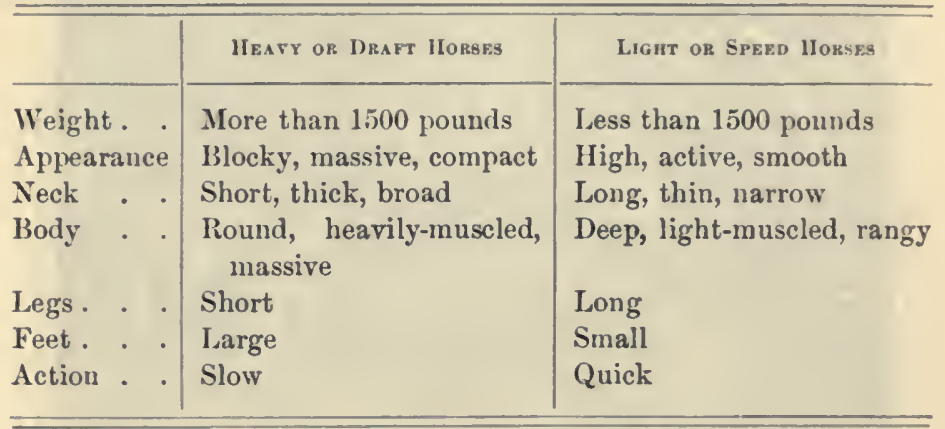

295. Heavy or draft horses are used for city teaming, for logging, and for such purposes of the farm is require great strength like plowing. They often are crossed with lighter horses to obtain the common farm horse.

The four leading breeds of draft horses are the Percheron, the Clydesdale, the Belgian, and the Shire.

(a) The Percheron came from La Perche, France, and was introduced into the United States more than a century ago. It has become widely popular for heavy drayage, both in the city and country. As a breed, it shows reliability and intelligence, is gentle, easily "broken" and has wonderful powers of endurance. A dapple gray color is held in high favor, although many are jet black.

(b) The Clydesdale is a Scotch breed. It was first inported into America about two centuries ago. The 
general color is brown or bay, with a white blaze on the forehead and with the lower parts of the legs white. Heavy fringes of shaggy hair hang from and below the hocks. Farmers sometimes criticize the breed on account of this hair.

(c) The Belgian Breed is a native of Belgium. Chestnut is the most common color. This breed was introduced into America much later than the Percheron or the "Clyde."

(d) The Shire is an English breed, much like the Clydesdale, but somewhat heavier and clumsier. The feet

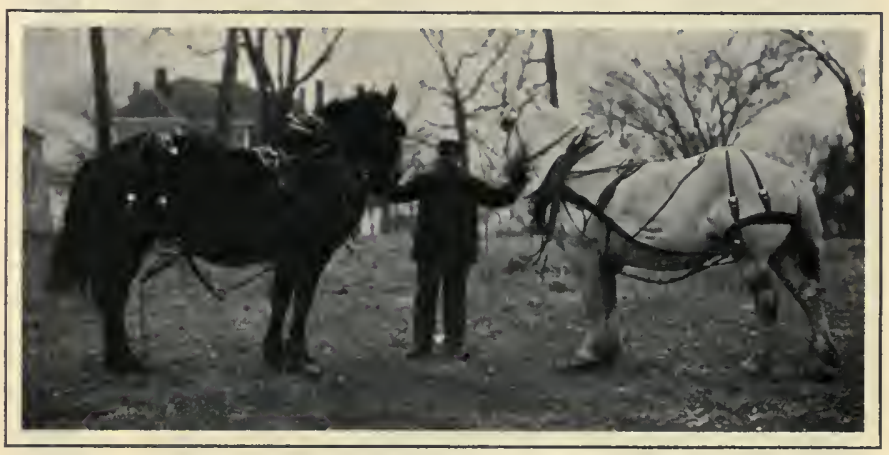

Percheron Brood Mares.

of the Shire are too flat, the legs too hairy, and the movement too sluggish, to suit American horse fanciers, and this breed has not met with much favor in our country. Bay and brown are the most common colors.

296. Light horses are bred in general varieties to suit different purposes.

(a) Road horses must show speed, smart action, and quality. The physician, the liveryman, and the rural mailman generally use this type. They should be reliable and intelligent (and thus must be able to learn 
quickly to face automobiles without shying). They range in weight from 900 to 1200 pounds.

(b) Carriage horses are usually slightly heavier than road horses. They are used mostly by coachmen and cab drivers, and should be active and alert. In appearance

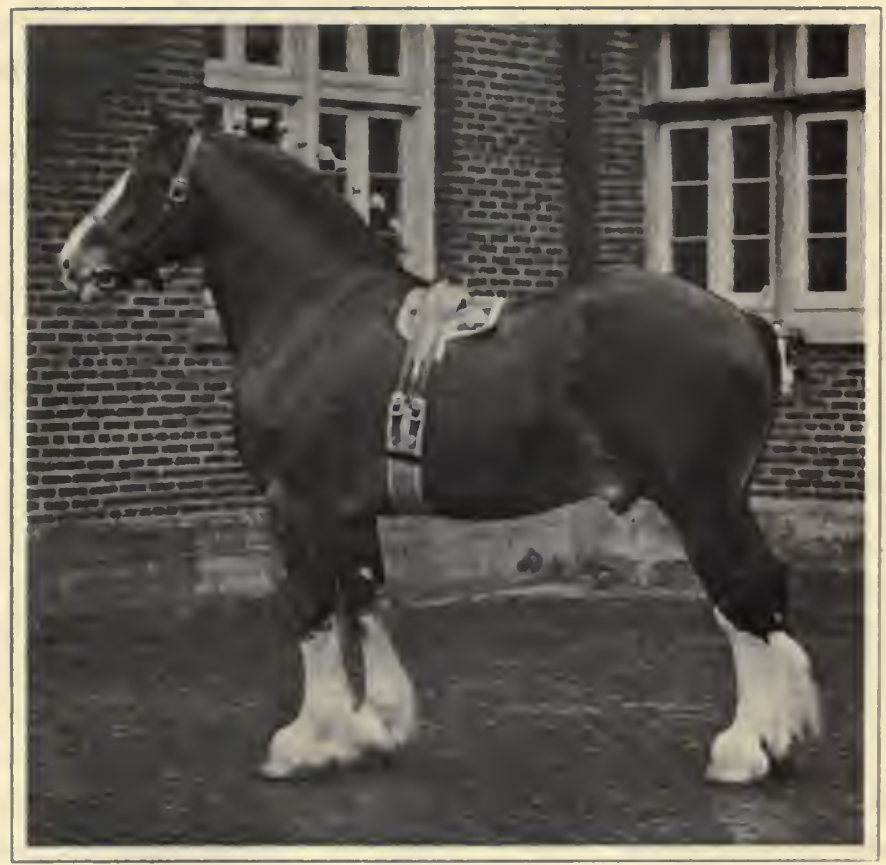

Clydesdale Stallion.

they should show "style," and be short in the back with an arehed neck.

(c) Wagon horses are heavier than carriage horses. They may weigh as much as 1700 pounds, and thus belong to the heavy type. They are used in the express service, in the artillery, and often for general farm purposes. 
Wagon horses need weight, action, and strong powers of endurance.

297. Mules are hybrids, or crosses between mares and jacks. For many years they have been popular in our country. According to the last census there were $4,209,769$ mules in the United States. A mule, if welltrained, is a hard and a faithful worker. In the mines, on the railroads, in the lumber camps, in the army, or in doing the plain work of the farm, the mule shows remarkable strength and endurance, resistance to disease, and ability to work well even at an advanced age.

298. Care of the Horse. - (a) Ventilation. - It has been estimated by Professor F. H. King that it is necessary to supply 4296 cubic feet of fresh air per hour to each horse weighing 1000 pounds, if the air

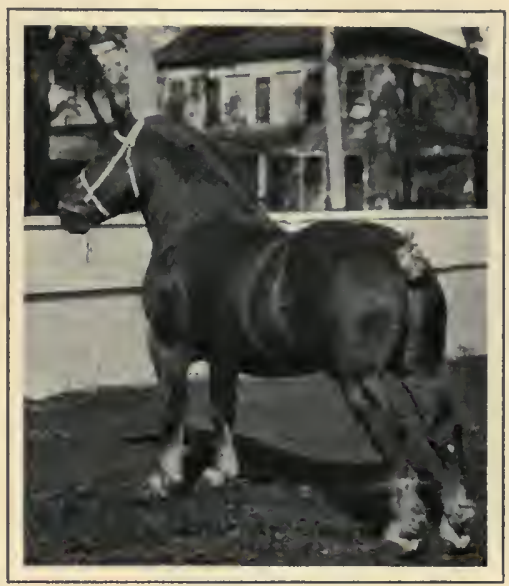

Belgian Stallion.

is to remain wholesome. This means that some method for the taking in of pure air and for the escape of foul air should be provided in the stable. Especially in winter is the problem of ventilation a difficult one.

The King system of barn ventilation draws the fresh air in near the ceiling at places which will not cause drafts, and removes the heavy foul air through openings near the floor. These openings are connected with long shafts or chimneys extending from above the roof to within a few feet of the stable floor. Some of the warm air is 
thus locked in between the eeiling and the lower opening into the shaft. If the stables become too warm, a door may be opened in the shaft near the ceiling, which will release the heated air more rapidly.

(b) Cleaning. - It is a good practice to sponge off the horse with eold water when it has come in sweaty from the field. Washing cools the skin and is a good treatment for hot shoulders. Currying not only removes the

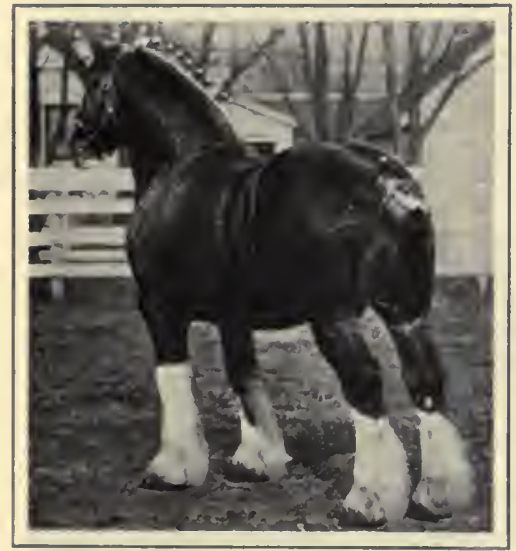

Shire Stallion. dirt, but opens the skin pores. The feet need frequent attention. Thrush, a foul-smelling diseharge of the frog of the foot, may usually be prevented by keeping the feet and the stall floor clean. Dirty stables are unsanitary, and promote general diseases.

(c) Abuse. - There are pliysical limits to the power of a horse to endure exposure to heat, cold, or rain. Unfortunately, a horse cannot tell when it is tired or does not feel well. Workers around dumb animals should be on the lookout for signs of distress, and remember that, like themselves, these animals liave the feelings and weaknesses of the flesh.

(d) Feeding. - A good farmer takes pride in the appearance of his horses. He wants them to look well, better, perhaps, than those of his neighbors. He knows that they must not only be eurried and brushed every morning, but be given regularly good nourishing food in proper quantities. 
When working hard, horses perspire freely and need plenty of water. Little water, however, should be given a horse when very warm. Unlike cattle, horses lack the extra pouch in which large quantities of food can be stored to be chewed at will. Hence, if a horse is deprived of its regular meal, it is likely to eat and drink too much the next time. This commonly leads to nervousness and digestive difficulties. Too rapid eating can usually be controlled by having a large feed box, and by feeding the hay before the grain.

Horses differ widely as feeders. Some are known as "easy feeders." Only a comparatively small amount of feed is needed to keep them in good condition. Others, on the other hand, especially those of a nervous temperament, eat rapidly, digest their feed poorly, and consequently require more feed.

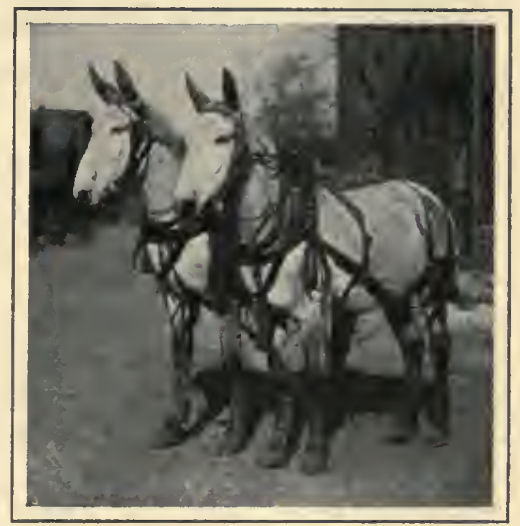

PAIR OF MULES.

Many owners feed timothy hay and oats with a little corn, the year around. This ration gives satisfactory results, but it is better and often cheaper to vary the diet now and then. During the cold months, when heat-producing substances like corn are needed, the proportion of corn should be increased to perhaps equal parts by weight of corn and oats. This will reduce the cost. Also the proportion of hay should be increased when the lorse is idle. At hard work the energy of the horse is needed for action, not for digestion. The energy in grains is more easily 
released than the energy in hay. But timothy hay, oats, and corn are all members of the grass fanily. Hence the addition of a little clover hay, alfalfa, and cottonseed meal adds variety. The clover hay must be free from dust or it may cause "heaves."

No definite quantities of feed can be prescribed for a horse. There is an old saying the "the eye of the master fattens his cattle." This saying means that, while feeding standards are useful if followed wisely, feeders must use good judgment.

In a general way scientific horse feeders seek to conform their feeding to the following well-known Wolff-Lehmann feeding standards:

Daily Ration perp 1000 Pounds Live Weight

\begin{tabular}{|c|c|c|c|c|c|}
\hline & Dex Mattes & P'óteIs & Carbouydrate & Fats & $\begin{array}{l}\text { NuTRI- } \\
\text { TIVE } \\
\text { RATIO }\end{array}$ \\
\hline Light work . & 20 pounds & 1.5 pounds & 19.5 pounds & .4 pound & $1: 7$ \\
\hline Medium work & 24 pounds & 2 pounds & 11 pounds & .6 pound & $1: 6.2$ \\
\hline Heavy work . & 26 pounds & 2.5 pounds & 13.3 pounds & .8 pound & $1: 6$ \\
\hline
\end{tabular}

As just said, however, good judgment must at all times be exereised. A driving horse may be idle in the stall for weeks and then taken on the road during a day or two for - long drives, which may be followed again by a long period of enforced idleness. Of course, the general prineiple of reducing the concentrates and of increasing the roughages for idle periods must be followed. But more than all else is the need of noting the condition of the coat and of the exereta, and the general appearance of the animal. If feeders read and follow these signs aright, they will find that they are on the track of the generally accepted feeding standards. 
299. The Colt. - The raising of a colt is an excellent home project. There is perhaps no farm animal more interesting to young people than a colt. It is certainly, too, a worth-while project. If a member of the class decides to raise a colt as a home exercise, it would be well to keep a few things in mind. A colt should be made to understand that the boy is his master. A colt learus quickly and seems in after years never to be able to forget the lessons learned in its early days. For this reason it should always be treated kindly but firmly and never be made to fear. We should attempt to teach a colt a little only at a time and have this lesson well learned before the next one is presented. The colt should become accustomed to a halter

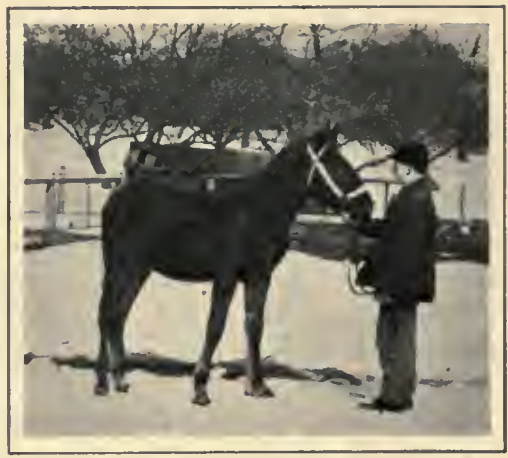

Raising a Colt. early in life. The halter must be a good one, for if the colt breaks it once he will try to do it the second time.

At two years of age he should be introduced to the bit and harness. The bit should be smooth and the harness loose. Lines may be fastened to the bridle and the colt driven around a little each day and taught the meaning of the words "whoa" and "get up." In all his relations to the young animal the trainer should be gentle but firm.

The colt should be trained to work double before single. His partner should be a quiet, active and reliable animal. It is always well to have separate lines on the colt the first few times he is hitched double.

If the colt is to be trained to work single, it is well to 
hitch him to a good strong vehicle with a seat from which it is easy to get on or off. A few lessons poorly taught at this stage of the colt's education will lessen his value for service for all time. He should be made to be quiet and stand still until the driver gives the signal to proceed. He must be taught confidence in himself and respeet for his master and thus should be led to see that automobiles, trains, trolleys, and other unusual sights by the roadside will not harm him.

\section{Practical Questions}

1. Give a brief account of the early history of the horse. 2. How has warfare affected the development of horses? 3. Contrast a heavy horse with a light horse. 4. What are the characteristics of the Percheron? 5. To which class does the general farm horse belong? 6. Discuss the care of horses. 7. Give a ration for a farm horse. $\quad 8$. How would you supply fresh air to a horse stable? 9. Cau a horse feel pain! 10. Will a horse respond to kind treatmeut? 11. If your father gives you a colt will you agree to raise it?

\section{IIOME EXERCISES}

1. Purdue Circular No. 29 gires a list of defects and unsonnduesses in horses. With a complete list, such as that one, examine your horses and report their condition.

2. A Colt Club Project is interesting and instructive for boys and girls.

The project should cover at least a year and should include questions of care, management, and cost. As recommended hy several state colleges of agriculture the basis of award may be as follows:

1) Management slown in training . . . . . 25

2) Cost of keeping . . . . . . . . . 25

3) Condition . . . . . . . . . . . 25

4) Story : My Year's Work with the Colt. . . . . . . . . . $\frac{25}{100}$
Total Score . . . . .

3. Report in detail on the feeding and care of your father's horses.

4. From the local assessor obtain the number of horses in your district and their value. Is the number and value increasing?

5. What does it cost your father to keep his horses? 


\section{Suggestions}

1. A member of the class should relate the story of "Black Beauty."

\section{Score Card for Light Horses}

\section{Appearance}

Height, measure in hands

Form, well built, smooth

Quality, smooth, stylish

Action, active.

Temperament, mild, gentle

\section{Head and Neck}

Head, lean, well-carried .

Muzzle, having thin lips, large nostrils

Forehead, broad

Ears, pointed, wide apart, standing forward. . .

Neck, having large windpipe, clean . . . . . .

\section{Fore Quarters}

Legs, straight solid, parallel, slender

Feet, having wide frog and heel, even

Knees, clean, wide, even .

\section{Hind Quarters}

Legs, similar in form, light but strong, well-muscled

Hocks, wide, straight, clean-cut . . . . . . .

Feet, having wide heel, large frog, dense horn . .

\section{Body}

Chest, deep, long . . . . . . . . . . . .

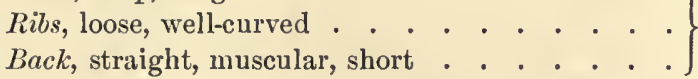

\section{Perfeut Pupil's}

$\mathrm{ScOR} \mathbf{L}$

SCORE

Total

2. Go to a barn near by and demonstrate the score card for light horses as here given. Send for fuller descriptions and for the score card for heary horses. These will be gladly sent by the State Ex- 
periment Station free of charge. The county agent may give this demonstration.

After the points of the score card have been made plain, and its use is thoroughly understood, each student should score every horse at home.

\section{REFERENCES}

Productive Horse Husbandry. (Gay.

Types and Breeds of Furm Animals. Plumb.

Manual of Farm Animals. IIarper.

The Horse. Roberts.

The Horse Book. Johnstone.

Farmers' Bulletins. Washington, D. C.

37. Market Classes of Ilorses.

137. The Preservation of Our Native Types of Horses.

170. Principles of Horse Feeding.

619. Breeds of Draft Horses.

667. Colts: Breaking and Training.

Circular No. 29, Live Stock Judging for Beginners. Lafayette, Ind. 


\section{CHAPTER XXXI}

\section{SHEEP AND SWINE}

And Abel was a keeper of sheep, but Cain was a tiller of the ground.

- Gevesis Iv. 2.

300. Where Sheep came From. - The wild ancestors of the horse and ox are no longer in existence; but the parent stock from which our sheep descended can still be found

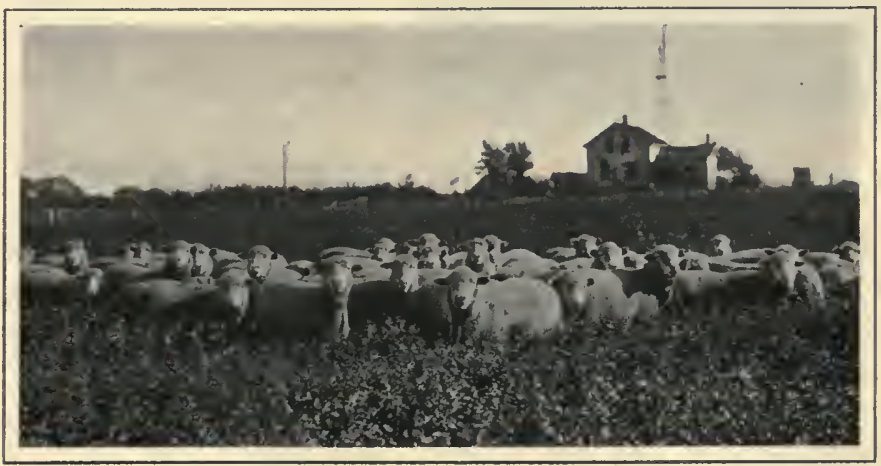

A FLOCK OF SHEEP.

in the mountains of Kamchatka, Barbary, and Greece. From the earliest times, sheep have been domesticated. Abraham measured his wealth in sheep and cattle. And as "The shepherds abided in the fields, keeping watch over their flocks by night," the angels sang the Good Will Song. On his second voyage to America, in 1493, Columbus brought over the sheep that became the ancestors of 
large flocks in Mexico and in the southwestern United States.

While there are many breeds of sheep, there are but two main types, the mutton type and the wool type. These types have been developed, to a great extent, by breeding to suit the needs of man. If mutton is needed, the body of the sheep must have a form similar to that of beef cattle, whereas, if the body is to produce large yields of

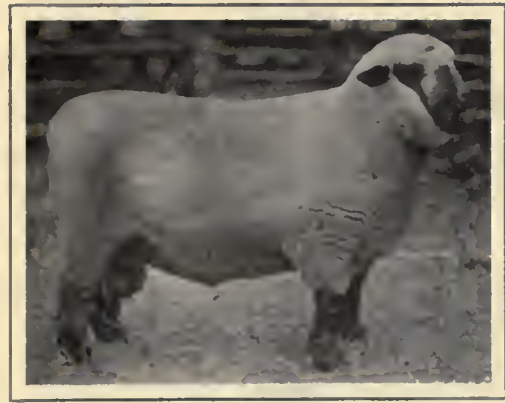

HAMPSHIRE. wool, it should have the general figure of dairy cattle.

301. The Mutton Type.

- To produce mutton most profitably, sheep should have a low, stocky form, great width of back, shortness of leg, and a deep, broad chest. The food consumed by the mutton animal should go principally to make flesh rather than wool. When the animal is killed for the market, the carcass should be full and plump, especially in the regions of the valuable cuts.

The mutton breeds are divided into two groups, medium wools and long wools. This division, however, is not important. It is not made on meat characteristics. There ean be in fact only one mutton type; and the market cares little whether the sheep have long or medium wool, or black or white faces, if they are only well developed in those parts which produce good mutton.

(a) The medium wools are found in eight different breeds, of which the leading ones are the Southdown, the Dorset, and the Shropshire. 
(1) The Southdowns are very active, but are easily fattened. They are small and hornless, with brown faces and legs. The Southdown for many years has held first place in the best markets. Its flesh possesses a fine flavor.

(2) The Dorsets are entirely white. Both ewes and rams have horns. As a feeder, the Dorset ranks high. It produces well-nourished lambs early, and these may quickly be made ready for the market.

(3) The Shropshires are dark brown in faces, ears, and legs. They rank next to the Southdown in mutton producing qualities.

(b) The long wools have three different breeds of

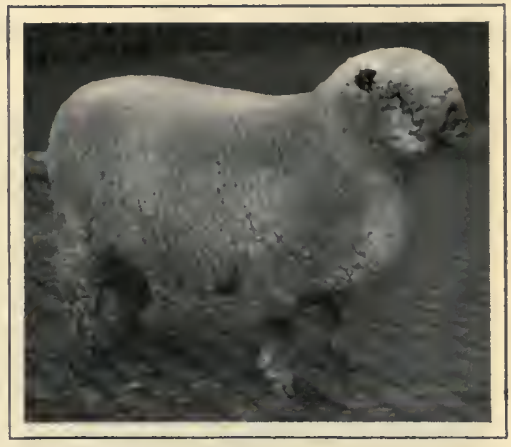

SHROPSHIRE.

some prominence locally, - Leicester, Cotswold, and Lincoln. In all three the sheep are of great size, and are covered with long, coarse, curling fleeces. The long wools are English breeds and are not extensively raised in the United States.

302. The wool type has the Merinos for its most noted breed. The Merinos produce the finest and heaviest weight of fleece. They have large folds or wrinkles in the skin, which increases the wool-bearing surface. The rams carry heavy curved horns. The fleece is short; and on the outside it is usually a dirty black because of an exuding oil.

303. The Feeding of Sheep. - D uring the summer it is the common practice to allow sheep to graze. In the south; where the grass remains green the year around, it is not 
customary to give any other feed to the wool-growing varieties. This fact makes possible the great sheep ranches of Australia and of the sonthwestern part of the United States. Sheep that must be cared for in stables during the cold months, or that are being fattened for the market, are given a balanced ration, consisting usually of such feeds as tumips, oats, corn, bran, middlings, silage, clover, and hay. "Hothouse lambs" are marketed when from six to twelve weeks old. The feeding is "forced"

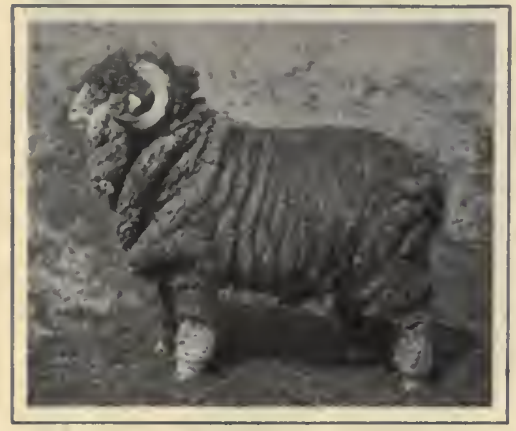

MERINO. to get the finest kind of tender meat. An increasing number of lambs, reared on the large ranches of the West until a few months old, are shipped East for fattening.

304. Care of Sheep. If properly managed, sheep bring quick returns. In England and France, where a careful study is made of the needs of the flock, the sheep industry is one of the most profitable branches of farming. In most of America, however, sheep are the rarest of all farm animals.

Sheep are good foragers, and will eat food which would otherwise be wasted. They graze freely on steep hillsides and in grain stubble, and they glean the husks of corn that are abandoned in the fields. They require little labor, and need but scant protection through the winter, provided the enclosures are kept dry and free from draughts. For these reasons, the raising of sheep should be encouraged in the United States.

Sheep are not subject to many diseases; but those that 
do afflict them are usually fatal. As with other farm animals, as soon as sheep become sick, especially with a contagious disease as sore eyes, tick, lice, or scab, they should be quarantined, or separated from the rest of the flock, and receive special attention. We should always be on the lookout for trouble of this nature and be able to recognize the early symptoms of common shcep diseases, in order to avoid heavy losses later on. If internal para-

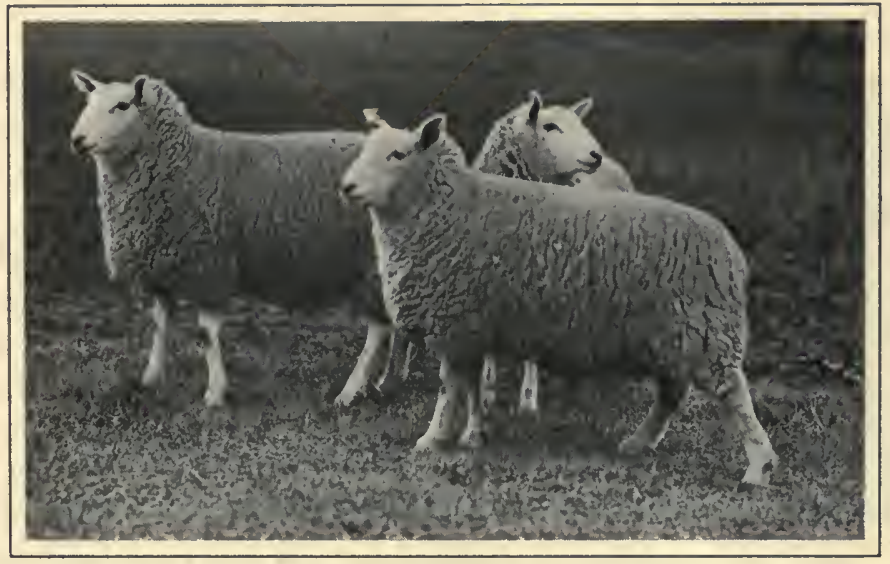

Cheviots.

sites in the brain or liver, where medicine cannot reach them, are the cause of the trouble, the animal should be killed at once and its carcass buried. When sickness appears, it generally pays to call in a veterinarian promptly, unless the farmer has had considerable experience with sick sheep. Prevention of diseases is always cheaper and wiser than cure.

305. Raising Lambs. - In some sections of our country the sheep industry is an important one. See Appendix A, Chart X, page 471. School boys and girls in these regions should be glad to raise a lamb, as a home project. They 
should take entire charge of the work and be entirely responsible for the results. For this reason it is well to know something about baby sheep before starting.

Of all farm animals, sheep are least understood, and one reason why many farmers do not make a success with sheep is because they do not understand thein. This is not only true of lambs but of the adult sheep also. The babies are leggy and delicate ereatures. "They are principally legs, the conneeting body being simply a contrivance for converting milk into more leg, so you understand how it is that they will follow the floek in two days and are able to take a trail in a fortnight, traveling four or five miles a day, falling asleep on their feet and tottering forward in the way."

The first day or two of their lives they are well-nigh helpless. It may be necessary to assist them to their first ineals. Sometimes the lamb does not have as good a mother as the colt or calf has. It often happens that the mother in her eagerness to forage seems to forget her child. If in this condition the lamb becomes dangerously chilled, it is a good practice to immerse it in warm water to bring the circulation to the skin. When thus warmed and stimulated, it should be removed from the bath and rubbed dry. Lambs should be kept warm and dry at all times. A young mother, or an old one, which is not well nourished sometimes disowns her bleating child. It is then advisable for the raiser to teach the parent a few lessons in maternal responsibility by confining the mother to a small enclosure while the baby is given a chance to nurse.

In a week or two the young begin to nibble at solid foods, as grain and hay. It is a good plan to encourage this desire, because it will then be easier to wean them later. Put a little grain in their boxes two or three times each 
day, as much as they care to eat. It will be noticed that they will make more rapid gains in weight if given this additional food.

If you wish to sell what is known in the trade as "spring lambs," it is not necessary to wean the lambs at all. But all others had better be weaned at three or four months of age. Do not fail to dock the tails of those which are intended to mature. The tail is not needed

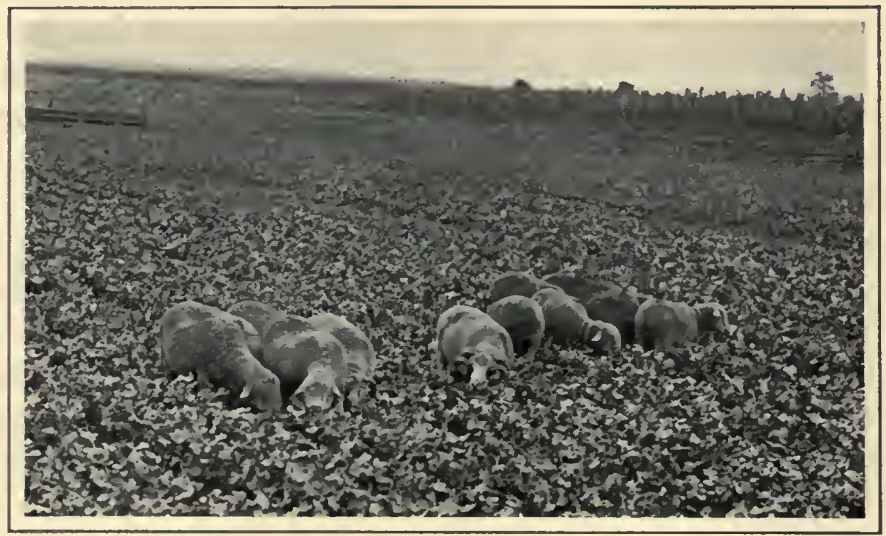

Sheep Feeding in Rape Field.

and is likely to become filthy. This operation should be performed when the lamb is about ten days old. Docking is a simple process. Take a mallet and chisel or pincers or even a sharp knife and one good cut will do the work.

The boy who raises a sheep should also be something of a nurse. The little lamb is bound to be overtaken with many ills, such as sore eyes, sore mouth, constipation, and diarrhea. Each trouble requires special treatment, and naturally the experiences of a successful sheep farmer should be sought, or better, perhaps, the advice given in a government publication. 
One thing more must not be forgotten. Dogs are the natural enemy of sheep. During 1915 according to the statistical bureau of the State Department of Agriculture of Pennsylvania 5808 sheep were killed by dogs in Pennsylvania alone and 3813 were injured. And Pennsylvania is not a leading sheep state. The bark or often even the presence of a dog may create a stampede. This excites and worries the sheep, even though the dog does no injury directly. 'Thus chased they soon become exhausted and rapidly lose weight. The collie, however, has been bred to be the friend and companion of sheep. Read the charming story of "Wully" in Wild Animals I Have Known, and you will readily understand why sheep will soon have confidence in a good sheep dog.

306. Swine. - The ancestors of our modern swine, still rouming at large in various parts of Europe and Asia, excite fear rather than eontempt. The wild boar is a huge, active beast, speedy as a deer and tough as a rhinoceros. He is provided with a pair of fierce-looking tusks, that make him no mean foe of the lion and the tiger.

'To many the domestic pig is merely a filthy, grunting creature, acting the glutton at the trough or wallowing in the mire. In justice to the pig, it can be said with truth that he must abide by the conditions imposed on him by his master. He prefers a clean, dry bed, and he shows this fact if he has a fair ehance to do so. But there is little evaporation from his body to cool his skin, and he has only a seant supply of hair for protection against flies. So, if no bath is at hand, he naturally wallows in the mud as the best means of keeping comfortable during hot weather.

307. Types of Swine. - There are two types of swine, the lard type and the bacon type. These types have been 
bred to meet two different market demands. We learned, in the study of horses, cattle, and sheep, that unlike purposes cannot best be served by one type of animal, but call for animals of contrasting builds. Swine are no exception to this rule. The choice cuts of bacon require one type of swine; and a good growth of the lardbearing tissues requires another type.

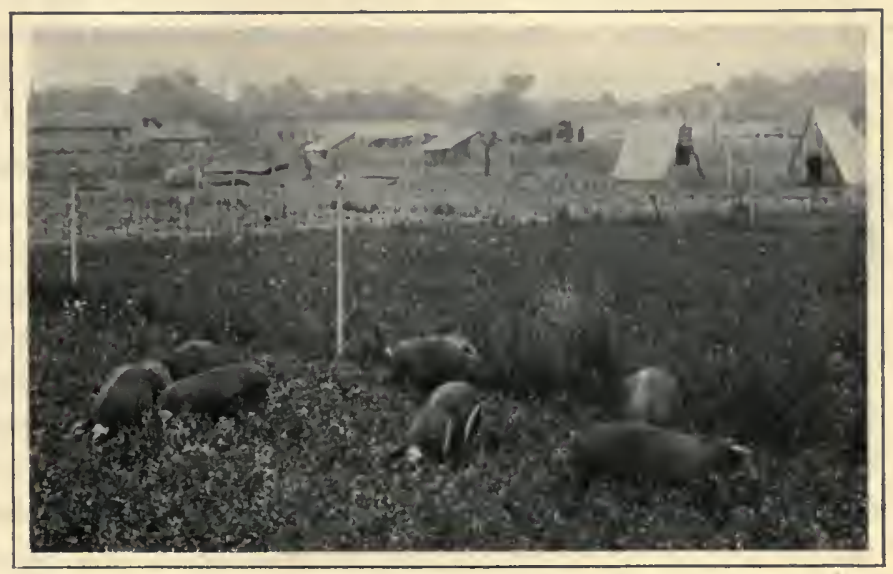

Pigs Feeding on Alfalfa.

308. The bacon swine are long and narrow. They have light loins and shoulders and produce a high proportion of lean meat. Comparatively few bacon swine are raised in the United States, for the reason that corn is not a profitable feed for them, and that the foreign trade in them has never been developed to the extent that the trade in the lard type has been. In the northern parts of the country, however, where corn is still a doubtful crop, it is becoming more and more common to raise a bacon type.

The two leading breeds of bacon swine are the Large Yorkshire (white hogs, with erect ears), and the Tams- 
worth, whose chief charaeteristics are a red eolor, notably long snout, and erect ears.

309. The lard type calls for great compactness of form, shortness of limb, width of body, and readiness to lay on fat rapidly and early in life. The common lard breeds are the Berkshire, the Poland China, the Chester White, and the Duroe-Jersey.

(a) The Berkshire can at once be reegnized by the "six white points," - one on the face, another on the tail, and one on each foot. The ears are erect; the face dished;

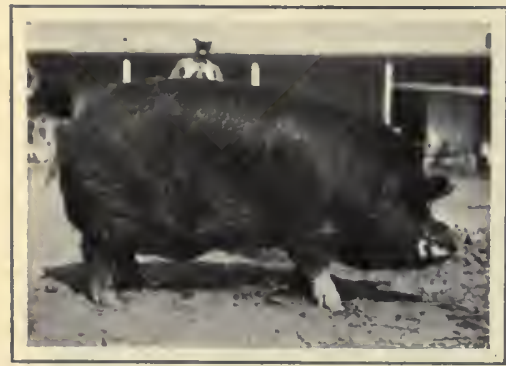

BERKSHIRE. the general color, black. This breed is very popular in the South. A feed high in protein, with little oil, tends to give the Berkshire a bacon form. As a breed, it matures early and produces good litters.

(b) The Poland China is also black in color, usually with patches of white about the head, legs, and tail. The ears are lopping. This breed is a strong favorite in the corn belt.

(c) The Chester White originated in Chester County, Pennsylvania. The members of the breed are entirely white with the exception of an occasional black spot. It was formerly the heaviest breed in the eountry, speeimens having been exhibited which weighed over 1000 pounds. During recent years, however, the breeder aims to secure a greater refinement and smaller size rather than excessive bulk and weight.

(d) The Duroc.Jersey is red in color, having large, lopping ears, wide backs, and an unusually deep body. 
The breed is becoming very popular in the central states.

310. Care of Swine. — "The hog does not need a palace or an upholstered cage, nor does he prosper in a dungeon." Some farmers go to extremes in erecting an expensive hog house with conveniences that add little to the comfort of the animals. Others, on the other hand, house their swine in a filthy hole under a stack or beneath a few rails covered with a little fodder. Swine need quarters which are well-lighted, well-aired, dry, and clean. It is best to locate the hog house near a pasture lot or orchard, so as to give them a rumway and a place in which to wallow.

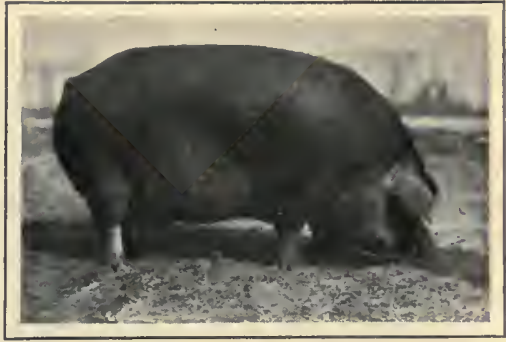

DUROC-JERSEY.

Some successful hog raisers are not in favor of hog wallows, for the reason that wallows soon become filthy and thus spread infectious diseases, particularly cholera. Such dangers, of course, must be guarded against. If the wallow is so arranged as to provide for the circulation of the water, and if a little coal tar is added occasionally to the water, scant fear need be entertained on this score. If the farm, however, has running water in the barn, it is not costly to build cement baths in the hog yard.

If cholera, the most dreaded hog disease, does break out, great care must be taken to establish a strict quarantine. Healthy animals must be kept apart from those afflicted. After the hogs that have died from the disease have been buried or burned, the entire quarters should be sprayed with a five per cent solution of crude carbolic acid. 
311. Feeding. - The results of extensive and careful experiments on hog feeding carried on by the Experinent Station at Manhattan, Kansas, are as follows:

1) "The feeding of corn alone in dry lots does not give satisfactory results.

2) "A ration of eorn and alfalfa hay is more economical than the feeding of corn alone.

3) "The feeding of protein supplements, such as tankage or meat meals and shorts, and tankage or meat meal, in connection with corn, increased the effieiency of the ration and the rate of the gain.

4) "With a grain ration of corn, shorts, and tankage, on alfalfa pasture, the profits were practically the same when the pigs were first grown on a limited amount of feed during the summer and then fattened in the fall as when full fed from the beginning until ready for market.

5) "Hogs fed on pasture made cheaper and more rapid gains than those fed in dry lots.

6) "Hogs can be profitably grown and fed when corn is supplemented with pasture crops and protein feed, such as alfalfa hay, soy beans, shorts, and meat meal and tankage."

312. Pig Raising. (a) Why. - In many cases pupils may be able to show better results in pig raising than their parents have done. Some boys have actually succeeded in doing this and their parents were eager to be shown how. Sooner or later every boy asks himself the question, "What can I do on my own aecount to help bear the burdens of the household?" A host of our best men and women are answering, "Why not raise a pig?"

No doubt there are lots of parents who do not realize that one of the ways of raising good boys is to have the boys raise good pigs. Keen observers say that when young folks care for and nurture a dependent creature 
some of the best qualities in the young folks are called forth and exercised. This means that the rising generation is not so likely to go wrong if it does constructive work, that is, if it is encouraged to rear a plant, a colt, a calf, or a pig.

Whenever we solve one problem on the farm we are likely to have solved a number of others which depend upon it. A boy raises corn and desires to market it. He may find that it is most profitable to market it through

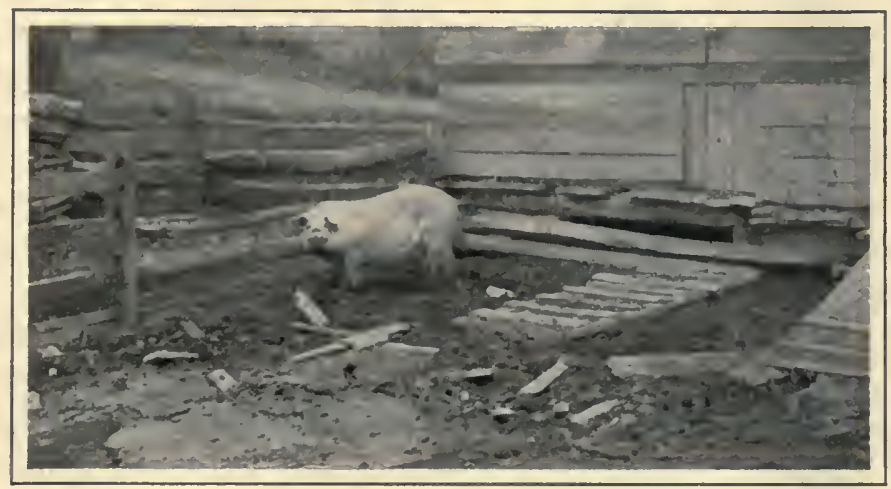

Chester White Pig in Unattractive Pen.

swine. The question of reducing the cost of high-priced feed recurs again and again. The growing of forage crops for the hogs may suggest the means to that end. In what way can some ready cash be obtained for the sole use of the country boy? This cash in large amounts has come to hundreds of American boys who were successful in raising pigs.

(b) How. - As is stated a little later, help to start a pig club, then follow the directions as given in Bulletin 566. We need give here a few suggestions only. It may happen that the mother has no milk for the baby pigs or 
not enough for the entire litter. The boy must then feed his pigship warmed cow's milk from a bottle with a nipple. There is danger of feeding too much at one time. Better feed a little every two hours and gradually increase the quantity of milk with the intervals of time between meals.

The mother pig, or brood sow as she is often called, must also be well cared for and fed properly if she is to

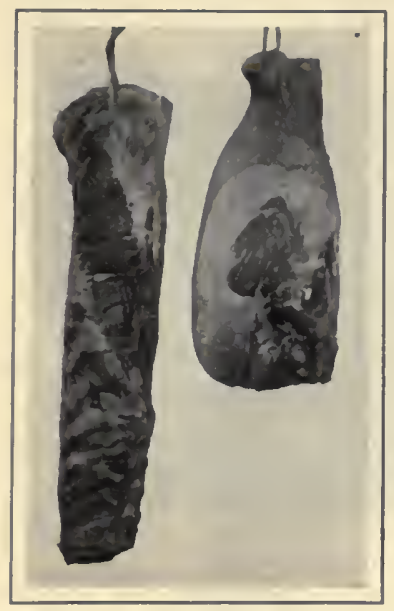

BACON AND HAM. supply a good flow of rich milk. Mashes of bran, shorts and ground oats have given satisfaction. If her feed is too rich, as it is liable to be when made up of liberal quantities of corn, linseed meal, and skim milk, the baby pigs are likely to be affected with digestive disorders.

You will notice that when the little ones are three or four weeks old they will begin to relish solid food. Now is the time to begin weaning them. The little ones should have a small trough all to themselves, since they must be given a special diet.

It is necessary to place obstructions around this trough so that the brood sow cannot eat the food intended for her children. Start with a little sweet milk, three times daily. Be sure that the trough is kept clean and that no leftover milk is allowed to sour in it.

In a few days some gruel made from scalded shorts and bran may be fed. Gradually a little cracked corn should be added to the bill of fare. Care must be taken at all times in changing a food to do it by degrees. Less and 
less of the mother's milk should be required as the quantity of extra food given is increased. When about eight weeks of age they should be weaned entirely, the mother being placed in another pen.

If the young pigs are to make their best growth after weaning they should not be exposed to the hot sun or inelosed within a dark, filthy pen. During the summer they need a cool place to forage and a wallow. Add some grain to their forage. During fall and winter they are to be made ready for the market. It is then best to eonfine them to a light, clean, well-ventilated pen and feed them aceording to the suggestions given under the foregoing chapter on Feeding.

\section{Practical Questions}

1. How do sheep differ from cattle? 2. Is sheep raising an ancient occupation? 3. What are the two chief uses of sheep? 4. Describe two breeds of the mutton type. 5. For what is the Merino breed famous? 6. Describe how sheep are cared for and fed. 7. What is the origin of our swine? 8. Why are there more lard than bacon hogs in America? 9. State a few characteristics of the lard type. 10. Give the chief differences between the common breeds of hogs. 11. What is hog cholera? 12. Explain how the hogs are cared for and fed at home. 13. How would you like to raise a pig?

\section{Home Exercises}

1. Start a pig club. Get all the information available from the state or national bureaus. As in the case of other farm animals, the pig should be a thoroughbred animal. Keep a careful record of all expenditures in the pig work. The basis of award suggested by the national bureau is as follows:

1) The exhibit of the hog and relation to its purposes judged by score card . . . . . . . . . . . . 25

2) Average gain per day or month . . . . . . . . . 25

3) Net profit and cost of production . . . . . . . . 25

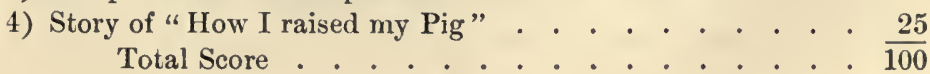


2. Make a pig and sheep census of your school district, giving the uumber of each breed of animals as far as possible.

3. Write a story on "How My Father keeps his Pigs," or use sheep instead of pigs in such a story.

\section{SUGG ESTIONS}

Draw or construct models of hog houses. Send to your local Experiment Station for plans. Correlate this work with that of the manual arts. Even if ordinary paper pasted together must be used, it will make the subject more real and lead to closer observation than mere book work. Books are only helps in the study of agriculture. The subject must be made real, practical, and fascinating.

2. Select samples of pure cotton and wool, and make a list of all the points of difference you can find. Determine the per cent of cotton or wool in some common fabric. Get information on this poiut from a local tailor.

3. A score eard for pig or sheep is also a very interesting means of arousing interest in these animals.

\section{REFEHENCES}

Manual of Farm Animals. Harper.

Types and Breeds of Farm Animals. Plumb.

Sheep Farming in America. Wing.

American Merino. Powers.

Swine Husbandry. Colburn.

IIome Pork Making. Fulton.

Hund Book of Nature Study. Comstock.

Farmers' Bulletins. Washington. D. C.

96. Raising Sheep for Mutton.

133. Profitable Crops for Pigs.

205. Pig Management.

222. Market. Classes and Grades of Swine.

329. Hogging off Corn.

438. Hog Houses.

566. Boys' Pig Clubs.

Circular No. 30. Hog Raising in the South.

Hog Feeding. Manhattan, Kansas. 


\section{CHAPTER XXXII}

\section{POULTRY}

The cock, with lively din

Scatters the rear of darkness thin

And to the stack or the barn-door

Stoutly struts his dames before.

- Milton.

313. Why the Raising of Poultry is Popular. - Poultry production has grown to be an important industry in the United States. The value of poultry products for the year

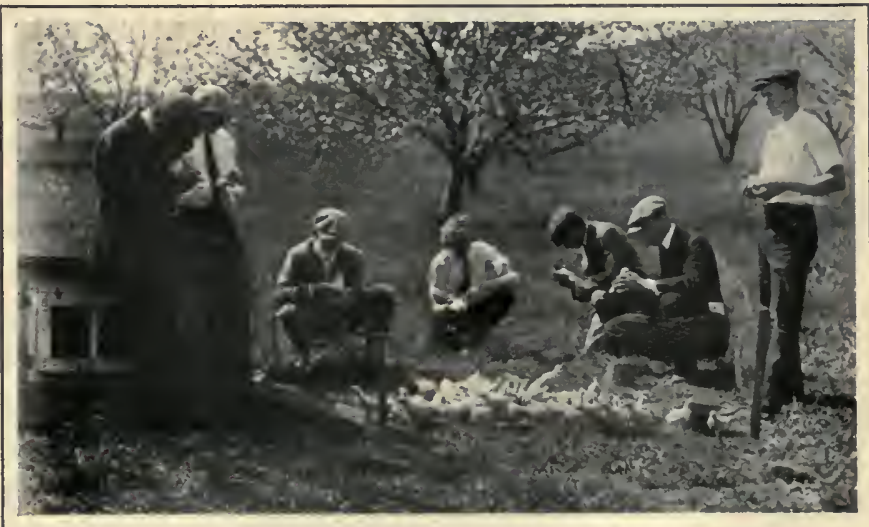

A POULtry Project.

1912 was estimated at $\$ 700,000,000$, which is more than five times the value of all the gold, silver, and iron ore mined in the United States that year. More than a quarter of a billion chickens and other forms of poultry 
are consumed yearly in this country. Chickens are raised on nearly every farm the world over, and are found even in the back yard of town dwellers.

There are many reasons for the popularity of poultry. Little capital is needed in the business. On the farm, during much of the year, fowls need hardly any attention. They consume large quantities of waste matters, and cost little for upkeep. 'The eggs and flesh are wholesome and universally relished. Hens are adapted to a restricted or to a free range; and fair success and profit come to keepers of only slight acquaintance with modern

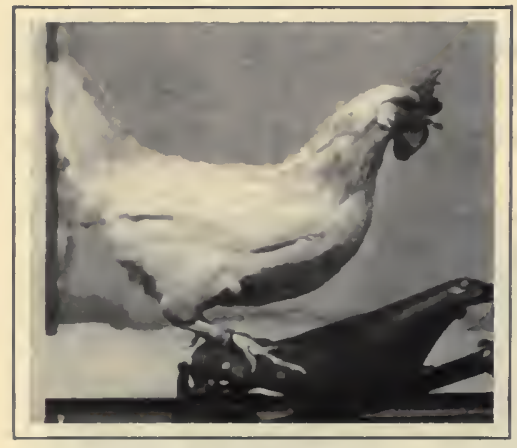

WHITE LEGHORN.

This hen, Lady Eglantine, has a record of 314 eggs in 365 days. poultry practices, provided they do not begin on too large a scale.

314. The First Chicken. - Chickens are dómesticated birds, distantly related to the grouse and other wild seratehers. So far as known, however, there are possibly four wild birds belonging to the, chicken species. These are the jungle fowls of India and Ceylon. It is quite possible that many thousand years ago a pair of these birds was caught and tamed, and that from it by selection and breeding the modern hen was produced. Certainly our breeds all came to us from Asia and southern Europe.

315. Types of Chickens. - IVe have already noticed that there are heavy horses, cattle, sheep, and hogs, as distinguished from light horses, cattle, sheep, and hogs; and that the heavy and light types are associated with dif- 
ferent purposes on the farm. Light sheep, for example, produce wool; light cattle, milk; and light hogs, bacon. Among poultry we have also the two great types, the light breeds, to produce eggs, and the heavy breeds, to produce meat. In addition to these two types, as might have been said of all the great divisions of live stock, a third type is often recognized, - a middle, or "general purpose," type.

\section{The Egg Breeds} belong to the "Mediterranean class." - The breeds and varieties of this class are small and nervous. They are good foragers, but poor sitters; they mature early and lay whiteshelled eggs at an early age. Two common breeds are the Leghorns and the Minorcas.

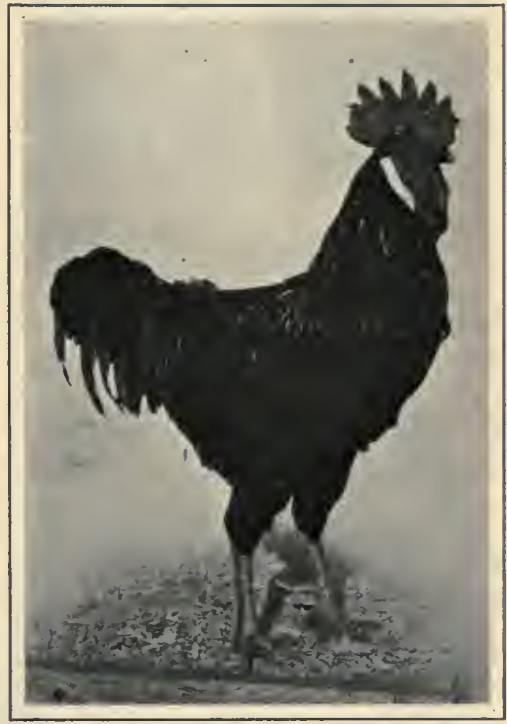

MiNORCA COCK.

317. The Leghorns, which are white, brown, buff, or black in color, have long slender bodies and white ear lobes. They lead all others in laying qualities.

318. The Minorca is distinctly larger than the Leghorn and has a larger comb. Black is its most popular color. It lays fewer but larger eggs than the Leghorn.

319. The Meat Breeds are known as the "Asiatic Class." The meat breeds are heavy, slow in movement, poor layers, but good sitters. All the members of this class have feathers on the shanks and feet. The three breeds 
of this class, in the order of their popularity, are the Brahma, the Langshan, and the Cochin. 'The Brahmas

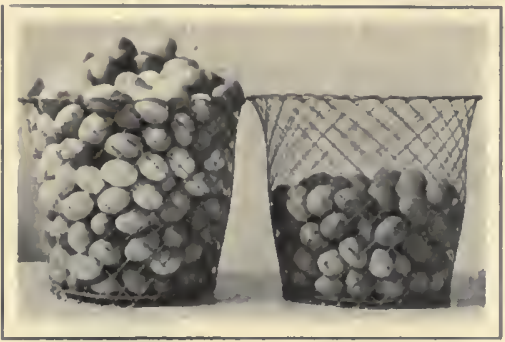

EGG YiELDS, compared with the work of the average hen (135 eggs).
Lady Eglantine's record (314 eggs)

are the heaviest, and the Langshans are the tallest of the threc. As large chickens for roasting, no breed excels these three. Poultry fanciers, however, have bred them more for feathers than for utility or use.

The meat breeds were formerly practically all in the Asiatic class, but with the almost entire disappearance of this type of chickens, breeds of the American class have taken their place.

320. The General Purpose Breeds, sometimes known as the "American class," combine with more or less success the characteristics of the egg and of the meat breeds. American poultry men, in developing this class, desired a medium-sized fowl of great vigor and plain type, adapted to a wide range of conditions, and a fowl that would produce at least a fair amount of both eggs and meat. To this class

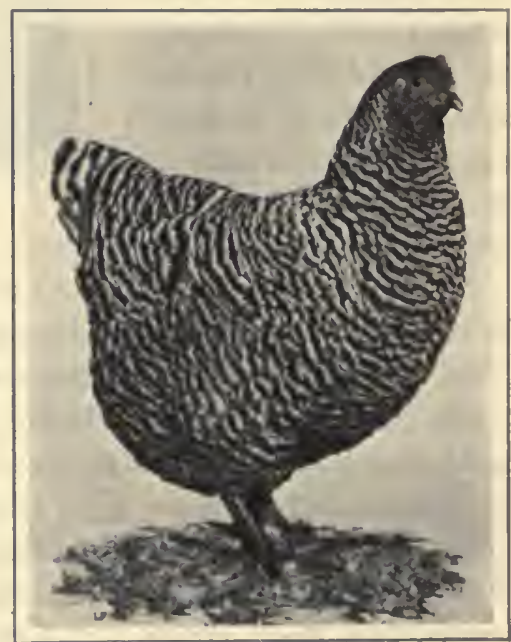

Barred Plymouth Rock Hen. 
belong many of our most common breeds. The following are a few:

(a) The Plymouth Rocks lead all others in the United States in numbers and popularity. They are quiet, easily controlled, good and reliable layers, and furnish meat of excellent quality, making good broilers at from eight to twelve weeks of age.

(b) The Wyandottes are shorter in body than the Rocks, and run about a pound lighter in weight. Their flesh is sweet and tender. A Wyandotte hen should average about 14 dozen eggs a year.

(c) The Rhode Island Reds are beginning to take high rank in poultry production. They weigh a trifle less than the Rocks, and are considerably longer and less compact than the Wyandottes. As foragers they equal the Leghorns, and do less mischief. They lay brown eggs, and are good sitters and mothers.

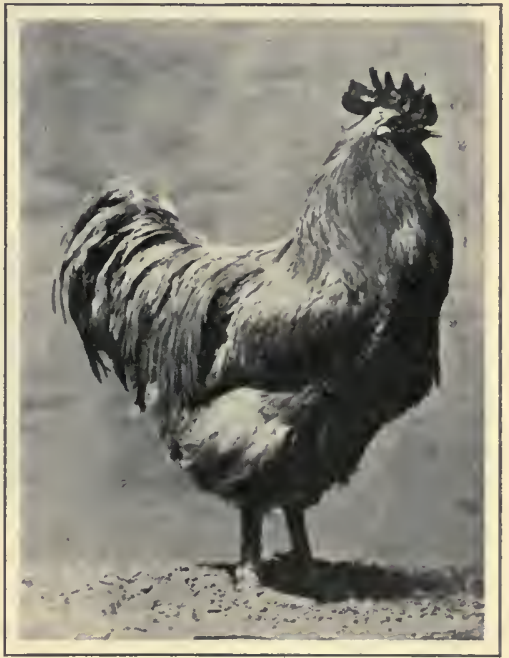

BufF-ORPINGTON.

(d) The Orpingtons are another general purpose breed that for a while were in great demand but are now somewhat neglected because of the prejudice in America against white-skinned poultry. They have round, deep bodies, broad backs, full breasts, short legs, white beaks, legs, and toes, and weigh nearly a pound more than the Rocks. 
321. Selecting Breeds. - The hen which the general farmer needs is one that lays well, especially in those seasons of the year when eggs are high in price, and one that will dress out a fair quantity of meat for the table. There are poor layers even among the Leghorns, and it is, therefore, wise to place much emphasis on those strains or families that are strong in egg production, regardless of breeds. It is a simple matter to select breeds for meat-

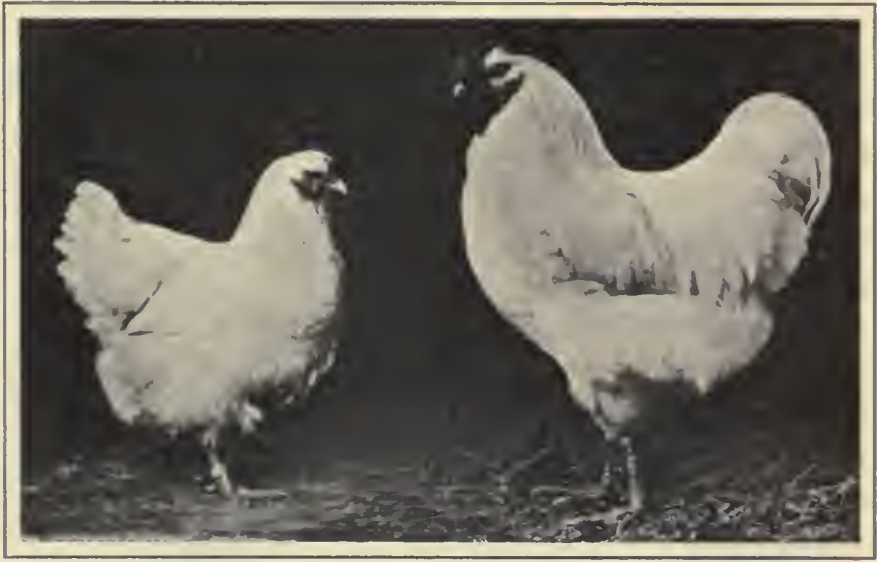

White Wyandottes.

producing qualities from mere appearances, but the ability to produce eggs must be determined by actual performance. 322. Housing of Poultry. - Chickens have a temperature much higher than man has, and in order to maintain in them what to us would be a fever heat, plenty of fresh air should enter the chicken houses. The movement for the fresh-air poultry house is a recent one. Enough practical farmers, however, have shown its advantages over a warm house, in securing better egg production, fertility of eggs, and vigor of chicks raised from the stock, to warrant a 
recommendation for fresh-air houses in preference to warm, closed-up houses.

A common fresh-air house has something like 50 per cent of the south fiont open. During the coldest nights, however, a muslin curtain may be let down over the opening. Glass windows may take up the rest of the sunny side. The plan is to admit plenty of sunlight and to get good ventilation without draughts.

It is best to locate the poultry houses upon soil that is well drained. A cold damp location is as unsuitable as is a closed-up lome. A raised site, or, lacking this, a few inches of gravel under a cement floor, will generally satisfy the deniands for dryness. The house had better not be placed near farm buildings that are apt to become filthy, since feeding at such unsanitary places affects the flavor of the eggs and even the flesh.

323. Some Diseases of Poultry. - Poultry are subjected to many diseases, each of which requires special treatment. We can mention only a few of them.

Gapes is caused by a worm left in the mouth in swallowing the ordinary food, or by angleworms infested with this parasite. The logical "prevention" is new or untainted ground, especially in a wet season. Diseased birds should be kept by themselves, and all droppings burned. Spraying the throat with spirits of camphor is a good remedy.

For lice rub lice powder into the feathers and use kerosene emulsion, to which a little creosote has been added, or use a little butter, lard, or some bland oil rubbed into the down and feathers of the head.

Roup is a foul-smelling and highly contagious form of catarrhal cold. Clean out the beaks, and spray the fowl with peroxide of hydrogen. Also add a few grains of permanganate of potash to the drinking water. 
For bleeding from the comb, wash with cold water, and coat the comb with vaseline to keep away the rest of the flock. Egg-eating trouble is due to thin shells, insufficient or improper nests, and lack of nest eggs in all nests. Feed cracked oyster shells and collect eggs frequently.

324. Raising Chickens. - One reason why chicken raising as a regular part of a pupil's school work is so intensely

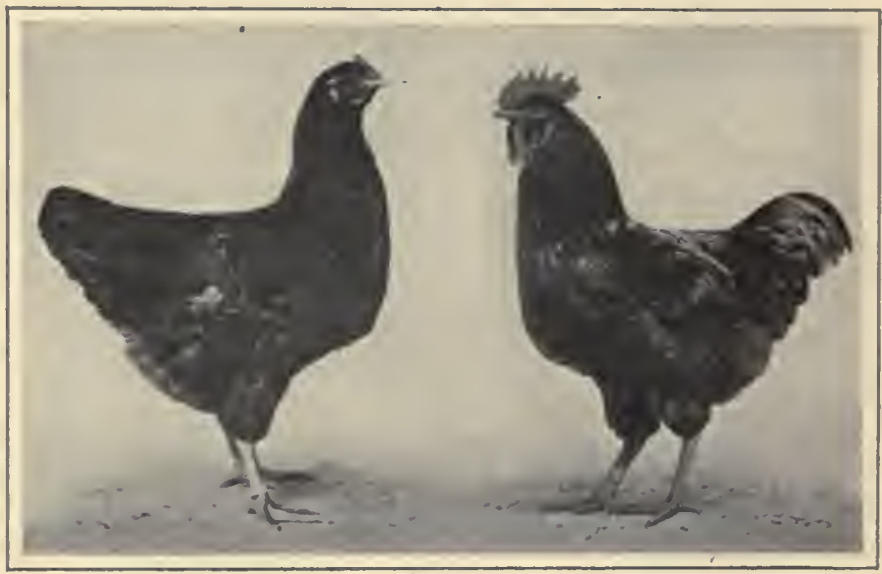

RHOdE ISLAND REDS.

interesting lies in the fact that chickens grow rapidly and mature early. They respond quickly to good or bad treatment. A boy can readily see the results of his care and foresight, on the one hand, or of his indifference and neglect, on the other. If a boy is successful in making money out of his flock, he can, perhaps, make money out of horses, cattle, corn or wheat when, as a man, he assumes charge of a farm.

Starting in the beginning, the first point of importance is to have, if possible, a pure-bred male bird at the head 
of the flock. It would be better if the hens were purebred also, because the poultry products would then be more uniform and hence could more readily be marketed at the best price. What breed is most desirable? That all depends on the purposes for which the chickens are to

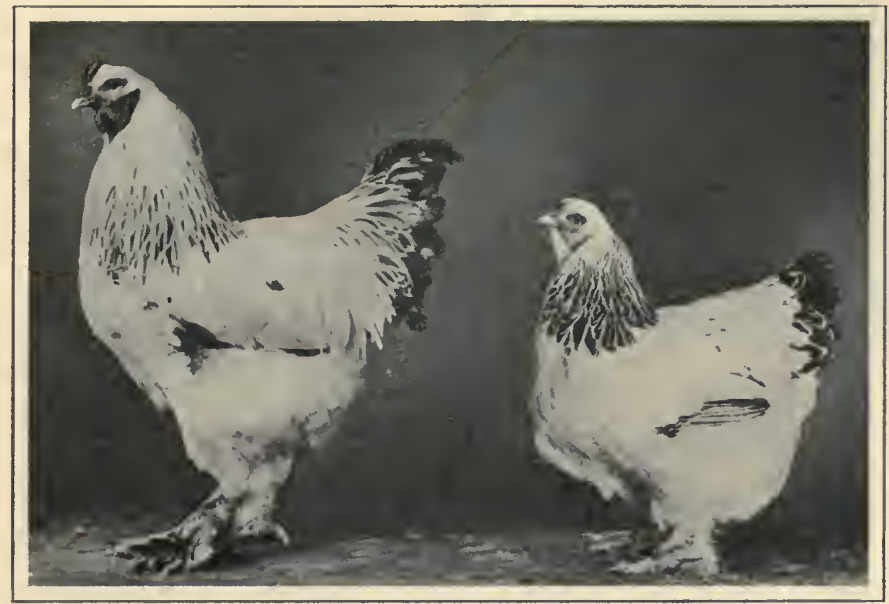

Brahma Cock and Hen.

be raised. It would be a good plan if all the pupils of the class would select the same breed.

(a) Natural or Hen Incubation. - You must be careful that the nest is a quiet one and properly constructed. If it is necessary for the hen to jump down on the nest when returning to it during the incubation period, there is danger of broken eggs. Occasionally some one will make a nest for a setting hen in the shape of a derby hat. The eggs in such a nest are likely to lie too close together at the center, thus making it difficult for the hen to turn them the required number of times.

It may be that the real reason why the mother fre- 
quently turns her eggs is not for the benefit of the growing chicks, as it certainly happens to be, but for making her sitting posture more

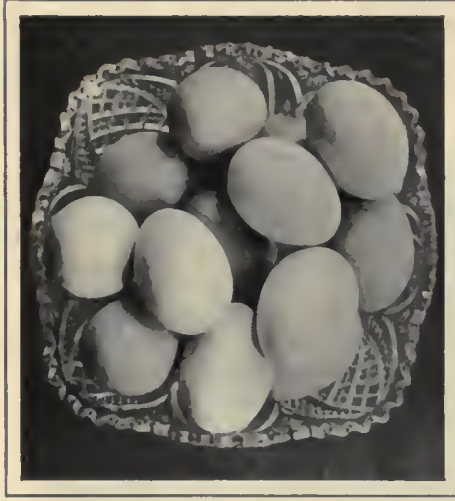

A Setting of Egas.

Eggs for breeding purposes should be carefully selected. comfortable. In winter, however, when the weather is yet very cold, a fairly deep nest made of soft meadow hay lined with chaff is to be preferred to a thin, shallow nest, especially if made of such poor nesting material as excelsior.

Select from 9 to 15 good, fertile eggs of uniform size and from the same breed. The greater number of eggs may be set in late spring. If you desire the pullets (females under a year) to be laying eggs early in the season, it is necessary to start hatching early in the spring.

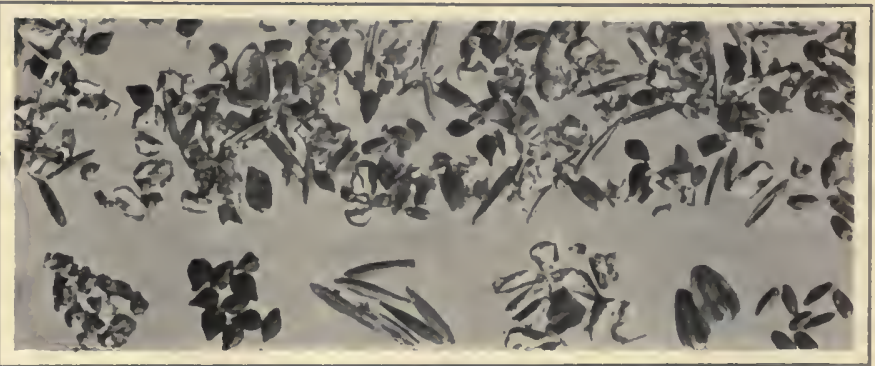

POULTRY FEed.

In the lower part of the picture the ingredients are separated. From left to right they are: grit, buckwheat, oats, cracked corn, sunflower seed, and wheat. 
When the sitting hen leaves the nest to secure food and water, it is best to have these necessities at a convenient place for her. Otherwise she may tarry too long, thus allowing the eggs to become dangerously cold. Hard grains and grit with a little green succulent food are best for her. Fresh food and water should be supplied daily.

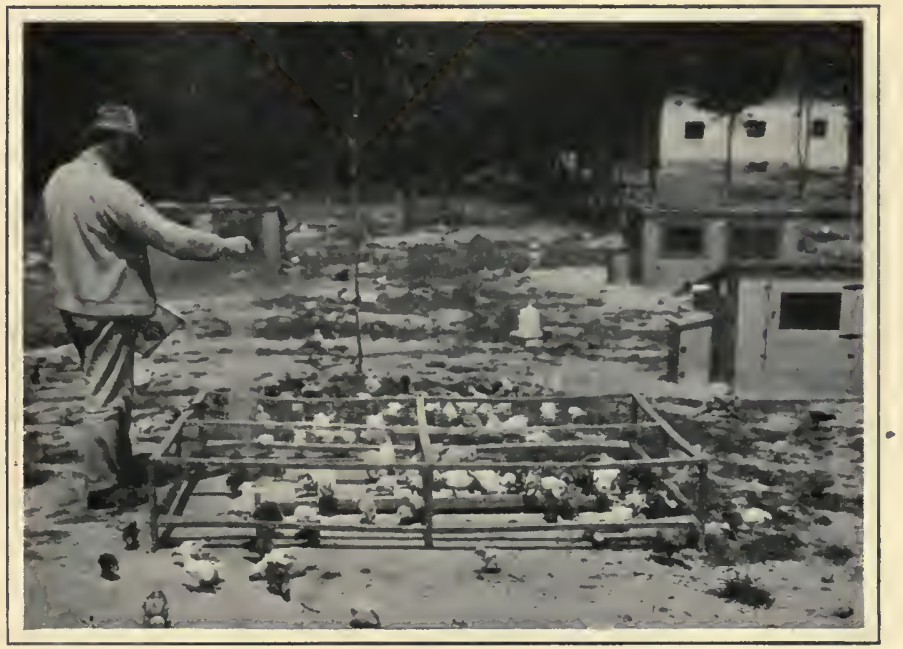

Feeding the Chickens.

At the end of 21 days the eggs should be hatched. Have a coop ready - a coop that can easily be kept clean and well ventilated. Place the coop where the mother with her chicks can enjoy a good range. After the first day give them a mash in the morning; cracked corn later in the forenoon; cracked corn and whole wheat toward the middle of the afternoon and cracked corn in the evening. A good chick grain is commonly sold everywhere. The little chicks can have no other purpose in life but to eat, sleep, exercise, and grow. 
When people raise chickens on a large scale they find that it is more profitable to incubate the eggs by what is known as

(b) Artificial or Machine Incubation. - Artificial incubation requires great care and a rather extended experience to be successful. Hundreds of little details, many of which in the natural method the hen herself takes care

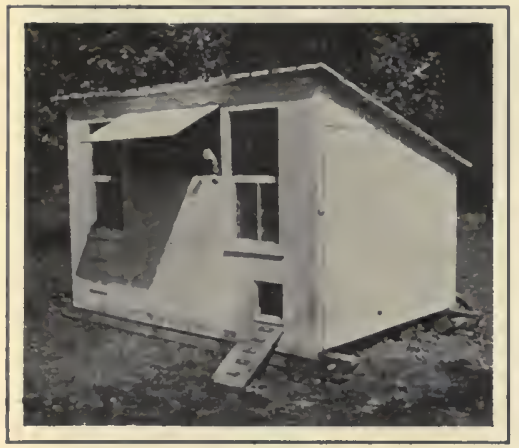

Small Chicken House. of, must be mastered. Usually, full directions accompany the apparatus; that is, the incubators and brooders, when purchased from the dealers. Just a few suggestions need be offered here.

Get ready a little beforehand by trying out the apparatus for several days to be sure you can operate it according to directions. Perhaps a wellventilated cellar is as good a place as any for the hatching. Select the best eggs obtainable. Keep the temperature as near $102^{\circ} \mathrm{F}$. as possible. Turn the eggs twice daily from the third to the eighteenth day. Cool the eggs each day for about fifteen minutes, or when the weather is warm a little longer. Testing is done on the seventh and the fourteenth days.

A simple device for "candling" or testing eggs can be made by folding, in the form of a tube an inch or two in diameter and about two feet long, a piece of heavy paper. Place the egg at one end and look through the tube toward a strong light. A large dark area indicates a live embryo. You understand why it is useless to keep on 
incubating eggs without live embryos. The two chief reasons for failures with incubators are : poor judgment and irregular attention.

It must be remembered that when the chicks appear they come as orphans and must be mothered. The most successful chicken men have learned their best lessons directly from the mother hen. The mother keeps the newly hatched chicks quiet and warm for the first day or two; she gives them plenty of fresh air ; and allows their bodies to dry off without the danger of a chill. So must we, their foster mothers.

(c) Brooders. - One of the first wants of chicks is a warm mother, and to supply this want to the orphans many kinds of brooders have been manufactured. The fireless brooder is really a modification of

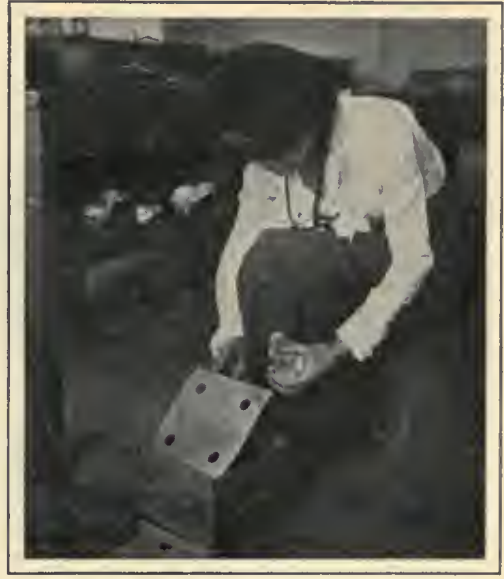

Putting Chicks in the Brooder. the basket or box, covered with a piece of flannel or old shawl, which is usually placed behind the kitchen stove. Our grandmothers have used this method for generations. The heat, when the brooder is taken outdoors, must come from the bodies of the chicks themselves. It is held that this brooder in midwinter then requires too much of the chick's energy to supply its own needed heat, leaving little for growth and development.

In another type of brooder, heat and ventilation are supplied artificially, commonly by a lamp. For the first 
week in such brooders the temperature should not be allowed to go below $95^{\circ} \mathrm{F}$. It will not hurt a young chick to run out in the cold, even in the snow, if it has a warm place to run back to and can find this place. Chicks should be encouraged early in life to take outlloor exercise and not spend all their time loafing in the warm brooder.

A cheap artificially heated brooder for indoors can be made from an ordinary flat store box. Remove the boards

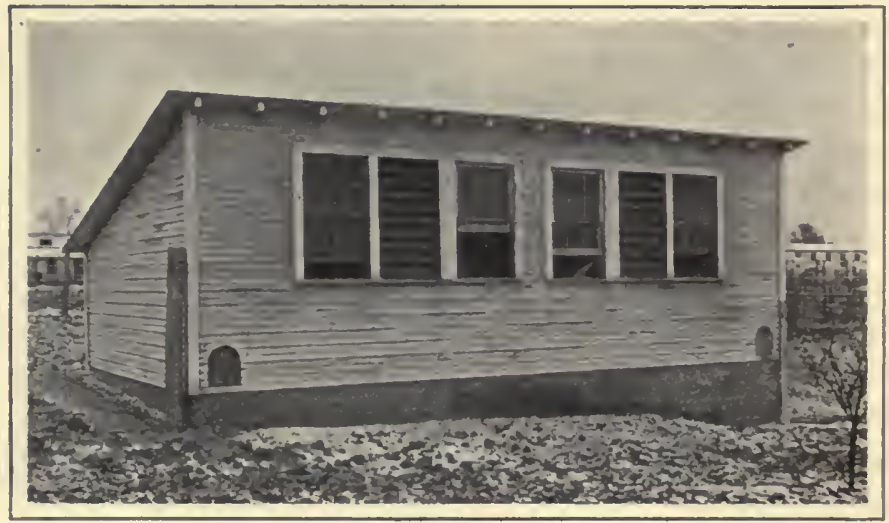

A Type of Colony Hen-house.

on the broadest side and nail across this a narrow board about 18 inches from one end. The open part of the box is the top. Cover one end of the top with burlap which is allowed to sag in the middle to within four inches of the bottom. On the burlap a hot water bottle filled twice each day and covered with newspapers is placed. The newspapers keep in the heat above. To the cross piece is hung a curtain extending nearly to the floor. Under the warm water bottle is the nursery. The other part of the box is used as a runway. This part should be covered with half- 
inch mesh wire to keep out rats and cats. If this brooder is kept dry it will serve outdoor's also. ${ }^{1}$

(d) Finishing. If the chicks are intended to be layers, the hatching should be done in early spring. When twelve weeks old they should be placed in small colony houses in a field and given a chance to run in the grass. They should now receive much the same care as to feeding as those raised by the hen. Broilers grown in the winter are kept in the brooder house until they weigh from one to two pounds.

Spring broilers if in free range are confined to a small yard or pen and are fed on a fattening ration including corn and meat. Fryers are confined two or three weeks before marketing. They should gain a half pound each week. Roasters are usually carried a little farther in a free range before fattening in the yard. The fattening process can be finished more quickly by placing the roasters for a week in a dark enclosure.

(e) Marketing. Chickens may be started properly; they may be reared with care and economy; and yet when their products are placed on the competitive market, scant return can be shown for the labor and money invested. While the raising of chickens may provide a high degree of intellectual pleasure, yet the pleasure is usually not complete unless it is rounded out with a handsome profit. If poultry is shipped alive, little need be done except sorting and grading. But when the poultry is to be dressed it must be fasted, killed, scalded, picked, cooled, graded, and packed.

On each point much valuable experience need be acquired. Often a seller is able to get several cents more a

It is much better for pupils to make such things than to buy them. An apparatus of this kind often serves the same purpose as the more expensive articles supplied by dealers. 
pound for his poultry products because he knows how to deliver these products in a way that is attractive to the best buyers. When you go to market watch with the utmost care how those poultrymen who get the fancy prices, market their goods. Not only imitate the best methods, but make the best better.

There is a great deal to be learned, too, in getting eggs ready for the market so as to satisfy the most exacting

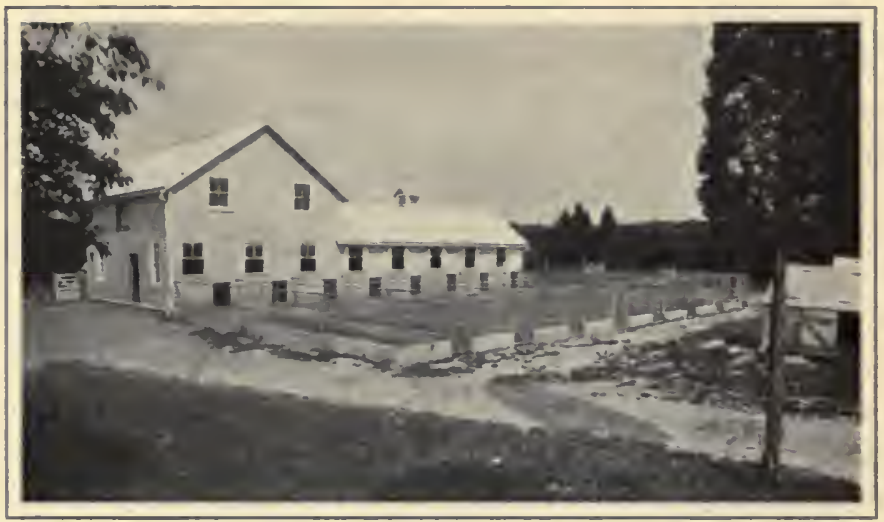

MOdERn POULTRY HOUSE AND YARD.

tastes of the best consumers. The eggs should be sorted for color and size, cleaned and shipped in suitable cases. If a producer clesires to preserve his eggs in water glass, which is done by using one part of the water glass to ten of water, that is his private affair; but if he places these preserved eggs on the market as fresh eggs then the affair becomes a matter of public concern. The producer will soon learn that honesty is the best policy in the egg market as well as in any other. Clean the fresh eggs thoroughly with warm water. If they are so stained as to make cleaning impossible, keep them for home use. 
In the trade, eggs are sorted as to color into three classes: white, gray, and brown. Even though the market has no special preference, a carton of mixed eggs does not look well. 'The size of the cartons depends on the quantity of eggs the buyer needs.

There is an increasing number of fresh eggs now being sold by producers directly to distant consumers through the medium of the parcel post. Pasteboard boxes holding from one to ten dozen eggs each are manufactured es-

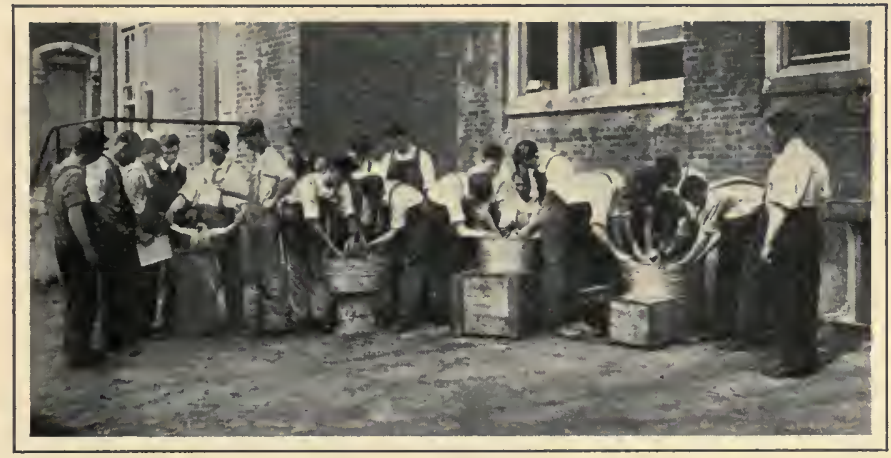

High School Boys Preparing for the Poultry Show.

pecially for this trade. The boxes are made of fiber board with corrugated lining and fillers or partitions of the same material. Each egg is securely wrapped in corrugated pasteboard. Farmers should avail themselves more and more of such opportunities afforded by the parcel post, and thus keep in their own pockets the profits that would go to middlemen.

If a storekeeper can sell fifteen dozen eggs a week, cartons of that size should be furnished him. To others using larger quantities the regulation case having two compartments each holding fifteen dozen eggs is most suitable. 
It is a good thing to advertise a little on the label of the carton. Select a suitable name for the farm, and ad-

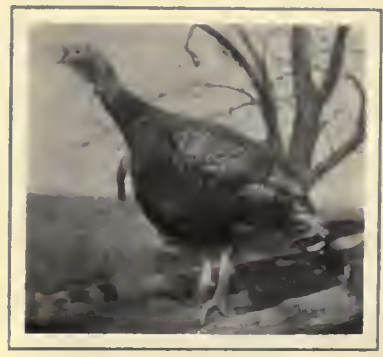

TURKEY. vertise this name not only on the pareel labels, but on the billheads and market wagon. Judicious advertising pays.

To sum up, then, pupils who wish to raise chickens for profit as a school project should see that proper care is taken in the selection of the eggs, which should come from the best available stock; that there is little loss in hatching; that the chicks are profitably brooded; and that their products, whether meat or eggs, are attractively presented to prospective buyers.

\section{Practical Questions}

1. How does our poultry industry compare with some of our other industries? 2. What is the origin of the common hen? 3. Deseribe the Leghorn and the Minorca breeds. 4. What is meant by the term, "general purpose fowls?" 5. Name three general purpose breeds. 6. Describe a fresh-air chicken house. 7. Describe the Rocks and the Wyandottes. 8. What are good succulent feeds for chickens? 9. In what way may eggs be spoiled before reaching the consumer? 10. What is roup? 11. How should eggs be marketed? 12. Give a ration for young chicks. 13. Will you not raise a pen of chickens?

\section{HoMe EXercises}

1. Report the number of different kinds of poultry at home, and your father's method of taking care of them.

2. Report the per cent of hens laying every day for one week. How do you determine which hens are not laying?

3. Start a Poultry Project. This project is interesting and highly instructive. The following is a copy of the poultry blank furnished by the Bureau of Animal Industry, Washington, D.C. 
Rearing Report From Weaning TIME UNTIL JANUARY First

Name

Post Office

Name of Poultry Club.
Age

County

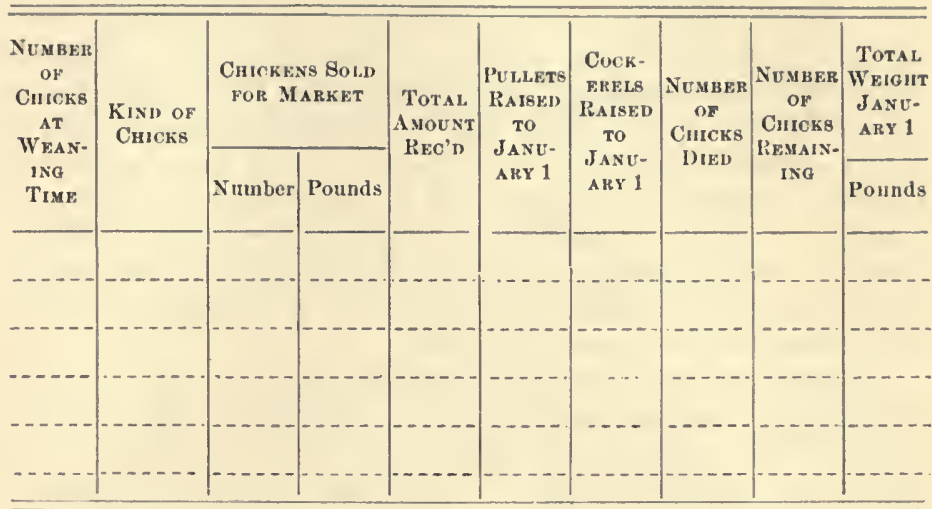

REMARKs. - Chickens sold for breeders: CockereIs - Number

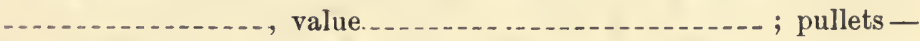
Number , value

Highest price received for a single bird : $\$$ ; cockerel or pullet.

Exhibited at. Fair. Number of birds exhibited. ; total prize money received, \$

Number of special premiums. ; nature of same

Chickens used at home should be credited at market prices.

Labor at 10 cents per hour: Number of hours ............. cost.

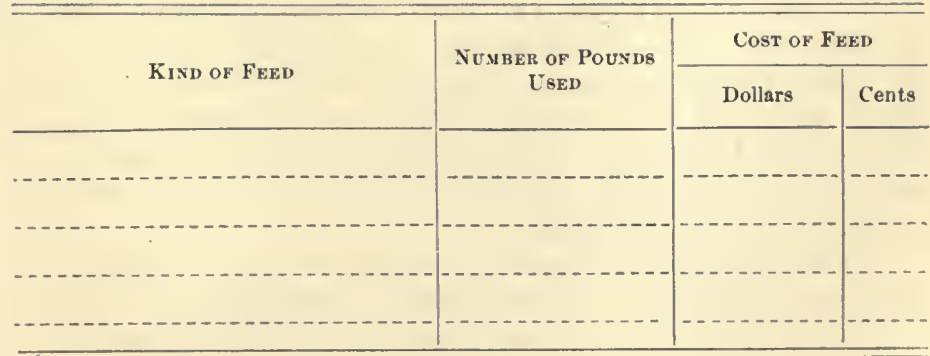


Two copies of this report must be filled out to January 1; one to be given to the teacher and the other to be retained by the club member.

\section{SugGestions}

1. Send to your Agricultural College for modern poultry house plans. Small models can readily be made in school. After the models have been completed, mount them on the floor or on a broad table. Sawdust stained with a green dye may be placed around them to resemble grass. Invite the patrons of the school to see the exhibit. Compare these models with the poultry houses of the community. If there is a planing mill or box factory in the neighborhood, the scraps of material needed for the sides and supports can be cheaply and easily obtained. The entire cost of an excellent poultryhouse model need not exceed ten cents.

2. Open up a fresh uncooked egg in a shallow cup or saucer. Note the germ, - a small red spot on the yolk. This is the vital spot where growth of the chick begins in a fertile egg. Notice the chalaza in the albumen or white of the egg. This is made up of denser layers of albumen, and is for the purpose of protecting the unhatched chick by keeping it away from the shell. Take a little of the albumen and of the yolk, and shake them separately in a glass containing a little water. Note which appears to be the more oily.

Examine the shell. Note the two membranes. Both membranes can be seen at the thicker end of the shell, where there is an air space. Hold a bit of the shell and membrane up to the light separately, to see if either is porous. If a microscope were available, the pupils would be better able to see the pores if any are present. Gases must enter and leave the egg during the hatching period. Can gases pass tbrough a membrane that is not porous?

3. Remove the shell from a hard-boiled egg. Study the membranes of the shell, and the layers of albumen. Notice the whitish layers in the yolk. Fat is lighter in weight than albumen, hence the yolk floats at its surface, as is seen when the shell is removed. For this reason eggs must be turned occasionally for a few days during the early period of hatching. Otherwise, the germ that is found on the top of the yolk would dry fast to the shell and die. A sitting hell, of course, turns the eggs herself.

4. Each pupil should keep a record of the home egg production. The number of hens should be counted, and a record kept of the number of eggs produced by them. Determine the per cent of laying hens. 


\section{References}

Productive Poultry Husbandry. Lewis.

Principles and Practice of Poultry Culture. Robinson. A merican Standard of Perfection. Drevenstedt.

Making Poultry Pay. Powell.

Farmers' Bulletins. Washington, D.C.

51. Standard Varieties of Chickens.

128. Eggs and Their Use.

200. Turkeys.

236. Incubation and Incubators.

287. Poultry Management.

445. Market Eggs through the Creamery.

452. Capons and Caponizing.

528. Hints to Poultry Raisers.

530. Important Poultry Diseases.

562. The Organization of Boys' and Girls' Poultry Clubs.

574. Poultry House Construction.

594. Shipping Eggs by Parcel Post.

624. Natural and Artificial Brooding of Chickens.

682. A Simple Trap Nest for Poultry. 


\section{PART V}

\section{FARM ECONOMICS}

\section{CHAP'TER XXXIII}

\section{FARM FINANOE}

"If thou lend money to any of my people that is poor by thee, thou shalt not be to him as an usurer, neither shalt thou lay upon him usury." - Exodus xxll. 25.

325. The Call of Better Farm Management. - We have now studied a few facts about rural life; and a few points on the soil, - its origin, composition, and treatment. We have noted certain peculiarities of farm plants, - how they can be best selected and grown with profit; and we have also become acquainted witl some of the well-recognized principles of feeding farm stock, also how cattle, horses, sheep, and poultry are grouped into types and breeds, each presenting its special point of interest. But a knowledge of all these things is valuable only so far as it can be made to serve useful purposes. Knowledge is power only when put into use. We must not conclude our study of the great subject of agriculture without a brief discussion of farm management, - the kind of management which spells farm, community, and national efficiency.

Agriculture is not only a science and an art, but a plain business proposition as well. And whenever we talk of business we talk of money and we deal with principles of finance.

In every chapter of this book "Home Exercises" have 446 
been outlined. We desired to give you, as you worked on these exercises, the skill to earn money for yourself. Outside of school, learning and earning go together. The more we learn of what is really useful in our work the more we shall probably earn. The amount, however, depends in large measure on whether we are good managers or not; in other words, on whether we have good judgment and show business ability as well.

American farmers have often been criticized for their lack of good business sense. Many of them do not keep records of receipts and expenditures of important farm operations. Many are at times extremely radical, then at other times extremely conservative, on scientific and financial questions. The only thing that has saved them against the competition of the world has been their boundless resources and their exceptional opportunities. Up to within a few years it was possible to waste our soil, destroy our forests, and neglect our capacity for developing and extending credit in rural sections, without feeling the effects of mismanagement severely either in the foreign or in the domestic trade. But these days are gone.

Farming is now coming to be more and more a business enterprise the world over; and it is our plain, patriotic duty as Americans to recognize the necessity of skillful management in directing this business, just as we have for year's recognized it in the organization and direction of our industrial affairs.

At bottom our agricultural problem is largely an economic one. It concerns capital and all the agencies, both individual and collective, which can attract and manage capital under conditions that will promote and not prevent rural development. We will first inquire as to

326. What is Capital? - Capital, according to Adam Smith, is all resources from which one expects revenues. 
It is wealth employed in production. Let us use a common illustration to show how capital differs from mere wealth with which it is often confused. You may own a fancy chicken, ornamented with feathers of an unusual design. You did not breed this chicken in order to make money out of it, but merely for the pleasure its presence gave you. This chicken is a form of wealth. If, however, you are raising this fancy stock for profit, it will then be capital, since it is used for production of more wealth.' The

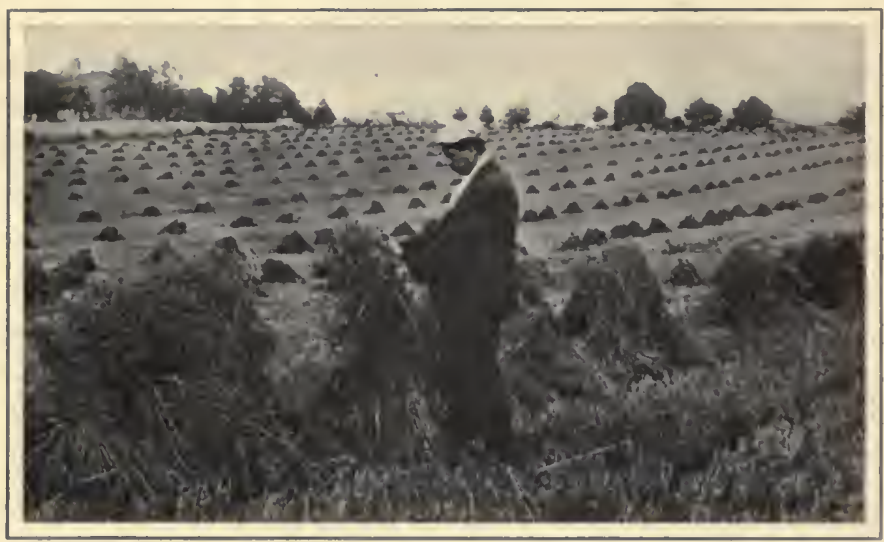

Successful Farming Requires Capital

essential feature of capital then, whether in the form of money, tools, machinery, stock, or land, is the use to which it is put, rather than the form which it takes.

Farm capital is sometimes regarded either as fixed or circulating. By the term fixed capital is meant such forms as land, bridges, and roads, which may be used many times in production. Circulating capital consists of such articles as fuel, fertilizer, and feed, which lose their value or are consumed when used. 
327. Need of Capital. - It was stated in Chapter IV that the per cent of tenant farmers in the United States is increasing. The following census table shows this:

\begin{tabular}{l|c|c|c|c}
\hline \hline & 1880 & 1890 & 1900 & 1910 \\
\hline Per cent of Tenants to Landlords & 25.6 & 28.4 & 35.3 & 37 \\
\cline { 2 - 4 } & & & & \\
\hline
\end{tabular}

This growth in tenancy is more of a symptom than a cause of any fundamental disturbance in our country life. It is a symptom that more capital is needed in successful farming to-day than was required a generation ago; that small farms poorly equipped with machinery and stock are placed at a disadvantage when competing with larger farms under modern management. Even small farms of less than 100 acres equipped in modern fashion may now be laboring under a handicap. Large farms of several hundred acres fitted out with up-to-date appliances can often produce yields most economically. All this means large capital.

In early days little capital was needed for farm purposes. If farmers did lay aside a little money each year, they were more likely to buy some municipal bond or welladvertised stock calculated to improve a distant city or industrial center than to invest these earnings in farm improvements. A few simple tools, many of which were made at home or at the local blacksmith shop, were all that they knew how to use. Land was either free or very cheap. Not only land, but expensive stock, tools, and machinery, are necessities in present day agriculture.

Our industrial development has outrun our agricultural development. We have watched the building of great 
trunk lines and the growth of industrial centers with satisfaction. Nor was it regarded of vital importance, to equalize the burdens of taxation on the property of the manufacturers and that of the farmers. The report of the commission which recently investigated the tax question in California, a typical state, reports that: "Manufacturers pay $\frac{1}{2}$ of one per cent on their capital in taxes;

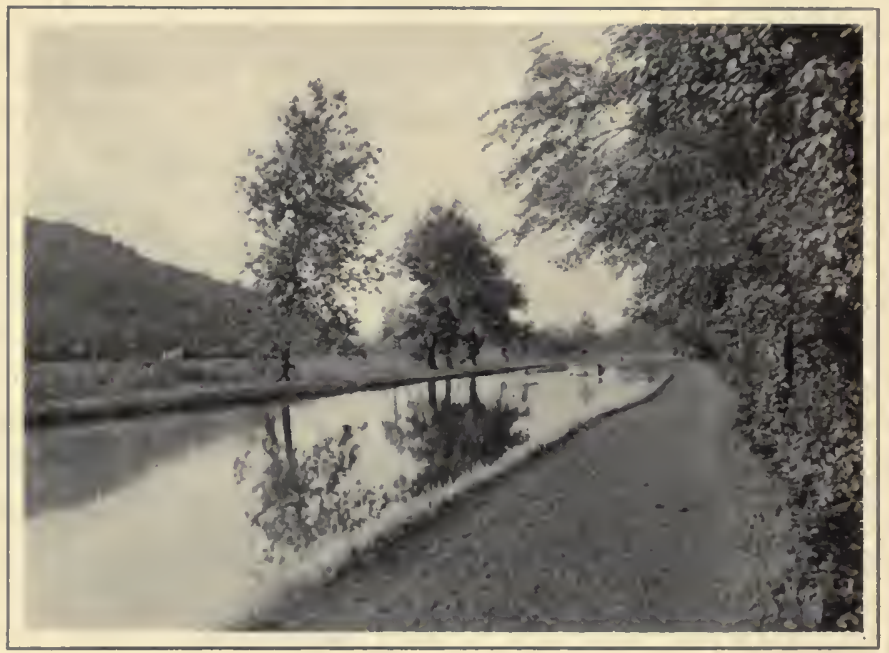

Transportation.

Here may be seen a railroad and a canal side by side, two common types of transportation.

farmers pay 1.14 per cent, or two and one third times as much. Manufacturers pay $\frac{1}{3}$ of one per cent of their gross income in taxes; farmers pay nearly 7 per cent, or twenty times as much. Manufacturers pay 2 per cent of their net income, while farmers pay 10 per cent, or five times as much."

It would doubtless be an error to consider the lack of capital in farming as the only cause of the alarming 
tendency of our foreign trade, but that it is a vital factor cannot be denied.

Our food animals and foodstuffs exported during the fiscal year of 1912 amounted to $\$ 99,900,000$ or 4.6 per cent of our total exports, while during the fiscal year 1900 they amounted to $\$ 227,300,000$ or 16.59 per cent of the total exports. Our similar imports for the year 1912 were $\$ 180,120,000$, but for the year 1900 were only $\$ 68,700,000$.

During this period our foreign trade was not affected by war, and when the present war is over the same tendency, unless arrested, will continue.

In plain language we are exporting less and less, and importing more and more, each succeeding year. What will the final effect of this be on splendid America?

Bankers, statesmen, - all patriotic citizens, are beginning to inquire why this is so and where it will lead to. It was once thought that a lack of scientific farming alone was responsible. Scientific farming is without doubt an important factor, but just as our industries, even with American ingenuity and skill, would have labored under a tremendous handicap without available capital, just so our agriculture has been for years, and is especially now, distressed because of a lack of financial accommodations suited to its peculiarities. These peculiarities call for low rates, long terms, and that type of security which is based in large measure on character, thrift, and intelligent industry.

Our national and state policies have been built up with the idea of encouraging manufacturing and of neglecting, or what is worse, of placing a handicap on the development of farming.

That farm capital is of vital importance to successful agriculture can be seen in part from an investigation 
made recently by Professor Warren of 615 farms operated by owners, of 'Tompkins County, New York. 'The following are the results of this investigation:

Relations of Capital, to Profits

\begin{tabular}{c|c|c}
\hline Capital & Number of Fatus & Avirage Iscome OF Laboz \\
\cline { 2 - 3 }$\$ 2,000$ or less & 36 & $\$ 192$ \\
$2,000-\$ 4,000$ & 200 & 240 \\
$4,000-6,000$ & 183 & 390 \\
$6,000-8,000$ & 94 & 530 \\
$8,000-10,000$ & 45 & 639 \\
$10,000-15,000$ & 44 & 870 \\
over 15,000 & 13 & 1164 \\
\hline
\end{tabular}

It will at once be noticed from the foregoing table that farmers with $\$ 4000$ capital were making less than the hired man, and that farmers with the larger capital were getting the larger labor income. Hence it is more profitable, ordinarily, unless a farmer can get control of about $\$ 5000$ worth of capital, to be a hired man, a share renter, a cash renter, or part owner, than to be a full owner. ${ }^{1}$

For this reason young farmers, especially, enter the tenant class, and, unless they can control later on a reasonable amount of capital, find it most profitable to remain indefinitely in this class.

But it is necessary, whether owners or tenants, to get the control of some capital - the more, within certain

1 A share renter is one in which the landlord may furnish the tenant the land only; or the land and some of the live stock, feed and fertilizer; or everything except human labor. The teuant and the landlord divide up or "share" the produee of the land, each taking the part agreed on, often one half.

The cash renter usually furnishes everything except the fixed capital land and buildings, and agrees to pay a stipulated sum to the laudlord for the use of the fixed capital. 
limits, the better, and this question of the need of capital takes us at once into one of the most pressing problems of American farm life, - how to secure, under the best terms, the capital requirements for the ordinary farmer.

How May Capital be Secured? - There are but two ways open to the farmer to secure the capital he needs, he may spend less than he earns or he may borrow what he requires from others. ${ }^{1}$

If a person is obliged to wait on his own efforts for the money he must have in business, he will be obliged very often to skimp along through life with scant productive power. If, however, he can borrow some money, not to pay living expenses, but to add to his power as a producer, he may be able soon to pay back the amount loaned from the increased earnings.

Some farmers think that it is not respectable to borrow money and thus carry a debt. It gives them greater joy to have a little bag of gold hid in a safe place in the floor, - having the sweet consciousness that they may be able to add a little to this sum in miserly fashion from year to year, - than to plan on borrowed capital a wider, a richer, and a more productive farm life. Wise borrowing is respectable, for the reason that it is the only means of increasing the earning power open to many farmers.

Where to secure the Capital. - There are four sources of supply open to the average farmer, - private individuals, stores, banks, and coöperative associations. ${ }^{2}$

When a farmer comes to one of these sources for funds the first question asked him is, What credit or security

${ }^{1}$ Neither of these methods, of course, includes what may be obtained by the laws of inheritance.

2 Borrowing from private individuals is the simplest method, and it would be the best if the borrower and the lender could readily find each other. 
does he possess, that is, what confidence can the lender place in him for the materials or money to be advanced. ${ }^{1}$

Why is it that when a farmer asks for assistance from one of the sources of supply, his credit is not regarded as good as that of the average manufacturer? A banker of Stark County, North Dakota, as quoted in a recent issue of The American Review of Reviews, says that often the farmers are themselves to blame.

"It is our belief," the banker says, " that the scarcity of money and the high interest rates are largely due to poor farming. The people having money to loan know well that our farmers here have an uncertain income, according to their present methods of farming, and would expect a much higher rate commensurate with the risk taken than when they can find people where money can be placed more safely. As conditions are now, some people have not paid all their interest for at least three or sometimes for four years.... As soon as farmers can show that they are safe and ean take care of their obligations promptly, they can command the lowest interest rates that may exist. We believe it is more necessary to work on better farming methods, encouraging them, than on better interest rates; for the lower interest rates are the natural consequence to better farming." 2

We will now take up the main loaning facilities open to farmers more in detail.

328. The Country Store. - The country store has always exerted a marked influence on the business and social activities of farm life. This influence, however, has often

1 Credit has come to be the chief iustrument of business. Most of the world's work is being carried on through credit. A manufacturer gives his note in payinent for the materials he must have. He expects to pay off the note from the proceeds of the busiuess made possible from these materials. The note based on credit is a substitute for money.

2 'This view, of course, expresses the lender's side of the question. 
been harmful to farmers. In no part of the country have local merchants developed a more vicious system of agricultural credit than they have in the South. It has been the custom of the storekeepers of this section to advance corn and bacon and such other produce as the poor farmers needed, expecting to be paid from the proceeds of the cotton crop. Cotton in the South is the main money crop, and this crop is often mortgaged to the storekeeper. The farmer in consequence is obliged to get his produce from the man who holds the mortgage and is further required to plant cotton to the exclusion of other crops. The evils of this one-crop system naturally multiply, the land becoming poorer and poorer. Diversified farming to the extent of raising corn and bacon is discouraged by the local merchants for the obvious reason that the raising of these necessities would decrease their trade, since corn and bacon are the chief articles advanced by the merchants. For years one of the chief handicaps to a better agricultural life in the South has been this baneful type of credit.

In justice to the local merchants it must be said, however, that it is often necessary for them to supervise the type of farming out of sheer self-defense on account of the fact that some of the farmers are thriftless and lightly regard their financial obligations.

It has been discovered in North Dakota, from a questionnaire sent to 54 hardware dealers supplying goods to farmers, that only 13 per cent pay cash and 87 per cent ask for credit; that most of the transactions are book transactions, and that the average account runs over a year, or more exactly 12.37 months. The average rate of interest on the notes held by these dealers against the farmers is 10.26 per cent. It often happens if a erop fails and the farmer is unable to pay the principal, the dealers must keep the account open for another year. While the country 
store has often been of genuine service to farmers in exchanging produce which farmers do not need for supplies which they must have, yet the main evil arises when merchants are in a position to dictate the type of agriculture to be followed.

We will now see what is the relation of commercial banks to rural credits.

329. Bank Credit. - Bank credit is better suited to the needs of agriculture than is store credit. When a farmer

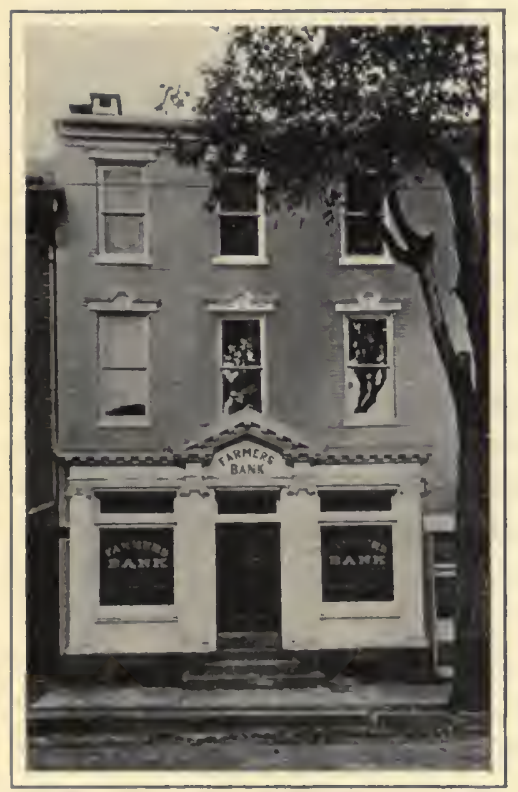

FARMERS' BANK. goes to the bank he gets cash and ean then buy where he pleases. He at once becomes more independent. Banks are middlemen and desire short or long loans on tangible security, short loans of from 30 to 90 days, so that they can often turn over their money during the year; long loans, and this is especially true of savings banks, so that they can have a permanent investment of their funds. In either case the terms and conditions of the loans may not fit in to the requirements of agriculture. However, from a recent report of the Comptroller of Currency of the United States our banks held outstanding loans of $\$ 1,769,000,000$, which was mostly on farm mortgages.

Mortgage loans, while of excellent help in securing title 
to land, are not well adapted to raising money for buying seeds, tools, fertilizers, and household supplies, for the reason that the long time the mortgage usually runs, from three to five years, is not well suited to such purposes. Neither do the terms of bank loans nor their rates suit the needs of farmers. A farmer must often pay from four to six per cent more interest than the manufacturer. For these and other reasons there are coming into existence in this country, as there have been in Europe for more than half a century, banks known as coöperative land banks.

330. Coöperative Land Banks. - The following are the chief characteristics of coöperative land banks.

1. They are organized and managed by and for the farmers themselves.

2. Loans are made to farmers at the lowest possible rate and for as long a time as needed, but for provident and productive enterprises only.

3. The funds for these loans are borrowed mostly from outside sources. Some coöperative banks sell stock to members to raise some of the funds.

4. The security required is personal, a responsible neighbor or two indorsing the note of the borrower.

5. Each member is jointly liable for his share of the debts of the bank, and in Europe that liability is often unlimited.

6. The sphere of activity of each of these banks is local, what we might call a school district, each member thus being able to investigate the purpose for which the loan is to be made.

These are the main characteristics of coöperative banks as they have been organized in Europe. We can understand much better the great part they can play in farm finance if we learn the thrilling story of Herr Raiffeisen. 
Who was Herr Raiffeisen? - During the middle of the last century there lived in Westerwald, a poverty-stricken section of the province of Westphalia, on the Rhine, a well-to-do and kind-hearted gentleman by the name of Raiffeisen. Herr Raiffeisen dearly loved his neighbors, who were mostly poor German peasants. He studied how he could relieve their sufferings and make their lives more enjoyable. He saw that these peasants were not ignorant as a rule and that they knew how to farm, how to sow their seeds, how to cultivate the soil, and how to garner their crops. But there was distress everywhere. No one doubted that, and no one seemed to know just why. The poor peasants had great confidence in the wisdom of Raiffeisen and for this reason they chose him to be the Burgomeister of the little farming village of Weyerbusch.

Herr Raiffeisen, after having made a most careful study of the causes of this widespread distress, gave it as his opinion that the chief cause was lack of coöperation, especially in money matters. Here he saw poor German women wending their weary way to a distant market, each bearing a load of sufficient weight to burden a horse, while a neighbor's team was standing idle, in the stall. There he saw Jewish and Christian money lenders, exacting their usurious and exorbitant gains from the peasant farmers, - farmers who individually were at the mercy of these loan sharks. Each farmer was trying to fight his battles alone. To add to their misfortunes a famine for which the peasants were in no way responsible was also upon them. This was in the years 1846 and $18 \pm 7$.

Herr Raiffeisen's first step toward practical coöperation was to establish a coöperative bakery through which the peasants might buy their bread at about one half the 
regular selling price. He then organized a coöperative association for the purchasing of cattle. Both ventures were highly successful from the start.

Raiffeisen then gathered these good, honest, but povertystricken peasants together and explained to them in plain speech that the cause of most of their woes was their own mistrust of one another. He told them to get together and combine their resources, forget their differences, and present a united front to the evils which oppressed them.

"If you who trust one another organize into a society to form a savings and loan bank to which character is the prime requisite for membership and to which you will pledge all the property you own, we can dig a cliannel for credit. We will keep our own money in the district and we will attract savings. Bankers will loan on the property of all of us, so that money will come to us when we need it to help us in our production. Indirectly the whole district will benefit.

"We can accept savings from anybody, but loan only to members, and to them only for purposes which will bring increase. We will pay only a moderate interest on savings, and then it will be necessary to ask members to pay only a little more for their loans. To make a loan we may take the same sort of securities as other banks. We may loan on personal security if we keep a high standard of membership. If money is needed for any reason, any one of you may go to your neighbor and show him what you want to do and why it will be profitable for you to do it. If he approves it, bring him with you to the bank. If he is willing to sign your note, becoming your surety, the bank must consider the loan, investigate it, and upon your promise to use it for the purpose stated will advance you the money. 
"You cannot borrow money to pay your debts, or to invest so the return will be uncertain or in any but provident ventures. Not all of you will need money, but there is none of you who may not require funds to buy seeds or fertilizer or machinery. It is clearly a matter of wisdom for you to protect yourself by having open to you some source of credit. This you may have if you all stand together in brotherhood. You must each watch to see that the bank's money is properly spent, and give service wisely, willingly, and unselfishly."

From this lengthy quotation, taken from a recent article by John L. Matthews, we shall not be surprised to learn that the Raiffeisen idea of coöperative credit spread widely over Germany. Indeed, the Raiffeisen banking system comprises about 15,000 local banks, having a membership of over 2,000,000. The aggregate yearly business of these banks is nearly $\$ 1,500,000,000.1$

331. Land Banks in America. - Fortunately, in America we do not have to work in the dark. In attempting to extend credit facilities to rural communities we have the light of foreign experience to guide us. It is not necessary, however, to remind the average American that Germany is not America and that German conditions are not exactly similar to American conditions. ${ }^{2}$

Nevertheless many of the principles worked out and so

'Sir Horace Plunkett, the famous Irish rural economist, states that the Raiffeisen idea has done as much for Germany as has the invention of the steam engine.

2 Farms in Germany average 10 to 15 acres apiece and throughout Europe farmers live mostly in small villages. The average farm in the United States is more than 100 acres. In the west the federal homestead aet requiring the domiciling of the farmer on his farm and regulating the size of the farm makes conditions there especially different from those abroad. Coöperation in Ameriea is naturally more difficult. Then, too, we do not have a real peasantry liere. Our farmers produce yearly from $\$ 8,000,000,000$ to $\$ 10,000,000,000$, and are virtually independent. See Appendix A, Chart VIII, page 470. 
successfully applied by Herr Raiffeisen and his co-workers of his own country and of France and Italy are so broad and sound that with proper adaptation to suit American conditions they should form a basis for the rural credit legislation of both state and nation.

The excellent record of our building and loan associations and of our mutual savings banks shows that the cooperative principle in banking can be extended to serve our farmers in a more vital way.

We need an agency which will aid the deserving man without property to borrow small amounts for provident purposes at low rates and on easy terms for repayment, the personal security being based largely on character, thrift, industry, and sobriety. We need an association of good members rather than a large supply of capital.

The first state to pass a law to provide for an adequate system of rural credits was Massachusetts. This was in the year 1909. The Massachusetts law, however, while based on the Raiffeisen idea and on the well-known principles of our savings and loan associations, provides for credit unions in general and is not restricted to credit accommodations to farmers. The credit union consider's the object for which the loan is to be used quite as much as its security. It seeks to discourage unwise borrowing. As M. Desjardins, a celebrated Canadian student of rural credits, observes, "It tries to transform moral qualities into valuable assets and brings to the industrious and thrifty man a higher reward than mere wages - the confidence of his fellow men."

In 1915 Massachusetts authorized the establishment of farm land banks with a capital stock of not less than $\$ 50,000$. 'These state land banks may issue debenture bonds (instruments issued as evidence of debt) based on 
farm mortgages, which are a first lien and may not be in excess of 50 per cent of the value of the property. The term of the farm loans ranges from five to thirty-five years. New York state also has a law with the same general features.

In order to meet the need for rural credits more effectively and to provide a more general scheme for their organization and supervision, it has been thought that Congress was in a better position to cope with the problem than the several states individually. Accordingly there was established in July, 1916, at Washington a new Federal Land Bank System.

332. Federal Land Banks. - The federal land bank bill for rural credits is the result of considerable agitation and study covering more than a decade. Congress sent a commission abroad to study the problem. The need of better financial facilities for the open country was clearly recognized by all parties alike. Little opposition to it in Congress was encountered. The provisions of the new law are generally held to be sound and well suited to American farm life.

The federal land bank law follows in a general way the main features of the recent Federal Reserve Banking Act, a companion measure. It provides for a Federal Farm Loan Board, consisting of five members, one of whom is the Secretary of the Treasury. The continental United States is divided into twelve districts, in each of which there is to be established a land bank with a capital stock of not less than $\$ 750,000$. The capital stock of these district banks may be subscribed by any one. However, 5 per cent of each loan made to farmers must be deposited in the farm loan association for the land bank stock of its district.

The farm loan associations reach the farm directly. 
Each of them is made up of ten or more farmers, and their affairs are managed by a secretary-treasurer.

Let us take a concrete case to see how the Federal Land Bank System works. A farmer desires to borrow money for farm purposes. He comes to the manager of the local loan association and says that his land is worth, let us say $\$ 1500$, and the improvements on it, $\$ 500$. The manager states that if he finds the land and improvements as claimed by the farmer and the farmer's title to the property unquestioned, he can advance him $\$ 900$ or 60 per cent of the value of the land and $\$ 100$ or 20 per cent of the value of the improvements, a total of $\$ 1000$ in all. But before advancing the money the farmer must join the loan association, unless he is already a member, must take 5 per cent of his loan in stock, and must assume 10 per cent of his loan as liability against the possible losses of the other members. Thus the farmer really receives but $\$ 950$ on his property. 'The $\$ 50$ worth of stock is to be turned over by the local association to the district land bank. When the loan is paid, the farmer is credited with the value of this stock, which is then canceled.

Farmers can also borrow on their crops and stock, and the Federal Reserve Banks will rediscount farmers' notes based on current farm operations.

The debentures issued by the land banks pay 1 per cent less interest than their underlying farm mortgages, and the redemption of the debentures issued by any land bank is guaranteed by the resources of all the land banks.

Some advantages of the Coöperative Land Bank System are: interest rates are reduced; small annual payments may be made on long term loans; farm first mortgages become bankable assets; the federal government supervises and secures money for the farmer at least cost ; there is also economic and social coöperation among the farmers. 
333. The Outlook. - Now that the Federal Land Bank System has been organized for the farmers; now that the Smith-Lever law (page 56) provides generous sums to the several states for agricultural extension work; and now that there are so many other evidences of coöperation among farmers themselves and between the government and the farmers we may confidently expect a general improvement in rural conditions, - better homes, better schools, better roads.

This new eoöperative point of view, while not weakening the farmer's rugged individuality, places strong emphasis on group action, community building, efficient citizenship. Agricultural preparedness is to-day, and probably will remain for years to eome, a pressing problem. Bankers, teachers, scientists, statesmen, - all leaders alike, must work together to mobilize our agricultural resources and must seek to make more effective the lives of our numerous farm folk, who live apart-often out of touch with the impulses which direct our national thinking. The call of America is the call to serve its institutions, and no institution is more typical of American life and more of a bulwark to it than our plain furm home, where there is prosperity and vision.

\section{Practical Questions}

1. Is unused knowledge of farming valuable? 2. What is the purpose of the "Home Exercises"? 3. How have American resources helped the American farmer? 4. In what sense is farming now coming to be a business? 5. What is farm capital? 6. How does wealth differ from capital? 7. In what sense does credit differ from capital ? 8. Discuss the relation between our growing tenancy and our lack of farm capital. 9. Why in the early days was there little need of capital? 10. In what sense has our industrial development outrun our agricultural development? 11. What has been the maiu cause of our decrease in exports and our increase in imports? 12. How has the country store been an injury to the southern farmer? 
13. What objection is there to credit given by ordinary commercial banks? 14. What are some of the characteristics of coopperative land banks? 15. What did Herr Raiffeisen do for his neighbors? 16. Discuss rural credits in the United States.

\section{Home Exercises}

1. Ask some one at home what the prevailing rate of interest is and how long different kinds of loans are usually made to run.

2. While it is very natural for people not to want the general public to have too much information on their private affairs, yet it is possible without giving the least offense to make a copy of blank mortgages, notes, and other business papers of the farm and have the copy brought to school for explanation. If no blank papers can be found among the patrons at home, no doubt the local Justice of the Peace would supply them.

3. If some one would loan your father $\$ 100$ for six months for any farm purpose, how much do you think he might make with the money?

4. Would it pay to borrow $\$ 200$ to buy improved farm machinery? Figure this out on the basis of labor cost which would be saved.

\section{Suggestions}

1. One of the first needs of many farmers is to keep accurate account of their business operations. If the average business man knew as little about the money end of his affairs as the average farmer knows about his receipts and expenditures, there would be much more financial distress to-day than there is. In most cases it is not necessary to keep on paper an elaborate account of all minor farm operations. Some transactions may be carried in the head. But the tendency is to try to carry too much in the head. Farmers should have a simple method of bookkeeping.

2. Before a dollar is borrowed the purpose for which it is to be used should be clearly thought out and discussed. Under the rural credit system this discussion must be with the other members of the union.

3. It will be easy to pay the interest on the loans, but the payment of the principal is the main difficulty. Better not borrow than be unable to repay.

4. The main point to be brought out in the discussion of rural credits is the long-term mortgage having low rates of interest with repayment of principal in easy annual installments. 


\section{Rerenexces}

Principles of Rural Economics. T. N. Carver.

Rural Wealth and Welfare. Fairchild.

Farn Management. Warren.

Principles of Rural Credits. J. B. Morman.

Survey. $31: 690 ; 32: 307,13$.

World's Work. 26:622; $27: 252,13$.

Rural Credit. No. Am. $199: 796-800,14$.

Rural Credit and Farm-land Banks. Ind., 78:18.5-6, '14.

Unfinuncial Farmer. J. Parr. Everybody's, 31:61-1; 188:200.

Credit Union Primer. liussell Sage Foundation.

Rural Credits. Commonwealth Club. San Francisco, Cal.

Coöperation in Agriculture, Marketing and Rural Credit. Austin and Wehrwein, University of Texas.

Farm Bulletins. Washington, D.C.

50. Diversified Agriculture and the Relation of the Banker to the Farm.

178. Coöperative Organization Business Methods.

511. Farm Bookkeeping.

572. A System of Farm Cost Accounting.

593. How to Use Farm Credit.

654. How Farmers may Improve their Personal Credit.

661. A Method of Analyzing the Farm Business. 
CHARTS OF UNITED STATES PRODUCTS

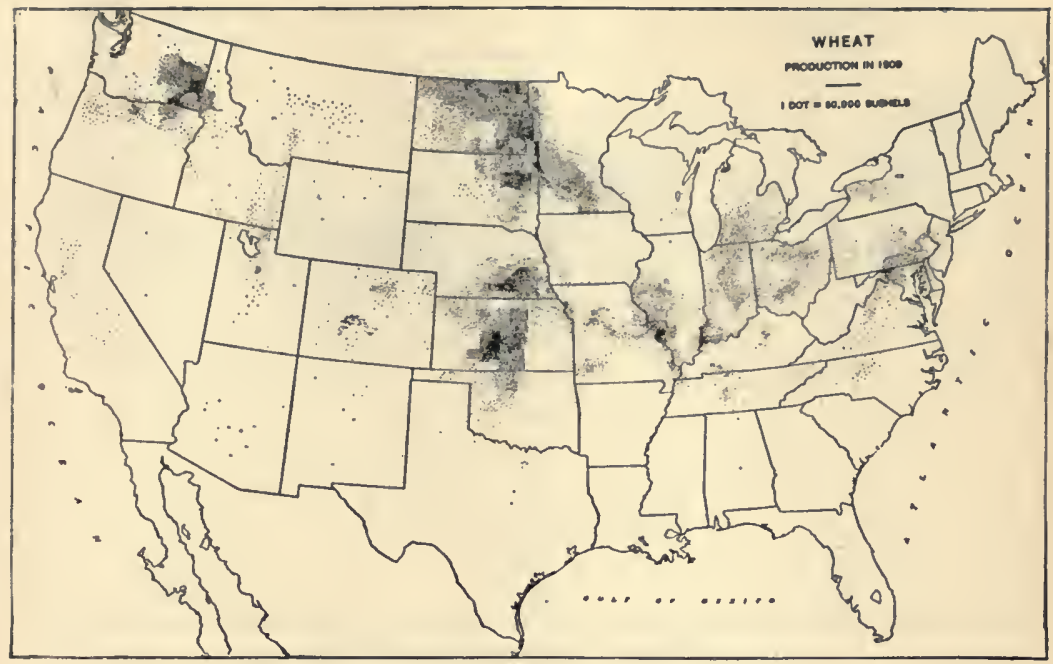

I. Wheat Production (Chapter XX.)

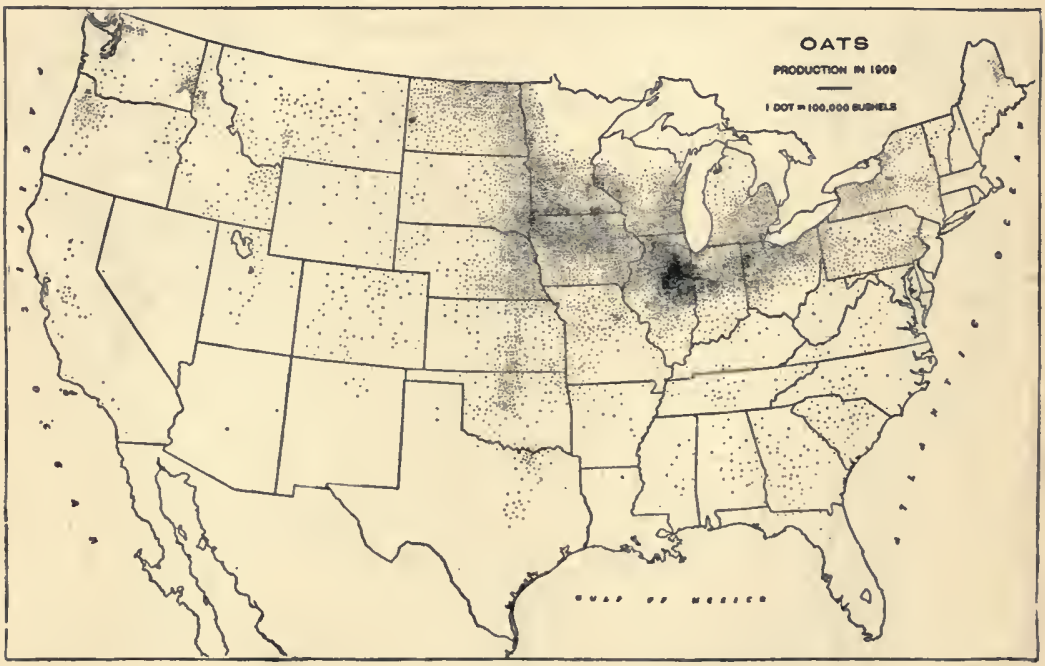

II. OAt Production (Chapter XX.) 


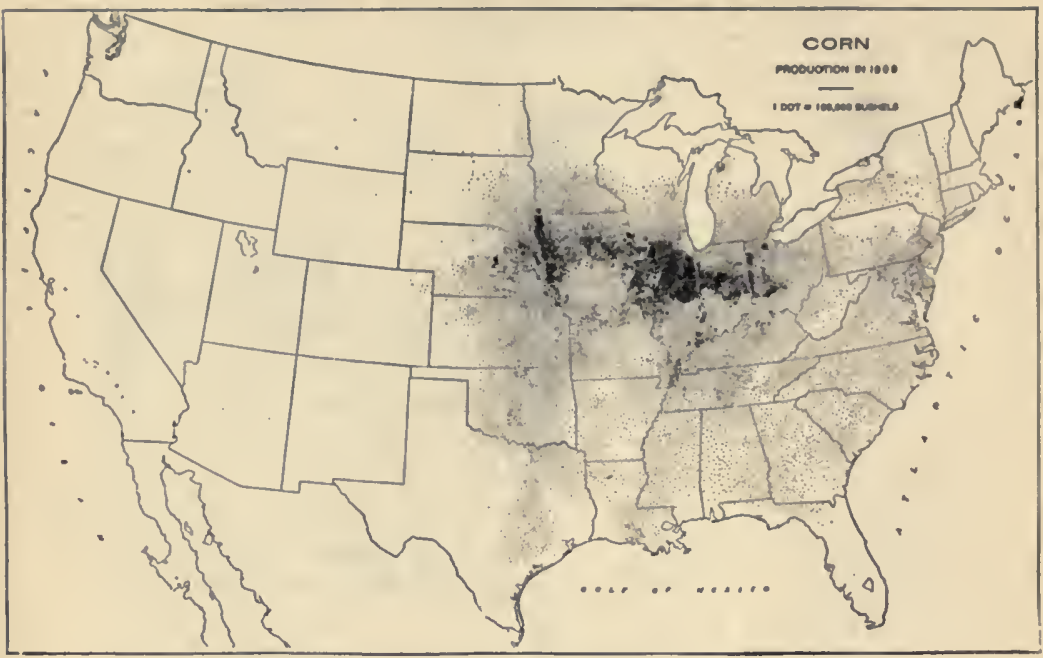

III. Corn Production (Chapters XIV and XIX.)

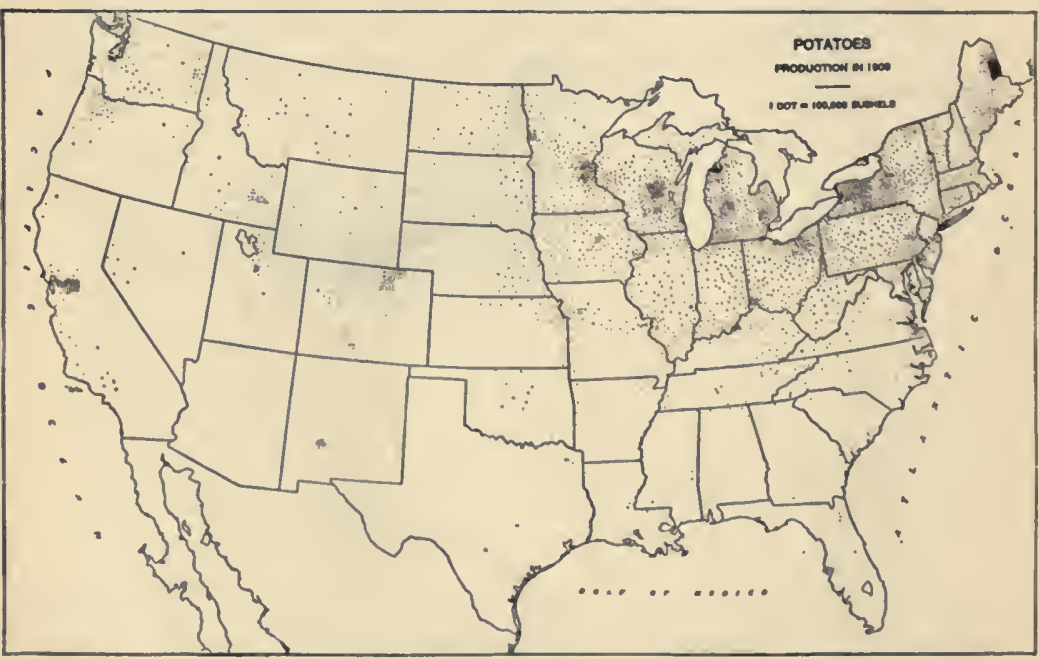

IV. Potato Production (Chapter XVIII.) 


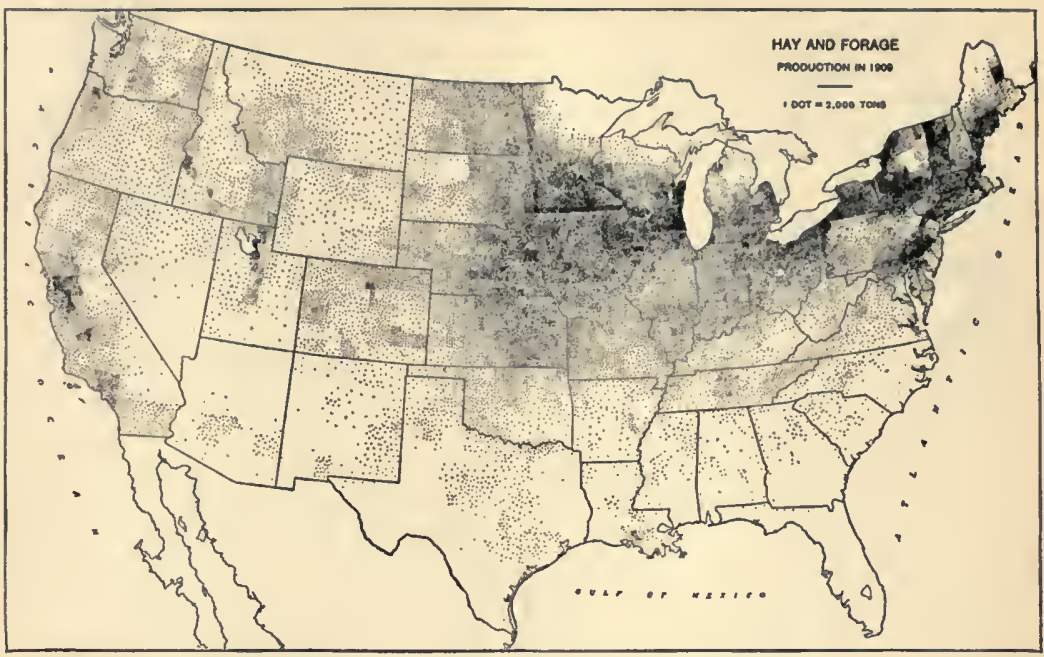

V. Hay Production (PAge 279)

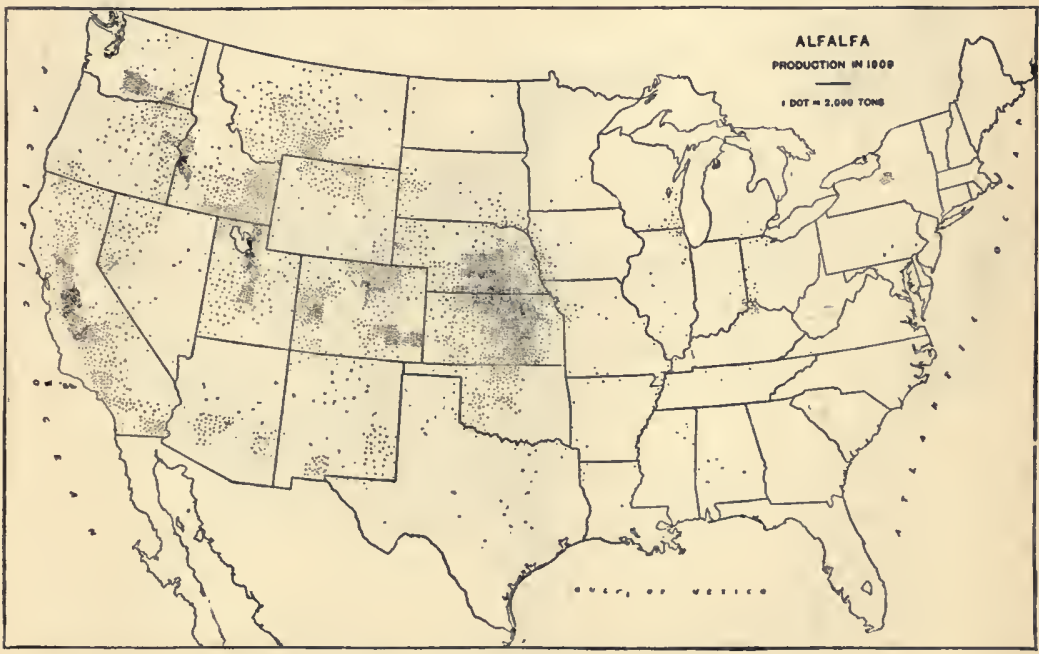

VI. Alfalfa Production (Page 280) 


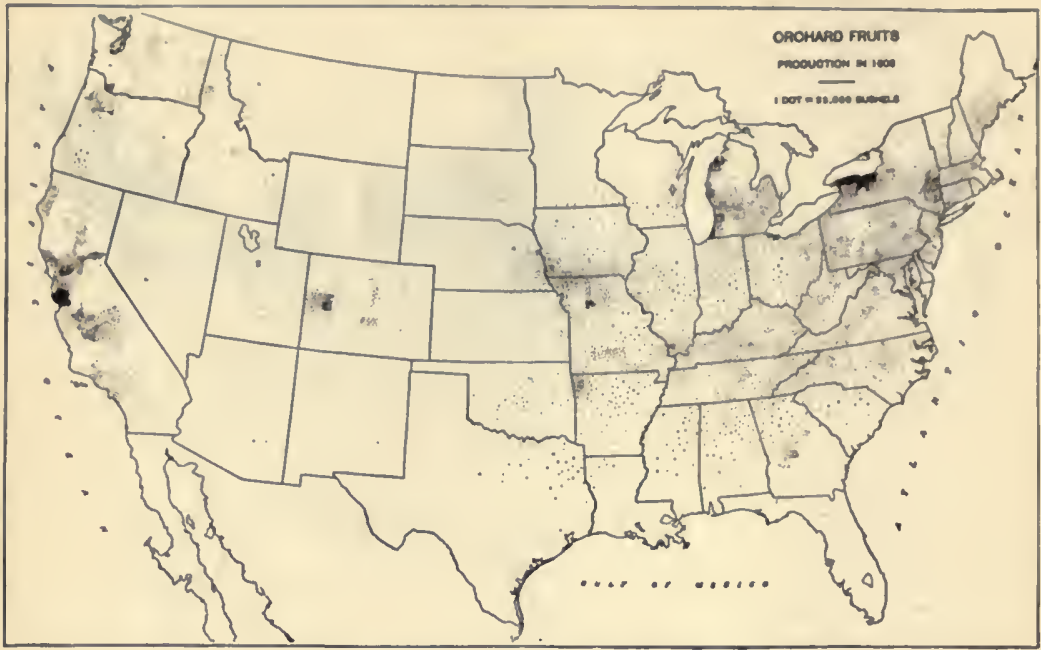

VII. Orchard Production (Page 301)

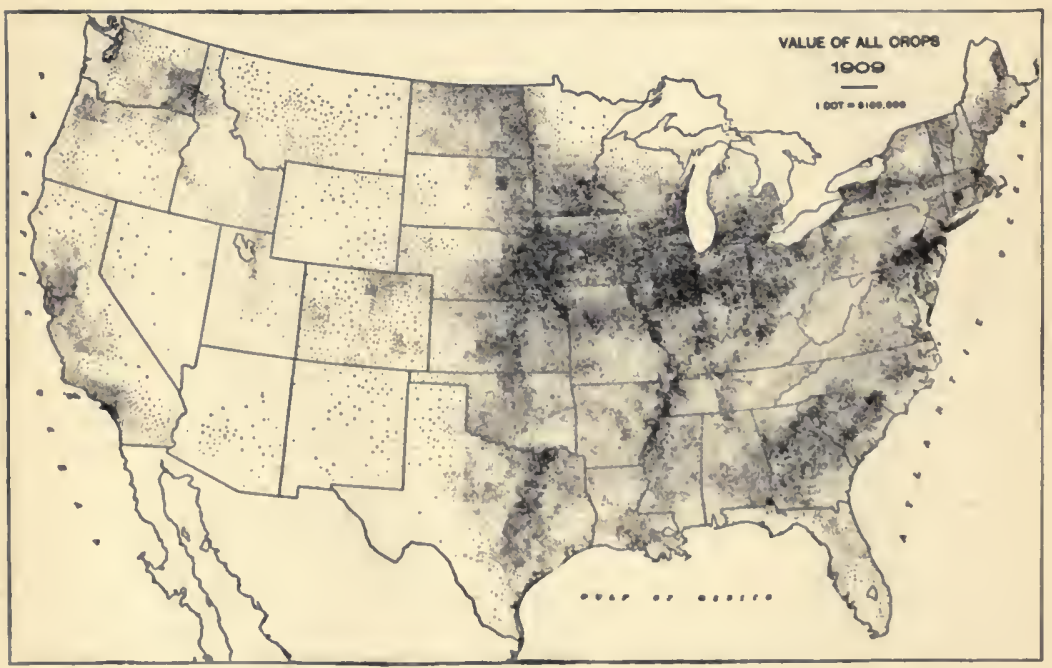

VIII. United States Crop Values (Page 460) 


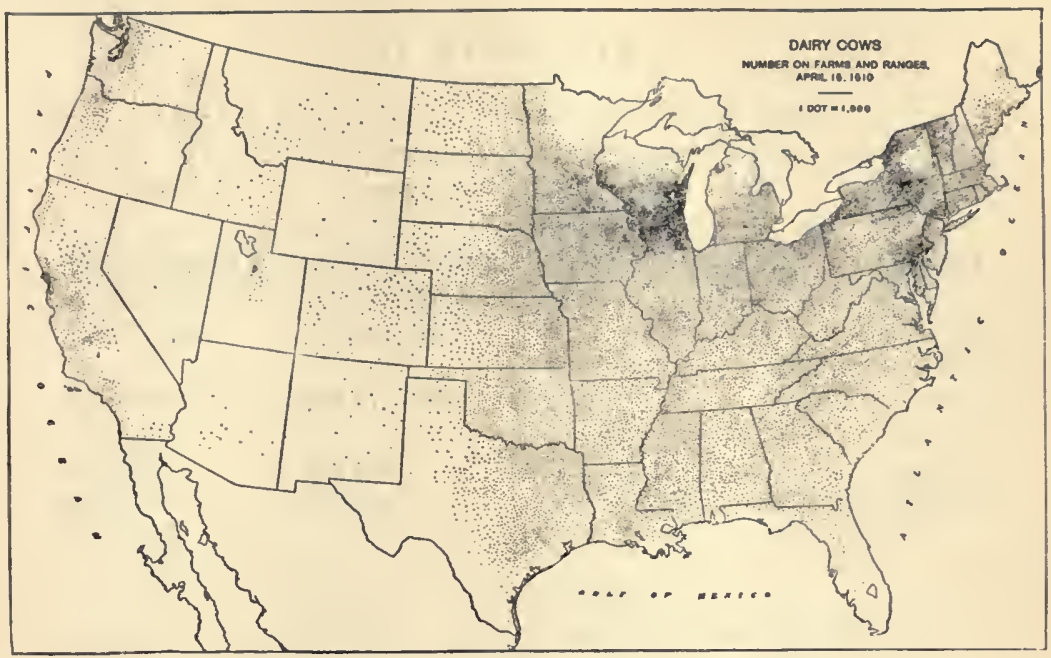

IX. Distribution of Dairy Cows (Page 372)

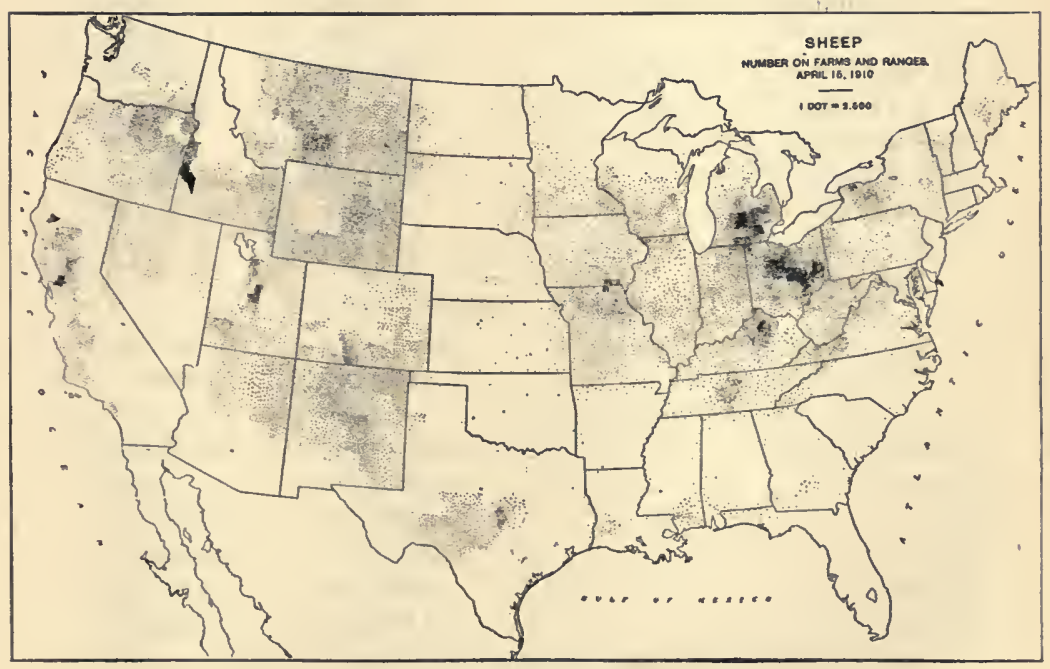

X. Distribution of Sheep (Page 413) 


\section{APPENDIX B}

I. Value of Farm Property of the United States 1

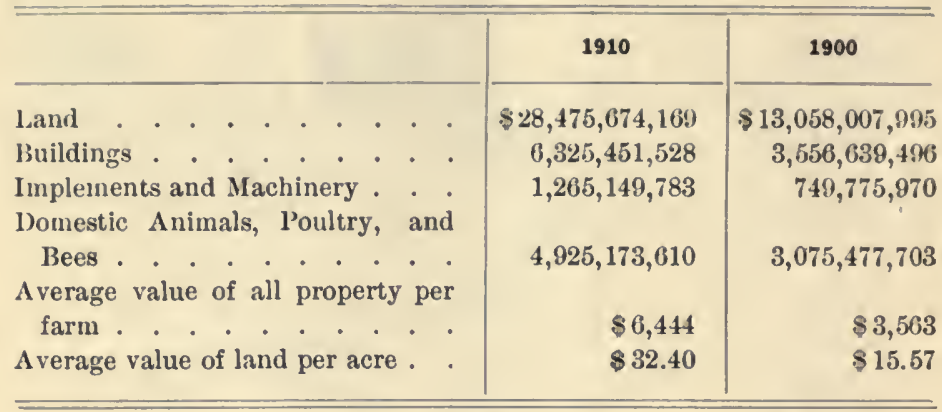

II. Farms Classified by Size

\begin{tabular}{|c|c|c|c|c|c|c|c|c|c|}
\hline \multirow{2}{*}{\multicolumn{8}{|c|}{ Size Grovp }} & \multicolumn{2}{|c|}{ Number of Farus } \\
\hline & & & & & & & & 1910 & 1900 \\
\hline \multirow{7}{*}{\multicolumn{3}{|c|}{$\begin{array}{l}\text { All farms under } 20 \\
20 \text { to } 49 \text { acres } \\
50 \text { to } 99 \text { acres } \\
100 \text { to } 174 \text { acres. } \\
175 \text { to } 499 \text { acres. } \\
500 \text { to } 999 \text { acres. } \\
1000 \text { acres and over }\end{array}$}} & res & . & . & • & & 839,160 & 673,870 \\
\hline & & & . & & • & & & $1,414,376$ & $1,257,496$ \\
\hline & & & . & 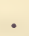 & - & & & $1,438,069$ & $1,366,038$ \\
\hline & & & . & • & • & & & $1,516,280$ & $1,422,262$ \\
\hline & & & . & • & . & • & • & 978,175 & 868,020 \\
\hline & & & . & . & . & - & • & 125,295 & 102,526 \\
\hline & & & . & . & . & . & . & 50,135 & 47,160 \\
\hline
\end{tabular}

III. Number of Domestic Avimals

\begin{tabular}{|c|c|c|c|c|c|c|c|c|c|c|c|c|}
\hline & & & & & & & & & & & 1910 & 1900 \\
\hline Chicken & & . & . & . & . & . & . & . & . & - & $280,345,133$ & $233,566,021$ \\
\hline Cattle & . & - & . & . & - & . & - & - & . & - & $61,803,866$ & $67,719,410$ \\
\hline Swine & . & . & . & . & . & . & . & . & . & - & $58,185,676$ & $62,868,041$ \\
\hline Sheep & . & . & . & - & . & . & . & - & - & - & $52,447,861$ & $61,503,713$ \\
\hline Horses & - & . & - & . & . & - & . & . & . & - & $19,893,113$ & $18,267,020$ \\
\hline Mules & - & . & - & - & - & - & - & - & - & - & $4,209,679$ & $3,264,615$ \\
\hline
\end{tabular}

1 From United States Census Report. 


\section{APPENDIX C}

\section{AGRICULTURAL COLLEGES OF THE UNITED STATES}

\begin{tabular}{llll}
\multicolumn{1}{c}{ State } & \multicolumn{1}{c}{ Post Ofrice } & \multicolumn{1}{c}{ State } & \multicolumn{1}{c}{ Posr OFfice } \\
Alabama & Auburn & Nebraska & Lincoln \\
Arizona & Tucson & Nevada & Reno \\
Arkansas & Fayetteville & New Hampshire & Durham \\
California & Berkeley & New Jersey & New Brunswick \\
Colorado & Fort Collins & New Mexico & Agricultural \\
Connecticut & Storrs & & College \\
Delaware & Newark & New York & Ithaca \\
Florida & Gainesville & North Carolina & West Raleigh \\
Georgia & Athens & North Dakota & Agricultural \\
Idaho & Moscow & & College \\
Illinois & Urbana & Ohio & Columbus \\
Indiana & Lafayette & Oklahoma & Stillwater \\
Iowa & Ames & Oregon & Cornwallis \\
Kentucky & Lexington & Pennsylvania & State College \\
Louisiana & Baton Roinge & Rhode Island & Kingston \\
Maine & Orono & South Carolina & Clemson College \\
Maryland & College Park & South Dakota & Brookings \\
Massachusetts & Amherst & Tennessee & Knoxville \\
Michigan & East $\cdot$ Lansing & Texas & College Station \\
Minnesota & St. Anthony Park, & Utah & Logan \\
& St. Paul & Vermont & Lexington \\
Mississippi & Agricultural & Washington & Pullman \\
& College & West Virginia & Morgantown \\
Missouri & Columbia & Wisconsin & Madison \\
Montana & Bozeman & Wyoming & Laramie \\
& & &
\end{tabular}




\section{APPENDIX D \\ MAGAZINE ARTICLES ON AGRICULTURE}

In addition to the publications of the United States Department of Agriculture, the state agricultural colleges and experiment stations, there is a variety of other very accessible agencies which are sending out valuable information on country life. Prominent among these agencies are the numérous farm journals. But just as vital as these journals, perhaps, and often more effective and resourceful, are the many excellent articles appearing from time to time in magazines and other high-class publications. All teachers and students of farm life can profit by reading these articles. In recent issues the following are noted :

Efficiency Movement in its Relation to Agriculture. N. J. Spillman.

Annals American Academy, 59 : 65- 76, May, 1915.

Marketing of Milk - How Furmers are driven out of Business. Current Opinion, $59: 355-356$, November, 1915.

Agricultural Efficiency a Foundation for National Defense. H. H. Gross. Scientific Monthly, $2: 380-384$, April, 1916.

Human Agriculture. Ontlook, 112 : 2-10, January 5, 1916.

Boys' and Girls' Agricuttural Clubs. G. A. Works. School and Society, $3: 740-750$, May $20,1916$.

Country Life and the Next Generation. L. H. Bailey. Independent, 85 : 336-338, March 6, 1916.

Farm Accounts as They should be Kept. D. Buffum. Country Life, $30: 84$, June, 1916.

The County Agent and the Home. Journal Home Economics, 8 : 199-201, A pril, 1916.

Open Letter in Secretary Houston from a Farmer's Wife. M. D. Shelby.

Outlook, 111 : 923-925, December 15, 1915.

Cost System.on a Missouri Farm. F. A. Zenders. Collier's, 57:26, April 8, 1916. 
Oh, the Poor Farmer's Wife! E. D. Gates. Woman's Home Companion, 43: 18, June, 1916.

How to make the Farmhouse Grounds look Attractive. A. E. P. Searing. Ladies' Home Journal, 33 : 70, March, 1916.

Who Feeds the Nation? E. Sears. Harper, $132: 860-870$, May, 1916.

Federated Boys' and Girls' Club Work. O. H. Benson. National Educational Association, $1914: 898-905$.

Pig Assumes an Educative Rôle. Outlook, $111: 347-348$, October 13, 1915.

Rural Education that Counts. D. Cunningham. Country Life, $28: 86$, October, 1915.

Agricultural Education and Agricultural Prosperity. A. C. True. Annals American Academy, 59 : 51-64, May, 1915.

Agricultural Instruction for the Millions. Scientific American, 113 : 461, November 27, 1915.

Massachusetts Home Project Plan of Vocational Agricultural Education. R. Stimson. School Review, 23 : 474-478, September, 1915.

Cities and Towns joining IFands in a Country-wide Get-together Movement. J. A. Scheuerle. Illustrated American City, $12: 312-317$, April, 1915. 


\section{APPENDIX E \\ SAMPLE CONSTITUTION AND BY-LAWS OF A BOYS' \\ PIG CLUB ${ }^{1}$}

CONSTITUTION

Article 1. - Name

The name of this association shall be the - County Boys' Pig Club Assoeiation.

\section{- Article 2.-Object}

The object of this association shall be to promote interest in the breeding and improvement of high-grade and purebred swine; to instruct its nembers in the prevention and eradication of the diseases peeuliar to swine ; and to instill in the boys a love for farm animals which will result in their taking more interest in farm life.

\section{Article 3. - Membership}

Any boy or girl between the ages of 10 and 18 years who will agree to secure at least one pig and care for it under the instruetions furnished by the State agent in pig-club work may at any time become a member.

\section{Article 4.- Organization}

The officers shall be a president, a vice president, and a secretary-treasurer.

\section{Article 5. - Meetings}

There shall be a regular annual meeting of the assoeiation and such special meetings at times and places as may be determined by the president.

\section{Article 6. - Elections}

The election of officers shall be held at the regular annual meeting, and such election shall be by ballot.

\section{Article: 7. - Amendments}

Amendments to this eonstitution may be made by a twothirds vote of the members present at the annual meeting.

1 From the Bulletin of the United States Department of Agriculture. 


\section{BY-L,AWS}

\section{Section 1.-Ditties and privileges}

It shall be the duty of each member to coöperate as far as possible with his fellow members in the use of purebred boars; also to solicit new members and to encourage them in better methods of caring for their animals. Each member shall be entitled to one vote in the business meetings of the association.

\section{Sectron 2.- Officers}

The officers shall be elected to serve one year and perform such services as are ordinarily required by their position. They shall serve until the election of their successors.

\section{Section 3.-President}

The president shall preside at all meetings of the association. He shall also collect all reports from the club members and send them to the State agent.

\section{Section 4.-Vice president}

The vice president shall perform the duties of the president in his absence.

\section{Section 5. - Secretary-Treasurer}

The secretary-treasurer shall keep a record of all proceedings of the association, and shall render a report of the same at the annual meeting; shall act as correspondent in matters pertaining to the business of the association, and shall keep a correct enrollment of all members.

\section{Section 6. - Order of business}

Reading of the minutes of the previous meeting.

Report of the secretary-treasurer.

Reports of committees.

Unfinished business.

New business.

Election of officers. 


\section{APPENDIX F}

\section{USE OF FARMERS' BULLETINS}

Teachers sometimes find that many Farmers' Bulletins are not very teachable, that is, their subject matter lacks good pedagogic form. To meet this difficulty free leaflets are being prepared by specialists of the United States Department of Elucation to aid teachers in the use of these Bulletius. The following suggestive outline is a type of many others that are now available.

\section{HOW TEACHERS MAY USE FARMERS' BULLETIN 537, HOW TO GROW AN ACRE OF CORN}

\section{BY E. A. MrLer, Specialist in Agricultural Education}

\section{Range of use. - General.}

Relation to the course of study. - This bulletin may be used in the study of agriculture in connection with crops in general and corn in particular. The topics of the publication lend themselves to correlation with other school subjects.

Topics. - The material of the bulletin should be grouped into six lessons for class study: (1) Getting a start with seed-kind of corn to grow, selecting seed for the acre, and preparing seed for planting, pages $5,6,7$, and 9 ; (2) making a start with the crop - selecting an acre for corn, fertilizing the acre, and preparing the seed bed, pages $10,11,12,13$, and 14 ; (3) planting, pages 14 and 15 ; (4) the growing period-combating cutworms, thinning, and cultivation, pages $15,16,17$, and 18 ; (5) improvement work - selecting seed and drying and caring for seed, pages $7,18,19$, and 20 ; (6) determining yield and conclusion, pages 20 and 21.

Study questions. - What races of corn are grown in the community ? Flint? Dent? Sweet? Pop? Soft? Which is the better adapted to the community, flint or dent? Is corn grown as a money crop? What varleties have succeeded best in the community? Are one-eared or prolific varieties best adapted to the section? Is it the practice in the 
community to sort and test seed com? What type of soil in the community produces the largest yield? What characteristics indicate a good corn soil? What leguminous crops should precede corn? What are guard rows? Why should they be planted? What are the advantages of good manure? When should it be applied to the land? Why and when should lime be applied? What essential elements are supplied by commercial fertilizers? In what inexpensive way may nitrogen be stored in the soil? How and when should commercial fertilizers be applied to the soil for corn? When and how should the seed bed be prepared? What kinds of plows are used in the community? What kinds of harrows? Is deep plowing practiced? What are the advantages of deep plowing? What constitutes good plowing? Poor plowing? What implements are used for planting corn? Is corn planted in drills or in checks? What should determine the distance in planting corn? To what depth should corn be covered? What are cutworms? In what way do they damage corn? How ean they be successfully combated? When and how should corn be thinned? Give reasons for cultivation. For shallow cultivation. How frequently should corn be cultivated? Why should seed be selected in the field? What should characterize a good stalk? A good ear? When should the selected ears be gathered ? Give directions for drying and storing seed corn. Give a desirable plan for determining the yield of an acre of corn.

Illustrative material. - Secure and label specimens of the different races and varieties of corn. Secure from farm papers and catalogues pictures of races and varieties of corn, plows, corn planters, cultivators, and harvesting machinery. Sce illustrations in the bulletin.

Practical exercises. - (1) Selecting in the field, gathering, storing, judging, and testing corn. Mixing fertilizers and studying farm machinery afford suitable practicums. (2) Corn-club nembers get profitable home work in growing an acre of corn.

Correlations. - Language : Require the members of the class to write accounts of field trips for seed selection, descriptions of sand tray and rag-doll testers, and descriptions of farm machinery. List and spell all new words appearing in these studies.

Drawing: Make drawings of the different seed testers used and proper and ill-shaped grains.

Geography: Locate on the map the 10 leading corn-producing States. Compare them as to location, climate, and other agricultural industries. In what other countries is corn grown? Compare these countries with the corll-growing States as to longitude, latitude, climate, and other agricultural industries. What part of the corn crop of the United States is exported? What countries constitute our corn markets? What is the 
principal grain market of the United States? Compare the total and the average production per acre lil your own State with that of the leading corn State. Is the average yield per acre in your State above or below the average for the whole country?

History: Where is corn native? Why is it called "Indian corn"? What other crop were the Indians growing? Require each member of the class to write an account of the corn-club movement.

Arithmetic : Problems adapted to the advancement of the pupils should be developed from the reports of corn-club members.

Make a community corn survey to determine these facts: (1) The number of farms growing corn, (2) the number of bushels produced on each farm, (3) the total number of bushels produced, (4) the average number of bushels produced per farm, (5) the average number of bushels produced per acre, (6) the total value of the crop produced in the community, and (7) the number of bushels bought or sold by the community. 


\section{APPENDIX G}

\section{REPORT OF A PUPIL'S PROJECT}

Mr. Layton S. Hawkins, Specialist in Agricultural Education for New York State, recently published the following record, which was prepared and submitted by a pupil in the agricultural department of a New York high school as part of his work for the year 1913. Also on page 486 may be found a condensed report on home projects as carried on by the different pupils of the high school.

\section{PUPIL'S PROJECT STUDY RECORD}

The equipment used consisted of two acres of land sloping toward the south and east, a barn 28 by 20 feet with three and one half stories. The two lower floors were fitted up with roosts, nests, dropping boards, and other essentials for a henhouse. Each fowl has 8 inches of roost and $2 \frac{1}{2}$ square feet of floor space. On the south side of the barn there are openings fitted with cloth frames to keep out rain, let in light, and provide good ventilation. Even on stormy days these frames are opened for a little while in order to air out the coops. The nests are placed under the dropping boards, where they are secluded and convenient. I try to make the coops as cheerful and bright as possible, because a happy hen is a laying hen. I whitewashed the interior of the coop thoroughly, adding a pint of carbolic acid to 50 gallons of whitewash. This was put on with a bucket sprayer. This spray is both a good disinfectant and insecticide.

For litter I use corn stalks cut into short lengths, because I liave these on hand.

There was also a coop 12 by 48 feet. This coop had a ground floor only, so I placed $12 \mathrm{inch}$, inch mesh, poultry netting around the bottom to keep the rats out. During the winter, hens are kept in this coop, but last spring it was used for a brooder house.

The chickens were hatched in eight Cycle hatchers with a capacity of 50 eggs each. These incubators are all metal, economic, durable, and 
have proved practical. The lamp is in the center and the eggs are placed around it in three rows, with the small end down and toward the lainp. The eggs are kepl at a temperature varying from 102 degrees Fahrenheit the first week to 103 the last week of incubation.

The chickens were left in the incubators until the oldest were 36 hours old, when all the healthy dried ones were removed to the brooder, where they were fed a mixture of sand, bread crumbs, and hard-boiled eggs chopped fine. The chickens were kept at a temperature of about 95 degrees for the first two days, then the heat was reduced gradually as the chickens grew older. Gradually a little oatmeal was added to the ration.

The brooder consists of a 3 foot square box, 12 inches high, with sheet iron nailed on top, with a 1 inch space between it and the board tloor. In the middle of the floor a hole 6 inches in diameter was cut and a 2 quart basin nailed over it, the basin having several holes in it. On the edge of the floor are upright boards to keep the litter and chickens inside. A 2 foot square hover with a slit flanmel drapery on the edge was placed over the basin on four 6-inch legs, one at each corner. Now a bracket lamp is put into the box under the hover. The chickens are led from the hovers by means of an inclined board covered with dirt.

There were eight of these hovers, with a capacity of 50 to 60 chicks each, placed in the 12 by 48 foot coop. The chickens were provided with runs inside and outdoors. These brooders were a constant worry because a kerosene lainp cannot be depended upon. I intend to install a hotwater system next season if possible.

At the beginning of the season the chickens grew well, but later, as the weather turned bad and rats got into the coop, we moved brooders and chickens outdoors. On account of the sudden change I lost quite a number of them, perhaps more than the rats would have killed.

When the chickens were eight weeks old, I separated the cockerels from the pullets and fed them a fattening ration. At ten weeks those that were not fit to save for breeding purposes I shipped alive to a commission merchant who handles our products. I received an average of twenty-four cents a pound for them.

We keep two strains of single-combed white leghorns, and so we had to leg-band some of the chickens. As soon as the young stock were old enough, I laid a cement floor in their coop to keep out rats. The coops were already fitted up with dropping boards, roosts, and nests. Of the 750 chickens hatched, we now have 320 pullets and 25 cockerels fit for breeding.

The first pullet cominenced laying September 1st.

The work of taking care of the young stock consisted of cutting hay 
for litter, cleaning the hovers at least once a week, regulating the diet of the chickens as far as possible, and spraying the hovers with kerosene and carbolic acid once every two weeks. The brooder lamps had to be filled every other day and trimmed every day. Green food was furnished in the form of finely cut lawn clippings and sprouted oats. The chickens of certain matings had to be leg-banded and kept separate.

In picking out the cockerels for next year's breeding pen, I chose them from the early hatches in order to have them mature next spring when I wish to use them. In picking out the cockerels, I follow the "American standard of perfection," and what I have learned. I select cockerels which are well formed, large, having pure white plumage, a well-developed tail standing at an angle of 45 degrees, clear colored yellow legs, bright eyed, five distinct points on their combs, white ear lobed, and which crow the most because crowing denotes vigor. Of course it is impossible to get all these good qualities well developed in one bird, that is, a cockerel may be well developed in shape and color but at the same time lacking in vigor. which is essential for breeding stock. I try to counterbalance the poor qualities of the male by picking out hens which have these qualities well developed, that is, if the cock is small, I would have large hens. My idea is to produce a strain of single-combed white leghorns which shall be good layers, well proportioned, pretty, healthy and vigorous, and which develop good-sized early broilers.

As to feeding, I feed all the fowls a ration to make them large and good layers of large, white, chalky eggs. To the old stock I feed each morning three quarts of grain, wheat, oats, and barley unixed, for each hundred fowls. I keep a dry mash before them all the time in a Cornell range hopper. This mash consists of one hundred pounds of bran, one hundred pounds of middlings, one hundred pounds oatmeal mill byproducts, ground corn, wheat bran, middlings, and oat refuse. Beef scrap is kept before them all the time, and I give them fresh ground green bone, about an ounce for each hen daily. During the molting season, August, September, October, and November, I add 50 pounds of linseed oil meal to the mash. This produces feathers and hurries them through their molt. Green food was supplied to them in the summer in the forms of lawn clippings, green oats, or alfalfa. In winter I used cut dried alfalfa, cabbages, and other vegetables.

The fowls run in an orchard of apple, pear, plum, cherry, and peach trees. I kept this sowed with oats during the summer while it was damp. At night I feed all the stock all the mixed grain that they will eat up clean, so that their crops will be full and they can digest the food while they sleep. All the grain is fed in litter to make them work, because exercise is necessary for vigor and egg production. 
In taking care of the fowls my work consisted of feeding and watering them, cleaning the dropping boards at least three times a week, going over the roosts with kerosene oil every two weeks, and changing the litter when it was worn out and dirty. One of the most essential qualities of a good poultry farm is eleanliness, and nothing can be done without it because the stock will sicken and lose vigor. So I kept the houses and yards as clean and dry as possible. Twice during the summer I had their yard cultivated.

Our main business is producing large, uniform, chalky-white eggs, and that is why we keep single-combed white leghorns because they lay an abundance of such eggs, which is what the New York City market demands. We are located near the railway, and our shipments reach their destination in New York City in twelve hours.

In marketing all our products we take great care in having them uniform and clean. With the broilers we like to have large hatches so that there will be enough cockerels for a shipment, that is, about fifty. But with the fowls we canuot be so particular, because we sell them mainly to get them out of the way. In selecting for market we pick out the poor layers, smallcombed, anæmic, or over-fat fowls, so our fowls do not bring good prices because they are sinall and not uniform, and, moreover, we could not expect good prices for meat fowls, when that is not our business. But in producing and marketing eggs we receive from 2 to 5 cents a dozen above market quotations. We keep the nests as clean as possible in order to keep the eggs white. The eggs are gathered three times a daty, and if in gathering the eggs I fonnd a tinted egg I watched to see which hen laid the egg, and when I found her I marked her to be killed when she stopped laying, because we are breeding for clear white eggs. The eggs are cleaned with a washing powder when necessary, but the eggs are never rubbed hard because that would remove the chalky appearance which denotes a fresh egg. The eggs are kept in a cool, dry place before shipping. They are not taken to the station until two hours before train time, so as to keep them from getting heated. We never keep eggs over ten days before shipping, either in winter or summer. In fact, we try to get them on the market as soon as possible after they are laid, because we have a reputation with our commission merchant that we ship only fresh eggs and so he relies on us. We try to furnish him the best eggs that can be produced and so he pays us from 2 to 5 cents more a dozen than market quotations. This merchant has always been more than square with us. He sends us egg cases free, excent for freight and cartage. which is 2 cents a case, and even pays return express on our shipping crates. So we are fully in favor of commission merchants, but of course when we can sell direct to a good reliable consumer, we will do so. 
I keep myself posted on poultry by reading farm papers, among which are: The Rural New Yorker, Rural Life, American Poultry Advocate, and Poultry Success. I intend to follow the poultry business for an occupation.

The following is a list of the supplies which we buy and an account of my summer work :

\begin{tabular}{|c|c|c|c|c|c|c|}
\hline Vheat & . & . & & . & $\$ .95$ & \\
\hline Oats & . & • & . & . & .45 & a bu \\
\hline Barley & 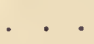 & . & 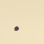 & 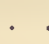 & .60 & a \\
\hline ran & . & & 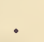 & . & 1.60 & red pounds \\
\hline Iiddlings & 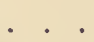 & . & . & . & 1.60 & a \\
\hline feed & . & . & . & 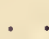 & . $1.40-1.50$ & \\
\hline d mea & 1 & . & & 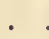 & 1.75 & a \\
\hline Bee & & . & & & 2.75 & red pc \\
\hline $\mathrm{Gr}$ & & . & & . & $.00 \frac{3}{4}$ & d \\
\hline . & D & . & & . & $.25^{4}$ & as \\
\hline itter & & & & & .50 & a hundred po \\
\hline
\end{tabular}

In closing I will say that a daily record was kept of the following: Number of hours of work and cost, Number of eggs laid, Eggs shipped, Fowls shipped, Returns from shipments, Eggs and fowls used in the house and price, Amount of feed and green bone bought, Miscellaneous - expenditures, Mortality in chicks, etc.

Every good poultry man who wishes to succeed should keep an account of his poultry just as if he were a business man, which he really is or needs to be. By doing so he is enabled to see mistakes and avoid or rectify them.

In addition to the equipment described, I might say that we have a two horse-power gasoline engine, a green bone cutter, clover cutter, and a water supply which furnishes water to all the coops and also provides fire protection. We now have about 400 head of old stock which we are keeping for breeding purposes next year.

During the summer I had practically entire charge of the poultry work, but I have only a third interest in the business. 


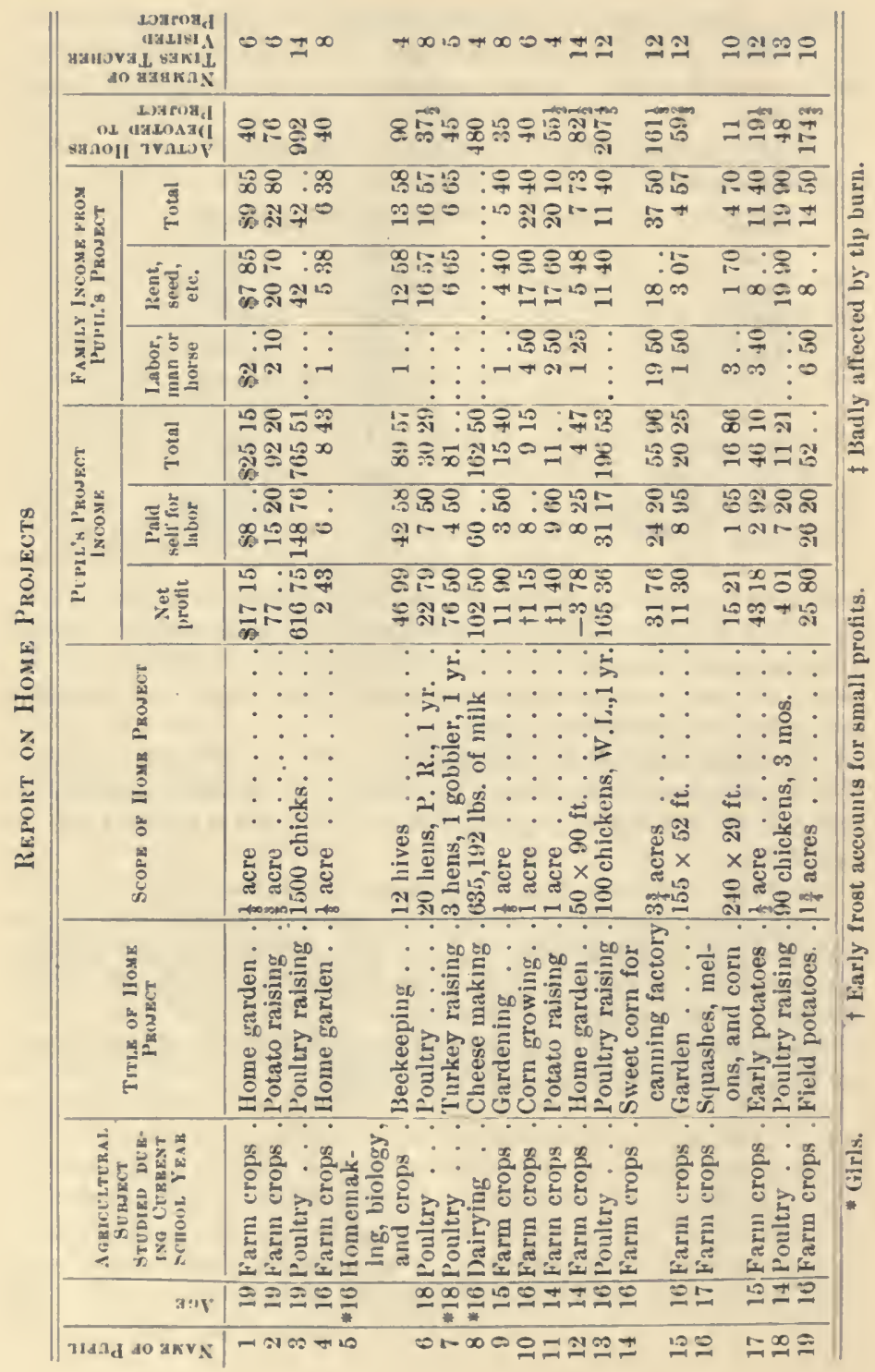




\section{APPENDIX H}

\section{SUPPLIES}

The farm and garden are the natural laboratories for agricultural work, and all work indoors should seek to explain and to interpret outdoor problems. The value of laboratory work in school depends vitally on how it is connected with real life. It must justify itself, not merely by the construction of neat and accurate notebooks or by providing for the actual handling of farm materials, but by its service to the pupils and to the community.

Agriculture should be regarded as essentially an industrial subject, and its study should be approached largely from the industrial side - the side of productive activity.

Many of the most valuable supplies for the successful teaching of Elementary Agriculture ean be obtained from the local farms, or village store, or they may be made by the pupils themselves. Some supplies, however, cannot be secured in this way, particularly if the course is to develop into an extensive one; they must be purchased from a distance.

The department of public instruction, or the agricultural college of many states, supplies its own manual to the schools free of charge. Helpful directions on various phases of school agriculture have also been published by the United States Department of Agriculture. These also are free. A Unit of Agriculture, by Elliff, published by Row, Peterson and Company, and A Laboratory Manual of Agriculture, by Call and Schafer, published by The Macmillan Company, are both teachable manuals. Botl list the required equipment for their exercises.

The few supplies needed for Elementary Agriculture which 
must be purchased at a distance can be obtained from Arthur H. Thomas Company, Philadelphia, or the Central Scientific Company, Chicago.

A mass of illustrative material can be obtained free of eharge from the following:

Foods, from the Postum Cereal Company, Battle Creek, Michigan.

Feeds and Fertilizers, from local dealers.

Wheat, from the Washburn-Crosby Company, Minneapolis, Minnesota. Silk, from Cheney Bros., South Manchester, Connecticut.

Corn, from the Corn Products Refining Company, New York City.

General Products and Raw Materials, from the local College of $\mathbf{A g r i c u l -}$ ture and Department of Agriculture, Washington. 


\section{APPENDIX I}

\section{FARM JOURNALS}

Farm journals are very helpful in the rural home as well as in the schoolroom. There are more than two hundred different farm publications in the United States. In Minnesota there are nine; in Pennsylvania, seven; and nearly every state has at least one. Below, under $A$, is a list of those which have the largest circulation in the various states. Under $B$ is a list of farm papers which are devoted to special lines.

\section{A. FARM JOURNALS}

Alabama. The Progressive Farmer. Birminghan . . . . $\begin{aligned} & \text { PER } \$ 1.00 \\ & .\end{aligned}$

Arizona. Southwestern Stockman-Farmer. Phœinix . . . . . 1.00

Arkansas. Arkansas Farmer and Homestead. Little Rock . . $\quad .50$

California. California Home and Farmer. San Francisco . . . $\quad .50$

Colorado. The Great Divide. Denver . . . . . . . . . . .50

Connecticut. Newo England Farms and Connecticut Farmer. New

Haven . . . . . . . . . . . . . . . . . . 1.00

Georgia. Southern Ruralist. Atlanta . . . . . . . . .50

Idaho. Idaho Farmer. Spokane, Washington . . . . . . . .50

Illinois. Better Farming. Chicago . . . . . . . . . - . .25

Indiana. Farm Life. Spencer . . . . . . . . . . . . .25

lowa. Successful Farming. Des Moines . . . . . . . . . .25

Kansas. Missouri Valley Farmer. Topeka . . . . . . . . .25

Kentucky. The Inland Farmer. Louisville . . . . . . . .50

Louisiana. Modern Farming. New Orleans . . . . . . . .50

Maine. Maine Farmer. Augusta . . . . . . . . . . . 1.00

Maryland. The Farmers' and Planters' Guide. Baltimore . . .25

Massachusetts. Farm and Home. Springfield . . . . . . . .50

Michigan. Gleaner and Business Farmer. Detroit . . . . . .50

Minnesota. The Farmer's Wife. St. Paul . . . . . . . . .25

Missouri. Journal of Agriculture. St. Louis . . . . . . . .50 
Montana. Montana Farmer. Great Falls

Nebraska. Deutsch-Amerikan Farmer. Lincolı . . . . . . .40

New Ilampshire. Mirror and Farmer. Manchester . . . . . .75

New York. The Rural New-Yorker. New York . . . . . . 1.00

North Carolina. Our Rural Home and Carriers' Messengr $r . \quad .50$

Winston-Salem . . . . . . . . . . . . . .50

North Dakota. North Dakota Farmer. Lisbon . . . . . .50

Ohio. Farm Nerss. Springfield . . . . . . . . . . . . .25

Oklahoma. Oklahoma Farmer-Stockman. Oklahoma City . . .50

Oregon. Western Farmer. Portland . . . . . . . . . . 1.00

Pennsylvania. The Farm Journal. Philadelphia . . . . . . .50

South Dakota. National Alfalfa Journal. Sioux Falls . . . . .25

'Tennessee. Southern Agriculturist. Iinoxville . . . . . . .50

Texas. Farm and Ranch. Dallas . . . . . . . . . . . 1.00

Virginia. Southern Planter. Richmond . . . . . . . . . .50

Washington. Northwest Farm and Orchard. Spokane . . . . .50

Wisconsin. Wisconsin Farmer. Madison . . . . . . 1.00

Wyoming. Wyoning Stockman-Farmer. Cheyenne . . . . . .25

\section{B. SPECIAL PUBLICATIONS}

Bees. American Bee Journal. Hamilton, Ill. . . . . . . . 1.00

Coöperation. The Coöperator's Herald. Fargo, North Dakota . 1.50

Dairy. Kimball's Dairy Farmer. Waterloo, Iowa . . . . . .25

Faru Home. The American Ilome Weekly. St. Paul, Minn. . . .35

Forestry. American Forestry. Washington, D.C. . . . . . 3.00

Horticulture. Green's Fruit Grower. Rochester, N.Y. . . . . .50

Livestock. The Breeder's Gazette. Chicago, Ill. . . . . . . 1.00

Machinery and Power. Farm Engineering. Chicago, III. . . . .50

Poultry. Reliable Poultry Journal. Quincy, Ill. . . . . . . 50 


\section{INDEX}

[References are to pages.]

Aberdeen Angus cattle . . 370

Acidity, test for . . . . . . 127

Adaptability of crops to soils 23

Advantages of country life,

attractiveness . . . . . 2i-29

natural beauty . . . . . . 13

physical endurance . . . . 34

physical welfare . . . . . 26

variety of activities . . . . 35

Affairs of the farm . . . 45-tio

Age of homespun . . . . . 19

Age of machlnery . . . . . 19

Age of steam . . . . . . . 142

Agricultural Education

Monthly . . . . . 15

Agricultural publications . 59

Air pressure tank . . . . . 88

Alabama . . . . . . . . 194

Albumen . . . . . . . 156

Alcohol . . . . . . . 235

Alfalfa,

as feed . . . . . . . 286-289

failure with, causes . . . . 281

good seed . . . . . . 174

history of . . . . . . 280

inoculation for . . . . . . 281

in rotation . . . . . . . 149

pigs feeding in (picture) . . 417

plant . . . . . . . . 282

poor seed . . . . . . . 172

quantity of seed to the acre . 173

testing seed of . . . . . . 174

tillage for . . . . . . 135

Allies of the farmer . . 10, 11, 347

American and European

farming compared . . . 67

American class of poultry . 428
American Review of Reviews 454

Ammonia . . . . . . . 115

Angoumols grain moth . . 336

Annual weeds . . . . . 291

Anther . . . . . . . 162

Anthracnose on beans . . . 21:

Apples . . . . . . 303-30!

Apricots . . . . . . . 237

Arbor day . . . . . . . . 324

Arsenate of lead . . . . . 336

Asiatic class of poultry . . 427

Asparagus. . . . . . . 222

Automobile . . . . . . 80

$\mathrm{Ax}$. . . . . . . . . 139

Ayrshire cattle . . . . . 374

Babcock, Dr. S. M. . . . . 385

Babcock milk test . . 14, 385

"Back to the farm" . . . . 23

Bacon. . . . . . $63,422,455$

Bacon swine . . . . . 417

Bacteria . . 10, 106, 117, 208, 239

how they multiply . . . . . 209

in milk . . . . . . . . 390

their growth, how hindered . 105

Bailey, L. H. . . . . . . 45,72

Balanced ration . . . . . 363

Bank credit . . . . . . . $450 t i$

Barley . . . . . . 272,273

Beach, Professor S. A. . . . 55

Beans . . . 117, 226, 227, 238

Beauty, uses of in farm life . . 11

Beef cattle. . . . . . 367-370

in pasture . . . . . . . . 359

Bee hives . . . . . . 349

Bees . . . . . . . 166, 348

Belgian horses . . . . . . 398 


\section{[References are to pages.]}

Berkshire swine

Biennial weeds

Biology

Bird boxes

Birds
418

292

59

318,350

317,334

how they have been studied . 351

Birthplace of prominent people

Blackberries . . . . . 200,201

Black knot. . . . . . . . 217

Blanching . . . . . . 237

Bluestone . . . . . . . 214

"Boarders" (cattle) . . . . 387

Bone meal . . . . . . . . 117

Bordeaux mixture . . . . 214

Border planting . . . . 328

Bottom lands . . . . . . 105

Box method of corn testing . 256

Boy scouts.

Bradford, Governor, quoted . 252

Brahma poultry . . . . 433

Bran . . . . 195, 362, 377

Breathing pores (stomata) 157,178

Breazeale, quoted . . . . . 231

Breeding new plants . . 190-205

corn . . . . . . . . . 194

tomatoes . . . . . . . . 197

wheat . . . . . . . 197

Brewer, quoted . . . . 25

Brollers . . . . . . . 439

Brooders . . . . . . . 437

Brood mares . . . . . . . 399

Brood sows . . . . . . 422

Broom making . . . . . . 19

Buckwheat . . . . .166,271

Budding . . . . . . . 185

Buds . . . . . . . 179

Bulbs . . . . . . . 182

Bull, Ephraim W. . . 199, 202, 203

Bulletins. . . . 47, 52, 59,75

(Also at the end of each ehapter.)

Bumble bees . . . . . 166

Burbank, Luther . . . . 190

Bush beans . . . . . 223

Business fallures on the farm 73

Butter . . . . . (33, 383, 391 ontfit for making . . . . . 384

Buttermilk . . . . . . 383

Cabbage

223,240

California
Calyx.

Camptire girls

162,346

Canada . . . . . . 272

Canada thistle . . . . . 294

Candling eggs . . . . . 436

Canning . . . . . . 236

Capllary attraction . . . 4, 103

Capillary water . . . . 103

loss of . . . . . . 104

Capital . . . . . $44-452$

how and where secured . . 453

Carbohydrate . $118,156,350-363$

Carbon dioxide . 102,113,114, 132

Carmen No. 3 . . . . . 244

Carriage horses . . . . 400

Carrots . . . . . . . 224

Cart . . . . . . . 139

Casein . . . . . . 383

Cattle . . . . . .366-379

care of . . . . . . . 378

feeding . . . . . 359,376

types of . . . . . . . 367, 371

Cauliflower . . . . . . 225

Celery . . . . . . 228, 241

Cells . . . . . . . . 155

Census bureau . . . . . . 17

Certifled milk . . . . . . 383

Cheese . . . . . . . . 341

Chemistry . . . . . . 58

Cherrles. . . . . . 310

Chester white swine . . 418

Cheviot sheep . . . . . 413

Chewers . . . . . . 335

Chicken, the first . . . . 426

Chlckens, see Poultry.

Chicory . . . . . . . 299

Chile seltpetre . . . . . . 117

Chlorophyll . . . . . 157

Church . . . . . . 70

Clay . . . . . 13, 95, 143

Clover . . . . . 166, 283

alsike . . . . . . 285

crimson . . . . . . . . 284

red . . . . . . 283

sweet . . . . . . 119

white . . . . . 284

Clubs,

corn growing . . . . . . . 194

orgauization of . . . . . 229

pig . . . . . . . 423

poultry . . . . . 52, 443 
[References are to puges.]

Clubs - continued purpose of . soil management

vegetable growing

Cochin poultry

Codling moth

Cold frames

College extension service

Colony henhouse

Colt

Community spirit

Companion cropping . . 223

Compound microscope . . 209

Concentrates

Concord grape . . . . . . 198

Condensed milk . . . . . 383

Conservation . . . . . . . 322

Contests . . . . . . . 50

Conveniences of farm home 77

Coöperation 45-54, 248, 298, 457, 458

Coöperative breeders' association.

388

Coöperative land banks

Cooper's hawk

Corms

Corn,

bagged . . . . . . . . 195

cauned . . . . . . . . 235

club work with . . . . 194, 263

culture of . . . . . . . . 259

dried. . . . . . . . . . 234

ear-to-row test . . . . . 257

festival . . . . . . . 52

improvement . . . . . 194-196

in rotation . . . . . . . 149

judging. . . . . . . . 260

kernels of (sections) . . . . 171

kinds of . . . . . . . . 258

maturity of . . . . . 256

pistilla te flowers of . . . 164

pollen of . . . . . . . . 162

poor pollination of . . . . 165

prize . . . . . . . . . 196

smut of . . . . . . . . 216

staminate flowers of . . . 162

stem of . . . . . . . . . 178

sweet

223,224

tassel of

Cornell University

Corolla

Correlations
Cotswold sheep

Cotton

411

Cotyledons . . . . . 172

Country and city people compared ..... 17

"Country Lifo Commis. sion," quoteri . . . . . 72

Country store . . . . . . 454

County agent . . . . . 51, 5t;

demonstrating . . . . . . 57

Cover crops . . . . . 104, 306

Cow peas . . . . 279, 284;,332

Cowper, quoted . . . . 16, 221

Cows (see cattle) . . . . 9,32

Crab apple. . . . . . . . 203

Craig, Professor John . . . 55

Cream . . . . . 387, 391

Creamery . . . . . 47,387

Cream separators. . . 14, 391

Credit unions . . . . . . 461

Creed of country boy . . . 41

Criminals . . . . . . 27

Crop rotation,

need of . . . . . . . . 146

reasous for … 148, 210

Crossbreds . . . . . 358

Crosses . . . . . . . 9, 192, 199

Cross-pollination . . 165, 166

the method of . . . . . . 192

two great ways of . . . . . 168

Crow . . . . . . . 352

Cucumbers . . . . . . 225

Cultivator . . . . . . 145

Curing . . . . . . . . 239

Currants . . . . . . 235

Cuttings,

green . . . . . . . . 181

liardwood . . . . . . 180

root . . . . . . . 181

Cutworms . . . . . 340

Dairy barn. . . . . 360,378

Dairy cattle . . . . . . 371-376

Death rates . . . . . . 27

Decrease in rate of growth

of rural population . . . 17

Demonstrations . . . . 57,311

Denmark . . . . . 48, 62

Desjardines, M., quoted . . . 461

Diseases of

cattle 


\section{[References are to pages.]}

Diseases of - continued

crops.

people

poultry

sheep)

swine

Ditching machine.

Diversifled farming

Dodder (a parasite)

Dorset sheep.

Draft horses.

Drainage, open and closed . 106-108

Drains, grade of . . . . . 108

Dried blood . . . . . . 117

Drill

18,271

Drudgery on the farm, $28,71,77,78$

Dry rot

Durum wheat

Ear selection of corn

Earth, the new

Ear-to-row experiment

Economic aspect in relation to

asthetics

commusity spirit

education

machinery .

public highways . . . . 81-86

rights of the child . . . . 31-33

ru ral migration . . . . . . 22

securing capital . . . . 446-462

Economics (rural) defined. . 59

Education for the farm . 46, 47

Egg breeds of poultry . . . 427

Egg plant . . . . . . . 237

Eggs . . . . . . . $(63,440,441$

Egyptians . . . . . . 8, 139

Electricity on the farm . . 78

Elms

3,314

Embryo . . . . . . . . 172

Endive . . . . . . . . 225

Endosperm . . . . . . . 172

England . . . . . . . . 67

English sparrows . . . . . 352

English style of decorative planting

Entomology

Environment

for rural child rearing

hostlle
Evaporated cream

Excursion to agricultural college

383

External poisons

338

Fairs (agricultural) .

54

Farm

"abandoned" . . . . . 23

animals. . . . . . 355

as a nursery . . . . . . . 36

attractiveness of . . . . 25

blacksmithing on . . . . 28

brook (plicture) . . . . . . 2

capital . . . . . . . 447

finance. . . . . . . . 446

former methods on . . 20-22, 447

garden . . . . . . 221-228

home (pletures) . . . . . 4, 23

imports and exports . . . . 451

influence on physlcal welfare . 26

labor. . . . . . . 16, 70

management . . . . .44-462

Farmer, the first . . . . . . $5-9$

and nature . . . . . 1-13

Farmers' bulletins . . . 75

(also at end of each chapter)

Farmers' hindrances

lack of capital . . . . . 524

poor judgment . . . . . . 73

shiftlessuess . . . . . . . 74

Fat . . . . $359,376,383,385$

Feeding

cattle . . . . . . . 376

horses . . . . . . 402

poultry . . . . . . . 434

principles of . . . . . . . 361

sheep . . . . . . . 411

swine . . . . . . 420

Feeds. . . . . . 359

Fennel . . . . . . 295

Fernow, quoted . . . . 321

Fertilizers. . . . . . 123-131

application of . . . . . 130

commerclal . . . . . 124

complete . . . . . . . 124

cost of . . . . . . . 124

direct . . . . . . . 124

formulas of . . . . . . . 125

indirect. . . . . . . 124

37 Festlvals . . . . . . 52

73 Fibres . . . . . 8 
[References are to pages.]

Fiske, John, quoted

Flail

Flax, spiuniug (picture of)

Flower garden

Flowers

kinds of

Fly

parts of .

\section{Fodder}

Foliage

Forage crops

kinds of

Forces of nature

heredity and variation

in improvements

regular action of

Forcing boxes

Foremen

Forestry

Formalin

Fox

Fox grape . . . . . . . 199

France

Franklin, Benjamin, quoted

Frazer, Professor .

Free water

Froebel, quoted

Fryers

Fungi .

diseases due to

Fungicide

Furnace (in cellar) .

Furrow

Galloway cattle

Game animals

Gapes

Garden

Garden tools .

Garfleld, James A., quoted

Gasolene engine

General-purpose breeds of poultry

Geometrical style of plant-

67

46

182

103

38

439

11,212

218

337

88

143

370

317

431

221-228

222

61

78 428

\section{ing}

Geranium cutting

Germany

Germ plasm

Gillette, Professor

Ginseng

Glumes

$68,78,458$

$167-168,176$
34

16

1

2

2

38

G

6

2

7

7

22

4

0

9

$\mathrm{H}$

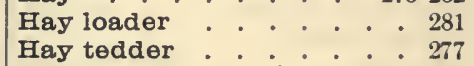

Health, in country : . . . 16, 45

of country children . . . . 37

Heat . . . . . . . 105

Heavy horses . . . . . 398

Henry's feed table . . . 362

Herbs . . . . . . . 327

Heredity . . . . . . . 7

in animal breeding . . . 356

in plant breeding . . . . 200

Hereford cattle. . . . . 368

Hessian fly, work of . . . . 336

High cost of living . . . . 65

"High grade" animals . . 358

Hills, Professor G. L. . . . 55

Hogs (see Swine)

Holly hocks . . . . . . 330

Holstein-Friesian cattle . . 375

Home, country

(exercises for, at the end of each chapter) as a nursery : . . . . . 36

the main object of farming $\quad 61$

work at the . . . . . 39, 446

Homestead Law . . . . 58

Honey . . . . . . . . 348

Horse barn . . . . . . 396 
[References are to puges.]

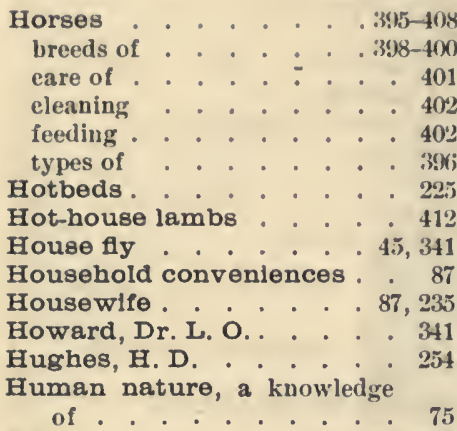

Humus . . . . . 100, 268, 306

Hybrids . . . . . . . . 204

Ice cream . . . . . . . . 392

Ichneumon flies . . . . . 347

Illinols . . . . . . 78

Immigrant farmers . . . . 70

Imperfect flowers . . . . 165

Improvement,

animals . . . . 355-359; 428

plants . . . . . 7-9, 190-205

Increase of city population rate

Incubation

artifiejal

natural

Indiana

Indian corn

Inoculation of soll . . . . 281

Insect breeding . . . . 353

Insecticides . . . . . 33t

Insects

method of control .

$334-350$

method of mounting

two great classes of . . . . 334

Internal polsons . . . . . 336

Internodes , . . . . . . 178

Irrigation . . . . . . . . 108

Irving, Washington, quoted . 25

Itallan style of decorative planting

Jackson, Helen Hunt

Jefferson, Thomas

139

Jelly making

Joe pye weed
Johanna Rue

375

"Johnny Appleseed" . . . 308

Jones, L. $\mathbf{R}$.

55

Kainit

118

Kale

Kansas

Experiment

115,225 tion

Sta-

Kentucky blue grass . 280, 33:

Kerosene emulsiou . . . 338

King, D. W. . . . . . 86

King, F. H. . . . . . . 401

Kitchen, country . . . . 88

eanning in . . . . . . 231

Kohl-rabl . . . . . . . . 225

Labor-saving devices . . . 63

Lady Eglantine . . . 35,426

Lambs . . . . . . 412,413

Lancaster county . . . . . itt

Land banks . . . . . . 4 4i

Landlords

duties of . . . . . . 70

inerease of . . . . . . . 449

Landscape gardenlng . . 325-333

Langshan poultry . . . . 428

Lard swine . . . . . . 418

Lawn . . . . . . . . . 331

Layering . . . . . . . 184

Lear

net-veined . . . . . . , 172

parallel-veined . . . . 172

Leghorn poultry . . . . . 427

Lelcester sheep . . . . 411

Lettuce . . . . . . . . . 224

Lice . . . . . . . . 431

Light horses . . . . . . . 399

Lime,

experiments with . . . . . 129

funetions of . . . . . . 127

kiln . . . . . . . . 126

preparing stone . . . . . 128

slaked . . . . . . . . 129

source of . . . . . . . 98

spreading . . . . . . . 138

stone . . . . . . . . 128

Lime and sulfur wash . . . 339

Llncoln sheep . . . . . . 411

Litmus paper test . . . 127

Live stock judging . . . . 366

291 Loam . . . . . . . . . 101 
[References are to pages.]

Longfellow, quoted

Long wool sheep

MacAdam, John

Macadam road .

Macaroni wheat

Machinery of the farm,

as to conveniences.

as to population

coöperative buying of

development of

drudgery relieved by

improvements in

tillage by

Maize .

Manure,

amount recovered in . . . 127

as a by-product . . . . . . 367

as a complete fertilizer . . . 126

as a direct fertilizer . . . . 126

barnyard . . . . . . . 125

care of . . . . . . . 125

composition of . . . . . 126

green . . . . . . . 126

in flower garden . . . . 331

in hotbed . . . . . . . 226

in rotation . . . . . . . 149

spreading of . . . . . . 123

Maps, township . . . . . 90

Market (picture of) . . . 15

Marketing,

by boat and rail.

fritit.

62,63

potatoes . . . . . . . . 248

poultry . . . . . . . . . 439

Maryland . . . . . . . . 147

Massachusetts . . . . . 108, 190

May Rilma . . . . . . . 357

McCormick, Cyrus H. . . 20

McKe日ver, William A: . : 31,39

Meadow . . . . . . 1, 278

Measurements of children compared

Meat breeds of poultry

Mediterranean class of poultry

Medium wool sheep .

Mendel, Gregor

33

427

Merino sheep.

427

410

204

Microscope, compound . . 209

Middlemen
Migration, rural . . . . 23

Mildews . . . . . . . . 213

Milk . . . . . . . .382-392

care of . . . . . . . . 66, 389

composition of . . . . . 383

definitions . . . . . . . 383

quality of . . . . . . . 385

quantity of . . . . . . 384

testing . . . . . . . 382

value of . . . . . . . 387

Milk fat . . . . . 376, 385-389

Milk pails . . . . . . . . 382

Milk sugar . . . . . . . . 382

Milk-testing associations . . 388

Milkweed . . . . . . . . 295

Millet. . . . . . . 160,286

Mill, John Stuart . . . . 69

Minnesota . . . . . . . 272

Minorca poultry . . . . . 427

Models of

pouitry houses . . . . . . 444

road building . . . . . . . 85

Molds . . . . . . . . 218, 233

Montana . . . . . . : 272

Mortgage . . . . . . . 455

Mosquitoes . . . . . . . 340

Moth mullein. . . . . . . 294

Motor power . . . . . . 77

Mulch,

function of . . . . . . . 104

how made . . . . . . . 104

Mules . . . . . . . . . 401

Musk melon . . . . . . 225

Nature,

her tools . . . . . . . 5

improvements on . . . . . 7

in breeding . . . . . . 198

in city (picture of) . . . . 12

our trust in . . . . . . 7

Nile (picture) . . . . . 8

Nitrate of soda . . . . . 117

Nitrates . . . . . . . 116

Nitrogen . . 115-117, 119, 282

Nodes . . . . . . . 178

Nodules . . . . . . 116,290

North Dakota . . . . . 33, 455

Norway spruce . . . . . 318

Nucleus . . . . . . . . 155

67 Nutritive ratio . . . . . 361 
[References are to pages.]

Oak

Oats

in rotation

Oat smut,

cause of

loss, due to

Ohio

Ol1

One-crop system, evils of .

Onions

Orchard .

masagement of ${ }^{\circ} \cdot{ }^{\circ} 12,000-311$

planting of

securing the stock for

the site of .

Ornamental plants

Orpington poultry

Overhead system of irrigation

Ovules

\section{Parcel post}

shipping eggs by . : . . . 441

Paris green . . . . 227, 336

Parsley . . . . . . . . 225

Parsnips . . . . . . . 224

Pasteurized milk . . . . . 383

Pasture . . . . . . . 278

Peaches . 186, 211, 236, 303, 305, 310

Peach rot

Pears

Pear stem

Peas

Pelsant farmers

Pedigree

Penngylvania,

lime experiment

manufacturing

milk yield .

Pepper

Percheron horses

Perennial weeds

Petal

Petri dish

$161,303,309$

Pets

Phenolphthalein

Phosphoric acid

Phosphorus

Physics

176
205,238

$68,458-460$

Pictures for country life

Plercers

129

19,20

376

225

398

292

162

225

37

290

117,119
Pig raising.

Pigs - see Swoine

Pigweed.

Pistillate flowers

Pith

Planker

Plantain.

Plant diseases

Plant food,

amount of, in soil . . . . 119

available . . . . . . 130

elements in . . . . . . 114

how secured . . . . . . 112

Plantings as a framed picture 328

Plants, as factories . . . . . 158

as storeliouses . . . . 156

ornamental . : . . . . 325

Play

38

Plow,

bull . . . . . . . 139

disk . . . . . . . . 140

gang . . . . . . . . . 9

moldboard . . . : . . 140

spaulding . . . . . . . 141

traction. . . . . . . 9, 142

Plowing,

ancient . . . . . . 8

depth of . . . . . . 142

fall . . . . . . 143

spring . . . . . . . 143

with oxen . . . . . . 18

with tractor . . . . : . 142

Plum . . . . . . 310

Plum rot . . . . . 210

Plumule . . . . . . . 172

117,246
Plunkett, Sir Horace

49,460

Plymouth Rock poultry . . 42!

Poland China swine . . . . $\$ 18$

Pollen . . . . . . 162, 163

Population. . : . . . . 17

per square mile . . . . . 69

Potash . . . . . 118, 119

Potassium . . . . . . . 118

Potato . . . . . .243-248

blight . . . . . . . 214

Burbauk . . . . . . 191

cultivation of . . . . . 247

flowers and seed balls of . . 168

harvesting. . . . . . (5.5, 248 in rotation. . . . . . 149 
[References are to pages.]

\section{Potato-continued}

marketing .

seab

selection of seed

soil for

storing

varieties of

Potato beetle

Potato-vine borer

Poultry

breeds of

diseases of .

feed

finishing

housing .

marketing .

project

raising of

types of .

Poultry houses

Poultry show

Preserves

Principles as farm tools . . 5-9

Prizes for home work . . . 52

Proflts in relation to capital 452

Projects.

baby beef .

bean .

colt

corn

flower-growing

fruit tree

pig

poultry

soil management

Propagation,

asexual . . . 168, 179-187, 204 sexual

Protein

Pruning

Pumpkin

Pure-bred animals

Pustules of smut

Quack grass

Quartz

10,297

Radicle

Rag doll test for corn

Ragweed
Raiffeisen

Rallroads

23,450

Rake . . . . . . 137

Rape, sheep feeding in (picture)

415

Raspberries . . . . . 235

Reaper . . . . . . . 63

"Record sheet" for milk . . 384

Red top . . . . . . . . 278

Rennet . . . . . . 392

Renter,

cash . . . . . . . . 452

share . . . . . . . 452

Reproduction,

asexual . . . . . .179-187

sexual . . . . . 171-175

Reversion . . . . 202, 203

Rhubarb. . . . . . 225

Road horses . . . . . . . 399

Roads . . . . . . . . . 81

construction of . . . . . . 84

economy of . . . . . . . 84

effect of broad and narrow

tires on . . . . . . 86,87

history of . . . . . . . 81

maintenance of . . . . . . 86

Roasters. . . . . . 439

Roberts, Professor, quoted . 123

Roller . . . . . . . . . 146

Roosevelt, Theodore, quoted 61

Root excretions . . . . 148

Root hairs . . . . . 112, 178

Roots,

function of . . . . . 99, 112

structure of . . . . . . . 178

Rootstocks . . . . . 183

Rope-splicing (picture) - . . 42

Rose cuttings . . . 181, 331

Rotation of crops . . . 146-149

Roughages . . . . . 363

Roup ...... 431

Runners . . . . . . . 183

Rural betterment,

aptitudes for . . . . . . . 23

community spirit a factor . . 49

leadership for . . . . . 53

the facts needed . . . . . 30

Rural credits. . . . . . . 440

Rural mail service . . . . 79

Rural New Yorker . . . . 244

292. Russia . . . . . : 368 
[References are to payes.]

Rust

216
273
149
225
46
390
46
88
344
217
347

Ryo.

Selection - continued

in rotation

potatoes

poultry

princlples of

$355-359$

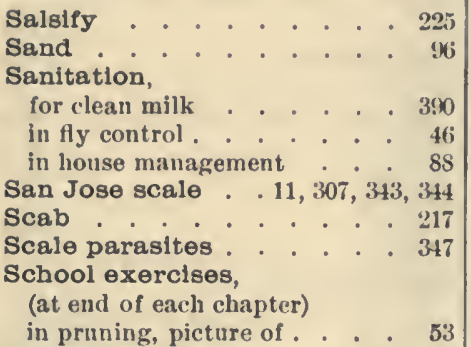

School garden . . . . 137, 229

Sclentiflc farming . . $57,361,451$

Scion and stock . . . 184, 186

Score cards,

corn . . . . . . . 261

dairy cattle . . . . . 380

horses . . . . . . . 407

Scythe . . . . . . . 139

Seed,

alfalfa . . . . . . 172, 174

amount sown . . . . . . 225

barley . . . . . . . . 272

buckwheat . . . . . . . . $2 \pi 1$

corn . . . . . . . . . 252

cowpeas. . . . . . . . 287

depth to plant . . . . . . 175

Kentucky blue gras. . . . . 280

millet . . . . . . . 160

needs of . . . . . . . 173

oat . . . . . . . . . 269

origin of . . . . . . . 161

planting . . . . . . 175

red clover . . . . . . . . 283

reproduction by . . . . . . 171

rye . . . . . . . . . 273

soybean . . . . . . . . . 286

testing . . . . . . 173, 225, 229

timothy . . . . . . . . . 279

wheat . . . . . . . . 205

Seedling . . . . . . . 174, 321

Selection,

Sharp-shinned hawk . . . 352

Sheep. . . . . . .409-116

breeds of . . . . . . 411

care of . . . . . . 412

fecding . . . . . 4 411, 415

types of . . . . . . 410

Shipping by

boat . . . . . . . . 63

parcel post . . . . . . 441

rail . . . . . . . . 62

Shire horses . . . . . . 399

Shorts . . . . . . 420,422

Shot-hole borer . . . . . 342

Shot-hole fungus . . . . . 212

Short-horn cattle . . . . 368

Shows,

corn . . . . . . . . 264

poultry . . . . . . . 441

Shropshire . . . . . . . 411

Shrubbery . . . . . . . 327

Slckle. . . . . . . . 139

"Signs". . . . . . . . . 7

Silage . . . . . . . . 286

feeding of . . . . . . . 289

S1It . . . . . . . . . . . 90

Skim milk . . . . . . 353, 382

Small grains . . . . . 20ir-275

Smith, Adam . . . . . . 447

Smith-Lever bll . . . . 56

Smut,

corn . . . . . . . 216

oats . . . . . . . . 215

Snakes . . . . . . . . 10

Soclal aspects of farm life,

boy scouts and campfiro girls . . . . . . . 40

clubs. . . . . . . . 51

conveniences which promote

the . . . . . . . 77-81

fairs. . . . . . . . 54

festivals . . . . . . . 52

organized play . . . . . . 39

Soll. . . . . . . . . 93-151

corll . . . . . 253

dalry cattle . . . . . 387

forest trees . . . . . . 319

analysis of . . . . . . . 131

as source of life . . . . . 93

composition of . 101-105, 114-120

horses

397

defined 
[References are to pages.]

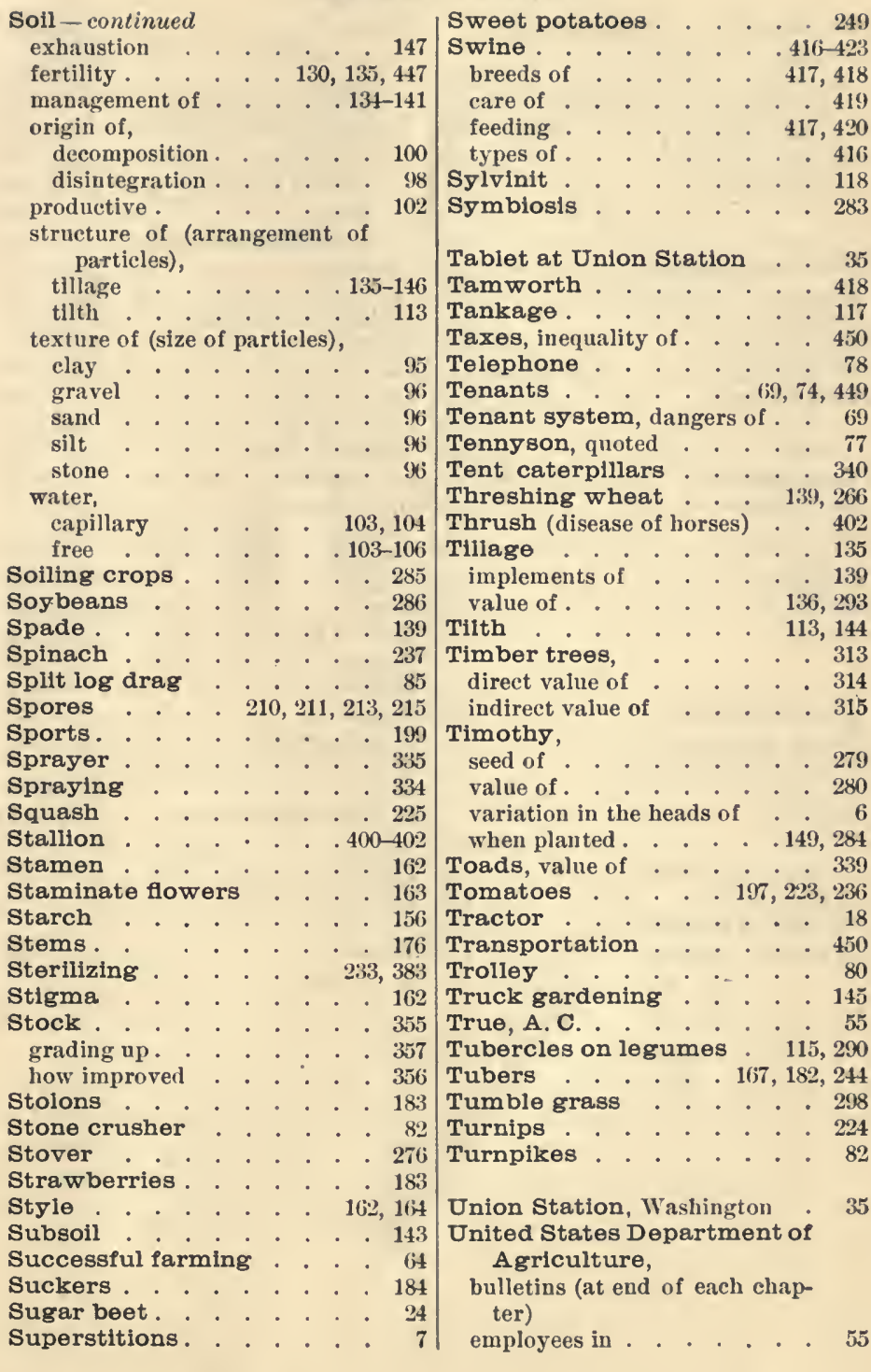




\section{[References are to pages.]}

United States Department of

Agriculture - continued

in project work . . . . . 22?

investigations in breeding . . 273

fnvestigations in labor income . 48

publications of . . . . . . 59

secretary of . . . . . . 54

Vacuum cleaners . . . . 78

Valgren, Prolessor : . . . 48

Van Hise, quoted . . . . 323

Van Slyke. . . . . . 383

Varfation . . . . .6, 193, 200

Varlety test, corn . . . . . . . 257 wheat . : . . . . 268

Vegetables . . . . 71, 221

Ventllation in barn . . . . . . . 401 house . . . . . . 88

Vermont . . . . . 18

Vetch . . . . . . . 286

Vines . . . . . . . 327

Wagon horses . . . . 400

Wald, Professor . . . 108

Walnut caterplllars . . . . 341

Washington, George, quoted 45 Water,

in soil . . . . . . . . 102-111

running, in house . . . . 88

Water table . . . . 105

Waugh, Professor . . . 55, 331

Webster, Danlel . . . . 141
${ }_{\text {controlled by }}^{\text {Weeds }} \cdot \ldots . .291-299$ chemicals . . . . . 2913

cutting and pulling . . . . 293

rotation of crops . . . . 149, 293

smothering . . . . . . 293

summer fallowing . . . . 294

tillage . . . . . 137

coöperation in control of . . 298

kinds of . . . . . 291, 2912

project work on . . . . . . 24y9

Weisman, August. . . . 167

Wheat . . . . 6, 21, 72, 265

culture of . . . . . . 268

elevators for . . . . . 91

harvesting . . . . . . 64, 270

improvements of . . . . . 197

in rotation. . . . . . . . 149

production of . . . . . . 21

seedlings of . . . . . . 112, 175

selection of seed of . . . . . 267

types of . . . . . . . 267

Whey . . . . . . 383

Wind breaks . . . . . 317

Windmills . . . . . . 78

Wood . . . . . 177, 313-323

Wood lot . . . . . . 321

Woodpecker . . . . . 351

Wordsworth, quoted . . . . 1

Work . . . . 27, 32, 39

Wyandotte poultry . . . 429

Yeast . . . . . . 233

Yorkshire swine . . . . . 417

Zinnias . . . . . . . . 332 





UNIVERSITY OF CALIFORNIA AT LOS ANGELES

THE UNIVERSITY LIBRARY

This book is DUE on the last date stamped below

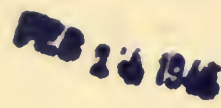

Form L-0

$20 m-1,42$ (8519)

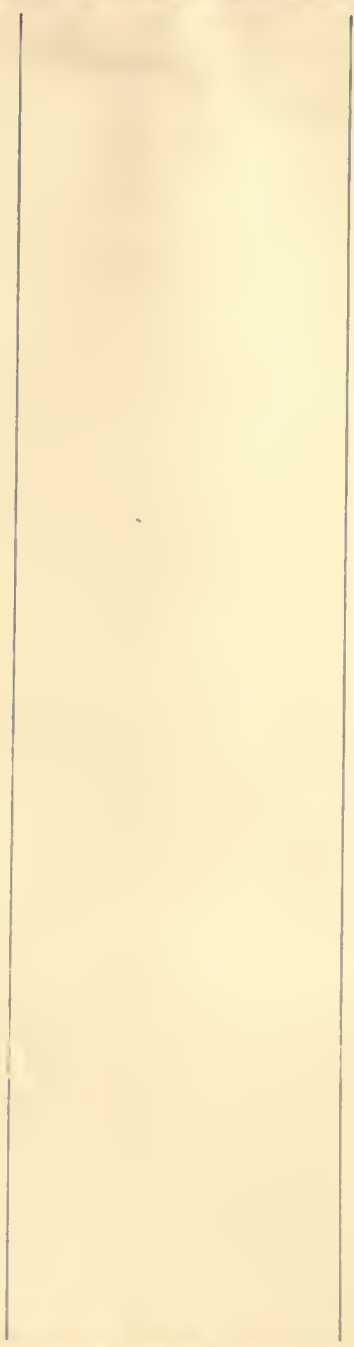

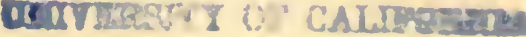

\section{A :}

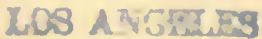

ITREARY 
3495

$23700 \%$ m -

Llomentary

acriculture.

A 0011075272

$\therefore * \therefore$

S495

G87e 
